\title{
DEZINWESTYCJE FUNDUSZY \\ PRIVATE EQUITY METODĄ IPO
}


盗 


\section{Tomasz Sosnowski}

\section{DEZINWESTYCJE FUNDUSZY}

PRIVATE EQUITY METODĄ IPO 
Tomasz Sosnowski - Uniwersytet Łódzki, Wydział Ekonomiczno-Socjologiczny

Katedra Analizy i Strategii Przedsiębiorstwa

90-214 Łódź, ul. Rewolucji 1905 r. 41/43

RECENZENT

Cezary Kochalski

PROJEKT OKŁADKI

Stämpfli Polska Sp. z o.o.

Zdjęcie na okładce: Cshutterstock.com

Wydrukowano z gotowych materiałów dostarczonych do Wydawnictwa UŁ

przez Katedrę Analizy i Strategii Przedsiębiorstwa

(C) Copyright by Uniwersytet Łódzki, Łódź 2014

Wydane przez Wydawnictwo Uniwersytetu Łódzkiego

Wydanie I. W.06696.14.0.D

ISBN (wersja papierowa) 978-83-7969-363-4

ISBN (wersja elektroniczna) 978-83-7969-501-0

Wydawnictwo Uniwersytetu Łódzkiego

90-131 Łódź, ul. Lindleya 8

www.wydawnictwo.uni.lodz.pl

e-mail: ksiegarnia@uni.lodz.pl

tel. (42) 66558 63, faks (42) 6655862 


\section{SPIS TREŚCI}

Wprowadzenie

Rozdział 1. Zarys funkcjonowania funduszy private equity

1.1. Pojęcie private equity i jego związek znaczeniowy z określeniem venture capital ..... 13

1.2. Struktura rynku kapitału podwyższonego ryzyka i jego segmenty ...............................

1.3. Etapy rozwoju przedsiębiorstw wspieranych przez fundusze private equity ................. 27

1.4. Korzyści i zagrożenia finansowania rozwoju przedsiębiorstw kapitałem podwyższo-

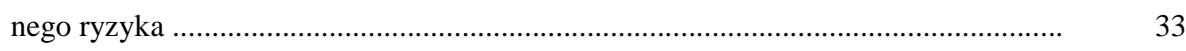

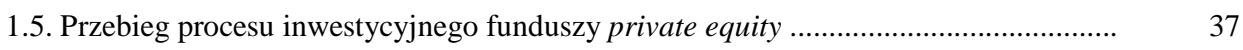

1.5.1. Pozyskanie kapitału przez fundusze private equity .......................................... $\quad 39$

1.5.2. Inwestycje funduszy private equity w przedsiębiorstwa działające w Polsce ... $\quad 42$

Rozdział 2. Dezinwestycja jako kluczowy etap procesu inwestycyjnego funduszy private equity ............................................................................................ 51

2.1. Pojęcie dezinwestycji i jej znaczenie dla funduszy kapitału podwyższonego ryzyka ...... 51

2.2. Charakterystyka sposobów wyjścia z inwestycji funduszy private equity ................... 56

2.2.1. Dezinwestycja poprzez wprowadzenie akcji spółki do publicznego obrotu i ich sprzedaż za pośrednictwem giełdy papierów wartościowych .................. 56

2.2.2. Rynek fuzji i przejęć przedsiębiorstw jako miejsce realizacji procesów wyj-

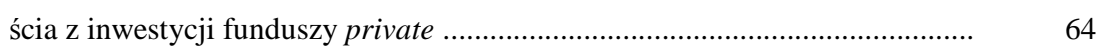

2.2.3. Wyjście funduszu private equity $\mathrm{z}$ inwestycji $\mathrm{w}$ wyniku transakcji wykupu menedżerskiego i lewarowanego ................................................................ 71

2.2.4. Write-off i likwidacja spółki jako formy dezinwestycji ..................................... 73

2.3. Rynkowe uwarunkowania procesów dezinwestycji funduszy private equity ............... 74

2.4. Metody dezinwestycji funduszy private equity na rynku polskim .............................. 86

Rozdział 3. Determinanty architektury procesu dezinwestycji funduszy private equity

3.1. Główne nurty teoretyczne kształtowania procesu dezinwestycji funduszy private equity 
3.1.1. Teoria agencji a dezinwestycje funduszy private equity .................................. $\quad 100$

3.1.2. Asymetria informacji a wyjście z inwestycji ................................................ 106

3.2. Wybór optymalnego momentu wyjścia $\mathrm{z}$ inwestycji funduszy private equity .............. 109

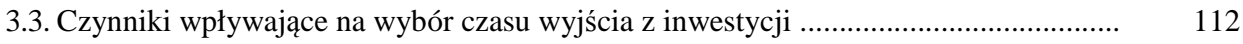

3.4. Czynniki wpływające na wybór metody dezinwestycji .............................................. 116

3.4.1. Zewnętrzne uwarunkowania wyboru metody dezinwestycji ............................ 118

3.4.2. Cechy specyficzne funduszu private equity a metoda dezinwestycji ................ 120

3.4.3. Wpływ cech charakterystycznych spółek portfelowych funduszy private equity na wybór metody dezinwestycji

3.4.4. Relacja między funduszem private equity i spółką portfelową a wybór metody wyjścia z inwestycji

3.5. Kierunki realizacji strategii dezinwestycji funduszy private equity na krajowym publicznym rynku papierów wartościowych

3.5.1. Metodyka badań nad dynamiką i czasem trwania dezinwestycji funduszy private equity na GPW w Warszawie

3.5.2. Wyniki badań empirycznych

3.5.3. Stopień dezinwestycji funduszu private equity a emisja nowych akcji przez spółkę portfelową

3.5.4. Wyniki badań empirycznych nad stopniem dezinwestycji funduszu private equity a emisją nowych akcji przez spółkę portfelową ...

3.5.5. Wybrane przykłady dezinwestycji funduszy private equity realizowanych za pośrednictwem warszawskiej giełdy

3.5.5.1. Redukcja zaangażowania kapitałowego funduszu private equity w spółkę Travelplanet.pl SA

3.5.5.2. Redukcja zaangażowania kapitałowego funduszu private equity w spółkę Opoczno SA

3.5.5.3. Redukcja zaangażowania kapitałowego funduszu private equity w Grupę Kapitałową W. KRUK

3.5.5.4. Redukcja zaangażowania kapitałowego funduszu private equity w spółkę K2 Internet $S A$

3.5.5.5. Wnioski z analizy przypadków

Rozdział 4. Rynkowe efekty procesów dezinwestycji zrealizowanych metodą pierwszej oferty publicznej

4.1. Rentowność kapitału własnego spółek portfelowych funduszy private equity objętych procesami dezinwestycji na publicznym rynku papierów wartościowych ......

4.1.1. Podstawy metodyczne badań nad zmianami rentowności kapitału własnego spółek portfelowych funduszy private equity 
4.1.2. Wyniki badań empirycznych nad rentownością kapitału własnego spółek portfelowych funduszy private equity

4.2. Koszty przeprowadzenia pierwszych ofert publicznych

4.2.1. Bezpośrednie koszty pierwszych ofert publicznych spółek portfelowych funduszy private equity

4.2.2. Pośrednie koszty pierwszych ofert publicznych spółek portfelowych funduszy private equity

4.2.2.1. Eksplikacja niedowartościowania pierwszych ofert publicznych w literaturze przedmiotu

4.2.2.2. Metodyka badań nad niedowartościowaniem akcji w pierwszym dniu notowań giełdowych spółek portfelowych funduszy private equity

4.2.2.3. Wyniki badań empirycznych nad niedowartościowaniem pierwszych ofert publicznych spółek portfelowych funduszy private equity

4.2.2.4. Alokacja kosztu niedowartościowania akcji w pierwszych ofertach publicznych spółek portfelowych funduszy private equity

4.2.2.5. Wyniki badań empirycznych nad alokacją kosztu niedowartościowania akcji w pierwszych ofertach publicznych spółek portfelowych funduszy private equity

4.3. Wyniki badań nad zmianami stóp zwrotu z pierwszych ofert publicznych spółek portfelowych funduszy private equity

4.3.1. Przewartościowanie pierwszych ofert publicznych w perspektywie średnioi długoterminowej - wnioski z badań literaturowych

4.3.2. Przyjęte w badaniach empirycznych rozwiązania metodyczne

4.3.3. Wyniki badań empirycznych nad zmianami stóp zwrotu z pierwszych ofert publicznych spółek portfelowych funduszy private equity

Zakończenie 



\section{WPROWADZENIE}

Fundusze private equity są alternatywą wobec bankowych źródeł pozyskania kapitału. W zamian za możliwość osiągnięcia wysokiej stopy zwrotu z zainwestowanego kapitału są gotowe zaakceptować ponadprzeciętne ryzyko. Specyficzną cechą inwestycji funduszy private equity jest różnorodność form i sposobów działania. Ich działalność nie ogranicza się wyłącznie do udostępnienia kapitału finansowego przedsiębiorstwom poszukującym środków na rozwój, lecz fundusze private equity także wspierają je kapitałem menedżerskim. Fundusz private equity jest nie tylko współwłaścicielem przedsiębiorstwa, ale strategiem wyznaczającym perspektywiczne cele i pomagającym spółkom portfelowym je realizować. Tego rodzaju wsparcie uznać można za kluczowy czynnik sukcesu ekonomicznego przedsiębiorstwa działającego na konkurencyjnym rynku.

Fundusze private equity są podmiotami inwestującymi zgromadzone wcześniej zasoby kapitału w przedsiębiorstwa wyróżniające się znaczącym potencjałem wzrostu wartości rynkowej. Wspomagając kapitałowo rozwój tych przedsiębiorstw działają one również w interesie swoich właścicieli i wierzycieli, którzy oczekują odpowiedniej stopy zwrotu z kapitału powierzonego w zarządzanie. Specyfiką działalności funduszy private equity jest odłożona w czasie realizacja zysku kapitałowego z inwestycji. Jest on realizowany dopiero w końcowej części całego cyklu inwestycyjnego tj. w fazie dezinwestycji, a jego podstawowym źródłem jest osiągnięta nadwyżka rynkowej wartości kapitału przedsiębiorstwa udziałowego w momencie wyjścia $\mathrm{z}$ inwestycji nad sumą zainwestowanego kapitału. Wyjście z inwestycji stanowi finalny etap w cyklu życia każdego przedsięwzięcia kapitałowego realizowanego przez fundusze private equity. Dezinwestycja jest bowiem swoistego rodzaju ukoronowaniem starań zarządzających funduszem o realizację określonej rentowności kapitału własnego.

Fundusze private equity stosują wiele różnorodnych metod zakończenia zaangażowania kapitałowego w spółkę portfelową. Forma oraz sposób realizacji zakończenia współpracy między spółkami portfelowymi i funduszem private equity wpływają nie tylko na efekty działań podejmowanych przez fundusz private equity, ale również niosą za sobą długofalowe skutki dla dalszego funkcjonowania spółek portfelowych objętych procesami dezinwestycji. Dezinwestycje realizowane za pośrednictwem publicznego rynku papierów wartościo- 
wych uznawane są za preferowany sposób realizacji zysku kapitałowego przez fundusze private equity.

Zasadniczym celem pracy jest ocena przebiegu i efektów procesu dezinwestycji funduszy private equity metodą pierwszej oferty publicznej w Polsce. Głównym sposobem realizacji tego celu jest przeprowadzenie analiz teoretycznych i badań empirycznych pozwalających rozpoznać i poddać ocenie działalność inwestycyjną funduszy private equity w Polsce z wykorzystaniem Giełdy Papierów Wartościowych w Warszawie dla wyjścia z inwestycji.

Podjęcie wskazanego powyżej zamierzenia badawczego uzasadnione jest występowaniem istotnej luki w badaniach teoretycznych i analizach empirycznych poświęconych funkcjonowaniu funduszy private equity w warunkach polskiego rynku kapitałowego. Krajowa literatura przedmiotu koncentruje się głównie na eksploracji zagadnień związanych z procesami gromadzenia środków na inwestycje oraz lokowania ich w przedsiębiorstwa udziałowe, a także na ogólnogospodarczych korzyściach wynikających ze stosowania tej formy finansowania innowacyjnych przedsiębiorstw. Dużo mniejsza uwaga badaczy skierowana jest na problemy zakończenia współpracy między funduszem private equity a spółką portfelową. Ubogie są zwłaszcza wyniki analiz empirycznych dla polskiego rynku. W zagranicznej literaturze przedmiotu odnaleźć można rezultaty badań empirycznych, dające częściową odpowiedź na podnoszone w pracy problemy badawcze. Wynikające $\mathrm{z}$ nich wnioski formułowane są dla wysoko rozwiniętych rynków kapitałowych.

Sformułowany powyżej cel opracowania odzwierciedla szerokie spektrum problemów teoretyczno-empirycznych badań naukowych zorientowanych na wielowymiarową analizę dezinwestycji funduszy private equity przeprowadzonych metodą pierwszej oferty publicznej. Problemy te dadzą się sprowadzić do analizy:

a) dezinwestycji funduszy private equity traktowanych jako złożony proces realizacji zysku kapitałowego na giełdzie papierów wartościowych oraz

b) efektów wyjścia z inwestycji funduszy private equity metodą pierwszej oferty publicznej.

Przeprowadzone badania dotyczą głównie wybranych podmiotów uczestniczących $\mathrm{w}$ procesie dezinwestycji, tj. funduszy private equity i przedsiębiorstw udziałowych.

Zasadnicze badania naukowe koncentrowały się na poszukiwaniu odpowiedzi na sześć następujących pytań badawczych:

1) w jaki sposób kształtował się czas realizacji i dynamika procesów dezinwestycji realizowanych za pośrednictwem GPW w Warszawie?

2) jak zmieniała się struktura akcjonariatu spółek portfelowych funduszy private equity $\mathrm{w}$ następstwie procesów dezinwestycji realizowanych $\mathrm{w}$ drodze pierwszej publicznej oferty sprzedaży akcji?

3) czy występowały bariery realizacji zysku kapitałowego przez fundusze private equity przy wykorzystaniu GPW w Warszawie? 
4) jak zmieniała się kondycja finansowa przedsiębiorstw udziałowych funduszy private equity, w których proces dezinwestycji przeprowadzono za pośrednictwem warszawskiego rynku giełdowego?

5) jaki był koszt implementacji strategii redukcji zaangażowania kapitałowego funduszy private equity $\mathrm{w}$ przedsiębiorstwa udziałowe za pośrednictwem publicznego rynku papierów wartościowych? oraz

6) jakie były rynkowe efekty pierwszych ofert publicznych spółek portfelowych funduszy private equity?

Praca ta ma charakter monografii naukowej, na którą składają się wprowadzenie, cztery rozdziały oraz zakończenie wraz z bibliografią, spisem tabel, schematów oraz wykresów.

Rozdział pierwszy pt. Zarys funkcjonowania funduszy private equity stanowi studium teoretyczne działalności funduszy private equity. Omówione zostały podstawowe pojęcia związane z rynkiem funduszy private equity, jego struktura oraz kluczowe segmenty inwestycji private equity. Następnie przedstawiona została ogólna charakterystyka procesu inwestycyjnego prowadzonego przez fundusze private equity. $\mathrm{W}$ tej części opracowania scharakteryzowane zostały etapy gromadzenia środków na inwestycje oraz lokowania kapitału w przedsiębiorstwa o znaczącym potencjale wzrostu wartości rynkowej.

Rozdział drugi, zatytułowany Wyjście z inwestycji funduszy private equity, został poświęcony dezinwestycji, która stanowi finalną część procesu inwestycyjnego na rynku kapitału podwyższonego ryzyka. $\mathrm{Z}$ jednej strony przedstawia teoretyczne kwestie strategii dezinwestycji funduszy private equity, z drugiej zaś ukazuje rozmiary i metody praktyki dezinwestycji funduszy private equity prowadzących działalność inwestycyjną w Polsce.

Rozważania zawarte w rozdziale trzecim, zatytułowanym Determinanty architektury procesu dezinwestycji funduszy private equity, dotyczą konceptualnych i praktycznych problemów zakończenia zaangażowania kapitałowego funduszu private equity w spółkę. Szczególną uwagę zwrócono na teorię agencji oraz teorię asymetrii informacji. Wśród efektów analizy determinant wyboru optymalnego momentu i sposobu zakończenia współpracy funduszu private equity z przedsiębiorstwem udziałowym znajdują się wyniki autorskich badań empirycznych nad realizowanymi strategiami dezinwestycji na polskim publicznym rynku papierów wartościowych.

Rozdział czwarty monografii, zatytułowany Rynkowe efekty procesów dezinwestycji realizowanych metoda pierwszej oferty publicznej, składa się z trzech części i w całości został poświęcony rozpoznaniu rynkowych implikacji wyjść $\mathrm{z}$ inwestycji funduszy private equity realizowanych za pośrednictwem publicznego rynku papierów wartościowych w Polsce. W pierwszej kolejności analiza dotyczy efektywności wykorzystania kapitału własnego przez przedsiębiorstwa udziałowe funduszy private equity $\mathrm{w}$ trakcie realizacji dezinwestycji metoda pierwszej oferty publicznej. Następnie analiza zawiera ocenę kosztów wyjścia 
z inwestycji za pośrednictwem publicznego rynku papierów wartościowych. W ostatniej części rozdziału przedstawiono wyniki badań własnych nad zmianami kursów akcji spółek, których akcje zostały wprowadzone do publicznego obrotu $\mathrm{z}$ intencją realizacji zysku kapitałowego poprzez wyjście $\mathrm{z}$ inwestycji funduszu private equity.

Zasadnicze badania empiryczne nad realizację procesów dezinwestycji funduszy private equity za pośrednictwem krajowego publicznego rynku papierów wartościowych dotyczą procesów dezinwestycji spółek portfelowych funduszy private equity, których akcje zostały wprowadzone po raz pierwszy do publicznego obrotu w latach 2002-2010 i zostały przeprowadzone w oparciu o analizę:

a) jednostkowych i skonsolidowanych rocznych sprawozdań finansowych spółek,

b) prospektów emisyjnych badanych jednostek,

c) raportów bieżących oraz informacji znajdujących się w Elektronicznym Systemie Przekazywania Informacji (ESPI),

d) informacji uzyskanych bezpośrednio od funduszy private equity,

e) informacji zawartych na stronach internetowych badanych spółek oraz innych ogólnodostępnych portalach internetowych,

f) gotowych zbiorów danych w postaci biuletynów i roczników statystycznych oraz raportów (np. Rocznik Gietdowy, Rocznik EVCA).

Książka adresowana jest do szerokiego grona obecnych i przyszłych interesariuszy rynku kapitału podwyższonego ryzyka w Polsce, zwłaszcza zarządzających funduszami private equity, właścicieli i menedżerów innowacyjnych spółek oraz inwestorów giełdowych. Chociaż książka ma charakter monografii naukowej, a nie podręcznika akademickiego, z powodzeniem może być wykorzystywana przez nauczycieli akademickich w kształceniu studentów ekonomii, finansów i zarządzania zainteresowanych tematyką finansów przedsiębiorstw oraz rynku kapitałowego, stanowiąc przy tym przyczynek do licznych dyskusji.

Prezentowana monografia jest efektem niezwykle inspirującej współpracy naukowej z Panem Profesorem Janem Durajem oraz całym Zespołem naukowym Katedry Analizy i Strategii Przedsiębiorstwa Uniwersytetu Łódzkiego. Na ostateczny kształt monografii wpłynęły również niezmiernie cenne, konstruktywne uwagi i sugestie wniesione przez Panią Profesor Małgorzatę Janicką z Uniwersytetu Łódzkiego oraz Pana Profesora Adama Samborskiego z Uniwersytetu Ekonomicznego w Katowicach, za które gorąco dziękuję. Osobne, z serca płynące podziękowania kieruję do Pana Profesora Cezarego Kochalskiego z Uniwersytetu Ekonomicznego w Poznaniu, za istotną pomoc w przygotowaniu ostatecznej wersji monografii. Sam jednak ponoszę odpowiedzialność za prezentowane treści, wykorzystane metody badań empirycznych oraz wnioski z nich płynące. 


\section{Rozdział 1}

\section{ZARYS FUNKCJONOWANIA FUNDUSZY PRIVATE EQUITY}

\subsection{Pojęcie private equity i jego związek znaczeniowy z określeniem venture capital}

Określenie private equity jest terminem stosunkowo nowym i jednocześnie niejednoznacznie rozumianym w polskiej literaturze $\mathrm{z}$ zakresu finansów przedsiębiorstwa. Jest ono przypisywane inwestycjom i funduszom private equity. Pojęciu temu nadawana jest wieloznaczna treść, wskazująca na różnice przyczyn i motywów realizacji inwestycji private equity ${ }^{1}$.

K. Sobańska, P. Sieradzan określają inwestycje private equity jako średnioi długoterminowe inwestycje o charakterze udziałowym, mające zwykle miejsce na rynku niepublicznym, połączone ze wsparciem menedżerskim ze strony funduszu w przedsiębiorstwa, które mają szansę osiągnięcia ponadprzeciętnego wzrostu wartości w określonym przez inwestora okresie ${ }^{2}$.

Fundusze private equity są jednostkami inwestującymi określony kapitał finansowy w spółki posiadające i wykorzystujące potencjał wzrostu wartości rynkowej. Istota ich działalności polega na poszukiwaniu, finansowaniu i wspieraniu przedsiębiorstw będących narzędziami Schumpeterowskiej twórczej destruk$c j i^{3}$. Rolą funduszy private equity jest pośredniczenie pomiędzy inwestorami kapitałowymi a spółkami portfelowymi. Z jednej strony fundusze zapewniają profesjonalne zasady selekcji obiecujących projektów inwestycyjnych, z drugiej strony - gromadzą kapitał i przyciągają dużą liczbę inwestorów, oferując im

\footnotetext{
${ }^{1}$ M. Pietraszewski, Proces inwestycyjny realizowany przez fundusze private equity, Wyższa Szkoła Humanistyczno-Ekonomiczna we Włocławku, Włocławek 2007, s. 28.

${ }^{2} \mathrm{~K}$. S o b ań s k a, P. S i e r a d z a n, Inwestycje private equity/venture capital, Key Text, Warszawa 2004, s. 13.

${ }^{3}$ M. P an fil, Globalizacja inwestycji venture capital, [w:] A. S z able w s ki (red.), Migracja kapitatu w globalnej gospodarce, Difin, Warszawa 2009, s. 169.
} 
wpływ na zarządzanie powierzonymi przez nich pieniędzmi, raportowanie i monitoring inwestycji ${ }^{4}$.

Odmienną definicję private equity sformułował M. Wrzesiński. Stwierdza on, iż jest to typowo średnio- lub długoterminowe zaangażowanie kapitału zarządzanego przez profesjonalnych pośredników finansowych przede wszystkim w znaczne pakiety akcji bądź pakiety udziałów przedsiębiorstw nienotowanych publicznie, znajdujących się w procesie radykalnych zmian, w celu uzyskania ponadprzeciętnej stopy zwrotu, przede wszystkim za sprawą realizacji zysku kapitałowego 5 . W tym podejściu podkreślone zostały pewne dodatkowe cechy inwestycji private equity. Zaakcentowano działanie polegające na inwestowaniu w znaczące pakiety papierów wartościowych o charakterze udziałowym, przez co zwiększa się ryzyko ponoszone przez inwestora oraz podkreślono nietypową sytuację, w której znajduje się na ogół przedsiębiorstwo korzystające z tej formy finansowania rozwoju.

Za symptomatyczne cechy działania funduszy private equity uznać można m. in.:

a) poszukiwanie niepublicznych spółek kapitałowych, wykazujących możliwości wzrostu wartości rynkowej kapitału własnego,

b) lokowanie w nich kapitału i aktywny udział w zarządzaniu spółkami dla skutecznego i efektywnego rozwoju tychże przedsiębiorstw oraz

c) sprzedaż posiadanych akcji, zapewniającą uzyskanie określonych korzyści kapitałowych.

Z kolei European Private Equity and Venture Capital Association (EVCA), organizacja, która od wielu lat wspiera rozwój private equity i pozostaje najistotniejszym źródłem informacji o działaniach podejmowanych przez podmioty funkcjonujące w tej części rynku finansowego w Europie wskazuje, iż przez private equity należy rozumieć inwestycje kapitału udziałowego w przedsiębiorstwa nienotowane na publicznym rynku papierów wartościowych. Kapitał ten może być wykorzystany do rozwoju nowych produktów i technologii, w celu zwiększenia kapitału obrotowego, dokonywania przejęć oraz do wzmocnienia bilansu przedsiębiorstwa. Może on mieć również wpływ na kształtowanie struktury właścicielskiej oraz zarządzanie. W zakres działalności funduszy private equity wchodzą również wykupy menedżerskie oraz udział w procesach związanych z dziedziczeniem w firmach rodzinnych ${ }^{6}$.

W tak sformułowanym wyjaśnieniu terminu private equity zaakcentowane są głównie cele, na które mogą być wydatkowane środki pochodzące od inwestorów. W ujęciu tym w znacznie mniejszym stopniu podkreślane są kwestie

${ }^{4}$ M. Panfil, Fundusze private equity. Wptyw na wartość spótki, Difin, Warszawa 2005, s. 87.

${ }^{5}$ M. Wrzesiński, Kapitat podwyższonego ryzyka. Proces inwestycyjny i efektywność, Szkoła Główna Handlowa w Warszawie, Warszawa 2008, s. 23.

${ }^{6} \mathrm{http}: / /$ www.evca.eu/toolbox/glossary.aspx?id=982, 09.07.2010 r. 
związane ze strukturą i przebiegiem procesu inwestycyjnego, ponadprzeciętnym ryzykiem związanym z tego rodzaju specyficzną działalnością inwestycyjną oraz oczekiwaniami w zakresie poziomu zysku kapitałowego.

Tabela 1.1

Fazy inwestycji private equity

\begin{tabular}{|c|c|}
\hline Faza inwestycji & Charakterystyka \\
\hline $\begin{array}{l}\text { Finansowanie zasiewu } \\
\quad \text { (ang. seed) }\end{array}$ & $\begin{array}{l}\text { Kapitał przeznaczany na sfinansowanie badań, ocenę i roz- } \\
\text { wój wstępnej koncepcji produktu, przed osiągnięciem fazy } \\
\text { start-up. }\end{array}$ \\
\hline $\begin{array}{l}\text { Kapitał początkowy } \\
\text { (ang. start-up) }\end{array}$ & $\begin{array}{l}\text { Kapitał przeznaczony na rozwój produktu i podjęcie działań } \\
\text { marketingowych. Przedsiębiorstwa mogą być w trakcie po- } \\
\text { wstawania lub mogą działać od krótkiego czasu, aczkol- } \\
\text { wiek nie prowadza sprzedaży na skale komercyjna. }\end{array}$ \\
\hline $\begin{array}{l}\text { Finansowanie pozostałych } \\
\text { etapów wczesnego rozwoju } \\
\text { (ang. other early stage) }\end{array}$ & $\begin{array}{l}\text { Kapitał przekazywany przedsiębiorstwom, które mają zakoń- } \\
\text { czony etap rozwoju produktu, a uzyskane środki pieniężne } \\
\text { niezbędne są do rozpoczęcia produkcji i sprzedaży na skalę } \\
\text { rynkową. Działalność nadal jest nierentowna. }\end{array}$ \\
\hline $\begin{array}{l}\text { Finansowanie rozwoju } \\
\text { (ang. expansion) }\end{array}$ & $\begin{array}{l}\text { Kapitał przeznaczony na rozwój działalności funkcjonującego } \\
\text { przedsiębiorstwa, które może, ale nie musi osiągnąć próg ren- } \\
\text { towności. Środki mogą być wykorzystane do sfinansowania } \\
\text { zwiększenia mocy produkcyjnych, rozwoju rynku, produktu } \\
\text { lub zapewnienie dodatkowego kapitału obrotowego. }\end{array}$ \\
\hline $\begin{array}{l}\text { Finansowanie pomostowe } \\
\text { (ang. bridge financing) }\end{array}$ & $\begin{array}{l}\text { Środki pieniężne przekazywane podmiotom przygotowującym } \\
\text { się do wprowadzenia akcji do publicznego obrotu na gieł- } \\
\text { dzie papierów wartościowych. }\end{array}$ \\
\hline $\begin{array}{l}\text { Wykup wtórny } \\
\text { (ang. seconadry purchase) }\end{array}$ & $\begin{array}{l}\text { Finansowanie nabycia akcji/udziałów w spółce przez fundusz } \\
\text { private equity od innego funduszu kapitału podwyższonego } \\
\text { ryzyka. }\end{array}$ \\
\hline $\begin{array}{l}\text { Kapitał zastępczy } \\
\text { (ang. replacement capital) }\end{array}$ & $\begin{array}{l}\text { Finansowanie nabycia akcji/udziałów spółki od innych udzia- } \\
\text { łowców (niebędących inwestorem private equity). }\end{array}$ \\
\hline $\begin{array}{l}\text { Finansowanie restrukturyzacji } \\
\quad \text { (ang. rescue/turnaround) }\end{array}$ & $\begin{array}{l}\text { Środki przeznaczone na finansowanie istniejących przedsię- } \\
\text { biorstw znajdujących się w trudnej sytuacji finansowej, ma- } \\
\text { jące na celu przywrócenie optymalnego stanu. }\end{array}$ \\
\hline $\begin{array}{l}\text { Refinansowanie zadłużenia } \\
\text { (ang. refinancing bank debt) }\end{array}$ & $\begin{array}{l}\text { Kapitał przeznaczony na zmniejszenie stopnia zadłużenia } \\
\text { przedsiębiorstwa. }\end{array}$ \\
\hline $\begin{array}{l}\text { Wykupy menedżerskie } \\
\text { (ang. management buyout) }\end{array}$ & $\begin{array}{l}\text { Finansowanie umożliwiające obecnemu zarządowi i inwesto- } \\
\text { rom przejęcie istniejącej linii produktów lub całego przed- } \\
\text { siębiorstwa. }\end{array}$ \\
\hline $\begin{array}{l}\text { Zewnętrzny wykup } \\
\text { menedżerski } \\
\text { (ang. management buyin) }\end{array}$ & $\begin{array}{l}\text { Wsparcie finansowe przejęcia przedsiębiorstwa przez mene- } \\
\text { dżera lub grupe menedżerów z zewnątrz jednostki przy } \\
\text { współudziale kapitału podwyższonego ryzyka. }\end{array}$ \\
\hline $\begin{array}{l}\text { Zakup akcji spółki giełdowej } \\
\text { (ang. venture purchase } \\
\text { of quoted shares) }\end{array}$ & $\begin{array}{l}\text { Finansowanie nabycia akcji spółki giełdowej mające na celu } \\
\text { wycofanie jej z obrotu publicznego. }\end{array}$ \\
\hline
\end{tabular}

Ź r ó d ł o: opracowanie własne na podstawie EVCA Yearbook 2008. 
Aktywność funduszy private equity ocenić można posługując się wieloma kryteriami i miernikami, które dotyczą $m$. in. rozmiarów, rodzajów i struktury celowego inwestowania kapitału w określone spółki dla ich późniejszej sprzedaży z zamiarem osiągnięcia zysku kapitałowego.

Inwestycje tych funduszy obejmują swym zakresem wiele różnorodnych faz rozwoju działalności przedsiębiorstw korzystających z tego źródła finansowania (zob. tab. 1.1).

Abstrahując od kwestii związanych z różnicami pomiędzy poszczególnymi definicjami określenia private equity można wskazać na kilka istotnych cech inwestycji, które wyróżniają omawianą formę inwestycji spośród innych. Są to:

- inwestycja dokonywana jest za pośrednictwem papierów wartościowych reprezentujących kapitał właścicielski (udziałowy) lub hybrydowych papierów wartościowych,

- przedmiotem inwestycji są zazwyczaj spółki nienotowane na publicznym rynku papierów wartościowych,

- inwestor private equity akceptuje ponadprzeciętne ryzyko inwestycyjne w oczekiwaniu na osiągnięcie ponadprzeciętnej stopy zwrotu z zainwestowanego kapitału w określonym horyzoncie inwestycyjnym,

- zysk z inwestycji wynika bezpośrednio z przyrostu wartości akcji lub udziałów spółki będącej przedmiotem inwestycji i jest głównie realizowany w momencie zakończenia inwestycji,

- zarządzaniem inwestycjami private equity najczęściej zajmują się wyspecjalizowane podmioty, które zwykle nie tylko inwestują kapitału w spółki portfelowe, lecz także oferują dodatkowe formy wsparcia w postaci tzw. kapitału menedżerskiego.

Termin private equity bywa wielokrotnie traktowany jako synonim innego, poniekąd pokrewnego określenia, a mianowicie venture capital.

W zależności od fazy rozwoju rynku kapitału podwyższonego ryzyka w literaturze przedmiotu można odnaleźć wiele definicji pojęcia venture capital. Początkowo terminem tym określano kapitał inwestowany w wysoce ryzykowne przedsięwzięcia z sektora małych i średnich przedsiębiorstw z zakresu nowoczesnych technologii ${ }^{7}$. Wraz z rozwojem rynku i gospodarki odstąpiono od tak wąskiego znaczenia pojęcia venture capital.

J. Węcławski określa venture capital jako kapitał własny wnoszony na ograniczony okres przez inwestorów zewnętrznych do małych i średnich przedsiębiorstw dysponujących innowacyjnym produktem, metodą produkcji bądź usługą, które nie zostały jeszcze zweryfikowane przez rynek, a więc stwarzają wysokie ryzyko niepowodzenia inwestycji, ale jednocześnie w przypadku sukce-

${ }^{7}$ Ch. C. Cle if i e, Venture capital in Europe, [w:] J. M. Gib b, Venture capital Markets for Regeneration of Industry, Amsterdam 1984, [za:] M. P a $\mathrm{fi}$ l, Fundusze Private equity. Wptyw na wartość spótki, Difin, Warszawa 2005, s. 16. 
su przedsięwzięcia, wspomaganego w zarządzaniu przez inwestorów, zapewniają znaczący przyrost wartości zainwestowanego kapitału, który jest realizowany przez sprzedaż udziałów ${ }^{8}$.

Podejście to akcentuje głównie pionierski i innowacyjny charakter działalności podmiotów będących przedmiotem inwestycji oraz wysokie ryzyko inwestycyjne. Zauważyć również należy, iż autor powyższej definicji zaznacza, że adresatem tego typu kapitału są przedsiębiorstwa małe i średnie.

Natomiast M. Panfil wskazuje, iż pojęcie venture capital odnosi się do inwestowania $\mathrm{w}$ kapitał udziałowy przedsiębiorstw nienotowanych na giełdzie, znajdujących się we wczesnych fazach rozwoju (tzn. zasiew lub start) lub w fazie ekspansji .

P. Gompers, J. Lerner zwracają uwagę, iż venture capital połączone jest wysokim ryzykiem. Ich zdaniem działalność venture capital polega na finansowaniu wysoce ryzykownych, potencjalnie wysoce zyskownych projektów, poprzez nabywanie udziałowych lub hybrydowych papierów wartościowych przedsiębiorstw nienotowanych na giełdzie papierów wartościowych ${ }^{10}$. Zakres omawianego pojęcia został również rozszerzony o papiery wartościowe inne niż tylko udziałowe, co w większym stopniu przystaje do praktyki gospodarczej ${ }^{11}$.

Również EVCA, określając zakres pojęcia venture capital, za istotny uznaje fakt, na jakim etapie rozwoju znajduje się przedsiębiorstwo będące przedmiotem inwestycji. Zgodnie z informacjami umieszczonymi na stronie internetowej tej organizacji, venture capital należy rozumieć jako kapitał profesjonalnie inwestowany przez fundusz przy współpracy z przedsiębiorcą, w przedsięwzięcia znajdujące się we wczesnych fazach rozwoju (zasiew lub start) lub w fazie ekspansji. W zamian za podejmowane przez inwestora wysokie ryzyko oczekuje on ponadprzeciętnej stopy zwrotu $\mathrm{z}$ inwestycji. W tym znaczeniu należy więc traktować venture capital jako podzbiór inwestycji private equity ${ }^{12}$. W tym miejscu należy również podkreślić, iż inwestycje venture capital, z racji inwestowania w dopiero rozwijające się koncepty biznesowe, wyróżnia zdecydowanie wyższy poziom ryzyka spośród pozostałych inwestycji private equity.

$\mathrm{Z}$ kolei J. Świderska wskazuje na nową formę finansowania rozwoju przedsiębiorstw przynależną do analizowanej grupy inwestycji, a mianowicie quasi-fundusze venture capital. Terminem tym określane są quasi-komercyjne i z reguły niewielkie fundusze, tworzone lub funkcjonujące przy kapitałowym zaangażo-

${ }^{8} \mathrm{~J}$. W ęc $ł$ a w ski, Venture capital. Nowy instrument finansowania przedsiębiorstw, Wydawnictwo Naukowe PWN, Warszawa 1997, s. 17.

${ }^{9}$ M. P a f fi 1, Fundusze private equity..., op. cit., s. 18-19.

${ }^{10}$ P. Gompers, J. Lerner, The Venture Capital Revolution, „The Journal of Economic Perspectives" 2001, Vol. 15, No. 2, s. 145

${ }^{11}$ S. Kaplan, P. Strömberg, Financial Contracting Theory Meets the Real World: An Empirical Analysis of Venture capital Contracts, ,Review of Economic Studies” 2002, s. 4, 15.

${ }^{12} \mathrm{http} / / / \mathrm{www}$. evca.eu/toolbox/glossary.aspx?id=982, 09.07.2010 r. 
waniu czynnika publicznego, prowadzące działalność o charakterze lokalnym lub regionalnym, nakierowaną na wspieranie przedsiębiorczości, innowacyjności i/lub procesów transformacyjnych zachodzących na ograniczonym terytorialnie obszarze, które oferują relatywnie niewielkie porcje kapitału małym i średnim przedsiębiorstwom znajdującym się najczęściej we wczesnych fazach rozwoju ${ }^{13}$.

Interpretacja pojęć private equity i venture capital bywa odmienna $\mathrm{w}$ amerykańskiej i europejskiej literaturze przedmiotu, co można bezpośrednio powiązać z różnicami w rozwoju i genezą tego segmentu rynku. Wielokrotnie zwraca się uwagę, iż amerykańskiej terminologii dla całej omawianej grupy inwestycji w kapitał udziałowy przedsiębiorstw stosuje się określenie venture capital, a pojęcie private equity utożsamiane jest $\mathrm{z}$ finansowaniem transakcji wykupów $^{14}$. Pojęcie private equity bywa również identyfikowane $\mathrm{z}$ inwestycjami dużych inwestorów instytucjonalnych $\mathrm{w}$ rozwinięte przedsiębiorstwa $\mathrm{w}$ okresie gruntownych zmian struktury właścicielskiej, co również można łączyć z transakcjami przejęć i wykupów ${ }^{15}$.

W niniejszej pracy pojęcie private equity odnosi się do określenia działalności polegającej na inwestowaniu przez wyspecjalizowane podmioty zgromadzonych przez nie środków finansowych głównie w udziałowe papiery wartościowe zwykle przedsiębiorstw niepublicznych, niezależnie od fazy ich rozwoju, aby poprzez budowanie wartości spółek portfelowych i wyjście z inwestycji zrealizować w określonym horyzoncie czasowym ponadprzeciętną stopę zwrotu z zainwestowanego kapitału.

Natomiast sformułowanie venture capital używane będzie w kontekście grupy inwestycji private equity w przedsiębiorstwa znajdujące się we wczesnych fazach rozwoju, co jest zgodne ze stanowiskiem EVCA.

W polskojęzycznej literaturze przedmiotu nie został dotychczas osiągnięty konsensus co do polskiego odpowiednika określenia terminu private equity. Najczęściej można spotkać się z terminem kapitat podwyższonego ryzyka. W niniejszej pracy określenia te będą traktowane jako synonimy. Ponadto w niektórych opracowaniach stosowany jest termin kapitat wysokiego ryzyka, jednakże takie ujęcie może powodować skojarzenia $\mathrm{z}$ działalnością funduszy typu hedge, co byłoby nieprzystające dla realizacji celu rozprawy. L. Lewandowska wprost podkreśla, że rozpatrywana grupa inwestycji w żadnym razie nie może być utożsamiana $\mathrm{z}$ kapitałem spekulacyjnym o ekstremalnie wysokim ryzyku ${ }^{16}$.

${ }^{13} \mathrm{~J}$. Ś wi de r sk a, Quasi-fundusze venture capital. Publiczne wsparcie innowacyjnych MSP, Difin, Warszawa 2008, s. 13-14.

${ }^{14}$ G. Fraser-Sampson, Private equity as an Asset Class, WilleyFinance, 2007, s. 5; J. Świderska, op. cit., s. 40.

${ }^{15}$ S. B loomfield, Venture capital Funding. A Practical Guide to Raising Finance, Kogan Page Limited 2005, s. 4.

${ }^{16}$ L. Le w a n d o w s ka, Niekonwencjonalne formy finansowania przedsiębiorczości, ODiDK Sp. z o.o., Gdańsk 2000, s. 111. 


\subsection{Struktura rynku kapitału podwyższonego ryzyka i jego segmenty}

W tradycyjnym ujęciu zapotrzebowanie przedsiębiorstw na kapitał obcy zaspokajane jest przez szeroką ofertę usług finansowych oferowanych przez systemy bankowe oraz dłużne papiery wartościowe. Postępujące procesy globalizacji, jak i rozwój technologii kapitałochłonnych przyczyniają się do zwiększenia popytu na kapitał, co skłania przedsiębiorców do poszukiwania innych jego źródeł ${ }^{17}$. Alternatywą, szczególnie dla małych i średnich przedsiębiorstw o wysokim poziomie innowacyjności i dużym potencjale wzrostu, mogą być fundusze private equity, które wydają się wręcz predestynowane do finansowania proinnowacyjnych projektów stymulujących wzrost gospodarczy ${ }^{18}$.

Zadaniem funduszy private equity jest stworzenie warunków skutecznego przepływu kapitału pomiędzy inwestorami dysponującymi określonymi zasobami kapitałowymi a spółkami potrafiącymi efektywnie wykorzystać te zasoby ${ }^{19}$, przynosząc jednocześnie korzyści wszystkim stronom zaangażowanym w dane przedsięwzięcie.

Rynek funduszy private equity umożliwia powiązanie kapitałowe pomiędzy podmiotami chcącymi efektywnie zarządzać posiadanymi wolnymi środkami a przedsiębiorstwami potrzebującymi dodatkowego kapitału na rozwój. Chociaż rynek ten nie należy do grupy rynków regulowanych to posiada on właściwą sobie strukturę, która może różnić się w poszczególnych krajach w zależności od systemu prawnego i struktury instytucjonalnej, płynności i budowy rynku kapitałowego oraz doświadczenia inwestorów w budowaniu wartości przedsiębiorstw $^{20}$. Przyjmuje się, iż na rynku kapitału podwyższonego ryzyka działają następujące trzy główne grupy uczestników:

- inwestorzy - podmioty o różnym profilu działania i strukturze własności, udostępniające kapitał na inwestycje $\mathrm{e}^{21}$,

- pośrednicy - fundusze typu private equity,

- emitenci - przedsiębiorstwa, będące przedmiotem inwestycji, które z reguły działają w dynamicznie rozwijających się sektorach gospodarki, odznaczają

${ }^{17}$ B. Zi ółk o w s k a, Proces tworzenia jednolitego rynku finansowego $w$ UE, [w:] J. D u raj (red.), Przedsiębiorstwo na rynku kapitałowym, Wydawnictwo Uniwersytetu Łódzkiego, Łódź 2008, s. 107.

${ }^{18}$ L. Lewandowska, Finansowanie $w$ kontekście pozycji konkurencyjnej firmy, [w:] J. Duraj (red.), Przedsiębiorstwo na rynku kapitałowym, Wydawnictwo Uniwersytetu Łódzkiego, Łódź 2008, s. 136.

${ }^{19}$ G. W. Fen n, N. Li an g, S. Prow se, The Economics of the Private equity Market, ,Federal Reserve Bulletin", January 1996, s. 3-5.

${ }^{20}$ D. C u m m in g, G. Fle min g, J-A. S u ch ard, Venture Capitalist Value-added Activities, Fundraising and Drawdowns, ,Journal of Banking\&Finance” 2005, Vol. 29, s. 297.

${ }^{21}$ M. Pietras zew ski, op. cit., s. 50. 
się wysokim poziomem aktywności innowacyjnej oraz posiadają wysoki potencjał wzrostu wartości rynkowej ${ }^{22}$.

Obok tych jednostek na rynku kapitału podwyższonego ryzyka istnieją liczne podmioty realizujące funkcje wspomagające procesy i mechanizmy działania na tym rynku. Należą do nich:

- doradcy inwestycyjni inwestorów,

- agenci funduszu ds. emisji oraz

- agenci spółki ds. emisji (zob. schemat 1.1) ${ }^{23}$.

INWESTORZY

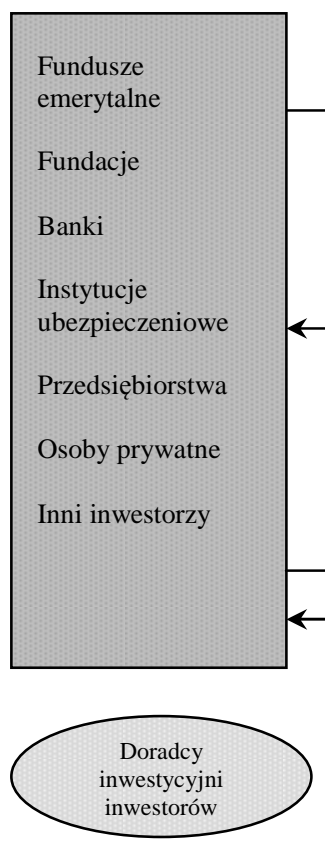

- wycena zobowiązań

- zarządzanie funduszami funduszy

POŚREDNICY

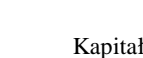

Kapitał

Monitoring

Doradztwo

equity: niezależ-

ne zależne od

instytucji

finansowych

pośrednicy

postednicy
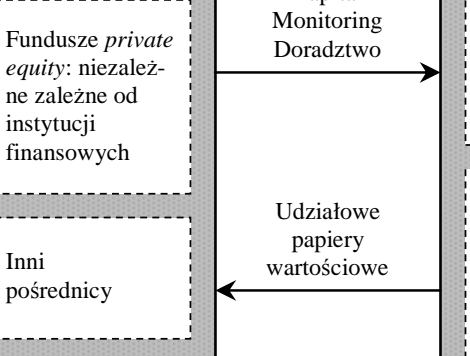

przedsię-

wzięcia:

- wczesne etapy

- późniejsze etapy

Przedsiebiorstwa

niepubliczne:

- ekspansja

- zmiana struktury

kapitału

- zmiana struktury

własności

Spółki publiczne:

- wykupy

-- zagrożenie

finansowe

- sytuacje

specjalne

Udziałowe papiery

wartościowe

Agenci funduszu ds. emisji

- poszukiwanie potencjalnych inwestorów

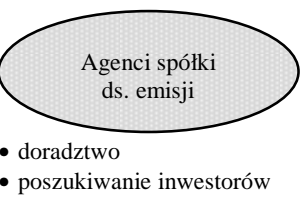

- poszukiwanie inwestorów

Schemat 1.1. Struktura rynku kapitału podwyższonego ryzyka

Źródło: opracowanie własne G. W. Fenn, N. Liang, S. Prowse, The Economics of the Private equity Market, ,Federal Reserve Bulletin”, January 1996, s. 4.

Fundusze private equity składają się z dwóch podmiotów: firmy zarządzającej oraz funduszu, którym firma ta zarządza w imieniu inwestorów ${ }^{24}$. Podstawową formą organizacyjno-prawną na rynku pośrednictwa kapitału podwyższo-

${ }^{22}$ G. W. Fe n n, N. Li an g, S. Prow se, op. cit., s. 3-5.

${ }^{23}$ Ibidem, s. 5.

${ }^{24}$ M. Wr ze si ń s ki, Kapitat podwyższonego ryzyka..., op. cit., s. 29. 
nego ryzyka jest limited partnership ${ }^{25}$, w której występują dwie grupy wspólni$\mathrm{ków}^{26}$, tzn. limited partners oraz general partners. $\mathrm{Z}$ reguły podmioty dostarczające niezbędny kapitał na inwestycje (inwestorzy) w ramach umowy partnerskiej występują w roli limited partners, natomiast przedsiębiorstwa zarządzające pozyskanymi środkami pełnią funkcję general partners.

Pomiędzy wymienionymi dwiema grupami wspólników zawierana jest umowa o zarządzanie funduszem. Jej zadaniem jest regulowanie wzajemnych stosunków pomiędzy stronami oraz określanie praw i obowiązków wszystkich uczestników funduszu. Zważywszy, iż zaangażowanie kapitałowe funduszu w spółkę portfelową trwa zwykle od 2 do 7 lat $^{27}$, fundusz powoływany jest na okres 10 lat, z możliwością kontynuacji jego istnienia o dodatkowe 3 lata w uzasadnionych okolicznościach ${ }^{28}$.

Umowa ta zawiera również zapisy dotyczące wynagrodzenia podmiotu zarządzającego funduszem oraz kwestie podziału całej sumy zysku wypracowanego przez fundusz. W praktyce gospodarczej zwyczajowo przyjęło się, iż firma zarządzająca funduszem otrzymuje stałą roczną opłatę za zarządzanie i administrowanie w zależności od wielkości funduszu w wysokości 1,5-2,5\% rocznie ogólnej wartości zebranych kapitałów oraz udział w wypracowanym zysku na poziomie $20 \%{ }^{29}$. Pozostałe środki trafiają do podmiotów udostępniających kapitał na inwestycje.

Limited partnership jest jedną $\mathrm{z}$ wielu dopuszczalnych form powstania i funkcjonowania funduszy private equity ${ }^{30}$. Wraz ze wzrostem zainteresowania inwestycjami tego typu pojawiały się również inne formuły prowadzenia tego typu działalności, np.: corporate venture funds, limited liability companies ${ }^{31}$. W polskim systemie prawnym nie istnieje specyficzna forma prawno-organizacyjna przewidziana wyłącznie do prowadzenia funduszu private equity. Podmioty działające na polskim rynku wykorzystują różne dostępne formy prowadzenia działalności tego typu. Zdecydowaną większość z nich stanowią podmioty mające swoją siedzibę poza granicami kraju ${ }^{32}$.

${ }^{25}$ Forma ta jest poniekąd odpowiednikiem występującej w prawie polskim spółki komandytowej, gdzie odpowiednikiem komplementariusza jest general partner, natomiast limited partner traktowany jest jako komandytariusz.

${ }^{26}$ A. Korn a siew ic z, Venture capital w krajach rozwiniętych i w Polsce, CeDeWu, Warszawa 2004, s. 40.

${ }^{27}$ Survey of the Economic and Social Impact of Venture capital in Europe, Research Paper EVCA, Zaventem, Belgium 2002, s. 11.

${ }^{28}$ D. J. Cumming, S. A. Joh a n, Venture capital and Private equity Contracting. An International Perspective, Elsevier 2009, s. 69.

${ }^{29}$ T. M e y e r, P.-Y. M a th o n e t, Beyond the J-curve. Managing a Portfolio of Venture capital and Private equity Funds, John Wiley\&Sons, 2005, s. 11-12.

${ }^{30}$ Zob. W. Pr z y b y lska-Ka puścińs ka, M. M o zale w ski, Kapitat wysokiego ryzyka, PWE, Warszawa 2011, s. 222-281.

${ }^{31}$ M. J. P. A n s o n, The Handbook of Alternative Assets, John Wiley\&Sons, 2002, s. 271.

${ }^{32}$ K. S o bań ska, P. S i e r a d z a n, op. cit., s. 261-262. 
Inwestorzy mogą również dokonywać inwestycji bezpośrednich w rozwijające się przedsiębiorstwa, pomijając przy tym wehikuł inwestycyjny w postaci funduszu. Taka działalność zależna jest od możliwości uzyskania wymaganych przez inwestora informacji o przedmiocie inwestycji oraz posiadanych przez inwestora umiejętności i zasobów niezbędnych do pomnażania wartości danego przedsiębiorstwa $^{33}$.

Dodatkowo wraz z rozwojem rynku kapitału podwyższonego ryzyka wykształciła się grupa podmiotów, których podstawowym zadaniem jest pomoc głównym podmiotom działającym na rynku. Podmioty te zwykle pełnią funkcje pełnomocników i doradców w zakresie doradztwa finansowego oraz prawnego. Wykorzystując unikatową na rynku wiedzę, doświadczenie oraz sieć posiadanych kontaktów biznesowych ułatwiają one pozyskiwanie środków uczestnikom rynku. Ich istnienie uzasadnione jest faktem, iż jednostki te pozwalają na redukcję kosztu dostępu do niezbędnych informacji ${ }^{34}$.

Przyjmuje się, iż w zakres rynku private equity wchodzą trzy segmenty inwestycji kapitałowych: venture capital, buyout capital oraz mezzanine capital $^{35}$ (zob. schemat 1.2).

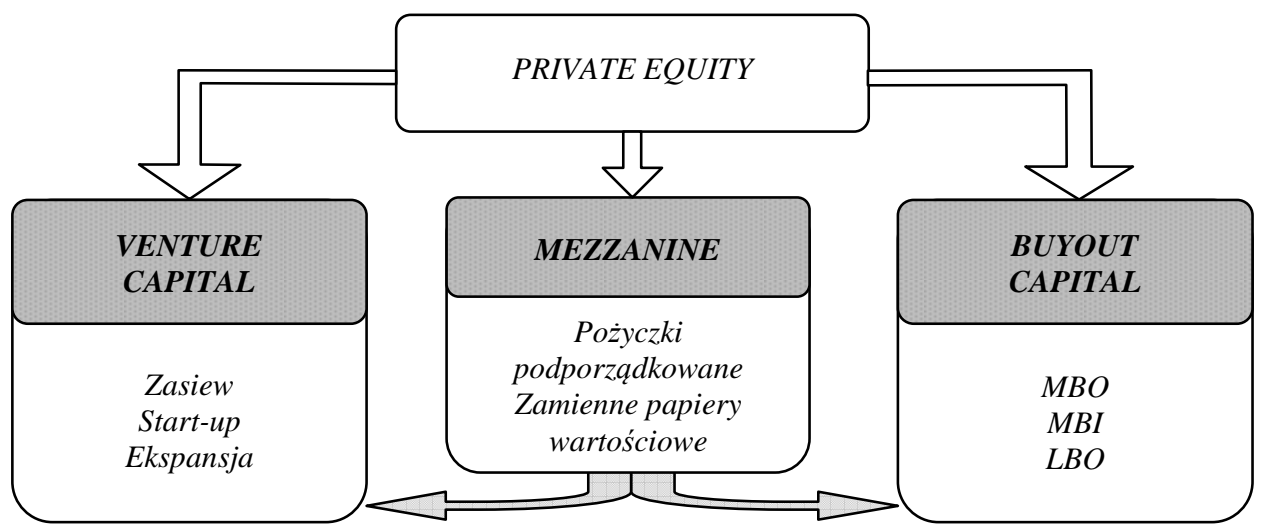

Schemat 1.2. Segmenty rynku private equity

Źr ódło: opracowanie własne na podstawie A. Kornasiewicz, Venture capital w krajach rozwiniętych iw Polsce, CeDeWu, Warszawa 2004, s. 21-22; M. Panfil, Mezzanine jako źródto finansowania przedsiębiorstwa, CEO Magazyn Top Menedżerów, czerwiec 2008, dostęp on-line. s. 74.

${ }^{33}$ D. J. C u m ming, S. A. J o h a n, Venture capital and Private Equity Contracting..., op. cit.,

${ }^{34}$ G. W. Fen n, N. Li ang, S. Prow se, op. cit., s. 5.

${ }^{35}$ D. Gladston e, L. Glad stone, Venture capital Handbook: An Enterpreneur's Guide to Raising Venture capital, Financial Times Prentice Hall, Londyn-New York 2001, s. 5; L. E. S w e d ro e, J. K i z e r, The only guide to alternative investments you'll ever need, Bloomberg Press, New Yourk 2008, s. 125; D. R. J o b m a n, The Handbook of Alternative Investment, John Wiley\&Sons, Inc., New York 2002, s. 141. 
Czasami za odrębny segment inwestycji private equity wskazuje się dokonywane przez fundusze zakupy instrumentów dłużnych przedsiębiorstw znajdujących się $\mathrm{w}$ trudnej sytuacji finansowej (ang. distressed debt investing) ${ }^{36}$. W praktyce gospodarczej przyjmuje on jednakże zwykle formę buyout capital lub finansowania typu mezzanine.

Podstawowym składnikiem private equity są fundusze venture capital. Ich wyróżniającą cechą jest przekazywanie kapitału przedsiębiorstwom znajdującym się we wczesnych fazach rozwoju ${ }^{37}$. Należy podkreślić, iż fundusze venture capital przeznaczone są do wspierania proinnowacyjnych przedsięwzięć. Przedmiotem ich działalności jest inwestowanie kapitału w przedsiębiorstwa rozpoczynające działalność i/lub chcące poszerzyć jej zakres. Innowacje są niezwykle ważnym środkiem budowania silnej pozycji przedsiębiorstwa na konkurencyjnym rynku oraz źródłem przewag konkurencyjnych ${ }^{38}$. Obejmują one swym zakresem zróżnicowane obszary działalności przedsiębiorstw. Są efektywną odpowiedzią organizacji na dynamiczne zmiany w jej otoczeniu, a im więcej przedsiębiorstwo wprowadza efektywnych innowacji, tym szybszy jest jego wzrost $^{39}$. Osiągnięcie przewagi nad konkurentami bezsprzecznie związane jest ze spełnianiem potrzeb i oczekiwań klientów. Zdobycie jej oznacza, że przedsiębiorstwo dostarcza więcej wartości klientom aniżeli rywale rynkowi, a odmienna strategia prowadzi do obniżania ceny oraz marży zysku ${ }^{40}$. Środki pochodzące z funduszy venture capital przeznaczane są na wdrażanie strategii wzrostu wartości rynkowej przedsiębiorstwa, w wyniku m. in. rozwoju nowych produktów, pozyskania nowych klientów, zarówno z dotychczasowego, jak i nowego rynku ${ }^{41}$. Kapitał z tego typu funduszy na ogół kierowany jest do małych i średnich przedsiębiorstw, dysponujących innowacyjnym produktem bądź usługą ${ }^{42}$.

Buyout capital w znacznym stopniu różni się swoimi cechami od venture capital. Transakcje tego typu polegają na przejęciu przez fundusz przy współudziale dotychczasowego lub nowego zarządu przedsiębiorstwa, zorganizowanej części lub całości istniejącego już przedsiębiorstwa. Cechą charakterystyczną transakcji wykupu jest wysoki udział długu w ogólnej strukturze źródeł finan-

${ }^{36}$ M. J. P. A n so n, op. cit., s. 261.

${ }^{37}$ K. S obańs ka, P. Si eradzan,op. cit., s. 14.

${ }^{38}$ Zob. I. Bielski, Innowacje $w$ kreowaniu zdolności konkurencyjnej przedsiębiorstwa, Wydawnictwa Uczelniane Uniwersytetu Technologiczno-Przyrodniczego, Bydgoszcz 2007, s. 43.

${ }^{39}$ J. P en c, Zarzadzanie innowacyjne. Sterowanie zmianami w procesie integracji europejskiej, Wyższa Szkoła Studiów Międzynarodowych w Łodzi, Łódź 2007, s. 110.

${ }^{40}$ C. Ko ch alski, Koszty w przedsiębiorstwie zarządzanym przez wartość. Ujęcie modelowe, Wydawnictwo Akademii Ekonomicznej w Poznaniu, Poznań 2006, s. 60.

${ }^{41}$ Zob. A. K. Koźmińs ki, W. P i o tro w ski (red.), Zarządzanie, Teoria i Praktyka, Wydawnictwo Naukowe PWN, Warszawa 2004, s. 142-143.

${ }^{42} \mathrm{~J}$. Grzywacz, A. Ok ońska, Venture capital a potrzeby kapitałowe matych i średnich przedsiębiorstw, Szkoła Główna Handlowa w Warszawie, Warszawa 2005, s. 45. 
sowania $^{43}$. U podstaw wykupów zwykle leży założenie o restrukturyzacji działalności operacyjnej przejmowanego przedsiębiorstwa ${ }^{44}$, mające na celu poprawę efektywności jego funkcjonowania oraz osiągnięcie efektu synergii, pochodzącego z planowanego wdrożenia różnorodnych form kooperacji ${ }^{45}$.

W zależności od przyjętej i realizowanej strategii wzrostu wewnętrznego lub wzrostu zewnętrznego wartości przedsiębiorstwa ${ }^{46}$ wykorzystuje się odmienne formy kapitału podwyższonego ryzyka. Venture capital jako kapitał wykorzystywany w początkowych etapach funkcjonowania przedsiębiorstwa na rynku, służy przede wszystkim do finansowania rozwoju wewnętrznego, wyrażającego się głównie w rozbudowie potencjału przedsiębiorstwa, tworzeniu nowych zdolności produkcyjnych, przerobowych, usługowych i innych w następstwie inwestycji rzeczowych ${ }^{47}$. Z kolei buyout capital stanowi alternatywę wobec venture capital i wykorzystywany jest w finansowaniu wzrostu zewnętrznego, który można utożsamiać z fuzjami i przejęciami ${ }^{48}$. Strategia rozwoju przedsiębiorstwa przez wzrost zewnętrzny pozwala osiągnąć zamierzony efekt w dość krótkim czasie, w przeciwieństwie do wzrostu wewnętrznego, który na ogół zajmuje dłuższy okres ${ }^{49}$.

Badania nad rozwojem rynku kapitału podwyższonego ryzyka w Europie wskazują, iż fundusze private equity wspierają rozwój głównie małych i średnich przedsiębiorstw. Warto wskazać, iż można zauważyć występowanie strukturalnego zróżnicowania pomiędzy biorcami wartości poszczególnych części kapitału ryzyka. Venture capital wykorzystywany jest przede wszystkim przez przedsiębiorstwa małe. Aż $64,4 \%$ przedsiębiorstw, które otrzymały finansowanie $\mathrm{z}$ funduszy $\mathrm{w}$ fazach seed i start-up zatrudniało $\mathrm{w}$ momencie inwestycji mniej niż 6 pracowników. W przypadku spółek, które pozyskały finansowanie w fazie ekspansji, $70 \%$ zatrudniało mniej niż 50 pracowników. Przeważająca część badanych przedsiębiorstw prowadziła działalność w sektorach związanych z nowoczesnymi technologiami. Wśród przedsiębiorstw, które znajdowały się w fazach seed i start-up było to $74 \%$, natomiast w fazie ekspansji $62 \%$ spółek należało do sektora high-tech, które działały głównie w branżach związanych z komputerami i łącznością ${ }^{50}$. Natomiast buyout capital wykorzystywany jest zarówno przez małe i średnie przedsiębiorstwa, jak i większe. Ma to miejsce

${ }^{43}$ M. Wrzesiński, Fuzje i przejęcia. Wykup lewarowany (LBO) i menedżerski (MBO). Uwarunkowania rozwoju w Polsce, Wydawnictwo K.E. LIBER, Warszawa 2000, s. 2.

${ }^{44}$ A. Kornasie wicz, op. cit., s. 31.

${ }^{45}$ R. Machała, Przejęcia i fuzje. Wptyw na wartość firm, Oficyna Wydawnicza „UNIMEX”, Wrocław 2007, s. 68.

${ }^{46}$ W. Frąc kowiak (red.), Fuzje i przejęcia, PWE, Warszawa 2009, s. 19.

${ }^{47}$ Ibidem.

${ }^{48}$ J. D u raj, Przedsiębiorstwo na rynku kapitałowym, PWE, Warszawa 1996, s. 252.

${ }^{49}$ Ibidem, s. 253.

${ }^{50}$ Survey of the Economic and Social Impact of Venture Capital in Europe, Research Paper EVCA, Zaventem, Belgium 2002. 
głównie w sytuacji braku strategicznego dopasowania ze spółką matką, rozwiązania kwestii związanych z dziedziczeniem, a także w przypadku pojawienia się trudności finansowych w przedsiębiorstwie. Wśród badanych przedsiębiorstw, w których przeprowadzono wykupy z udziałem funduszu private equity, zaledwie $16 \%$ zatrudniało mniej niż 50 pracowników. Mediana zatrudnienia wynosiła 170, natomiast aż 37\% badanych przedsiębiorstw zatrudniało powyżej 250 pracowników. Spółki te, w odróżnieniu do inwestycji venture capital, prowadziły działalność w branżach uznawanych za mniej innowacyjne, przede wszystkim w przetwórstwie $(22,6 \%)$ oraz w branżach związanych z produktami i usługami przemysłowymi $(13,8 \%)$. Zaledwie niecałe $10 \%$ spółek prowadziło działalność w sektorze nowoczesnych technologii ${ }^{51}$.

Mezzanine capital posiada zarówno charakterystyczne cechy finansowania długiem, jak i pewne własności kapitału własnego. W skład mezzanine capital wchodzą głównie pożyczki podporządkowane, obligacje zamienne na akcje oraz obligacje $z$ warrantem ${ }^{52}$. Wykorzystywany jest on przez przedsiębiorstwa znajdujące się w późniejszych fazach rozwoju, które przygotowują się do wprowadzenia do publicznego obrotu ${ }^{53}$, a także jako finansowanie wspomagające strategie fuzji i przejęć. Na ogół występuje w sytuacji, kiedy rozwijające się przedsiębiorstwo, ale nie w pełni dojrzałe, potrzebuje finansowania dłużnego, a banki są niechętne do jego udzielenia ${ }^{54}$. Jest to swoistego rodzaju uzupełnienie dwóch omawianych powyżej form finansowania przedsiębiorstwa kapitałem podwyższonego ryzyka. Mezzanine capital odróżnia się od innych form finansowania private equity tym, iż w wyniku jego wykorzystania na ogół nie następuje rozproszenie struktury właścicielskiej, wynikające ze zwiększenia kapitału własnego przedsiębiorstwa, a jego koszt zawiera się z reguły pomiędzy ceną długu bankowego a ceną kapitału własnego ${ }^{55}$.

G. W. Fenn, N. Liang, S. Prowse scharakteryzowane powyżej segmenty rynku kapitału podwyższonego ryzyka określają mianem zorganizowanego ryn$\mathrm{ku}$ private equity (ang. organized private equity market), podkreślając $\mathrm{w}$ ten sposób profesjonalizm oraz instytucjonalny charakter podmiotów funkcjonujących na nim. Autorzy ci jednocześnie wskazują, iż w szerszym znaczeniu terminu private equity zawarte są także inwestycje podmiotów nieposiadających for-

${ }^{51}$ Survey of the Economic and Social Impact of Management Buyouts \& Buyins in Europe, Research Paper EVCA, Zaventem, Belgium 2001.

${ }^{52} \mathrm{M}$. Panfil, Mezzanine jako źródto finansowania dla przedsiębiorstwa, CEO Magazyn Top Menedżerów, czerwiec 2008.

${ }^{53}$ M. Pietraszews ki, op. cit., s. 46.

${ }^{54}$ A. Kornasiewicz, op. cit., s. 22.

${ }^{55}$ W. Przybylska-Kapuścińska, M. Mozalewski, op. cit., s. 35. 
malnej struktury funduszu i dokonujących inwestycji o zbliżonym charakterze. Są to aniołowie biznesu $u^{56}$ oraz nieformalny rynek private equity ${ }^{57}$.

Terminem anioł biznesu określa się inwestorów prywatnych, którzy oferują wsparcie głównie w postaci kapitału, ale również własnej wiedzy i doświadczenia przedsiębiorstwom znajdującym się w początkowej fazie rozwoju. Swoją działalnością wypełniają oni istotną lukę pomiędzy przyjaciółmi i rodziną jako inwestorami a funduszami venture capital oraz systemem bankowym ${ }^{58}$. Wśród pobudek skłaniających osoby prywatne do podjęcia tego typu działalności inwestycyjnej poza względami ekonomicznymi znajdują się m. in. korzyści prestiżowe, potrzeba samorealizacji, dążenie do współudziału w postępie technologicznym czy wspieranie rozwoju regionalnego ${ }^{59}$. $\operatorname{cech}^{60}$ :

W przypadku inwestycji aniołów biznesu można wskazać kilka zasadniczych

- działania inwestycyjne są zwykle podejmowane wspólnie i przy współpracy z przyjaciółmi lub partnerami biznesowymi,

- w głównym obszarze zainteresowań inwestycyjnych znajdują się przedsiębiorstwa znajdujące się na wczesnych etapach rozwoju,

- stanowią oni grupę aktywnych inwestorów, mających często nieformalne wzajemne powiązania z członkami zarządu spółek korzystających z ich wsparcia,

- odznaczają się wysokim stopniem koncentracji geograficznej, a przedsiębiorstwa prosperują zwykle w pobliżu miejsca zamieszkania anioła biznesu,

- istotnym motywem skłaniającym anioła biznesu do podjęcia działalności inwestycyjnej są również niematerialne korzyści, wykraczające poza utylitarną wartość wynikającą z inwestycji, a także poczucie spełnienia społecznej odpowiedzialności, nawet jeżeli uzyskiwane one są kosztem akceptacji niższego zwrotu $\mathrm{z}$ inwestycji.

Określenie rynek nieformalny private equity w kontekście inwestycji kapitału podwyższonego ryzyka odnosi się do sprzedaży papierów wartościowych poza formalnym rynkiem kapitałowym zarówno inwestorom instytucjonalnym, jak i osobom fizycznym. W szerokim ujęciu można mówić o ofertach prywatnych (ang. private placement). Liczba inwestorów zewnętrznych w transakcjach dokonywanych na nieformalnym rynku private equity jest na ogół zdecydowanie większa, a minimalna kwota inwestycji mniejsza w porównaniu do analogicznych in-

${ }^{56} \mathrm{~W}$ literaturze anglojęzycznej najczęściej stosuje się określenia angel capital, business angel lub angel investor.

${ }^{57}$ G. W. Fen n, N. Li ang, S. Prow se, op. cit., s. 2.

${ }^{58}$ W. Przybyls ka-Kapuścińs ka, M. Mozalew ski,op. cit., s. 35.

${ }^{59}$ B. Mikołajczy k, M. Krawczy k, Aniołowie Biznesu w sektorze MSP, Difin, Warszawa 2007, s. 53; K. Brzozowska, Business Angels na rynku kapitatowym. Motywacje, inwestowanie, efekty, CeDeWu, Warszawa 2008, s. 47-48.

${ }^{60}$ H. Landstroem, Handbook of Research on Venture capital, Edward Elger, 2007, s. $55-56$. 
westycji dokonywanych na zorganizowanym rynku private equity. Podkreślić również należy, iż mimo wprowadzenia do grona właścicieli nowych podmiotów, $\mathrm{z}$ reguły prawo decydowania o dalszych losach przedsiębiorstwa pozostaje w rękach dotychczasowych udziałowców ${ }^{61,62}$.

\subsection{Etapy rozwoju przedsiębiorstw wspieranych przez fundusze private equity}

Rynek private equity, podobnie jak każdy inny rynek, jest miejscem spotkań podmiotów reprezentujących popyt i podaż. Inwestorzy private equity zgłaszają popyt na przedsięwzięcia inwestycyjne, natomiast menedżerowie poszukujący kapitału na realizację planów rozwojowych w zarządzanych jednostkach oferują pomysły, w jaki sposób osiągnąć dynamiczny wzrost wartości przedsiębiorstwa. Środki pozyskane z funduszu mogą być przeznaczone na realizację różnych koncepcji, które są pochodną indywidualnej sytuacji, w jakiej znajduje się dany podmiot gospodarczy. Przedsiębiorstwo charakteryzuje swoisty cykl rozwojowy będący pochodną cyklu życia produktu ${ }^{63}$. Stadium rozwoju, na jakim znajduje się biorca kapitału private equity jest najczęściej wykorzystywane do dokonywania klasyfikacji etapów finansowania kapitałem podwyższonego ryzyka oraz charakterystyki przedsiębiorstw korzystających z funduszy private equity. Jednakże należy zaznaczyć, iż inwestycje kapitału podwyższonego ryzyka są wysoce zróżnicowane zarówno ze względu na wielkość, strukturę jak i formę.

J. Węcławski wskazuje, iż zmiany w zakresie stopnia dojrzałości technicznej i rynkowej wyrobu, ryzyko związane z podjęciem i realizacją jego produkcji, możliwości finansowania przedsiębiorstwa, sfery rozwoju przedsięwzięcia i punkty ciężkości w zarządzaniu nim, oczekiwania i szanse na osiągnięcie zysku stanowią istotny czynnik w klasyfikacji faz inwestycji kapitału podwyższonego ryzyka. Autor ten zaproponował podział inwestycji private equity na sześć etapów zagregowanych w dwóch głównych zbiorach: fazy początkowe i fazy

${ }^{61}$ G. W. Fe n n, N. Li a ng, S. Prow se, op. cit., s. 2.

${ }^{62}$ Chociaż aniołowie biznesu, jak i rynek nieformalny private equity są z pewnością ważnym elementem rynku private equity oraz są one znaczącą stymulantą rozwoju przedsiębiorstw znajdujących się w początkowych fazach rozwoju, to w dalszej części pracy nie są one analizowane. Spowodowane jest to faktem, iż infrastruktura instytucjonalna dla wspierania tej części rynku znajduje się nadal w początkowej fazie rozwoju lub jest jej brak, a uzyskanie wiarygodnych i wyczerpujących informacji o tej grupie inwestorów jest prawie niemożliwe. Skutkiem tego w dalszej części pracy termin rynek private equity będzie używany w znaczeniu określenia zorganizowany rynek private equity.

${ }^{63}$ J. Grzywacz, A. Okońska, op. cit., s. 69. 
ekspansji $^{64}$ (zob. schemat 1.3). Klasyfikacja ta poniekąd zbliżona jest do ujęcia zaproponowanego przez S. E. Pratta ${ }^{65}$.

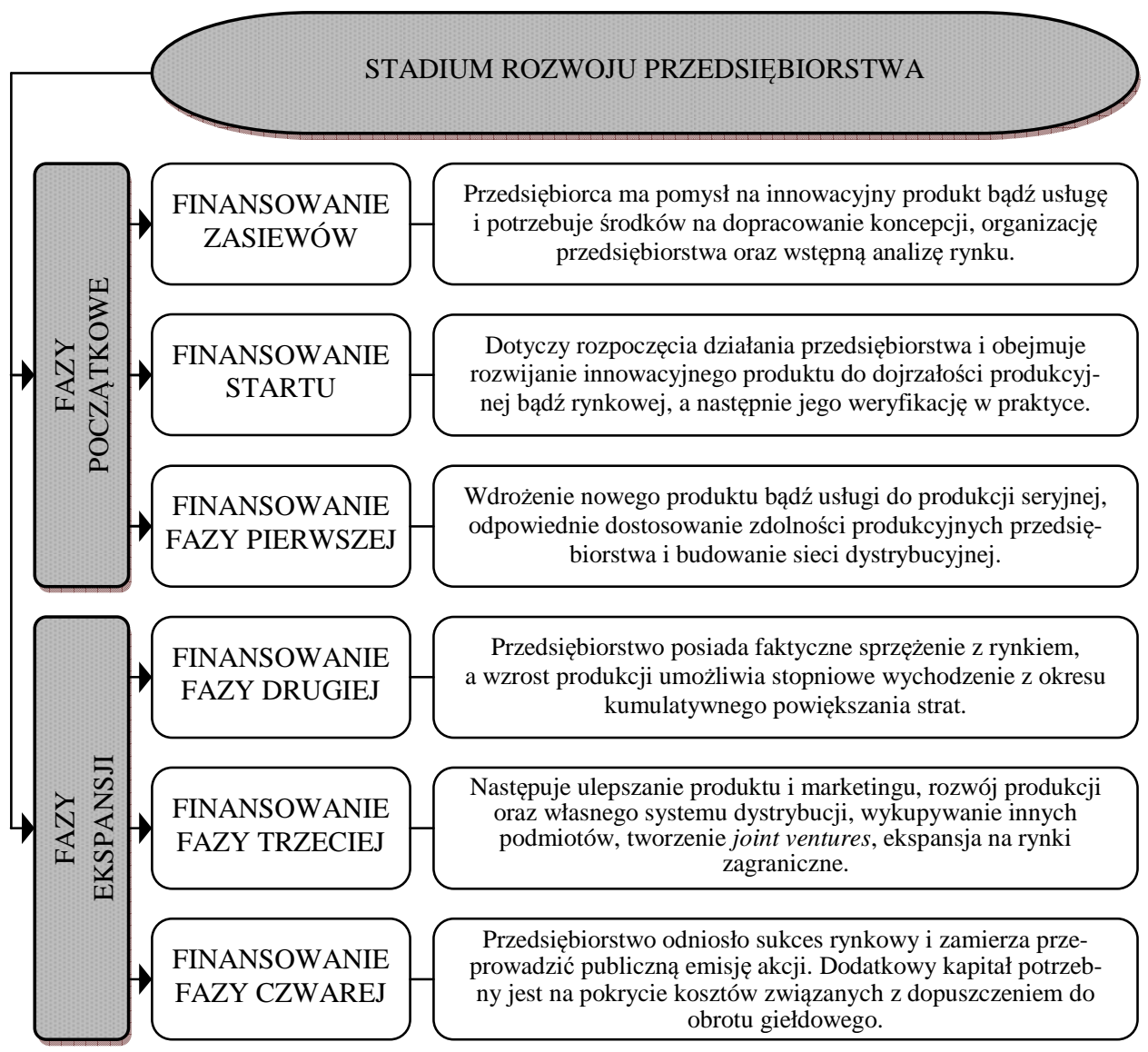

Schemat 1.3. Inwestycje private equity w poszczególnych fazach rozwoju przedsiębiorstw

Źr ódło: opracowanie własne na podstawie J. Węcławski, Venture capital. Nowy instrument finansowania przedsiębiorstw, Wydawnictwo Naukowe PWN, Warszawa 1997, s. 24-29.

Nieco odmienną klasyfikację i charakterystykę stadiów inwestycyjnych funduszy private equity zaproponował M. Wrzesiński (zob. tab. 1.2). W swojej czterostopniowej klasyfikacji zaznaczył on, iż spektrum zainteresowań inwestycyjnych kapitału podwyższonego ryzyka wykracza poza finansowanie wyłącznie nowych, dynamicznie rozwijających się przedsiębiorstw. Istotnym elementem

${ }^{64} \mathrm{~J}$. W ęc $ł$ a w ski, op. cit., s. 23.

${ }^{65}$ S. E. Pratt, Guide to Venture capital Sources, Wydanie 5, Capital Publishing, Wellesley (MA), 1981, s. 12. 
tego rynku jest też inwestowanie w podmioty poszukujące szansy na sukces ekonomiczny inną drogą niż rozwój organiczny.

Tabela 1.2

Stadia rozwoju przedsiębiorstw pozyskujących finansowanie private equity

\begin{tabular}{|c|c|c|}
\hline $\begin{array}{l}\text { Stadium } \\
\text { rozwoju }\end{array}$ & $\begin{array}{c}\text { Przewidziany czas } \\
\text { inwestycji }\end{array}$ & Cel inwestycji \\
\hline $\begin{array}{ll}1 \\
\end{array}$ & 2 & 3 \\
\hline \multicolumn{3}{|c|}{ Wczesna faza rozwoju } \\
\hline $\begin{array}{l}\text { Zasiew } \\
\text { (ang. seed) }\end{array}$ & $7-12$ lat & $\begin{array}{l}\text { środki w tej fazie służą do finansowania wstępnego } \\
\text { etapu rozwoju przedsiębiorstwa: badań rynko- } \\
\text { wych, tworzenia biznesplanu, analizy przedinwe- } \\
\text { stycyjnej, budowy prototypu produktu; najczęściej } \\
\text { są to inwestycje w przedsięwzięcia z zakresu no- } \\
\text { wych technologii; firmy te charakteryzują się wy- } \\
\text { sokim ryzykiem działalności związanym z faktem, } \\
\text { że wytwarzany przez nie produkt lub stosowana } \\
\text { strategia rynkowa nie zostały jeszcze zweryfiko- } \\
\text { wane w praktyce gospodarczej; }\end{array}$ \\
\hline $\begin{array}{l}\text { Komercjalizacja } \\
\text { działalności } \\
\text { (ang. start-up) }\end{array}$ & 5-10 lat & $\begin{array}{l}\text { finansowanie końcowego etapu prac nad powstaniem } \\
\text { produktu, wyposażenie przedsiębiorstwa w majątek } \\
\text { produkcyjny; najczęściej w ten sposób finansowane } \\
\text { są firmy, które posiadają środki pozwalające na } \\
\text { produkcję i/lub sprzedaż na małą skalę, a finanso- } \\
\text { wanie potrzebne jest im na osiągnięcie na rynku } \\
\text { tzw. masy krytycznej; }\end{array}$ \\
\hline \multicolumn{3}{|r|}{ Ekspansja } \\
\hline $\begin{array}{c}\text { Pierwsza faza } \\
\text { ekspansji }\end{array}$ & $2-5$ lat & $\begin{array}{l}\text { finansowanie wzrostu firmy działającej na rynku; } \\
\text { w szczególności finansowanie inwestycji rzeczo- } \\
\text { wych, kapitału obrotowego, inwestycji rynkowych } \\
\text { (reklama, tworzenie sieci dystrybucji); }\end{array}$ \\
\hline $\begin{array}{l}\text { Druga faza } \\
\text { ekspansji }\end{array}$ & $3-5$ lat & $\begin{array}{l}\text { zróżnicowane finansowanie działalności firm nieno- } \\
\text { towanych na giełdach papierów wartościowych, } \\
\text { w tym przypadku jest to alternatywa dla finanso- } \\
\text { wania kapitałem zewnętrznym; bardzo istotnym } \\
\text { elementem tej fazy inwestowania jest finansowa- } \\
\text { nie transakcji fuzji i przejęć; }\end{array}$ \\
\hline $\begin{array}{l}\text { Faza przed wpro- } \\
\text { wadzeniem na } \\
\text { rynek giełdowy } \\
\text { (ang. pre-IPO) }\end{array}$ & $<2$ lata & $\begin{array}{l}\text { finansowanie przedsiębiorstwa planującego wpro- } \\
\text { wadzenie akcji na rynek publiczny; }\end{array}$ \\
\hline \multicolumn{3}{|r|}{ Wykupy } \\
\hline $\begin{array}{c}\text { Wykup } \\
\text { lewarowany } \\
\text { (ang. Leveraged } \\
\text { Buy-Out, LBO) }\end{array}$ & $2-5$ lat & $\begin{array}{l}\text { finansowanie wykupu przedsiębiorstwa od obecnych } \\
\text { właścicieli; w tym przypadku stroną inicjującą } \\
\text { i wiodącą jest inwestor finansowy; }\end{array}$ \\
\hline $\begin{array}{c}\text { Wykup } \\
\text { menedżerski } \\
\text { (ang. Management } \\
\text { Buy-Out, MBO) }\end{array}$ & $2-5$ lat & $\begin{array}{l}\text { finansowanie wykupu przedsiębiorstwa przez obec- } \\
\text { nych menedżerów firmy, wspomaganych przez } \\
\text { fundusze; }\end{array}$ \\
\hline
\end{tabular}


Tabela 1.2 (cd.)

\begin{tabular}{|c|c|c|}
\hline 1 & 2 & 3 \\
\hline \multicolumn{3}{|r|}{ Wykupy (cd.) } \\
\hline $\begin{array}{l}\text { Zewnętrzny } \\
\text { wykup } \\
\text { menedżerski } \\
\text { (ang. Manage- } \\
\text { ment Buy-In, } \\
\text { MBI) }\end{array}$ & $2-5$ lat & $\begin{array}{l}\text { finansowanie wykupu przedsiębiorstwa od aktual- } \\
\text { nych właścicieli przez menedżerów spoza firmy } \\
\text { - w tym przypadku czynniki ryzyka stanowią } \\
\text { ewentualne trudności w dopasowaniu kulturowym } \\
\text { nowego zarządu do zastanej organizacji oraz brak } \\
\text { pełnych informacji odnośnie do celu przejęcia; }\end{array}$ \\
\hline \multicolumn{3}{|c|}{ Sytuacje specjalne } \\
\hline $\begin{array}{l}\text { Restrukturyzacja } \\
\text { (ang. recovery, } \\
\text { turnaround) }\end{array}$ & $2-5$ lat & $\begin{array}{l}\text { finansowanie przedsiębiorstwa znajdującego się } \\
\text { w trudnej sytuacji finansowej: dostarczenie do- } \\
\text { datkowego kapitału i know-how; }\end{array}$ \\
\hline $\begin{array}{l}\text { Inne sytuacje } \\
\text { specjalne }\end{array}$ & $2-5$ lat & $\begin{array}{l}\text { do innych sytuacji specjalnych można zaliczyć } \\
\text { współfinansowanie inwestora strategicznego, po- } \\
\text { życzki pomostowe (ang. bridge financing). }\end{array}$ \\
\hline
\end{tabular}

Ź ród ło: M. Wrzesiński, Kapitat podwyższonego ryzyka. Proces inwestycyjny $i$ efektywność, Szkoła Główna Handlowa w Warszawie, Warszawa 2008, s. 133-134.

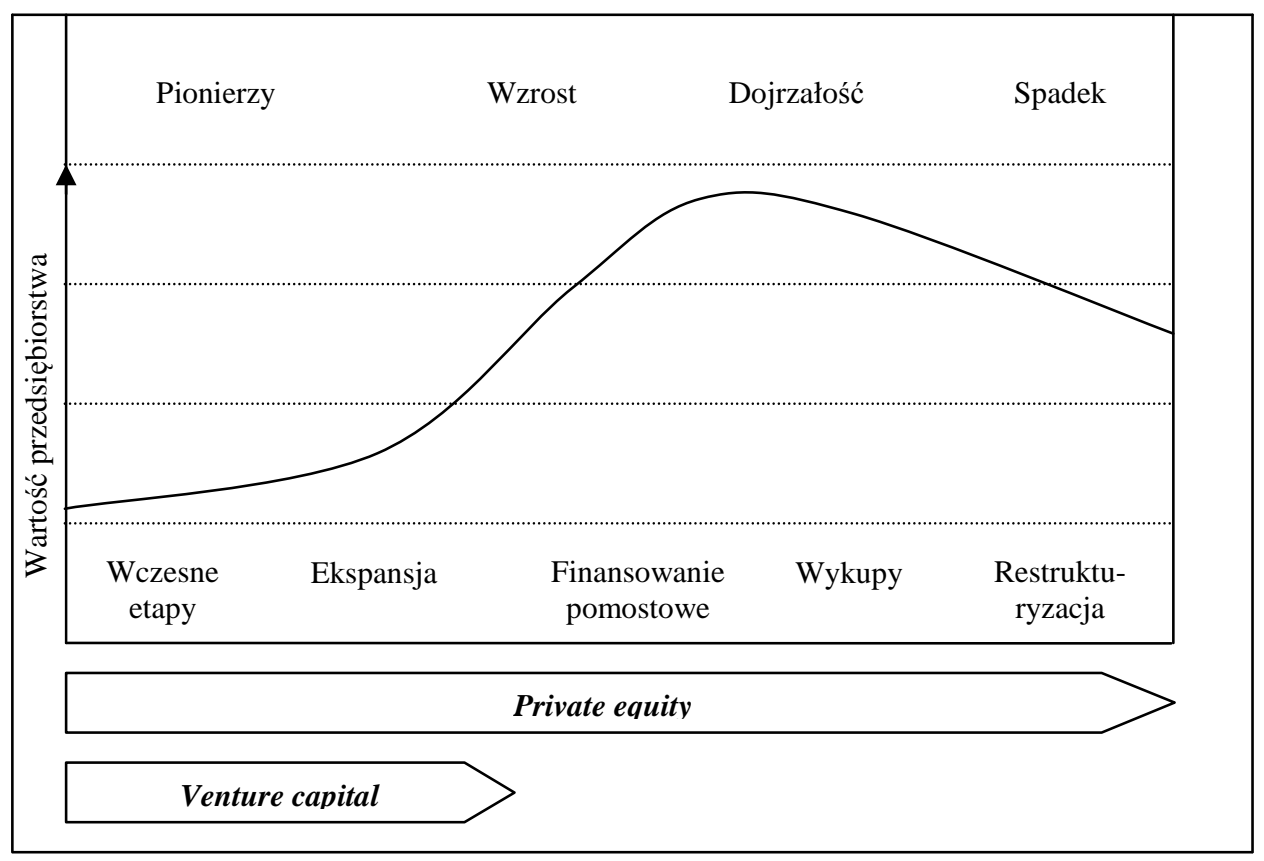

Schemat 1.4. Finansowanie private equity na różnym etapie rozwoju przedsiębiorstwa

Ź r ó d ł o: V. Kraft, Erfolgreiches Managment von Private equity-Investitionen in Turnarounds und Restrukturierungen, Universität St. Gallen Working Paper, 2001, s. 4. 
Na uwagę zasługuje również model finansowania private equity zaproponowany przez V. Krafta ${ }^{66}$ (zob. schemat 1.4). Autor ten w sposób bezpośredni powiązał inwestycje private equity z cyklem życia przedsiębiorstwa korzystającego z tego źródła finansowania oraz cyklem życia produktu w ujęciu marketingowym.

Z kolei G. W. Fenn, N. Liang, S. Prowse zaproponowali sześciostopniową klasyfikację poszczególnych etapów rozwoju przedsiębiorstw korzystających $\mathrm{z}$ finansowania private equity. Ich zdaniem po kapitał z tego źródła mogą zwracać się zarówno podmioty prywatne, jak i spółki publiczne, znajdujące się we wszystkich fazach funkcjonowania na rynku (zob. tab. 1.3).

Tabela 1.3

Charakterystyka głównych odbiorców kapitału z funduszy private equity

\begin{tabular}{|l|l|l|l|l|}
\hline \multicolumn{1}{|c|}{ Właściwość } & Cechy finansowe & $\begin{array}{c}\text { Przyczyny } \\
\text { poszukiwania } \\
\text { kapitału } \\
\text { z funduszy } \\
\text { private equity }\end{array}$ & $\begin{array}{l}\text { Główne źródła } \\
\text { kapitału private } \\
\text { equity }\end{array}$ & $\begin{array}{l}\text { Zakres dostępu } \\
\text { do innych źródeł } \\
\text { finansowania }\end{array}$ \\
\hline \hline 1 & \multicolumn{1}{|c|}{3} & \multicolumn{1}{c|}{4} & \multicolumn{1}{|c|}{5} \\
\hline $\begin{array}{l}\text { Wczesne etapy } \\
\text { nowych przed- } \\
\text { sięwzięć }\end{array}$ & $\begin{array}{l}\text { Wysoki potencjał } \\
\text { wzrostu }\end{array}$ & $\begin{array}{l}\text { Rozpoczęcie } \\
\text { działalności } \\
\text { gospodarczej }\end{array}$ & $\begin{array}{l}\text { Anioły biznesu } \\
\text { Fundusze venture } \\
\text { capital }\end{array}$ & $\begin{array}{l}\text { Ograniczony } \\
\text { dostęp do kredy- } \\
\text { tów }\end{array}$ \\
\hline $\begin{array}{l}\text { Późniejsze etapy } \\
\text { nowych przed- } \\
\text { sięwzięć }\end{array}$ & $\begin{array}{l}\text { Wysoki potencjał } \\
\text { wzrostu }\end{array}$ & $\begin{array}{l}\text { Rozwój parku } \\
\text { maszynowego } \\
\text { i działalności } \\
\text { operacyjnej } \\
\text { Spłata innych } \\
\text { inwestorów }\end{array}$ & $\begin{array}{l}\text { Fundusze venture } \\
\text { capital }\end{array}$ & $\begin{array}{l}\text { Dostęp do kredy- } \\
\text { tów na finanso- } \\
\text { wanie kapitału } \\
\text { obrotowego }\end{array}$ \\
\hline $\begin{array}{l}\text { Średniej wielko- } \\
\text { ści przedsiębior- } \\
\text { stwa prywatne }\end{array}$ & $\begin{array}{l}\text { Zróżnicowane } \\
\text { perspektywy } \\
\text { wzrostu }\end{array}$ & $\begin{array}{l}\text { Finansowanie } \\
\text { wymaganych } \\
\text { zmian struktury } \\
\text { własności i kapitału } \\
\text { Rozwój parku } \\
\text { maszynowego } \\
\text { przez zakup lub } \\
\text { przejęcie }\end{array}$ & $\begin{array}{l}\text { Fundusze venture } \\
\text { capital } \\
\text { Fundusze finan- } \\
\text { sujące późniejsze } \\
\text { etapy rozwoju }\end{array}$ & $\begin{array}{l}\text { Dostęp do kredy- } \\
\text { tów } \\
\text { W przypadku } \\
\text { bardziej rozwinię- } \\
\text { tych przedsię- } \\
\text { biorstw dostęp do } \\
\text { ofert prywatnych }\end{array}$ \\
\hline $\begin{array}{l}\text { Przedsiębiorstwa } \\
\text { publiczne i pry- } \\
\text { watne w niebez- } \\
\text { pieczeństwie } \\
\text { finansowym }\end{array}$ & $\begin{array}{l}\text { Zbyt duże zadłu- } \\
\text { żenie lub proble- } \\
\text { my w działalności } \\
\text { operacyjnej }\end{array}$ & $\begin{array}{l}\text { W celu dokonania } \\
\text { restrukturyzacji }\end{array}$ & $\begin{array}{l}\text { Fundusze finan- } \\
\text { sujące restruktu- } \\
\text { ryzację }\end{array}$ & $\begin{array}{l}\text { Bardzo ograni- } \\
\text { czony dostęp }\end{array}$ \\
\hline
\end{tabular}

${ }^{66} \mathrm{~V} . \mathrm{Kraft}$, Erfolgreiches Managment von Private equity-Investitionen in Turnarounds und Restrukturierungen, Universität St. Gallen Working Paper, 2001, s. 4. 
Tabela 1.3 (cd.)

\begin{tabular}{|l|l|l|l|l|}
\hline \multicolumn{1}{|c|}{1} & \multicolumn{1}{|c|}{2} & \multicolumn{1}{c|}{3} & \multicolumn{1}{c|}{4} & \multicolumn{1}{c|}{5} \\
\hline \hline $\begin{array}{l}\text { Wykupy spółek } \\
\text { publicznych }\end{array}$ & $\begin{array}{l}\text { Negatywne } \\
\text { perspektywy } \\
\text { rozwoju } \\
\text { Wysoki poziom } \\
\text { wolnych prze- } \\
\text { pływów pienięż- } \\
\text { nych }\end{array}$ & $\begin{array}{l}\text { Stymulowanie } \\
\text { zmian w zarzą- } \\
\text { dzaniu }\end{array}$ & $\begin{array}{l}\text { Buyout capital } \\
\text { Mezzanine }\end{array}$ & $\begin{array}{l}\text { Zazwyczaj brak } \\
\text { ograniczeń }\end{array}$ \\
\hline $\begin{array}{l}\text { Pozostałe spółki } \\
\text { publiczne }\end{array}$ & $\begin{array}{l}\text { Zależne od przy- } \\
\text { czyn poszukiwa- } \\
\text { nia kapitału } \\
\text { z funduszy priva- } \\
\text { te equity }\end{array}$ & $\begin{array}{l}\text { Zachowanie } \\
\text { poufności } \\
\text { Przeprowadzenie } \\
\text { małych ofert } \\
\text { Dla wygody } \\
\text { Z powodu czaso- } \\
\text { wej niechęci } \\
\text { rynku publicznego } \\
\text { do danej branży }\end{array}$ & $\begin{array}{l}\text { Fundusze finan- } \\
\text { sujące późniejsze } \\
\text { etapy rozwoju }\end{array}$ & $\begin{array}{l}\text { Zazwyczaj brak } \\
\text { ograniczeń }\end{array}$ \\
& & & \\
& & & \\
\hline
\end{tabular}

Ź r ó d ło: G. W. Fen n, N. Li ang, S. Prow se, The Economics of the Private Equity Market, „Federal Reserve Bulletin”, January 1996, s. 18.

Przy gromadzeniu danych o transakcjach dokonywanych przez fundusze private equity EVCA również korzysta z klasyfikacji opartej na etapach rozwoju przedsiębiorstw finansowanych $\mathrm{z}$ kapitału podwyższonego ryzyka. W celu prezentowania danych statystycznych wszystkie transakcje grupowane są przez EVCA w następujące główne kategorie ${ }^{67}$ :

- zasiew (ang. seed) - kapitał przeznaczony na finansowanie badań, opracowanie i ocenę wstępnego modelu biznesowego przed osiągnięciem przez spółkę kolejnej fazy rozwoju,

- start-up - kapitał przeznaczony na rozwój produktu oraz wstępną działalność marketingową dla istniejących lub nowotworzonych przedsiębiorstw, przed wprowadzeniem produktu na rynek,

- późniejszy etap venture - finansowanie dalszego rozwoju działalności operacyjnej przedsiębiorstwa balansującego na granicy progu rentowności, na ogół związane z kolejnymi rundami finansowania przedsiębiorstw, które wcześniej uzyskały kapitał z funduszy venture capital,

- finansowanie wzrostu - z reguły inwestycja o charakterze mniejszościowym (ale nie jest to warunek konieczny) w stosunkowo dojrzałe przedsiębiorstwa poszukujące kapitału na rozszerzenie lub modyfikację prowadzonej działalności gospodarczej,

\footnotetext{
${ }^{67}$ EVCA Yearbook 2012, http://www.evca.eu/, s. 19.
} 
- restrukturyzacja - kapitał udostępniany jest przedsiębiorstwom funkcjonującym na rynku, aczkolwiek znajdującym się w trudnej sytuacji, w celu przywrócenia im sprawności i efektywności działania,

- refinansowanie - zakup udziałów mniejszościowych w funkcjonujących spółkach od innych podmiotów funkcjonujących na rynku private equity lub innych inwestorów,

- wykupy - kapitał przeznaczony na finansowanie fuzji i przejęć.

\subsection{Korzyści i zagrożenia finansowania rozwoju przedsiębiorstw kapitałem podwyższonego ryzyka}

Finansowanie rozwoju przedsiębiorstw kapitałem podwyższonego ryzyka jest strategią, która cechuje się wieloma różnorodnymi właściwościami. Fundusze private equity charakteryzują się bowiem mniejszą awersją do ryzyka w porównaniu do podmiotów uznawanych za konwencjonalne źródła kapitału przeznaczonego na wspieranie rozwoju przedsiębiorstw. Dzięki temu możliwa jest realizacja innowacyjnych projektów inwestycyjnych, obarczonych ponadprzeciętnym poziomem ryzyka

Fundusze private equity oferują finansowanie zewnętrzne kapitałem własnym o długoterminowym charakterze. W początkowych okresach rozwoju przedsiębiorstwa, z racji udziałowego charakteru inwestycji, kapitał pozyskany od funduszu private equity jest kapitałem niegenerującym kosztów związanych z jego obsługą. Nie jest wymagany regularny i terminowy zwrot rat kapitałowych wraz z odsetkami, jak to ma miejsce w przypadku kredytów bankowych. Praktyką w inwestycjach typu private equity, zwłaszcza w przypadku przedsiębiorstw dopiero rozpoczynających funkcjonowanie na rynku jest również rezygnacja $\mathrm{z}$ wypłat z zysków czy dywidendy. Umożliwia to w konsekwencji reinwestowanie wypracowanych zysków i osiągnięcie dynamicznego wzrostu. Ponadto przystąpienie funduszu private equity do spółki kształtuje strukturę pasywów przedsiębiorstwa udziałowego, poprawiając jego zdolność do obsługi długu. Można powiedzieć, iż współpraca pomiędzy funduszem private equity i pierwotnymi właścicielami przedsiębiorstwa ma partnerski charakter, gdyż w długoterminowej perspektywie wszystkim stronom przyświeca nadrzędny, wspólny cel, jakim efektywne budowanie wartości przedsiębiorstwa.

Nadto, fundusze private equity oferują wsparcie w postaci dodatkowych wartości ${ }^{68}$, tzw. kapitału menedżerskiego, co ma na celu poprawę konkurencyjności przedsiębiorstw zarówno na rynku lokalnym, jak i ponadregionalnym oraz

${ }^{68}$ J. Ś widerska, Quasi-fundusze venture capital. Publiczne wspieranie innowacyjnych MSP, Difin, Warszawa 2008, s. 108. 
dynamiczny wzrost ich wartości rynkowej ${ }^{69}$. Kadra kierownicza przedsiębiorstw znajdujących się we wczesnych etapach rozwoju, często nie ma odpowiedniego doświadczenia $\mathrm{w}$ profesjonalnym zarządzaniu rozwijającym się przedsiębiorstwem. Wraz ze wsparciem kapitałowym fundusz dostarcza spółce know-how z zakresu zarządzania na szczeblu strategicznym, operacyjnym i taktycznym. Obecność przedstawicieli inwestora private equity we władzach spółki, np. zarządzie lub radzie nadzorczej, umożliwia korzystanie z jego dotychczasowych doświadczeń zdobytych podczas pracy na rzecz zakończonych sukcesem, wcześniejszych inwestycji funduszu oraz na implementację efektywnych rozwiązań organizacyjnych sprawdzonych w innych spółkach portfelowych. Przedsiębiorstwa, w których inwestorem jest fundusz private equity pozyskują do pracy osoby z wysokimi kwalifikacjami. Z racji na opinię funduszy jako jednostek będących gwarantem dynamicznego rozwoju przedsiębiorstw, czołowi menedżerowie oraz inne osoby uchodzące za specjalistów w swoim środowisku, chętnie podejmują współpracę z takim partnerem. Dodatkowym atutem obecności specjalistów z funduszu w przedsiębiorstwie jest fakt, iż posiadają oni rozbudowaną sieć kontaktów biznesowych, co umożliwia szybsze pozyskanie nowych klientów, czy dostawców niezbędnych surowców. W anglojęzycznej literaturze można spotkać termin private equity keiretsu ${ }^{70}$. Spółka portfelowa funduszu nawiązuje kontakty handlowe i współpracę na innych polach z pozostałymi spółkami portfelowymi funduszu.

Kluczową rolę funduszy private equity w rozwoju przedsiębiorstw potwierdzają jednostki, które skorzystały z tej formy finansowania. Według raportów Survey of the Economic and Social Impact of Venture Capital in Europe ${ }^{71}$, aż $94,5 \%$ badanych przedsiębiorstw stwierdziło, iż bez wsparcia funduszy venture capital zaprzestałoby swojej działalności lub rozwijałoby się znacznie wolniej. $\mathrm{Z}$ kolei według Survey of the Economic and Social Impact of Management Buyouts \& Buyins in Europe ${ }^{72}$ analogiczne stwierdzenie potwierdza $84 \%$ przedsiębiorstw, które dokonały wykupów z udziałem funduszy private equity (zob. wykres 1.1).

${ }^{69}$ M. P anfil, Fundusze private equity. Wpływ na wartość spótki, Difin, Warszawa 2005, s. 12

${ }^{70}$ L. Lind s e y, The Venture Capital Keiretsu Effect: An Empirical Analysis of Strategic Alliances Among Portfolio Firms, Stanford Institute for Economic Policy Research Discussion Paper No. 02-17, 2002; Y. V. Hoch berg, A. Ljung q vist, Y. Lu, Whom You Know Matters: Venture Capital Networks and Investment Performance, „The Journal of Finance” 2007, Vol. 62, No. 1, s. 251-252; D. H s u, What Do Entrepreneurs Pay for Venture capital Affiliation?, „Journal of Finance", August 2004, Vol. LIX, No. 4, s. 1805-1844.

${ }^{71}$ Survey of the Economic and Social Impact of Venture Capital in Europe, Research Paper EVCA, Zaventem, Belgium 2002.

${ }^{72}$ Survey of the Economic and Social Impact of Management Buyouts\&Buyins in Europe, Research Paper EVCA, Zaventem, Belgium 2001. 
Bez wsparcia typu buyout capital przedsiębiorstwo:

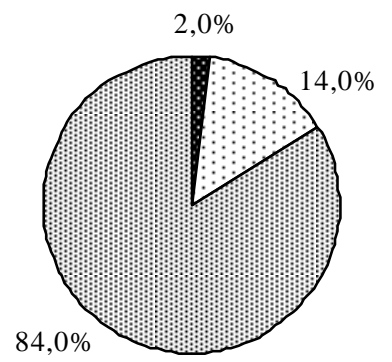

Bez wsparcia funduszu venture capital przedsiębiorstwo:

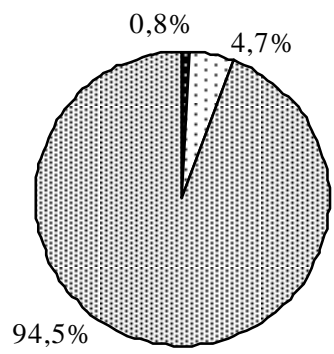

rozwijałoby się szybciej

$\square$ rozwijałoby się w tym samym tempie

圈 rozwijałoby się wolniej lub zakończyło działalność

Wykres 1.1. Znaczenie funduszy venture capital oraz finansowania typu buyout capital w rozwoju przedsiębiorstw udziałowych

Ź r ó dło: opracowanie własne na podstawie Survey of the Economic and Social Impact of Venture Capital in Europe, Research Paper EVCA, Zaventem, Belgium 2002 oraz Survey of the Economic and Social Impact of Management Buyouts\&Buyins in Europe, Research Paper EVCA, Zaventem, Belgium 2001.

Przedsiębiorcy, którzy skorzystali ze współpracy z funduszem private equity zauważają znaczenie nie tylko wsparcia finansowego, ale również podkreślają istotną rolę innych czynników związanych z obecnością takiego inwestora w przedsiębiorstwie (zob. tab. 1.4).

Typowy inwestor private equity w Europie cechuje się aktywnym zaangażowaniem w działalność operacyjną przedsiębiorstwa. Częstotliwość spotkań przedstawicieli funduszu z przedsiębiorcą zmniejsza się wraz z rozwojem przedsiębiorstwa. Zarządzający spółką portfelową z biegiem czasu nabywają nowe umiejętności związane z prowadzeniem działalności operacyjnej, a także potrafią sprawniej zarządzać. Zwiększa się również poziom zaufania pomiędzy inwestorem a przedsiębiorcą. Finansowanie private equity pozwala uzyskać nie tylko kapitał finansowy. Umożliwia również korzystanie z kapitału intelektualnego specjalistów z funduszu private equity, co jest istotnym czynnikiem zdobywania licznych przewag konkurencyjnych na rynku.

Wskazane czynniki mające wpływ na budowanie wartości i zwiększenie korzyści dla interesariuszy przekładają się na zmiany w efektywności działalności przedsiębiorstw. Obecność inwestora private equity w spółce sprzyja jej dynamicznemu rozwojowi (zob. tab. 1.5). 
Tabela 1.4

Formy wpływu funduszy private equity na rozwój spółek portfelowych

\begin{tabular}{|c|c|c|c|c|}
\hline \multicolumn{2}{|c|}{ Wyszczególnienie } & $\begin{array}{c}\text { Faza } \\
\text { Seed/Start-up }\end{array}$ & Ekspansja & Wykupy \\
\hline \multicolumn{2}{|c|}{ Główne nośniki wartości } & \multicolumn{2}{|c|}{$\begin{array}{l}\text { Poprawa przepływów pieniężnych } \\
\text { Rozwój nowych produktów } \\
\text { Osiągnięcie akceptacji rynku }\end{array}$} & $\begin{array}{l}\text { Poprawa efektywności } \\
\text { Poprawa obsługi klientów } \\
\text { Poprawa kontroli finansowej }\end{array}$ \\
\hline \multicolumn{2}{|c|}{$\begin{array}{l}\text { Pozafinansowe zaangażowanie } \\
\text { inwestora private equity }\end{array}$} & $\begin{array}{l}\text { Doradztwo stra- } \\
\text { tegiczne } \\
\text { Sieć kontaktów } \\
\text { biznesowych }\end{array}$ & $\begin{array}{l}\text { Poprawa zdolno- } \\
\text { ści kredytowej } \\
\text { Wyznaczenie } \\
\text { celu biznesowego }\end{array}$ & $\begin{array}{l}\text { Doradztwo finansowe } \\
\text { Sieć kontaktów bizneso- } \\
\text { wych } \\
\text { Doradztwo w zarzadzaniu }\end{array}$ \\
\hline $\begin{array}{c}\text { Częstotliwość } \\
\text { kontaktów }\end{array}$ & $\begin{array}{l}\text { Częściej niż raz } \\
\text { w miesiącu } \\
\text { Rzadziej niż raz } \\
\text { w miesiącu }\end{array}$ & $\begin{array}{l}93,8 \% \\
6,2 \%\end{array}$ & $91,6 \%$ & $68 \%$ \\
\hline
\end{tabular}

Ź r ó d ło: opracowanie własne na podstawie Survey of the Economic and Social Impact of Venture Capital in Europe, Research Paper EVCA, Zaventem, Belgium 2002 oraz Survey of the Economic and Social Impact of Management Buyouts\&Buyins in Europe, Research Paper EVCA, Zaventem, Belgium 2001.

Tabela 1.5

Wybrane wskaźniki przedstawiające efekty zaangażowania inwestorów private equity w spółki portfelowe

\begin{tabular}{|c|c|c|c|c|}
\hline \multicolumn{2}{|c|}{ Wyszczególnienie } & $\begin{array}{c}\text { Faza } \\
\text { Seed/Start-up }\end{array}$ & Ekspansja & Wykupy \\
\hline \multirow{2}{*}{ Udział EBIT w przychodach } & Rok $0^{*}$ & $\begin{array}{c}\text { mniej niż } \\
-200 \%\end{array}$ & $1,2 \%$ & $4,2 \%$ \\
\hline & Rok +3 & około $-10 \%$ & $1,4 \%$ & $7 \%$ \\
\hline Zmiany w zatrudnieniu & $\begin{array}{l}\text { Wzrost } \\
\text { Bez zmian } \\
\text { Spadek }\end{array}$ & \multicolumn{2}{|c|}{$\begin{array}{c}89,7 \% \\
3,1 \% \\
7,1 \%\end{array}$} & $\begin{array}{l}61,4 \% \\
13,1 \% \\
25,5 \%\end{array}$ \\
\hline $\begin{array}{l}\text { Udział przedsiębiorstw } \\
\text { eksportujących }\end{array}$ & $\begin{array}{c}\text { Rok 0 } \\
\text { Ostatni rok }^{* *}\end{array}$ & $\begin{array}{l}37,2 \% \\
59,7 \%\end{array}$ & $\begin{array}{l}55 \% \\
72 \%\end{array}$ & $\begin{array}{l}72,6 \% \\
83,8 \%\end{array}$ \\
\hline Udział eksportu w sprzedaży & $\begin{array}{c}\text { Rok 0* } \\
\text { Ostatni rok }^{* *}\end{array}$ & $\begin{array}{l}17,2 \% \\
30,6 \%\end{array}$ & $\begin{array}{l}26,4 \% \\
36,4 \%\end{array}$ & $\begin{array}{l}24,7 \% \\
28,3 \%\end{array}$ \\
\hline
\end{tabular}

* „Rok 0” oznacza rok, w którym została dokonana inwestycja funduszu venture capital lub ostatni rok przez przeprowadzeniem transakcji wykupu.

** „Ostatni rok” oznacza albo 1999 r. dla transakcji wykupów oraz 2001 r. dla inwestycji venture capital, jeżeli zaangażowanie kapitałowe funduszu private equity było kontynuowane albo ostatni rok przed wyjściem funduszu z inwestycji.

Źr ó d ło: jak do tab. 1.4. 
Wśród przedsiębiorstw objętych badaniem zauważalna jest ewidentna poprawa osiąganych wyników finansowych. Wprawdzie przedsiębiorstwa znajdujące się $w$ momencie inwestycji w początkowych fazach rozwoju po trzyletnim okresie inwestycji nadal nie wypracowały zysku, to zauważyć należy, iż zaobserwowana tendencja jest bardzo pozytywna. Dowodem na dynamiczny rozwój badanych spółek jest również wzrost zatrudnienia oraz ekspansja na zagraniczne rynki zbytu.

Chociaż pozyskanie wsparcia funduszy private equity na realizację planów dynamicznego rozwoju bez wątpienia może przynieść przedsiębiorstwu wiele korzyści, to należy mieć również świadomość pewnych ograniczeń i zagrożeń związanych z tą formą kapitału. Przede wszystkim wskazać należy na konsekwencje wprowadzenia nowego kapitału udziałowego do spółki. Pozyskanie inwestora private equity oznacza, iż dotychczasowi właściciele wyrażają zgodę na przekazanie części praw własności do podmiotu, którego byli pomysłodawcami i twórcami. Charakter nowego wspólnika odbiega znacząco od innych podmiotów udostępniających kapitał z zewnętrznych źródeł finansowania, np. banków. Fundusze private equity na ogół aktywnie angażują się w proces kierowania przedsiębiorstwem udziałowym, wymagając od dotychczasowego zarządu współuczestnictwa w podejmowaniu wielu kluczowych dla rozwoju przedsiębiorstwa decyzji. Dla sprawnej realizacji procesu kreowania wartości spółek portfelowych, poza wdrożeniem wielu rozwiązań umożliwiających sprawny nadzór korporacyjny, przedstawiciele funduszu na ogół mają dostęp do informacji poufnych, w tym $\mathrm{m}$. in. danych dotyczących realizacji innowacyjnych rozwiązań technologicznych. W wielu przypadkach sytuacja to może budzić pewne obawy pierwotnych właścicieli spółki. Ponadto w umowach inwestycyjnych często stosowane są klauzule, które pozwalają funduszowi private equity w określonych okolicznościach wymagać od pierwotnego właściciela przedsiębiorstwa zbycia posiadanych przez niego udziałów w spółce ${ }^{73}$. W konsekwencji pomysłodawca i twórca danego przedsiębiorstwa może być zmuszony do ograniczenia lub zakończenia swojego zaangażowania w dany podmiot.

\subsection{Przebieg procesu inwestycyjnego funduszy private equity}

Inwestycje private equity dotyczą lokowania środków głównie w przedsiębiorstwa prywatne. Każda inwestycja posiada swój indywidualny charakter, gdyż warunki na jakich kapitał jest udostępniany przedsiębiorcom, są ustalane w drodze negocjacji pomiędzy inwestorem a określoną spółką. Sam proces in-

${ }^{73}$ Zob. K. S o b a ń s k a, P. S i e r a d z a n, Inwestycje private equity/venture capital, Key Text, Warszawa 2004, s. 25. 
westycyjny w kontekście funkcjonowania kapitału podwyższonego ryzyka można określić jako cykl przepływu kapitału pomiędzy inwestorami powierzającymi środki na inwestycje private equity, funduszami private equity oraz spółkami portfelowymi, mający na celu zapewnienie funduszom wysokiego zwrotu z zainwestowanych środków, przy jednoczesnym utrzymaniu ryzyka inwestycyjnego na akceptowalnym poziomie ${ }^{74}$.

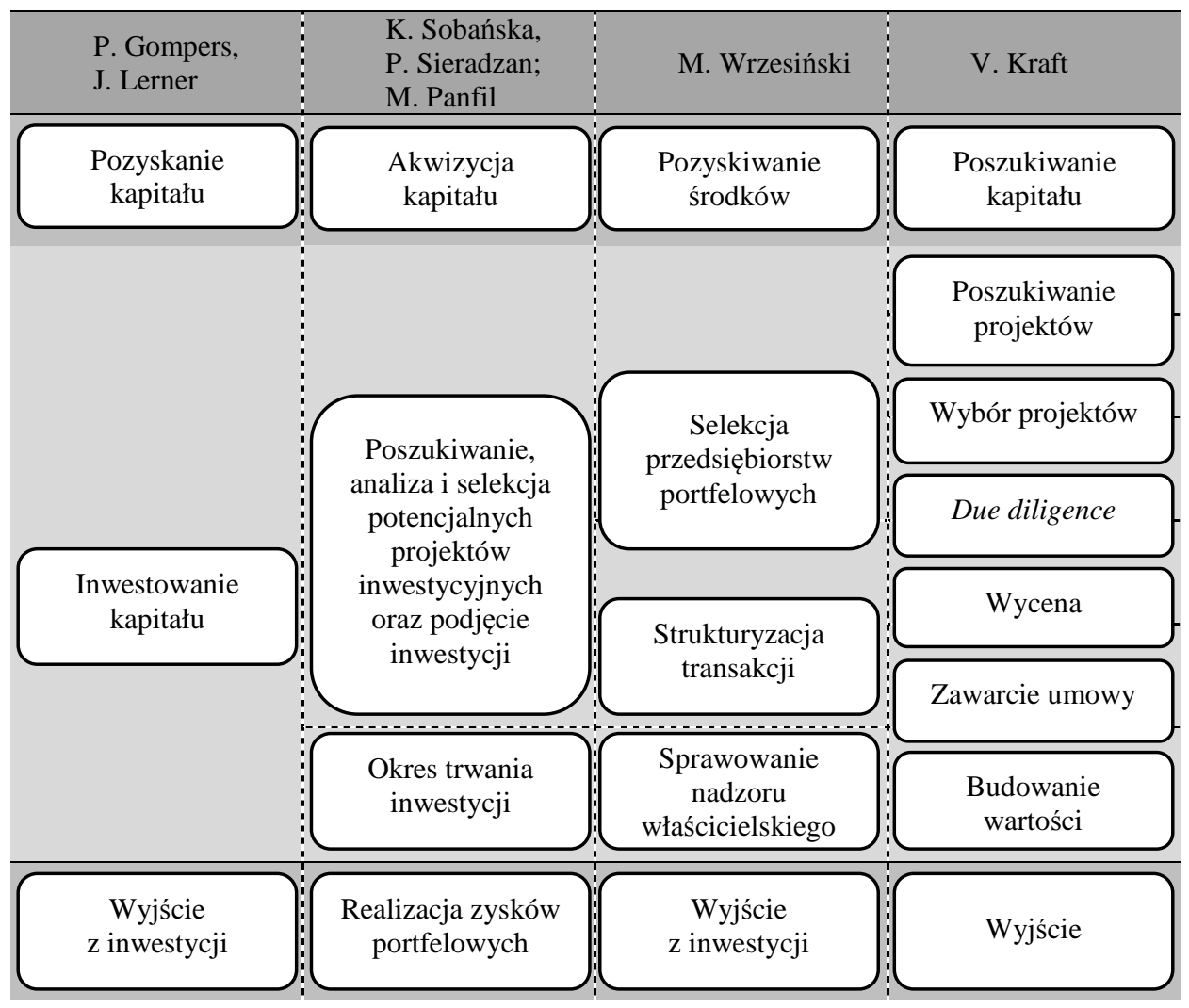

Schemat 1.5. Unifikacja wybranych ujęć cyklu inwestycyjnego funduszy private equity

Ź r ód ł o: opracowanie własne na podstawie P. Go mpers, J. Lerner, The Venture capital Cycle, MIT Press, Cambridge Massachusetts 2006, s. 3; K. S o b ań s k a, P. S i r r ad z a n, Inwestycje private equity/venture capital, Key Text, Warszawa 2004, s. 33; M. Panfil, Fundusze Private equity. Wptyw na wartość spótki, Difin, Warszawa 2005, s. 85; M. Wrzesińs ki, Kapitat podwyższonego ryzyka. Proces inwestycyjny i efektywność, Szkoła Główna Handlowa w Warszawie, Warszawa 2008, s. 31-32; V. K r a ft, op. cit., s. 6.

${ }^{74}$ M. Wr ze siń s ki, Kapitat podwyższonego ryzyka..., op. cit., s. 31, 33. 
W literaturze podmiotu dokonywana jest różnorodna fragmentacja tego pro$\operatorname{cesu}^{75}$. Zawarta na schemacie 1.5 unifikacja wybranych ujęć faz procesu inwestycyjnego funduszy private equity wskazuje, iż proces ten można sprowadzić do pozyskiwania kapitału, jego inwestowania oraz wyjścia $z$ inwestycji ${ }^{76}$. Te trzy fazy procesu inwestycyjnego konstytuują zbiór działań składających się na cykl kapitału podwyższonego ryzyka.

\subsubsection{POZYSKANIE KAPITAŁU PRZEZ FUNDUSZE PRIVATE EQUITY}

Bezpośrednią przesłanką powstania funduszy private equity jest fakt, iż działalność inwestycyjna przez nie podejmowana charakteryzuje się ponadprzeciętnym poziomem ryzyka $i$ jest znacznie bardziej skomplikowana od tradycyjnych inwestycji w akcje spółek publicznych czy obligacje ${ }^{77}$. Fundusze kapitału podwyższonego ryzyka pozwalają na dywersyfikację i ograniczenie ryzyka towarzyszącego tego typu inwestycjom poprzez odpowiedni dobór spółek portfelowych, przy jednoczesnym zapewnieniu perspektywy osiągnięcia ponadprzeciętnych stóp zwrotu z zainwestowanego kapitału. W opinii inwestorów inwestycje tego typu cechują się wyższym poziomem ryzyka. Należą do inwestycji o niskim poziomie płynności, a ich udział $\mathrm{w}$ całym portfelu inwestycyjnym inwestora nie przekracza $\mathrm{z}$ reguły $10 \%{ }^{78}$.

Środki na inwestycje private equity pozyskiwane są $\mathrm{z}$ wielu różnorodnych źródeł, a ich podaż uwarunkowana jest wieloma czynnikami ${ }^{79}$. Inwestorami mogą być podmioty o różnym profilu działania i strukturze własności, zarówno wchodzące w skład systemu finansowego, jak i spoza niego ${ }^{80}$. Charakter i struktura źródeł pochodzenia środków oddziałują na przyjmowaną przez fundusz politykę inwestycyjną ${ }^{81}$. Co więcej, obserwowane jest również sprzężenie

${ }^{75}$ Szczególnie można podkreślić atrakcyjność ujęć zaprezentowanych w opracowaniach: V. K r a f t, op. cit., s. 6; K. S obańs ka, P. Si e radzan, op. cit., s. 33; M. Pan fi 1, Fundusze private equity..., op. cit., s. 85; M. W r ze siń s k i, Kapitat podwyższonego ryzyka..., op. cit., s. 31-32.

${ }^{76}$ P. Go mpers, J. Lerner, The Venture Capital Cycle, MIT Press, Cambridge Massachusetts 2006, s. 3.

${ }^{77}$ M. Wr ze siń s ki, Kapitat podwyższonego ryzyka..., op. cit., s. 84.

${ }^{78}$ D. J. Cumming, S. A. Johan, Venture capital and Private Equity Contracting..., op. cit., s. 73.

${ }^{79}$ A. S a m b or s ki, Finansowanie przedsiębiorstw poprzez emisje papierów wartościowych - diagnoza uwarunkowań i zależności, Wydawnictwo Akademii Ekonomicznej w Katowicach, Katowice 2007, s. 265-268.

${ }^{80}$ M. Pietraszewski, op. cit., s. 50.

${ }^{81}$ C. Mayera, K. Schoorsb, Y. Yafeh, Sources of funds and investment activities of venture capital funds: Evidence from Germany, Israel, Japan and the United Kingdom, „Journal of Corporate Finance" 2005, Vol. 11, s. 603; A. S chertle r, European venture capital markets: Fund providers and investment characteristics, „Applied Financial Economics” 2005, Vol. 15, s. 367-380; T. Hell man n, A theory of strategic venture investing, „Journal of Financial Economics" 2002, Vol. 64, s. 285-314. 
zwrotne w tym zakresie ${ }^{82}$. Kapitałodawcy funduszy private equity na ogół nie posiadają odpowiednio wykwalifikowanych kadr ani możliwości przeprowadzenia niezbędnych analiz efektywności inwestycji bezpośrednich w prywatne przedsiębiorstwa, czy oceny szans rynkowych nowatorskich koncepcji biznesowych. Głównymi inwestorami w fundusze private equity na ogół są banki, fundusze emerytalne, instytucje ubezpieczeniowe, przedsiębiorstwa i korporacje, agencje rządowe, instytucje publiczne, instytuty naukowe, osoby prywatne oraz tzw. fundusze funduszy ${ }^{83}$.

Fundusze private equity działające w Europie Środkowo-Wschodniej ${ }^{84}$ są przedmiotem wyraźnego zainteresowania podmiotów udostępniających nowy kapitał na inwestycje (zob. wykres 1.2). Region Europy Środkowo-Wschodniej jest przy tym bardzo często postrzegany jako jednolity obszar inwestycyjny bez wyróżniania poszczególnych jego obszarów ${ }^{85}$.

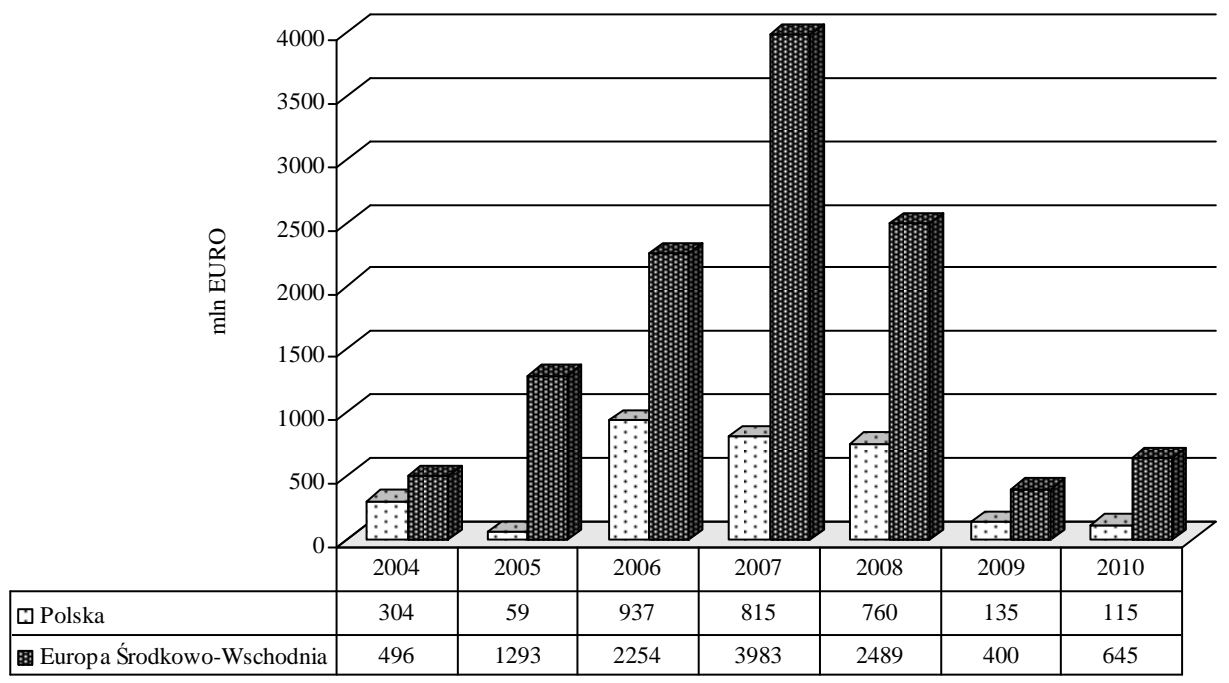

W y k res 1.2. Napływ nowego kapitału do funduszy private equity w Europie Środkowo-Wschodniej w latach 2004-2010 (w mln EURO)

Ź ródło: opracowanie własne na podstawie EVCA Yearbook 2005-2011 (Poland) oraz Central and Eastern Europe Statistics 2010, An EVCA Special Paper, 2011, s. 5.

${ }^{82}$ D. J. Cu mming, G. A. Fleming, J-A. S u ch ard, op. cit., s. 295-331.

${ }^{83}$ K. S obańs ka, P. Sier ad za n, op. cit., s. 33-34.

${ }^{84} \mathrm{Za}$ Central and Eastern Europe Statistics 2010, An EVCA Special Paper, 2011 przyjęto, iż określenie Europa Środkowo-Wschodnia odnosi się do następujących krajów: Estonia, Polska, Ukraina, Bośnia i Hercegowina, Rumunia, Bułgaria, Litwa, Serbia, Chorwacja, Łotwa, Słowacja, Czarnogóra, Macedonia, Słowenia, Czechy, Mołdawia, Węgry.

${ }^{85}$ EVCA Yearbook 2008, s. 211. 
Analizując podaż kapitału na rynku private equity w Polsce z punktu widzenia źródeł jego pochodzenia należy zauważyć, iż udział krajowych inwestorów jest wręcz symboliczny. W latach 2004-2010 przeważająca część środków zgromadzonych przez krajowe fundusze private equity pochodziła ze źródeł zagranicznych, głównie z innych krajów europejskich (zob. wykres 1.3).

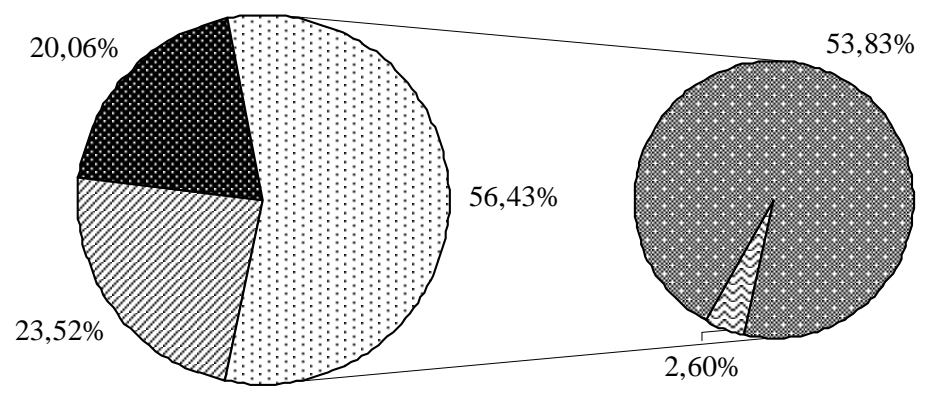

田 Kraje pozaeuropejskie Brak informacji $\square$ Polska Inne kraje europejskie

Wykres 1.3. Przekrój geograficzny źródeł kapitału funduszy private equity w Polsce w latach 2004-2010

Ź r ód ł o: opracowanie własne na podstawie EVCA Yearbook 2005-2011 (Poland).

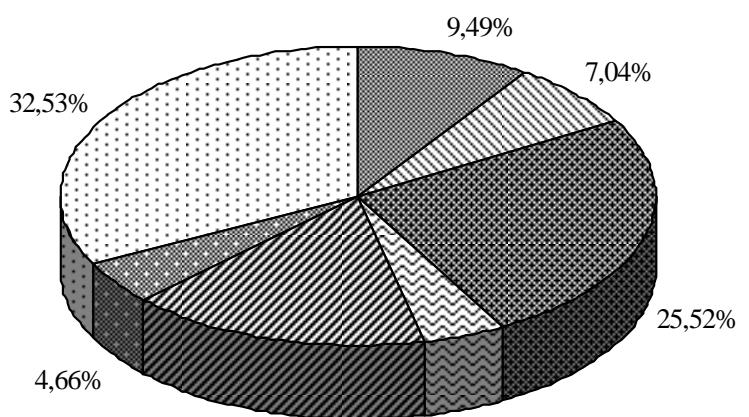

$16,52 \%$

$4,24 \%$

Banki

国 Fundusze funduszy

$\boldsymbol{\nabla}$ Fundusze emerytalne

$\square$ Pozostałe źródła
Q Fundacje

$\square$ Towarzystwa ubezpieczeniowe

圆 Agencje rządowe

Wykres 1.4. Źródła kapitału funduszy private equity według typów kapitałodawców w Polsce w latach 2004-2010

Źr ó d ło: jak do wykresu 1.3. 
Rozpatrując źródła kapitału pozyskanego przez fundusze private equity z punktu widzenia kluczowych grup inwestorów można zauważyć, iż najważniejszym źródłem nowych kapitałów w latach 2004-2010 były fundusze funduszy. Z tego źródła pochodziło ponad $25 \%$ wszystkich nowych środków pozyskanych na inwestycje w tym okresie (zob. wykres 1.4).

Znaczącym źródłem kapitału na inwestycje funduszy private equity mających siedzibę w Polsce są fundusze emerytalne oraz banki. Udział tych źródeł podaży kapitału na polskim rynku w analizowanym okresie wynosił odpowiednio 16,52\% oraz $9,49 \%$. Nieco mniejszy udział w sumie nowych kapitałów udostępnionych funduszom private equity miały różnego rodzaju fundacje, agencje rządowe oraz towarzystwa ubezpieczeniowe. Ponad 32,5\% wszystkich środków pozyskanych w latach 2004-2010 pochodziło z innych źródeł.

\subsubsection{INWESTYCJE FUNDUSZY PRIVATE EQUITY W PRZEDSIĘBIORSTWA DZIALAJĄCE W POLSCE}

Inwestowanie środków funduszy podwyższonego ryzyka stanowi złożony i wieloetapowy proces. Chociaż każda transakcja posiada swój indywidualny charakter można wyróżnić sześć bazowych etapów właściwych dla procesu inwestowania kapitału, realizowanego przez fundusze private equity ${ }^{86}$ (zob. schemat 1.6).

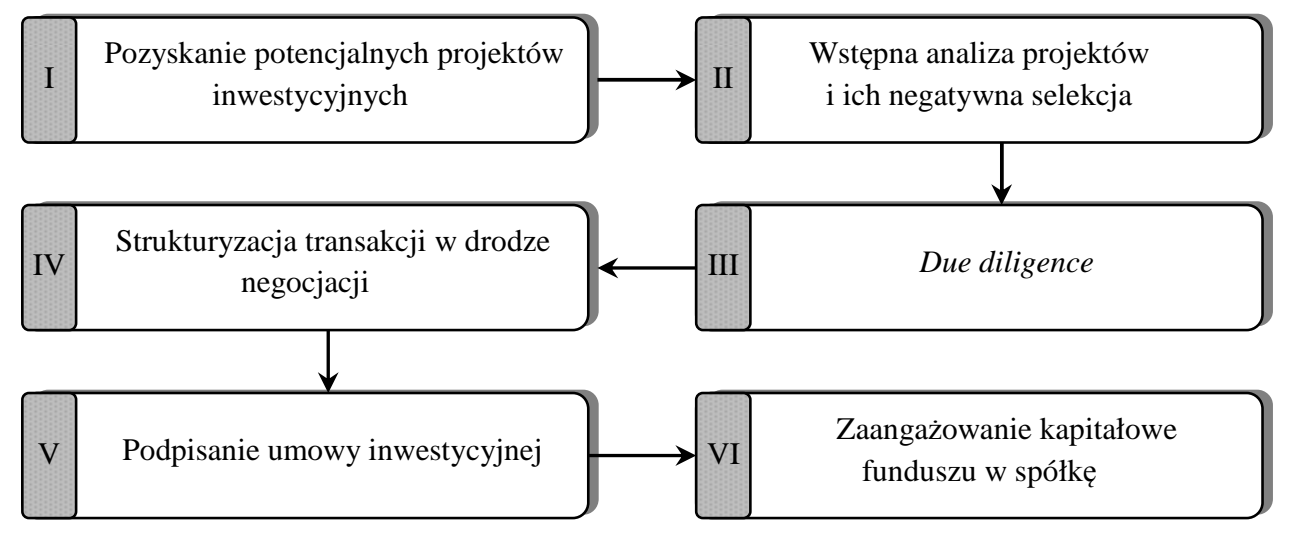

Schemat 1.6. Etapy procesu inwestowania przez fundusze private equity zgromadzonych środków w spółki portfelowe

Źr ó d ł o: opracowanie własne.

${ }^{86}$ Zaprezentowany przebieg procesu inwestycyjnego stanowi swojego rodzaju ilustrację i nie ma charakteru ściśle obowiązującego. Procedury stosowane w poszczególnych funduszach mogą od niego znacząco odbiegać. 
Pierwszym krokiem zmierzającym do rozpoczęcia inwestycji przez fundusz podwyższonego ryzyka jest pozyskanie potencjalnych projektów, które mogą w wyniku dalszych prac przekształcić się w realne przedsięwzięcia. W dalszej części procesu inwestycyjnego następuje wstępna selekcja zgromadzonych projektów. Ma ona charakter analizy wieloszczeblowej i wielokryterialnej, uwzględniającej liczne ograniczenia związane $\mathrm{z}$ inwestycjami funduszy private equity (zob. tab. 1.6).

Tabela 1.6

Kluczowe ograniczenia w zakresie inwestowania kapitału przez fundusze private equity w przedsiębiorstwa udziałowe

\begin{tabular}{|c|c|}
\hline Czynnik ograniczający & Charakterystyka \\
\hline Ryzyko bankructwa & $\begin{array}{l}\text { Kluczowym problemem jest wybór przedsiębiorstw, które zdol- } \\
\text { ne są funkcjonować na rynku w długim okresie, gdyż znaczna } \\
\text { część nowych podmiotów gospodarczych upada. }\end{array}$ \\
\hline Brak potencjału wzrostu & $\begin{array}{l}\text { Większość małych podmiotów gospodarczych nie ma wymaga- } \\
\text { nego potencjału istotnego zwiększenia skali działania, chociaż } \\
\text { zapewniają one dotychczasowym właścicielom godziwy zwrot } \\
\text { z kapitału (np. wynagrodzenie). Wynikać to może np. z cha- } \\
\text { rakteru branży czy specyfiki rynku. }\end{array}$ \\
\hline $\begin{array}{l}\text { Ryzyko nieosiągnięcia suk- } \\
\text { cesu rynkowego }\end{array}$ & $\begin{array}{l}\text { Nawet w przypadku projektów z branż uznawanych za rozwojo- } \\
\text { we tylko niewielka część ma szansę powodzenia. Wśród no- } \\
\text { wych produktów czy usług tylko wybrane znajdują uznanie } \\
\text { konsumentów, zapewniając przedsiębiorstwu sukces rynkowy. }\end{array}$ \\
\hline $\begin{array}{l}\text { Ustabilizowane sektory } \\
\text { gospodarki }\end{array}$ & $\begin{array}{l}\text { Większość sektorów gospodarki nie rozwija się dynamicznie, } \\
\text { między innymi dlatego, że rynek jest podzielony pomiędzy } \\
\text { firmy posiadające mocną pozycję rynkową i uznaną markę lub } \\
\text { występują istotne bariery wejścia na rynek. }\end{array}$ \\
\hline $\begin{array}{l}\text { Sektory, w których fundusze } \\
\text { private equity w ogóle nie } \\
\text { inwestują }\end{array}$ & $\begin{array}{l}\text { Część sektorów gospodarki znajduje się poza obszarem zaintere- } \\
\text { sowania funduszy kapitału podwyższonego ryzyka. Wynikać } \\
\text { to może z niskiej atrakcyjności inwestycyjnej tych sektorów, } \\
\text { zbyt wysokiego poziomu regulacji państwowych bądź kwestii } \\
\text { etycznych. }\end{array}$ \\
\hline $\begin{array}{l}\text { Brak możliwości wyjścia } \\
\text { z inwestycji }\end{array}$ & $\begin{array}{l}\text { Zaledwie część przedsiębiorstw jest w stanie osiągnąć w okre- } \\
\text { ślonym okresie taką wielkość, która pozwoli funduszowi na } \\
\text { efektywne wyjście z inwestycji, np. w drodze emisji pu- } \\
\text { blicznej. }\end{array}$ \\
\hline
\end{tabular}

Ź r ó d ł o: opracowanie własne na podstawie M. Wr ze s iń s ki, Kapitał podwyższonego ryzyka..., op. cit., s. 114-116.

Wymagania stawiane podmiotom, które chcą uzyskać finansowanie z funduszy private equity są z reguły bardzo wysokie i trudne do spełnienia. Podstawowym kryterium selekcji projektów inwestycyjnych jest jakość i wiarygodność pomysłu udokumentowana analizą rynku, wysokimi kwalifikacjami wykonawców i przedsiębiorców, a ostatecznie spodziewana stopa zysku od zainwestowa- 
nych kapitałów ${ }^{87}$. Szacuje się, iż na każde 100 biznes planów, które otrzymują fundusze private equity zazwyczaj tylko $10 \mathrm{z}$ nich kwalifikowanych jest do następnego etapu ${ }^{88}$.

Trzeci etap procesu inwestowania kapitału przez fundusze private equity dotyczy oceny możliwości aprecjacji wartości przedsiębiorstwa. Badanie określane jako due diligence jest złożoną i pogłębioną analizą realnej oceny potencjału wzrostu wartości rynkowej i wyceny nabywanego lub doinwestowywanego przedsiębiorstwa, a także przedstawieniem pełnego obrazu zagadnień prawnych, które wiążą się $\mathrm{z}$ jego funkcjonowaniem ${ }^{89}$. Analiza ta ma charakter wielopłaszczyznowy, a badaniu poddawane są różne aspekty funkcjonowania spółki m. in. sposób realizacji działalności operacyjnej, stasowana technika i/technologia, stosunki prawno-majątkowe, źródła finansowania działalności, zobowiązania podatkowe, zarządzanie zasobami ludzkimi oraz wpływ na środowisko naturalne ${ }^{90}$.

Wynikiem analizy due diligence jest weryfikacja prognoz finansowych spółki, będących podstawą do przeprowadzenia wyceny nabywanego podmiotu gospodarczego oraz ustalenia warunków ${ }^{91}$. Finalny dokument sporządzony w wyniku badania powinien ponadto wskazywać na istniejące i potencjalne źródła ryzyka ${ }^{92}$. Szczególną uwagę przywiązuję się do ryzyka wynikającego z przyjętej strategii i modelu biznesowego, konkurencyjności, wielkości rynku, zastosowanej technologii, skłonności potencjalnych nabywców do akceptacji produktu, a także $\mathrm{z}$ indywidualnych cech kadry kierowniczej ${ }^{93}$.

Efektem pozytywnej ewaluacji przedsiębiorstwa w drodze analizy due diligence jest strukturyzacja transakcji w drodze negocjacji prowadzonymi pomiędzy przedstawicieli funduszu private equity i podmiotu ubiegającego się o finansowanie. Przedmiotem rozmów są zarówno kwestie związane z finansowymi aspektami transakcji, jak i z alokacją praw korporacyjnych. Na tym etapie wyznaczana jest m. in. ilość obejmowanych przez fundusz udziałów i ich cena, forma w jakiej fundusz private equity zaangażuje się $\mathrm{w}$ spółkę, system motywowania kadry menedżerskiej oraz uprawnienia poszczególnych podmiotów w zakresie sprawowania kontroli nad przedsiębiorstwem, w szczególności w przypadku niezrealizowania pożądanego scenariusza rozwoju spółki portfelowej ${ }^{94}$.

${ }^{87}$ L. Le w a n d ow s ka, Niekonwencjonalne formy..., op. cit., s. 109.

${ }^{88}$ Venture Impact - The Economic Importance of Venture capital Backed Companies to the U.S. Economy, National Venture capital Association, 2009, s. 4.

${ }^{89}$ K. Sobańska, P. Sieradzan, op. cit., s. 57; W. Przybylska-Kapuścińska, M. Mozalewski, op. cit., s. 75-98.

${ }^{90}$ P. Tamowicz, Venture capital - kapitat na start, Polska Agencja Rozwoju Przedsiębiorczości, Gdańsk 2004 s. 38-39.

${ }^{91}$ M. W r ze siń s ki, Kapitat podwyższonego ryzyka..., op. cit., s. 123.

${ }^{92}$ K. S obań ska, P. Si eradza n, op. cit., s. 57.

${ }^{93}$ S. N. Kapla n, P. Strö mberg, Characteristics, Contracts, and Actions: Evidence from Venture capitalist Analyses, „The Journal of Finance” 2004, Vol. LIX, No. 5, s. 2173-2206.

${ }^{94}$ G. W. Fe n n, N. Li ang, S. Prow se, op. cit., s. 31. 
Podpisanie umowy inwestycyjnej stanowi ostatni etap procesu inwestowania przed rzeczywistym zaangażowaniem kapitałowym funduszu private equity w przedsiębiorstwo chcące pozyskać środki finansowe z tego źródła. Umowa inwestycyjna w sposób formalny konstytuuje wcześniejsze ustalenia poczynione w drodze negocjacji. Określa ona szczegółowo warunki dalszej współpracy, obejmując zbiór praw i obowiązków obu stron, także zabezpieczając ich intere$\mathrm{sy}^{95}$. Inwestycje private equity dokonywane są $\mathrm{z}$ reguły w podmioty prowadzące działalność w formie kapitałowych spółek prawa handlowego, a co zatem idzie kluczowe kwestie pomiędzy spółką i właścicielem w minimalnym zakresie wyznaczone są przepisami ustawy kodeks spółek handlowych ${ }^{96}$. Umowa inwestycyjna może wyłącznie precyzować i rozszerzać określone prawa i obowiązki stron, w żadnym wypadku jednak nie może ograniczać uprawnień wynikających z przepisów prawa, chyba że stanowią one inaczej.

Dopełnienie wszystkich formalności związanych z przystąpieniem funduszu private equity do spółki kończy starania o pozyskanie przez nią wsparcia nowego inwestora i jednocześnie rozpoczyna nowy, wieloletni okres współpracy pomiędzy partnerami. Przeprowadzone badania wskazują, iż wsparcie finansowe funduszy private equity otrzymuje zaledwie 1-4\% wszystkich przedsiębiorstw, jakie ubiegają się o te środki ${ }^{97}$.

Po podpisaniu umowy inwestycyjnej wszelkie wysiłki podejmowane przez obie strony są zorientowane na realizację jednego zasadniczego celu: w przewidywanym czasie spółka powinna zrealizować cele wskazane w swojej strategii rozwoju, tak aby osiągnąć oczekiwany przyrost wartości rynkowej ${ }^{98}$.W trakcie zaangażowania kapitałowego w spółkę portfelową fundusz private equity realizuje trzy powiązane ze sobą funkcje ${ }^{99}$ :

- monitoruje bieżące wyniki działalności przedsiębiorstwa udziałowego,

- uczestniczy w podejmowaniu strategicznych decyzji oraz

- prowadzi doradztwo w odniesieniu do newralgicznych obszarów rozwoju spółki.

Chociaż zwraca się uwagę, iż większość działań podejmowanych przez fundusz ma charakter pozaumowny i jest efektem własnej inicjatywy przedstawicie-

${ }^{95}$ J. Grzy wacz, A. Okońska, op. cit., s. 108.

${ }^{96}$ Ustawa z dnia 15 września 2000 r. Kodeks spótek handlowych, DzU 2000, nr 94, poz. 1037 z późn. zm.

${ }^{97}$ J. B. Mai er, D. A. Walker, The role of venture capital in financing small business, „Journal of Business Venturing” 1987, Vol. 2, Issue 3, s. 207-214.

${ }^{98}$ P. T a mowicz, op. cit., s. 43.

${ }^{99}$ K. S ob ań sk a, P. Si eradzan,op. cit., s. 104. 
li funduszu ${ }^{100}$ to pod względem formalnym zakres zaangażowania funduszu private equity $\mathrm{w}$ działalność spółki uzależniony jest $\mathrm{od}^{101}$ :

- uregulowań ustawowych dotyczących kompetencji organów spółki, których członkiem jest przedstawiciel funduszu,

- postanowień dotyczących wzajemnych praw i obowiązków stron zawartych w umowie inwestycyjnej,

- statutu lub umowy spółki.

Łączna wartość kapitału zainwestowanego przez fundusze private equity w spółki prowadzące działalność w Europie Środkowo-Wschodniej w latach 2004-2010 przekracza 11 mld EURO, z czego na przedsiębiorstwa prowadzące działalność gospodarczą w Polsce przypada ponad 22\% tej kwoty (zob. wykres 1.5$)$.

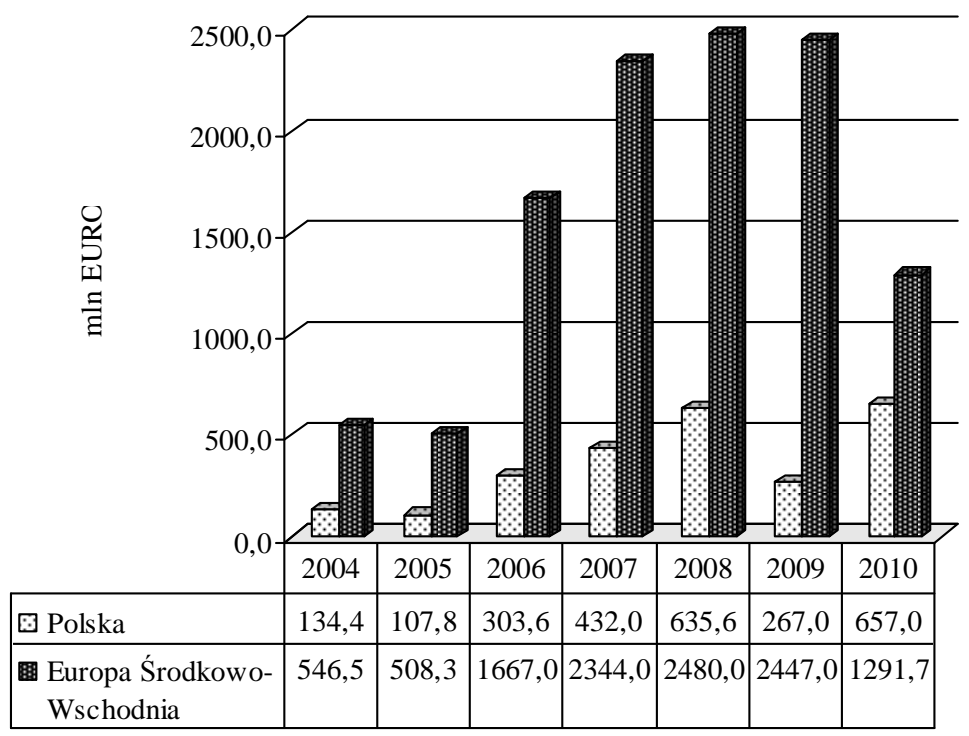

Wykres 1.5. Wartość kapitału zainwestowanego przez fundusze private equity w Europie Środkowo-Wschodniej w latach 2004-2008 (w mln EURO)

Źródło: opracowanie własne na podstawie EVCA Yearbook 2008-2011 (Poland) oraz Central and Eastern Europe Statistics 2005-2010, An EVCA Special Paper, 2006-2011.

W latach 2005-2008 można zaobserwować tendencję wzrost środków zainwestowanych w przedsiębiorstwa prowadzące działalność na terenie Europy Środkowo-Wschodniej. Polska zajmuje dominującą pozycję wśród odbiorców

${ }^{100}$ L. B ottazzi, M. Da Rin, T. Hellmann, Who are the active investors? Evidence from venture capital, ,Journal of Financial Economics” 2008, Vol. 89, s. 489.

${ }^{101}$ K. S ob ań ska, P. S i e r a d za n, op. cit., s. 105. 
inwestycji private equity w Europie Środkowo-Wschodniej, a udział wielkości zainwestowanych kapitałów private equity w wielkości produktu krajowego brutto kształtuje się powyżej średniej dla całego regionu (zob. wykres 1.6).

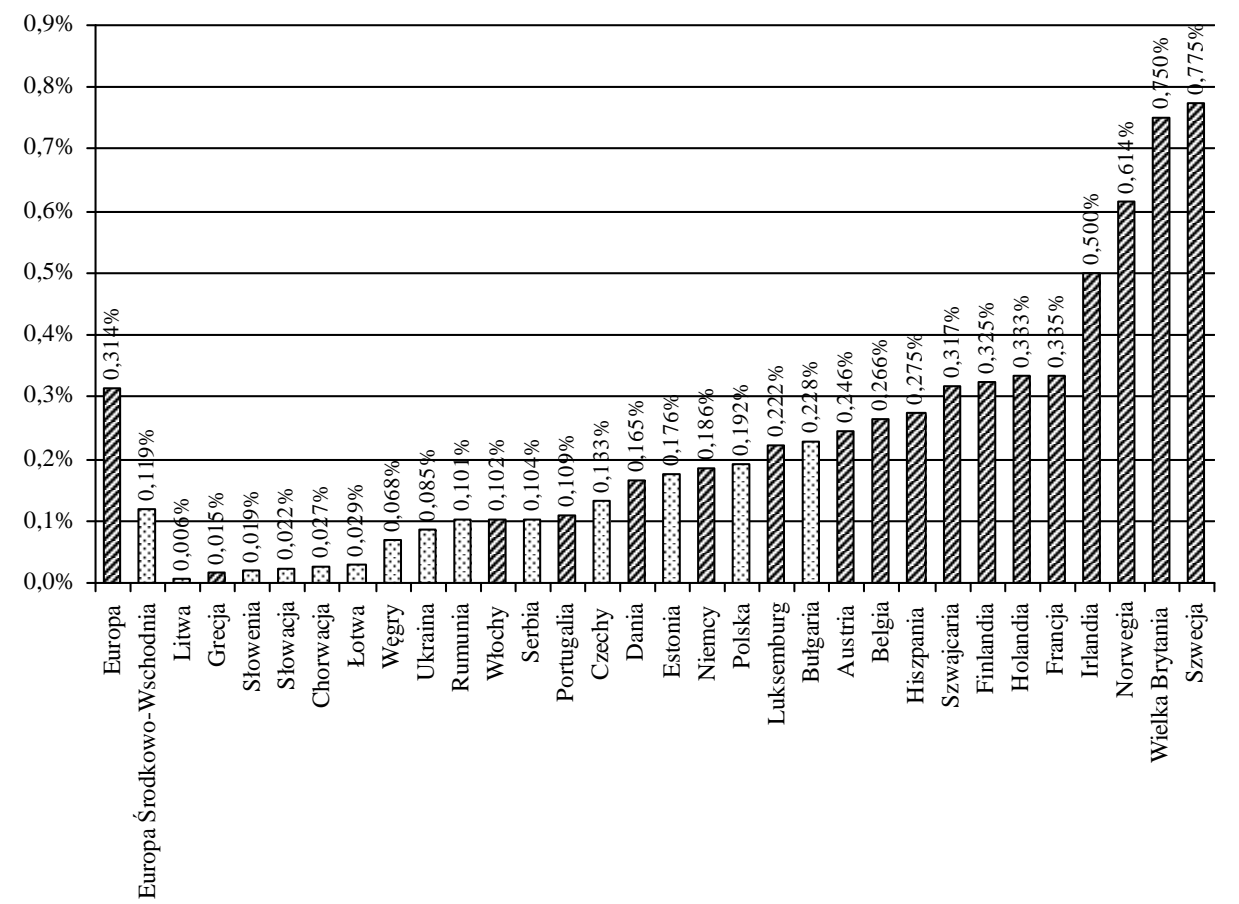

Wykres 1.6. Stosunek inwestycji private equity do PKB w wybranych krajach europejskich, Europie oraz Europie Środkowo-Wschodniej w 2010 r. (w \%)

Ź r ó d ło: opracowanie własne na podstawie Central and Eastern Europe Statistics 2010, An EVCA Special Paper, 2011, s. 16.

Inwestycje funduszy private equity w Polsce stanowiły 0,192\% PKB wypracowanego w 2010 r. Był to drugi wynik w Europie Środkowo-Wschodniej, a wyższą wartość tego wskaźnika zaobserwowano tylko w Bułgarii. Jednakże jest to wynik utrzymujący się znacznie poniżej średniego poziomu zanotowanego dla całej Europy, który wynosił 0,314\%. Najwyższy stosunek inwestycji private equity do w PKB w 2010 r. w Europie miały Norwegia, Wielka Brytania i Szwecja.

Analizując wewnętrzną strukturę inwestycji funduszy private equity w Pol$\operatorname{sce}^{102}$ należy zwrócić uwagę na niewielki udział venture capital (zob. wykres 1.7).

${ }^{102}$ Zakres czasowy dalszej analizy ograniczono do lat 2007-2010, co jest podyktowane koniecznością zachowania porównywalności prezentowanych danych liczbowych. Od 2008 r. 


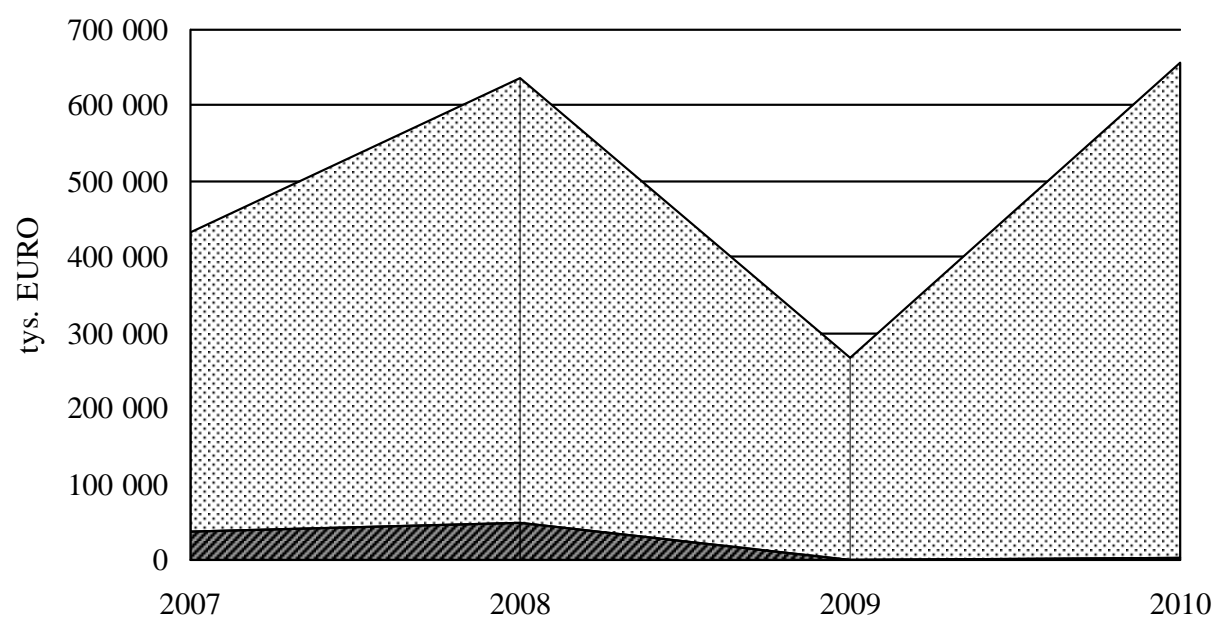

Venture capital Pozostałe private equity

Wykres 1.7. Inwestycje private equity w Polsce w latach 2007-2010 według segmentów

Ź r ó d ł o: opracowanie własne na podstawie EVCA Yearbook 2008-2011.

Najistotniejszą część rynku kapitału ryzyka w Polsce stanowią transakcje związane z wykupami. W latach 2007-2010 stanowiły one ponad 76\% wszystkich środków przekazanych do polskich spółek w ramach działalności funduszy (zob. tab. 1.7). W analizowanym okresie, a zwłaszcza w latach 2009-2010, wyraźnie zauważalna jest awersja funduszy private equity do inwestycji w najbardziej ryzykowne przedsiębiorstwa, znajdujące się w początkowych fazach rozwoju, tj. zasiew oraz start-up.

Większość kapitału na rynku polskim alokowana jest w finansowanie wykupów oraz na finansowanie wzrostu przedsiębiorstw znajdujących się w późniejszych fazach rozwoju. Warto również zwrócić uwagę na wyraźną różnicę pomiędzy średnimi wielkościami inwestycji przypadającymi na jedno przedsiębiorstwo w poszczególnych segmentach kapitału podwyższonego ryzyka.

Przedsiębiorstwa będące beneficjentami kapitału podwyższonego ryzyka w Polsce prowadzą działalność gospodarczą w różnych sektorach (zob. wykres 1.8).

w zestawieniach statystycznych EVCA uprzednio przedstawiana faza ekspansji została podzielona na dwie odrębne fazy finansowania inwestycji venture - późniejszy etap oraz finansowanie wzrostu (finansowanie na tym etapie nie jest już zaliczane do inwestycji venture capital). Zob. http://www.ppea.org.pl/new/aktualnosci.php?art=425. 
Tabela 1.7

Inwestycje private equity w polskie przedsiębiorstwa w latach 2007-2010 według poszczególnych segmentów

\begin{tabular}{|c|c|c|c|c|c|c|c|c|c|}
\hline \multirow[b]{2}{*}{ Faza rozwoju } & \multicolumn{2}{|c|}{2007} & \multicolumn{2}{|c|}{2008} & \multicolumn{2}{|c|}{2009} & \multicolumn{2}{|c|}{2010} & \multirow{2}{*}{\begin{tabular}{|c|} 
Ogółem \\
{$[\%]$}
\end{tabular}} \\
\hline & $\begin{array}{c}\text { [tys. } \\
\text { EURO] }\end{array}$ & {$[\%]$} & $\begin{array}{c}\text { [tys. } \\
\text { EURO] }\end{array}$ & {$[\%]$} & $\begin{array}{c}\text { [tys. } \\
\text { EURO] }\end{array}$ & {$[\%]$} & \begin{tabular}{|c|} 
[tys. \\
EURO]
\end{tabular} & {$[\%]$} & \\
\hline Zasiew & 2483 & 0,57 & 4004 & 0,63 & 0 & 0,00 & 0 & 0,00 & 0,33 \\
\hline Start-up & 3110 & 0,72 & 10660 & 1,68 & 0 & 0,00 & 1541 & 0,23 & 0,77 \\
\hline $\begin{array}{l}\text { Późniejsze etapy } \\
\text { venture }\end{array}$ & 33218 & 7,69 & 35687 & 5,61 & 634 & 0,24 & 1272 & 0,19 & 3,56 \\
\hline Razem venture & 38811 & 8,98 & 50350 & 7,92 & 634 & 0,24 & 2813 & $\mathbf{0 , 4 3}$ & 4,65 \\
\hline Wzrost & 101813 & 23,57 & 69454 & 10,93 & 61559 & 23,06 & 114454 & 17,42 & 17,44 \\
\hline $\begin{array}{l}\text { Rescue / Turna- } \\
\text { round }\end{array}$ & 1256 & 0,29 & 68 & 0,01 & 6100 & 2,28 & 3073 & 0,47 & 0,53 \\
\hline $\begin{array}{l}\text { Replacement } \\
\text { capital }\end{array}$ & $\begin{array}{ll}8069 \\
\end{array}$ & 1,87 & 0 & 0,00 & 99 & 0,04 & 16145 & 2,46 & 1,22 \\
\hline Wykupy & 282035 & 65,29 & 515759 & 81,14 & 198602 & 74,38 & 520517 & 79,23 & 76,17 \\
\hline Razem & 431984 & 100,00 & 635631 & 100,00 & 266994 & 100,00 & 657002 & 100,00 & 100,00 \\
\hline $\begin{array}{l}\text { Srednia wielkość } \\
\text { inwestycji typu } \\
\text { venture capital } \\
\text { w jedno przedsię- } \\
\text { biorstwo }\end{array}$ & 1437 & - & 1095 & - & 106 & - & 281 & - & \\
\hline $\begin{array}{l}\text { Średnia wielkość } \\
\text { inwestycji typu } \\
\text { pozostałe private } \\
\text { equity w jedno } \\
\text { przedsiębiorstwo }\end{array}$ & 13106 & - & 23411 & - & 14019 & - & 18691 & - & \\
\hline
\end{tabular}

Ź r ó d ł o: opracowanie własne na podstawie EVCA Yearbook 2008-2011.

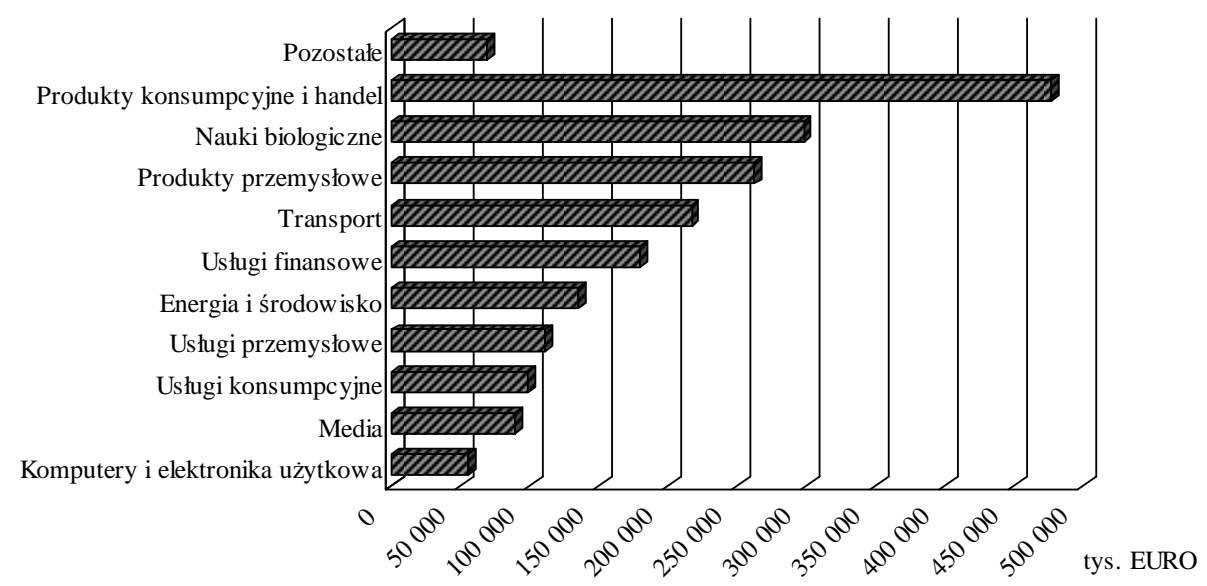

Wykres 1.8. Sektorowe ujęcie inwestycji private equity w Polsce w latach 2007-2010 Ź ró d ło: jak do wykresu 1.7 . 
W latach 2007-2010 największym zainteresowaniem inwestorów cieszyły się spółki produkujące i sprzedające produkty konsumpcyjne. Ogólna wartość zainwestowanych w nie środków w tym okresie wynosiła 477,7 mln EURO. Istotna część inwestycji ulokowana została również w przedsiębiorstwa działające $\mathrm{w}$ takich sektorach jak nauki biologiczne, produkty przemysłowe oraz transport. 


\section{Rozdział 2}

\section{DEZINWESTYCJA JAKO KLUCZOWY ETAP PROCESU INWESTYCYJNEGO FUNDUSZY PRIVATE EQUITY}

\subsection{Pojęcie dezinwestycji i jej znaczenie dla funduszy kapitału podwyższonego ryzyka}

W procesie inwestycyjnym funduszy private equity newralgicznym problemem jest realizacja zysku kapitałowego z inwestycji. Spółki portfelowe, szczególnie te znajdujące się na początkowych etapach rozwoju, nie wypłacają dywidendy ani odsetek za udostępniony kapitał ${ }^{1}$. Podstawowym źródłem zysku kapitałowego funduszy private equity jest przyrost wartości zainwestowanego kapitału, osiągany podczas rozwoju działalności gospodarczej spółek będących własnością funduszu. Zysk z inwestycji realizowany jest dopiero w momencie wyjścia z inwestycji, co jest bezpośrednim wyznacznikiem uznania tego etapu za określający sukces inwestycyjny.

Wyjście z inwestycji uznawane jest za jeden z kluczowych czynników decydujących o wyborze spółki portfelowej już na etapie analizy przedinwestycyj$n^{2}$. Sam zaś etap wyjścia z inwestycji stanowi integralną część całego procesu inwestycyjnego ${ }^{3}$. O sukcesie przedsięwzięcia decyduje rynek. L. Lewandowska wskazuje, że aktualność zachowuje teza L. Misesa, według której dopiero cena rynkowa faktycznie przyznana produktowi określa trafność podjętej decyzji inwestycyjnej, a zarazem i decyzji finansowej ${ }^{4}$.

${ }^{1}$ D. J. Cu mming, J. G. Mac Into sh, Venture-capital exits in Canada and United States, „University of Toronto Law Journal” 2003, s. 101.

${ }^{2} \mathrm{~A} . \mathrm{S} \mathrm{ch}$ w i e $\mathrm{n}$ b a c h e r, An empirical analysis of venture capital exits in Europe and United States, EFA 2002 Berlin Meetings Discussion Paper, 2005, http://ssrn.com/abstract=302001; M. Wrzesiński, Kapitał podwyższonego ryzyka. Proces inwestycyjny i efektywność, SGH w Warszawie, Warszawa 2006, s. 226.

${ }^{3}$ G. W. Fe n n, N. Li an g, S. Prow s e, The Economics of the Private equity Market, „Federal Reserve Bulletin", January 1996, s. 29, http://www.federalreserve.gov.

${ }^{4} \mathrm{~L}$. Le w a d ow s ka, Niekonwencjonalne formy finansowania przedsiębiorczości, ODiDK Sp. z o.o., Gdańsk 2000, s. 115. 
Wyjście z inwestycji polega na sprzedaży przez fundusz private equity posiadanych udziałów w spółkach portfelowych ${ }^{5}$. Jest to działanie inwestora, mające doprowadzić do wycofania się z inwestycji, czyli zbycia na rynku prywatnym lub publicznym, jednemu lub więcej podmiotom, posiadanych udziałów w spółce portfelowej ${ }^{6}$. Inwestor może zbyć wszystkie posiadane udziały jednocześnie $\mathrm{i}$ w ten sposób definitywnie zakończyć zaangażowanie kapitałowe w spółkę (tzw. full exit), lub też może sprzedać tylko część posiadanych udziałów, pozostając wciąż współwłaścicielem spółki portfelowej (tzw. partial exit) ${ }^{7}$.

Można wskazać na dwie główne przesłanki ekonomiczne uzasadniające wyjście funduszu private equity $\mathrm{z}$ inwestycji. Po pierwsze potrzeba dokonania dezinwestycji wynika bezpośrednio ze specyfiki funkcjonowania rynku private equity. Podmioty posiadające wolne środki na inwestycje udostępniają je funduszowi na określony okres. Immanentną cechą funduszy private equity jest z góry ograniczony czas, na który zostają utworzone. $\mathrm{Z}$ reguły wynosi on 10 lat, z możliwością ewentualnego przedłużenia o dodatkowy okres. Następnie fundusz jest zamykany i pierwotnie zainwestowany kapitał powiększony/pomniejszony o efekty ekonomiczne jego działalności jest dystrybuowany do kapitałodawców funduszu (zob. schemat 2.1).

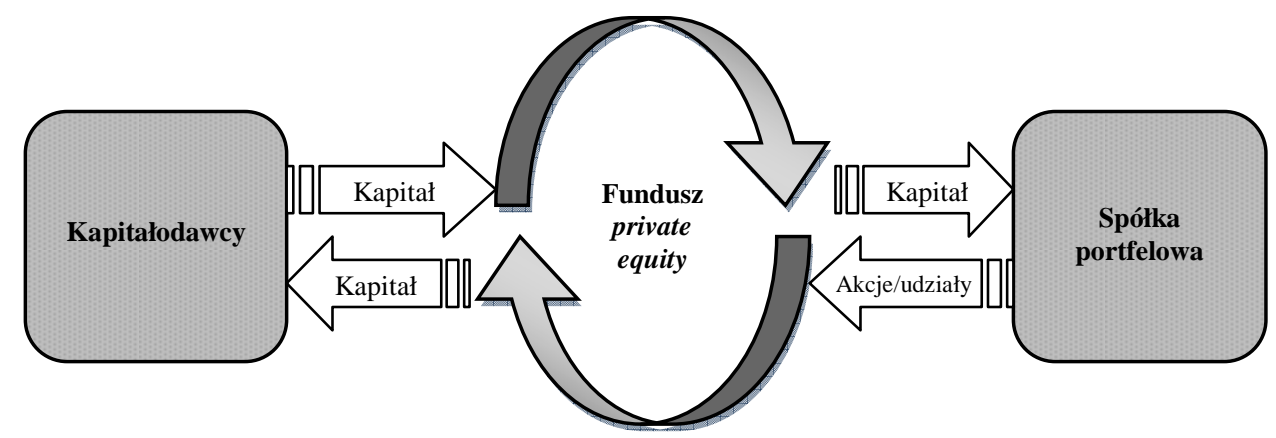

Schemat 2.1. Konwersja kapitału w procesie inwestycyjnym funduszu private equity Źródło: opracowanie własne.

W pierwszym etapie procesu inwestycyjnego następuje konwersja kapitału dostarczonego przez inwestorów funduszu na charakteryzujące się niskim stopniem płynności właścicielskie papiery wartościowe spółek posiadających potencjał wzrostu wartości rynkowej. W momencie likwidacji danego funduszu za-

${ }^{5}$ D. J. C u m ming, S. A. J o h a n, Venture capital and Private equity Contracting. An International Perspective, Elsevier 2009, s. 583.

${ }^{6} \mathrm{~K}$. S o b ań s k a, P. S i e r a d z a n, Inwestycje private equity/venture capital, Key Text, Warszawa 2004, s. 112.

${ }^{7}$ D. J. C u m ming, J. G. M a c In t o s h, A cross-country comparsion of full and partial venture capital exits, ,Journal of Banking \& Finance” 2003, Vol. 27, s. 512. 
chodzi konieczność ponownej transformacji posiadanych w portfelu inwestycyjnym funduszu private equity akcji i udziałów, jednakże w przeciwnym kierunku niż poprzednio. Papiery wartościowe o niskim stopniu płynności $\mathrm{w}$ procesie dezinwestycji wymieniane są na instrumenty finansowe o wysokim stopniu płynności, a te z kolei przekazywane są inwestorom, którzy wcześniej powierzyli funduszowi $w$ zarządzanie środki finansowe. Zwrot $\mathrm{z}$ inwestycji $\mathrm{w}$ fundusz private equity $\mathrm{w}$ określonych przypadkach może przybierać formę akcji bądź udziałów spółek z portfela inwestycyjnego funduszu. Sytuację taką należy uznać jednak za wysoce niepożądaną z punktu widzenia kapitałodawców funduszu. Będą oni bowiem narażeni na skutki ograniczonej płynności takich aktywów. Ponadto, w wyniku posiadania niewielkich udziałów w kapitale zakładowym określonych spółek, ograniczona zostanie możliwość sprawowania nad nimi efektywnego nadzoru korporacyjnego ${ }^{8}$.

Drugą przesłanką realizacji wyjścia z inwestycji jest obligatoryjność maksymalizacji efektów ekonomicznych działalności inwestycyjnej funduszu private equity. Wynika ona z potrzeby kreowania przewagi konkurencyjnej private equity nad alternatywnymi możliwościami lokowania kapitału. Wraz z rozwojem przedsiębiorstw, będących przedmiotem inwestycji funduszy private equity, zwiększa się ich skala działania, zmniejsza się ryzyko inwestycyjne, a w konsekwencji trudne bądź niemożliwe staje się również otrzymanie nadzwyczajnej stopy zwrotu z zainwestowanego kapitału'. Możliwości stymulowania wzrostu wartości przedsiębiorstw wchodzących w skład portfela inwestycyjnego funduszy private equity są największe na początku zaangażowania kapitałowego funduszu w spółki. Krańcowa wartość dodana, wynikająca $\mathrm{z}$ wprowadzenia dyscypliny finansowej, doradztwa $\mathrm{w}$ zakresie zarządzania operacyjnego, wyznaczenia strategicznych kierunków rozwoju przedsiębiorstwa, z biegiem czasu maleje ${ }^{10}$. Spółki portfelowe stają się więc stopniowo przedmiotem inwestycji znajdującym się w obszarze zainteresowania inwestorów charakteryzujących się niższą awersją do ryzyka, jak również dla inwestorów wymagających od potencjalnego celu przejęcia osiągnięcia istotnej skali działania lub znaczącego udziału w rynku niż dla funduszy private equity, które są zainteresowane przede wszystkim uzyskiwaniem wysokiej stopy zwrotu z inwestycji ${ }^{11}$. Restrukturyzacja portfela inwestycyjnego oraz reinwestowanie kapitału uzyskanego w wyniku dezinwestycji w kolejne innowacyjne przedsiębiorstwa umożliwia funduszom osiąganie wysokiego poziomu efektywności, mierzonego wysokością stopy zwrotu z inwestycji ${ }^{12}$.

\footnotetext{
${ }^{8}$ G. W. Fenn, N. Li an g, S. Prowse, op. cit., s. 34.

${ }^{9}$ M. W rze sińs ki, Kapitał podwyższonego ryzyka..., op. cit., s. 225.

${ }^{10}$ D. J. C u m min g, J. G. M a c In to s h, Venture-capital exits in Canada and United States, „University of Toronto Law Journal” 2003, s. 110.

${ }^{11}$ M. W r ze s i ń s ki, Kapitat podwyższonego ryzyka..., op. cit., s. 225.

${ }^{12}$ B. S. B lack, R. J. Gils o n, op. cit., s. 245.
} 
Zdaniem B. S. Blacka i R. J. Gilsona przeprowadzone dezinwestycje wpływają znacząco na strukturę i ekonomikę funkcjonowania rynku kapitału podwyższonego ryzyka. Cena, po jakiej zostanie sprzedana spółka portfelowa, stanowi bowiem miarę zdolności menedżerów danego funduszu w zakresie budowania wartości przedsiębiorstw będących przedmiotem inwestycji ${ }^{13}$. Przewaga inwestowania poprzez fundusze private equity nad bezpośrednimi inwestycjami w przedsiębiorstwa prowadzące działalność gospodarczą wynika z posiadania przez fundusze specyficznej wiedza i kompetencji. Atuty te nie mają charakteru uniwersalnego i w różnym stopniu mogą przystawać do występującej w danym momencie sytuacji gospodarczej, a także pojawiających się okazji rynkowych. Poziom rentowności zrealizowanych projektów inwestycyjnych stanowi benchmark pozwalający na ocenę możliwości generowania wysokich zysków z inwestycji w ramach danego funduszu. Dezinwestycja umożliwia transfer środków z funduszy zapewniających mniejszy zwrot z zainwestowanego kapitału do jednostek o wyższym stopniu sprawności operacyjnej ${ }^{14}$. Taka obiektywna ewaluacja kompetencji osób zarządzających powierzonym kapitałem pozwala w przyszłości na realokację posiadanych zasobów z funduszy osiągających słabe wyniki inwestycyjne do podmiotów, które są zdolne wypracować wyższy poziom zysków kapitałowych. Poniekąd można stwierdzić, iż dezinwestycja sama w sobie jest elementem działalności funduszy private equity stymulującym wzrost ich efektywności. W perspektywie długoterminowej efektywne dezinwestycje stanowią bowiem ekonomiczne uzasadnienie istnienia określonych funduszy na rynku.

Możliwość realizacji wyjścia $\mathrm{z}$ inwestycji jest brana pod uwagę przez fundusze private equity jako kryterium wyboru przedsiębiorstw udziałowych w początkowej fazie selekcji projektów inwestycyjnych. W swoich badaniach A. Kornasiewicz wskazuje, iż kryterium to uwzględnia $63,6 \%$ badanych funduszy, przy czym daje się zauważyć następującą prawidłowość - im większe zaangażowanie kapitałowe w inwestycję, tym większą wagę przywiązuje się do tego kryterium ${ }^{15}$. W grupie funduszy o kapitale powyżej 100 mln USD aż 85,7\% respondentów wskazało na istotne znaczenie tego czynnika. Ponadto A. Kornasiewicz podkreśla, iż inne kryteria selekcji projektów uwzględniane na etapie analizy przedinwestycyjnej sprawiają, że wyjście z inwestycji staje się łatwiejsze. Są to głównie ${ }^{16}$ :

- dobra strategia rozwoju przedsiębiorstwa (77,3\% respondentów),

- wysokie kwalifikacje kadry zarząazającej (81,8\% respondentów),

- przewidywana rentowność spółki (81,8\% respondentów),

- atrakcyjna branża (68,2\% respondentów).

${ }^{13}$ Ibidem, s. 246.

${ }^{14}$ Ibidem, s. 255-256.

${ }^{15}$ A. Korna siewicz, Venture capital $w$ krajach rozwiniętych $i$ w Polsce, CeDeWu, Warszawa 2004, s. 220-222.

${ }^{16}$ Ibidem, s. 221. 
Fundusze private equity dążą do uregulowania już w umowie inwestycyjnej zasadniczych kwestii związanych z zakończeniem inwestycji (zob. tab. 2.1).

Tabela 2.1

Klauzule stosowane w umowach inwestycyjnych przez fundusze private equity związane $\mathrm{z}$ procesem dezinwestycji

\begin{tabular}{|c|c|}
\hline $\begin{array}{l}\text { Rodzaj klauzuli } \\
\text { umownej }\end{array}$ & Opis \\
\hline $\begin{array}{l}\text { Prawo przymuszenia } \\
\text { do sprzedaży } \\
\text { (ang. drag-along } \\
\text { clauses) }\end{array}$ & $\begin{array}{l}\text { Ma zastosowanie w sytuacji sprzedaży przedsiębiorstwa stronie trze- } \\
\text { ciej. Podmiot posiadający to prawo może zażądać od pozostałych } \\
\text { właścicieli, aby oni również dołączyli do transakcji i sprzedali stro- } \\
\text { nie nabywającej, jeżeli tylko zgłosi ona taką wolę, posiadane w spół- } \\
\text { ce akcje bądź udziały na identycznych warunkach. Prawo to pozwala } \\
\text { wyeliminować ryzyko opóźniania bądź blokowania sprzedaży spółki } \\
\text { przez pozostałych wspólników, którzy nie są zainteresowani jej } \\
\text { przeprowadzeniem. Z reguły przysługuje ono funduszowi private } \\
\text { equity, który nawet w sytuacji posiadania pakietów akcji nie gwaran- } \\
\text { tujących pełnej kontroli nad przedsiębiorstwem jest w stanie spraw- } \\
\text { nie przeprowadzić proces dezinwestycji. }\end{array}$ \\
\hline $\begin{array}{l}\text { Prawo pierwokupu } \\
\text { (ang. pre-emption } \\
\text { right) }\end{array}$ & $\begin{array}{l}\text { Podmiot uprawniony posiada pierwszeństwo kupna akcji bądź udzia- } \\
\text { łów od pozostałych wspólników po cenie odzwierciedlającej ich } \\
\text { wartość godziwą, w sytuacji zgłoszenia przez zbywających chęci } \\
\text { sprzedaźy tychże papierów wartościowych stronie trzeciej. Wartość } \\
\text { godziwa jest na ogół w takiej sytuacji interpretowana jako cena, za } \\
\text { którą nowy inwestor jest skłonny nabyć przedmiot transakcji. Prawo } \\
\text { to pozwala uniknąć sytuacji, gdzie w spółce pojawi się niechciany } \\
\text { nowy wspólnik, a układ sił w przedsiębiorstwie zostanie zmieniony } \\
\text { na niekorzyść dotychczasowych właścicieli. }\end{array}$ \\
\hline $\begin{array}{l}\text { Prawo przyłączenia } \\
\text { (ang. tag-along } \\
\text { clauses) }\end{array}$ & $\begin{array}{l}\text { Zapis ten wyklucza sytuację, w której jeden wspólnik sprzedaje posia- } \\
\text { dane udziały w spółce inwestorowi zewnętrznemu, uniemożliwiając } \\
\text { posiadaczowi tego prawa przyłączenie się do sprzedaży. Wspólnik, } \\
\text { posiadający to prawo może żądać, aby zbywający sprzedał również } \\
\text { jego akcje na identycznych warunkach, ewentualnie włączył je pro- } \\
\text { porcjonalnie do transakcji sprzedaży. Dzięki temu, że dany podmiot } \\
\text { nie może zbyć tylko swoich udziałów w spółce, prawo to zapobiega } \\
\text { wykluczeniu z transakcji sprzedaży np. akcjonariuszy mniejszościo- } \\
\text { wych, jeżeli to na ich rzecz zapis ten został poczyniony. }\end{array}$ \\
\hline $\begin{array}{l}\text { Prawo włączenia akcji } \\
\text { do oferty publicznej } \\
\text { (ang. piggy-back } \\
\text { rights) }\end{array}$ & $\begin{array}{l}\text { Zapis ten uprawnia akcjonariusza do włączenia posiadanych przez } \\
\text { niego akcji spółki do publicznej oferty sprzedaży, proporcjonalnie do } \\
\text { udziału w kapitale zakładowym. Dzięki temu, żaden akcjonariusz nie } \\
\text { może być wykluczony ze sprzedaży posiadanych akcji poprzez gieł- } \\
\text { dę papierów wartościowych. }\end{array}$ \\
\hline $\begin{array}{l}\text { Prawo żądania zgody } \\
\text { na wprowadzenie akcji } \\
\text { do publicznego obrotu } \\
\text { (ang. demand rights) }\end{array}$ & $\begin{array}{l}\text { Posiadacz takiego prawa może żądać od pozostałych akcjonariusz } \\
\text { wyrażenia zgody na wprowadzenie akcji spółki do publicznego ob- } \\
\text { rotu. Zapobiega to sytuacji, kiedy pozostali akcjonariusze chą } \\
\text { uniemożliwić lub opóźnić debiut giełdowy. }\end{array}$ \\
\hline
\end{tabular}

Źródło: opracowanie własne na podstawie C. B i en z, U. W alz, Venture Capital Exit Rights, CFS Working Paper No. 05, 2009, s. 8. 
W późniejszych etapach rozwoju spółek portfelowych mogą pojawić się rozbieżne oczekiwania różnych grup interesariuszy w kwestii dalszych jej losów. Wprowadzenie do umowy inwestycyjnej odpowiednich klauzul regulujących proces zbywania posiadanych akcji bądź udziałów pozwala zapobiegać potencjalnym nieporozumieniom i ewentualnym konfliktom ${ }^{17}$. M. Wrzesiński wskazuje, że jednym z głównych źródeł konfliktów pomiędzy funduszem private equity i pozostałymi akcjonariuszami jest niezgodność co do czasu i sposobu wyjścia z inwestycji. Najczęściej spór wynika z tego, iż fundusz jest zdecydowany by zrealizować wyjście z inwestycji, podczas gdy pozostali akcjonariusze nie są tym zainteresowani bądź chcą odsunąć ten moment w czasie ${ }^{18}$.

\subsection{Charakterystyka sposobów wyjścia $\mathrm{z}$ inwestycji funduszy private equity}

Dezinwestycja stanowi finalny etap w cyklu życia każdego przedsięwzięcia kapitałowego realizowanego przez fundusze private equity. Jest ona bowiem swoistego rodzaju ukoronowaniem starań inwestorów o realizację określonej rentowności powierzonego im w zarządzanie kapitału, ulokowanego w spółkę kapitałową wyróżniającą się potencjałem wzrostu wartości rynkowej.

Wyjście z inwestycji przybierać może zróżnicowane formy, tym samym tworzyć funduszom private equity odmienne szanse osiągnięcia sukcesu ekonomicznego. Fundusze private equity mają do dyspozycji pięć podstawowych metod zakończenia współpracy ze spółką portfelową ${ }^{19}$. Są to:

- wprowadzenie akcji spółki do publicznego obrotu i ich sprzedaż za pośrednictwem giełdy papierów wartościowych,

- sprzedaż spółki strategicznemu inwestorowi branżowemu,

- wykup menedżerski,

- zbycie udziałów na rzecz innego inwestora finansowego oraz

- umorzenie udziałów/likwidacja spółki.

\subsubsection{DEZINWESTYCJA POPRZEZ WPROWADZENIE AKCJI SPÓŁKI DO PUBLICZNEGO OBROTU I ICH SPRZEDAŻ ZA POŚREDNICTWEM GIELDY PAPIERÓW WARTOŚCIOWYCH}

Pierwsza oferta publiczna (ang. initial public offering) uznawana jest za klasyczną i najbardziej atrakcyjną formę wyjścia $\mathrm{z}$ inwestycji funduszy private equ-

${ }^{17}$ C. B i en z, U. W a l z, Venture capital Exit Rights, CFS Working Paper No. 05, 2009, s. 8.

${ }^{18}$ M. Wr ze siń s ki, Kapitat podwyższonego ryzyka..., op. cit., s. 221.

${ }^{19}$ Por. P. Z a s ęp a, Venture capital - sposoby dezinwestycji, CeDeWu.pl Wydawnictwa Fachowe, Warszawa 2010, s. 90-91; K. S o b ań s k a, P. S i e r a d z a n, op. cit., s. 115. 
$i t y^{20}$. W środowisku osób aktywnych na rynku kapitału podwyższonego ryzyka postrzega się ją jako niemalże „Święty Graal”21. Nie jest to jednak metoda uniwersalna, która może być wykorzystana do realizacji zysku kapitałowego z każdej inwestycji. Znajduje ona zastosowanie tylko spółek w miarę dużych, o znaczącym poziomie rentowności, rosnących zyskach, przejrzystych strukturach organizacyjnych i przepływach finansowych ${ }^{22}$.

Określenie pierwsza oferta publiczna w literaturze przedmiotu jest traktowane bardzo ogólnie i bywa różnie interpretowane ${ }^{23}$. Rozumiane jest jako oferowanie po raz pierwszy w sposób publiczny akcji danej spółki i utożsamiane jest z jej debiutem giełdowym ${ }^{24}$. Pierwszą ofertą może być:

- emisja akcji po raz pierwszy za pośrednictwem rynku publicznego (pierwsza subskrypcja) oraz

- sprzedaż przez obecnych akcjonariuszy akcji już istniejących, ale po raz pierwszy za pośrednictwem rynku publicznego (pierwsza sprzedaż) ${ }^{25}$.

Zgodnie z zapisami Ustawy z dnia 29 lipca 2005 r. o ofercie publicznej $i$ warunkach wprowadzania instrumentów finansowych do zorganizowanego systemu obrotu oraz spótkach publicznych ofertą publiczną jest udostępnianie, co najmniej 100 osobom lub nieoznaczonemu adresatowi, w dowolnej formie i w dowolny sposób, informacji o papierach wartościowych i warunkach dotyczących ich nabycia, stanowiących dostateczną podstawę do podjęcia decyzji o odpłatnym nabyciu tych papierów wartościowych ${ }^{26}$. Natomiast przez pierwszą ofertę publiczną rozumie się dokonywaną po raz pierwszy ofertę publiczną dotyczącą określonych papierów wartościowych ${ }^{27}$.

Procedura wprowadzenia akcji danej spółki do publicznego obrotu, a w konsekwencji umożliwienie sprzedaży funduszowi private equity posiadanych akcji, jest długotrwałym i skomplikowanym procesem wymagającym podjęcia szeregu działań biznesowych i formalnoprawnych, w realizację którego zaangażowanych jest wiele podmiotów na poszczególnych etapach (zob. schemat 2.2).

${ }^{20} \mathrm{~J} . \mathrm{W}$ ę cław ski, Venture capital: nowy instrument finansowania przedsiębiorstw, Wydawnictwo Naukowe PWN, Warszawa 1997, s. 181.

${ }^{21}$ J. W all, J. S mith, op. cit., s. 8.

${ }^{22}$ K. S ob ań ska, P. S i er adzan,op. cit., s. 122.

${ }^{23}$ R. S ob otni k, Pierwsza oferta publiczna - zmieniajace się trendy, [w:] A. S zable w s k i (red.), Migracja kapitału w globalnej gospodarce, Difin, Warszawa 2009, s. 268-269. s. $12-13$.

${ }^{24}$ P. S i w e k, Praktyka pierwszych ofert publicznych w Polsce, CeDeWu.pl, Warszawa 2005,

${ }^{25}$ Ibidem, s. 13.

${ }^{26}$ Art. 3, pkt. 3 Ustawy z dnia 29 lipca 2005 r. o ofercie publicznej $i$ warunkach wprowadzania instrumentów finansowych do zorganizowanego systemu obrotu oraz spótkach publicznych, DzU 2005, nr 184, poz. 1539.

${ }^{27}$ Art. 4, pkt. 5, Ustawy z dnia 29 lipca 2005 r..., op. cit. 
Faza I: Przygotowanie spółki do IPO

- dostosowanie sprawozdawczości finansowej do wymogów obowiązujących spółki publiczne;

- $\quad$ podjęcie uchwały WZA w sprawie przeprowadzenia pierwszej oferty publicznej i wprowadzenia akcji spółki do publicznego obrotu;

- $\quad$ wybór biegłego rewidenta i podmiotu oferującego akcje (domu maklerskiego lub banku prowadzącego działalność maklerską).

Faza II: Przygotowanie i złożenie prospektu emisyjnego,
postępowanie przed KNF
$\bullet \begin{aligned} & \text { analizy due diligence oraz wycena spółki; } \\ & \text { sporządzenie prospektu emisyjnego i jego skrótu; } \\ & \text { złożenie prospektu emisyjnego do Komisji Nadzoru Finansowego } \\ & \text { z wnioskiem o zatwierdzenie; } \\ & \text { zatwierdzenie prospektu emisyjnego przez KNF; } \\ & \text { publikacja prospektu emisyjnego. }\end{aligned}$

Schemat 2.2. Sekwencja działań w procesie pierwszej oferty publicznej

Źródło: opracowanie własne na podstawie Droga na giełdę. Jak przygotować spótkę do emisji publicznej, praca zbiorowa ekspertów BDO, Difin, Warszawa 2008, s. 175-429; P. S i w e k, Praktyka pierwszych ofert publicznych w Polsce, CeDeWu.pl, Warszawa 2005, s. 68-80. 
Proces wchodzenia spółki na warszawską giełdę trwa średnio 6-9 miesięcy, licząc od momentu podjęcia formalnej decyzji właścicieli spółki w tym zakresie do rozpoczęcia notowań jej akcji na rynku publicznym ${ }^{28}$.

Jednym $\mathrm{z}$ najistotniejszych działań umożliwiających funduszowi private equity wyjście z inwestycji przez giełdę papierów wartościowych jest sporządzenie prospektu emisyjnego.

Prospekt emisyjny jest najważniejszym źródłem informacji dla potencjalnych nabywców akcji spółki o prowadzonej działalności i związanych z nią czynnikach ryzyka, sytuacji finansowo-majątkowej, strukturze organizacyjnej, powiązaniach kapitałowych, jak również o historii jej działania i dotychczasowych właścicielach. Przedstawia on całościowy obraz spółki. Prospekt emisyjny jest dokumentem szczególnego rodzaju. Jego treść i forma określone są przepisami prawa ${ }^{29}$.

W literaturze przedmiotu jako główny motyw dążeń przedsiębiorstw do uzyskania statusu spółki publicznej wskazuje się chęć pozyskania dodatkowego kapitału na rozwój ${ }^{30}$. Poprzez publiczną emisję akcji spółka zyskuje dostęp do alternatywnych względem systemu bankowego źródeł finansowania prowadzonej działalności.

Przedsiębiorstwa dzięki posiadaniu statusu spółki publicznej zyskują również możliwości większego, tańszego i łatwiejszego pozyskania kapitału z banków. M. Pagano, F. Panetta oraz L. Zingales wskazują, że w grupie przedsiębiorstw, które zadebiutowały na rynku giełdowym można zaobserwować zmniejszenie kosztu kredytu bankowego oraz zmniejszenie koncentracji jego źródeł ${ }^{31}$. Spółki publiczne posiadały kredyty w większej liczbie banków w porównaniu $\mathrm{z}$ okresem poprzedzającym debiut giełdowy, przez co zmniejszyły swoje ryzyko finansowe.

Wzrost zdolności spółek publicznych do pozyskiwania kapitału w formie kredytów bankowych może wynikać głównie z dwóch powodów. Po pierwsze, konsekwencją emisji nowych akcji jest zmiana struktury pasywów spółki. Następuje zwiększenie kapitału własnego, przez co zwiększa się zdolność przed-

${ }^{28}$ Droga na giełdę. Jak przygotować spótkę do emisji publicznej, praca zbiorowa ekspertów BDO, Difin, Warszawa 2008, s. 154.

${ }^{29}$ Zakres informacyjny prospektu emisyjnego określony został przez kombinację modułów i schematów w Rozporządzeniu Komisji (WE) Nr 809/2004 z dnia 29 kwietnia 2004 r. wykonujace dyrektywe 2003/71/WE Parlamentu Europejskiego $i$ Rady $w$ sprawie informacji zawartych w prospektach emisyjnych oraz formy, wtaczenia przez odniesienie i publikacji takich prospektów emisyjnych oraz rozpowszechniania reklam, DzUrz UE 2004, L 149/1.

${ }^{30}$ Zob. D. C u mming (red.), The Oxford Handbook of Entrepreneurial Finance, Oxford University Press, New York 2012, s. 468-469; W o oj in Ki m, M. S. W e i s b a ch, Do firms go public to raise capital?, NBER Working Paper Series, Working Paper 11197, http://www.nber.org/papers/w11197.

${ }^{31}$ M. Pagano, F. Panetta, L. Zingales, Why Do Companies Go Public? A Empirical Analysis, „The Journal of Finance” 1998, Vol. LIII, No. 1, s. 29. 
siębiorstwa do obsługi długu. Drugim czynnikiem wpływającym na wzrost zdolności kredytowej spółek giełdowych jest zwiększenie ich wiarygodności i transparentności w stosunkach $\mathrm{z}$ interesariuszami. Spółki publiczne podlegają wysokim standardom sprawozdawczości finansowej. Ich działania podlegają kontroli nie tylko ze strony właścicieli przedsiębiorstwa, ale również innych podmiotów działających na rynku kapitałowym.

W literaturze przedmiotu zwraca się również uwagę na inne pobudki skłaniające podmioty do uzyskania statusu spółki publicznej. Do motywów tych należą: wykorzystanie sprzyjających warunków rynkowych, uczestnictwo w rynku fuzji i przejęć, uzyskanie dodatkowych korzyści wynikających z premii pierwszeństwa wśród przedsiębiorstw z danej branży, redukcja kosztów agencji $^{32}$.

Spotkać się można również z opinią, że decyzja o upublicznieniu spółki jest naturalnym etapem w swoistym cyklu życia przedsiębiorstwa. Po uzyskaniu pewnego poziomu wzrostu dalszy rozwój spółki możliwy jest bowiem przez jej wejście na publiczny rynek papierów wartościowych ${ }^{33}$. W praktyce gospodarczej zaobserwować jednakże można wiele przykładów wskazujących, iż duże oraz posiadające silną i ugruntowaną pozycję na rynku przedsiębiorstwa nie decydują się na debiut giełdowy. Sytuację taką można m. in. zaobserwować w gospodarkach, gdzie rynek kapitałowy nie jest dostatecznie rozwinięty i nie stanowi centralnego punktu rynku finansowego.

$\mathrm{Z}$ punktu widzenia inwestorów działających na rynku private equity można wskazać dwa kluczowe powody skłaniające do podjęcia decyzji o wprowadzeniu akcji spółki do publicznego obrotu.

Przede wszystkim, pierwsza oferta publiczna jest metodą realizacji zamierzonych dezinwestycji. Fundusz private equity może sprzedać posiadane w portfelu inwestycyjnym akcje i zrealizować oczekiwany zysk kapitałowy. Motyw ten istotny jest również dla innych grup inwestorów dążących do wyjścia $\mathrm{z}$ inwestycji, np. w przypadku realizowanych procesów prywatyzacji majątku Skarbu Państwa.

Z kolei, dla pierwotnych właścicieli spółek portfelowych funduszy private equity istotną przesłanką debiutu giełdowego jest możliwość odzyskania kontroli nad przedsiębiorstwem. W wyniku publicznej sprzedaży akcji spółki portfelowej przez fundusz następuje zmiana struktury właścicielskiej spółki objętej procesem dezinwestycji. Dotychczas silnie skoncentrowane, konsekwentnie egzekwowane przez fundusz prawa majątkowe i korporacyjne mogą zostać rozproszone na wielu drobnych, często niezainteresowanych aktywnym nadzorem właścicielskim inwestorów. Chociaż udział pierwotnego właściciela w kapitale

${ }^{32}$ J. R. Ritte r, I. W e lc h, A Review of IPO Activity, Pricing and Allocations, „,The Journal of Finance" 2002, Vol. LVII, No. 4, s. 1796-1799.

${ }^{33}$ Ibidem, s. 1822. 
spółki nie zwiększa się, to jego faktyczne możliwości wpływu na jej funkcjonowanie znacznie rosną.

Według raportu Kierunek - Giełda: przebieg procesu wchodzenia spótek na Giełdę Papierów Wartościowych w Warszawie w latach 2004-2006 głównym powodem podejmowania starań przedsiębiorstw o debiut giełdowy była chęć pozyskania dodatkowego kapitału na rozwój spółki ${ }^{34}$. Przeto, rynek giełdowy jest ważnym miejscem realizacji procesów dezinwestycji dla różnych grup inwestorów. Aż $41 \%$ respondentów stwierdziło, iż relewantną przesłanką debiutu giełdowego jest chęć sprzedaży akcji spółki przez jej dotychczasowych akcjonariuszy (zob. wykres 2.1).

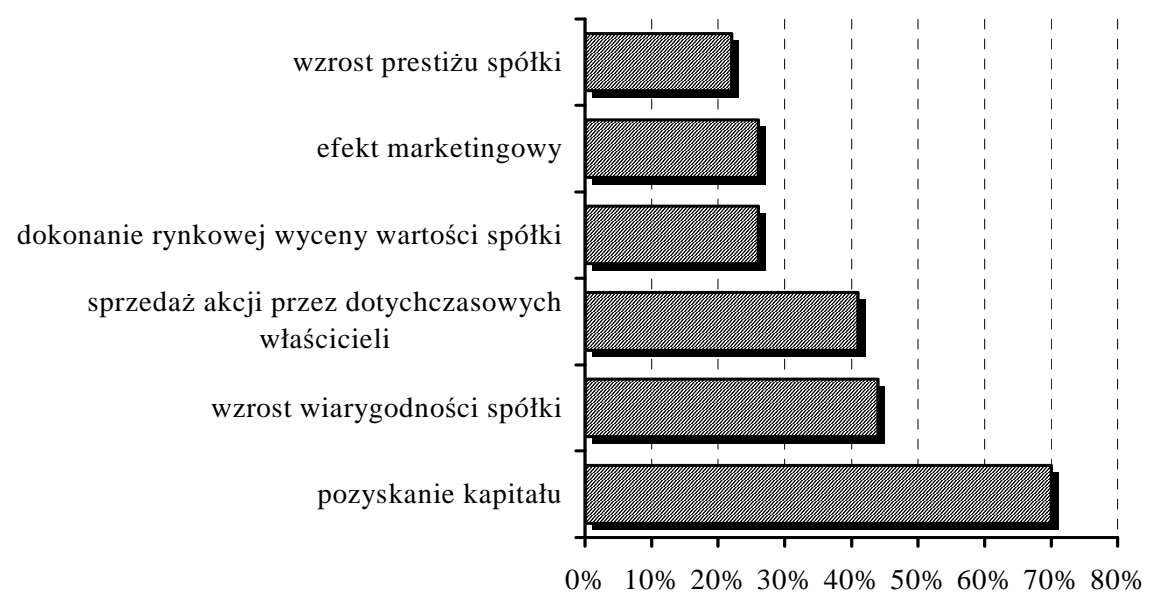

Wykres 2.1. Motywy debiutów giełdowych

Źródło: opracowanie własne na podstawie Kierunek - Giełda: przebieg procesu wchodzenia spótek na Gietdę Papierów Wartościowych w Warszawie w latach 2004-2006, Raport KPMG/GPW, Warszawa 2006, s. 6.

Sprzedaż akcji za pośrednictwem giełdy papierów wartościowych uchodzi za preferowaną przez zarządzających inwestycjami funduszy private equity metodę realizacji zysku kapitałowego. Związane jest to z jej licznymi zaletami oraz przewagami w stosunku do pozostałych form dezinwestycji. Nie jest to jednak rozwiązanie wolne od wad będących źródłem określonego ryzyka. Zawarte w tab. 2.2 zestawienie wad i zalet pierwszej oferty publicznej jako metody wyjścia z inwestycji funduszy private equity, pozwala dostrzec liczne i zarazem różnorodne w swym charakterze i skutkach przesłanki i ograniczenia stosowania tej metody dezinwestycji.

${ }^{34}$ Kierunek - Giełda: przebieg procesu wchodzenia spótek na Giełdę Papierów Wartościowych w Warszawie w latach 2004-2006, Raport KPMG/GPW, Warszawa 2006, s. 6. 
Wady i zalety pierwszej oferty publicznej jako metody wyjścia z inwestycji funduszy private equity

\begin{tabular}{|c|c|}
\hline $\begin{array}{l}\text { Zalety dezinwestycji w formie pierwszej } \\
\text { oferty publicznej }\end{array}$ & $\begin{array}{l}\text { Wady dezinwestycji w formie pierwszej } \\
\text { oferty publicznej }\end{array}$ \\
\hline 1 & 2 \\
\hline $\begin{array}{l}\text { Możliwość uzyskania najwyższej wyceny } \\
\text { spółki }\end{array}$ & Wysokie koszt transakcji \\
\hline $\begin{array}{l}\text { W przeszłości spółki portfelowe sprzedawane } \\
\text { poprzez giełdę uzyskiwały wyższą wycenę } \\
\text { w porównaniu z przedsiębiorstwami objętymi } \\
\text { innymi formami dezinwestycji. Inwestorzy } \\
\text { nabywający akcje publicznych spółek płacą } \\
\text { swoistą premię za płynność, która może } \\
\text { przewyższać premie za kontrolę występującą } \\
\text { np. w sprzedaży udziałów inwestorowi bran- } \\
\text { żowemu, innemu inwestorowi private equity. }\end{array}$ & $\begin{array}{l}\text { Wprowadzenie akcji do publicznego obrotu } \\
\text { związane jest z koniecznością poniesienia } \\
\text { nierzadko znacznych kosztów, wynikających } \\
\text { np. z obowiązku wypełnienia wymogów } \\
\text { prawnych, dodatkowych obowiązków in- } \\
\text { formacyjnych oraz innych opłat. }\end{array}$ \\
\hline Preferowana przez kierownictwo spółki & $\begin{array}{l}\text { Długi oraz skomplikowany proces } \\
\text { przygotowań i realizacji }\end{array}$ \\
\hline $\begin{array}{l}\text { Wzrost dywersyfikacji akcjonariatu związany } \\
\text { jest ze zwiększeniem swobody decyzyjnej } \\
\text { zarządzających spółką. Jednocześnie dzięki } \\
\text { posiadaniu statusu spółki publicznej zwięk- } \\
\text { sza się jej atrakcyjność w oczach obecnych } \\
\text { i potencjalnych partnerów biznesowych. }\end{array}$ & $\begin{array}{l}\text { Przygotowanie prospektu emisyjnego, kampa- } \\
\text { nii marketingowej oraz wypełnienie obo- } \\
\text { wiązków formalnych związanych z pierwszą } \\
\text { ofertą publiczną wymaga znacznego zaanga- } \\
\text { żowania kierownictwa wyższego szczebla, } \\
\text { pracowników, przedstawicieli funduszu pri- } \\
\text { vate equity oraz licznych doradców. }\end{array}$ \\
\hline $\begin{array}{l}\text { Udziały kapitałowe jako zachęty } \\
\text { dla interesariuszy }\end{array}$ & $\begin{array}{l}\mathrm{Z} \text { reguły możliwe tylko częściowe } \\
\text { natychmiastowe wyjście z inwestycji }\end{array}$ \\
\hline $\begin{array}{l}\text { Programy motywacyjne oparte o akcje i opcje } \\
\text { na akcje stanowią komplementarną i wysoce } \\
\text { skuteczną formę zachęt dla pracowników. } \\
\text { Inne grupy interesariuszy, np. klienci, do- } \\
\text { stawcy czy partnerzy strategiczni mogą na- } \\
\text { bywać akcje spółki portfelowej w celu } \\
\text { umocnienia wzajemnych relacji bizneso- } \\
\text { wych. }\end{array}$ & $\begin{array}{l}\text { Ofertom publicznym spółek często towarzy- } \\
\text { szy zobowiązanie dotychczasowych właści- } \\
\text { cieli do niesprzedawania posiadanych akcji } \\
\text { przez z góry określony czas (lock-up). Kon- } \\
\text { tynuacja zaangażowania kapitałowego fun- } \\
\text { duszu private equity w spółkę związana jest } \\
\text { z koniecznością dalszego monitorowania jej } \\
\text { działalności. }\end{array}$ \\
\hline Rozgłos i inne korzy & Ryzyko braku płynności \\
\hline $\begin{array}{l}\text { Debiuty giełdowe związane są ze znacznym } \\
\text { zainteresowaniem wszystkich uczestników } \\
\text { rynku kapitałowego i ogólnodostępnych, po- } \\
\text { pularnych mediów, np. telewizji, prasy itp. } \\
\text { Spółka publiczna może kształtować wizeru- } \\
\text { nek stabilnego, niezawodnego, godnego za- } \\
\text { ufania partnera biznesowego wobec wszyst- } \\
\text { kich grup interesariuszy. Wzrasta również } \\
\text { prestiż spółki na rynku rekrutacji kluczo- } \\
\text { wych pracowników. }\end{array}$ & $\begin{array}{l}\text { Zastrzeżenia w zakresie swobody zbywania } \\
\text { akcji przez dotychczasowych właścicieli } \\
\text { spółki mogą narażać nowych akcjonariuszy } \\
\text { na ryzyko występowania ograniczonej płyn- } \\
\text { ności i ich następstw w zakresie wyceny } \\
\text { rynkowej walorów. }\end{array}$ \\
\hline
\end{tabular}


Tabela 2.2 (cd.)

\begin{tabular}{|c|c|}
\hline 1 & 2 \\
\hline Prowokowanie ofert fuzji i przejęć & Konieczność przekonania wielu inwestorów \\
\hline $\begin{array}{l}\text { Rozgłos towarzyszący ofertom publicznym } \\
\text { często wywołuje zainteresowanie podmio- } \\
\text { tów aktywnych na rynku fuzji i przejęć, } \\
\text { prowokując atrakcyjne cenowo oferty. Wia- } \\
\text { rygodne informacje przygotowywane i pu- } \\
\text { blikowane w procesie oferty publicznej } \\
\text { mogą zaspokoić wymagania informacyjne } \\
\text { potencjalnych kupujących, a w konsekwen- } \\
\text { cji umożliwić szybką i sprawną realizację } \\
\text { transakcji zbycia udziałów kapitałowych } \\
\text { w spółce. }\end{array}$ & $\begin{array}{l}\text { W przeciwieństwie do transakcji sprzedaży } \\
\text { spółki inwestorowi branżowemu, gdzie tyl- } \\
\text { ko jeden podmiot należy przekonać o per- } \\
\text { spektywach wzrostu wartości rynkowej } \\
\text { spółki, w procesie uwieńczonej sukcesem } \\
\text { oferty publicznej należy zachęcić wielu in- } \\
\text { westorów do nabycia akcji spółki. }\end{array}$ \\
\hline $\begin{array}{l}\text { Zachowanie potencjału przyszłego wzrostu } \\
\text { wartości }\end{array}$ & $\begin{array}{c}\text { Krótkoterminowa orientacja na } \\
\text { maksymalizację wyników działalności }\end{array}$ \\
\hline $\begin{array}{l}\text { Utrzymując częściowe zaangażowanie kapita- } \\
\text { łowe w spółkę portfelową po debiucie gieł- } \\
\text { dowym fundusz private equity może być } \\
\text { beneficjantem zysków wynikających z ge- } \\
\text { nerowanych w przyszłości wyników finan- } \\
\text { sowych oraz wzrostu wartości rynkowej } \\
\text { akcji. }\end{array}$ & $\begin{array}{l}\text { Spółki publiczne narażone są na silną presję } \\
\text { ze strony inwestorów giełdowych, nalega- } \\
\text { jących na ciągłą dynamiczną poprawę efek- } \\
\text { tywności prowadzonej działalności. Prowa- } \\
\text { dzić to może do zmiany spojrzenia na stra- } \\
\text { tegię rozwoju przedsiębiorstwa ze średnio- } \\
\text { lub długoterminowej perspektywy, w kie- } \\
\text { runku osiągania widocznych, krótkotermi- } \\
\text { nowych celów i wyników. }\end{array}$ \\
\hline Dostęp do nowego źródła finansowania & Rygorystyczne wymogi informacyjne \\
\hline $\begin{array}{l}\text { Wraz z realizacją procesu wyjścia z inwesty- } \\
\text { cji funduszu private equity w wielu przy- } \\
\text { padkach przeprowadzana jest również emi- } \\
\text { sja nowych akcji. Pochodzące z niej wpły- } \\
\text { wy trafiają do spółki i wykorzystywane są } \\
\text { do realizacji przyszłych działań prorozwo- } \\
\text { jowych. Spółki mają również możliwość } \\
\text { przeprowadzania kolejnych emisji w przy- } \\
\text { szłości. }\end{array}$ & $\begin{array}{l}\text { Spółki, których akcje notowane są na giełdzie } \\
\text { zobligowane są do przedstawiania opinii } \\
\text { publicznej wielu informacji dotyczących } \\
\text { prowadzonej działalności. Część z nich } \\
\text { może być wykorzystana przez konkurentów } \\
\text { ze szkodą dla spółki. }\end{array}$ \\
\hline \multirow[t]{2}{*}{$\cdot$} & Ryzyko związane z odwołaniem oferty \\
\hline & $\begin{array}{l}\text { Mając na uwadze rozgłos towarzyszący de- } \\
\text { biutom giełdowym, ryzyko związane z od- } \\
\text { wołaniem oferty publicznej spółki ma zde- } \\
\text { cydowanie większe znaczenie w porówna- } \\
\text { niu z innymi metodami dezinwestycji. } \\
\text { Spółki, które w przeszłości odwołały debiut } \\
\text { mogą mieć znaczne trudności z ponownym } \\
\text { dostępem do publicznych rynków kapita- } \\
\text { łowych. }\end{array}$ \\
\hline
\end{tabular}


Tabela 2.2 (cd.)

\begin{tabular}{|c|l|}
\hline 1 & \multicolumn{1}{|c|}{2} \\
\hline \hline$\cdot$ & Wyłącznie dla wąskiej grupy przedsiębiorstw \\
& Dopuszczone do publicznego obrotu mogą \\
& zostać akcje wyłącznie spółek spełniających \\
& rygorystyczne wymagania ze strony regula- \\
& torów rynku. Poza kryteriami formalnymi \\
& oferowane przedsiębiorstwa muszą również \\
& stanowić interesujący cel inwestycyjny dla \\
& wymagających inwestorów giełdowych. \\
& W rezultacie pierwsza oferta publiczna prze- \\
& znaczona jest dla dużych spółek, charaktery- \\
& zujących się określoną rentownością, generu- \\
& jących odpowiednie przepływy pieniężne \\
& oraz nadal posiadających potencjał wzrostu \\
& wartości. \\
\hline
\end{tabular}

Źródło: opracowanie własne na podstawie S. Povaly, Private equity exits: Divestment process management for leveraged buyouts, Springer, Berlin Heidelberg 2007, s. 252-253.

\subsubsection{RYNEK FUZJI I PRZEJĘĆ PRZEDSIĘBIORSTW JAKO MIEJSCE REALIZACJI PROCESÓW WYJŚCIA Z INWESTYCJI FUNDUSZY PRIVATE EQUITY}

Rynek fuzji i przejęć przedsiębiorstw stanowi wraz z giełdą papierów wartościowych bardzo ważne miejsce realizacji procesów wyjścia z inwestycji funduszy private equity. $\mathrm{Z}$ jednej strony rynek ten umożliwia zaangażowania kapitału w nowe przedsięwzięcia, z drugiej zaś stwarza sposobność wyjścia z inwestycji $^{35}$.

Można wskazać dwie główne metody dezinwestycji realizowane na rynku fuzji i przejęć, a mianowicie:

- sprzedaż spółki strategicznemu inwestorowi branżowemu (ang. trade sale) oraz

- zbycie akcji/udziałów spółki portfelowej na rzecz inwestora finansowego (ang. secondary sale, secondary buyout).

Pierwszy wskazany sposób wyjścia z inwestycji polega na sprzedaży akcji bądź udziałów niepublicznej spółki portfelowej, stanowiących własność funduszu private equity, na rzecz innego przedsiębiorstwa, niebędącego inwestorem finansowym ${ }^{36}$. Podmiot przejmujący przedsiębiorstwo udziałowe może prowadzić działalność w tej samej bądź pokrewnej branży lub też realizując strategię

\footnotetext{
${ }^{35}$ M. Wr ze siń s ki, Kapitał podwyższonego ryzyka..., op. cit., s. 240.

${ }^{36}$ K. S ob ań ska, P. Si e radzan,op. cit., s. 135.
} 
dywersyfikacji pochodzić z zupełnie innej gałęzi gospodarki. Z reguły w tego typu transakcjach wraz $\mathrm{z}$ funduszem private equity pierwotny właściciel przedsiębiorstwa również zbywa część lub całość posiadanych praw własności w spółce.

Druga metoda dezinwestycji realizowana przez fundusze private equity na rynku fuzji i przejęć polega na zbyciu akcji bądź udziałów spółki portfelowej na rzecz inwestora finansowego. Metodę tę od sprzedaży spółki strategicznemu inwestorowi branżowemu odróżnia charakter podmiotu nabywającego zbywane przez fundusz akcje bądź udziały. Nowymi właścicielami stają się bowiem instytucje finansowe prowadzące bezpośrednią działalność inwestycyjną poza publicznym rynkiem papierów wartościowych, np. inne fundusze private equity, banki, fundusze inwestycyjne, czy towarzystwa ubezpieczeniowe ${ }^{37}$. Pierwotni właściciele przedsiębiorstwa udziałowego często utrzymują lub redukują w nieznacznym stopniu swoje zaangażowanie w zbywane przedsiębiorstwo.

Szczególną formą realizacji wyjścia z inwestycji za pośrednictwem rynku $M \& A$ jest zastosowanie mechanizmu odwrotnego przejęcia (ang. reverse takeover). Ta specyficzna forma dezinwestycji polega na zbyciu spółki portfelowej przez fundusz private equity na rzecz innego inwestora $\mathrm{w}$ zamian za jego akcje/udziały. W wyniku realizacji tego typu transakcji fundusz private equity nie otrzymuje środków pieniężnych lub innych zbliżonych do nich charakterem form zapłaty. W zamian fundusz private equity staje się udziałowcem w nowej spółce, a jeżeli fundusz posiada już udziały podmiotu przejmującego, zwiększa w nim swoje dotychczasowe zaangażowanie kapitałowe.

Specyfika wskazanych powyżej form dezinwestycji polega na transferze kontroli nad podmiotem poddanym procesowi dezinwestycji na rzecz trzeciej strony. Kontrola ta powinna być pojmowana dwojako ${ }^{38}$ :

- jako kontrola nad działalnością gospodarczą przejmowanego przedsiębiorstwa, oraz

- kontrola nad samym przedsiębiorstwem.

Transfer kontroli dokonuje się przez objęcie własności dotychczasowych akcjonariuszy (udziałowców) przez inny podmiot, co w konsekwencji pozwala nowemu właścicielowi, poprzez uzyskanie pozycji większościowej, kontrolować zarówno sposób wykorzystania aktywów przedsiębiorstwa, jak i samą własność $^{39}$. W przypadku wyjścia z inwestycji w drodze sprzedaży spółki inwestorowi branżowemu następuje $\mathrm{z}$ reguły całkowite przekazanie kontroli nad zbywanym podmiotem, wcześniej przynależnej zarówno funduszowi private equity, jak i pierwotnemu właścicielowi spółki. Z kolei zbycie akcji/udziałów spółki portfelowej na rzecz inwestora finansowego wiąże się z przekazaniem upraw-

\footnotetext{
${ }^{37}$ Ibidem, s. 141.

${ }^{38}$ W. Frą c k ow i a k (red.), Fuzje i przejęcia, PWE, Warszawa 2009, s. 27.

${ }^{39}$ Ibidem, s. 27.
} 
nień kontrolnych należących do funduszu, a tylko w wybranych przypadkach temu procesowi towarzyszy deprecjacja pozycji pierwotnego właściciela przedsiębiorstwa.

Fundusze private equity prowadzące procesy wyjścia z inwestycji za pośrednictwem rynku fuzji i przejęć korzystają z pomocy podmiotów wspomagających sprawną realizację procesów sprzedażowych ${ }^{40}$. Wśród nich można wymienić chociażby banki inwestycyjne, firmy consultingowe, doradców prawnych, finansowych itp. Do głównych zalet współpracy funduszy private equity z tego typu podmiotami można zaliczyć:

- bazę kontaktów umożliwiającą skuteczne i sprawne poszukiwanie oraz selekcję potencjalnych nabywców,

- know-how z zakresu fuzji i przejęć, wzmacniający pozycję funduszu podczas negocjowania warunków transakcji,

- większą zdolność do oceny wiarygodności nabywcy oraz częściowej weryfikacji jego deklarowanych planów względem spółki,

- dysponowanie wiedzą o odległych geograficznie rynkach (np. azjatyckich), umożliwiającą przy tym pozyskanie inwestorów z tych regionów, co jest niezwykle utrudnione dla funduszy private equity prowadzących działalność inwestycyjną lokalnie,

- oferowanie wsparcia w przygotowaniu memorandum informacyjnego dla potencjalnych nabywców oraz dokumentacji związanej z procesem sprzedaży,

- współpracę z renomowanym doradcą pozwalającą na wykorzystanie jego marki do umocnienia posiadanej pozycji negocjacyjnej ${ }^{41}$.

Możliwości przeprowadzenia skutecznej transakcji wyjścia z inwestycji za pośrednictwem rynku fuzji i przejęć zależą także od źródeł korzyści dla podmiotów nabywających spółki portfelowe. Inwestor branżowy przejmując przedsiębiorstwo udziałowe funduszu private equity realizuje strategię ekspansji w oparciu o wzrost zewnętrzny ${ }^{42}$. Motywy, którymi kierują się zarządzający i właściciele przedsiębiorstw przy podejmowaniu decyzji o realizacji transakcji fuzji lub przejęcia mogą być liczne i zróżnicowane (zob. schemat 2.3$)^{43}$.

${ }^{40}$ R. da Silva Rosa, P. Lee, M. Skott, T. Walter, Competition in the Market for Takeover Advisers, „Australian Journal of Management” 2004, Vol. 29, s. 61-92; P. R. R a u, Investment bank market share, contingent fee payments, and the performance of acquiring firms, „Journal of Financial Economics” 2000, Vol. 56, s. 293-324.

${ }^{41}$ K. Sobańs ka, P. Sieradzan, op. cit., s. 136.

${ }^{42}$ M. Szymański, B. Nogalski, Obrona przed wrogim przejęciem, Wolters Kluwer, Warszawa 2011, s. 43.

${ }^{43}$ R. M a chała, Przejęcia i fuzje. Wptyw na wartość firm, Oficyna Wydawnicza UNIMEX, Wrocław 2007, s. 67. 
Motywy nabywców na rynku fuzji i przejęć

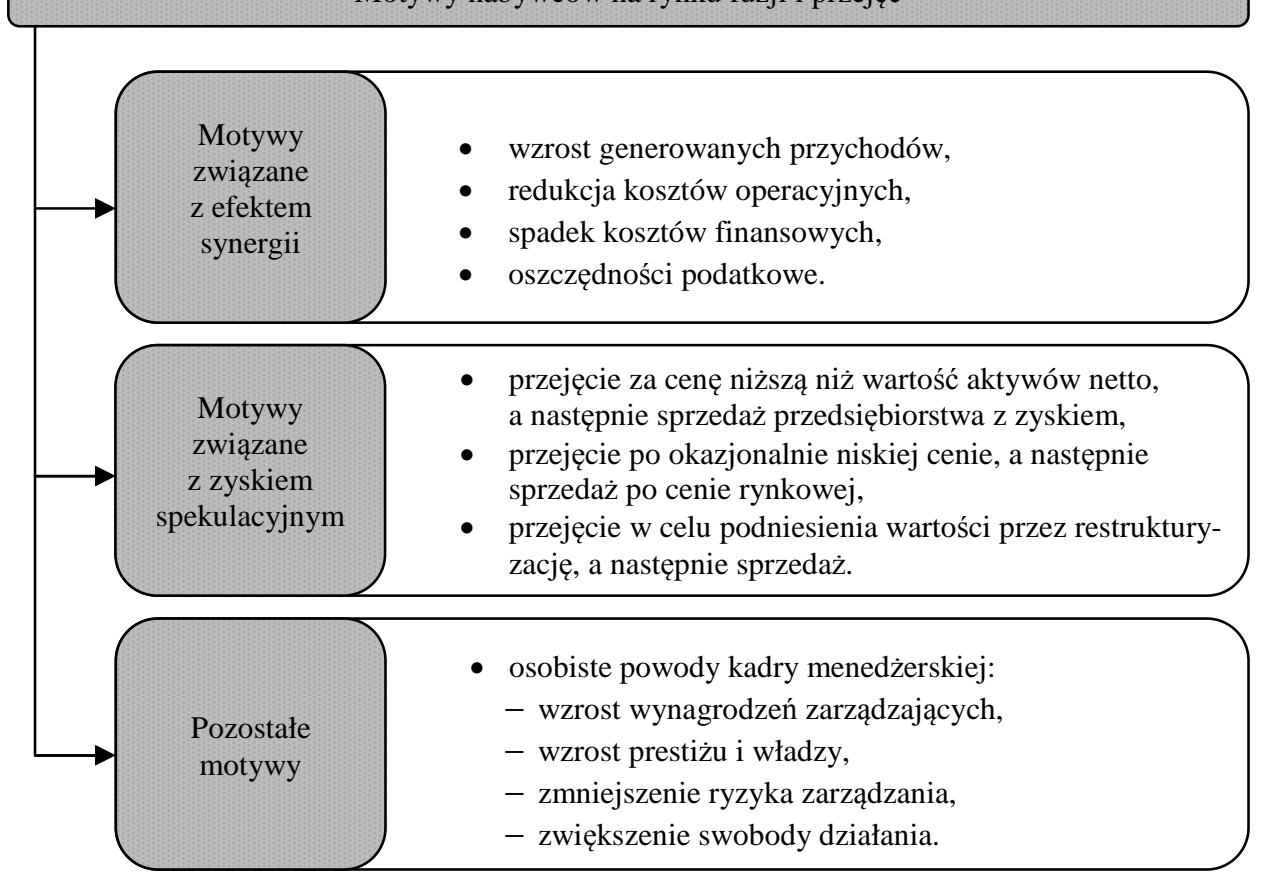

Schemat 2.3. Przesłanki skłaniające nabywców do fuzji i przejęć

Źródło: opracowanie własne na podstawie R. M achała, Przejęcia i fuzje. Wpływ na wartość firm, Oficyna Wydawnicza UNIMEX, Wrocław 2007, s. 68-77; W. Frą ck ow iak, Fuzje i przejęcia w przedsiębiorstwie, PWE, Warszawa 1998, s. 23.

W literaturze przedmiotu często przytaczana jest opinia, iż największe korzyści finansowe fundusze private equity mogą uzyskać z dezinwestycji zrealizowanych w drodze publicznej oferty sprzedaży akcji. Mając na uwadze korzyści wynikające dla podmiotu nabywającego z przejęcia przedsiębiorstwa udziałowego funduszu private equity, można wskazać w wybranych przypadkach możliwość uzyskania wyższej wyceny sprzedawanych przez fundusz udziałów na rynku $M \& A$ niż na publicznym rynku papierów wartościowych. Głównymi źródłami potencjału wyższej wyceny mogą być:

- premia za synergię, zarówno finansową i operacyjną,

- zmniejszenie oczekiwanej premii za ryzyko - inwestorzy strategiczni oraz inwestorzy finansowi dysponujący rozbudowanym zapleczem analitycznym są w stanie lepiej rozpoznać zagrożenia i szanse związane z funkcjonowaniem przejmowanego podmiotu niż większość inwestorów na publicznym rynku akcji ${ }^{44}$,

${ }^{44}$ Zob. D. J. C u m min g, J. G. M a c In to s h, Venture capital investment..., op. cit., s. 449. 
- premia akwizycyjna (premia za kontrolę) - wyższa wycena kontrolnego pakietu akcji/udziałów niż pakietu mniejszościowy związana jest z możliwością sprawowania efektywnej kontroli nad danym podmiotem, chociażby poprzez wybór władz spółki, czy też możliwość podejmowania decyzji strategicznych zarezerwowanych dla walnego zgromadzenia ${ }^{45}$. Na polskim rynku wysokość tej premii jest szacowana w przedziale od $12 \%$ do $20 \%$ i jest nieznacznie niższa niż na rozwiniętych rynkach ${ }^{46}$,

- wykorzystanie efektu dźwigni finansowej - występowanie tego czynnika uzależnione jest od warunków panujących na rynku długu.

Podobnie jak w pozostałych formach wyjścia z inwestycji funduszy private equity, tak i w przypadku dezinwestycji realizowanych na rynku fuzji i przejęć można wskazać na liczne zalety oraz ograniczenia zakończenia współpracy pomiędzy funduszem a spółką portfelową w tej formie (zob. tab. 2.3).

Tabela 2.3

Wady i zalety dezinwestycji realizowanych na rynku fuzji i przejęć

\begin{tabular}{|c|c|}
\hline Zalety dezinwestycji na rynku $M \& A$ & Wady dezinwestycji na rynku $M \& A$ \\
\hline 1 & 2 \\
\hline Pewne i bezzwłoczne wyjście $\mathrm{z}$ inwestycji & Budzi sprzeciw i opór kadry menedżerskiej \\
\hline $\begin{array}{l}\text { Dezinwestycje realizowane w oparciu o rynek } \\
\text { fuzji i przejęć jako jedyne formy wyjścia } \\
\text { z inwestycji pozwalają funduszowi na ogół } \\
\text { na natychmiastową sprzedaż posiadanych } \\
\text { udziałów w spółce portfelowej. Najczęstszą } \\
\text { formą zapłaty za zbywane papiery warto- } \\
\text { ściowe są środki pieniężne, co znacznie } \\
\text { wpływa na pewność korzyści finansowych } \\
\text { będących efektem inwestycji funduszu. }\end{array}$ & $\begin{array}{l}\text { Osoby zarządzające spółka portfelową często } \\
\text { sprzeciwiają się jej sprzedaży inwestorowi } \\
\text { strategicznemu lub finansowemu w obawie } \\
\text { o utratę stanowiska pracy, bądź też zmniej- } \\
\text { szenie posiadanej niezależności. Silny, } \\
\text { skoncentrowany nadzór korporacyjny z re- } \\
\text { guły ogranicza swobodę decyzyjną. Dodat- } \\
\text { kowo w wyniku dezinwestycji realizowa- } \\
\text { nych na rynku } M \& A \text { nie wzrasta prestiż za- } \\
\text { rządu i innych interesariuszy spółki, jak to } \\
\text { ma miejsce w przypadku posiadania statusu } \\
\text { spółki publicznej. }\end{array}$ \\
\hline
\end{tabular}

${ }^{45}$ P. E. H a n o un a, A. S a r in, A. C. S h a p ir o, Value of Corporate Control: Some International Evidence, USC Finance \& Business Econ. Working Paper No. 01-4, 2001, s. 2-33, Available at SSRN: http://ssrn.com/abstract=286787 or http://dx.doi.org/10.2139/ssrn.286787.

${ }^{46}$ L. S zerszen ow ic z, J. Kaczyńska, Trend: Ile kosztuje władza nad spótka, Harvard Bussines Review Polska, http://www.hbrp.pl/news.php?id=493\&t=trend-ile-kosztuje-wladza-nadspolka\&PHPSESSID=da688565cfdea27b06df32239251e514, 20.03.2012. 
Tabela 2.3 (cd.)

\begin{tabular}{|c|c|}
\hline 1 & 2 \\
\hline $\begin{array}{c}\text { Możliwość uzyskania wysokiej wyceny } \\
\text { rynkowej spółki }\end{array}$ & $\begin{array}{c}\text { Potencjalnie ograniczona liczba kupujących } \\
\text { - bariera popytowa }\end{array}$ \\
\hline $\begin{array}{l}\text { Efekty synergii, premia za kontrolę, redukcja } \\
\text { premii za ryzyko oraz możliwość wykorzy- } \\
\text { stania dźwigni finansowej w realizacji } \\
\text { transakcji na rynku } M \& A \text { kreują potencjał } \\
\text { do wzrostu wyceny spółki portfelowej } \\
\text { w oczach potencjalnych nabywców. }\end{array}$ & $\begin{array}{l}\text { W wielu branżach, zwłaszcza wysoko wyspe- } \\
\text { cjalizowanych, może wystąpić problem ma- } \\
\text { łej liczby podmiotów potencjalnie zaintere- } \\
\text { sowanych zakupem danego przedsiębior- } \\
\text { stwa udziałowego. Dodatkowym utrudnie- } \\
\text { niem jest fakt, iż w przypadku niewielkiej } \\
\text { liczby podmiotów zainteresowanych prze- } \\
\text { jęciem, utrudnione może być uzyskanie } \\
\text { atrakcyjnej wyceny zbywanych udziałów. }\end{array}$ \\
\hline $\begin{array}{l}\text { Szybkie, proste i elastyczne } \\
\text { procedury realizacji }\end{array}$ & Mało atrakcyjna dla pracowników \\
\hline $\begin{array}{l}\text { Dezinwestycje realizowane w oparciu } \\
\text { o rynek fuzji i przejęć wymagają mniej- } \\
\text { szych nakładów na przygotowanie i orga- } \\
\text { nizację samego procesu, dzięki czemu są } \\
\text { stosunkowo mniej absorbujące dla zarządu } \\
\text { spółki niż transakcje sprzedaży akcji na } \\
\text { publicznym rynku. Należy pamiętać, że } \\
\text { chociaż mniej czasu trzeba poświęcić na } \\
\text { przygotowanie akcji marketingowej oraz } \\
\text { formalne procedury związane z dopusz- } \\
\text { czeniem akcji do publicznego obrotu, to } \\
\text { nadal transakcje } M \& A \text { wymagają plano- } \\
\text { wania i przygotowań. Sama forma i prze- } \\
\text { bieg realizacji transakcji jest w zdecydo- } \\
\text { wanie mniejszym stopniu regulowany } \\
\text { przepisami prawa, a w przeważającej czę- } \\
\text { ści wynika z potrzeb i ustaleń pomiędzy } \\
\text { kupującym i sprzedającym. }\end{array}$ & $\begin{array}{l}\text { Z uzyskaniem statusu spółki giełdowej wiążą } \\
\text { się często dla pracowników korzyści w po- } \\
\text { staci premii, czy też włączenia do systemu } \\
\text { wynagrodzeń instrumentów związanych } \\
\text { z rynkiem kapitałowym. W przypadku } \\
\text { transakcji w postaci fuzji lub przejęcia takie } \\
\text { formy wynagrodzeń znajdują ograniczone } \\
\text { zastosowanie. Co więcej, pracownicy mogą } \\
\text { stracić motywację do pracy w obawie } \\
\text { o bezpieczeństwo posiadanego stanowiska } \\
\text { i przyszłość własnej kariery zawodowej po } \\
\text { włączeniu macierzystej jednostki do więk- } \\
\text { szej grupy. }\end{array}$ \\
\hline $\begin{array}{l}\text { Mniejsza w porównaniu do publicznego rynku } \\
\text { kapitałowego cykliczność rynku }\end{array}$ & $\begin{array}{l}\text { Cykliczność popytu zgłaszanego przez } \\
\text { inwestorów finansowych }\end{array}$ \\
\hline $\begin{array}{l}\text { Rynek fuzji i przejęć wydaje się bardziej } \\
\text { odporny na wahania koniunktury oraz na- } \\
\text { strojów panujących na rynku. W sytuacji } \\
\text { braku zainteresowani inwestorów ofertami } \\
\text { publicznymi, przeprowadzenie korzystnej } \\
\text { dla funduszu transakcji sprzedaży akcji in- } \\
\text { westorowi branżowemu lub finansowemu } \\
\text { wydaje się nadal możliwe. }\end{array}$ & $\begin{array}{l}\text { Popyt inwestorów finansowych na nowe } \\
\text { aktywa oraz ich skłonność do zwiększania } \\
\text { wyceny są silnie uzależnione od stanu ryn- } \\
\text { ku długu, a ten podlega znaczącym waha- } \\
\text { niom. W okresach niskich stóp procento- } \\
\text { wych, dzięki agresywnej dźwigni finanso- } \\
\text { wej, inwestorzy ci mogą przedstawić ko- } \\
\text { rzystniejsze oferty nabycia określonych } \\
\text { spółek. Jednakże w okresach zaostrzania } \\
\text { polityki pieniężnej możliwość uzyskania } \\
\text { atrakcyjnej wyceny znacznie maleje. }\end{array}$ \\
\hline
\end{tabular}


Tabela 2.3 (cd.)

\begin{tabular}{|c|c|}
\hline 1 & 2 \\
\hline Niskie koszty transakcyjne & Obawy o lojalność kadry zarządzającej \\
\hline $\begin{array}{l}\text { Z realizacją transakcji na rynku } M \& A \text { związane są } \\
\text { niższe koszty niż w przypadku publicznych ofert } \\
\text { sprzedaży akcji. Z przygotowaniem oraz prze- } \\
\text { prowadzeniem sprzedaży spółki portfelowej } \\
\text { poza publicznym rynkiem papierów wartościo- } \\
\text { wych wiąże się mniejsze zaangażowanie wy- } \\
\text { kwalifikowanych doradców i innych podmiotów } \\
\text { wspomagających ten proces, co przekłada się } \\
\text { wprost na wysokość opłat. Co więcej, transakcje } \\
M \& A \text { nie są obciążone kosztami pośrednimi } \\
\text { w formie zjawiska niedowartościowania akcji } \\
\text { typowego dla ofert publicznych. }\end{array}$ & $\begin{array}{l}\text { Wątpliwości tego typu pojawiają się głównie } \\
\text { w sytuacji, kiedy przedsiębiorstwo udziałowe } \\
\text { zbywane jest na rzecz innego inwestora finan- } \\
\text { sowego. Z jednej strony zarząd spółki może } \\
\text { sprzyjać procesowi dezinwestycji i atrakcyjnej } \\
\text { wycenie w oczekiwaniu na uzyskanie prywat- } \\
\text { nych korzyści w wyniku udanej transakcji. } \\
\text { Jednakże z drugiej strony im mniejszą kwotę } \\
\text { za nabywane udziały zapłaci inwestor, tym } \\
\text { łatwiej będzie w przyszłości wykazać się przed } \\
\text { nowym właścicielem umiejętnościami budo- } \\
\text { wania wartości przedsiębiorstwa. }\end{array}$ \\
\hline $\begin{array}{l}\text { Do zakupu spółki musi być przekonany tylko } \\
\text { jeden nabywca, a nie cały rynek }\end{array}$ & $\begin{array}{l}\text { Mało użyteczna w procesie budowania } \\
\text { reputacji funduszu private equity }\end{array}$ \\
\hline $\begin{array}{l}\text { W celu uzyskania atrakcyjnej wyceny w procesie } \\
\text { fuzji i przejęć wystarczy tylko jeden nabywca } \\
\text { przekonany o jakości i perspektywach rozwoju } \\
\text { zbywanej spółki portfelowej. Znacznie trudniej- } \\
\text { szym zadaniem jest zainspirowanie i zmotywo- } \\
\text { wanie do zakupu akcji spółki w procesie oferty } \\
\text { publicznej. }\end{array}$ & $\begin{array}{l}\mathrm{Z} \text { dezinwestycjami realizowanymi na rynku fuzji } \\
\text { i przejęć wiąże się mniejsze zainteresowanie } \\
\text { opinii publicznej niż w przypadku wyjścia } \\
\text { z inwestycji przez giełdę. Działania promocyj- } \\
\text { ne w tym zakresie są ograniczone, a informacje } \\
\text { o samej transakcji docierają do zdecydowanie } \\
\text { mniejszego grona zainteresowanych osób } \\
\text { i podmiotów. Ponadto mają one charakter do- } \\
\text { raźny, a ich efekty z reguły są krótkotrwałe. }\end{array}$ \\
\hline Wysoki poziom poufności & \multirow[t]{2}{*}{ 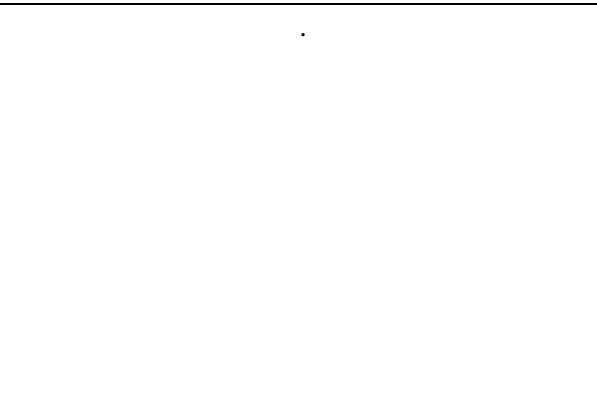 } \\
\hline $\begin{array}{l}\text { W wielu przypadkach wyjście z inwestycji może } \\
\text { być zorganizowane i wykonane w sposób kon- } \\
\text { fidencjonalny, bez konieczności ujawniania } \\
\text { wielu informacji poufnych i utraty ewentual- } \\
\text { nych przewag konkurencyjnych. Istotną kwe- } \\
\text { stią jest również niższe ryzyko związane } \\
\text { z możliwym unieważnieniem transakcji. Nega- } \\
\text { tywne skutki dla reputacji wszystkich stron } \\
\text { transakcji byłyby zdecydowanie mniejsze niż } \\
\text { w przypadku odwołania debiutu giełdowego. }\end{array}$ & \\
\hline $\begin{array}{l}\text { Możliwość sprzedaży wydzielonej części } \\
\text { przedsiębiorstwa udziałowego }\end{array}$ & \multirow[t]{2}{*}{. } \\
\hline $\begin{array}{l}\text { W sytuacji, kiedy odrębne elementy składowe } \\
\text { spółki portfelowej mogą tworzyć znaczące efek- } \\
\text { ty synergii dla różnych nabywców, może zaist- } \\
\text { nieć potencjał do uzyskania wyższej wyceny. } \\
\text { Wówczas poszczególne części spółki mogą być } \\
\text { zbyte różnym inwestorom. Trzeba wyraźnie } \\
\text { podkreślić, że taka forma dezinwestycji wymaga } \\
\text { właściwego, wcześniejszego zaplanowania i jest } \\
\text { ona trudna do realizacji w praktyce, gdyż część } \\
\text { elementów przedsiębiorstwa może być wspólna, } \\
\text { np. infrastruktura, know-how, zarząd. }\end{array}$ & \\
\hline
\end{tabular}

Źr ó dło: opracowanie własne na podstawie S. P o val y, op. cit., s. 252-253. 


\subsubsection{WYJŚCIE FUNDUSZU PRIVATE EQUITY Z INWESTYCJI W WYNIKU TRANSAKCJI WYKUPU MENEDŻERSKIEGO I LEWAROWANEGO}

Istota transakcji wykupu realizowanego w procesie dezinwestycji funduszu private equity polega na sprzedaży akcji bądź udziałów spółki portfelowej będących własnością danego funduszu na rzecz pierwotnych właścicieli tego przedsiębiorstwa, osób nim zarządzających, pracowników bądź samej spółce. W zależności od podmiotu będącego nabywcą zbywanych praw do spółki, jak i struktury finansowania samej transakcji wyróżnić można wiele różnych form wykupów. Należą do nich wewnętrzny i zewnętrzny wykup menedżerski, wykup pracowniczy oraz menedżersko-pracowniczy, a także wykup lewarowany (zob. tab. 2.4).

Wykupy menedżerskie stosowane są najczęściej przez przedsiębiorstwa, które generują wysoki poziom wolnych przepływów pieniężnych, mają stabilną pozycję rynkową, charakteryzują się stosunkowo niskim ryzykiem operacyjnym, a jednocześnie także przez te, które nie znajdują się w grupie najbardziej atrakcyjnych przedsiębiorstw z punktu widzenia inwestorów giełdowych i branżo$\mathrm{wych}^{47}$.

Tabela 2.4

Główne rodzaje wykupów stosowane jako formy dezinwestycji funduszy private equity

\begin{tabular}{|l|l|}
\hline \multicolumn{1}{|c|}{ Rodzaj wykupu } & \multicolumn{1}{c|}{ Charakterystyka } \\
\hline $\begin{array}{l}\text { Wewnętrzny wykup menedżerski } \\
\text { (ang. Management Buy Out, MBO) }\end{array}$ & $\begin{array}{l}\text { Polega na zbyciu właścicielskich papierów warto- } \\
\text { ściowych przedsiębiorstwa udziałowego na rzecz } \\
\text { menedżerów dotychczas w nim zatrudnionych. }\end{array}$ \\
\hline $\begin{array}{l}\text { Zewnętrzny wykup menedżerski } \\
\text { (ang. Management Buy In, MBI) }\end{array}$ & $\begin{array}{l}\text { Spółka portfelowa sprzedawana jest na rzecz ze- } \\
\text { wnętrznej grupy menedżerskiej, która po przepro- } \\
\text { wadzeniu transakcji zarządza nią. }\end{array}$ \\
\hline $\begin{array}{l}\text { Wykup menedżersko-pracowniczy } \\
\text { (ang. Management-employee Buy Out, } \\
M E B O \text { ) }\end{array}$ & $\begin{array}{l}\text { Nabywcami przedsiębiorstwa udziałowego fundu- } \\
\text { szu private equity poza kadrą zarządzającą są rów- } \\
\text { nież inni pracownicy przedsiębiorstwa. }\end{array}$ \\
\hline $\begin{array}{l}\text { Wykup pracowniczy (nazywany rów- } \\
\text { nież leasingiem pracowniczym, } \\
\text { ang. Employees Buy Out, EBO) }\end{array}$ & $\begin{array}{l}\text { Przedsiębiorstwo udziałowe nabywane jest przez } \\
\text { pracowników spółki spoza kadry zarządzającej. }\end{array}$ \\
\hline $\begin{array}{l}\text { Wykup lewarowany (nazywany również } \\
\text { wykupem wspomagany finansowo, } \\
\text { ang. Leveraged Buy Out, } \text { BBO) }\end{array}$ & $\begin{array}{l}\text { Oznacza wykup spółki z portfela inwestycyjnego } \\
\text { funduszu private equity głównie za pomocą kapitału } \\
\text { udostępnianego w formie finansowania zewnętrz- } \\
\text { nego przez pożyczkodawców (prywatnych inwesto- } \\
\text { rów, banki, inne instytucje kredytowe), bądź zby- } \\
\text { wającego w formie przesunięcia terminu zapłaty. }\end{array}$ \\
\hline
\end{tabular}

Źródło: opracowanie własne na podstawie K. Sobańska, P. Sieradzan, op. cit., s. $142-151$.

${ }^{47}$ M. Wr zes siń s ki, Kapitat podwyższonego ryzyka.., op. cit., s. 227. 
Wyjście z inwestycji w drodze wykupu menedżerskiego może być także wynikiem realizacji zapisów włączonych do umowy inwestycyjnej zawartej pomiędzy funduszem private equity a pierwotnymi właścicielami spółki w momencie nawiązania współpracy. Tego typu uregulowania są pewnego rodzaju zabezpieczeniem dla funduszu przed niezrealizowaniem planowanych efektów inwestycyjnych. Pierwotny właściciel odkupi posiadane przez fundusz udziały w spółce i w ten sposób umożliwi przeprowadzenie sprawnej dezinwestycji ${ }^{48}$.
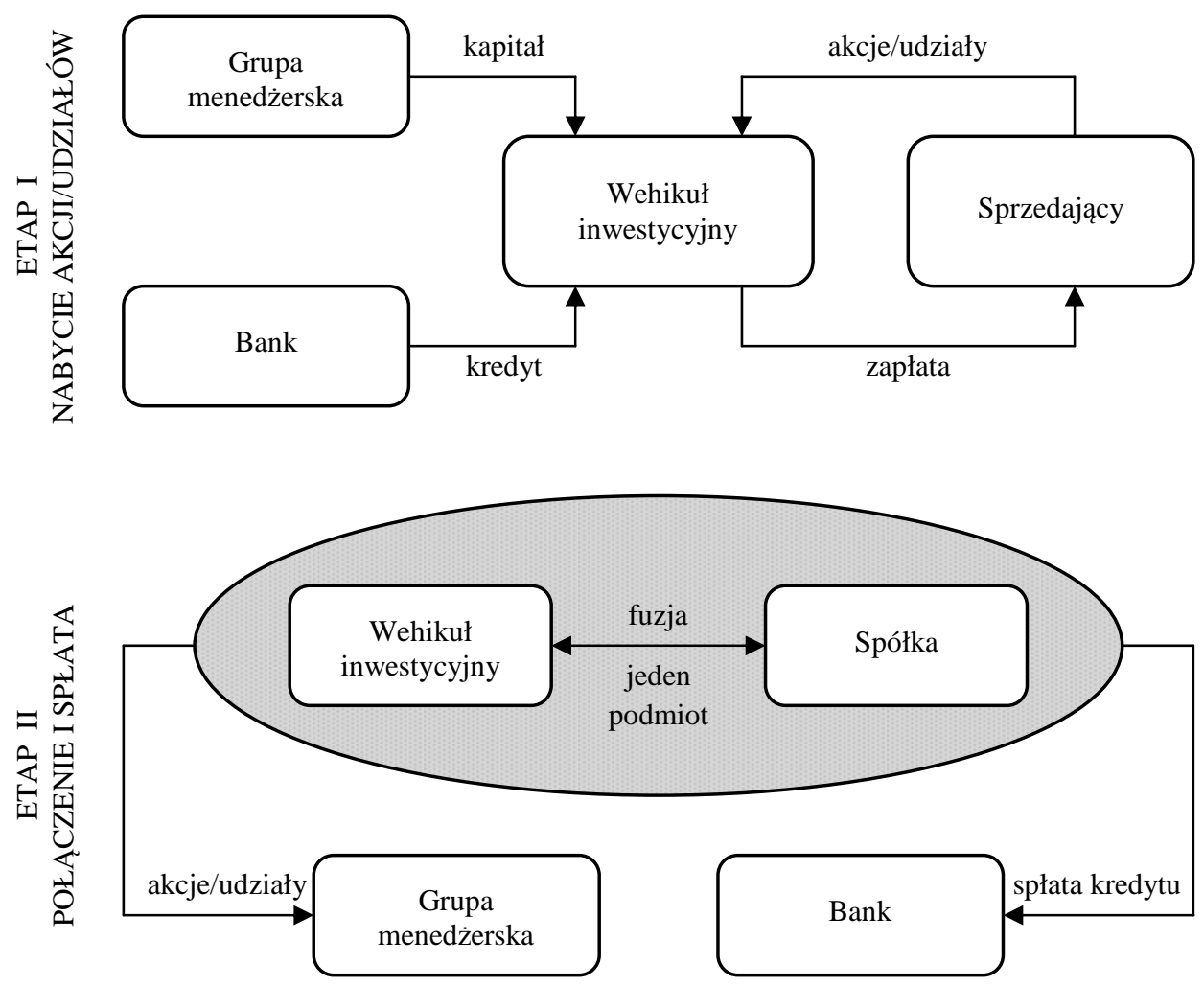

Schemat 2.4. Schemat realizacji transakcji wykupu menedżerskiego

Źródło: opracowanie na podstawie materiałów informacyjnych Avallon, http://www.mbo.pl/Informacje-Ogolne/schemat-transakcji-wykupu/.

Realizacja wyjścia z inwestycji funduszu private equity w formie wykupu menedżerskiego może przybierać zróżnicowane formy i jest dopasowywana do indywidualnego charakteru każdej transakcji. Wynika to $\mathrm{z}$ konieczności

${ }^{48}$ D. J. Cu mming, J. G. M a c In to s h, Venture-capital exits..., op. cit., s. 107. 
uwzględnienia uwarunkowań podatkowych i innych regulacji prawnych oraz form i zakresu zaangażowania innych partnerów kapitałowych. Odwołując się do klasycznego ujęcia transakcji wykupu menedżerskiego prezentowanego przez fundusz Avallon, będącego pionierem na rynku wykupów menedżerskich w Polsce, transakcja ta realizowana jest w dwóch etapach. Pierwszym etapem jest nabycie akcji/udziałów, drugim zaś połączenie i spłata ${ }^{49}$ (zob. schemat 2.4).

$\mathrm{W}$ pierwszym etapie realizacji transakcji grupa menedżerów tworzy odpowiedni wehikuł inwestycyjny w postaci spółki celowej, mającej za zadanie zgromadzenie środków finansowych niezbędnych do przeprowadzenia wykupu przedsiębiorstwa udziałowego od funduszu private equity. Tego typu transakcje cechuje z reguły wysoki stopień finansowania przez podmioty spoza grupy, gdyż menedżerowie inwestując zaledwie 3\% środków niezbędnych do sfinansowania wykupu, uzyskują średnio do $30 \%$ udziałów w kapitale przejmowanej spółki ${ }^{50}$.

Po nabyciu praw własności do wykupywanej spółki w kolejnym etapie następuje fuzja spółki celowej będącej wehikułem inwestycyjnym ze spółką. Wówczas to akcje/udziały połączonego podmiotu trafiają do właścicieli tejże spółki, a wykorzystane do przeprowadzenia transakcji wykupu finansowanie dłużne spłacane jest przez utworzone w ten sposób przedsiębiorstwo.

\subsubsection{WRITE-OFF I LIKWIDACJA SPÓłKI JAKO FORMY DEZINWESTYCJI}

Każda inwestycja funduszu private equity poprzedzona jest szeregiem kompleksowych, niezwykle szczegółowych analiz. Ich celem jest wybór takich projektów inwestycyjnych, które zapewnią funduszowi osiągnięcie zaplanowanej stopy zwrotu przy określonym poziomie ryzyka inwestycyjnego. Jednakże nie wszystkie przedsiębiorstwa udziałowe okazują się sukcesem inwestycyjnym, a na rynku może nie być podmiotów czy osób zainteresowanych ich nabyciem. Wówczas jedyną formą zakończenia inwestycji jest umorzenie udziałów spółki i jej likwidacja oraz próba odzyskania chociaż części zainwestowanego przez fundusz kapitału z majątku samej spółki.

Write-off, czyli odpisanie wartości inwestycji jako sposób dezinwestycji polega na dokonaniu przez fundusz private equity zapisów księgowych, w rezultacie których wartość posiadanych w spółce portfelowej udziałów zostaje obniżona do zera, a inwestycja zostanie usunięta $\mathrm{z}$ bilansu funduszu. $\mathrm{Z}$ księgowego punktu widzenia operacja ta kończy zaangażowanie kapitałowe funduszu w dane przedsiębiorstwo ${ }^{51}$.

${ }^{49} \mathrm{http}: / / \mathrm{ww} w . m b o . p 1 /$ Informacje-Ogolne/schemat-transakcji-wykupu/.

${ }^{50}$ M. Wrzesiński, Fuzje i przejęcia. Wykup lewarowany (LBO) i menedżerski (MBO) - uwarunkowania rozwoju w Polsce, Wydawnicwo K.E. Liber, Warszawa 2000, s. 4.

${ }^{51}$ K. S obańska, P. S i er adzan,op. cit., s. 154. 
Operacja odpisania inwestycji zakończonych niepowodzeniem nie jest równoznaczna z utratą posiadanych przez fundusz praw własności do spółki. Na ogół jest to jeden z etapów poprzedzających likwidację spółki i umorzenie jej udziałów, w wyniku których następuje dopiero ostateczne unicestwienie praw i obowiązków funduszu private equity związanych z partycypacją w spółce.

Wyjście $\mathrm{z}$ inwestycji $\mathrm{w}$ drodze likwidacji przedsiębiorstwa udziałowego nie jest także równoznaczne $\mathrm{z}$ utratą wszystkich kapitałów zainwestowanych w spółkę. Chociaż bez wątpienia jest przyznaniem się zarządzających danym funduszem do porażki inwestycyjnej, część ulokowanych w spółce środków może być odzyskana z majątku likwidowanej spółki. O ile taka forma dezinwestycji nie pozwala na uzyskanie oczekiwanego zysku kapitałowego, to jednak przynajmniej umożliwia zminimalizowanie raportowanych strat.

M. Gorman i W. Sahlamn zwracają uwagę, iż porażka jest powszechna w procesie inwestycyjnym na rynku kapitału podwyższonego ryzyka i należy ją traktować jako zwykłe, a nawet oczekiwane wydarzenie ${ }^{52}$. Podjęcie decyzji wyjściu $\mathrm{z}$ inwestycji w drodze likwidacji spółki i realokacji posiadanych zasobów kapitałowych, ludzkich i informacyjnych do realizacji nowych, optymistycznie rokujących projektów jest rozwiązaniem korzystniejszym z punktu widzenia kapitałodawców funduszu niż lokowanie kapitału w przedsiębiorstwo bez żadnych perspektyw, w nadziei na odwrócenie sytuacji rynkowej i wątpliwy sukces ekonomiczny. Skuteczność zarządzania portfelem inwestycyjnym funduszy private equity zależy od ich zdolności do uczenia się na podstawie zarówno sukcesów, jak i porażek swoich wcześniejszych inwestycji ${ }^{53}$.

\subsection{Rynkowe uwarunkowania procesów dezinwestycji funduszy private equity}

Otoczenie instytucjonalne funduszy kapitału podwyższonego ryzyka jest wyjątkowo złożone i skomplikowane, co wynika m. in. z rozlicznych kierunków i wysokiego stopnia dywersyfikacji prowadzonej działalności inwestycyjnej. Zaakcentowane szczególne znaczenie publicznego rynku papierów wartościowych oraz rynku fuzji i przejęć w realizacji efektywnych procesów dezinwestycji znajduje potwierdzenie w badaniach zagranicznych. W opinii wielu osób tylko sprze-

${ }^{52}$ M. Gorman, W. Sahlman, What do venture capitalists do?, „Journal of Business Venturing", July 1989, Vol. 4, No. 4, s. 231-248.

${ }^{53}$ D. De Clerc q, D. Di mov, Internal Knowledge Development and External Knowledge Access in Venture Capital Investment Performance, ,Journal of Management Studies”, May 2008, Vol. 45, s. 586 . 
daż akcji inwestorowi branżowemu oraz pierwsza oferta publiczna stwarzają funduszom private equity możliwość efektywnej dezinwestycji ${ }^{54}$.

Polski rynek fuzji i przejęć rozwija się w ostatnich latach dynamicznie i odgrywa istotną rolę w regionie Europy Środkowo-Wschodniej ${ }^{55}$ (zob. tab. 2.5).

Tabela 2.5

Liczba i wartość transakcji zrealizowanych na rynku fuzji i przejęć w okresie od $2008 \mathrm{r}$. do pierwszej połowy $2010 \mathrm{r}$.

\begin{tabular}{|c|c|c|c|c|c|c|c|}
\hline \multicolumn{2}{|c|}{ Wyszczególnienie } & 2008 & 2009 & $\begin{array}{c}\text { Zmiana } \\
2009 / \\
2008 \\
{[\%]} \\
\end{array}$ & 1Н 2009 & 1H 2010 & $\begin{array}{c}\text { Zmiana } \\
1 \mathrm{H} \mathrm{2010/} \\
1 \mathrm{H} 2009 \\
{[\%]}\end{array}$ \\
\hline \multirow{3}{*}{ Polska } & Liczba transakcji & 548 & 556 & 1,46 & 245 & 283 & 15,51 \\
\hline & $\begin{array}{l}\text { Wartość transakcji } \\
(\text { (w mln EUR })^{*}\end{array}$ & 8538 & 8522 & $-0,19$ & 3554 & 5127 & 44,26 \\
\hline & $\begin{array}{l}\text { Teoretyczna war- } \\
\text { tość transakcji }^{* * *}\end{array}$ & 11867 & 11748 & $-1,00$ & 5213 & 8244 & 58,14 \\
\hline \multirow{3}{*}{$\begin{array}{l}\text { Region } \\
\text { Europy } \\
\text { Środkowo- } \\
\text {-Wschodniej }\end{array}$} & Liczba transakcji & - & 1663 & - & 817 & 869 & 6,36 \\
\hline & $\begin{array}{l}\text { Wartość transakcji } \\
(\text { w mln EUR })^{* * *}\end{array}$ & - & 24933 & - & 12442 & 10183 & $-18,16$ \\
\hline & $\begin{array}{l}\text { Teoretyczna war- } \\
\text { tość transakcji }\end{array}$ & - & 42918 & - & 22539 & 20532 & $-8,90$ \\
\hline \multirow{3}{*}{$\begin{array}{l}\text { Udział } \\
\text { Polski } \\
\text { w regionie } \\
\text { Europy } \\
\text { Środkowo- } \\
\text {-Wschodniej }\end{array}$} & Liczba transakcji & - & 33,4 & - & 30,0 & 32,6 & - \\
\hline & $\begin{array}{l}\text { Wartość transakcji } \\
(\text { w mln EUR })^{*}\end{array}$ & - & 34,2 & - & 28,6 & 50,3 & - \\
\hline & $\begin{array}{l}\text { Teoretyczna war- } \\
\text { tość transakcji }{ }^{* * *}\end{array}$ & - & 27,4 & - & 23,1 & 40,2 & - \\
\hline
\end{tabular}

* w oparciu o dane za pierwszą połowę 2010 r. o 176 transakcjach (62\% ogółu) oraz za 2009 r. o 398 transakcjach ( $72 \%$ ogółu).

** w oparciu o dane o transakcjach z ujawnioną wartością.

*** teoretyczna wartość transakcji obliczona została na podstawie średniej wartości transakcji danego sektora pomnożonej przez liczbę transakcji o nieujawnionej wartości i dodanej do tych o wartości znanej.

Źródło: opracowanie własne na podstawie Rynek fuzji i przejęć. Polska na tle Europy Środkowej. Edycja 2010, Badanie KPMG i DealWatch, s. 13 oraz Rynek fuzji i przejęć. Polska na tle Europy Środkowo-Wschodniej. I pótrocze 2010, Badanie KPMG i DealWatch, s. 15.

${ }^{54} \mathrm{R}$. N ah ata, Venture capital reputation and investment performance, ,Journal of Financial Economics", November 2008, Vol. 90, Issue 2, s. 127-151; J. A. Brander, R. Amit, W. Antweiler, Venture-Capital Syndication: Improved Venture Selection vs. the Value-Added Hypothesis, „Journal of Economics\&Management Strategy” 2002, Vol. 11, No. 3, s. 446; Y. V. Hochberg, A. Lju ng vis t, Y. Lu, Venture Capital Networks and Investment Performance, „The Journal of Finance" 2007, Vol. 62, No. 1, s. 253; J. H. C oc hr a ne, The risk and return of venture capital, „Journal of Financial Economics” 2005, Vol. 75, s. 3-52; I. G u l e r, Throwing Good Money after Bad? Political and Institutional Influences on Sequential Decision Making in the Venture Capital Industry, „Administrative Science Quarterly” 2007, Vol. 52, s. 254.

${ }^{55}$ Za rynek Europy Środkowo-Wschodniej przejęto następujące kraje: Albanię, Estonię, Polskę, Bośnię i Hercegowinę, Kosowo, Rumunię, Bułgarię, Litwę, Serbię, Chorwację, Łotwę, Słowację, Czarnogórę, Macedonię, Słowenię, Czechy, Mołdawię, Węgry. 
Analizując udział polskiego rynku fuzji i przejęć w rynku fuzji i przejęć krajów regionu Europy Środkowo-Wschodniej warto zwrócić uwagę, iż w analizowanym okresie w Polsce zrealizowano ponad 30\% wszystkich transakcji jakie miały miejsce w Europie Środkowo-Wschodniej. Z kolei w pierwszej połowie 2010 r. w ujęciu wartościowym według transakcji ujawnionych udział ten wynosił ponad 50\%. Zaobserwowane zmiany świadczyć mogą o korzystnych uwarunkowaniach rozwoju tego rynku z punktu widzenia funduszy private equity prowadzących działalność inwestycyjną i dezinwestycyjną w Polsce.

Ważnym sygnałem świadczącym o rozwoju rynku fuzji i przejęć oraz możliwości realizowania na nim procesów wyjścia $\mathrm{z}$ inwestycji funduszy private equity są wskaźniki charakteryzujące wycenę przedsiębiorstw będących przedmiotem zawieranych umów. Jak podaje KPMG również w tym obszarze można zaobserwować pewne zmiany (zob. tab. 2.6).

Tabela 2.6

Przeciętne wartości mnożników transakcyjnych w okresie od 2008 r. do pierwszej połowy 2010 r.

\begin{tabular}{|l|c|c|c|c|}
\hline \multirow{2}{*}{ Wyszczególnienie } & 2008 & 2009 & $1 \mathrm{H} 2009$ & $1 \mathrm{H} 2010$ \\
\cline { 2 - 6 } & \multicolumn{4}{|c|}{ Polska } \\
\hline \hline Wartość transakcji/Sprzedaż & $1,1-1,4 \mathrm{x}$ & $0,8-1,2 \mathrm{x}$ & $0,8-1,2 \mathrm{x}$ & $1-1,2 \mathrm{x}$ \\
\hline Wartość transakcji/EBITDA & $10,1-10,9 \mathrm{x}$ & $8,2-9,2 \mathrm{x}$ & $8,8-9 \mathrm{x}$ & $8,4-11,2 \mathrm{x}$ \\
\hline Wartość transakcji/Wartość księgowa & $2,2-2,6 \mathrm{x}$ & $1,6-2 \mathrm{x}$ & $1,2-1,7 \mathrm{x}$ & $2-2,4 \mathrm{x}$ \\
\hline & \multicolumn{5}{|c|}{ Europa Środkowo-Wschodnia } \\
\hline \hline Wartość transakcji/Sprzedaż & - & $0,9-1,3 \mathrm{x}$ & $1-1,3 \mathrm{x}$ & $1-1,4 \mathrm{x}$ \\
\hline Wartość transakcji/EBITDA & - & $6,9-7,9 \mathrm{x}$ & $6,2-7,1 \mathrm{x}$ & $8,1-10,2 \mathrm{x}$ \\
\hline Wartość transakcji/Wartość księgowa & - & $1,3-1,8 \mathrm{x}$ & $1,2-1,7 \mathrm{x}$ & $1,7-2,3 \mathrm{x}$ \\
\hline
\end{tabular}

Źródło: opracowanie własne na podstawie Rynek fuzji i przejęć. Polska na tle Europy Środkowej. Edycja 2010, op. cit., s. 13 oraz Rynek fuzji i przejęć. Polska na tle Europy Środkowo-Wschodniej, op. cit., s. 16.

Obliczone przeciętne wartości mnożników transakcyjnych na rynku fuzji i przejęć przedsiębiorstw wskazują, iż w pierwszym półroczu 2010 r. można zaobserwować poprawę wycen spółek będących przedmiotem transakcji w porównaniu $\mathrm{z}$ okresem analogicznym roku poprzedniego. Jest to pozytywny sygnał dla funduszy realizujących dezinwestycję za pośrednictwem rynku fuzji i przejęć. Jednakże należy zauważyć, że wyceny spółek w całym 2009 r. na skutek negatywnych nastrojów rynkowych pogorszyły się w porównaniu do 2008 r. Mnożniki transakcji zawieranych na polskim rynku mają wartości zbliżone do poziomu w całym regionie Europy Środkowej, z niewielką przewagą na korzyść polskiego rynku. 
Tabela 2.7

Największe transakcje na rynku fuzji i przejęć w Polsce ogłoszone w okresie od 1 stycznia 2009 r. do 30 czerwca 2010 r.

\begin{tabular}{|c|c|c|c|c|c|c|}
\hline $\begin{array}{c}\text { Data } \\
\text { ogłoszenia }\end{array}$ & $\begin{array}{c}\text { Cel } \\
\text { przejęcia }\end{array}$ & Przejmujący & $\begin{array}{c}\text { Kraj } \\
\text { przejmującego }\end{array}$ & Sprzedający & $\begin{array}{c}\text { Wartość } \\
(\mathrm{mln} \\
\text { EUR) }\end{array}$ & \begin{tabular}{|c|} 
Wielkość \\
przejmowanego \\
udziału [\%]
\end{tabular} \\
\hline $\begin{array}{l}27 \text { stycznia } \\
2010\end{array}$ & $\begin{array}{l}\text { PGE Energia } \\
\text { PGE Górnic- } \\
\text { two i Energe- } \\
\text { tyka }\end{array}$ & PGE & Polska & $\begin{array}{l}\text { Ministerstwo } \\
\text { Skarbu } \\
\text { Państwa }\end{array}$ & 806,10 & 15,00 \\
\hline 14 maja 2009 & $\begin{array}{l}\text { Kompania } \\
\text { Piwowarska }\end{array}$ & $\begin{array}{l}\text { SABMiller } \\
\text { Plc. }\end{array}$ & RPA & $\begin{array}{l}\text { Kulczyk } \\
\text { Holding }\end{array}$ & 797,10 & 28,10 \\
\hline 22 lipca 2009 & PKN Orlen & $\begin{array}{l}\text { Ministerstwo } \\
\text { Skarbu Pań- } \\
\text { stwa }\end{array}$ & Polska & Nafta Polska & 470,68 & 17,32 \\
\hline \begin{tabular}{|l}
30 stycznia \\
2009
\end{tabular} & $\begin{array}{l}\text { DB Schenker } \\
\text { Rail Polska }\end{array}$ & DB Schenker & Niemcy & PCC SE & 400,00 & 100,00 \\
\hline $\begin{array}{l}29 \text { stycznia } \\
2009\end{array}$ & Getin Bank & Noble Bank & Polska & Getin Holding & 356,85 & 100,00 \\
\hline 22 lipca 2009 & Grupa Lotos & $\begin{array}{l}\text { Ministerstwo } \\
\text { Skarbu Pań- } \\
\text { stwa }\end{array}$ & Polska & Nafta Polska & 303,90 & 51,91 \\
\hline 27 maja 2009 & \begin{tabular}{|l|} 
Vattenfall \\
Heat Poland, \\
Vattenfall \\
Distribution \\
Poland \\
\end{tabular} & Vattenfall & Szwecja & $\begin{array}{l}\text { Ministerstwo } \\
\text { Skarbu } \\
\text { Państwa }\end{array}$ & 295,17 & 25,10 \\
\hline $\begin{array}{l}10 \text { lutego } \\
2010\end{array}$ & Enea & $\begin{array}{l}\text { Inwestorzy } \\
\text { instytucjonalni }\end{array}$ & - & $\begin{array}{l}\text { Ministerstwo } \\
\text { Skarbu Pań- } \\
\text { stwa }\end{array}$ & 280,90 & 16,05 \\
\hline $\begin{array}{l}2 \text { listopada } \\
2009\end{array}$ & TP SA & - & - & \begin{tabular}{|l} 
Capital Re- \\
search and \\
Management \\
Company
\end{tabular} & 272,44 & 4,94 \\
\hline $\begin{array}{l}24 \text { czerwca } \\
2010\end{array}$ & \begin{tabular}{|l} 
Europolis \\
Invest
\end{tabular} & $\begin{array}{l}\text { CA Immo } \\
\text { International }\end{array}$ & Austria & $\begin{array}{l}\text { Volksbank } \\
\text { International }\end{array}$ & 272,00 & 100,00 \\
\hline $\begin{array}{l}3 \text { sierpnia } \\
2009\end{array}$ & $\begin{array}{l}\text { Nowaco } \\
\text { Czech Repu- } \\
\text { blic, Farutex }\end{array}$ & Bidvest Group & RPA, inne & $\begin{array}{l}\text { Bancroft } \\
\text { Private Equity, } \\
\text { Nova Invest- } \\
\text { ments }\end{array}$ & 250,00 & 100,00 \\
\hline $\begin{array}{l}14 \text { czerwca } \\
2010\end{array}$ & Agros Nova & $\begin{array}{l}\text { IK Investment } \\
\text { Partners }\end{array}$ & Wielka Brytania & Sonda & 248,40 & 99,53 \\
\hline $\begin{array}{l}8 \text { październi- } \\
\text { ka } 2009\end{array}$ & HTL-Strefa & $\begin{array}{l}\text { Terantium } \\
\text { Investments }\end{array}$ & Polska & $\begin{array}{l}\text { Noryt N.V., } \\
\text { OFE Polsat, } \\
\text { inni }\end{array}$ & 208,36 & 97,32 \\
\hline 8 lutego 2010 & $\begin{array}{l}\text { C. H. Arkadia } \\
\text { w Warszawie }\end{array}$ & $\begin{array}{l}\text { Rodamco } \\
\text { Europe }\end{array}$ & Holandia & \begin{tabular}{|l|} 
Ivanhoe \\
Cambridge \\
Simson Prop- \\
erty Group
\end{tabular} & 200,00 & 100,00 \\
\hline \begin{tabular}{|l|}
6 listopada \\
2009
\end{tabular} & ITI Neovision & TVN & Polska & ITI Group & 188,00 & 49,00 \\
\hline
\end{tabular}

Źródło: opracowanie własne na podstawie Rynek fuzji i przejęć. Polska na tle Europy Środkowej. Edycja 2010, op. cit., s. 7 oraz Rynek fuz.ji i przejęć. Polska na tle Europy Środkowo-Wschodniej, op. cit., s. 11. 
Przedstawiona w tab. 2.7 lista 15 największych pod względem wartości transakcji na rynku fuzji i przejęć w Polsce ogłoszonych od początku 2009 r. do końca pierwszej połowy $2010 \mathrm{r}$. wskazuje, iż wśród aktywnych podmiotów na tym rynku można wskazać również fundusze private equity.

Analiza sektorowa rynku fuzji i przejęć wskazuje, iż większość realizowanych na polskim rynku transakcji koncentruje się w trzech następujących sektorach (zob. wykres 2.2):

- informatyka, media, komunikacja, rozrywka,

- budownictwo i nieruchomości oraz

- produkcja przemysłowa.

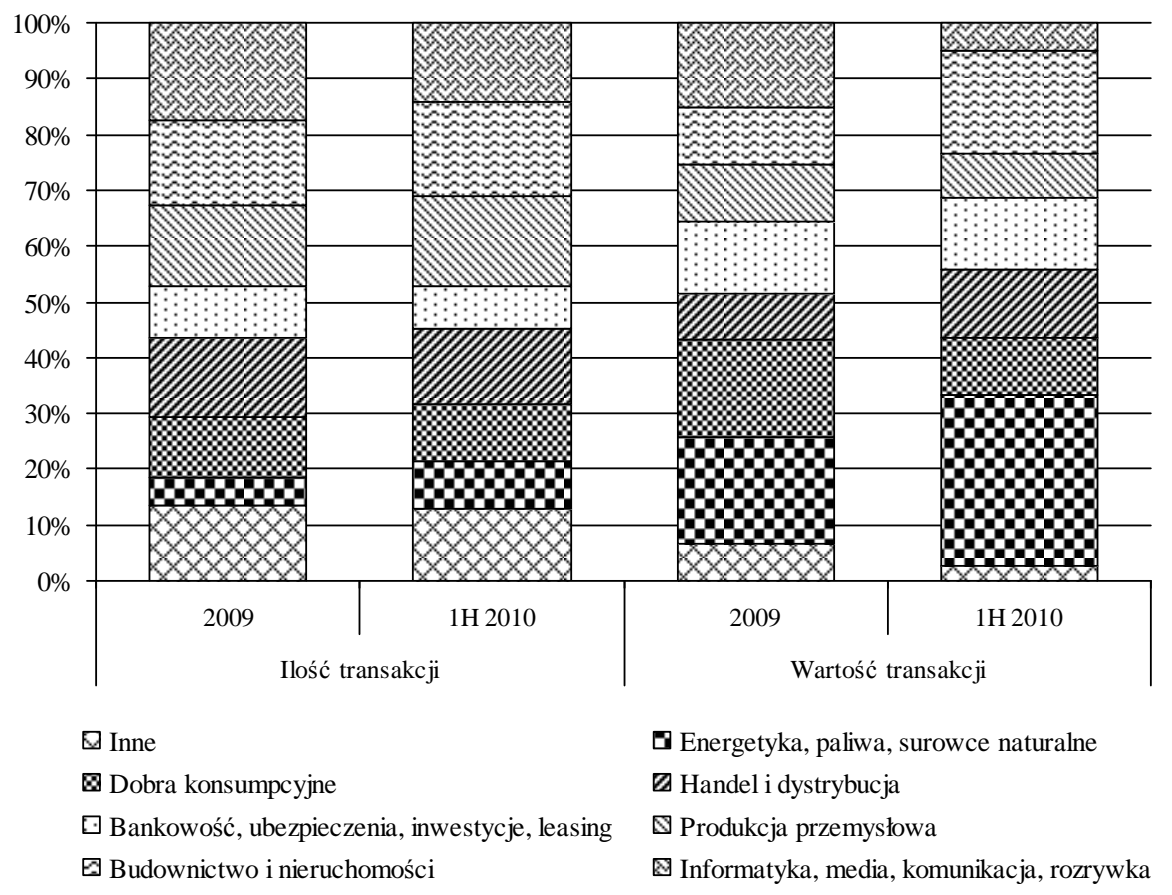

Wykres 2.2. Ujęcie sektorowe polskiego rynku fuzji i przejęć w okresie od 2009 r. do pierwszej połowy $2010 \mathrm{r}$.

Źródło: opracowanie własne na podstawie Rynek fuzji i przejęć. Polska na tle Europy Środkowej. Edycja 2010, Badanie KPMG i DealWatch, s. 9 oraz Rynek fuzji i przejęć. Polska na tle Europy Środkowo-Wsch odniej. I pótrocze 2010, Badanie KPMG i DealWatch, s. 13.

Z kolei analiza polskiego rynku fuzji i przejęć w ujęciu wartościowym w obu badanych okresach wskazuje na występowanie dominacji sektora energetyka, paliwa i surowce naturalne. $Z$ punktu widzenia realizacji procesów wyjścia $\mathrm{z}$ inwestycji funduszy private equity można stwierdzić, iż uwidoczniony zróżni- 
cowany i zrównoważony rozkład sektorowy zawieranych transakcji jest korzystny, gdyż stwarza dobre warunki do sprzedaży spółek portfelowych prowadzących działalność w różnych obszarach gospodarki.

Centralnym miejscem realizacji procesów dezinwestycji funduszy private equity za pośrednictwem polskiego rynku kapitałowego jest Giełda Papierów Wartościowych w Warszawie. Warszawski parkiet od rozpoczęcia swojej działalności w 1991 r. stwarza warunki do sprawnego przepływu zasobów finansowych między różnymi uczestnikami tego rynku, należącymi nie tylko do krajowego rynku finansowego.

Tabela 2.8

Podstawowe informacje charakteryzujące rozwój GPW w Warszawie w latach 1991-2011

\begin{tabular}{|c|c|c|c|c|c|c|}
\hline Rok & $\begin{array}{l}\text { Liczba } \\
\text { spółek }\end{array}$ & $\begin{array}{l}\text { Kapitalizacja } \\
\text { spółek } \\
\text { krajowych } \\
\text { [mln zł] } \\
\end{array}$ & $\begin{array}{l}\text { Obroty } \\
\text { akcjami } \\
{[\mathrm{mln} \mathrm{zł}]}\end{array}$ & $\begin{array}{c}\text { Obroty } \\
\text { obligacjami } \\
\text { [mln zł }]\end{array}$ & $\begin{array}{l}\text { Wolumen } \\
\text { obrotu } \\
\text { kontraktami }\end{array}$ & $\begin{array}{c}\text { Stopa zwrotu } \\
\text { WIG } \\
{[\%]}\end{array}$ \\
\hline 1991 & 9 & 161,00 & 15 & 0 & - & $-8,09$ \\
\hline 1992 & 16 & 351,00 & 114 & 11 & - & 13,20 \\
\hline 1993 & 22 & 5845,00 & 3937 & 279 & - & 1095,30 \\
\hline 1994 & 44 & 7450,00 & 11710 & 1650 & - & $-39,90$ \\
\hline 1995 & 65 & 11271,00 & 6836 & 9638 & - & 1,50 \\
\hline 1996 & 83 & 24000,00 & 14948 & 8110 & - & 89,10 \\
\hline 1997 & 143 & 43766,00 & 26171 & 6744 & - & 2,30 \\
\hline 1998 & 198 & 72442,00 & 31191 & 4291 & 24320 & $-12,80$ \\
\hline 1999 & 221 & 123411,00 & 44672 & 2383 & 207372 & 41,30 \\
\hline 2000 & 225 & 130085,00 & 84637 & 2295 & 1516042 & $-1,30$ \\
\hline 2001 & 230 & 103369,91 & 40300 & 2567 & 3754854 & $-21,99$ \\
\hline 2002 & 216 & 110564,64 & 31834 & 2066 & 3175890 & 3,19 \\
\hline 2003 & 203 & 140001,47 & 40118 & 6337 & 4231949 & 44,92 \\
\hline 2004 & 230 & 214312,57 & 59759 & 4177 & 3609125 & 27,94 \\
\hline 2005 & 255 & 308417,62 & 98517 & 2754 & 5378517 & 33,66 \\
\hline 2006 & 284 & 437719,22 & 169348 & 2768 & 6386046 & 41,60 \\
\hline 2007 & 351 & 509887,41 & 239740 & 1748 & 9477868 & 10,39 \\
\hline 2008 & 374 & 267359,31 & 165658 & 2500 & 12233935 & $-51,07$ \\
\hline 2009 & 379 & 421178,00 & 175943 & 1476 & 13424593 & 46,85 \\
\hline 2010 & 400 & 542646,12 & 234288 & 1428 & 14009202 & 18,77 \\
\hline 2011 & 426 & 446151,22 & 268139 & 836 & 14608953 & $-20,83$ \\
\hline
\end{tabular}

Źródło: http://www.gpw.pl/analizy_i_statystyki. 
Począwszy od pierwszego notowania polska giełda rozwijała się bardzo dynamicznie (zob. tab. 2.8) i nawet pomimo występujących okresów spowolnienia i dekoniunktury uznawana jest obecnie za najlepiej rozwinięty parkiet giełdowy Europy Środkowo-Wschodniej ${ }^{56}$.

Polski rynek kapitałowy jest znacznie uzależniony od napływu kapitału zagranicznego (zob. wykres 2.3), co może wpływać na wzrost ryzyka związanego $\mathrm{z}$ realizacja procesów dezinwestycji funduszy private equity.

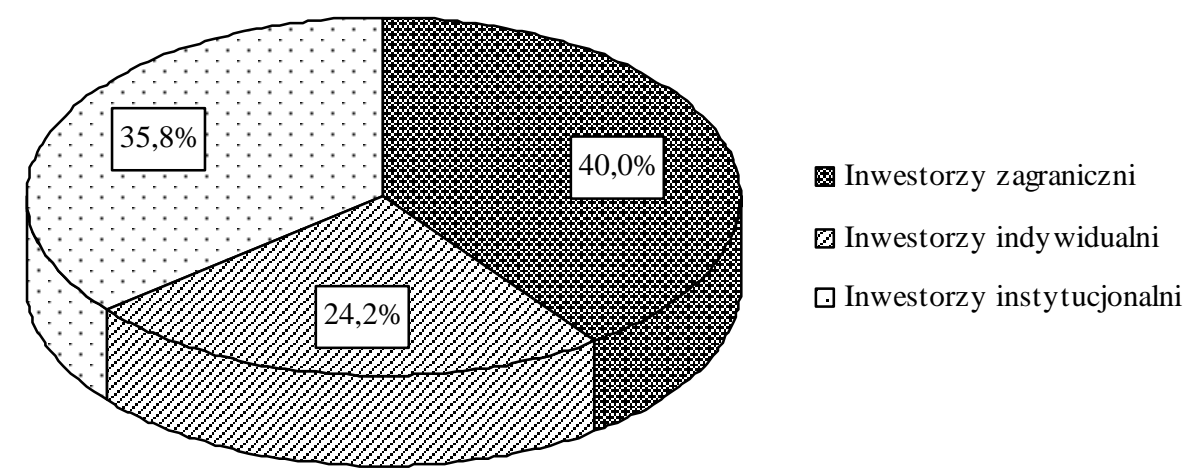

Wykres 2.3. Udział poszczególnych grup inwestorów w obrotach na GPW w Warszawie w latach 2006-2011

Źródło: opracowanie własne na podstawie www.gpw.pl.

Analizując dane przedstawione na wykresie 2.4 można wskazać na niepokojący sygnał o osłabieniu aktywności krajowych uczestników rynku kapitałowego. Bardzo wiele czynników ma wpływ na skłonność inwestorów indywidualnych $\mathrm{i}$ instytucjonalnych do inwestowania na rynku kapitałowym ${ }^{57}$. W ostatnich latach znaczący wpływ na tę sytuację z pewnością miało pogorszenie koniunktury giełdowej. Istotną determinantą czynnego udziału krajowych inwestorów instytucjonalnych były również znaczące umorzenia jednostek uczestnictwa w akcyjnych

${ }^{56}$ Zob. K. N erm e n d, A. Ku c ińs s i, Pozycja Giełdy Papierów Wartościowych w Warszawie na tle europejskich parkietów, „Studia i Materiały Polskiego Stowarzyszenia Zarządzania Wiedzą" 2011, nr 56, s. 150-162; W. Pr z y b yls k a-Ka pu ścińs k a, Rozwój polskiego rynku giełdowego na tle sytuacji giełd europejskich w XX, [w:] Roczniki Ekonomiczne KujawskoPomorskiej Szkoty Wyższej, $n r$ 1, Wydawnictwo Kujawsko-Pomorskiej Szkoły Wyższej w Bydgoszczy, Bydgoszcz 2008, s. 117-137; A. Wój cik-Mazu r, Analiza rozwoju systemu finansowego w Polsce na tle państw europy środkowo-wschodniej w latach 2006-2009, ,Zeszyty Naukowe Politechniki Śląskiej, Organizacja i Zarządzanie nr 59” 2011, s. 25-37; Rocznik gietdowy 2012, Giełda Papierów Wartościowych w Warszawie, Warszawa 2012, s. 17.

${ }^{57}$ Zob. M. Janicka, Wptyw procesów prywatyzacyjnych na rozwój rynku kapitałowego $w$ Polsce, „Acta Universitatis Lodziensis”, Folia Oeconomica 151, Wydawnictwo Uniwersytetu Łódzkiego, Łódź 2000, s. 135-140. 
funduszach inwestycyjnych obserwowane w 2008 r. i okresach późniejszych ${ }^{58}$. Klienci tych instytucji przenosili swoje aktywa do produktów o znacznie mniejszym poziomie ryzyka, takich jak fundusze dłużne czy lokaty bankowe.

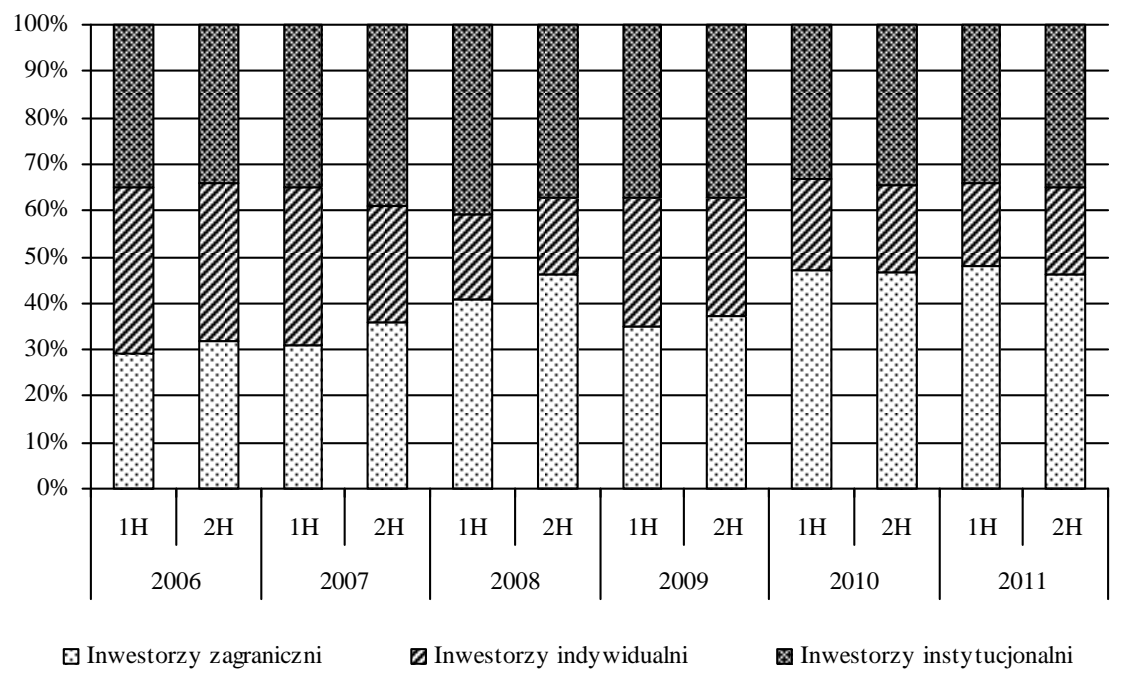

Wykres 2.4. Udział poszczególnych grup inwestorów w obrotach na GPW w Warszawie w latach 2006-2011 w półrocznych interwałach (w \%)

Źródło: jak do wykresu 2.3.

Niekorzystny wpływ na możliwości realizacji dezinwestycji funduszy private equity za pośrednictwem rynku giełdowego mogą mieć zmiany regulacji prawnych z zakresie funkcjonowania otwartych funduszy emerytalnych dotyczące przesunięcia części składki emerytalnej $\mathrm{z}$ otwartych funduszy emerytalnych do ZUS ${ }^{59}$. Na GPW w Warszawie to właśnie towarzystwa funduszy inwestycyjnych oraz otwarte fundusze emerytalne generują znaczącą część obrotów papierami wartościowymi (zob. wykres 2.5).

Nastroje rynkowe panujące na publicznym rynku papierów wartościowych znacząco wpływały również na skłonność przedsiębiorstw do wprowadzania akcji nowych spółek na warszawską giełdę. W okresach bessy (np. lata 1999-2002, 2007-2009) malała liczba spółek, których akcje były po raz pierwszy wprowadzane do publicznego obrotu, jednakże w czasie hossy (np. lata 2005-2007) można zaobserwować odwrócenie trendu i znaczący wzrost liczby debiutujących spółek (zob. wykres 2.6).

${ }^{58}$ B. W a s z c z y k, Fundusze agresywne caty czas w odstawce, Open Finance, http://www.open.pl/news/fundusze_agresywne_caly_czas_w_odstawce.html.

${ }^{59}$ Ustawa z dnia 25 marca 2011 r. o zmianie niektórych ustaw zwiąanych z funkcjonowaniem systemu ubezpieczeń społecznych, DzU 2011, nr 75, poz. 398. 


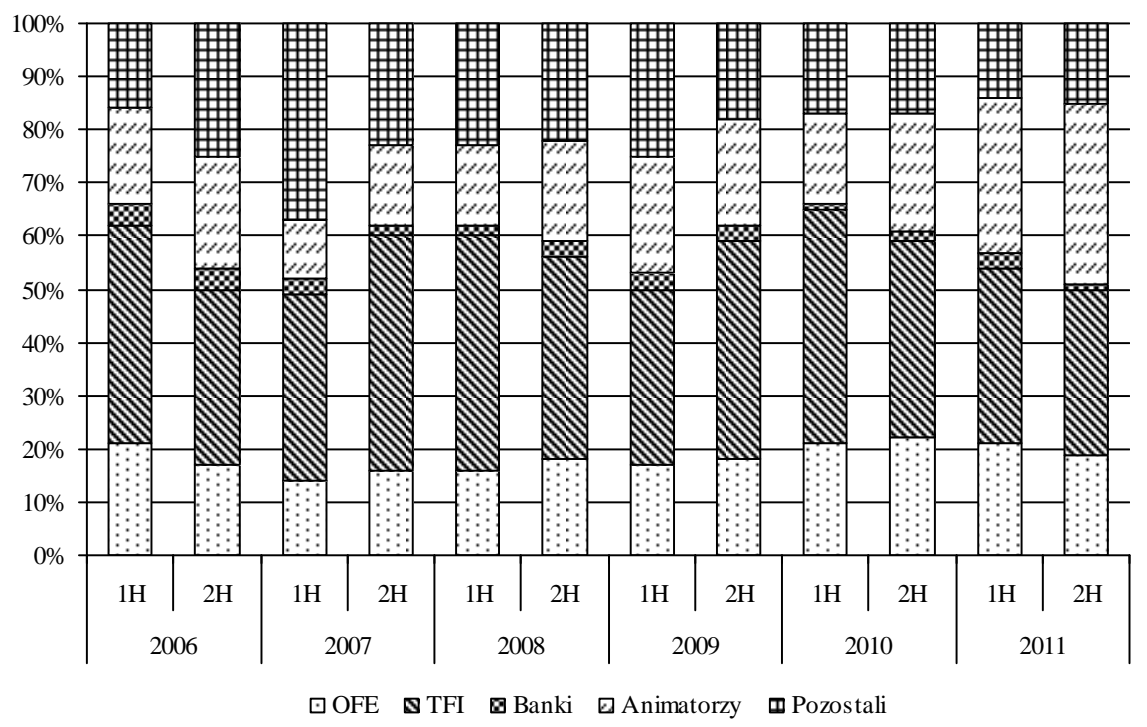

Wy kres 2.5. Udział poszczególnych rodzajów krajowych inwestorów instytucjonalnych w obrotach na GPW w Warszawie w latach 2006-2011 w półrocznych interwałach (w \%) Źródło: jak do wykresu 2.3.

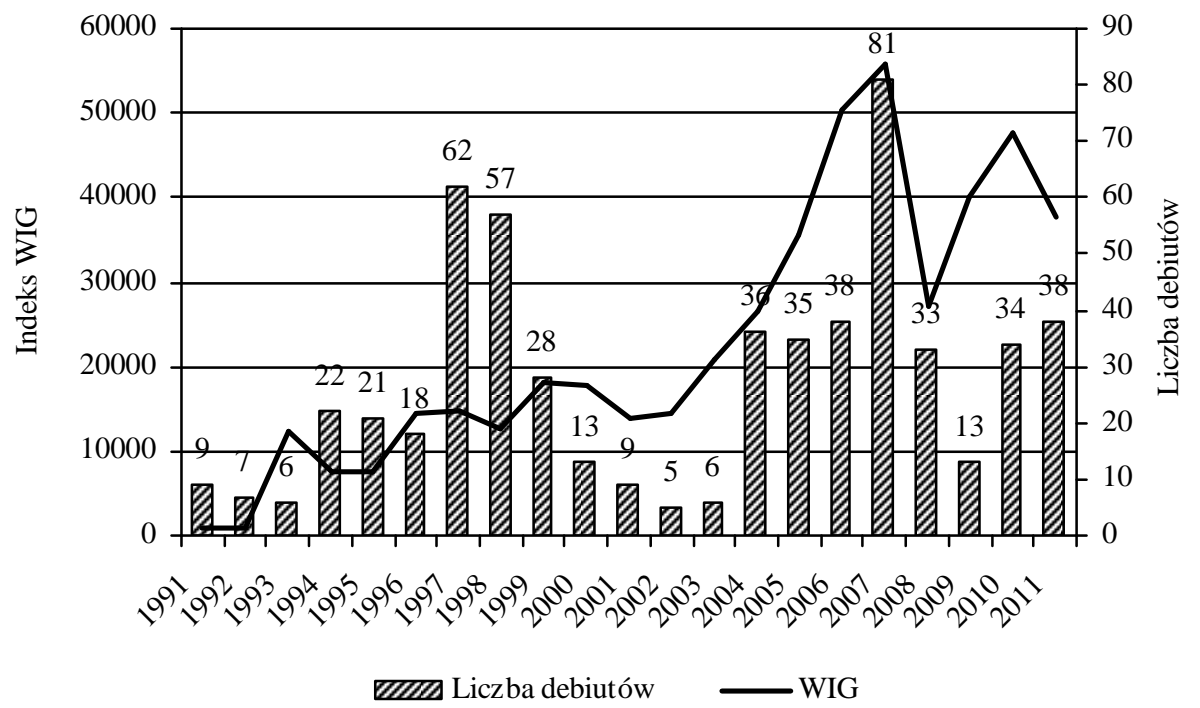

Wykres 2.6. Liczba debiutów i wartość indeksu WIG na GPW w Warszawie w latach 1991-2011

Źródło: jak do wykresu 2.3. 
Na podstawie analizy danych liczbowych przedstawionych na wykresie 2.6 można zauważyć negatywny wpływ kryzysu gospodarczego na liczbę debiutów na warszawskim rynku giełdowego. Po 2007 r., kiedy to zanotowano 81 debiutów giełdowych, zauważalny jest wyraźny spadek liczby nowych spółek, które podjęły decyzję o wprowadzeniu po raz pierwszy akcji do publicznego obrotu. Wpływ niekorzystnych uwarunkowań makroekonomicznych na skalę i zakres pierwszych ofert publicznych był charakterystyczny również dla innych giełd europejskich (zob. wykres 2.7).

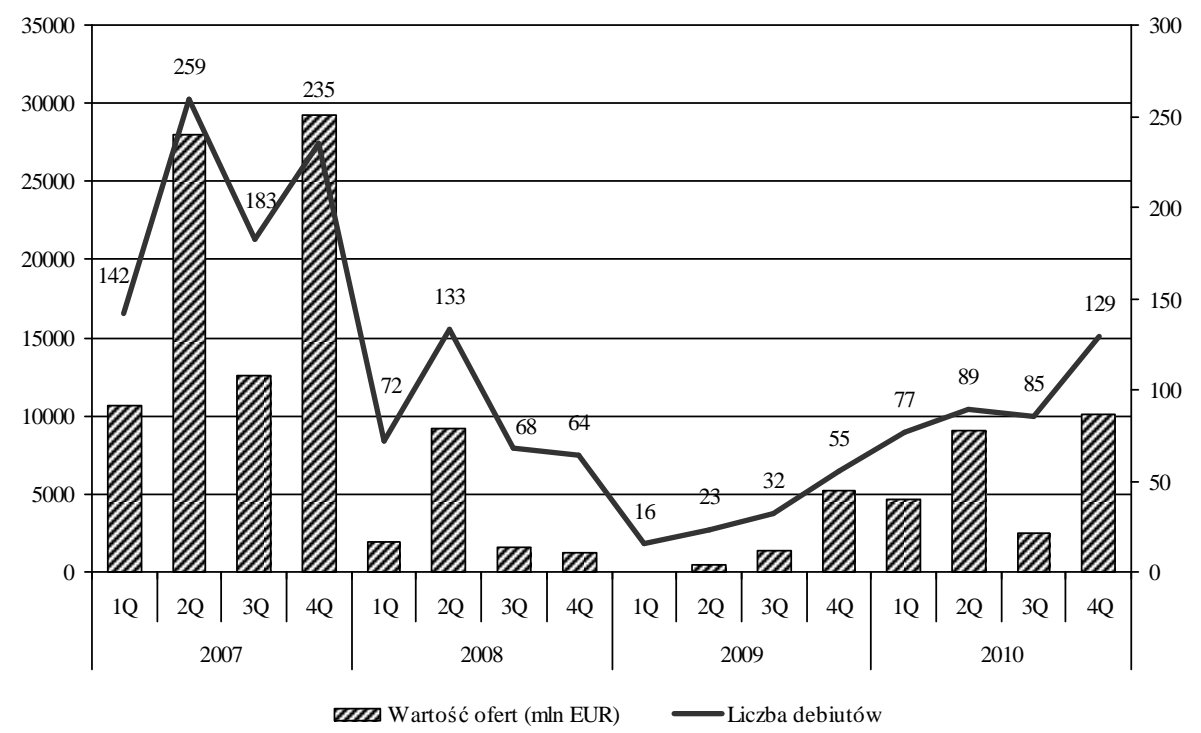

Wykres 2.7. Liczba i wartość pierwszych ofert publicznych na giełdach w krajach Unii Europejskiej w latach 2007-2010 w interwałach kwartalnych

Źródło: opracowanie własne na podstawie IPO Watch Europe - Review of the year 2008, PricewaterhouseCoopers, 2009, s. 3; IPO Watch Europe - Review of the year 2010, PricewaterhouseCoopers, 2011, s. 8 opublikowanych na www.pwc.com.

Największe załamanie na europejskim rynku debiutów giełdowych nastąpiło w pierwszym kwartale 2009 r. Wówczas swoje pierwsze notowanie miało miejsce zaledwie 16 spółek, które zaoferowały akcje o łącznej wartości $35 \mathrm{mln}$ EUR (zob. wykres 2.7). Taki obraz wskazuje na ograniczenia możliwości przeprowadzenia sprawnego wyjścia z inwestycji funduszy private equity za pośrednictwem publicznego rynku papierów wartościowych. W kolejnych kwartałach można było jednak zaobserwować powolną odbudowę rynku pierwszych ofert publicznych w Unii Europejskiej.

Polski rynek giełdowy w porównaniu z innymi giełdami Unii Europejskiej pod względem liczby oraz wartości realizowanych debiutów giełdowych ocenić można pozytywnie, biorąc zarówno pod uwagę główny parkiet warszawskiej 
giełdy, jak i rynek NewConnect. Można stwierdzić, iż polska giełda znajduje się w obszarze zainteresowania inwestorów chcących aktywnie uczestniczyć w pierwotnym rynku akcji.

Dane zawarte w tab. 2.9 wskazują, iż w analizowanym okresie centralnym ośrodkiem realizacji pierwszych publicznych ofert sprzedaży akcji na rynku pierwotnym w Unii Europejskiej był London Stock Exchange. W latach 2007-2010 na głównym parkiecie tej giełdy zrealizowano łącznie 198 pierwszych ofert publicznych o łącznej wartości prawie 44,5 mld EURO, co stanowiło niemalże 55\% ogółu wartości wszystkich publicznych ofert związanych z debiutami giełdowymi spółek na unijnym rynku. Znaczną aktywność w zakresie pierwszych ofert publicznych można również zauważyć na NYSE Euronext, Giełdzie Papierów Wartościowych w Warszawie oraz NASDAQ OMX.

Analizując informacje zawarte w tab. 2.9 można ponadto wskazać, iż istotną rolę w rozwoju pierwotnego rynku akcji w Unii Europejskiej odgrywają również alternatywne systemy obrotu akcjami, tworzone i funkcjonujące przy głównych giełdach papierów wartościowych. Na rynku polskim jest to NewConnect. Warto podkreślić, iż liczba zrealizowanych ofert na tych rynkach była wyraźnie większa od liczby ofert przeprowadzonych na głównych parkietach, jednakże wartość kapitału pozyskanego w wyniku tych ofert jest dużo niższa, co znajduje odzwierciedlenie w różnicy pomiędzy średnimi wartościami ofert.

Rozwój alternatywnych możliwości dostępu do rynku kapitałowego należy odbierać jako jednoznacznie pozytywny sygnał z punktu widzenia działalności funduszy private equity. Rynek NewConnect jest to bowiem miejscem, gdzie mogą być realizowane procesy dezinwestycji w tych spółkach portfelowych, które nie spełniają jeszcze rygorystycznych wymogów stawianych spółkom na głównym parkiecie GPW w Warszawie.

Analiza sektorowego rozkładu przeprowadzonych w analizowanym okresie pierwszych ofert publicznych dowodzi ich znacznego zróżnicowania (zob. tab. 2.10).

W latach 2007-2010 najwięcej pierwszych ofert publicznych przeprowadziły spółki, które prowadziły działalność gospodarczą w sektorach produktów i usług przemysłowych, działalność inwestycyjną oraz funkcjonowały w obszarach związanych z nowymi technologiami. Oferty tych przedsiębiorstw stanowiły ponad $42 \%$ wszystkich transakcji tego typu. Spółki działające w innych sektorach gospodarki również aktywnie uczestniczyły na rynku pierwszych ofert publicznych, jednakże ich udział w ogólnej liczbie zrealizowanych ofert był mniejszy, a w poszczególnych latach ulegał pewnym fluktuacjom. Tego typu dywersyfikacja powinna być interpretowana jako pozytywny sygnał dla funduszy zainteresowanych realizacją wyjść z inwestycji za pośrednictwem publicznego rynku papierów wartościowych, gdyż nie wskazuje na występowanie barier w tym względzie. Inwestorzy giełdowi są skłonni do uczestnictwa w ofertach przedsiębiorstw prowadzących działalność w różnych sektorach gospodarki. 
Tabela 2.9

Liczba i wartość pierwszych ofert publicznych na poszczególnych giełdach w krajach Unii Europejskiej w latach 2007-2010

\begin{tabular}{|c|c|c|c|c|c|c|c|c|}
\hline \multirow[b]{2}{*}{ Wyszczególnienie } & \multicolumn{2}{|c|}{2007} & \multicolumn{2}{|c|}{2008} & \multicolumn{2}{|c|}{2009} & \multicolumn{2}{|c|}{2010} \\
\hline & $\begin{array}{c}\text { liczba } \\
\text { ofert }\end{array}$ & $\begin{array}{c}\text { wartość } \\
\text { ofert } \\
\text { [mln } \\
\text { EUR] }\end{array}$ & $\begin{array}{c}\text { liczba } \\
\text { ofert }\end{array}$ & $\begin{array}{c}\text { wartość } \\
\text { ofert } \\
\text { [mln } \\
\text { EUR] }\end{array}$ & $\begin{array}{c}\text { liczba } \\
\text { ofert }\end{array}$ & $\begin{array}{c}\text { wartość } \\
\text { ofert } \\
\text { [mln } \\
\text { EUR] }\end{array}$ & $\begin{array}{c}\text { liczba } \\
\text { ofert }\end{array}$ & $\begin{array}{c}\text { wartość } \\
\text { ofert } \\
\text { [mln } \\
\text { EUR] }\end{array}$ \\
\hline \multicolumn{9}{|c|}{ Rynki główne } \\
\hline London (Main) & 99 & 27641 & 38 & 7137 & 91 & 620 & 52 & 9034 \\
\hline NYSE Euronext (Euronext) & 40 & 7563 & 16 & 2466 & 6 & 1907 & 11 & 344 \\
\hline WSE (Main) & 80 & 1980 & 30 & 2455 & 12 & 1584 & 26 & 3770 \\
\hline Deutsche Börse & 28 & 6734 & 2 & 324 & 11 & 48 & 10 & 2297 \\
\hline BME (Spanish Exchanges) & 12 & 10084 & 1 & 292 & 1 & - & 2 & 1514 \\
\hline SIX Swiss Exchange & 10 & 1975 & 6 & 169 & 4 & - & 4 & 163 \\
\hline NASDAQ OMX (Main) & 35 & 2301 & 10 & 152 & 6 & 66 & 15 & 2007 \\
\hline Borsa Italiana & 29 & 3943 & 6 & 129 & 1 & 105 & 2 & 2099 \\
\hline Luxembourg & $1 \stackrel{1}{1}$ & - & 4 & 18 & - & - & - & - \\
\hline Oslo Børs & 18 & 1264 & 4 & 2 & -1 & - & 9 & 2362 \\
\hline ISE & 11 & 1495 & 11 & - & -1 & - & - & - \\
\hline Wiener Börse & 6 & 1427 & -1 & - & -1 & - & - & - \\
\hline Athens Stock Exchange & 3 & 479 & - & - & 1 & 10 & - & - \\
\hline Razem $^{*}$ & 360 & 65292 & 115 & 11736 & 41 & 4340 & 130 & 23590 \\
\hline Średnia wartość oferty & & 181,37 & & 102,05 & & 105,85 & & 181,46 \\
\hline \multicolumn{9}{|c|}{ Alternatywne systemy obrotu } \\
\hline London (AIM) & 220 & 9537 & 58 & 1423 & 14 & 655 & 58 & 1180 \\
\hline Luxembourg (EuroMTF) & 18 & 1401 & 15 & 267 & 22 & 1575 & 36 & 797 \\
\hline London (PSM) & 5 & 1909 & 2 & 255 & $1 \stackrel{1}{1}$ & 355 & - & - \\
\hline London (SFM) & -1 & - & 11 & 69 & 1 & 30 & 4 & 305 \\
\hline Oslo Axess & 19 & 729 & 10 & 63 & 2 & 91 & 7 & 83 \\
\hline NASDAQ OMX (First North) & 50 & 837 & 16 & 56 & 5 & - & 9 & 22 \\
\hline WSE (NewConnect) & 24 & 41 & 61 & 47 & 26 & 10 & 86 & 40 \\
\hline NYSE Euronext (Alternext) & 39 & 445 & 7 & 31 & 3 & - & 21 & 73 \\
\hline $\begin{array}{l}\text { Deutsche Börse (Entry Stan- } \\
\text { dard) }\end{array}$ & 34 & 250 & 10 & 6 & $4 \stackrel{3}{1}$ & 5 & 13 & 116 \\
\hline $\begin{array}{l}\text { NYSE Euronext (Marché } \\
\text { Libre) }\end{array}$ & 48 & 24 & 42 & 4 & -1 & - & - & - \\
\hline ISE (IEX) & 9 & 183 & -1 & - & -1 & - & - & - \\
\hline $\begin{array}{lll}\text { BME } & \text { (Spanish } & \text { Exchanges) } \\
\text { MAB } & & \\
\end{array}$ & - & - & - & - & 2 & 19 & 10 & 48 \\
\hline Borsa Italiana (AIM) & -1 & - & - & - & 5 & 32 & 6 & 32 \\
\hline Razem $^{*}$ & 459 & 15181 & 222 & 2221 & 85 & 2772 & 250 & 2696 \\
\hline Średnia wartość oferty & & 33,07 & & 10,00 & & 32,61 & & 10,78 \\
\hline
\end{tabular}

* dane zawarte w tabeli nie sumują się, gdyż część spółek przeprowadzała oferty sprzedaży akcji jednocześnie na kilku rynkach; więcej szczegółów w dokumentach źródłowych.

Źr ó dło: opracowanie własne na podstawie IPO Watch Europe - Review of the year 2008, PricewaterhouseCoopers, 2009, s. 7; IPO Watch Europe - Review of the year 2010, PricewaterhouseCoopers, 2011, s. 13 opublikowanych na www.pwc.com. 
Tabela 2.10

Ujęcie sektorowe pierwszych publicznych ofert sprzedaży akcji na rynkach kapitałowych Unii Europejskiej w latach 2007-2010 [w \%]

\begin{tabular}{|l|r|r|r|r|r|}
\hline \multicolumn{1}{|c|}{ Wyszczególnienie } & \multicolumn{1}{c|}{2007} & \multicolumn{1}{c|}{2008} & \multicolumn{1}{c|}{2009} & 2010 & $2007-2010$ \\
\hline \hline Produkty i usługi przemysłowe & 18,08 & 17,80 & 14,84 & 16,41 & 17,39 \\
\hline Działalność inwestycyjna & 14,64 & 14,54 & 14,06 & 12,50 & 14,08 \\
\hline Nowe technologie & 11,07 & 10,98 & 12,50 & 9,38 & 10,77 \\
\hline Usługi finansowe & 6,15 & 5,64 & 7,81 & 5,99 & 6,14 \\
\hline Nieruchomości & 6,03 & 5,34 & 6,25 & 4,17 & 5,48 \\
\hline Ropa naftowa i gaz & 4,55 & 5,34 & 3,13 & 3,91 & 4,45 \\
\hline Farmaceutyki i biotechnologia & 3,94 & 2,67 & 3,13 & 7,03 & 4,33 \\
\hline Żywność i napoje & 3,57 & 4,45 & 2,34 & 4,95 & 3,97 \\
\hline Media & 4,06 & 2,97 & 3,91 & 4,69 & 3,97 \\
\hline Artykuły osobiste i gospodarstwa domowego & 3,20 & 4,15 & 2,34 & 3,65 & 3,43 \\
\hline Handel & 2,71 & 3,86 & 3,13 & 4,69 & 3,43 \\
\hline Górnictwo & 2,95 & 2,37 & 1,56 & 5,99 & 3,43 \\
\hline Usługi komunalne & 2,34 & 4,15 & 5,47 & 3,91 & 3,31 \\
\hline Budownictwo i materiały budowlane & 1,97 & 3,86 & 7,03 & 2,86 & 2,95 \\
\hline Usługi telekomunikacyjne & 2,58 & 4,15 & 1,56 & 2,86 & 2,89 \\
\hline Podróże i rekreacja & 3,69 & 2,67 & 0,78 & 2,08 & 2,89 \\
\hline Opieka zdrowotna & 1,48 & 1,78 & 2,34 & 1,30 & 1,56 \\
\hline Przemysł drzewny i metalowy & 1,97 & 0,30 & 2,34 & 1,04 & 1,44 \\
\hline Banki & 1,72 & 0,89 & 1,56 & 0,52 & 1,26 \\
\hline Ubezpieczenia & 1,11 & 0,30 & 2,34 & 1,04 & 1,02 \\
\hline Motoryzacyjny i części samochodowych & 1,48 & 0,59 & 0,78 & 0,26 & 0,96 \\
\hline Chemiczny & 100,00 & 100,00 & 100,00 & 100,00 & 100,00 \\
\hline Razem & & & & & 0,84 \\
\hline
\end{tabular}

Źródło: opracowanie własne na podstawie kwartalnych załączników do raportów IPO Watch Europe publikowanych na www.pwc.com.

\subsection{Metody dezinwestycji funduszy private equity na rynku polskim}

Głównym celem analizy stosowanych na polskim rynku metod wyjścia $\mathrm{z}$ inwestycji funduszy private equity jest rozpoznanie i wskazanie na najczęściej wykorzystywane na krajowym rynku kapitału podwyższonego ryzyka metody dezinwestycji. Zasadnicza analiza empiryczna stosowanych przez fundusze me- 
tod wyjścia z inwestycji na polskim rynku została przeprowadzona $\mathrm{z}$ uwzględnieniem dwóch mierników oceny, a mianowicie: liczby przedsiębiorstw oraz kwoty dezinwestycji, wyrażonej w koszcie początkowym inwestycji ${ }^{60}$.

Fundusze private equity działające w Polsce podejmują aktywne działania w zakresie wyjść $\mathrm{z}$ inwestycji i realizacji planowanego zysku $\mathrm{z}$ inwestycji. W latach 2002-2010 zakończone zostały inwestycje o początkowej wartości prawie 723 mln EUR. (zob. wykres 2.8).

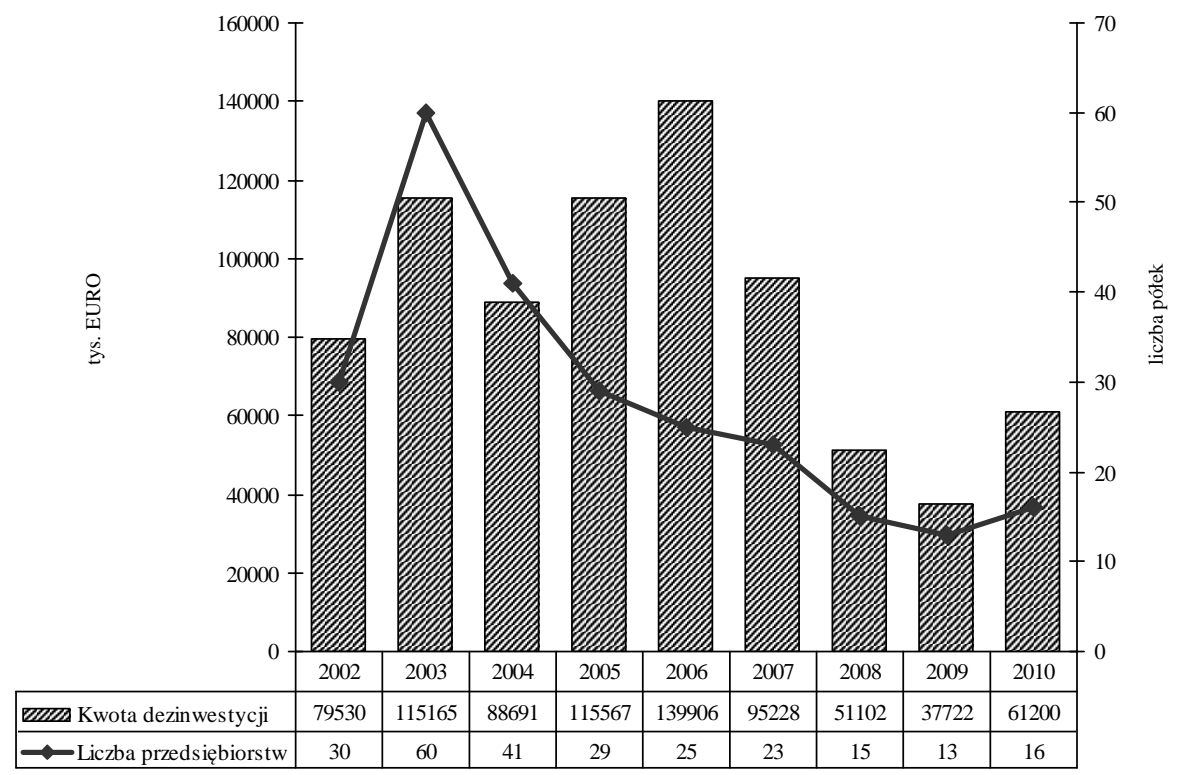

Wykres 2.8. Wyjścia z inwestycji funduszy mających siedzibę w Polsce w latach 2002-2010

Źródło: opracowanie własne na podstawie EVCA Yearbook 2003-2011.

Analizując jednakże aktywność funduszy private equity w zakresie dezinwestycji ze względu na liczbę przedsiębiorstw można wskazać na pesymistyczny obraz tego rynku. W latach 2003-2009 zauważalny jest wyraźny spadek liczby przedsiębiorstw udziałowych objętych procesami wyjścia $\mathrm{z}$ inwestycji. W 2009 r. zakończono inwestycje zaledwie w 13 spółkach. W 2010 r. można wskazać na pojawienie się pewnych oznak ożywienia na tym rynku, gdyż liczba spółek, z którymi fundusze zakończyły współpracę wzrosła w porównaniu

${ }^{60}$ Tak skromne studium diagnostyczne w żadnym stopniu nie upoważnia do formułowania wniosków w zakresie poziomu efektywności osiąganej przez fundusze private equity prowadzące działalność na polskim rynku. Niemniej jednak wyniki badań stanowić mogą - jak się wydaje - ważną podstawę poznawczą analizowanego procesu. 
z poprzednim rokiem, aczkolwiek nadal kształtuje się ona na bardzo niskim poziomie.

Najczęściej stosowanymi metodami zakończenia współpracy pomiędzy spółką kapitałową i funduszem są sprzedaż spółki inwestorowi branżowemu oraz zbycie posiadanych udziałów w drodze emisji publicznej (zob. wykres 2.9).
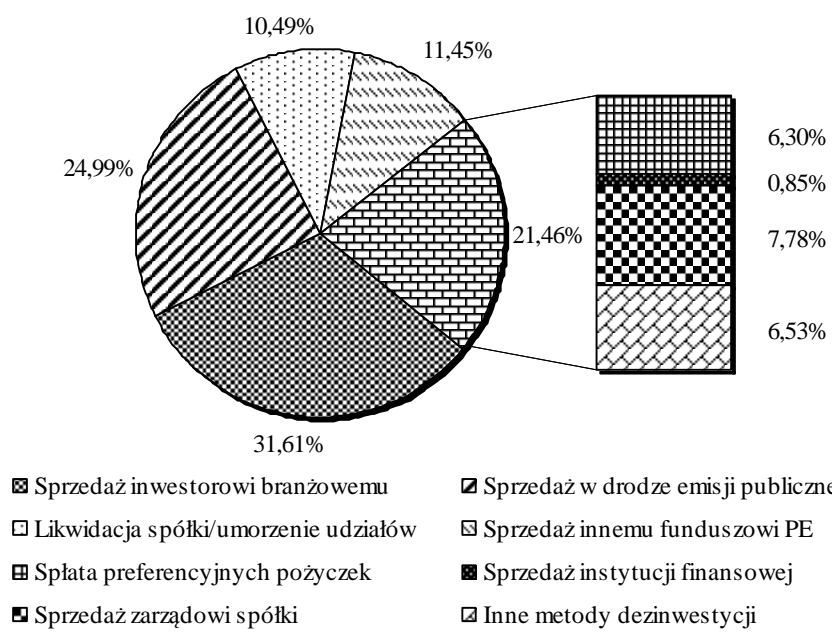

\ Sprzedaż w drodze emisji publicznej

๑ Sprzedaż innemu funduszowi PE

Sprzedaż instytucji finansowej

$\triangle$ Inne metody dezinwestycji

Wykres 2.9. Udział poszczególnych metod dezinwestycji w łącznej wartości wyjść z inwestycji funduszy private equity mających siedzibę w Polsce w latach 2002-2010

Źródło: jak do wykresu 2.8 .

W latach 2002-2010 najczęściej stosowaną metodą zakończenia współpracy pomiędzy spółką portfelową oraz funduszem private equity według kryterium kwoty dezinwestycji była sprzedaż spółki inwestorowi branżowemu. Tę ścieżkę wyjścia z inwestycji zastosowano w 31,61\% sumy wszystkich dezinwestycji w tym okresie. Sprzedaż akcji spółki w drodze emisji publicznej w warunkach polskiego rynku odgrywa również istotną rolę, gdyż w ten sposób przeprowadzona została ponad jedna czwarta wszystkich dezinwestycji w tym okresie. Trzecią najczęściej wybieraną formą wyjścia z inwestycji była sprzedaż spółki portfelowej innemu funduszowi private equity. Warto podkreślić, iż likwidacja spółki/umorzenie udziałów w praktyce dezinwestycji krajowych funduszy private equity stanowiła stosunkowo niewielki udział i wynosiła zaledwie 10,49\%. Pozostałe metody dezinwestycji były stosowane przez polskie firmy zarządzające w znacznie mniejszej skali.

Zbliżony obraz struktury stosowanych metod zakończenia współpracy pomiędzy funduszem private equity a spółką portfelową otrzymujemy analizując te procesy $\mathrm{w}$ oparciu o liczbę przedsiębiorstw objętych procesami dezinwestycji poszczególnymi metodami (zob. wykres 2.10). 


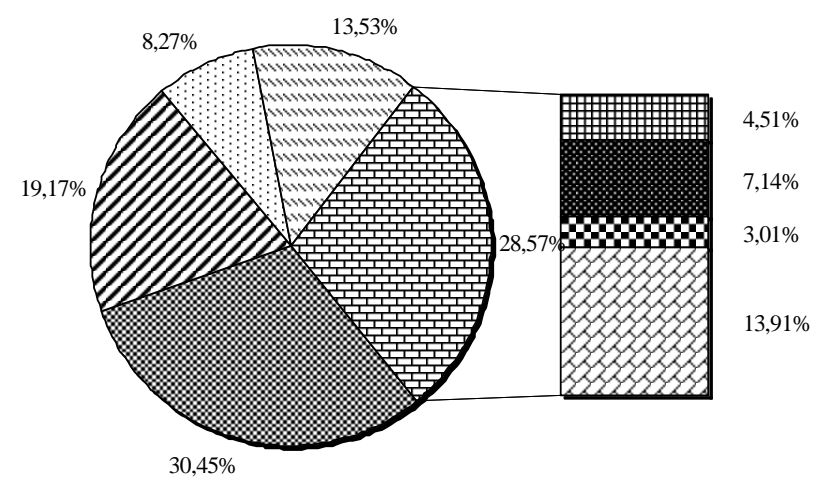

\begin{tabular}{|c|c|}
\hline ( Sprzedaż inwestorowi strategicznemu & $\boldsymbol{\nabla}$ Sprzedaż w drodze oferty publicznej \\
\hline ๑Likwidacja spółki/umorzenie udziałów & @ Sprzedaż zarządowi spółki \\
\hline$\boxplus$ Spłata preferencyjnych pożyczek & Sprzedaż innemu funduszowi PE \\
\hline Q Sprzedaż innej instytucji finansowej & QInne metody dezinwestycji \\
\hline
\end{tabular}

Wykres 2.10. Zastosowanie poszczególnych metod dezinwestycji w procesach wyjść z inwestycji funduszy private equity mających siedzibę w Polsce według liczby przedsiębiorstw w latach 2002-2010

Źródło: jak do wykresu 2.8.

W analizowanym okresie udział poszczególnych metod zakończenia współpracy pomiędzy funduszem a spółką portfelową nie miał charakteru stałego i zmieniał się w poszczególnych latach (zob. wykres 2.11).

Dane zawarte na wykresie 2.11 wskazują, iż niemalże w każdym z analizowanych lat sprzedaż spółki inwestorowi branżowemu stanowiła znaczącą część wszystkich przeprowadzonych dezinwestycji, przy czym największy jej udział odnotowany został w 2008 r. Z kolei sprzedaż spółki w drodze publicznej emisji akcji stanowiła znaczącą metodę dezinwestycji w warunkach polskiego rynku do 2006 r., kiedy to tym sposobem zrealizowano ponad 53\% wszystkich wyjść $\mathrm{z}$ inwestycji. W kolejnych dwóch latach zauważalna jest marginalizacja znaczenia giełdy papierów wartościowych $\mathrm{w}$ procesie wyjść $\mathrm{z}$ inwestycji funduszy private equity na krajowym rynku. Natomiast w 2009 r. prawie połowa wszystkich dezinwestycji została zrealizowana za pośrednictwem publicznego rynku akcji. Było to jednak krótkotrwałe ożywienie, gdyż w 2010 r. znaczenie tej formy dezinwestycji ponownie zmalało. Wykorzystanie pozostałych metod dezinwestycji było zróżnicowane w poszczególnych latach. Należy podkreślić, iż 2010 r. przedstawia bardzo niepokojący obraz tego rynku. Udział inwestycji zakończonych likwidacją spółki/umorzeniem udziałów wzrósł do niespotykanego dotąd w warunkach polskich poziomu i wynosił prawie $60 \%$. Świadczyć to może także o negatywnym wpływie sytuacji makroekonomicznej na funkcjonowanie i rozwój przedsiębiorstw udziałowych. 


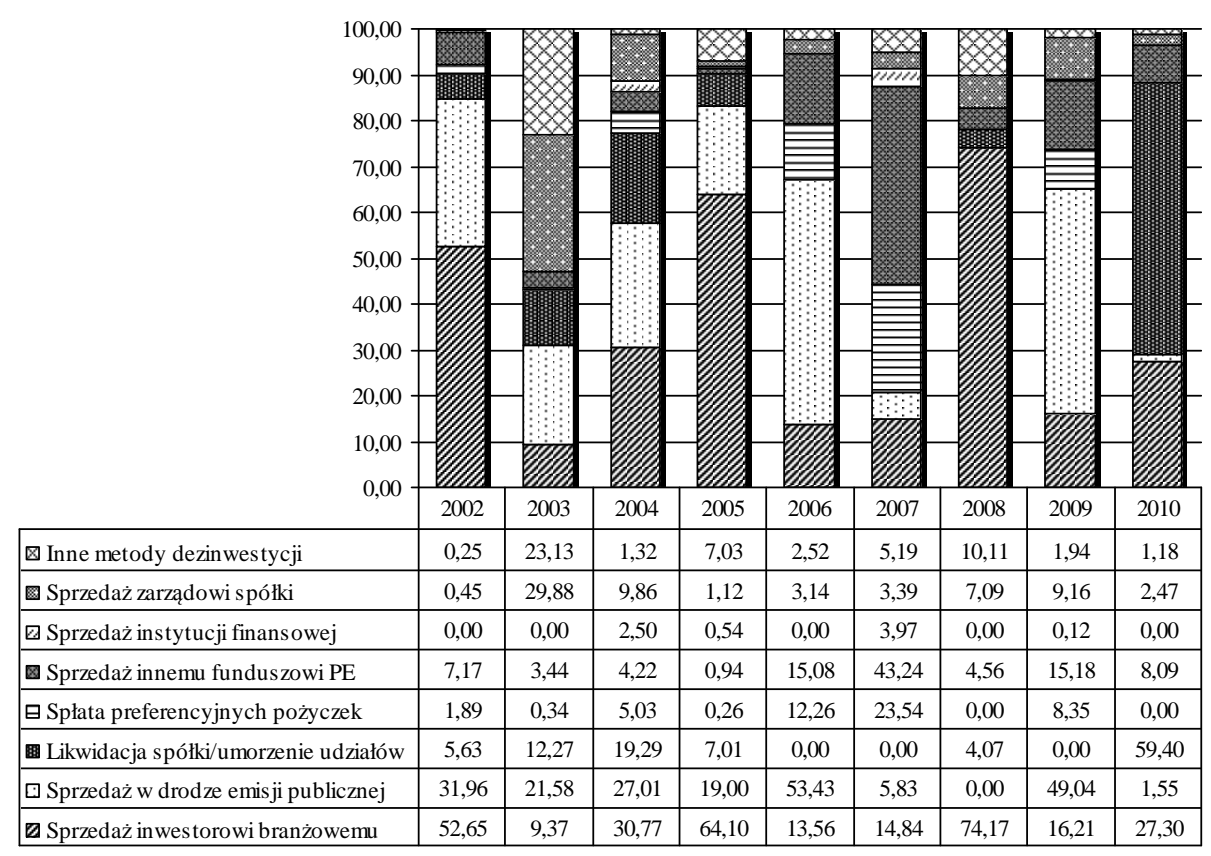

Wykres 2.11. Metody dezinwestycji stosowane przez fundusze private equity mające siedzibę w Polsce w latach 2002-2010

Źródło: jak do wykresu 2.8.

Pełniejszy obraz rynku wyjść z inwestycji funduszy private equity w Polsce można uzyskać analizując go w oparciu o informacje prezentowane według siedziby spółki portfelowej, a nie według siedziby firmy zarządzającej danym funduszem $^{61}$.

Na podstawie danych zawartych w tab. 2.11 można wskazać, iż struktura stosowanych metod dezinwestycji wobec spółek portfelowych mających siedzibę w Polsce w latach 2007-2010 była wyraźnie zdywersyfikowana. W praktyce realizowanych wówczas wyjść z inwestycji dużą rolę odgrywały sprzedaż spółki innemu funduszowi private equity oraz zbycie przedsiębiorstwa udziałowego na rzecz inwestora branżowego. Niepokojącym sygnałem jest niewielkie znaczenie publicznego rynku kapitałowego $\mathrm{w}$ analizowanych procesach dezinwestycji. $\mathrm{Wy}-$ jątek stanowi 2009 r., kiedy za pośrednictwem giełdy papierów wartościowych fundusze wyszły z inwestycji o początkowej wartości ponad $14 \mathrm{mln}$ EURO, co stanowiło ponad $45 \%$ wszystkich zrealizowanych $\mathrm{w}$ tym roku dezinwestycji.

${ }^{61}$ Tego typu analiza możliwa jest jednakże dopiero od 2007 r., co wynika z dostępności i porównywalności danych empirycznych. W 2007 r. EVCA zmieniła stosowane przekroje klasyfikacyjne. Dalsza analiza prowadzona będzie zatem w tzw. ujęciu market. 
Transakcje te miały jednakże miejsce na rynku wtórnym. Zauważalny niedostatek aktywności funduszy na rynku pierwotnym jest wyraźnym negatywnym sygnałem w zakresie realizacji efektywnych procesów wyjścia z inwestycji. Ponadto wysoki, dotychczas niepotykany na polskim rynku udział inwestycji zakończonych przez likwidację spółki/umorzenie udziałów w 2010 r., świadczyć może o bardzo niepokojącej sytuacji na krajowym rynku kapitału podwyższonego ryzyka.

Z kolei analiza sektorowa prowadzonych w latach 2007-2010 procesów dezinwestycji wskazuje, iż spółki portfelowe z którymi fundusze zdecydowały się zakończyć współpracę prowadziły działalność w różnych sektorach gospodarki (zob. tab. 2.11). Istotna część z nich funkcjonowała w sektorach związanych $\mathrm{z}$ produktami przemysłowymi, produktami konsumpcyjnymi i handlem oraz naukami biologicznymi. W poszczególnych latach struktura sektorowa procesów była odmienna, jednakże w każdym roku można wskazać pewne wiodące w tym zakresie sektory gospodarki.

Analiza prowadzonych przez fundusze private equity wyjść $\mathrm{z}$ inwestycji z punktu widzenia segmentu kapitału podwyższonego ryzyka wskazuje, że w analizowanym okresie przeważająca część dezinwestycji dotyczyła spółek znajdujących się na późniejszych etapach rozwoju w momencie inwestycji (zob. wykres 2.12).

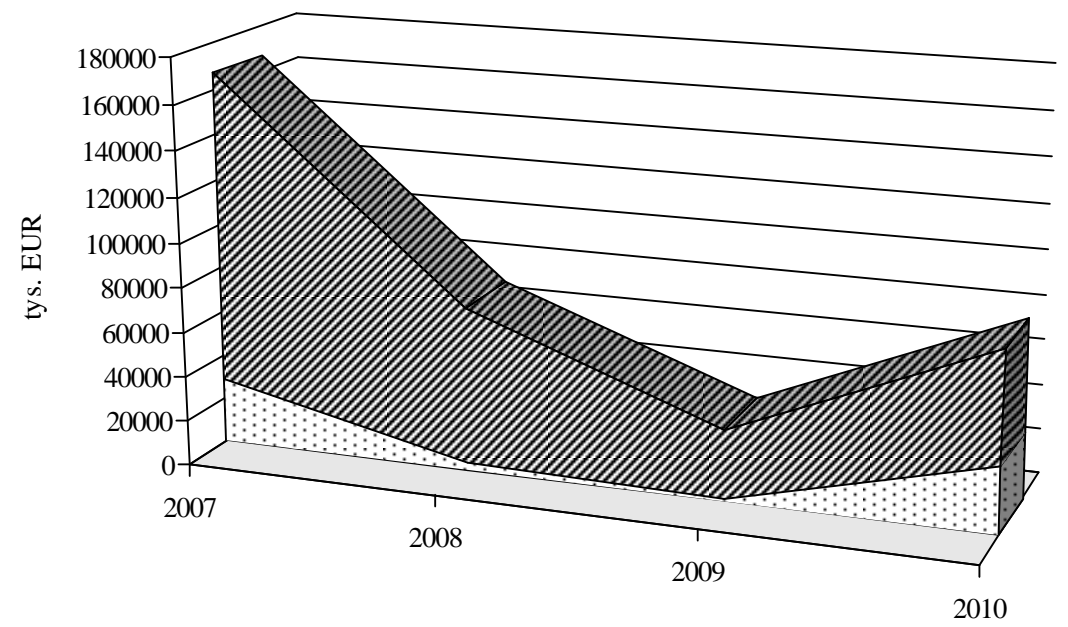

$\square$ Venture capital Pozostałe private equity (Buyout\&Growth)

W y kres 2.12. Kwota dezinwestycji według segmentu rynku kapitału podwyższonego ryzyka w latach 2007-2010

Źródło: opracowanie własne na podstawie EVCA Yearbook 2008-2011. 


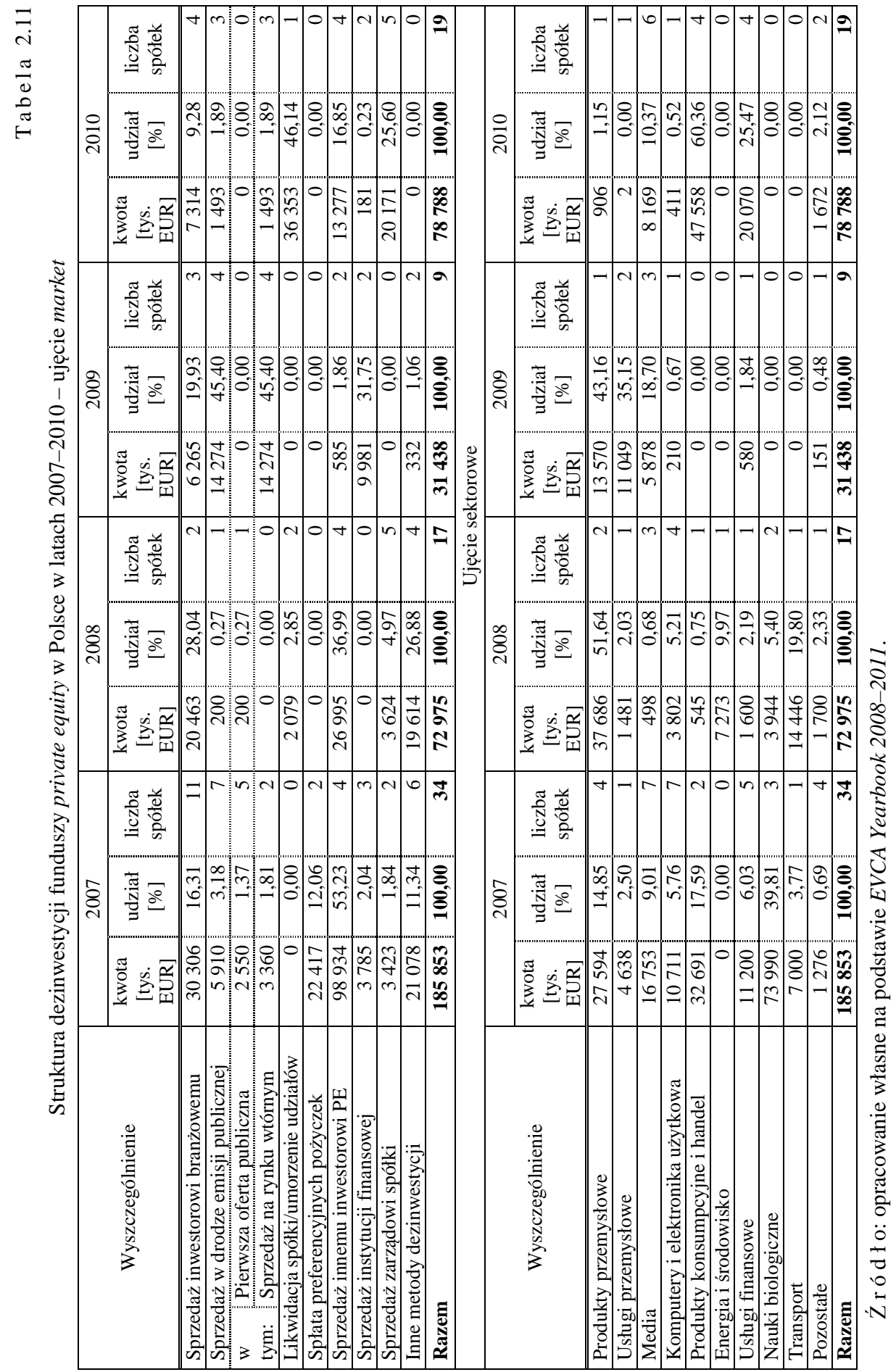




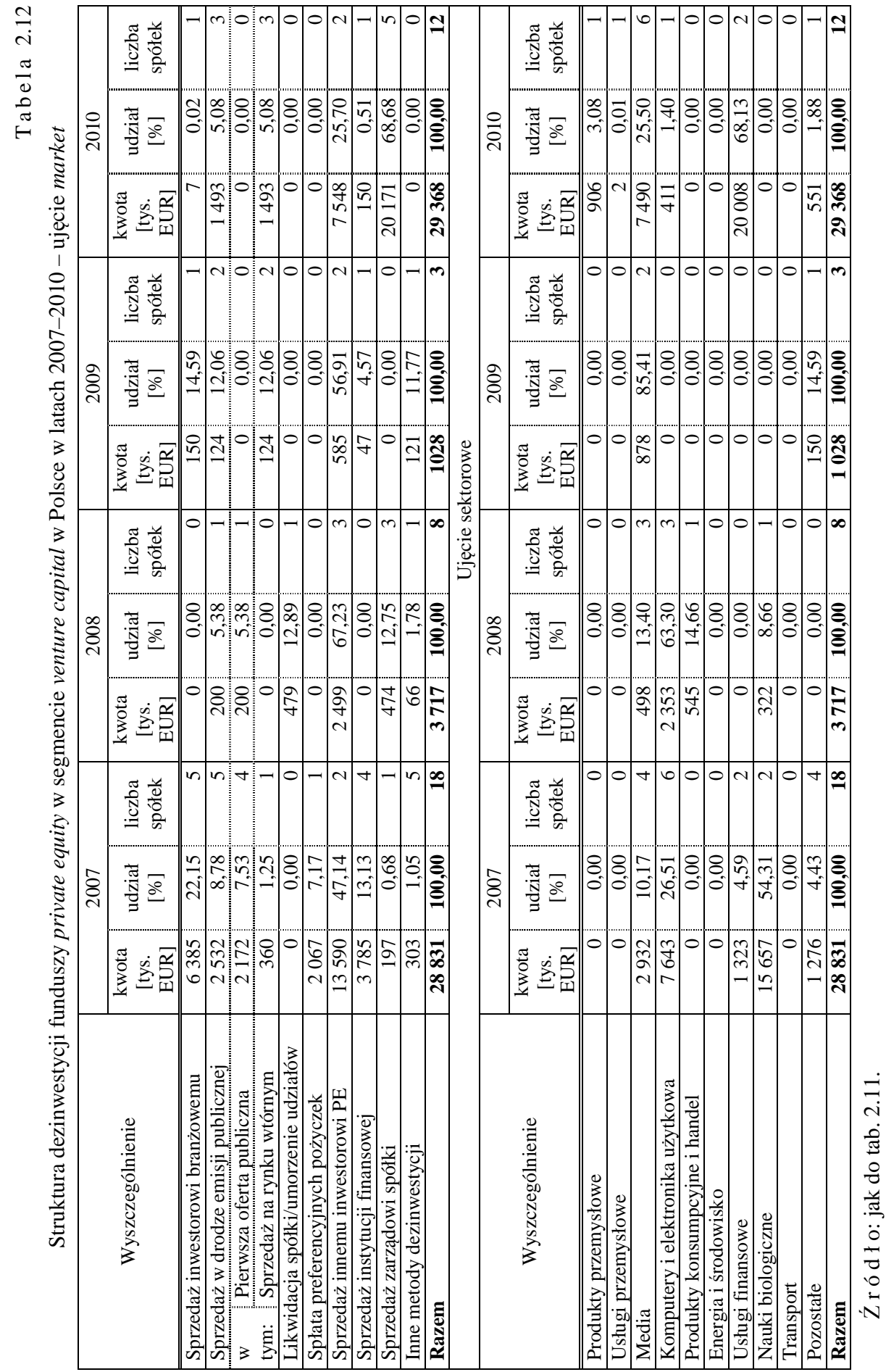




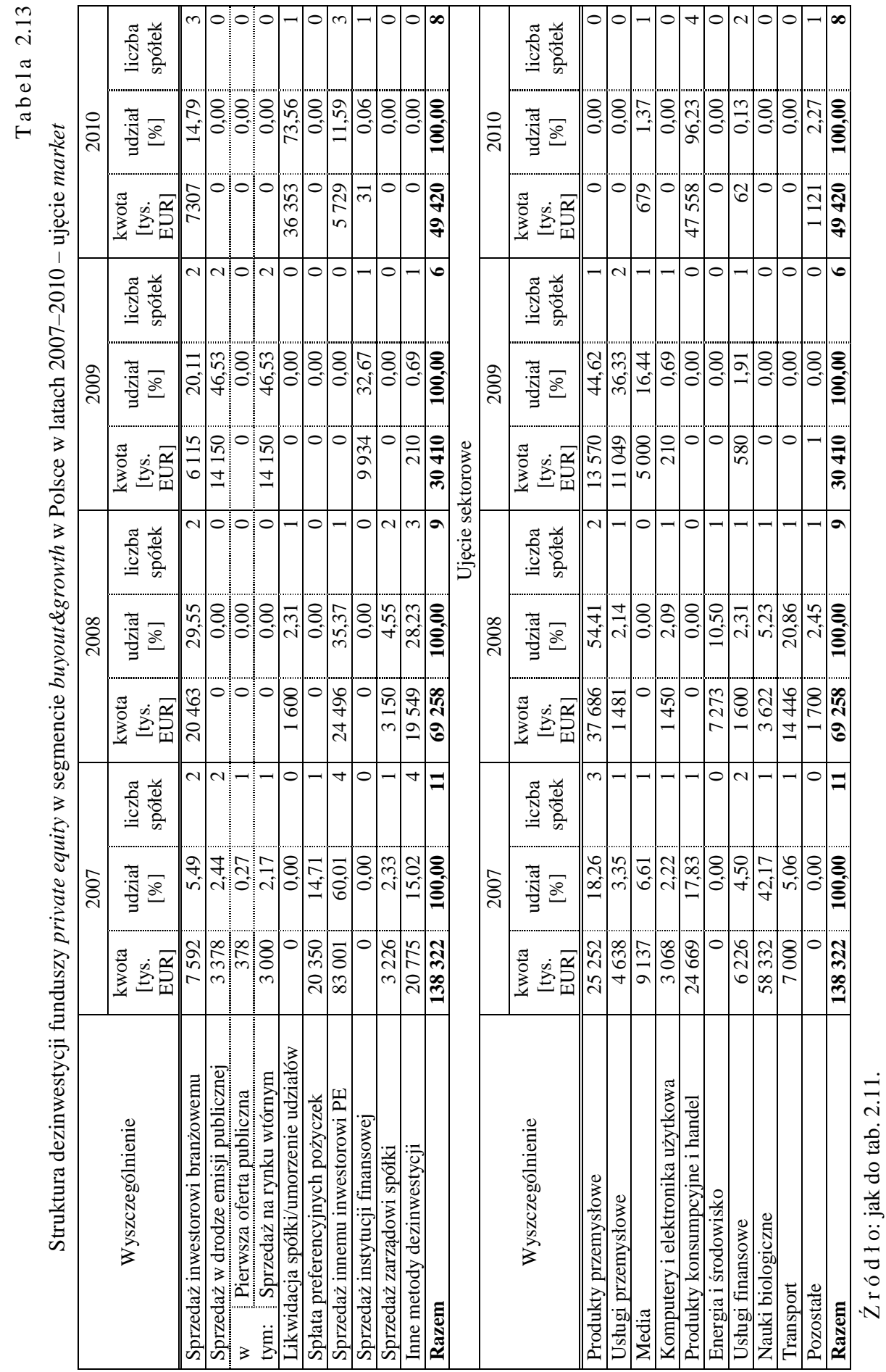


Na podstawie analizy danych liczbowych zawartych w tab. 2.12 można wskazać, iż dominującą metodą dezinwestycji w sektorze venture capital w latach 2007-2010 z punktu widzenia wielkości zainwestowanego kapitału była sprzedaż spółki innemu funduszowi private equity. Z kolei w 2010 r. duża część inwestycji w tym sektorze została zakończona przez sprzedaż spółki jej zarządowi. Sprzedaż akcji na publicznym rynku kapitałowym nie odgrywała znaczącej roli $w$ procesach dezinwestycji w tym segmencie inwestycji kapitału podwyższonego ryzyka. Z kolei analiza sektorowa wskazuje, że spółki portfelowe objęte procesami dezinwestycji prowadziły działalność zwłaszcza w obszarze komputerów i elektroniki użytkowej, mediów, usług finansowych oraz nauk biologicznych.

Dane zawarte w tab. 2.13 wskazują, że w segmencie inwestycji w przedsiębiorstwa znajdujące się na późniejszych etapach rozwoju w momencie nawiązania współpracy z funduszem, w procesach dezinwestycji poza sprzedażą spółki innemu funduszowi private equity istotną rolę odgrywały również pozostałe metody, a zwłaszcza sprzedaż spółki inwestorowi branżowemu. Większe znaczenie $\mathrm{w}$ porównaniu $\mathrm{z}$ segmentem venture capital mają transakcje realizowane za pośrednictwem giełdy papierów wartościowych. Znacząca większość transakcji dotyczyła spółek prowadzących działalność w sektorach związanych z produktami i usługami przemysłowymi, produktami konsumpcyjnymi i handlem, a także naukami biologicznymi.

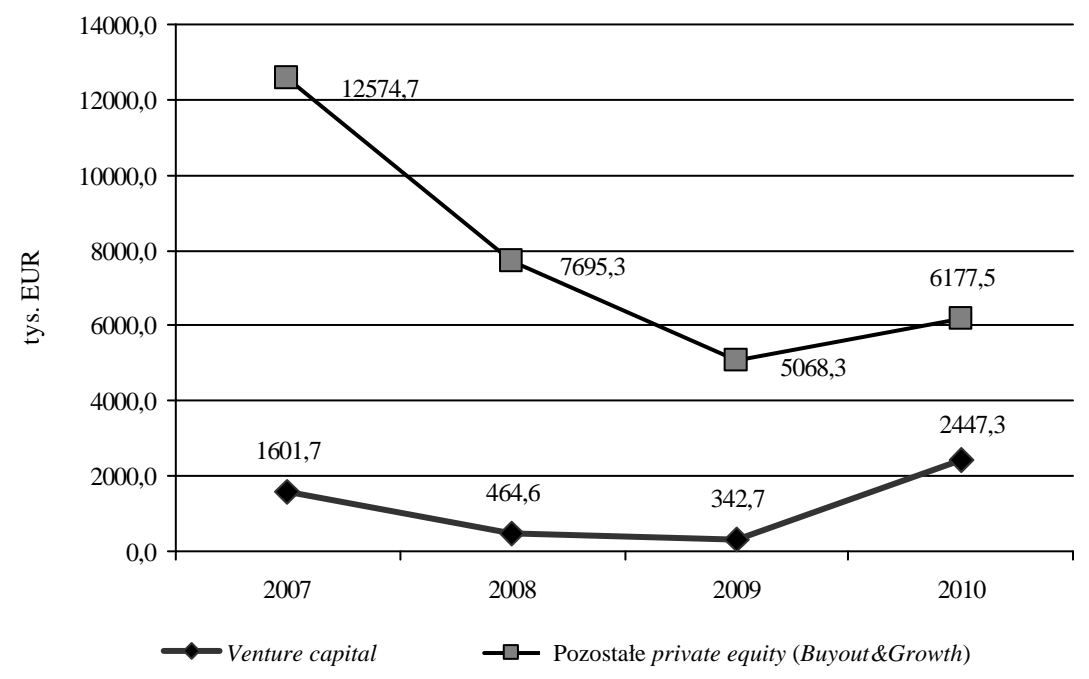

Wykres 2.13. Średnia wartość dezinwestycji przypadająca na jedno przedsiębiorstwo w latach $2007-2010$

Źródło: jak do wykresu 2.12. 
Można wskazać, iż średnia wielkość dezinwestycji w segmencie private equity związanym w lokowaniem kapitału w przedsiębiorstwa znajdujące się na późniejszych etapach wzrostu jest znacząco wyższa w porównaniu z wyjściami $\mathrm{z}$ inwestycji typu venture capital (zob. wykres 2.13).

Na polskim rynku realizowanych jest niespełna $30 \%$ wszystkich dezinwestycji z regionu środkowoeuropejskiego. Jednakże cały rynek dezinwestycji Europy Środkowo-Wschodniej nadal stanowi niewielki ułamek całego rynku europejskiego (zob. wykres 2.14).

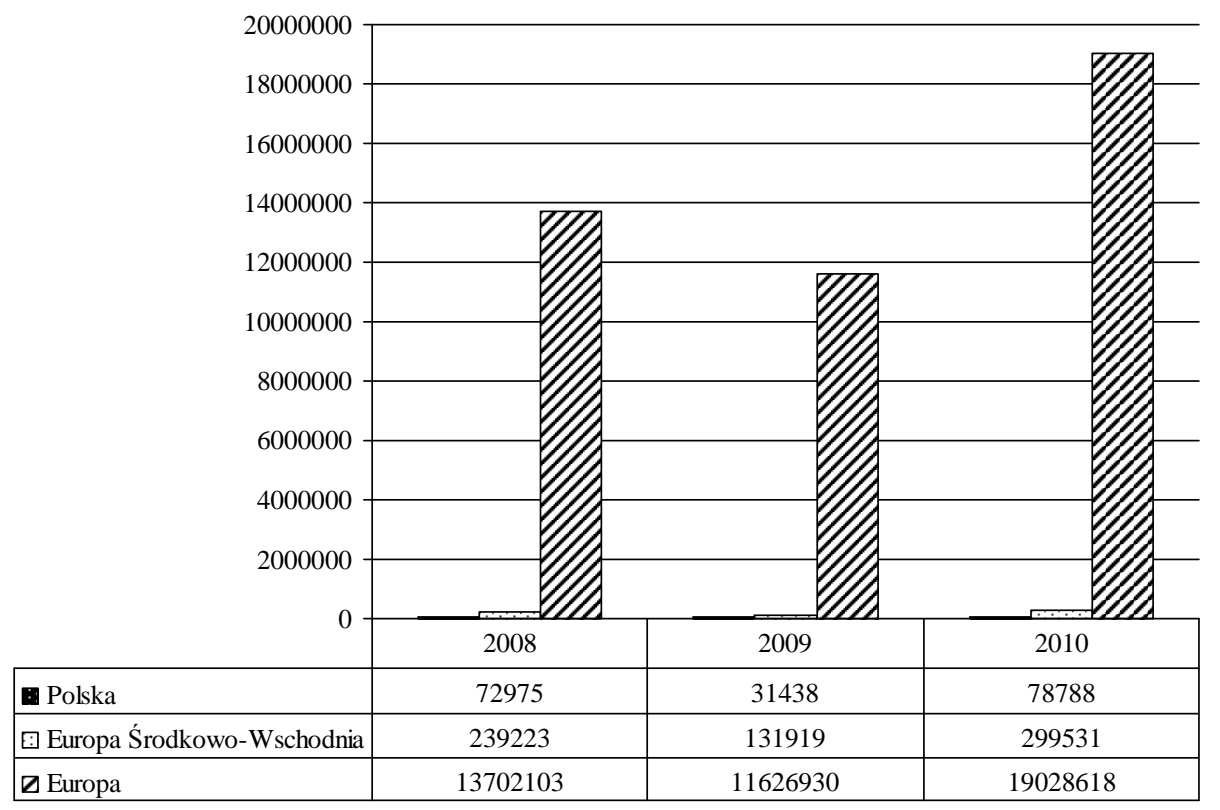

Wykres 2.14. Wartość dezinwestycji funduszy private equity w Europie w latach 2008-2010

Źródło: opracowanie własne na podstawie Central and Eastern Europe Statistics 2009 -2011, An EVCA Special Paper.

Z punktu widzenia stosowanych metod dezinwestycji rynek Europy Środkowo-Wschodniej nie różni się znacznie od krajowego rynku. Na podstawie danych zawartych w tab. 2.14 można wskazać, iż najczęściej wykorzystywanymi sposobami zakończenia współpracy pomiędzy funduszem private equity i spółką portfelową w latach 2007-2010 były sprzedaż spółki innemu funduszowi private equity oraz zbycie przedsiębiorstwa udziałowego inwestorowi branżowemu. Niepokojącą cechą dezinwestycji w całym regionie jest niewielki udział rynków kapitałowych w zawieraniu transakcji. Tylko 2009 r. przyniósł pewne ożywienie w tym względzie, aczkolwiek już w kolejnym roku zauważyć można ponowną marginalizację tej części rynku finansowego. Pozytywnym sygnałem o stanie rynku private equity jest natomiast niewielki udział przedsiębiorstw objętych procesami likwidacji/umorzenia udziałów. 


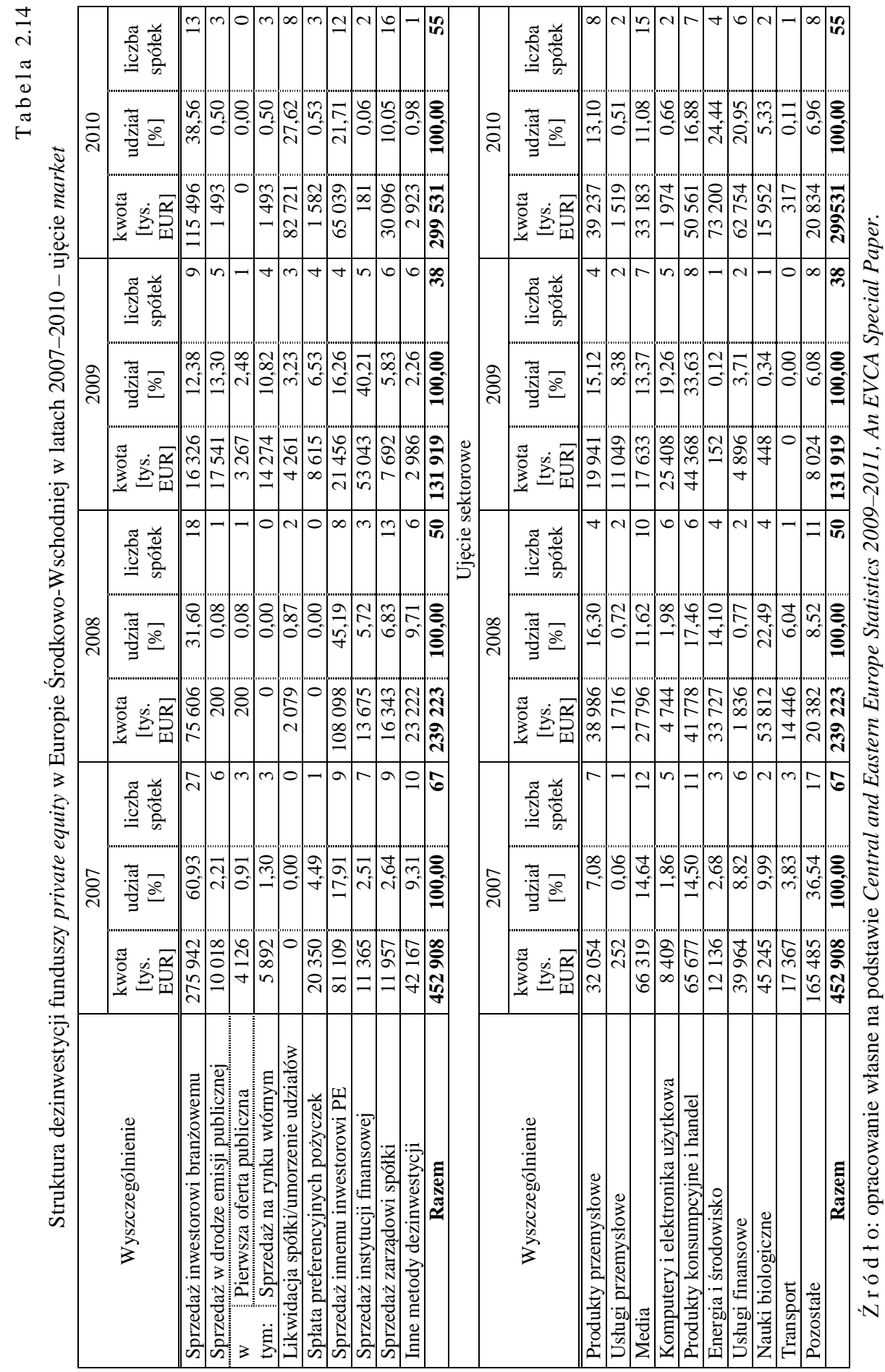


Analiza wyjść z inwestycji zrealizowanych w regionie Europy Środkowo-Wschodniej w ujęciu sektorowym wskazuje, iż znacząca część przedsiębiorstw udziałowych prowadziła działalność związaną z produktami konsumpcyjnymi i handlem. Ponadto znaczącą część zrealizowanych dezinwestycji stanowiły spółki funkcjonujące $\mathrm{w}$ sektorach związanych $\mathrm{z}$ produktami przemysłowymi, energią i środowiskiem, nauk biologicznych oraz usług finansowych (zob. tab. 2.14). 


\section{Rozdział 3}

\section{DETERMINANTY ARCHITEKTURY PROCESU DEZINWESTYCJI FUNDUSZY PRIVATE EQUITY}

\subsection{Główne nurty teoretyczne kształtowania procesu dezinwestycji funduszy private equity}

Proces wyjścia z inwestycji stanowi kluczowy etap w cyklu życia każdej inwestycji dokonywanej przez fundusze private equity. O wadze decyzji podejmowanych na tym etapie świadczy ich znaczący wpływ zarówno na efekty ekonomiczne działalności funduszu, jak i na dalszy rozwój spółki portfelowej. Skutki procesu dezinwestycji będą odczuwalne przez fundusz i spółkę portfelową przez wiele lat, nawet po całkowitym ustaniu jakichkolwiek powiązań kapitałowych pomiędzy stronami.

Można wskazać na trzy główne problemy decyzyjne mające miejsce w procesie dezinwestycji funduszy private equity i dotyczą one wyboru ${ }^{1}$ :

a) metody wyjścia $z$ inwestycji,

b) momentu - czasu wyjścia z inwestycji oraz

c) stopnia realizacji dezinwestycji (całkowite lub częściowe wyjście z inwestycji).

Problemy dezinwestycji funduszy private equity są jednak rzadko uwzględniane w rozważaniach teoretycznych, a w literaturze przedmiotu brak jest teorii, na gruncie których możliwe byłoby pełniejsze wyjaśnienie działań podejmowanych przez uczestników tego rodzaju transakcji ${ }^{2}$. Można jednak wskazać, że problemy te podjęte i rozwinięte są $\mathrm{w}$ teorii agencji oraz teorii asymetrii informacji.

${ }^{1}$ Por. D. J. Cumming, S. A. Johan, Venture capital and Private equity Contracting. An International Perspective, Elsevier 2009, s. 584.

${ }^{2}$ P. Gompers, J. Lerner, The Venture capital Cycle, MIT Press, Cambridge Massachusetts 2006 , s. 350 . 


\subsubsection{TEORIA AGENCJI A DEZINWESTYCJE FUNDUSZY PRIVATE EQUITY}

Fundusze private equity działają jako pewnego rodzaju pośrednicy inwestujący zgromadzone środki w wybrane koncepty biznesowe. Specyficzna struktura funkcjonowania rynku private equity rodzi swoiste konsekwencje dla relacji występujących pomiędzy stronami transakcji. Relacje te odnoszą się nie tylko do zakończenia współpracy pomiędzy określoną spółką portfelową a funduszem private equity, lecz także do całego procesu inwestycyjnego. Zwracając uwagę przede wszystkim na analizę postępowania uczestników procesu dezinwestycji wskazać należy na możliwość i zasadność wyjaśnienia zachowań funduszy private equity z perspektywy teorii agencji, która powszechnie uznawana jest za dominujący paradygmat $\mathrm{w}$ literaturze $\mathrm{z}$ zakresu ładu korporacyjnego ${ }^{3}$.

Rozdzielenie własności od zarządzania i tym samym powstanie relacji między właścicielem przedsiębiorstwa a zarządzającym tą jednostką wskazuje, iż jedna ze stron, określana jako agent, działa w imieniu i na rzecz drugiej strony, określanej jako pryncypat ${ }^{4}$. Agent podejmuje, realizuje i kontroluje decyzje, których skutki są odczuwalne nie tylko przez niego samego, ale także przez pryncypała i pozostałych interesariuszy. Skala i siła odczuwania efektów rozdzielenia własności od zarządzania zależą m. in. od różnicy maksymalizowanych przez nich własnych funkcji użyteczności oraz predyspozycji do rozwiązywania powstałego problemu agencji. Każda ze stron uczestniczących w tego typu relacji dąży do maksymalizacji własnej funkcji użyteczności i jest skłonna do wykorzystywania we własnym interesie okoliczności warunkujących wystąpienie problemu agencji ${ }^{5}$. Jeśli mechanizmy monitoringu i kontroli nie funkcjonują efektywnie agenci koncentrują się na realizacji własnych celów - pomnażaniu własnego bogactwa - w miejsce celów pryncypała ${ }^{6}$. W kontekście bogatych efektów licznych dyskusji o efektywności systemów governance w przedsiębiorstwie ${ }^{7}$ warto również zwrócić uwagę na alternatywne perspektywy oceny tych mechanizmów ${ }^{8}$.

${ }^{3}$ Zob. J. Je ża k, Ład korporacyjny. Doświadczenia oraz kierunki rozwoju, Wydawnictwo C. H. Beck, Warszawa 2010, s. 147.

${ }^{4}$ K. M. Eis en hardt, Agency theory. An assessment and review, „The Academy of Management Review" 1989, Vol. 14, No. 1, s. 58.

${ }^{5}$ M. Gorynia, Przedsiębiorstwo w nowej ekonomii instytucjonalnej, „Ekonomista” 1999, nr 6, s. 780 .

${ }^{6}$ M. Marcin kowska, Wptyw władztwa korporacyjnego na tworzenie wartości przedsiębiorstwa, [w:] S. R u d olf (red.), Rola nadzoru korporacyjnego w kreowaniu wartości przedsiębiorstwa, Wydawnictwo Uniwersytetu Łódzkiego, Łódź 2008, s. 34.

${ }^{7}$ J. J e żak (red.), Struktury i formy sprawowania władzy w spótkach kapitałowych, Wydawnictwo Uniwersytetu Łódzkiego, Łódź 2005, s. 36-42.

${ }^{8}$ A. S a mb or ski, Governance w przedsiębiorstwie w kontekście spotecznej odpowiedzialności, „Przegląd organizacji” 2012, nr 1, s. 14-15. 
Cechami charakterystycznymi dla problemu agencji jest nie tylko występowanie rozbieżności interesów między pryncypałem i agentem, lecz także istnienie $^{9}$ :

a) niepewności,

b) niemożliwości obserwacji wszystkich zachowań agenta przez pryncypała,

c) kosztów zawarcia oraz wykonania kontraktów oraz

d) asymetrii informacji pomiędzy stronami transakcji.

Problemy teorii agencji i towarzyszącej jej asymetrii informacji odzwierciedla m. in. występowanie dwóch zjawisk: pokusy nadużycia (ang. moral hazard) oraz negatywnej selekcji (ang. adverse selection).

Określenie pokusa nadużycia związane jest z oportunistycznymi działaniami agenta. Jest to sytuacja, w której agent podejmuje działania, mające na celu jak najlepsze zaspokojenie własnych interesów, nawet gdy są one sprzeczne $\mathrm{z}$ interesem pryncypała $^{10}$. Pryncypał nie posiada wystarczającej $\mathrm{i}$ adekwatnej wiedzy oraz obiektywnej informacji nie tylko o postępowaniu agenta, lecz także o sytuacji i warunkach działania przedsiębiorstwa. Co więcej, jego reakcje mogą być spóźnione i nie wynikając z systemu wczesnego ostrzegania, mogą wytworzyć pryncypałowi wiele strat finansowych i/lub społecznych. Agent, wykorzystując przewagę informacyjną, zwiększać może osiągane dla siebie korzyści kosztem strat ponoszonych przez pryncypała.

Zjawisko negatywnej selekcji wiąże się z kwestią ryzyka dokonania niewłaściwego wyboru wynikającego z niedostatku informacji ${ }^{11}$. O jego występowaniu mówi się w sytuacji, kiedy agent posiada prywatne informacje, natomiast pryncypał nie posiadając tej wiedzy dokonuje wyborów, które nie są dla niego optymalne. Gdyby obie strony transakcji dysponowały taką samą informacją, wówczas postępowanie pryncypała byłoby odmienne. W literaturze przedmiotu występujące zjawisko negatywnej selekcji określane jest często jako cytryny Akerlofa ${ }^{12}$.

Wydaje się, że sytuacja, określana mianem asymetrii informacji, odnosi się nieomal do wszystkich zdarzeń i procesów mających miejsce w działalności gospodarczej i społecznej. Jest ona wykreowana przez zbiór okoliczności oraz warunków funkcjonowania i rozwoju sprzyjających osiąganiu korzyści przez jedną ze stron w wyniku zdobywania, gromadzenia, przetwarzania i wykorzystania pełniejszej, szybszej, wiarygodniejszej i cenniejszej informacji. Z reguły

${ }^{9}$ M. Gorynia, op. cit., s. 780.

${ }^{10} \mathrm{R} . \mathrm{Mü} 11 \mathrm{e}$ r, J. R. Tu rner, The impact of principal-agent relationship and contract type on communication between project owner and manager, „International Journal of Project Management" 2005, Vol. 23, s. 399.

${ }^{11}$ M. Janicka, Liberalizacja przeptywów kapitałowych $w$ gospodarce światowej. Przypadek Polski, Wydawnictwo Uniwersytetu Łódzkiego, Łódź 2010, s. 74.

${ }^{12} \mathrm{G}$. A. A kerlof, The Market for 'Lemons': Quality Uncertainty and the Market Mechanism, „The Quarterly Journal of Economics” 1970, Vol. 84, No. 3, s. 488-500. 
taką informacją dysponuje agent. Zarządzanie problemem agencji można utożsamiać z optymalizacją problemu konfliktu interesów związanego z istnieniem zdecentralizowanej, asymetrycznej informacji ${ }^{13}$. Brak dostępu udziałowców do właściwych źródeł informacji powoduje w zasadzie ich swoiste wywłaszczenie w posiadanej własności, jaką jest przedsiębiorstwo, na rzecz menedżerów, którzy uzyskują daleko idącą władzę nad nim ${ }^{14}$. Jak wskazuje M. Janicka, wykorzystywanie przewagi informacyjnej przez uprzywilejowaną stronę transakcji w konsekwencji prowadzić może nie tylko do indywidualnych strat drugiej strony, ale również oznaczać może stratę dla całej gospodarki ${ }^{15}$.

Chociaż teoria agencji pierwotnie skupiała się na analizie relacji pomiędzy właścicielami przedsiębiorstwa a menedżerami zajmującymi się jego zarządzaniem, to ma ona charakter uniwersalny i znajduje szerokie zastosowanie do analizy związków pomiędzy różnymi grupami interesariuszy w przedsiębiorstwie ${ }^{16}$.

Problemy agencji w przypadku inwestycji private equity mają charakter niezwykle złożony. W. A. Sahlman zauważa, iż można wskazać na trzy podstawowe relacje agent - pryncypał zachodzące pomiędzy pierwotnymi inwestorami funduszu, funduszem private equity oraz spółką portfelową ${ }^{17}$ (zob. schemat 3.1):

- inwestor - fundusz private equity,

- fundusz private equity - przedsiębiorca ${ }^{18}$,

- przedsiębiorca - fundusz private equity.

W pierwszym przypadku mamy do czynienia z sytuacją, w której fundusz private equity, działając jako agent, może przedkładać własny interes ponad korzyści podmiotów, które, znajdując się w sytuacji pryncypała, udostępniają posiadany kapitał na inwestycje. W tej relacji ma miejsce wysoki poziom asymetrii informacji. W procesie inwestycyjnym fundusz jest wysoce aktywnym uczestnikiem rynku private equity, czynnie zarządzając posiadanym portfelem inwestycyjnym, w którego skład wchodzą z reguły różne spółki o odmiennych

${ }^{13}$ M. Stradomski, Finansowanie obce firm rodzinnych na rynku niedoskonatym, PWE, Warszawa 2010, s. 83.

${ }^{14}$ J. Adamczyk, Społeczna odpowiedzialność przedsiębiorstw, PWE, Warszawa 2009, s. 68.

${ }^{15}$ M. J a n i c k a, Liberalizacja przeptywów kapitałowych..., op. cit., s. 74.

${ }^{16} \mathrm{~S}$. A. Ross, The economic theory of agency. The principal's problem, „American Economic Review" 1973, Vol. 63, No. 2, s. 134.

${ }^{17}$ W. A. S a h $1 \mathrm{~m}$ a n, Structure of venture-capital organizations, ,Journal of Financial Economics" 1990, Vol. 27, s. 473-521; Por. M. Meuleman, M. Wright, S. Manigart, A. Locket t, Private equity Syndication: Agency Costs, Reputation and Collaboration, „Journal of Business Finance\&Accounting", June/July 2009, Vol. 36(5)\&(6), s. 616-644.

${ }^{18}$ Termin ,przedsiębiorca” posiada w opracowaniu swoistą treść i nie jest on w pełni przystający do ogólnie przyjętego znaczenia tego pojęcia, spotykanego chociażby na gruncie prawa, ekonomii czy psychologii. Używany jest on do określenia osoby, która była pomysłodawcą i założycielem określonego przedsiębiorstwa, a także pozostaje właścicielem jego części po przystąpieniu do spółki funduszu private equity. Por. J. Duraj, M. P a pi ernik-Wojder a, Przedsiębiorczość i innowacyjność, Difin, Warszawa 2010, s. 9-18. 
przedmiotach i rynkach działania, posiadanej technice i realizowanej technologii oraz programach i strategiach rozwoju swojej działalności. Podmioty, które udostępniły kapitał na inwestycje nie mają możliwości bezpośredniego nadzorowania działalności poszczególnych spółek portfelowych. Na ich oczekiwania odnoszące się do uzyskania określonej stopy zwrotu z inwestycji bezpośredni wpływ wywiera efektywność zarządzania spółkami portfelowymi funduszy private equity.

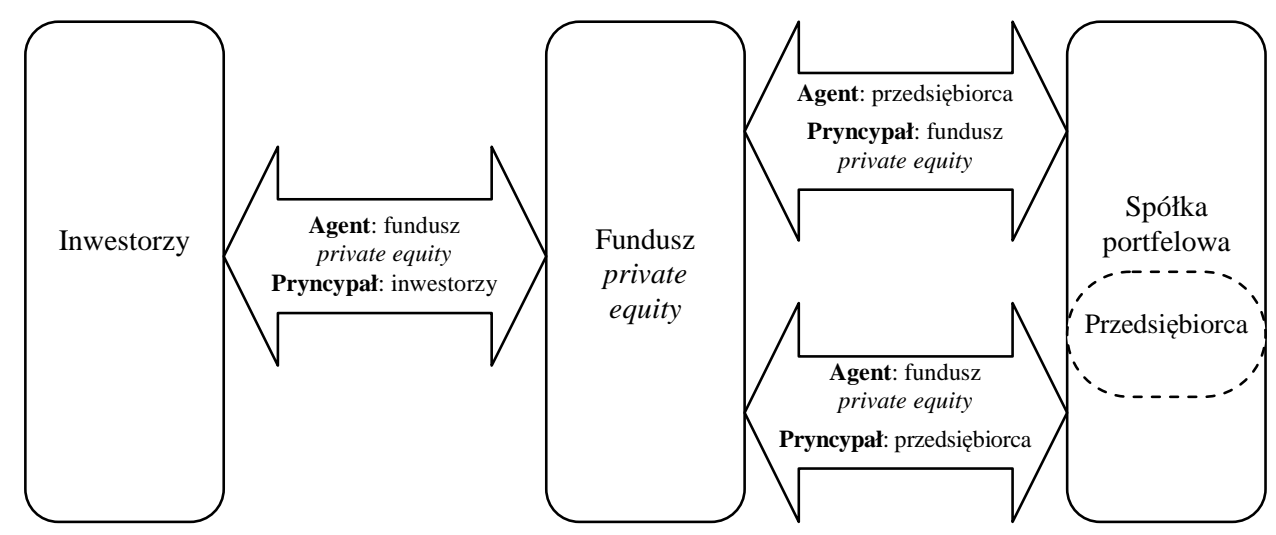

Schemat 3.1. Relacje agencji w inwestycjach funduszy private equity

Ź r ó d ł o: opracowanie własne na podstawie W. A. S a hl m a n, Structure of venture-capital organizations, „Journal of Financial Economics” 1990, Vol. 27, s. 473-521.

Uwidocznione na schemacie 3.1 relacje agencji w inwestycjach funduszy private equity wskazują także, iż relacja między funduszem private equity a spółką portfelową ma charakter dualny. $\mathrm{Z}$ jednej strony przedsiębiorca, rozumiany jako pierwotny posiadacz praw własności do spółki portfelowej, występuje w roli agenta, a fundusz znajduje się w sytuacji pryncypała. Jednakże można wskazać sytuacje, w których to fundusz private equity może być skłonny do podjęcia i realizacji działań sprzecznych z najlepiej pojętym interesem przedsiębiorcy $\mathrm{i}$ to on będzie w tej sytuacji występował w roli agenta ${ }^{19}$.

Pomiędzy funduszem private equity a przedsiębiorcą występuje również asymetria informacji. Choć jej skala i poziom z reguły są mniejsze niż pomiędzy funduszem a jego inwestorami, to ma ona znaczący wpływ na podejmowane i realizowane decyzje o celach, które przecież nie zawsze są wspólne.

${ }^{19} \mathrm{D}$. De Clercq, S. M a n igart, The venture capital post-investment phase: Opening the black box of involvement, [w:] H. L a n d s t rö m (red.), Handbook of research on Venture capital, Edward Elger, 2007, s. 196-198; D. J. C u m min g, J. G. M a c In t o s h, Venture-capital exits in Canada and United States, „University of Toronto Law Journal” 2003, s. 103. 
Szczególnie istotnym wymiarem problemu agencji w procesie dezinwestycji wydaje się kwestia relacji między funduszem a dotychczasowym zarządem spółki portfelowej.

A. Bascha i U. Walz oraz S. Gifford wskazują, że z różnymi metodami dezinwestycji związane są odmienne korzyści osiągane zarówno przez fundusz, jak i dotychczasowych właścicieli ${ }^{20}$. Wyjście $z$ inwestycji przez sprzedaż spółki inwestorowi strategicznemu zwykle wiąże się ze zbyciem wszystkich albo przeważającej części udziałów posiadanych przez fundusz i pierwotnych właścicieli spółki $^{21}$. Przedsiębiorca, który był inicjatorem i założycielem danego przedsiębiorstwa często traci wówczas przywileje związane z pełnieniem w niej funkcji kierowniczych. Obok tych strat ma miejsce występowanie u tego rodzaju przedsiębiorcy społecznych kosztów utraty więzi ze spółką ${ }^{22}$. W wielu bowiem przypadkach rozstaje się on z przedsiębiorstwem, co do którego odczuwać może swoisty sentyment i szczególnego rodzaju więź. W związku z tym dotychczasowy zarząd spółki będzie dążył do przeprowadzenia dezinwestycji w drodze publicznej sprzedaży akcji, nawet gdy nie będzie to zapewniało najwyższej stopy zwrotu z zainwestowanego kapitału.

$\mathrm{Z}$ kolei fundusz private equity może nie być zainteresowany ponoszeniem wysokich kosztów emisji i wprowadzenia papierów wartościowych do obrotu giełdowego, czy też godzeniem się na poniesienie dodatkowego kosztu niedowartościowania akcji w ofercie publicznej. Giełda papierów wartościowych nie zawsze umożliwia uzyskanie najwyższej wyceny przedsiębiorstwa. Inwestor strategiczny, który będzie beneficjentem korzyści skali wynikających z akwizycji może zaoferować zdecydowanie lepsze warunki transakcji nabycia akcji przy jednocześnie znacznie niższych kosztach jej przeprowadzenia. Ponadto w sytuacji występowania co najmniej dwóch podmiotów zainteresowanych nabyciem oferowanej do sprzedaży spółki portfelowej fundusz może uzyskać dodatkową premię. Przedstawiciele funduszu będą więc $\mathrm{w}$ określonych okolicznościach skłonni do podejmowania działań zmierzających do sprzedaży spółki inwestorowi strategicznemu.

Relacja agencji, występująca między funduszem a przedsiębiorcą, również generuje koszty agencji ${ }^{23}$. Ich wysokość i charakter zależą od konstrukcji kon-

${ }^{20} \mathrm{~A} . \mathrm{B}$ a s c h a, U. W al z, Convertible securities and optimal exit decisions in venture capital finance, „Journal of Corporate Finance” 2001, Vol. 7, s. 289-290; S. Gi f f or d, The allocation of limited entrepreneurial attention, Kulwer Academic Publisher, 1998, s. 11.

${ }^{21}$ D. J. C u m ming, J. G. M a c In to s h, A cross-country comparsion of full and partial venture capital exits, ,Journal of Banking\&Finance” 2003, Vol. 27, s. 515.

${ }^{22}$ O. B a y ar, T. J. Che mmanur, IPOs versus Acquisitions and the Valuation Premium Puzzle: A Theory of Exit Choice by Entrepreneurs and Venture capitalists, „Journal of Financial and Quantitative Analysis" (JFQA), August 2010, Forthcoming. Available at SSRN: http://ssrn.com/abstract=966004, s. 6 .

${ }^{23}$ Zob. E. F. F a ma, M. C. J en s e n, Separation of ownership and control, „Journal of Law and Economics" 1983, Vol. 26, No. 2, s. 304. 
traktów, monitorowania postępowania agentów oraz budowy instrumentów zachęcających do działania w interesie pryncypałów ${ }^{24}$. D. J. Cumming, J. G. MacIntosh wskazują na możliwości zmniejszenia tych kosztów przez przeprowadzenie dezinwestycji w drodze pierwszej oferty publicznej ${ }^{25}$.

Wprowadzenie spółki na giełdę nie musi być równoznaczne z natychmiastowym wycofaniem się funduszu private equity ze spółki portfelowej. Akcje znajdujące się w portfelu inwestycyjnym funduszu z reguły zbywane są w późniejszym terminie. Upublicznienie spółki umożliwia włączenie do systemu wynagrodzeń kadry zarządzającej opcji na akcje. Opcje te w świetle regulacji podatkowych $^{26}$ okazać się mogą skuteczniejszą formą motywowania od klasycznego wynagrodzenia.

Redukcja kosztów agencji pozwoli funduszowi w przyszłości zrealizować wyższą stopę zwrotu z inwestycji. Co więcej, w wyniku wprowadzenia spółki na giełdę, działania zarządu spółki będą poddawane kontroli nie tylko przez przedstawicieli funduszu, ale również innych właścicieli i uczestników rynku kapitałowego. Efektywny rynek kapitałowy powinien zagwarantować skuteczny nadzór nad spółką i w konsekwencji wpłynąć na obniżenie kosztów agencji ${ }^{27}$.

Proces dezinwestycji może być również wykorzystywany przez fundusz do zbudowania wizerunku funduszu na rynku, a w konsekwencji znaczącego wzmocnienia posiadanej przez niego pozycji konkurencyjnej. Sposób, w jaki fundusz private equity jest postrzegany przez otoczenie i ocena jego działalności stanowią niezwykle istotny czynnik warunkujący sukces ekonomiczny na rynku kapitału podwyższonego ryzyka. Dobra reputacja umożliwia funduszowi pozyskiwanie nowych inwestorów skłonnych do udostępnienia posiadanych zasobów kapitału, ułatwia współpracę pomiędzy funduszami nad realizacją określonych projektów, a także jest kluczowa w procesie lokowania nowych spółek do portfela inwestycyjnego ${ }^{28}$. W procesach dezinwestycji fundusz private equity może kreować wizerunek jako jednostki odpowiedzialnej społecznie, rozwijającej kapitał społeczny, a w konsekwencji znacząco umacniającej posiadaną pozycję konkurencyjną.

Wprowadzenie akcji spółki portfelowej do obrotu giełdowego jest dobrym sposobem przekazania otoczeniu informacji o sprawności funduszu w kreowaniu

${ }^{24}$ A. S a m b or ski, Governance w przedsiębiorstwie..., op. cit., s. 15.

${ }^{25}$ D. J. C u mming, J. G. M a c In to s h, Venture-capital exits..., op. cit., s. 104.

${ }^{26}$ M. R e t k a, Opcje lepsze niż premia, ,Rzeczpospolita”, 26 sierpnia 2011, s. D4.

${ }^{27}$ M. C. Jensen, W. H. Meckling, Theory of the Firm: Managerial Behavior, Agency Costs and Ownership Structure, „Journal of Financial Economics”, October 1976, Vol. 3, No. 4, s. 305-360.

${ }^{28}$ B. S. B lack, R. J. Gils o n, Venture capital and the structure of capital markets: Banks versus stock markets, ,Journal of Financial Econimics” 1998, Vol. 47, s. 254. 
wartości podmiotów wchodzących w skład portfela inwestycyjnego ${ }^{29}$. Udany debiut giełdowy w większym stopniu niż inne metody dezinwestycji wzmacnia reputację i wiarygodność funduszu, gdyż informacja o sukcesie trafia do zdecydowanie większego grona odbiorców ${ }^{30}$. W proces sprzedaży spółki inwestorowi branżowemu, finansowemu czy dotychczasowemu zarządowi zaangażowana jest zdecydowanie mniejsza liczba inwestorów, a informacje o transakcji znacznie rzadziej przekazywane są $\mathrm{w}$ do publicznej wiadomości, chociażby przez prasę czy telewizję.

Skokowa aprecjacja kapitału reputacji funduszu private equity, osiągnięta w wyniku wprowadzenia spółki do obrotu giełdowego, jest na tyle atrakcyjna, iż działania funduszu mogą nie być w zgodzie $\mathrm{z}$ interesem spółki portfelowej i jej pierwotnych właścicieli. P. Gompers zauważył, iż zwłaszcza stosunkowo nowe fundusze, które nie mają jeszcze ugruntowanej pozycji na rynku, wykazują się większą skłonnością do wykorzystywania debiutów giełdowych spółek portfelowych $\mathrm{w}$ celu budowania reputacji ${ }^{31}$. Ze stosowaniem takiej praktyki wiąże się konieczność poniesienia dodatkowych kosztów. Mianowicie na giełdę wchodzą spółki, które nie są jeszcze odpowiednio przygotowane i nie wszystkie możliwości kreowania wzrostu ich wartości zostały właściwie wykorzystane. Zbyt wczesne wyjście z inwestycji rodzi dla funduszu konsekwencje w postaci niższej stopy zwrotu z zainwestowanego kapitału. Co więcej, aby sprzedaż akcji w ofercie publicznej zakończyła się sukcesem oferowane są one po cenie niższej od tej, jaką nowi inwestorzy byliby skłonni zapłacić w „normalnych” warunkach. Efektem takiego działania jest wyższy stopień niedowartościowania akcji sprzedawanych $\mathrm{w}$ trakcie pierwszej oferty publicznej. Fundusze, które cieszą się uznaniem wśród uczestników rynku kapitałowego wykazują znacznie mniejszą skłonność do wykorzystywania tego typu kosztownych narzędzi promocji.

\subsubsection{ASYMETRIA INFORMACJI A WYJŚCIE Z INWESTYCJI}

W proces zakończenia współpracy pomiędzy spółką portfelową a funduszem private equity zaangażowanych jest wielu uczestników. Na gruncie teorii agencji zwraca się uwagę na relacje pomiędzy inwestorami funduszu, funduszem, spółką i jej pierwotnym właścicielem a przebiegiem procesu dezinwestycji. W momencie wyjścia funduszu $\mathrm{z}$ inwestycji, w większości przypadków występuje jeszcze jedna strona transakcji, a mianowicie podmiot, który stanie

${ }^{29}$ P. Go m per s, J. Le rn e r, The Venture capital Cycle, op. cit., s. 379.

${ }^{30}$ A. B a s c h a, U. W al z, op. cit., s. 292.

${ }^{31}$ P. Go mpers, Grandstanding in the venture capital industry, ,Journal of Financial Economics" 1996, Vol. 42, s. 133-156. 
się nowym właścicielem zbywanych praw własności. Sytuacja taka tworzy nowe problemy asymetrii informacji.

Fundusz private equity podczas dezinwestycji z reguły jest stroną uprzywilejowaną w stosunku do nabywcy spółki portfelowej w kwestii dostępu do informacji i możliwości jej oceny. Poprzez swoje długotrwałe zaangażowanie kapitałowe posiada on łatwiejszy dostęp do pełniejszych informacji o przedsiębiorstwie, sposobie jego funkcjonowania, otoczeniu oraz perspektywach dalszego rozwoju. Podmiot, który nabywa udziały w takiej spółce nie ma możliwości uzyskania tak szerokiego dostępu do informacji.
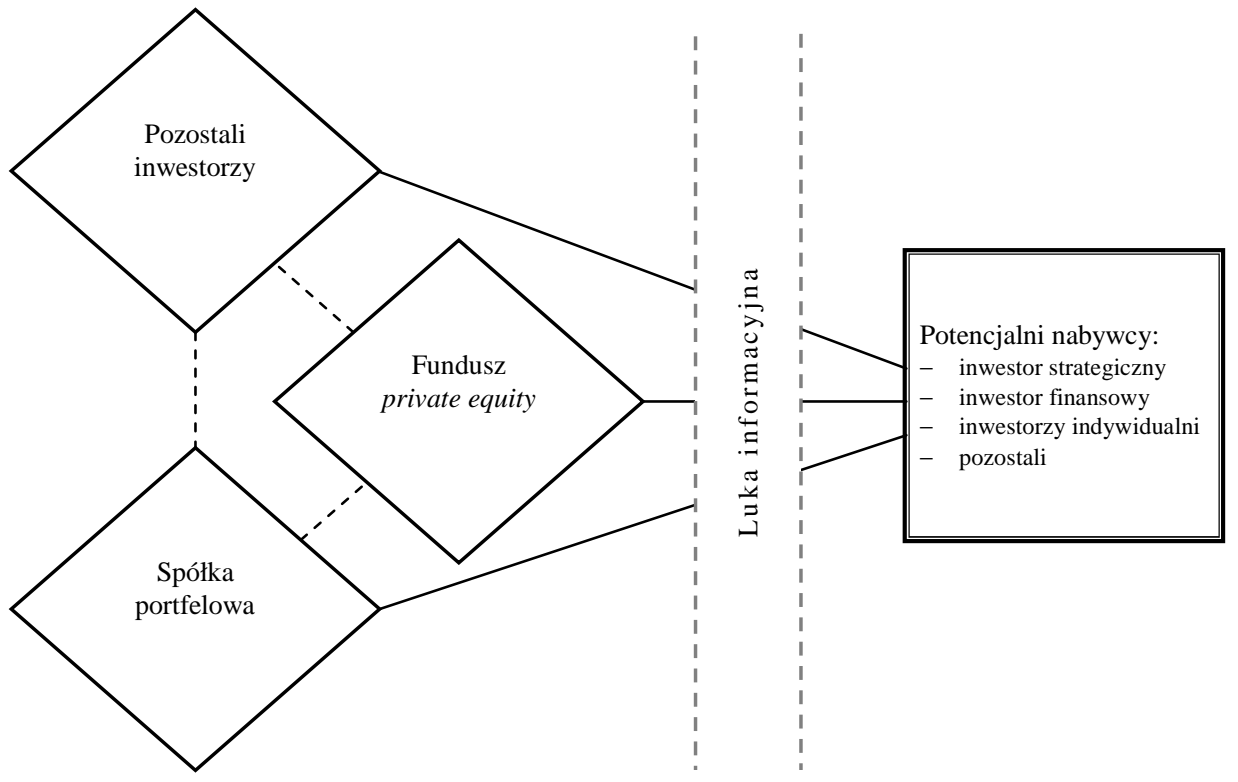

Schemat 3.2. Asymetria informacji w procesie dezinwestycji

Ź ródło: opracowanie własne na podstawie M. Eckermann, Venture capitalists' Exit Strategies under Information Asymmetry. Evidence from the U.S. Venture capital Market, Deutscher Universität-Verlag, Wiesbaden 2006, s. 13.

D. J. Cumming, J. G. MacIntosh podkreślają, iż konsekwencją nierównego dostępu do informacji może być skłonność potencjalnego nabywcy do niższej wyceny akcji sprzedawanego przedsiębiorstwa ${ }^{32}$. Asymetria informacji może bowiem wpływać na wzrost poziomu stopy dyskontowej używanej podczas szacowania wartości przyszłych przepływów pieniężnych. Nie zawsze cena przed-

\footnotetext{
${ }^{32}$ D. J. C u mming, J. G. M a c In to s h, Venture-capital exits..., op. cit., s. 103-104.
} 
siębiorstwa jest równoznaczna z jego wartością ${ }^{33}$, a rozmiar luki informacyjnej bez wątpienia ma wpływ na dyferencję tych kategorii ekonomicznych.

Możliwość rozwiązania problemu asymetrii informacji zależy od sposobu wyjścia z inwestycji, gdyż różne metody dezinwestycji adresowane są do różnych grup nabywców, którzy nadto w różnym stopniu są zdolni do poradzenia sobie $\mathrm{z}$ występującym problemem nierównego dostępu do informacji ${ }^{34}$. Pozycje dotychczasowego zarządu, strategicznego inwestora branżowego czy indywidualnego inwestora giełdowego będą w tym zakresie skrajnie odmienne (zob. schemat 3.3). Nowi inwestorzy, którzy nie mają możliwości wpływu na zmniejszenie asymetrii informacji pomiędzy stronami transakcji, będą skłonni zaoferować znacznie niższą cenę za nabywane udziały, ze względu na duże ryzyko inwestycyjne wywołane luką informacyjną.
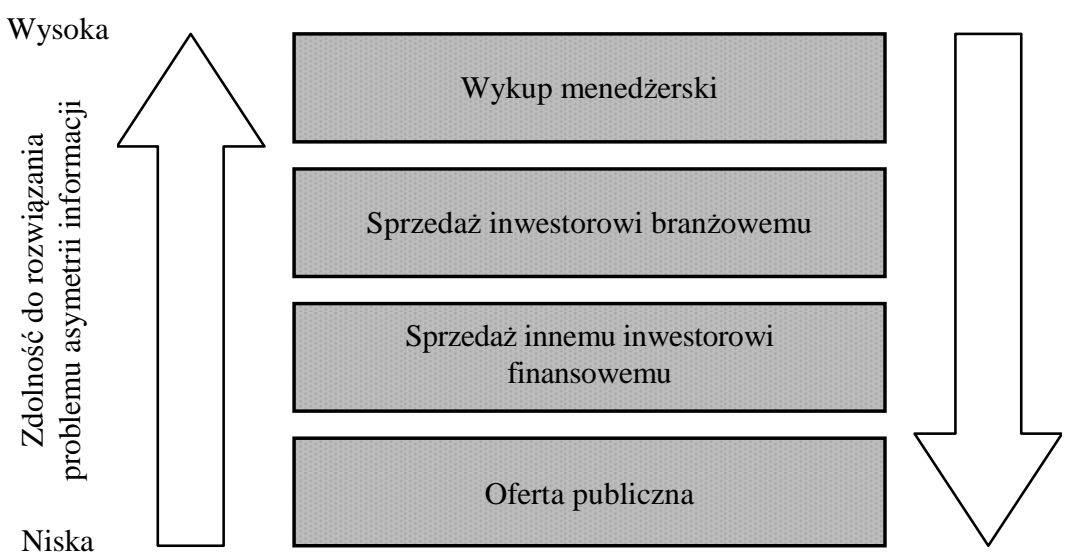

Krótki

$\mathrm{S} \mathrm{ch}$ e m at 3.3. Metody dezinwestycji a asymetria informacji

Ź r ó d ł o: S. P o valy, Private equity exits: Divestment Process Management for Leveraged Buyouts, Springer, Berlin Heidelberg New York 2007, s. 140.

W interesie funduszu private equity będzie zatem dążenie do minimalizacji asymetrii informacji. Efekt ten może być osiągnięty chociażby przez wydłużenie okresu zaangażowania kapitałowego funduszu w spółkę $e^{35}$ oraz odpowiednie komunikowanie się ze społecznością giełdową ${ }^{36}$. Dezinwestycja nie ma charak-

${ }^{33}$ R. B orowiecki, A. Jaki, K. Misi ołe k, T. Roj e k, Nadzór korporacyjny w procesie kreowania wartości i rozwoju przedsiębiorstwa, Wydawnictwo ABRYS, Kraków 2005, s. 81.

${ }^{34} \mathrm{D}$. C u m min g, S. J o h a n, Information asymmetries, agency costs and venture capital exit outcomes, „Venture capital” 2008, Vol. 10, No. 3, s. 198.

${ }^{35}$ D. J. C u m min g, J. G. M a c In t o s h, Venture capital investment duration in Canada and the United States, ,Journal of Multinational Financial Management” 2001, Vol. 11, s. 446.

${ }^{36}$ Zob. E. M. W roń s k a, Asymetria informacyjna. Potrzeba $i$ znaczenie budowania relacji z inwestorami w procesie tworzenia wartości dla akcjonariuszy, [w:] J. Du raj (red.), Wartość 
teru jednorazowego wydarzenia, lecz jest rozłożonym w czasie ciągiem działań. Podejście procesowe ma szczególnie istotne znaczenie w przypadku wyjścia z inwestycji za pośrednictwem giełdy papierów wartościowych. Dłuższy czas zaangażowania kapitałowego funduszu private equity w spółkę portfelową po wprowadzeniu jej akcji do publicznego obrotu może być uznany za sygnał, iż spółka posiada potencjał dalszego wzrostu wartości rynkowej. W ten sposób fundusz dokonuje niejako transferu własnej reputacji i doświadczenia na spółkę portfelową. Rezultatem wydłużonego czasu trwania inwestycji będzie zatem wzmocnienie pozytywnej opinii otoczenia o spółce ${ }^{37}$.

Późniejsze wyjście z inwestycji pozwala na redukcję kosztów asymetrii informacji, a w konsekwencji sprzyjać może sprzedaży spółki portfelowej po cenie zbliżonej do jej wartości godziwej. Z drugiej strony, działanie takie związane jest z koniecznością ponoszenia znaczących kosztów utraconych korzyści, wynikających z braku możliwości reinwestowania kapitału ulokowanego w niezakończonej inwestycji ${ }^{38}$. Optymalna strategia dezinwestycji wymaga znalezienia równowagi między malejącymi w czasie kosztami asymetrii informacji a rosnącymi kosztami utraconych możliwości. Wydłużenie okresu zaangażowania kapitałowego funduszu private equity będzie miało miejsce, gdy rozwiązanie problemów wynikających z asymetrii informacji staje się trudniejsze.

\subsection{Wybór optymalnego momentu wyjścia $\mathrm{z}$ inwestycji funduszy private equity}

D. J. Cumming, J. G. MacIntosh, prowadząc badania nad procesami dezinwestycji realizowanymi w USA i Kanadzie, stworzyli ogólną teorię dezinwestycji, wskazującą m. in. na wybór optymalnego momentu wyjścia z inwestycji przez inwestora private equity ${ }^{39}$. Teoria ta opiera się na następujących założeniach:

- fundusz private equity posiada wyjątkową zdolność kreowania wartości przedsiębiorstwa poprzez działanie jako aktywny inwestor;

- w dowolnym momencie, inwestycja funduszu w spółkę może zostać sprzedana trzeciej stronie po cenie najlepiej odpowiadającej jej prawdziwej wartości (brak asymetrii informacji);

i kapitat spótek akcyjnych, „Acta Universitatis Lodziensis”, Folia Oeconomica 262, Wydawnictwo Uniwersytetu Łódzkiego, Łódź 2012, s. 115-124.

${ }^{37}$ W. L. M e g g in s o n, K. A. W e is s, Venture capitalists certification in initial public offerings, ,Journal of Finance" 1991, No. 46, s. 879-903.

${ }^{38} \mathrm{~W}$. N e u s, U. W a l z, Exit timing of venture capitalists in the course of an initial public offering, ,Journal of Financial Intermediation” 2005, Vol. 14, s. 254.

${ }^{39}$ D. J. C u m min g, J. G. M a c Int o s h, Venture-capital exits..., op. cit., s. 108 i nast. 
- cena, po której inwestycja jest sprzedawana nie zależy od zastosowanej metody wyjścia z inwestycji;

- okres działania funduszu private equity jest nieograniczony, więc wybór momentu zakończenia inwestycji jest dokonywany niezależnie od potrzeby dezinwestycji w związku z koniecznością zwrotu kapitału i wypracowanego zysku inwestorom funduszu;

- fundusz może swobodnie reinwestować kapitał pozyskany z jednej inwestycji w kolejną.

Fundusz private equity będzie dążył do osiągnięcia największej wartości dodanej inwestycji. Wartość tę można zapisać następująco ${ }^{40}$ :

$$
\underset{e, T}{\operatorname{Max}} \operatorname{PVA}(e(T), x(T), T)-P C(e(T), z(T), T)
$$

gdzie:

PVA - przewidywana wartość dodana (ang. projected value added),

$P C$ - przewidywany koszt (ang. projected cost),

$e \quad-$ działania funduszu private equity podjęte w celu kreowania wartości spółki portfelowej (ang. effort),

$T \quad-\quad$ czas trwania inwestycji,

$x(t) \quad$ - inne czynniki mające wpływ na położenie funkcji $P V A$,

$z(x) \quad-\quad$ inne czynniki mające wpływ na położenie funkcji $P C$.

Przewidywana wartość dodana inwestycji jest rozumiana jako spodziewana suma korzyści pieniężnych uzyskana przez fundusz w wyniku realizacji danej inwestycji, po uwzględnieniu kosztu zainwestowanego kapitału. Wartość ta jest realizowana dopiero w momencie wyjścia funduszu z inwestycji, gdyż spółki będące beneficjentami dynamicznego wzrostu z reguły nie wypłacają dywidend. Z kolei przewidywane koszty zawierają wszystkie bezpośrednie i pośrednie koszty związane $\mathrm{z}$ zaangażowaniem funduszu w dany projekt inwestycyjny, w tym również koszty implicite wynikające z braku możliwości realizowania alternatywnych projektów. Podkreślić należy, iż w omawianym modelu nie są wydzielone bieżące, faktycznie poniesione koszty, lecz suma wszystkich przyszłych kosztów wynikających z zaangażowania funduszu w spółkę portfelową.

Fundusz private equity będzie skłonny do wyjścia $\mathrm{z}$ inwestycji w momencie, gdy przewidywana krańcowa wartość dodana (PMVA) wynikająca z podjętych czynności związanych z zarządzaniem inwestycją będzie mniejsza niż przewidywany krańcowy koszt $(P M C)$ powzięcia tego typu działań ${ }^{41}$. Sytuację tę wyraża następująca nierówność:

\footnotetext{
${ }^{40}$ D. J. Cu m ming, J. G. M a c In to s h, Venture capital investment..., op. cit., s. 447.

${ }^{41}$ Ibidem, s. 447-448.
} 


$$
P M V A\left(e\left(T^{*}\right), x\left(T^{*}\right), T^{*}\right) \leq P M C\left(e\left(T^{*}\right), z\left(T^{*}\right), T^{*}\right)
$$

gdzie:

PMVA - przewidywana krańcowa wartość dodana,

$P M C$ - przewidywany krańcowy koszt,

$T^{*} \quad-$ określony czas trwania inwestycji,

pozostałe jak wyżej.

Przedstawione na wykresie 3.1 krzywa przewidywanej krańcowej wartości dodanej i krzywa przewidywanego krańcowego kosztu wskazują, iż zrównanie wartości tych kategorii ma miejsce w punkcie równowagi $E\left(t_{2} ; P M C=P M V A\right)$.

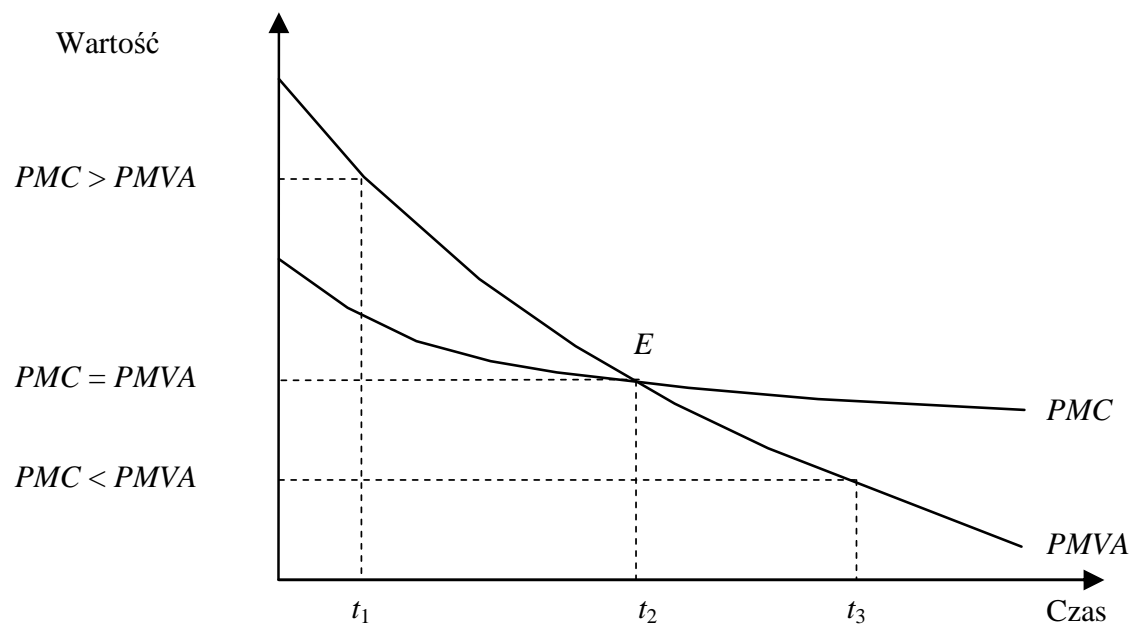

Wykres 3.1. Wybór momentu wyjścia z inwestycji według ogólnej teorii dezinwestycji

Źr ódło: opracowanie własne na podstawie D. J. Cumming, J. G. MacIntosh, Venture-capital exits in Canada and United States, „University of Toronto Law Journal” 2003.

Gdy koszty utrzymania inwestycji ponoszone przez fundusz private equity są równe krańcowej wartości dodanej generowanej przez tę inwestycję, wówczas współpraca funduszu ze spółką portfelową powinna zostać zakończona.

Powyższy model wyznaczania optymalnego czasu wyjścia z inwestycji funduszy private equity wskazuje na trzy podstawowe sytuacje, w których należy zrealizować proces dezinwestycji ${ }^{42}$ :

1. Przecięcie się krzywej krańcowej wartości dodanej z krzywą kosztu utrzymania inwestycji oznaczające wyczerpanie się możliwości funduszu dalszego kreowania wartości.

\footnotetext{
${ }^{42}$ D. J. C u m ming, J. G. M a c In to s h, Venture-capital exits..., op. cit., s. 110-111.
} 
Możliwości kreowania dodatkowej wartości w spółce portfelowej przez inwestora są największe na początku procesu inwestycyjnego, gdzie przez wsparcie zarówno finansowe, jak i kapitał menedżerski przedsiębiorstwo jest w stanie osiągać lepsze wyniki $\left(t_{1}\right)$. Jednak kolejne działania inwestora przynoszą coraz mniejsze efekty w postaci $P M V A$. Krzywa $P M C$ również ma kształt malejący, to jednak spadek krańcowych kosztów utrzymywania inwestycji jest zdecydowanie wolniejszy. Wraz z upływem czasu dochodzi do przecięcia się obu krzywych w punkcie $E\left(t_{2} ; P M C=P M V A\right)$. Dalsze zaangażowanie funduszu w spółkę portfelową należy uznać za niecelowe, gdyż prowadziłoby do spadku efektywności inwestycji $\left(t_{3}\right)$.

2. Wewnętrzne lub zewnętrzne czynniki (zdarzenia, szoki) powodują przesunięcie się jednej lub obu krzywych.

Niezależnie od działań podejmowanych przez fundusz private equity otoczenie przedsiębiorstwa może wpłynąć na położenie zarówno krzywej PMVA oraz $P M C$. Działalność konkurencyjnych podmiotów względem spółki portfelowej, występująca dekoniunktura na rynku, a nawet technologiczne uwarunkowania realizowanych procesów operacyjnych mogą zmienić wartość oczekiwanych efektów i nakładów, a w konsekwencji wpłynąć na wybór momentu dezinwestycji.

3. Fundusz private equity staje się posiadaczem nowych informacji o położeniu krzywej krańcowej wartości dodanej lub krzywej kosztu utrzymania inwestycji.

W początkowej fazie inwestycji i w sytuacji niepełnej informacji może mieć miejsce błędne określenie położenia krzywych PMVA lub PMC. Wraz z upływem czasu inwestor w oparciu o pełniejszą informację będzie mógł precyzyjniej określić moment efektywnego wyjścia z inwestycji.

Zaangażowanie funduszu private equity w spółkę w sytuacji, kiedy oczekiwany koszt takiego działania przewyższy oczekiwane korzyści byłoby działaniem nieracjonalnym z punktu widzenia efektywności gospodarowania kapitałem. Naturalnym rezultatem takiego stanu powinno być więc wyjście z takiej inwestycji, a następnie pozyskanie nowego, satysfakcjonującego projektu inwestycyjnego, który pozwoli funduszowi wykorzystać posiadaną unikatową zdolność do budowania dynamicznego wzrostu wartości posiadanych spółek portfelowych.

\subsection{Czynniki wpływające na wybór czasu wyjścia z inwestycji}

Długość zaangażowania kapitałowego funduszu private equity w spółkę portfelową jest kwestią indywidualną, niewątpliwie związaną $\mathrm{z}$ potencjałem wzrostu jej wartości rynkowej ${ }^{43}$.

${ }^{43} \mathrm{~J} . \mathrm{H} . \mathrm{Coch}$ ran e, The risk and return of venture capital, „Journal of Financial Economics" 2005, Vol. 75, s. 3-52. 


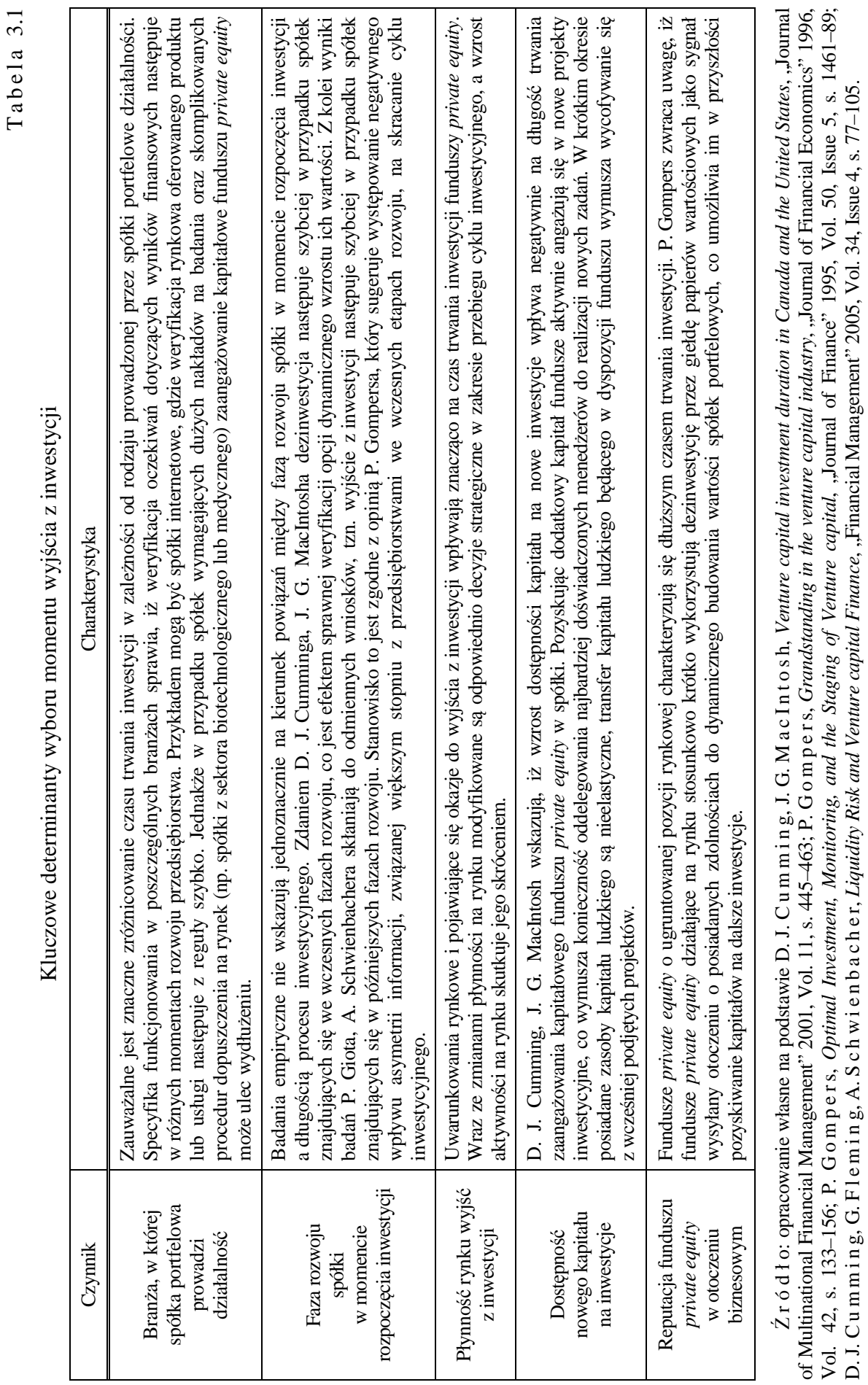


Dla funduszu private equity konieczne jest określenie terminu wyjścia z inwestycji nie tyle przez podanie konkretnej daty, ale przede wszystkim na podstawie osiągnięcia oczekiwanych efektów ekonomicznych w danym okresie ${ }^{44}$.

$\mathrm{W}$ praktyce prowadzenia działalności inwestycyjnej funduszy private equity wskazuje się na wiele różnorodnych czynników mających wpływ na czas zaangażowania kapitałowego funduszu w spółkę portfelową. Literatura przedmiotu w tym zakresie jako główne czynniki wpływające na czas trwania inwestycji wskazuje fazę rozwoju spółki w momencie zainicjowania inwestycji oraz rodzaj prowadzonej działalności, podaż nowego kapitału na inwestycje, płynność rynku wyjść z inwestycji oraz reputację funduszu private equity (zob. tab. 3.1).

Okres zaangażowania kapitałowego funduszu private equity w spółkę portfelową powiązany jest ze sposobem wyjścia z danej inwestycji. Wyniki badań empirycznych wskazują na zróżnicowanie czasu trwania procesu inwestycyjnego funduszy private equity w zależności od metody dezinwestycji (zob. tab. 3.2). Inwestycje, które zostały zakończone przez wykorzystanie pierwszej oferty publicznej charakteryzowały się średnio krótszym czasem współpracy pomiędzy spółką portfelową i funduszem private equity.

Tabela 3.2

Czas trwania procesu inwestycyjnego funduszy private equity w zależności od metody dezinwestycji (w latach)

\begin{tabular}{|l|c|c|c|}
\hline \multirow{2}{*}{\multicolumn{1}{c|}{ Metoda dezinwestycji }} & \multirow{2}{*}{\begin{tabular}{c} 
P. Giot \\
\cline { 3 - 4 }
\end{tabular}} & A. Schwienbacher & \multicolumn{2}{c|}{$\begin{array}{c}\text { D. J. Cumming } \\
\text { J. G. MacIntosh }\end{array}$} \\
\cline { 3 - 4 } & & USA & Kanada \\
\hline \hline Pierwsza oferta publiczna & 3,34 & 4,70 & 5,86 \\
\hline Sprzedaż inwestorowi strategicznemu & 4,56 & 5,17 & 6,94 \\
\hline Sprzedaż inwestorowi finansowemu & b.d. & 6,33 & 3,08 \\
\hline Buy-back & b.d. & 4,00 & 6,34 \\
\hline Likwidacja & 3,30 & 4,36 & 4,07 \\
\hline
\end{tabular}

* do obliczeń przyjęto założenie, iż 1 rok to 365 dni.

Ź r ó d ło: opracowanie własne na podstawie P. Giot, A. Schwienbacher, IPOs, trade sales and liquidations: Modeling venture capital exits using survival analysis, ,Journal of Banking and Finance" 2007, Vol. 31, s. 692; D. J. Cu mming, J. G. M a c In to sh, Venture capital investment duration in Canada and the United States, ,Journal of Multinational Financial Management" 2001, Vol. 11, s. 456-457.

${ }^{44}$ K. Sobańska, P. Sieradzan, Inwestycje private equity/venture capital, Key Text, Warszawa 2004, s. 113. 

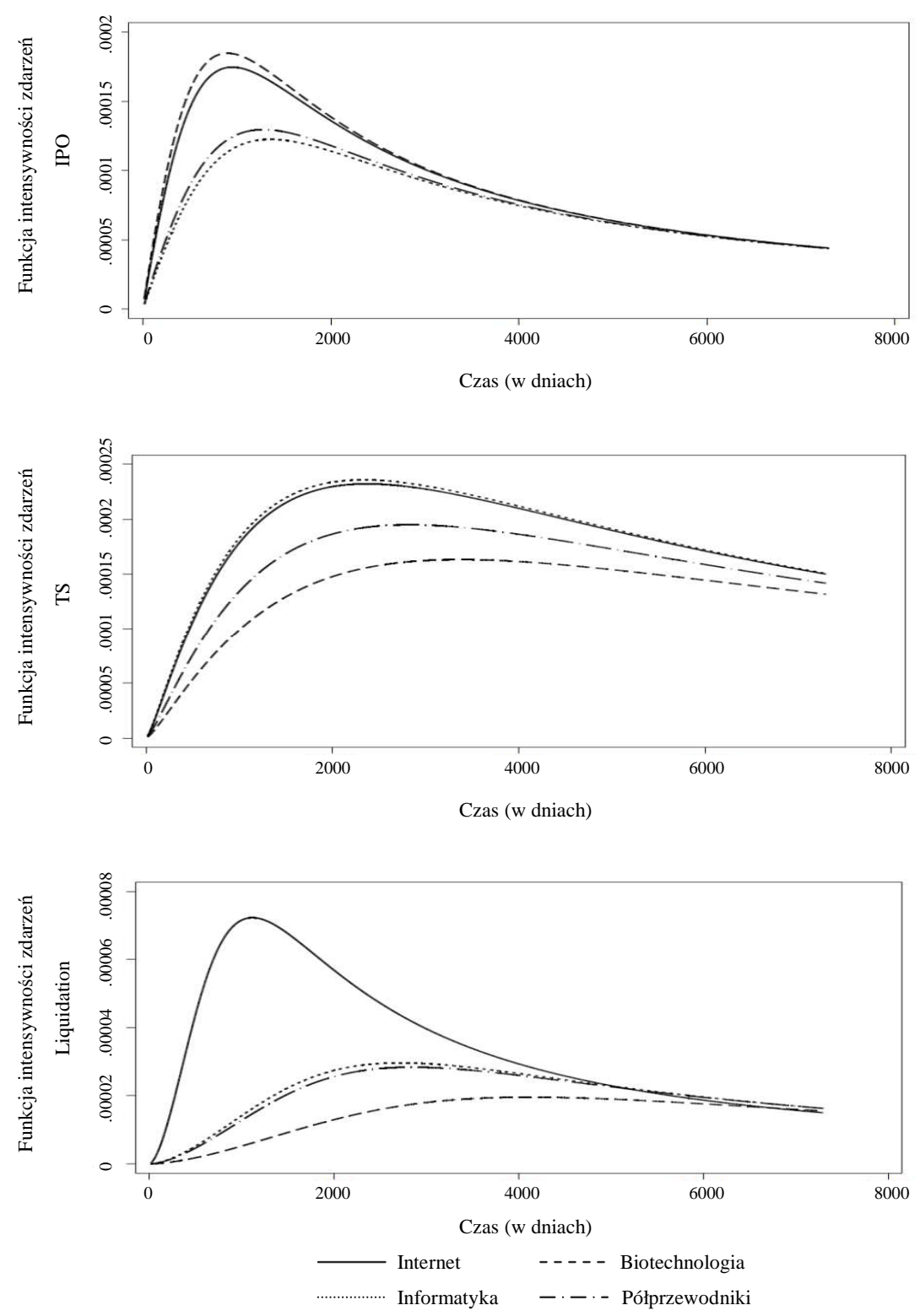

Wykres 3.2. Funkcja prawdopodobieństwa wyjścia z inwestycji metodą pierwszej oferty publicznej (IPO), sprzedaży przedsiębiorstwa inwestorowi strategicznemu (TS) oraz likwidacji (Liquidation) inwestycji w zależności od branży, w której spółka portfelowa prowadzi działalność Ź ród ł o: P. Giot, A. S chwien ba cher, op. cit., s. 696. 
P. Giot i A. Schwienbacher do modelowania procesu wyjścia z inwestycji funduszy private equity i analizy związku pomiędzy metodą dezinwestycji a długością procesu inwestycyjnego wykorzystali analizę przeżycia (ang. survival analysis $)^{45}$. Wskazali oni, iż prawdopodobieństwo debiutu giełdowego spółki portfelowej początkowo szybko rośnie, a po osiągnięciu górnych wartości w okresie około 2,75-4 lat, wyjście z inwestycji przez giełdę papierów wartościowych staje się z biegiem czasu coraz mniej prawdopodobne. Funkcja intensywności zdarzeń ${ }^{46}$ dla pierwszej oferty publicznej w tym przedziale czasu wyraźnie maleje. Natomiast funkcja intensywności zdarzeń obrazująca możliwość sprzedaży przedsiębiorstwa inwestorowi branżowemu w początkowym okresie również dynamiczne wzrasta, jednak osiąga ona swoje maksimum znacznie później (w zależności od branży od 6,8 do 11 lat). Zauważalny w późniejszym okresie spadek prawdopodobieństwa wykorzystania tej metody do zakończenia współpracy pomiędzy spółką a funduszem private equity charakteryzuje się mniejszą dynamiką niż w przypadku pierwszej oferty publicznej (zob. wykres 3.2).

Wyniki te stanowią wyraźne wsparcie dla tezy, iż pierwsza oferta publiczna jest $\mathrm{z}$ reguły preferowaną metodą wyjścia $\mathrm{z}$ inwestycji funduszy private equity, a sprzedaż spółki inwestorowi branżowemu jest drugim wyborem.

Ciekawym wydaje się, iż o ile w przypadku funkcji intensywności zdarzeń pierwszej oferty publicznej, czy sprzedaży przedsiębiorstwa inwestorowi branżowemu nie zauważa się znacznego zróżnicowania jej przebiegu pomiędzy poszczególnymi branżami, to w przypadku likwidacji inwestycji sytuacja jest odmienna. Prawdopodobieństwo doznania porażki inwestycyjnej w przypadku spółek internetowych w początkowym okresie rośnie znacznie dynamicznej, aby po osiągnięciu szczytu po około 3,3 lat drastycznie zmaleć. Dla przedsiębiorstw działających w pozostałych branżach funkcja intensywności zdarzeń ma znacznie bardziej płaski przebieg, a maksimum osiąga w późniejszym okresie. Ryzyko niepowodzenia danej inwestycji jest bowiem mocno związane ze specyficznymi uwarunkowaniami prowadzenia działalności gospodarczej w poszczególnych branżach, w tym odmiennym cyklem życia produktów.

\subsection{Czynniki wpływające na wybór metody dezinwestycji}

Decyzja o wyborze określonej metody wyjścia z inwestycji pozwalającej na realizację celów zarówno funduszu private equity, jak i spółki portfelowej, jest

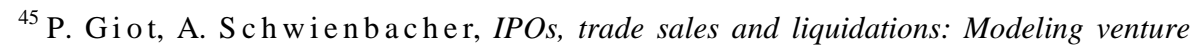
capital exits using survival analysis, ,Journal of Banking and Finance” 2007, Vol. 31, s. 679-702.

${ }^{46}$ Funkcja ta przedstawia graniczne prawdopodobieństwo wystąienia zdarzenia w chwili $t$, pod warunkiem że do tej chwili obiekt takiego wydarzenia nie doznał. Zob. A. B ali ck ki, Analiza przeżycia i tablice wymieralności, PWE, Warszawa 2006, s. 30-34. 
jedną z najtrudniejszych w całym procesie dezinwestycji. Trudność ta wynika z licznych i odmiennych czynników, które mają wpływ na podejmowane decyzje co do sposobu zakończenia współpracy pomiędzy obiema stronami.

Czynniki te można zgrupować w dwie główne kategorie, a mianowicie odnoszące się do:

- uwarunkowań zewnętrznych, wynikających z ogólnych warunków prowadzenia działalności w danym otoczeniu gospodarczym oraz

- uwarunkowań wewnętrznych, które są pochodną specyficznych cech podmiotów uczestniczących w danej transakcji oraz relacji zachodzącej pomiędzy tymi jednostkami (zob. schemat 3.4).

W ramach wewnętrznych uwarunkowań wyodrębnić można trzy rodzaje czynników, a mianowicie: czynniki wynikające ze specyfiki funduszu private equity, czynniki mające genezę w spółce portfelowej, a także grupa czynników wynikająca $\mathrm{z}$ charakteru współpracy pomiędzy funduszem private equity i spółką portfelową ${ }^{47}$.

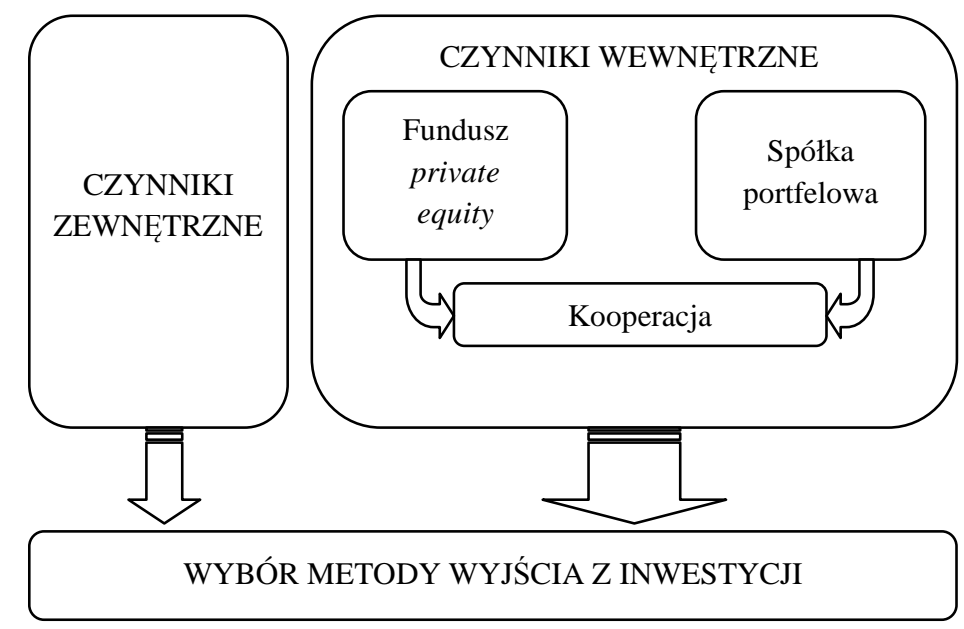

Schemat 3.4. Klasyfikacja czynników wpływających na wybór metody dezinwestycji funduszy private equity

Ź r ó d ł o: opracowanie własne.

Wydaje się, że uwidoczniona na schemacie 3.4 klasyfikacja czynników wpływających na wybór metody dezinwestycji ułatwia poznanie i zrozumienie prawidłowości zachodzących w procesie zakończenia współpracy pomiędzy funduszem private equity i spółką portfelową.

${ }^{47}$ Por. J. C. B rau, B. Francis, N. Kohers, The Choice of IPO versus Takeover: Empirical Evidence, „Journal of Business” 2003, Vol. 76, No. 4, s. 583-584. 


\subsubsection{ZEWNECTRZNE UWARUNKOWANIA WYBORU METODY DEZINWESTYCJI}

Ważnym czynnikiem mającym wpływ na wybór określonej strategii wyjścia $\mathrm{z}$ inwestycji przez fundusze private equity jest poziom rozwoju rynku kapitałowego $^{48}$. Możliwość sprawnego wprowadzenia akcji spółki portfelowej do publicznego obrotu jest jedną z podstawowych kwestii, w sytuacji kiedy rozważane są różne opcje wyjścia z inwestycji dla przedsiębiorstw udziałowych, w których zostały zrealizowane zamierzone cele strategiczne.

B. S. Black, R. J. Gilson podkreślają istotność poziomu rozwoju rynku kapitałowego zarówno w kontekście strategii dezinwestycji, jak i możliwości rozwoju całego rynku inwestycji private equity ${ }^{49}$. Ich zdaniem, dobrze rozwinięty rynek papierów wartościowych daje możliwość sprawnej realizacji zysków z inwestycji poprzez ofertę publiczną. Ze względu na skalę korzyści dla wszystkich uczestników procesu inwestycyjnego, poziom rozwoju rynku kapitałowego może być uznawany za konieczny warunek dynamicznego rozwoju rynku kapitału podwyższonego ryzyka w ogóle. Badania empiryczne wskazują na pozytywny związek pomiędzy napływem kapitału przeznaczanego na inwestycje a liczbą debiutów giełdowych spółek korzystających ze wsparcia funduszu private equity ${ }^{50}$.

Poza stopniem rozwoju rynku giełdowego w danym kraju za bardzo istotne przy wyborze metody dezinwestycji z pewnością należy również uznać warunki i nastroje na nim panujące. E. Ball, H-H. Chiu, R. Smith przeanalizowali rynek dezinwestycji w Stanach Zjednoczonych pod kątem wpływu nastrojów na NASDAQ a liczbą debiutów giełdowych i przejęć spółek portfelowych funduszy private equity $^{51}$. Wyniki ich badań wskazują, iż w okresach wzrostów na rynku zauważalne było zwiększenie liczby pierwszych ofert publicznych spółek portfelowych funduszy private equity. Zjawiska tego jednak nie zaobserwowano w przypadku przejęć, gdzie korelacja była na niskim poziomie ${ }^{52}$. Wyniki te są zbieżne z rezultatami badań J. Lernera oraz P. Gompersa, którzy analizując inwestycje w spółki z sektora biotechnologicznego zauważyli, iż fundusze venture capital decydują się na wprowadzenie akcji spółek portfelowych do publicznego obrotu w okresach szczytu hossy na giełdach ${ }^{53}$. Dodatkowo warto zauważyć, iż w okresach tzw. gorącego rynku, tzn. w okresach wzmożonej aktywności pierwszych ofert publicznych, wraz ze zwiększającą się liczbą nowych spółek na gieł-

${ }^{48}$ A. P. Groh, H. von Liechtenstein, How Attractive is Central Eastern Europe for Risk Capital Investors?, „Journal of International Money and Finance” 2009, Vol. 28, No. 4, s. 625-647.

${ }^{49}$ B. S. B la c k, R. J. Gils o n, op. cit., s. 243-277.

${ }^{50}$ Ibidem.

${ }^{51}$ E. B all, H-H. Chiu, R. S mith, Exit Choices of Venture-Backed Firms: IPO v. Acquisition, 2008, http://ssrn.com/abstract=1301288.

\footnotetext{
${ }^{52}$ Ibidem.

${ }^{53}$ P. Go mpers, J. Le rn e r, The Venture capital Cycle, op. cit., s. 375.
} 
dach papierów wartościowych rośnie liczba debiutów spółek portfelowych funduszy private equity. Zjawisko to tłumaczyć można zwiększającym się optymizmem inwestorów i wzrostem ich skłonności do akceptacji wyższej wyceny ofert publicznych w tym czasie ${ }^{54}$.

System prawny, w jakim funkcjonują przedsiębiorstwa, odgrywa znaczącą rolę w kreowaniu zachowań na rynku kapitału podwyższonego ryzyka ${ }^{55}$. D. Cumming, G. Fleming, A. Schwienbacher przeanalizowali wpływ ogólnych regulacji prawno-finansowych na wybór metody dezinwestycji ${ }^{56}$. Główną przesłanką do podjęcia badań w tym kierunku było stwierdzenie, iż panujący porządek prawny jest bezpośrednio związany z ochroną inwestora, co poprzez wpływ na rozwój całego rynku kapitałowego w danym kraju ${ }^{57}$ określa możliwości sprawnego przeprowadzenia procesu dezinwestycji przez fundusz private equity. Badaniu poddane zostały inwestycje w 468 spólek korzystających ze wsparcia funduszy venture capital z 12 krajów rejonu Azji Pacyficznej: Australii, Chin, Hong-Kongu, Indii, Indonezji, Malezji, Nowej Zelandii, Filipin, Singapuru, Korei Południowej, Tajwanu i Tajlandii. Wymienieni wyżej autorzy, tworząc indeks opisujący poziom uwarunkowań prawnych danego kraju, wzięli pod uwagę takie czynniki jak rodzaj systemu prawnego (prawo zwyczajowe a cywilne), efektywność systemu sądownictwa, przestrzeganie prawa, poziom korupcji, ryzyko wywłaszczenia, ryzyko odmowy niewypełnienia zobowiązań umownych oraz uprawnienia akcjonariuszy. W wyniku przeprowadzonych badań autorzy ci wykazali, iż wzrost jakości systemu prawnego w danym kraju zwiększa prawdopodobieństwo wyboru pierwszej oferty publicznej jako sposobu wyjścia z inwestycji w stosunku do pozostałych metod ${ }^{58}$.

A. Samborski również stwierdza, że im mniejszy poziom ochrony prawnej inwestorów mierzony wykładnią przepisów prawnych i jakością wprowadzanego prawa w życie, tym słabszy poziom rozwoju rynku akcji ${ }^{59}$. Odpowiednie regulacje zawarte $\mathrm{w}$ systemie prawnym pozwalają zmniejszyć niebezpieczeństwo pojawienia się negatywnych konsekwencji wynikających $\mathrm{z}$ teorii agencji

${ }^{54}$ E. Ball, H-H. Chiu, R. Smith, op. cit.; Por. J. C. Brau, B. Francis, N. Kohers, op. cit., s. 592.

${ }^{55} \mathrm{~J}$. W ong limpi y arat, The influence of capital market laws and initial public offering (IPO) process on venture capital, „European Journal of Operational Research” 2009, Vol. 192, Issue 1, s. 293-301.

${ }^{56}$ D. Cu m ming, G. Fle ming, A. S chwi e $\mathrm{n}$ b a che r, Legality and venture capital exits, „Journal of Corporate Finance” 2006, Vol. 12, s. 214-245.

${ }^{57} \mathrm{R}$. La Port a, F. Lopez-de-Silanes, A. Shleifer, R. Vish ny, Investor protection and corporate governance, ,Journal of Financial Economics” 2000, Vol. 58, s. 3-27.

${ }^{58}$ D. Cumming, G. Fleming, A. Schwienbacher, Legality and venture capital..., op. cit., s. 214-245.

${ }^{59}$ A. S a m bor s ki, Finansowanie przedsiębiorstw poprzez emisje papierów wartościowych - diagnoza uwarunkowań i zależności, Wydawnictwo Akademii Ekonomicznej w Katowicach, Katowice 2007, s. 270-282. 
i asymetrii informacji pomiędzy dotychczasowymi i nowymi właścicielami spółki portfelowej.

Wybór strategii wyjścia z inwestycji jest również powiązany z dostępnością kapitału na rynku. R. Nahata wskazuje, iż spółki które uzyskały finansowanie $\mathrm{z}$ funduszy private equity w momencie, gdy kapitał na inwestycje był łatwy do pozyskania, mają mniejsze prawdopodobieństwo debiutu giełdowego niż przejęcia $^{60}$. Można to tłumaczyć tym, iż w okresach w których fundusze mają większe trudności z pozyskaniem kapitału na inwestycje, $\mathrm{z}$ większym pietyzmem dokonują one wyboru przedsiębiorstw będących przedmiotem inwestycji, zwracając większą uwagę na jakość i perspektywy rozwoju potencjalnych spółek portfelowych.

\subsubsection{CECHY SPECYFICZNE FUNDUSZU PRIVATE EQUITY A METODA DEZINWESTYCJI}

Uwarunkowania zewnętrzne $\mathrm{z}$ pewnością odgrywają istotną rolę $\mathrm{w}$ procesie wyboru metody dezinwestycji. Sama jednak decyzja podejmowana jest w drodze konsultacji pomiędzy przedsiębiorcą a inwestorem, często już we wstępnych etapach procesu inwestycyjnego ${ }^{61}$.

Poszczególne fundusze private equity różnią się między sobą pod wieloma względami. Jednym z nich jest rodzaj inwestorów udostępniających kapitał niezbędny do inwestowania. To zróżnicowanie ma wpływ na wybór strategii dezinwestycji. D. J. Cumming, S. Johan wykazali istnienie związku między typem kapitałodawców funduszu private equity a stosowaną metodą dezinwestycji ${ }^{62}$. Fundusze private equity zastały podzielone przez tych badaczy na trzy główne grupy: fundusze niezależne, fundusze korporacyjne oraz fundusze korzystające ze środków publicznych. Wykorzystując informacje dotyczące wyjść z inwestycji z 518 spółek zrealizowanych w Kanadzie w latach 1991-2004 wykazali oni, że fundusze działające jako spółki zależne od dużych korporacji (ang. corporate $V C s)$ częściej niż inne wybierały akwizycję jako metodę dezinwestycji. Ten typ funduszy charakteryzuje się ograniczoną autonomią w zakresie podejmowania decyzji inwestycyjnych. Przedsiębiorstwa wchodzące w skład portfela inwestycyjnego wybierane są między innymi pod kątem przydatności opracowywanej technologii dla korporacji będącej założycielem danego funduszu private equity. Rozwiązania technologiczne, będące efektem współpracy spółki i funduszu, często nabywane są przez daną korporację lub inne podmioty z nią współpracu-

${ }^{60} \mathrm{R}$. N a h a t a, Venture capital reputation and investment performance, ,Journal of Financial Economics", November 2008, Vol. 90, Issue 2, s. 127-151.

${ }^{61}$ K. S obań ska, P. S ie radzan,op. cit., s. 113.

${ }^{62}$ Badania dotyczyły wyjść z inwestycji z 518 spółek zrealizowanych w Kanadzie w latach 1991-2004. Zob. D. J. C u m m in g, S. J o h a n, Information asymmetries..., op. cit., s. 197-231. 
jące. Tymczasem z działalnością niezależnych funduszy private equity związane są w podobnym stopniu zarówno wyjścia $\mathrm{z}$ inwestycji poprzez giełdy papierów wartościowych, jak i w drodze sprzedaży przedsiębiorstwa inwestorowi strategicznemu. Natomiast w przypadku funduszy, w których dominującym inwestorem są instytucje państwowe zdecydowanie częściej stosowanymi metodami wyjścia z inwestycji były sprzedaż spółki dotychczasowemu zarządowi, zbycie udziałów innemu funduszowi lub likwidacja spółki. Wiąże się to z mniejszą efektywnością działalności funduszy wspieranych ze środków publicznych.

Wybór metody dezinwestycji jest również mocno powiązany z wizerunkiem funduszu private equity. Kształtowanie odpowiedniego wizerunku funduszu i podnoszenie jego reputacji w oczach potencjalnych inwestorów umożliwia w dłuższym okresie jego funkcjonowania pozyskiwanie nowych środków na rozwój działalności inwestycyjnej. Wprowadzenie spółki do publicznego obrotu uznaje się zaś za najskuteczniejszy sposób sygnalizowania zdolności funduszu do kreowania wzrostu wartości spółek portfelowych ${ }^{63}$.

P. Gompers twierdzi, wskazując na wyniki badań przeprowadzonych w oparciu o próbę 339 debiutów giełdowych spółek korzystających z funduszy venture capital w Stanach Zjednoczonych w latach 1978-1987, iż fundusze private equity, które uznaje się za stosunkowo młode (poniżej 6 lat), są bardziej skłonne do wykorzystywania debiutów giełdowych jako środka budowania reputacji, skracając jednocześnie okres zaangażowania funduszu w spółkę (ang. grandstanding hypothesis) ${ }^{64}$. Podobna analiza została również przeprowadzona w Wielkiej Brytanii ${ }^{65}$. Przeanalizowano pierwsze oferty publiczne z udziałem funduszy venture capital w latach 1992-99 na London Stock Exchange, a wnioski płynące z tych badań w tej kwestii są zbieżne.

\subsubsection{WPLYW CECH CHARAKTERYSTYCZNYCH SPÓŁEK PORTFELOWYCH FUNDUSZY PRIVATE EQUITY NA WYBÓR METODY DEZINWESTYCJI}

Inwestycje funduszy private equity mają w znacząco wysokim stopniu zindywidualizowany charakter. Każda spółka jest inna, a jej specyficzne cechy z pewnością mogą mieć wpływ na sposób zakończenia współpracy pomiędzy stronami transakcji.

${ }^{63}$ P. Go mpe r s, J. Le rn e r, The Venture capital Cycle, op. cit., s. 379.

${ }^{64}$ P. G o m pe r s, Grandstanding..., op. cit., s. 133-156.

${ }^{65} \mathrm{E}$. Barnes, Y. McCarthy, Grandstanding in the UK Venture capital Industry, EFMA 2002 London Meetings. Available at SSRN: http://ssrn.com/abstract=313935, DOI: 10.2139/ssrn.313935. 
Sposób przeprowadzenia dezinwestycji zależy głównie od potencjału wzrostu wartości rynkowej spółki i osiąganych przez nią wyników finansowych. W przypadku inwestycji, które nie osiągnęły oczekiwanego wyniku finansowego i generują straty, dojdzie prawdopodobnie do likwidacji przedsiębiorstwa. Jednakże dla inwestycji efektywnych wachlarz metod, które mogą być zastosowane do zrealizowania zysku z inwestycji przez fundusz private equity jest o wiele szerszy. Sprzedaż spółki inwestorowi strategicznemu wydaje się stosunkowo uniwersalną metodą, która znajduje zastosowanie zarówno do przedsiębiorstw, które osiągają wysokie pozytywne wyniki, jak i tych, które mają umiarkowane rezultaty. Wprowadzenie akcji spółki do publicznego obrotu, a następnie ich sprzedaż przez giełdę dedykowana jest dla inwestycji będących ewidentnym sukcesem rynkowym. Związane to jest zarówno $\mathrm{z}$ wysokimi oczekiwaniami inwestorów giełdowych co do oferowanych im akcji, jak i wysokimi kosztami przeprowadzenia oferty publicznej.

C. Bienz oraz T. Leite stwierdzili, że z grupy inwestycji, które odniosły sukces rynkowy, na giełdę papierów wartościowych trafiają spółki, które osiągają relatywnie wyższą rentowność w stosunku do innych spółek ${ }^{66}$. Udane inwestycje, które charakteryzują się mniejszą rentownością prowadzonej działalności gospodarczej zbywane są poprzez sprzedaż inwestorowi strategicznemu. Spostrzeżenie to związane jest z tym, iż spółki osiągające lepsze wyniki finansowe - zdaniem w/w autorów - nie wymagają nadmiernej kontroli, a ta zapewniana jest przez publiczny rynek i rozproszony akcjonariat jest wystarczająca ${ }^{67}$. W przypadku spółek o niższym stopniu rentowności niezbędny jest mocniejszy nadzór ze strony nowych właścicieli, który może być zapewniony chociażby przez inwestora branżowego. Również A. Schwienbacher wskazuje, iż w przypadku spółek odznaczających się wyższym stopniem innowacyjności i rentowności wzrasta prawdopodobieństwo wyjścia $\mathrm{z}$ inwestycji $\mathrm{w}$ drodze oferty publicznej ${ }^{68}$.

D. J. Cumming oraz S. Johan wskazują, iż spółki wobec których zastosowana została pierwsza oferta publiczna były $\mathrm{z}$ reguły większe niż inne przedsiębiorstwa wchodzące $w$ skład portfela inwestycyjnego ${ }^{69}$. Fakt ten można poniekąd łączyć z wymogami kapitałowymi stawianymi podmiotom, które wyrażają chęć zadebiutowania na giełdzie papierów wartościowych. Z kolei niepowodzenie inwestycji i jej likwidacja dotyczyły stosunkowo mniejszych przedsięwzięć.

${ }^{66}$ C. B i en z, T. Le i te, A Pecking-Order of Venture capital Exit, Norwegian School of Economics and Business Administration. SSRN Working Paper, available at:

http://ssrn.com/abstract=916742, s. 14-15.

${ }^{67}$ Ibidem.

${ }^{68}$ A. Schwienbacher, Innovation and venture capital exits, „The Econimic Journal” 2008, Vol. 118, Royal Economic Society, s. 1911.

${ }^{69}$ D. C u m m in g, S. J o h a n, Information asymmetries..., op. cit., s.197-231. 
Fundusze private equity udostępniają kapitał przedsiębiorstwom będącym na różnym etapie rozwoju, począwszy od finansowania wczesnych faz takich jak zasiew, start-up przez ekspansję, aż do udostępniania kapitału dojrzałym spół$\mathrm{kom}^{70}$. S. R. Das, M. Jagannathan, A. Sarin przeprowadzili badania na grupie 23208 amerykańskich przedsiębiorstw dla ustalenia wpływu etapu rozwoju spółki portfelowej w momencie inwestycji na wybór metody wyjścia z inwestycji ${ }^{71}$. Autorzy ci wykazali, iż prawdopodobieństwo wykorzystania pierwszej oferty publicznej jako metody dezinwestycji zwiększa się dla spółek będących w fazie ekspansji $\mathrm{w}$ porównaniu do inwestycji znajdujących się na wcześniejszym etapie rozwoju $^{72}$. Sprzedaż spółki inwestorowi strategicznemu dla tej grupy spółek była stosowana w mniejszym stopniu. Ta metoda dezinwestycji znajduje szersze zastosowanie dla inwestycji w spółki znajdujące się na późniejszym etapie rozwoju.

\subsubsection{RELACJA MIĘDZY FUNDUSZEM PRIVATE EQUITY I SPÓŁKĄ PORTFELOWĄ A WYBÓR METODY WYJŚCIA Z INWESTYCJI}

Proces inwestycyjny funduszy private equity jest niezwykle złożony i różni się w zależności od charakteru spółki i inwestora. Specyfika współpracy pomiędzy inwestorem a przedsiębiorcą i jej wpływ na wybór metody wyjścia z inwestycji znalazły swoje odzwierciedlenie w badaniach A. Schwienbachera ${ }^{73}$. Autor ten, analizując różnice pomiędzy działalnością funduszy podwyższonego ryzyka w Europie i Stanach Zjednoczonych wskazał, iż zwiększenie obowiązku częstego składania raportów z działalności spółki jest negatywnie skorelowane z prawdopodobieństwem wykorzystania pierwszej oferty publicznej jako sposobu wyjścia $\mathrm{z}$ inwestycji ${ }^{74}$. Autor ten podkreśla też, iż dodatkowe wymagania odnośnie raportowania bieżącej działalności przedsiębiorstwa mogą prowadzić do ograniczenia wysiłków przedsiębiorcy mających na celu wprowadzenia spółki do publicznego obrotu. Nadto jego badania wykazały, iż obecność przedstawicieli funduszu we władzach spółki portfelowej nie ma wpływu na wybór metody dezinwestycji.

${ }^{70}$ Por. J. Grzy wacz, A. Ok oń ska, Venture capital a potrzeby kapitatowe matych $i$ średnich przedsiębiorstw, SGH w Warszawie, Warszawa 2005, s. 69-80.

${ }^{71}$ S. R. D a s, M. J a g a n n th a n, A. S a r i n, Private equity returns: An empirical examination of the exit of venture-backed companies, „Journal of Investment Managment” 2003, Vol. 1, s. $1-26$.

${ }^{72}$ Por. P. A. Gompers, J. Lerner, The Determinants of Corporate Venture capital Success: Organizational Structure, Incentives, and Complementarities, NBER Working Paper No. 6725, http://www.nber.org/papers/w6725.pdf.

${ }^{73} \mathrm{~A}$. S ch w i e $\mathrm{n}$ b a ch e r, An empirical analysis of venture capital exits in Europe and United States, EFA 2002 Berlin Meetings Discussion Paper, 2005 http://ssrn.com/abstract=302001 or DOI: $10.2139 / \mathrm{ssrn} .302001$.

${ }^{74}$ Ibidem. 


\subsection{Kierunki realizacji strategii dezinwestycji funduszy private equity na krajowym publicznym rynku papierów wartościowych}

W literaturze przedmiotu dominuje pogląd, iż wyjście z inwestycji za pośrednictwem rynku giełdowego wiąże się na ogół z rozłożoną w czasie redukcją zaangażowania kapitałowego funduszu private equity ${ }^{75}$, co związane jest $\mathrm{z}$ występowaniem znaczącej asymetrii informacji pomiędzy właścicielami spółki przed jej upublicznieniem a nabywcami akcji oferowanych na publicznym rynku papierów wartościowych, negatywnie wpływającej na wycenę rynkową spółki ${ }^{76}$.

$\mathrm{W}$ praktyce realizowanych wyjść $\mathrm{z}$ inwestycji przez fundusze private equity poszczególne metody dezinwestycji w różnym zakresie i różnym natężeniem znajdują zastosowanie $\mathrm{w}$ procesie redukcji zaangażowania kapitałowego funduszu private equity w spółkę portfelową. Dezinwestycja może bowiem przybierać formę całkowitego lub częściowego wyjścia z inwestycji, stwarzając przy tym odmienne szanse na sukces finansowy.

W ramach poszczególnych sposobów redukcji zaangażowania kapitałowego funduszu private equity w spółkę portfelową określenie częściowe i całkowite wyjście z inwestycji jest odmiennie pojmowane ${ }^{77}$. W przypadku realizacji procesu dezinwestycji poprzez sprzedaż akcji spółki portfelowej w drodze oferty publicznej za całkowite wyjście $\mathrm{z}$ inwestycji uznaje się sytuację, kiedy fundusz private equity sprzeda wszystkie posiadane akcje spółki portfelowej w okresie nieprzekraczającym jednego roku od jej debiutu giełdowego. Jeżeli po tym czasie fundusz będzie nadal pozostawał akcjonariuszem w tej spółce, wówczas mówi się o częściowym wyjściu z inwestycji ${ }^{78}$.

\subsubsection{METODYKA BADAŃ NAD DYNAMIKĄ I CZASEM TRWANIA DEZINWESTYCJI FUNDUSZY PRIVATE EQUITY NA GPW W WARSZAWIE}

W badaniach nad dynamiką i czasem trwania dezinwestycji funduszy private equity realizowanych na GPW w Warszawie wykorzystany został wskaźnik udziału funduszu private equity w kapitale zakładowym spółki portfelowej, przedstawiający iloraz liczby akcji, których właścicielem jest fundusz private

${ }^{75}$ Zob. P. Gompers, J. Le rn er, The Venture capital Cycle, op. cit., s. 423; M. Wrzes ińs ki, Kapitat podwyższonego ryzyka. Proces inwestycyjny i efektywność, SGH w Warszawie, Warszawa 2006, s. 231.

${ }^{76}$ Zob. D. C u m min g, S. J o h a n, Information asymmetries..., op. cit., s. 198.

${ }^{77}$ Zob. D. J. Cumming, J. G. Mac Intosh, A cross-country comparison..., op. cit., s. 514-516.

${ }^{78}$ Ibidem. 
equity oraz całkowitej liczby akcji spółki. Formuła wskaźnika udziału funduszu private equity w kapitale zakładowym spółki przyjęła zatem następującą postać:

$$
p_{P E}=\frac{N S_{P E}}{T N S}
$$

gdzie:

$p_{P E}$ - wskaźnik udziału funduszu private equity w kapitale zakładowym spółki,

$N S_{P E}$ - liczba akcji spółki będąca własnością funduszu private equity oraz

TNS - liczba akcji spółki ogółem.

Dla identyfikacji zakresu i tempa zmian zaangażowania funduszu private equity w kapitał zakładowy spółki portfelowej konieczne jest porównanie wartości tego wskaźnika przed wprowadzeniem jej akcji do publicznego obrotu, jak i po przeprowadzeniu publicznej oferty sprzedaży akcji oraz rozpoznanie kształtowania się tej miary w okresie późniejszym.

W tym celu zaproponowana została poniższa formuła wskaźnika obrazującego skalę zmian udziału funduszu private equity w kapitale zakładowym spółki portfelowej:

$$
\begin{aligned}
& \Delta p_{P E}={ }^{{ }^{A F T E R-I P O}} p_{P E}-{ }^{P R E-I P O} p_{P E} \\
& \Delta p_{P E}=\frac{{ }_{\text {AFTER-IPO }} N S_{P E}}{{ }^{A F T E R-I P O} T N S}-\frac{{ }^{P R E-I P O} N S_{P E}}{{ }^{P R E-I P O} T N S}
\end{aligned}
$$

gdzie:

$\Delta_{p_{P E}} \quad-$ zmiana wskaźnika udziału funduszu private equity w kapitale zakładowym spółki,

${ }^{P R E-I P O} X$ - wielkość danej zmiennej w okresie bezpośrednio poprzedzającym pierwszą ofertę publiczną danej spółki,

${ }^{A F T E R-I P O} X$ - wielkość danej zmiennej w okresie bezpośrednio następującym po pierwszej ofercie publicznej danej spółki.

Dla potwierdzenia statystycznej istotności wyników z zakresie zmian udziału funduszu private equity w kapitale zakładowym spółek portfelowych przed i po debiucie giełdowym przeprowadzony został test istotności różnic wartości średnich $t$-Studenta dla prób zależnych ${ }^{79}$.

\footnotetext{
${ }^{79}$ Przyjęto założenie o rozkładzie normalnym badanych zmiennych.
} 
Sformułowano zatem hipotezę zerową $H_{0}$ mówiącą o równości średnich:

$$
H_{0}: \mu_{n_{-1}}=\mu_{n_{+1}}
$$

wobec hipotezy alternatywnej $H_{l}$ :

$$
H_{1}: \mu_{n_{-1}} \neq \mu_{n_{+1}}
$$

Zmiana udziału funduszu private equity w kapitale zakładowym spółki portfelowej po debiucie giełdowym może być efektem zarówno sprzedaży posiadanych przez fundusz akcji danej spółki portfelowej, jak i zwiększeniem łącznej liczby akcji spółki w wyniku emisji nowych akcji. Kwantyfikacja siły i kierunku wpływu tych czynników możliwa jest m. in. przy zastosowaniu deterministycznych metod analizy ekonomicznej. W tym celu można dokonać dekompozycji wskaźnika $p_{P E}$ do następującej formuły:

$$
\begin{aligned}
& p_{P E}=\frac{N S_{\text {OTHER }}}{T N S} \times \frac{N S_{P E}}{N S_{\text {OTHER }}} \\
& N S_{\text {OTHER }}=T N S-N S_{P E}
\end{aligned}
$$

gdzie:

$N S_{\text {OTHER }}$ - liczba akcji spółki będąca własnością pozostałych akcjonariuszy, pozostałe jw.

Wyrażenie wskaźnika udziału funduszu private equity w kapitale zakładowym spółki w powyższej postaci pozwala stwierdzić, iż jego poziom zależy od wielkości udziału pozostałych akcjonariuszy w kapitale spółki oraz stosunku liczby akcji będących własnością funduszu private equity a pozostałą liczbą akcji określonej spółki. Ponadto, uwzględniając czynniki związane ze specyfiką procesów dezinwestycji realizowanych metodą pierwszej oferty publicznej, udział funduszu private equity w kapitale zakładowym spółki portfelowej można przedstawić za pomocą następującej formuły:

$$
p_{P E}=\frac{N S_{N E W}}{T N S} \times \frac{S O L D}{N S_{P E}} \times\left(\frac{S O L D}{N S_{N E W}} S_{P E}\right)^{-1}
$$

gdzie:

$N S_{N E W}$ - liczba akcji nowej emisji,

${ }_{S O L D} N S_{P E}$ - liczba akcji sprzedawana przez fundusz private equity w ramach pierwszej oferty publicznej,

pozostałe jw. 
Tabela 3.3

Podmioty zakwalifikowane do badań empirycznych (skład próby badawczej)

\begin{tabular}{|c|c|c|}
\hline Nazwa spółki & $\begin{array}{c}\text { Podmiot zarządzający } \\
\text { funduszem private equity }\end{array}$ & $\begin{array}{c}\text { Data debiutu } \\
\text { giełdowego }\end{array}$ \\
\hline HARPER HYGIENICS SA & Enterprise Investors & 23.07.2010 \\
\hline$A B C D A T A S A$ & MCI Management SA & 17.06.2010 \\
\hline$H A R D E X S A$ & $\begin{array}{l}\text { BBI CAPITAL } \\
\text { Narodowy Fundusz Inwestycyjny SA }\end{array}$ & 3.04 .2008 \\
\hline K2 INTERNET SA & bmp $A G$ & 24.04.2008 \\
\hline MERCOR SA & Innova Capital & 19.07.2007 \\
\hline$C P$ Energia $S A$ & Capital Partners $S A$ & 29.11.2007 \\
\hline MAGELLAN SA & Enterprise Investors & 1.10 .2007 \\
\hline BIPROMET SA & $\begin{array}{l}\text { Capital Partners SA } \\
\text { AVALLON Spótka z o.o. }\end{array}$ & 31.10 .2007 \\
\hline SFINKS POLSKA SA & Enterprise Investors & 8.06 .2006 \\
\hline $\begin{array}{l}\text { ERGIS-EUROFILMS SA } \\
\text { (d. Eurofilms SA) }\end{array}$ & Arx Equity Partners Sp. z o.o. & 12.06.2006 \\
\hline Bankier.pl SA & MCI Management SA, bmp AG & 19.06.2006 \\
\hline$Q U M A K-S E K O M S A$ & Krokus Private equity Sp. z o.o. & 3.08 .2006 \\
\hline$O N E-2-O N E S A$ & MCI Management SA & 22.08 .2006 \\
\hline$A B S A$ & Enterprise Investors & 21.09 .2006 \\
\hline HTL-STREFA SA & Noryt Company Establishment & 15.11 .2006 \\
\hline LSI SOFTWARE SA & Regionalne Fundusze Inwestycji Sp. z o.o. & 21.12.2006 \\
\hline POLISH ENERGY PARTNERS SA & Enterprise Investors & 13.05 .2005 \\
\hline OPOCZNO SA & \begin{tabular}{|l} 
Enterprise Investors \\
Credit Suisse First Boston PE
\end{tabular} & 24.06.2005 \\
\hline TRAVELPLANET.PL SA & MCI Management SA & 12.07 .2005 \\
\hline FIRMA HANDLOWA JAGO SA & Krokus Private equity Sp. zo.o. & 8.11 .2005 \\
\hline TETA SA & Enterprise Investors & 29.11.2005 \\
\hline TECHMEX SA & $\begin{array}{l}\text { Krokus Private equity Sp. zo.o. } \\
\text { European Renaissance Capital } \\
\text { Handlowy Investments II S.a.r.l }\end{array}$ & 19.05.2004 \\
\hline PRATERM SA & \begin{tabular}{|l|} 
Krokus Private equity Sp. zo.o. \\
Nederlandse Financieringsmaatschappij voor \\
Ontwikkelingslanden NV
\end{tabular} & 6.12 .2004 \\
\hline COMP Rzeszów SA & Enterprise Investors & 27.09.2004 \\
\hline $\begin{array}{l}\text { EMPERIA HOLDING SA } \\
\text { (d. Eldorado SA) }\end{array}$ & Enterprise Investors & 3.01 .2002 \\
\hline W. KRUK SA & Enterprise Investors & 2.07.2002 \\
\hline
\end{tabular}

Źr ó d ł o: opracowanie własne. 
Z zaproponowanej formuły wynika, że wielkość udziału funduszu private equity w kapitale zakładowym spółki portfelowej zależna jest od:

a) udziału akcji nowej emisji w ogólnej liczbie akcji spółki,

b) struktury publicznej oferty sprzedaży akcji wyrażonej stosunkiem liczby akcji sprzedawanych przez fundusz private equity i liczby akcji nowej emisji,

c) stopnia dezinwestycji przedstawionego jako udział akcji zbywanych przez fundusz w drodze publicznej oferty sprzedaży w ogólnej liczbie akcji będących własnością funduszu private equity.

Badania empiryczne zostały przeprowadzone na grupie 26 spółek notowanych na GPW w Warszawie (zob. tab. 3.3).

Spółki zakwalifikowane do badań empirycznych spełniły następujące kryteria wyboru:

- przed dopuszczeniem do publicznego obrotu przeprowadziły publiczną ofertę sprzedaży akcji i/lub publiczną subskrypcję akcji,

- fundusz private equity był w formie pośredniej lub bezpośredniej akcjonariuszem,

- pierwsze notowanie ich akcji odbyło się w latach 2002-2010 oraz

- posiadały główną siedzibę działalności w Polsce.

\subsubsection{WYNIKI BADAŃ EMPIRYCZNYCH}

Poprzedzając analizę procesu redukcji zaangażowania kapitałowego funduszy private equity $\mathrm{w}$ badanych podmiotach oceną udziału funduszu private equity w kapitale zakładowym spółek portfelowych bezpośrednio przed wprowadzeniem na GPW w Warszawie, wskazać można na występowanie dość znacznych różnic w wartości tego wskaźnika w badanych 26 spółkach akcyjnych.

Dane zaprezentowane w tab. 3.4 wskazują, iż fundusze private equity posiadały w tym okresie istotną część kapitału zakładowego spółek objętych procesami dezinwestycji metodą pierwszej oferty publicznej.

$\mathrm{W}$ analizowanych podmiotach przed ich upublicznieniem średnio prawie $60 \%$ akcji było własnością funduszu private equity. Wartość mediany badanej zmiennej w niewielkim stopniu różniła się od średniej arytmetycznej i wynosiła $55,78 \%$, natomiast zaledwie w jednej czwartej spółek udział ten był mniejszy od 42,07\%. Rozkład badanej zmiennej jest prawostronnie asymetryczny, co wskazuje na przesunięcie w kierunku wyższych wartości. Udział funduszu private equity w kapitale zakładowym poszczególnych spółek był wyraźnie zróżnicowany i wahał się od zaledwie 17,03\% w przypadku spółki Eurofilms SA, aż do $100 \%$ dla spółki Harper Hygienics SA, gdzie w wszystkie akcje spółki były własnością funduszy zarządzanych przez Enterprise Investors (zob. wykres 3.3). 
Tabela 3.4

Wartość podstawowych statystyk opisowych udziału funduszu private equity w kapitale zakładowym spółki portfelowej bezpośrednio przed wprowadzeniem na GPW w Warszawie

\begin{tabular}{|l|c|}
\hline \multicolumn{1}{|c|}{ Wyszczególnienie } & $\begin{array}{c}\text { PRE-IPO } p_{\text {PE }} \\
{[\mathrm{w} \%]}\end{array}$ \\
\hline \hline Średnia arytmetyczna & 59,77 \\
\hline Kwartyl pierwszy & 42,07 \\
\hline Mediana & 55,78 \\
\hline Kwartyl trzeci & 80,97 \\
\hline Odchylenie standardowe & 24,41 \\
\hline Minimum & 17,03 \\
\hline Maksimum & 100,00 \\
\hline Liczba spółek & 26 \\
\hline
\end{tabular}

Ź r ó d ł o: opracowanie własne na podstawie prospektów emisyjnych analizowanych spółek.

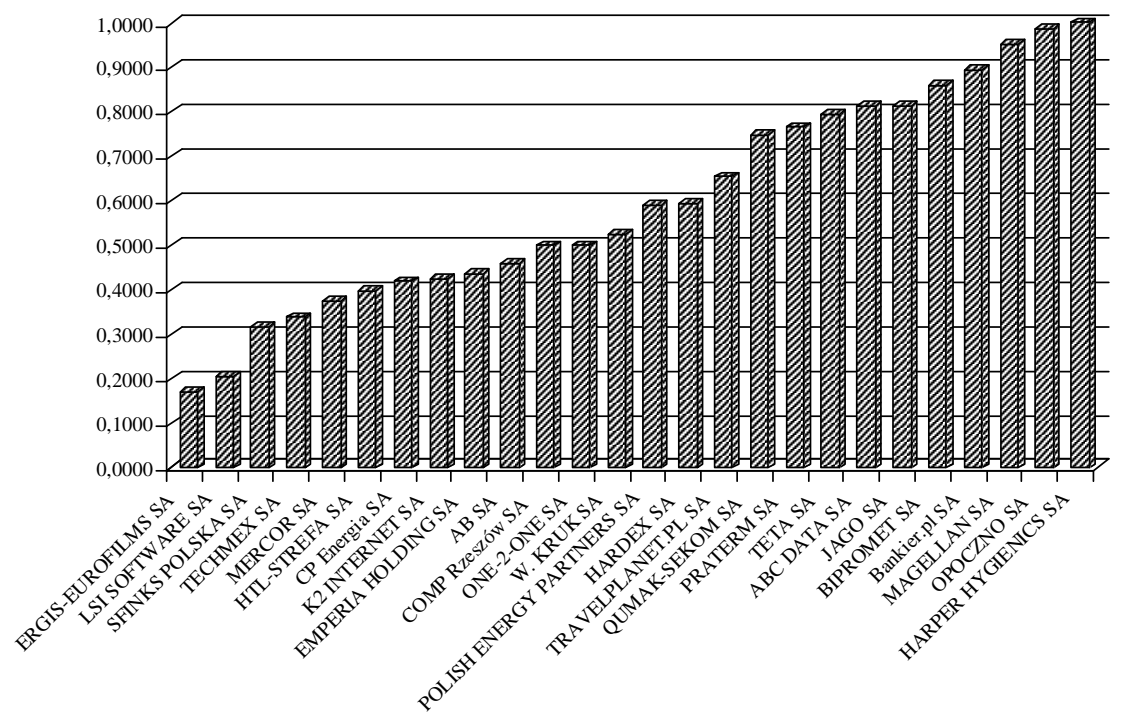

Wykres 3.3. Udział funduszu private equity w kapitale zakładowym analizowanych spółek bezpośrednio przed wprowadzeniem na GPW w Warszawie

Ź r ó d ło: opracowanie własne na podstawie prospektów emisyjnych analizowanych spółek. 
W praktyce dezinwestycji realizowanych poprzez warszawską giełdę, wprowadzenie do publicznego obrotu akcji spółki portfelowej nie zawsze związane jest z publiczną ofertą sprzedaży akcji będących własnością funduszu private equity (zob. wykres 3.4). W przypadku 6 spółek fundusze private equity rozpoczęły zbywanie określonej liczby posiadanych akcji w późniejszym okresie.

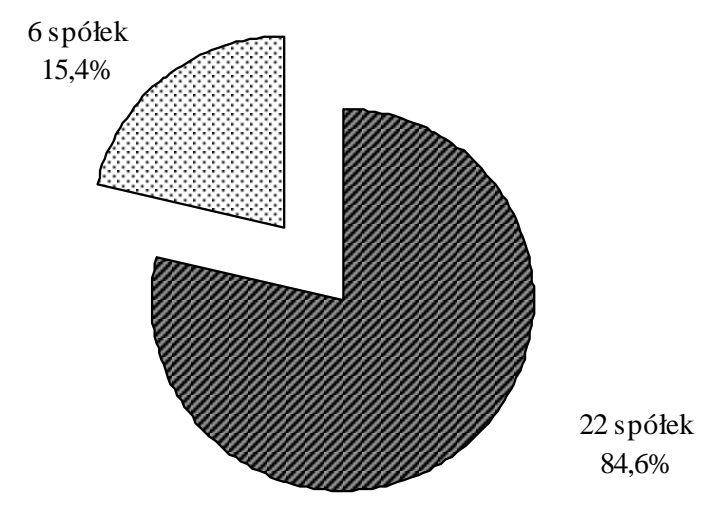

Fundusze private equity zbywały akcje w ofercie publicznej

. Fundusze private equity nie zbywały akcji w ofercie publicznej

Wykres 3.4. Struktura debiutów giełdowych spółek portfelowych funduszy private equity według kryterium zbywania akcji spółki portfelowej przez fundusz private equity $\mathrm{w}$ ofercie publicznej

Ź r ó d ł o: opracowanie własne na podstawie prospektów emisyjnych analizowanych spółek.

Poza licznymi korzyściami, jakie niesie za sobą posiadanie przez przedsiębiorstwo statusu spółki publicznej ${ }^{80}$, debiut giełdowy jest również okazją do pozyskania dodatkowego kapitału na rozwój. We wcześniejszych etapach rozwoju analizowanych podmiotów ważnym źródłem finansowania były również środki dostarczane przez fundusze private equity. W momencie rozpoczęcia procesu dezinwestycji fundusze $\mathrm{z}$ reguły dążą jednak do ograniczenia zaangażowania kapitałowego i spółki portfelowe dla utrzymania dynamicznego wzrostu muszą poszukiwać nowych źródeł kapitału. W zdecydowanej większości analizowanych podmiotów wprowadzenie akcji spółki na GPW w Warszawie związane było z emisją nowych akcji (zob. wykres 3.5).

${ }^{80}$ Zob. M. Mi kołaj e k-Gocj en a, IPO jako źródto finansowania rozwoju spótki, Szkoła Główna Handlowa w Warszawie, Warszawa 2008, s. 79-82. 


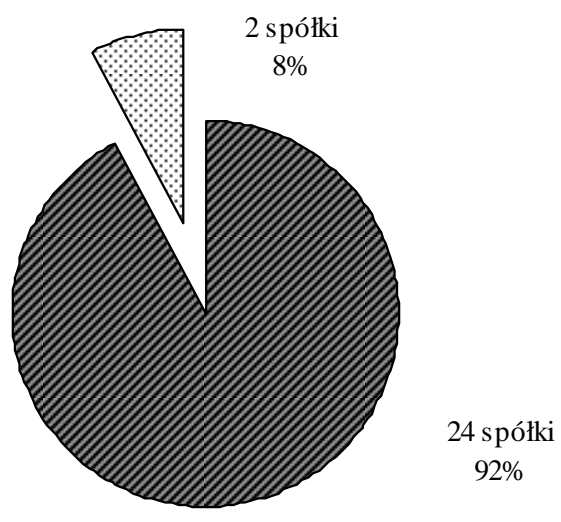

๑ Spółki, które emitowały nowe akcje

$\Xi$ Spółki, które nie emitowały nowych akcji

Wykres 3.5. Struktura debiutów giełdowych spółek portfelowych funduszy private equity według kryterium powiązania $\mathrm{z}$ emisją nowych akcji

Ź ród ło: jak do wykresu 3.3.

Zmniejszenie udziału funduszu private equity w kapitale zakładowym spółki portfelowej po debiucie giełdowym może być zatem efektem wpływu dwóch czynników:

- sprzedaży posiadanych akcji oraz/lub

- zwiększenia łącznej liczby akcji spółki w wyniku emisji nowych akcji.

Fundusze private equity, realizując procesy dezinwestycji $\mathrm{w}$ ramach publicznej oferty sprzedaży akcji, zbywały akcje stanowiące znaczną część kapitału zakładowego spółek portfelowych (zob. tab. 3.5).

$\mathrm{Z}$ analizy danych liczbowych dla 26 badanych podmiotów wynika, iż akcje zbywane przez fundusz private equity $\mathrm{w}$ ramach publicznej oferty sprzedaży stanowiły średnio 20,36\% kapitału zakładowego spółki przed jego podwyższeniem oraz $16,67 \%$ po jego podwyższeniu w wyniku emisji nowych akcji (zob. tab. 3.5). W poszczególnych przypadkach wielkości te były mocno zróżnicowane, na co wskazują wartości wskaźnika odchylenia standardowego. Największy pakiet akcji, bo aż 57,42\% kapitału zakładowego przed jego podwyższeniem w wyniku emisji nowych akcji zbywał fundusz NFI Magna Polonia realizując wyjście ze spółki Qumak-Sekom SA w 2006 r.

$\mathrm{W}$ części przedsiębiorstw udziałowych funduszy private equity debiutowi giełdowemu nie towarzyszyła jednoczesna sprzedaż papierów wartościowych znajdujących się w portfelu inwestycyjnym funduszu (zob. wykres 3.4). Przeprowadzając bowiem analogiczne badania na „oczyszczonej” próbie liczącej 
20 spółek okazało się, że w tej grupie przedsiębiorstw średni udział akcji sprzedawanych przez fundusz $\mathrm{w}$ ramach publicznej oferty w kapitale zakładowym wzrósł do poziomu 26,47\% przed powiększeniem go o emisję nowych akcji oraz odpowiednio do $21,79 \%$ po jego zwiększeniu.

Tabela 3.5

Udział akcji zbywanych przez fundusze private equity bezpośrednio w publicznej ofercie sprzedaży w kapitale zakładowym analizowanych podmiotów

\begin{tabular}{|l|c|c|c|c|}
\hline \multirow{1}{*}{ Wyszczególnienie } & \multicolumn{2}{|c|}{ Wszystkie spółki } & $\begin{array}{c}\text { Spółki, których akcje fundusze } \\
\text { private equity zbywały w ofercie } \\
\text { publicznej }\end{array}$ \\
\cline { 2 - 5 } & $\begin{array}{c}\text { udział akcji } \\
\text { sprzedawanych } \\
\text { w kapitale zakła- } \\
\text { dowym przed } \\
\text { jego podwyższe- } \\
\text { niem w wyniku } \\
\text { emisji nowych } \\
\text { akcji }\end{array}$ & $\begin{array}{c}\text { udział akcji } \\
\text { sprzedawanych } \\
\text { kapitale zakła- } \\
\text { dowym po jego } \\
\text { podwyższeniu } \\
\text { w wyniku emisji } \\
\text { nowych akcji }\end{array}$ & $\begin{array}{c}\text { udział akcji } \\
\text { sprzedawanych } \\
\text { w kapitale zakła- } \\
\text { dowym przed } \\
\text { jego podwyższ- } \\
\text { niem w wyniku } \\
\text { emisji nowych } \\
\text { akcji }\end{array}$ & $\begin{array}{c}\text { udział akcji } \\
\text { sprzedawanych } \\
\text { k kapitale zakła- } \\
\text { dowym po jego } \\
\text { podwyższeniu } \\
\text { w wyniku emisji } \\
\text { nowych akcji }\end{array}$ \\
\hline \hline Średnia arytmetyczna & 0,2036 & 0,1667 & 0,2647 & 0,2179 \\
\hline Mediana & 0,1708 & 0,1282 & 0,2462 & 0,1567 \\
\hline Odchylenie standardowe & 0,1771 & 0,1547 & 0,1558 & 0,1412 \\
\hline Minimum & 0,0000 & 0,0000 & 0,0432 & 0,0373 \\
\hline Maksimum & 0,5742 & 0,5040 & 0,5742 & 0,5040 \\
\hline Liczba spółek & 26 & 26 & 20 & 20 \\
\hline
\end{tabular}

Ź r ó d ł o: opracowanie własne na podstawie prospektów emisyjnych oraz raportów bieżących analizowanych spółek.

Tabela 3.6

Udział funduszu private equity w kapitale zakładowym spółki po wprowadzeniu na GPW w Warszawie

\begin{tabular}{|l|c|c|}
\hline \multicolumn{1}{|c|}{ Wyszczególnienie } & $\begin{array}{c}\text { AFTER-IPO } p_{P E} \\
{[\%]}\end{array}$ & $\begin{array}{c}\text { Zmiana w stosunku do okresu } \\
\text { przed debiutem } \\
\text { [punkty procentowe] }\end{array}$ \\
\hline \hline Średnia arytmetyczna & 32,67 & $-27,10$ \\
\hline Kwartyl pierwszy & 11,14 & $-30,93$ \\
\hline Mediana & 32,55 & $-23,22$ \\
\hline Kwartyl trzeci & 49,45 & $-31,52$ \\
\hline Odchylenie standardowe & 23,28 & $-0,59$ \\
\hline Minimum & 0,00 & $-17,03$ \\
\hline Maksimum & 76,03 & $-23,97$ \\
\hline Liczba spółek & 26 & - \\
\hline
\end{tabular}

Źr ó d ło: jak do tab. 3.5. 
W rezultacie zrealizowanych transakcji na akcjach spółek portfelowych związanych $\mathrm{z}$ ich wprowadzeniem do publicznego obrotu nastąpiła zmiana struktury właścicielskiej tych przedsiębiorstw. Dane zawarte w tab. 3.6 wskazują na znaczące zmniejszenie udziału funduszu private equity w kapitale zakładowym analizowanych spółek akcyjnych po wprowadzeniu na GPW w Warszawie.

Udział funduszu private equity w kapitale zakładowym spółki portfelowej po jej debiucie giełdowym wynosił średnio $32,67 \%$ i zmniejszył się przeciętnie o 27,1 punktów procentowych. Analiza przedstawionych miar położenia rozkładu również wskazuje na znaczące zmniejszenie udziału funduszu w kapitale zakładowym spółki. Warto zauważyć, iż kwartyl trzeci po upublicznieniu spółki obniżył się do poziomu poniżej 50\% (zob. tab. 3.6). Rozkład badanej zmiennej jest lewostronnie asymetryczny.

Przeprowadzony test istotności różnic wartości średnich $t$-Studenta dla prób zależnych dla $\alpha=0,05$ potwierdził istotność otrzymanych wyników z zakresie zmian udziału funduszu private equity w kapitale zakładowym spółek portfelowych przed i po debiucie giełdowym. Wartość parametru $t$-Stat wynosi 8,00 przy wartości krytycznej 2,06, czyli należy odrzucić hipotezę $H_{0}$ na rzecz hipotezy alternatywnej $H_{1}$, mówiącej o istotnych różnicach w zakresie poziomu badanych parametrów.

Fundusze private equity po przeprowadzeniu oferty publicznej w wielu przypadkach nadal pozostawały znaczącymi akcjonariuszami analizowanych spółek publicznych. Proces wychodzenia $\mathrm{z}$ inwestycji był kontynuowany. W części badanych przedsiębiorstw dalsza realizacja procesów dezinwestycji była znacznie utrudniona ze względu na podjęte zobowiązanie do niesprzedawania posiadanych akcji przez $\mathrm{z}$ góry określony czas, czyli tzw. lock-up (zob. wykres 3.6).

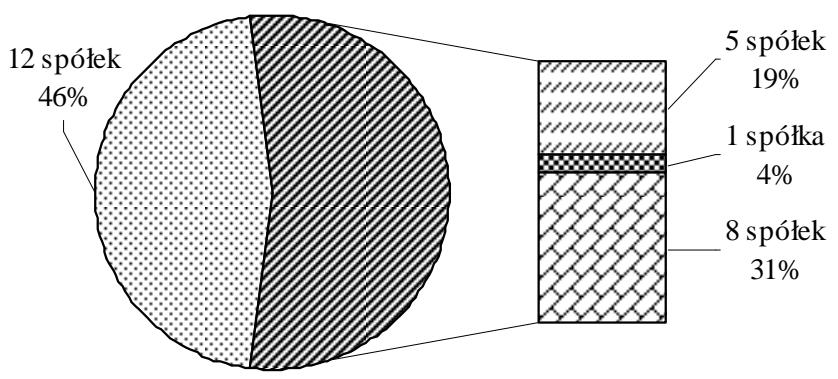

๑brak zobowiązania $\square 6$ miesięcy $\quad$ O miesięcy $\square 12$ miesięcy

Wykres 3.6. Długość okresu lock-up dla funduszy private equity w analizowanych spółkach*

* przyjęto podstawowy deklarowany okres zamknięcia bez uwzględnienia warunków dodatkowych.

Ź r ó d ło: opracowanie własne na podstawie prospektów emisyjnych oraz raportów bieżących analizowanych spółek. 
W przypadku 14 z 26 analizowanych spółek fundusze private equity zadeklarowały, iż przez z góry ustalony czas nie będą sprzedawały posiadanych $\mathrm{w}$ portfelu inwestycyjnym akcji, natomiast $\mathrm{w}$ pozostałych podmiotach tego rodzaju zobowiązanie nie miało miejsca. Zadeklarowany lock-up wynosił od 6 do 12 miesięcy.

Pierwsza publiczna oferta sprzedaży akcji spółki portfelowej oraz wprowadzenie ich do publicznego obrotu $\mathrm{w}$ wielu przypadkach otwiera proces redukcji zaangażowania kapitałowego funduszu w spółkę. Dla realizacji celu dysertacji podjęta została próba określenia czasu, jaki fundusze private equity potrzebują do dokonania całkowitego wyjścia $\mathrm{z}$ inwestycji $\mathrm{w}$ warunkach polskiego rynku kapitałowego. Jednakże precyzyjne określenie momentu, w którym fundusz private equity przestaje być akcjonariuszem danej spółki jest w wielu przypadkach niemożliwe ze względu $\mathrm{m}$. in. na mało transparentne powiązania kapitałowe pomiędzy badanymi podmiotami oraz zakres obowiązków informacyjnych akcjonariuszy wynikający z przepisów prawa ${ }^{81}$. W oparciu o analizę zgromadzonych i przetworzonych danych należy stwierdzić, iż w przeważającej części przedsiębiorstw pierwsza oferta publiczna była stosowana jako częściowe wyjście z inwestycji (zob. tab. 3.7).

Tabela 3.7

Okres kontynuacji zaangażowania kapitałowego funduszu private equity w spółkę portfelową po jej debiucie giełdowym

\begin{tabular}{|l|c|c|}
\hline $\begin{array}{c}\text { Okres kontynuacji zaangażowania kapitałowego funduszu } \\
\text { private equity w spółkę po debiucie giełdowym }\end{array}$ & $\begin{array}{c}\text { Liczba } \\
\text { podmiotów }\end{array}$ & $\begin{array}{c}\text { Udział } \\
{[\%]}\end{array}$ \\
\hline \hline Dezinwestycja w wyniku pierwszej oferty publicznej & 4 & 15,38 \\
\hline (0-12 miesięcy) & 4 & 15,38 \\
\hline$(12-24$ miesięcy) & 3 & 11,54 \\
\hline (24-36 miesięcy) & 3 & 11,54 \\
\hline (36-48 miesięcy) & 5 & 19,23 \\
\hline Powyżej 48 miesięcy & 1 & 3,85 \\
\hline Inwestycje niezakończone $^{*}$ & 6 & 23,08 \\
\hline Razem & 26 & 100,00 \\
\hline
\end{tabular}

* okres kontynuacji zaangażowania kapitałowego funduszu private equity w spółkę po jej debiucie giełdowym wynosi od 19 do 52 miesięcy na dzień 31.01.2012 r.

Ź r ó d ło: opracowanie własne na podstawie raportów bieżących oraz sprawozdań finansowych analizowanych spółek.

${ }^{81}$ Art. 69 oraz art. 69a Ustawy z dnia 29 lipca 2005 r. o ofercie publicznej $i$ warunkach wprowadzania instrumentów finansowych do zorganizowanego systemu obrotu oraz o spótkach publicznych, DzU 2005, nr 184, poz. 1539. 
Analizując dane zawarte $w$ tab. 3.7 można zauważyć, iż fundusze private equity zbyły wszystkie posiadane akcje $\mathrm{w}$ ramach pierwszej publicznej oferty sprzedaży zaledwie w 4 spośród wszystkich analizowanych przedsiębiorstw. W kolejnych 4 spółkach dezinwestycja zakończona została w okresie nieprzekraczającym 1 roku. W niemalże $70 \%$ analizowanych procesów wyjścia z inwestycji okres zaangażowania funduszu w spółkę portfelową licząc od dnia debiutu na GPW w Warszawie przekraczał 12 miesięcy. W znaczącej części analizowanych przedsiębiorstw czas potrzebny do sprzedaży publicznie notowanych akcji z portfela inwestycyjnego funduszu przekraczał 3 lata.

\subsubsection{STOPIEŃ DEZINWESTYCJI FUNDUSZU PRIVATE EQUITY A EMISJA NOWYCH AKCJI PRZEZ SPÓŁKĘ PORTFELOWĄ}

Z racji na unikatowość relacji łączących poszczególne spółki portfelowe $\mathrm{z}$ funduszem, problematyka kształtowania procesu wyjścia z inwestycji funduszy private equity ma charakter wieloaspektowy i wielce złożony. Na tym etapie mogą zaistnieć rozbieżności pomiędzy oczekiwaniami funduszu private equity związanymi z realizacją korzyści kapitałowych a zamierzeniami spółki odnoszącymi się do dalszego jej rozwoju. Obie strony mogą dążyć do osiągnięcia własnych, często rozbieżnych celów. W procesie dezinwestycji realizowanym przez sprzedaż akcji za pośrednictwem rynku kapitałowego wystąpić może konflikt interesów między funduszem private equity a spółką portfelową, zwłaszcza w sytuacji ograniczonego popytu na sprzedawane akcje.

Wpływy z emisji nowych akcji stanowić będą źródło kapitału dla spółki, stąd $w$ jej interesie będzie dążenie do zbywania w ofercie właśnie tych akcji. $\mathrm{Z}$ kolei sprzedaż akcji już istniejących, będących własnością funduszu private equity zapewni wpływ środków pieniężnych na rachunek funduszu, ograniczając przy tym wspomaganie kapitałowe przedsiębiorstwa udziałowego. Ewentualny konflikt interesów i oczekiwań może znaleźć odzwierciedlenie w strukturze papierów wartościowych proponowanych do nabycia inwestorom giełdowym w ramach pierwszej publicznej oferty sprzedaży akcji spółki objętej procesem dezinwestycji. W pierwszych ofertach publicznych spółek portfelowych funduszy private equity obserwowana może być substytucja akcji nowej emisji papierami wartościowymi pochodzącymi z portfela inwestycyjnego funduszu.

$\mathrm{Z}$ punktu widzenia inwestora private equity, realizacja zysku kapitałowego umożliwia szybką reinwestycję uzyskanych zasobów finansowych w nowe, rokujące uzyskanie ponadprzeciętnej stopy zwrotu projekty inwestycyjne. Nadmierne wydłużenie okresu zaangażowania kapitałowego w dane przedsiębiorstwo udziałowe skutkować będzie rosnącymi kosztami utraconych możliwości. Stąd oczekiwania w zakresie dążeń funduszu do oferowania posiadanych w portfelu inwestycyjnym akcji kosztem innych podmiotów mogących uczestniczyć w ofercie po stronie podażowej wydają się uzasadnione. 
Jednakże z punktu widzenia przedsiębiorstwa, zrealizowany proces dezinwestycji oznacza wyjście strategicznego partnera, który poza wsparciem finansowym zapewniał również swoją obecnością gwarancję wiarygodności oraz kapitał współpracy. W ramach emisji nowych akcji w związku z pierwszą ofertą publiczną spółka jest w stanie zgromadzić kapitał na dalszy rozwój i w ten sposób zapewnić sobie bezpieczeństwo finansowe nawet po wycofaniu się funduszu private equity ze spółki. W interesie spółki będzie zatem dążenie do zaoferowania akcji nowej emisji, gdyż wpływy z ich sprzedaży zasilą jej kapitał.

\subsubsection{WYNIKI BADAŃ EMPIRYCZNYCH NAD STOPNIEM DEZINWESTYCJI FUNDUSZU PRIVATE EQUITY A EMISJĄ NOWYCH AKCJI PRZEZ SPÓŁKĘ PORTFELOWĄ}

Stopień dezinwestycji realizowany przez fundusze private equity w 26 spółkach objętych badaniami był znacznie zróżnicowany. W ramach publicznej oferty sprzedaży akcji związanej z debiutem spółki w przypadku 4 podmiotów fundusze zbyły wszystkie posiadane akcje i definitywnie zakończyły zaangażowanie kapitałowe $\mathrm{w}$ te podmioty, natomiast w 6 przypadkach fundusze podjęły decyzję o niesprzedawaniu akcji znajdujących się w ich portfelu inwestycyjnym.

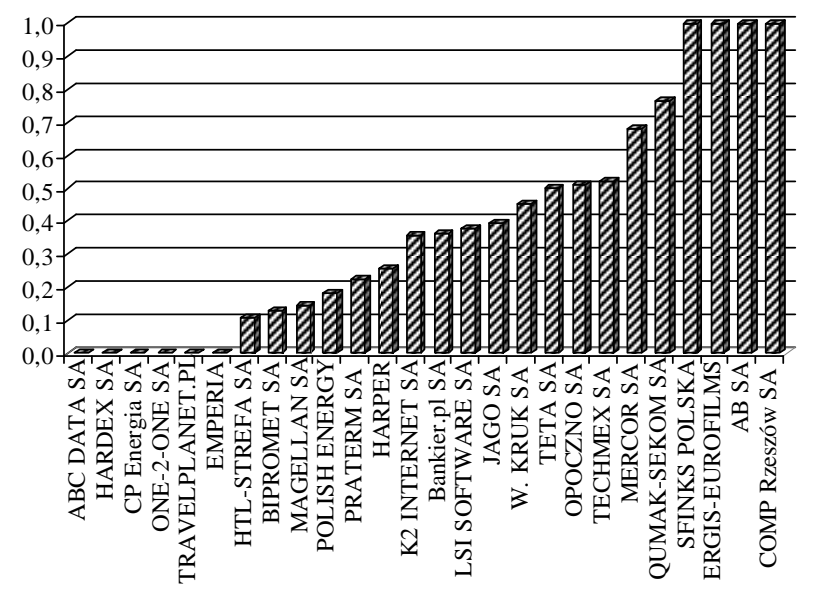

Wykres 3.7. Stopień dezinwestycji realizowanej przez fundusze private equity w drodze pierwszej oferty publicznej w poszczególnych spółkach

$$
\left(\frac{{ }_{S O L D} N S_{P E}}{{ }^{P R E-I P O} N S_{P E}}\right)
$$

Ź r ó d ł o: jak do wykresu 3.6. 
W większości analizowanych przedsiębiorstw wprowadzenie akcji spółki do publicznego obrotu związane było z rozpoczęciem procesu zbywania posiadanych w portfelu inwestycyjnym papierów wartościowych (zob. wykres 3.7).

Fundusze private equity w rezultacie realizowanych transakcji publicznej oferty sprzedaży zbywały średnio 38,36\% akcji spółek będących ich własnością, redukując $\mathrm{w}$ ten sposób znacznie swój udział w strukturze akcjonariatu tych podmiotów (zob. tab. 3.8).

Tabela 3.8

Stopień dezinwestycji realizowanej przez fundusze private equity $\mathrm{w}$ drodze pierwszej oferty publicznej - wybrane statystyki opisowe

\begin{tabular}{|l|c|}
\hline \multicolumn{1}{|c|}{ Wyszczególnienie } & Wartość \\
\hline \hline Średnia arytmetyczna & 0,3836 \\
\hline Mediana & 0,3606 \\
\hline Odchylenie standardowe & 0,3449 \\
\hline Minimum & 0,0000 \\
\hline Maksimum & 1,0000 \\
\hline Liczba spółek & 26 \\
\hline
\end{tabular}

Ź ródło: opracowanie własne na podstawie prospektów emisyjnych oraz raportów bieżących spółek.

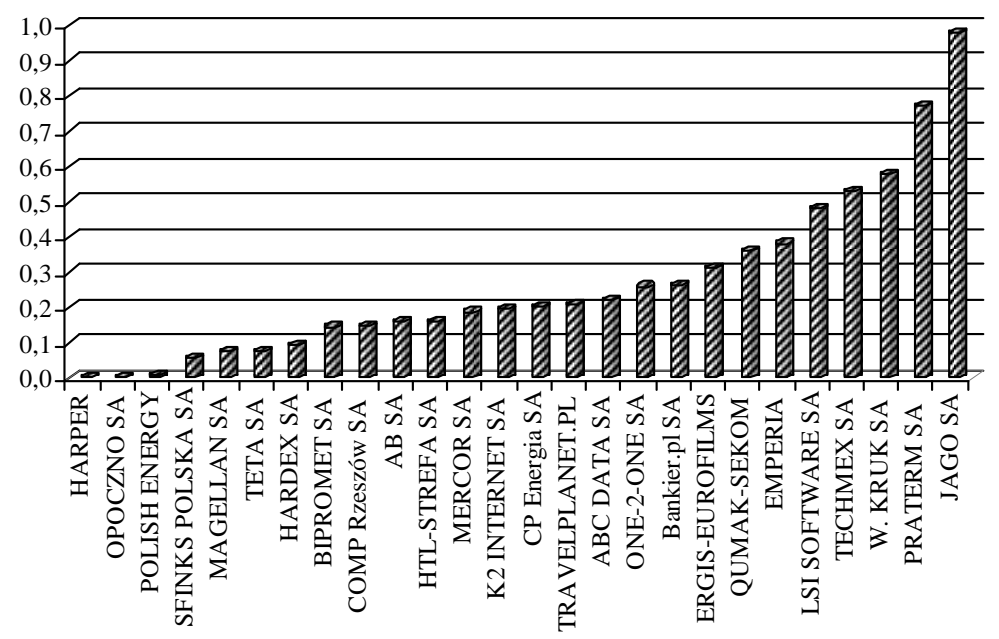

Wykres 3.8. Stosunek liczby akcji nowej emisji do liczby akcji istniejących przed pierwszą ofertą publiczną w poszczególnych spółkach

$$
\left(\frac{N S_{N E W}}{{ }^{\text {PRE-PPO } T N S}}\right)
$$

Źr ó d ło: jak do wykresu 3.6. 
Debiuty giełdowe spółek portfelowych funduszy private equity związane są nie tylko z realizacją zamierzeń funduszu w zakresie wyjścia z inwestycji. Spółki portfelowe dążą do tego, by pozyskać nowy kapitał do spółki od inwestorów giełdowych. Dla rozpoznania stopnia wykorzystania tych możliwości w poszczególnych spółkach analizie poddany został wskaźnik przedstawiający jaką część kapitału zakładowego spółki przed jego powiększeniem stanowią akcje nowej emisji. Wartość tego wskaźnika w poszczególnych badanych podmiotach była niezwykle zróżnicowana. Spośród 26 analizowanych spółek, zaledwie w przypadku 2 podmiotów nie została podjęta decyzja o emisji nowych akcji. W obu przypadkach oferowane $w$ ramach publicznej oferty były wyłącznie akcje należące do funduszu private equity. Warto zauważyć, iż sytuacja taka miała miejsce między innymi w spółce Harper Hygienics $S A$, w której fundusze zarządzane przez Enterprise Investors były jedynym akcjonariuszem spółki (zob. wykres 3.8).

Analizując stopień zwiększenia liczby akcji badanych spółek na skutek emisji nowych akcji wskazać należy, iż nowe akcje oferowane do sprzedaży w związku z debiutem giełdowym stanowiły średnio $26,36 \%$ akcji już istniejących (zob. tab. 3.9).

Tabela 3.9

Stosunek liczby akcji nowej emisji do liczby akcji istniejących przed pierwszą ofertą publiczną - statystyki opisowe

\begin{tabular}{|l|c|}
\hline \multicolumn{1}{|c|}{ Wyszczególnienie } & Wartość \\
\hline \hline Średnia arytmetyczna & 0,2636 \\
\hline Odchylenie standardowe & 0,2393 \\
\hline Mediana & 0,1984 \\
\hline Zakres & 0,9817 \\
\hline Minimum & 0 \\
\hline Maksimum & 0,9817 \\
\hline Liczba spółek & 26 \\
\hline
\end{tabular}

Ź ró d ło: jak do tab. 3.8.

Wartość mediany badanej zmiennej była niższa od średniej arytmetycznej i kształtowała się na poziomie $19,84 \%$. Najwyższą wartość analizowanego wskaźnika $(98,17 \%)$ zanotowano w przypadku spółki Jago SA, gdzie w związku z pierwszą publiczną ofertą sprzedaży akcji oferowanych było 7500000 szt. nowych walorów, przy kapitale zakładowym dzielącym się na 7640100 szt. akcji przed upublicznieniem spółki.

Na podstawie analizy danych dotyczących struktury akcji oferowanych do sprzedaży w ramach pierwszych ofert publicznych spółek portfelowych funduszy private equity można wskazać, iż przeważającą część stanowiły akcje nowej emisji, a prawie $40 \%$ wszystkich oferowanych akcji stanowiły walory wchodzące w skład portfela inwestycyjnego funduszy private equity (zob. wykres 3.9). 


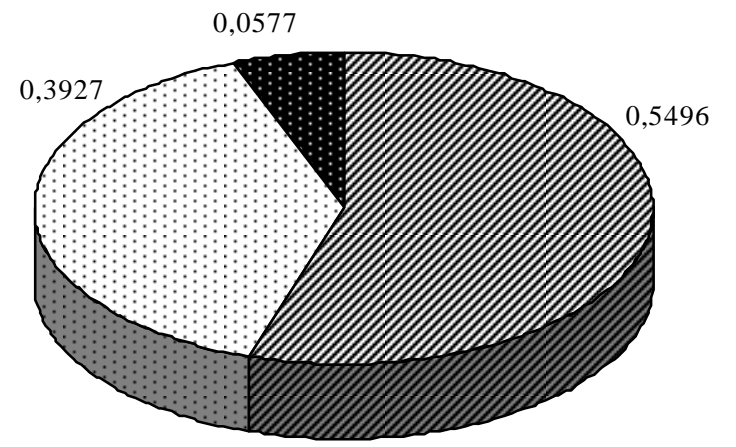

$\square$ akcje nowej emisji

$\square$ akcje sprzedawane przez fundusz private equity

akcje sprzedawane przez

pozostałych akcjonariuszy

Wykres 3.9. Struktura pierwszych ofert publicznych spółek portfelowych według źródła pochodzenia sprzedawanych akcji

Ź r ó d ło: jak do wykresu 3.6.

W poszczególnych spółkach struktura ofert ze względu na źródło pochodzenia sprzedawanych akcji była wyraźnie zróżnicowana (zob. wykres 3.10).

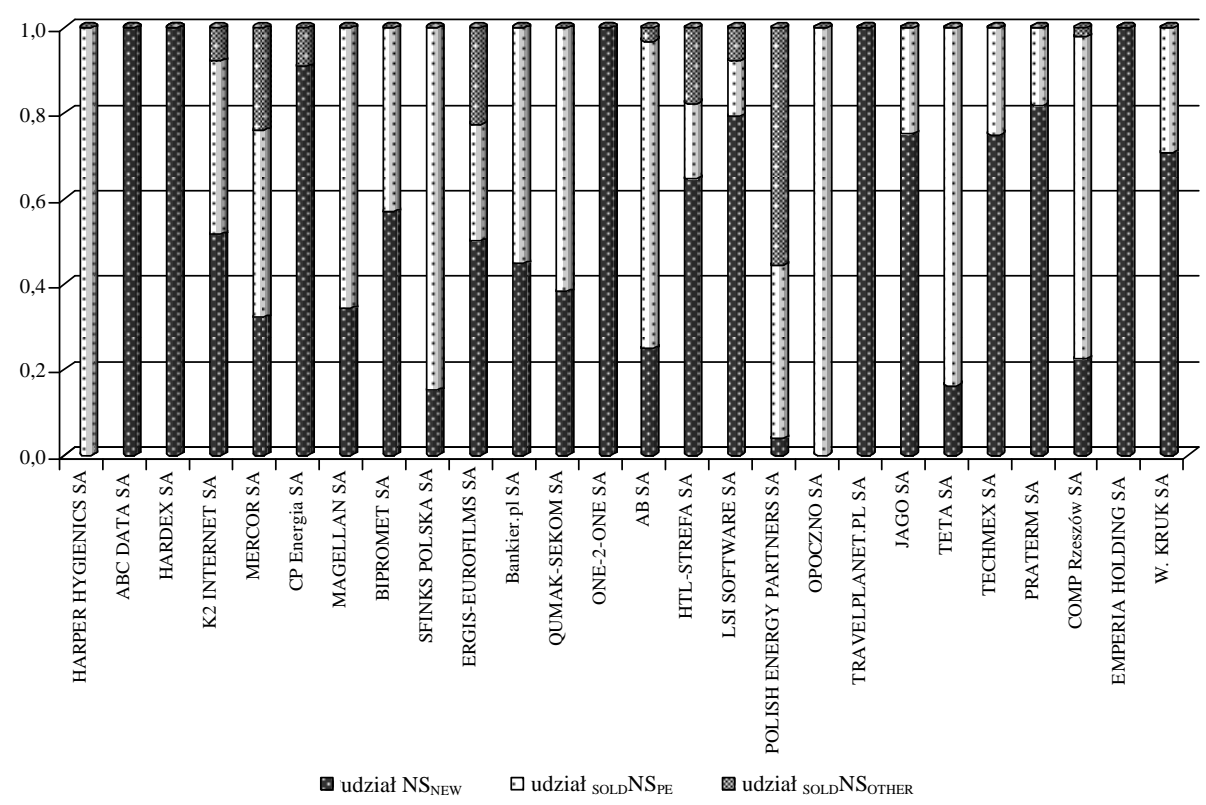

Wykres 3.10. Struktura oferty w poszczególnych spółkach

Ź r ó d ło: jak do wykresu 3.6. 
Struktura pierwszej oferty publicznej spółek portfelowych według źródła pochodzenia sprzedawanych akcji - statystyki opisowe

\begin{tabular}{|l|c|c|c|}
\hline \multicolumn{1}{|c|}{ Wyszczególnienie } & $\mathrm{NS}_{\mathrm{NEW}}$ & SOLD $_{\mathrm{NS}}$ & SOLD $_{\mathrm{PE}}$ \\
\hline \hline Średnia arytmetyczna & 0,5496 & 0,3927 & 0,0577 \\
\hline Odchylenie standardowe & 0,3404 & 0,3275 & 0,1239 \\
\hline Kwartyl pierwszy & 0,2668 & 0,1391 & 0,0000 \\
\hline Mediana & 0,5423 & 0,3482 & 0,0000 \\
\hline Kwartyl trzeci & 0,8120 & 0,6462 & 0,0670 \\
\hline Minimum & 0,0000 & 0,0000 & 0,0000 \\
\hline Maksimum & 1,0000 & 1,0000 & 0,5555 \\
\hline Liczba spółek & 26 & 26 & 26 \\
\hline
\end{tabular}

Źr ó d ło: jak do tab. 2.8 .

Analiza przedstawionych $\mathrm{w}$ tab. 3.10 miar położenia rozkładu również wskazuje, iż przeważającym źródłem akcji oferowanych w ramach pierwszych publicznych ofert sprzedaży spółek portfelowych funduszy private equity była emisja nowych akcji.

\subsubsection{WYBRANE PRZYKLADY DEZINWESTYCJI FUNDUSZY PRIVATE EQUITY REALIZOWANYCH ZA POŚREDNICTWEM WARSZAWSKIEJ GIEŁDY}

Analiza przykładów dezinwestycji funduszy private equity zrealizowanych za pośrednictwem GPW w Warszawie zawiera wyniki badań empirycznych zmierzających do scharakteryzowania procesu wyjścia z inwestycji w 4 wybranych podmiotach. Do spółek tych należą:

- Travelplanet.pl SA,

- Opoczno SA,

- Grupa Kapitałowa W. KRUK oraz

- K2 Internet SA.

O wyborze tych spółek do dalszych badań zadecydowała głównie specyfika realizowanych transakcji oraz zakres dostępnych informacji. Akcjonariuszem w badanych spółkach były różne fundusze private equity o zróżnicowanej przedmiotowo działalności i historii rozwoju.

Dla realizacji założonego celu badania każda prezentowana spółka została poddana analizie w następujących etapach: 
1) charakterystyka spółki, która zawiera podstawowe informacje o badanym przedsiębiorstwie tj.: rodzaj prowadzonej działalności, oferowane produkty i usługi, pozycja rynkowa,

2) historia rozwoju analizowanej spółki, ze szczególnym uwzględnieniem roli funduszy private equity - w tym punkcie przedstawiono informacje dotyczące m. in. daty powstania podmiotu, charakteru współpracy $\mathrm{z}$ funduszem private equity, udziału funduszu w kapitale zakładowym spółki,

3) warunki pierwszej oferty sprzedaży akcji spółki, zawierające podstawowe parametry opisujące wielkość i strukturę oferowanych akcji wraz z wyszczególnieniem podmiotu oferującego akcje do sprzedaży,

4) korzyści finansowe oferty dla funduszu i spółki, mierzone wartością kapitału pozyskanego przez spółkę i innych sprzedających akcje w ramach oferty,

5) dalsze procesy redukcji udziału funduszu private equity w spółce portfelowej, w których przedstawiono transakcje na akcjach, dzięki którym funduszy private equity dopełniły wyjście z inwestycji,

6) efektywność zrealizowanej inwestycji.

Informacje wykorzystane w badaniach pochodzą z prospektów emisyjnych, raportów bieżących i okresowych badanych spółek, stron internetowych badanych podmiotów, publikacji z prasy fachowej oraz innych ogólnodostępnych źródeł.

W trakcie badań empirycznych natrafiono na liczne ograniczenia badawcze. Należą do nich przede wszystkim:

- dokładne ustalenie terminu całkowitego wyjścia z inwestycji było utrudnione bądź niemożliwe ze względu na

- mało transparentne powiązania pomiędzy wybranymi akcjonariuszami badanych spółek,

- zakres obowiązków informacyjnych akcjonariuszy wynikający z przepisów prawa dotyczący obligatoryjnego ujawnienia stanu posiadania ${ }^{82}$,

- informacje dotyczące poziomu zysku kapitałowego osiągniętego przez fundusz w wyniku danej inwestycji oraz jej efektywności są w większości przypadków objęte tajemnicą, a strony transakcji zobowiązane są do nieupubliczniania jakichkolwiek informacji na ten temat,

- dotychczas nie została stworzona baza danych zawierająca kompleksowe informacje o zrealizowanych transakcjach na rynku private equity w Polsce.

${ }^{82}$ Zob. art. 69 oraz art. 69a Ustawy z dnia 29 lipca 2005 r..., op. cit. 


\subsubsection{Redukcja zaangażowania kapitałowego funduszu private equity w spótkę Travelplanet.pl SA}

\section{Charakterystyka spółki}

Travelplanet.pl SA jest przedsiębiorstwem z obszaru e-commerce oferującą sprzedaż szeroko pojętych usług turystycznych przez Internet i inne nowoczesne kanały dystrybucji. Działalność spółki polega na agencyjnej sprzedaży imprez turystycznych, biletów lotniczych, rezerwacji hoteli i sprzedaży usług marketingowych za pośrednictwem dwóch głównych kanałów dystrybucji: portali internetowych oraz call center. Podstawową działalnością spółki jest sprzedaż produktów i usług jego partnerów handlowych w zakresie turystyki, szczególnie turystyki zagranicznej. Swoją ofertę spółka uzupełnia o możliwość zakupu turystycznych bonów płatniczych oraz usługi reklamy internetowej. Oferowane przez Emitenta produkty i usługi podzielić można na pięć grup (zob. tab. 3.11)

Oferta rynkowa spółki Travelplanet.pl SA w 2005 r.

\begin{tabular}{|l|l|c|}
\hline \multicolumn{1}{|c|}{$\begin{array}{c}\text { Rodzaj } \\
\text { produktu }\end{array}$} & \multicolumn{1}{|c|}{ Charakterystyka } & $\begin{array}{c}\text { Szacowany } \\
\text { udział } \\
\text { w rynku } \\
\text { w 2004 r. }\end{array}$ \\
\hline $\begin{array}{l}\text { Pakiety } \\
\text { turystyczne }\end{array}$ & $\begin{array}{l}\text { Spółka posiada w ofercie pakiety turystyczne obejmujące m. in. wy- } \\
\text { cieczki lotnicze i wycieczki autokarowe. W ofercie skierowanej do } \\
\text { klientów instytucjonalnych znajdują się zindywidualizowane wyjazdy } \\
\text { grupowe. Przychody ze sprzedaży pakietów turystycznych spółka } \\
\text { uzyskuje z prowizji, która jest negocjowana indywidualnie z każdym } \\
\text { z touroperatorów i wynosi 10-16\% wartości sprzedawanych produk- } \\
\text { tów. }\end{array}$ & $38 \%$ \\
\hline $\begin{array}{l}\text { Bilety } \\
\text { lotnicze }\end{array}$ & $\begin{array}{l}\text { Spółka oferuje bilety na ponad 2 mln połączeń lotniczych, do wszyst- } \\
\text { kich części świata. Sprzedaż biletów lotniczych jest prowadzona przez } \\
\text { Travelplanet.pl SA pod marką Aero.pl istniejącą na polskim rynku od } \\
\text { 1999 r. }\end{array}$ & $18 \%$ \\
\hline $\begin{array}{l}\text { Rezerwacje } \\
\text { hoteli }\end{array}$ & $\begin{array}{l}\text { Poprzez serwis Hotele24.pl spółka umożliwia wyszukanie, rezerwację } \\
\text { on-line, dokonanie płatności oraz uzyskanie potwierdzenia rezerwacji } \\
\text { miejsc w hotelach. }\end{array}$ & $\begin{array}{c}\text { Początek } \\
\text { działalno- } \\
\text { ści 2005 r. }\end{array}$ \\
\hline Reklama & $\begin{array}{l}\text { Spółka w swojej ofercie posiada także usługi reklamowe, które można } \\
\text { podzielić na: reklamę internetową, product placement oraz pozostałe } \\
\text { usługi marketingowo-reklamowe. }\end{array}$ & $1,4 \%$ \\
\hline $\begin{array}{l}\text { Turystycz- } \\
\text { ne bony } \\
\text { płatnicze }\end{array}$ & $\begin{array}{l}\text { Bony turystyczne TravelPass to produkt dedykowany dla klientów } \\
\text { korporacyjnych. Dystrybuowane przez TravelPass bony umożliwiają } \\
\text { zakup wycieczek znajdujących się w ofercie Travelplanet.pl SA. }\end{array}$ & $\begin{array}{c}\text { Brak podmio- } \\
\text { tów z ofertą } \\
\text { konkuren- } \\
\text { cyjną }\end{array}$ \\
\hline
\end{tabular}

Ź r ó d ł o: opracowanie własne na podstawie prospektu emisyjnego Travelplanet.pl SA. 
Historia rozwoju analizowanej spółki, ze szczególnym uwzględnieniem roli funduszy private equity

Pierwszą czynnością zmierzającą do utworzenia analizowanej spółki było zawarcie umowy inwestycyjnej w dniu 6 grudnia 2000 r. pomiędzy MCI Management $S A$ z siedzibą we Wrocławiu, P. Multanem, T. Morozem i Ł. Bartoszewiczem, której przedmiotem była realizacja inwestycji polegającej na utworzeniu spółki akcyjnej pod firmą: Travelplanet.pl działającej w obszarze sprzedaży ofert turystycznych oraz dostarczania informacji turystycznych $\mathrm{z}$ wykorzystaniem Internetu. W dniu 15 grudnia 2000 r. spółka Travelplanet.pl została wpisana do KRS. W kapitale zakładowym spółki zostało utworzonych 50000 zwykłych, imiennych Akcji serii A o wartości nominalnej i emisyjnej 10,00 zł.

Wszystkie akcje pokryte zostały wkładami gotówkowymi i objęte przez założycieli spółki w następujący sposób:

- MCI Management SA objęła 45500 akcji o łącznej wartości 455000 zł,

- Piotr Multan objął 1500 akcji o łącznej wartości 15000 zł,

- Tomasz Moroz objął 1500 akcji o łącznej wartości 15000 zł,

- Łukasz Bartoszewicz objął 1500 akcji o łącznej wartości 15000 zł.

W dniu 24 października 2001 r. Spółka została zgłoszona do Krajowego Rejestru Sądowego, gdzie w rejestrze przedsiębiorców nadano jej numer KRS 0000055057.

W dniu 10 maja 2002 r. WZA Travelplanet.pl SA zdecydowało o podwyższeniu kapitału zakładowego spółki do kwoty 1718100 zł poprzez emisje 121810 akcji zwykłych imiennych serii B o wartości nominalnej 10 zł i wartości emisyjnej 20 zł. Powyższe akcje zostały w całości pokryte wkładami pieniężnymi i zostały objęte przez dotychczasowych akcjonariuszy w następujących częściach:

- 116810 akcji objęte zostało przez MCI Management SA,

- 3750 akcji objął P. Multan,

- 1750 akcji objętych zostało przez T. Moroza.

Podwyższenie kapitału zakładowego zarejestrowane zostało w dniu 25 września 2002 r.

Ponadto w 2004 r. spółka wyemitowała nowe akcje w ramach realizacji programu opcji menedżerskiej, w wyniku czego nastąpiło podwyższenie jej kapitału zakładowego o kwotę 57270 zł, tj. do kwoty 1775370 zł w drodze emisji 5727 zwykłych imiennych akcji serii $\mathrm{C}$ o wartości nominalnej i wartości emisyjnej 10 zł za każdą akcję.

Na dzień sporządzenia prospektu emisyjnego kapitał zakładowy spółki wynosił 1775370 zł i dzielił się na:

- 500000 akcji na okaziciela serii A, o wartości nominalnej 1 zł każda,

- 1218100 akcji na okaziciela serii B, o wartości nominalnej1 zł każda,

- 57270 akcji na okaziciela serii C, o wartości nominalnej 1 zł każda. 
Powyższa liczba istniejących akcji wynikała ze zmian dokonanych w dniu 11 lutego 2005 r., kiedy to NWZ spółki podjęło decyzję w sprawie podziału istniejących w ten sposób, że każda akcja o wartości nominalnej 10 zł została podzielona na 10 akcji po $1 \mathrm{zl}$.

$\mathrm{Na}$ dzień sporządzenia prospektu emisyjnego związanego z pierwszą publiczną ofertą akcji i debiutem giełdowym podmiotem dominującym wobec spółki był MCI Management SA (zob. wykres 3.11).

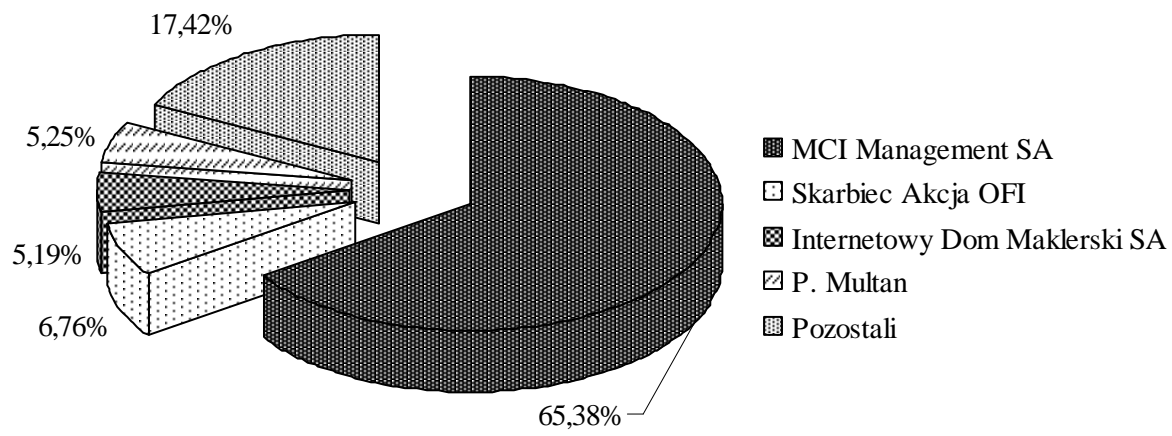

Wykres 3.11. Struktura akcjonariatu Travelplanet.pl SA

Ź r ó d ł o: opracowanie własne na podstawie prospektu emisyjnego Travelplanet.pl SA.

Warunki pierwszej oferty sprzedaży akcji spółki

Debiut giełdowy spółki Travelplanet.pl SA związany był z wprowadzeniem do publicznego obrotu:

- 500000 akcji zwykłych na okaziciela serii A,

- 1218100 akcji zwykłych na okaziciela serii B,

- 57270 akcji zwykłych na okaziciela serii C,

- od 154320 do 370370 akcji zwykłych na okaziciela serii D.

Na podstawie prospektu oferowane było wyłącznie 370370 akcji o wartości nominalnej 1,00 zł każda w trybie publicznej subskrypcji. Ofertą objęte były wyłącznie nowo emitowane akcje serii D.

W pierwszym etapie przedział cenowy emisji akcji serii D oferowanych w publicznej ofercie został ustalony na poziomie 16,20-18 zł za jedną akcję. W dniu 23 czerwca 2005 r. w wyniku przeprowadzonego procesu budowy księgi popytu ostatecznie ustalono cenę emisyjną akcji na poziomie $18 \mathrm{zł}$.

Korzyści finansowe oferty dla funduszu i spółki

Publiczna oferta sprzedaży akcji spółki Travelplanet.pl SA została uznana za udaną. W jej wyniku w dniu 4 lipca 2005 r. dokonano przydziału wszystkich 
oferowanych w ramach publicznej oferty akcji serii D. Zgłoszony popyt znacznie przewyższał liczbę oferowanych papierów wartościowych. W trakcie trwania subskrypcji inwestorzy indywidualni i instytucjonalni złożyli zapisy na 1008670 szt. akcji. W procesie budowy księgi popytu złożono zapisy na 821729 szt. akcji. Redukcja zleceń złożonych przez inwestorów, którzy nie złożyli zapisów w trakcie budowania księgi popytu wyniosła 79,65\%. Redukcja zleceń inwestorów, którzy wzięli udział w budowaniu księgi popytu wyniosła 59,3\%, ze względu na dwukrotnie większą alokację zapisów na akcje dla tych inwestorów.

Pierwsze notowanie akcji spółki na GPW w Warszawie odbyło się 12 lipca 2005 r. Równocześnie z papierami Travelplanet.pl SA na giełdzie pojawiły się prawa do akcji serii D. Na otwarciu sesji kosztowały $21,1 \mathrm{zł}$. W trakcie pierwszego dnia notowań PDA cieszyły się zainteresowaniem. Właściciela zmieniło 37000 praw, a obroty wyniosły 1,5 mln zł. Wolumen obrotu na akcjach był mniejszy i wyniósł 7600 szt., a obroty sięgnęły 322000 zł. Na zamknięciu notowań akcje spółki kosztowały 20 zł, a PDA 19,65 zł.

Satysfakcji z przebiegu debiutu giełdowego nie krył również prezes Travelplanet.pl SA. Na konferencji prasowej stwierdził: Jesteśmy bardzo zadowoleni $z$ wyceny, tym bardziej że Traveplanet.pl jest pierwsza giełdowa firma e-commerce nie tylko w Warszawie, ale catej Europie Środkowo-Wschodniej.

Wzrost kursu akcji był pozytywną informacją dla MCI Management SA. Fundusz już w czerwcu 2004 r. zrealizował częściowe wyjście z inwestycji, sprzedając 42953 akcji spółki portfelowej Travelplanet.pl SA stanowiących $25 \%$ jej kapitału zakładowego w wyniku serii tzw. transakcji pre-IPO. Za sprzedany pakiet akcji MCI Management SA otrzymała kwotę 5798655 zł przy wartości ewidencyjnej zbytych papierów wartościowych w kwocie 429953 zł. Wśród inwestorów, którzy nabyli akcje Travelplanet.pl SA znajdowały się dwie instytucje finansowe, dwie osoby prawne i dziesięciu inwestorów indywidualnych. MCI Management S.A. zrealizowała bezpośrednio na tej transakcji blisko $1350 \%$ stopy zwrotu z inwestycji. Fundusz objął sprzedane akcje Travelplanet.pl $S A$ w 2000 r. po 10 zł za sztukę, zaś cena z transakcji sprzedaży wyniosła 135 zł za jedną akcję. Sprzedaż pre-IPO Travelplanet.pl SA była pierwszą na rynku tego typu transakcją kapitałową dotyczącą spółki e-commerce.

MCI Management SA, który nie zbywał swoich akcji w ramach oferty, deklarował gotowość sprzedaży części posiadanych w portfelu inwestycyjnym akcji po debiucie giełdowym spółki. T. Czechowicz, Prezes MCI Management SA stwierdził: Podtrzymujemy nasze zapowiedzi o chęci sprzedaży do końca tego roku czesści akcji Travelplanet.pl. - zaznaczając jednocześnie, iż spółka doskonale się rozwija i nie ma żadnej presji na pozbywanie się akcji.

Dalsze procesy redukcji udziału funduszu private equity w spółce portfelowej Zob. tab. 3.12. 


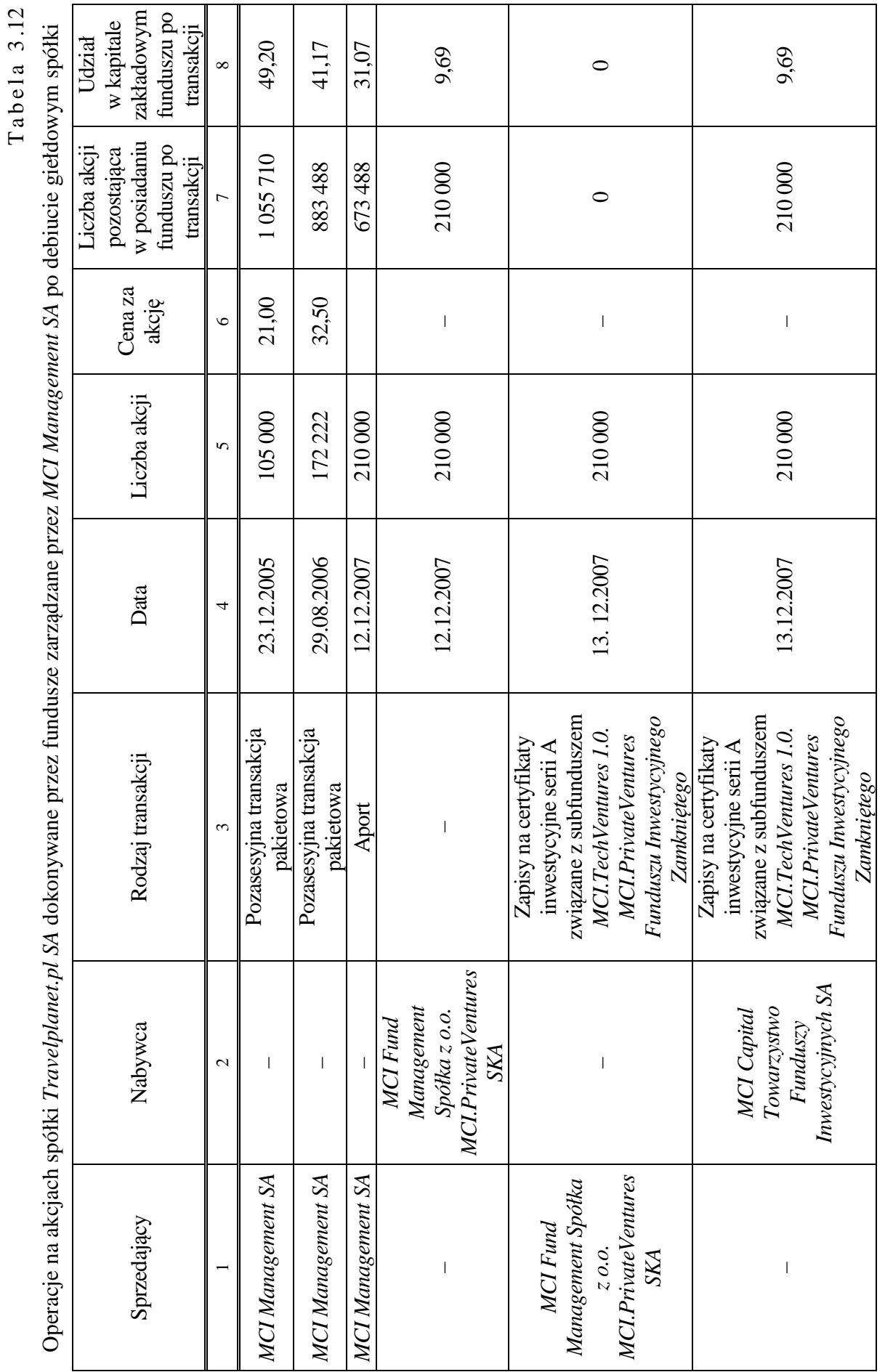




\begin{tabular}{|c|c|c|c|c|c|c|}
\hline$\infty$ & 0 & o. & $\sigma_{2}$ & $\begin{array}{l}n \\
\overrightarrow{\vec{\lambda}}\end{array}$ & 0 & $\begin{array}{l}\bar{\sigma} \\
\stackrel{2}{0}\end{array}$ \\
\hline$r$ & 0 & $\begin{array}{l}8 \\
\stackrel{8}{\circ} \\
\stackrel{0}{N}\end{array}$ & $\begin{array}{l}8 \\
\dot{8} \\
\stackrel{n}{N}\end{array}$ & $\mid \begin{array}{l}\infty \\
\infty \\
o \\
\infty \\
\infty \\
q \\
q\end{array}$ & 0 & $\begin{array}{l}8 \\
8 \\
\dddot{y} \\
\gamma\end{array}$ \\
\hline 0 & 1 & 1 & $\begin{array}{l}\text { ळे } \\
\text { ळे }\end{array}$ & $\begin{array}{l}\partial \\
\dot{m}\end{array}$ & 1 & 1 \\
\hline in & $\begin{array}{l}\stackrel{8}{\circ} \\
\stackrel{\circ}{\sim}\end{array}$ & $\begin{array}{l}\stackrel{8}{8} \\
\stackrel{0}{\sim}\end{array}$ & $\begin{array}{l}8 \\
\frac{8}{n} \\
\frac{n}{N}\end{array}$ & $\mid \begin{array}{l}8 \\
8 \\
i \\
\\
\end{array}$ & $\begin{array}{l}8 \\
8 \\
\frac{n}{2}\end{array}$ & $\begin{array}{l}8 \\
\frac{8}{n} \\
\frac{n}{2}\end{array}$ \\
\hline + & 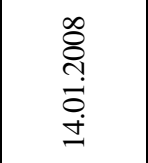 & 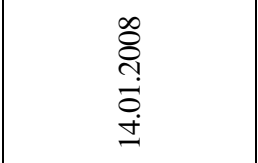 & 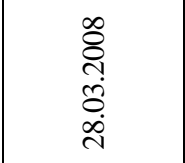 & 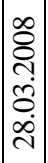 & $\begin{array}{l}\infty \\
\stackrel{ి}{1} \\
\stackrel{\text { }}{0} \\
\infty \\
\infty\end{array}$ & 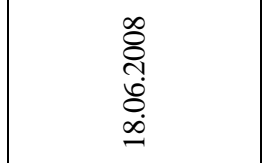 \\
\hline$m$ & 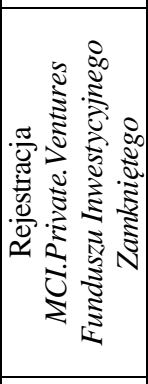 & 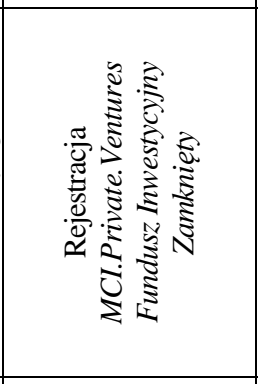 & 䓂 & $\mid \begin{array}{l}\mid \overrightarrow{0} \\
\text { 安 }\end{array}$ & 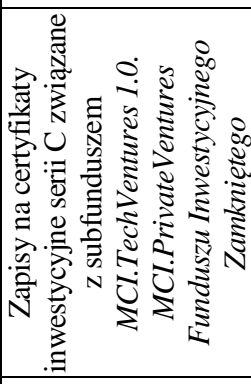 & 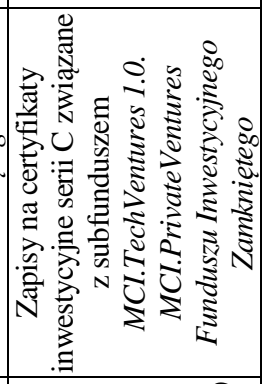 \\
\hline$\sim$ & 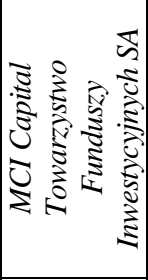 & 1 & 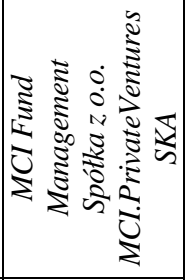 & & 1 & 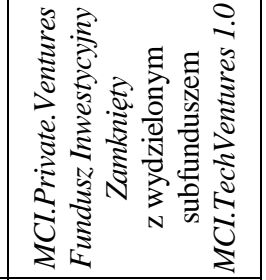 \\
\hline- & 1 & 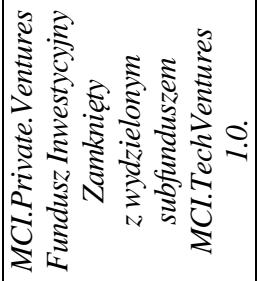 & & 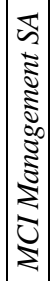 & 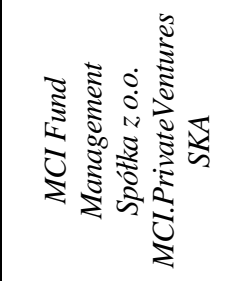 & 1 \\
\hline
\end{tabular}




\begin{tabular}{|c|c|c|c|c|c|c|c|}
\hline$\infty$ & $\stackrel{\tilde{n}}{=}$ & مू & 0 & $\begin{array}{l}\tilde{n} \\
\text { ते }\end{array}$ & $\overline{\mathfrak{r}}$ & $\alpha$ & 0 \\
\hline 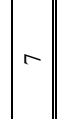 & $\mid$\begin{tabular}{|l}
$\infty$ \\
$\infty$ \\
$\infty$ \\
+ \\
\multirow{+}{\tau}{} \\
$\sim$
\end{tabular} & $\begin{array}{l}8 \\
\frac{8}{n} \\
\frac{n}{1}\end{array}$ & 0 & $\begin{array}{l}8 \\
8 \\
\text { q }\end{array}$ & 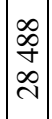 & $\begin{array}{l}8 \\
\text { in } \\
\text { in }\end{array}$ & 0 \\
\hline 0 & 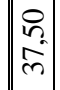 & $\begin{array}{l}\stackrel{n}{n} \\
\stackrel{n}{n}\end{array}$ & $\begin{array}{l}n \\
\text { nn } \\
\text { m. }\end{array}$ & $\begin{array}{l}n \\
\text { nn } \\
\text { m. }\end{array}$ & $\begin{array}{c}8 \\
\text { m. } \\
\text { | }\end{array}$ & $\begin{array}{l}8 \\
\text { m }\end{array}$ & 1 \\
\hline in & $\mid \begin{array}{l}8 \\
\vdots \\
i n \\
\sim\end{array}$ & $\begin{array}{l}8 \\
\frac{8}{2} \\
i\end{array}$ & $\begin{array}{l}8 \\
\frac{1}{2} \\
i\end{array}$ & $\begin{array}{l}8 \\
\vdots \\
\frac{n}{2}\end{array}$ & $\begin{array}{c}8 \\
8 \\
\cdots \\
\sim\end{array}$ & $\begin{array}{l}8 \\
\frac{8}{2} \\
\frac{n}{2}\end{array}$ & $\begin{array}{l}8 \\
\frac{n}{2} \\
\frac{n}{2}\end{array}$ \\
\hline$\nabla$ & 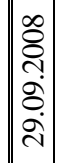 & $\begin{array}{l}\text { oे } \\
\stackrel{0}{0} \\
\stackrel{0}{0} \\
\text {. }\end{array}$ & $\begin{array}{l}\infty \\
\stackrel{\leftrightarrow}{1} \\
\stackrel{0}{0} \\
\dot{0}\end{array}$ & $\begin{array}{l}\infty \\
\stackrel{\leftrightarrow}{0} \\
\dot{ก} \\
\dot{0} \\
\dot{\infty}\end{array}$ & 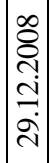 & 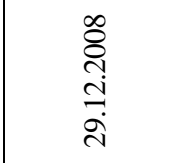 & 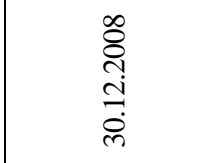 \\
\hline$m$ & $\mid$\begin{tabular}{|l|l}
$\mid \overrightarrow{0}$ \\
$\frac{0}{<}$ \\
$\mid$
\end{tabular} & 总 & 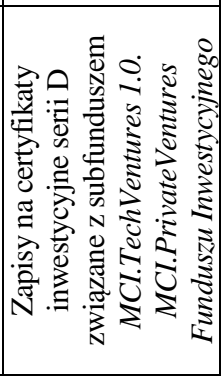 & 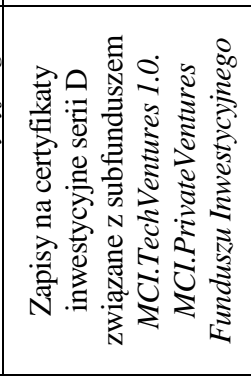 & $\left|\begin{array}{l}\mid \\
0 \\
0 \\
0\end{array}\right|$ & $\begin{array}{l}\text { 营 } \\
\text {. }\end{array}$ & 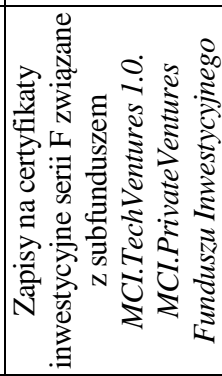 \\
\hline$\sim \mid$ & & 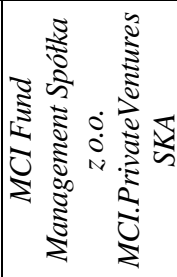 & 1 & 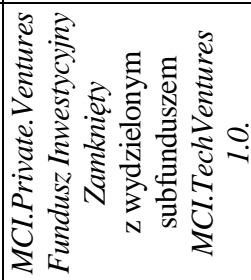 & & 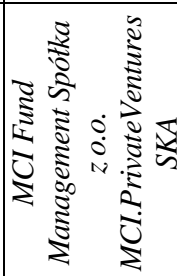 & 1 \\
\hline- & 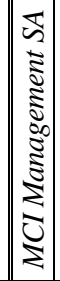 & 1 & 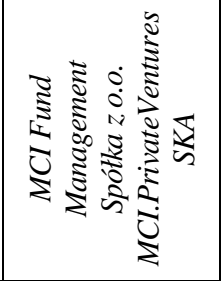 & 1 & 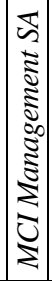 & 1 & 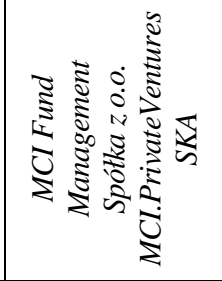 \\
\hline
\end{tabular}




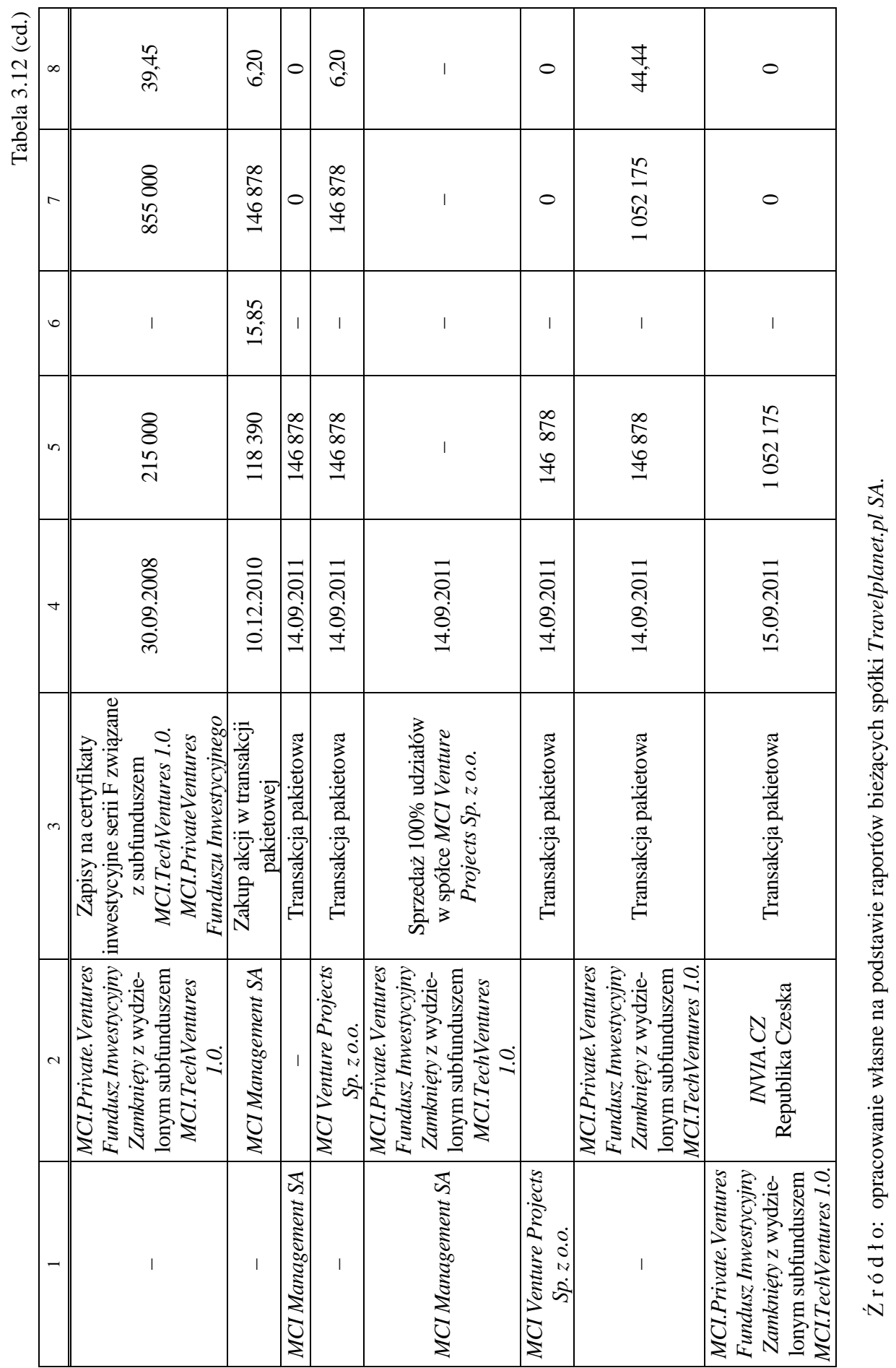


Efektywność zrealizowanej inwestycji

Fundusze private equity zarządzane przez MCI Management SA zakończyły swoje bezpośrednie zaangażowanie w spółkę Travelplanet.pl SA 15 września 2011 r. Całkowity okres trwania inwestycji wynosił prawie 11 lat. W wyniku zrealizowanych transakcji pakietowych fundusz sprzedał cały posiadany akcji Travelplanet.pl SA. Wartość transakcji wyniosła blisko $13 \mathrm{mln}$ zł i była zbliżona do wyceny rynkowej. Nabywcą akcji spółki była Invia.cz., która jest liderem czeskiego rynku e-travel. Transakcja została rozliczona gotówkowo.

Transakcję można byłoby uznać za bezdyskusyjny sukces, gdyby nie fakt, iż głównym właścicielem posiadającym pakiet kontrolny spółki Invia.cz. jest MCI Management SA. Czeska spółka środki na zrealizowanie tej transakcji pozyskała z pożyczki udzielonej jej właśnie przez MCI Management SA.

S. Janik, partner MCI Management SA stwierdził, iż oczekuje szybkiej spłaty należności i wyjaśnił: Udzieliliśmy jako fundusz pożyczki pomostowej Invii.cz, która zostanie spłacona ze środków wtasnych spótki oraz poprzez finansowanie dtużne pozyskane $w$ celu refinansowania transakcji.

Rynkowe komentarze wygłaszane na temat tej transakcji nie były jednak zbyt pochlebne. Nie brakowało opinii, iż fundusz private equity dokonał zamiany w ten sposób posiadanych akcji Travelplanet.pl SA, które biorąc pod uwagę ówczesne uwarunkowania rynkowe ciężko by było w ogóle sprzedać, na dużą pożyczkę na rzecz Invia.cz. W okresie poprzedzającym transakcję kurs spółki Travelplanet.pl $S A$ był w wyraźnym trendzie spadkowym i negatywnie wpływał na raportowane wyniki funduszu. Jednakże mając na uwadze wysokość przyjętego przez Invia.cz zobowiązania względem MCI Management SA oraz osiągany przez nią stosunkowo niewielki zysk można stwierdzić, iż będzie to znaczące obciążenie dla spółki.

Fundusze zarządzane przez MCI Management SA nie podały do publicznej wiadomości dokładnych charakterystyk opisujących poziom efektywności inwestycji w spółkę Travelplanet.pl SA.

\subsubsection{Redukcja zaangażowania kapitałowego funduszu private equity w spółkę Opoczno $S A$}

\section{Charakterystyka spółki}

W okresie poprzedzającym debiut giełdowy Opoczno $S A$ było głównym producentem płytek ceramicznych w Polsce. Oferta spółki zawierała wówczas blisko 100 kolekcji oraz ponad 1000 wzorów płytek do wnętrz mieszkalnych oraz obiektów komercyjnych. Spółka oferowała płytki we wszystkich głównych segmentach rynkowych obejmujących:

- gresy,

- płytki ścienne, 
- płytki podłogowe,

- dekoracje ceramiczne.

Gamę oferowanych produktów uzupełniały płytki przemysłowe, kwasoodporne oraz przeciwpoślizgowe. Spółka posiadała trzy znane marki produktów, a mianowicie Opoczno, Primacer oraz GresTeQ.

Spółka oferowała swoje produkty poprzez dobrze rozwiniętą ogólnopolską sieć dystrybucji, na którą składa się tradycyjny kanał dystrybucji obejmujący około 120 hurtowni dostarczających produkty do około 2200 punktów sprzedaży oraz sześć sieci supermarketów budowlanych obejmujących około 150 placówek handlowych.

W 2004 r. spółka ta była największym dostawcą płytek ściennych i podłogowych w ujęciu ilościowym, dysponującym udziałami rynkowymi sięgającymi odpowiednio $29 \%$ i $32 \%$ w każdym z tych segmentów rynku. Jednocześnie spółka była drugim co do wielkości producentem w segmencie płytek gresowych, z udziałem w tym rynku równym około $20 \%$. Opoczno było najbardziej rozpoznawalną marką płytek ceramicznych w Polsce, z 62\% spontaniczną rozpoznawalnością pośród krajowych klientów, podczas gdy drugi w tym rankingu producent płytek ceramicznych odnotował 5\% rozpoznawalność (według badań rynku przeprowadzonych przez SMG KRC na zlecenie spółki w sierpniu 2004 r.).

Historia rozwoju analizowanej spółki, ze szczególnym uwzględnieniem roli funduszy private equity

Historia przedsiębiorstwa sięga końca XIX w. Przedsiębiorstwo produkujące płytki kamionkowe do wykładania podłóg „Firma Dziewulski i Bracia Lange" zostało utworzone w 1883 r. jako trzyosobowa spółka działająca w Opocznie. W 1913 r. w celu podwyższenia kapitału „Firma Dziewulski i Bracia Lange" przekształciła się w spółkę akcyjną pod firmą Towarzystwo Akcyjne Zakładów Ceramicznych „Dziewulski i Lange”. Od 1931 do 1945 roku spółka funkcjonowała pod firmą „Towarzystwo Zakładów Ceramicznych Dziewulski i Lange” Spółka Akcyjna. Bezpośrednio w okresie powojennym przedsiębiorstwo to zostało podporządkowane tymczasowemu zarządowi państwowemu, a w $1949 \mathrm{r}$. zostało przejęte na własność państwa.

Po nacjonalizacji aż do 1998 r. Opoczno było przedsiębiorstwem państwowym i jedynym znaczącym producentem płytek ceramicznych w Polsce. Proces prywatyzacji przedsiębiorstwa rozpoczął się w 2000 r., nabyciem przez Credit Suisse First Boston Ceramic Partners (Poland) S.a.r.l. pakietu 50,2\% akcji poprzez zakup akcji od Skarbu Państwa oraz objęcie akcji w podwyższonym kapitale zakładowym spółki. Credit Suisse First Boston Ceramic Partners (Poland) S.a.r.l stanowi własność funduszy zarządzanych przez CSFB Private equity (będącego globalnym funduszem typu private equity należącym do grupy Credit Suisse) oraz Enterprise Investors. Po przejęciu większościowego pakietu akcji nowi właściciele, wspólnie z Zarządem przystąpili do restrukturyzacji, mającej 
na celu poprawę efektywności działania i pozycji konkurencyjnej spółki, w tym poprzez modernizację i rozbudowę infrastruktury produkcyjnej.

Credit Suisse First Boston Ceramic Partners (Poland) S.a.r.l. zwiększał swoje zaangażowanie kapitałowe w spółkę poprzez realizację następujących transakcji zakupu:

- 3510000 akcji serii A o wartości nominalnej 10 zł każda na podstawie umowy sprzedaży akcji z dnia 7 czerwca 2000 r. zawartej ze Skarbem Państwa po cenie 6,5194 USD za jedną akcję,

- 4750000 akcji serii B objętych w wyniku podwyższenia kapitału akcyjnego (zakładowego) na podstawie uchwały Walnego Zgromadzenia z dnia 15 września 2000 r. po cenie emisyjnej równej sumie 7,5 zł oraz równowartości w złotych kwoty 3,0881 USD według średniego kursu ogłoszonego przez NBP i obowiązującego w dniu podjęcia uchwały, co zgodnie z przyjętym kursem NBP stanowiło kwotę 21,37 zł.

- 1572880 akcji serii A nabytych od pracowników spółki na podstawie umów sprzedaży akcji po cenie 12 zł za jedną akcję.

- 6442591 akcji serii A na podstawie umowy sprzedaży akcji z dnia 7 maja 2004 r. zawartej ze Skarbem Państwa po cenie 26,3 zł za jedną akcję.

Ponadto, w dniu 24 listopada 2003 r. zbytych zostało 20000 akcji serii A.

Proces prywatyzacji zakończył się w 2004 r. W jego wyniku 98,8\% akcji znalazło się w posiadaniu Credit Suisse First Boston Ceramic Partners (Poland) S.a.r.l.

Warunki pierwszej oferty sprzedaży akcji spółki

Prospekt został przygotowany w związku z wprowadzeniem do publicznego obrotu:

- 11700000 akcji zwykłych na okaziciela serii A,

- 4750000 akcji zwykłych na okaziciela serii B,

- do 152000 akcji zwykłych na okaziciela serii C,

- do 152000 akcji zwykłych na okaziciela serii D.

Wartość nominalna wszystkich wprowadzanych do obrotu papierów wartościowych była równa i wynosiła $10 \mathrm{zł}$.

W ramach publicznej oferty sprzedaży akcji Credit Suisse First Boston Ceramic Partners (Poland) S.a.r.l. zamierzał zbyć wszystkie akcje posiadane w spółce Opoczno SA. Oferta publiczna obejmowała zatem:

- 11505471 Akcji Serii A oraz 4750000 Akcji Serii B oraz

- w ramach programu motywacyjnego 152000 akcji serii C właścicielom obligacji serii A i 152000 akcji serii D właścicielom obligacji serii B (oferta emitenta).

Oferta publiczna akcji spółki oferowanych przez Credit Suisse First Boston Ceramic Partners (Poland) S.a.r.l. w ramach prowadzonego procesu dezinwestycji została według informacji znajdujących się w pierwszej wersji prospektu 
emisyjnego podzielona na 3 transze przeznaczone odpowiednio dla krajowych inwestorów detalicznych (TKID), dużych inwestorów krajowych (TDIK) oraz instytucjonalnych inwestorów zagranicznych (TIIZ). Ponadto 6503000 akcji stanowiło dodatkową pulę akcji (zob. wykres 3.12).

Harmonogram przeprowadzenia oferty publicznej akcji spółki, przedstawiony w prospekcie emisyjnym zakładał, iż rozpocznie się ona 25 maja 2005 r., a przewidywany termin debiutu giełdowego to 16 czerwca 2005 r. Jednakże w noc poprzedzającą planowany termin rozpoczęcia oferty spółka opublikowała niespodziewaną informację o jej przesunięciu.

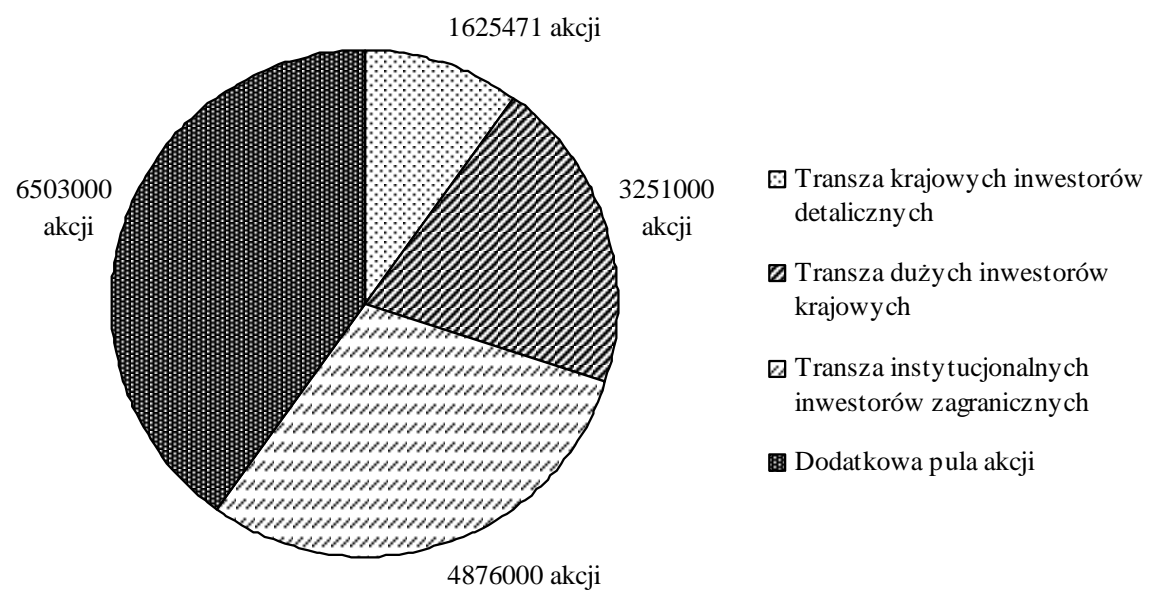

Wykres 3.12. Struktura pierwszej publicznej oferty sprzedaży akcji spółki Opoczno SA

Ź r ó d ł o: opracowanie własne na podstawie prospektu emisyjnego Opoczno SA.

R. Wojtkowski, reprezentujący w radzie nadzorczej Opoczno $S A$ fundusz Enterprise Investors, wskazując na przyczynę owej zmiany powiedział: Zdecydowaliśmy się przesunać termin $m$. in. dlatego, że chcemy przeanalizować, $w$ jakim okresie inwestorzy zdąża wycofać pieniądze z Lotosu i jaki wptyw może mieć emisja PGNiG. Również komentarze innych uczestników rynku wskazywały na obawy zbywających akcje na rynku pierwotnym związane z konkurencyjnymi ofertami publicznymi. M. Wujec, ówczesny wiceprezes Allianz PTE podkreślił, że: Spótka nie jest mała, jest istotnym graczem na rynku, sądzę, że $z$ pewnościa znajdzie się $w$ kręgu zainteresowania funduszy. Przesunięcie oferty spowodowane może być chęcia przeczekania ofert Lotosu i PGNiG.

Poza oficjalnie podawanymi przyczynami opóźnienia oferty na rynku nie brakowało komentarzy osób zwracających uwagę na inne możliwe przesłanki z tym związane. Przełożenie debiutu może być spowodowane obawa przed wydrenowaniem rynku przez oferty Lotosu i PGNiG. Ale myślę, że nie bez znaczenia jest także fakt, że obecnie warszawska giełda jest w koniunkturalnym dołku. 
I może się okazać, że przesunięcie oferty - mimo pewnych kosztów z tym zwiąanych - pozwoli na zebranie $i$ tak większych pieniędzy z tej emisji. Jest i trzecia możliwość, że spótka spodziewa się polepszenia wyników $w$ kolejnych miesiacach, co powinno pozwolić na uzyskanie lepszej ceny od inwestorów - stwierdził A. Adamiec, doradca inwestycyjny TUnŻ Nationwide.

Wielu ekspertów wskazywało również na czynniki związane ze zbyt wysokimi oczekiwaniami właścicieli spółki co do ceny zbywanych walory. A. Ruciński, dyrektor departamentu zarządzania funduszami TFI PZU stwierdził, że w tym przypadku problemem jest głównie cena. W zeszłym roku emisje sprzedawane byty z premiq i nie byto z nimi większego problemu. Teraz jednak sytuacja się zmienita, a inwestorzy oczekuja dyskonta. Poza tym Opoczno nie wypada najlepiej $w$ wycenach porównawczych $z$ notowanym już Cersanitem. Sadzę, że przesunięcie oferty to wtaśnie problem rozminięcia się oczekiwań inwestorów $i$ wtaścicieli. Takie duże oferty poprzedzone sa rozmowami z potencjalnymi inwestorami i pewnie wstępne cenowe oczekiwania byty różne.

Akcjonariusze Opoczno SA zdecydowali się nie zwlekać ze wznowieniem oferty i przedstawili wkrótce jej nowy harmonogram (zob. tab. 3.13).

Zaktualizowany harmonogram pierwszej oferty publicznej Opoczno SA

\begin{tabular}{|l|l|}
\hline \multicolumn{1}{|c|}{ Data } & \multicolumn{1}{c|}{ Wyszczególnienie } \\
\hline \hline 1 czerwca 2005 r. & Podanie do publicznej wiadomości przedziału cenowego. \\
\hline 2 czerwca $2005 \mathrm{r}$. & $\begin{array}{l}\text { Rozpoczęcie oferty publicznej. } \\
\text { Rozpoczęcie budowania księgi popytu. } \\
\text { Rozpoczęcie przyjmowania zleceń w TKID. }\end{array}$ \\
\hline 15 czerwca $2005 \mathrm{r}$. & Zakończenie przyjmowania zleceń w TKID. \\
\hline 16 czerwca $2005 \mathrm{r}$. & Zakończenie budowania księgi popytu. \\
\hline 17 czerwca $2005 \mathrm{r}$. & $\begin{array}{l}\text { Ustalenie oraz podanie do publicznej wiadomości ceny sprzedaży. } \\
\text { Przygotowanie wstępnej listy przydziału. } \\
\text { Wysłanie zawiadomień o liczbie przydzielonych akcji w TDIK oraz } \\
\text { TIIZ. }\end{array}$ \\
\hline 21 czerwca $2005 \mathrm{r}$. & $\begin{array}{l}\text { Przydział akcji w TKID w ramach sesji. } \\
\text { Ostateczny termin złożenia zamówienia na akcje oferowane w TIIZ. }\end{array}$ \\
\hline 22 czerwca $2005 \mathrm{r}$. & $\begin{array}{l}\text { Zakończenie przyjmowania płatności za akcje oferowane w TDIK. } \\
\text { Zakończenie przyjmowania płatności za akcje oferowane w TIIZ. }\end{array}$ \\
\hline 23 czerwca $2005 \mathrm{r}$. & Zakończenie oferty publicznej. \\
\hline 24 czerwca $2005 \mathrm{r}$. & Przewidywana data rozpoczęcia notowań giełdowych akcji spółki. \\
\hline
\end{tabular}

Ź r ó d ł o: opracowanie własne na podstawie raportu bieżącego spółki nr 14/2005.

Przedział cenowy w ofercie ustalony został na poziomie od 54,70 zł do 69,90 zł za jedną akcję spółki. Ponadto zmieniona została również liczba akcji oferowana w poszczególnych transzach: 
- 1380290 [było 1625 471] akcji w transzy krajowych inwestorów detalicznych,

- 2765000 [było 3251000 ] akcji w transzy dużych inwestorów krajowych, oraz

- 4145000 [było 4876 000] akcji w transzy instytucjonalnych inwestorów zagranicznych,

- 7965181 [było 6503 000] akcji stanowiło pulę dodatkową.

Ostatecznie cena, po jakiej były sprzedawane akcje spółki w ofercie publicznej została ustalona na $55 \mathrm{zł} \mathrm{za} \mathrm{jedną} \mathrm{akcję.}$

Korzyści finansowe oferty dla funduszu i spółki

W związku z ustaleniem ceny sprzedaży akcji spółki w granicy dolnych widełek Enterprise Investors zdecydował się odstąpić od sprzedaży akcji znajdujących się w jego portfelu inwestycyjnym. Fundusze private equity z grupy Credit Suisse zdecydowały się na szybką dezinwestycję. Nasz konsorcjant sprzedat wszystkie akcje, my zdecydowaliśmy się nie sprzedawać ani jednej po takiej cenie. Przy 55 zt za akcję, wskaźnik cena/zysk dla Opoczna wynosi niespetna 12. Dużo wyżej wyceniani sq wszyscy konkurenci spótki - powiedział R. Wojtkowski, partner Enterprise Investors. Akcje posiadane przez Enterprise Investors objęte zostały półrocznym okresem zamknięcia. Po tym okresie zobaczymy, czy wyjdziemy z inwestycji. Najprawdopodobniej poczekamy, aż spótka zrealizuje któryś z zapowiadanych celów strategicznych - mówi reprezentant Enterprise Investors.

W podsumowaniu publicznej oferty akcji spółka podała, że inwestorzy złożyli zapisy na 10796406 akcji, w tym:

- 3406406 akcji w transzy krajowych inwestorów detalicznych,

- 3540000 akcji w transzy dużych inwestorów krajowych,

- 3850000 akcji w transzy instytucjonalnych inwestorów zagranicznych.

Stopa redukcji w transzy krajowych inwestorów detalicznych wyniosła $73,57 \%$, w pozostałych transzach akcje przydzielono zgodnie ze złożonymi zamówieniami.

Inwestorom przydzielono 8290290 akcji sprzedawanych, w tym:

- 900290 akcji transzy krajowych inwestorów detalicznych,

- 3540000 akcji transzy dużych inwestorów krajowych,

- 3850000 akcji transzy instytucjonalnych inwestorów zagranicznych.

Jednakże Credit Suisse First Boston (Europe) Limited, działający jako podmiot stabilizacyjny, wykonał opcję stabilizacyjną przyznaną mu na podstawie umowy opcji stabilizacyjnej, sprzedając Credit Suisse First Boston Ceramic Partners (Poland) S.a.r.l. 69697 akcji spółki. W konsekwencji wykonania owej opcji ostatecznie sprzedano w wyniku oferty publicznej 8220593 akcji Opoczno SA Wartość zrealizowanej oferty sprzedaży wyniosła 455965950 zł, a uwzględniając wykonaną opcję stabilizacyjną 452132615 zł. 
W wyniku zbycia powyższych akcji, Credit Suisse First Boston Ceramic Partners (Poland) S.a.r.l. zmniejszył swoje zaangażowanie kapitałowe w spółkę do poziomu 48,4 \% kapitału zakładowego i posiadał bezpośrednio 7965181 akcji spółki.

Dalsze procesy redukcji udziału funduszu private equity w spółce portfelowej

W okresie bezpośrednio następującym po debiucie giełdowym Opoczno SA kurs giełdowy spółki znalazł się w trendzie spadkowym. Na rynku pojawiły się też skrajnie odmienne wyceny i rekomendacje w zakresie proponowanych dla tej spółki strategii inwestycyjnych. Osiągane przez spółkę w kolejnych okresach wyniki również nie były satysfakcjonujące dla inwestorów. Na pozycję ówczesnego lidera rynkowego wychodził bezpośredni konkurent spółki, również notowany na warszawskim parkiecie Cersanit SA, który zwiększał swój udział w rynku, przy jednoczesnym wzroście realizowanych marż na produktach. W kolejnych okresach sytuacja konkurencyjna spółki Opoczno SA ulegała pogorszeniu, co znajdowało odzwierciedlenie w kształtowaniu się kursu giełdowego akcji tej spółki.

W dniu 15 września 2006 r. do publicznej wiadomości została przekazana informacja, iż zarząd Cersanit SA podpisał z Credit Suisse First Boston Ceramic Partners (Poland) S.a.r.l. umowę nabycia 7965181 akcji spółki Opoczno SA uprawniających do 48,42\% ogólnej liczby głosów na walnym zgromadzeniu, jednakże nie mniej niż 7402500 akcji uprawniających do 45\% ogólnej liczby głosów na walnym zgromadzeniu Opoczno SA. W umowie tej Cersanit SA zobowiązał się do ogłoszenia wezwania na zakup $100 \%$ akcji spółki Opoczno SA po cenie sprzedaży nie niższej niż 33 zł. Zgodnie z postanowieniami umowy Credit Suisse First Boston Ceramic Partners (Poland) S.a.r.l. był uprawniony do sprzedaży nie więcej niż 562681 akcji spółki Opoczno SA w obrocie na ryn$\mathrm{ku}$ regulowanym, $\mathrm{w}$ drodze transakcji giełdowych $\mathrm{w}$ okresie do dnia ogłoszenia wezwania.

Ostatecznie spółka celowa Credit Suisse First Boston Ceramic Partners (Poland) S.a.r.l. posiadającą akcje Opoczno SA należące do portfeli funduszy zarządzanych przez Enterprise Investors zbyła 7965181 posiadane przez siebie akcje na rzecz Cersanit SA 28 grudnia 2006 r., wychodząc ostatecznie ze spółki. Akcje zostały zbyte po cenie 33,50 zł za jedną akcję, co daje łączną wartość transakcji w wysokości 266833 563,50 zł.

\section{Efektywność zrealizowanej inwestycji}

Credit Suisse First Boston Ceramic Partners (Poland) S.a.r.l. ani inne podmioty związane z funduszami private equity zaangażowanymi w spółkę $O p o c z-$ no $S A$ nie podały informacji w zakresie parametrów opisujących stopień efektywności analizowanej inwestycji. 


\subsubsection{Redukcja zaangażowania kapitałowego funduszu private equity w Grupę Kapitałową W. KRUK}

\section{Charakterystyka spółki}

Grupa Kapitałowa $W$. KRUK jest podmiotem działającym na polskim rynku dóbr luksusowych. W. KRUK SA zarządzał markami wyrobów jubilerskich (m. in. W. KRUK, KRUK Fashion, Miluna) oraz marką wyrobów odzieżowych Deni Cler. Podstawową działalnością Grupy Kapitałowej W. KRUK jest projektowanie, wytwarzanie i dystrybucja markowych, wysokiej jakości dóbr luksusowych - wyrobów jubilerskich, zegarków, odzieży i innych przedmiotów o charakterze upominków. Działalność przedsiębiorstwa w zakresie wytwarzania i dystrybucji wyrobów jubilerskich trwa nieprzerwanie od $1840 \mathrm{r}$.

W momencie przygotowywania spółki do wprowadzenia na GPW w Warszawie w 2002 r. sieć sprzedaży Grupy Kapitałowej W. KRUK składała się z 49 sklepów zlokalizowanych na terenie Polski w prestiżowych punktach. Ponadto w ramach prowadzonej działalności spółka zajmowała się sprzedażą hurtową i sprzedażą skierowaną do klientów instytucjonalnych. Stosunkowo niewielką część przychodów ze sprzedaży stanowiły wpływy z eksportu.

Rozwój i budowa przewagi konkurencyjnej na krajowym rynku odbywały się poprzez odpowiednie zarządzanie posiadanymi markami, rozbudowę selektywnej sieci dystrybucji, a także przez kreowanie nowych i przejmowanie istniejących już marek dóbr luksusowych oraz integrowanie ich z dotychczasową ofertą handlową. Decydujący wpływ na osiągane wyniki grupy miały produkcja i dystrybucja luksusowych wyrobów jubilerskich, zegarków oraz luksusowej odzieży damskiej (zob. wykres 3.13).

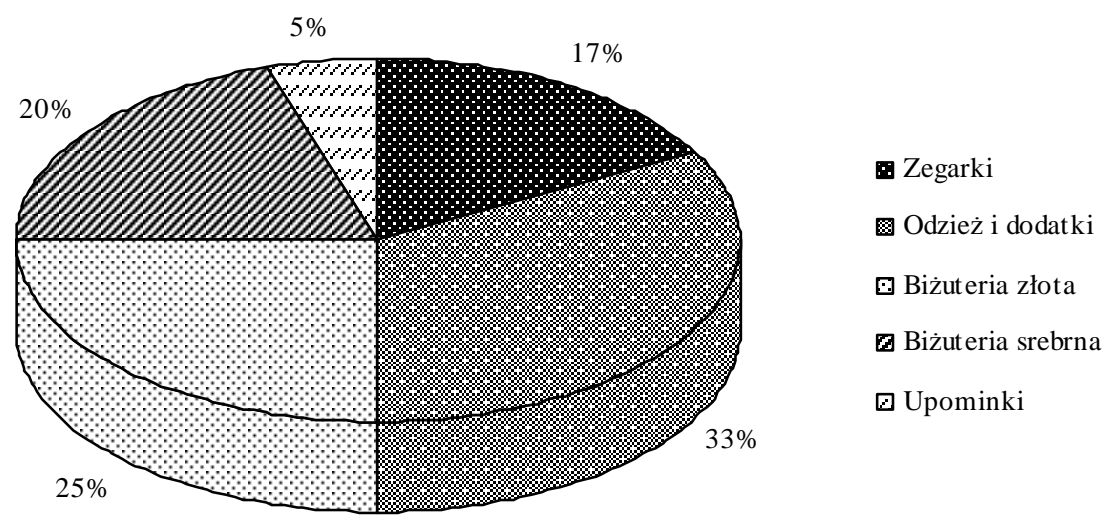

Wykres 3.13. Udział grup produktowych w przychodach ze sprzedaży Grupy Kapitałowej W. KRUK w 2001 r.

Ź r ód ł o: prospekt emisyjny Grupy Kapitałowej W. KRUK. 
Historia rozwoju analizowanej spółki, ze szczególnym uwzględnieniem roli funduszy private equity

Historia analizowanego podmiotu sięga pierwszej połowy XIX w., kiedy to w 1840 r. złotnik Leon Skrzetuski otworzył w Poznaniu pracownię, specjalizującą się w wykonywaniu i naprawie przedmiotów liturgicznych. W 1887 r. złotnik przekazał warsztat w ręce siostrzeńca Władysława Kruka. Po przekształceniu pracowni w jeden $\mathrm{z}$ największych warsztatów jubilerskich w Poznaniu Władysław Kruk przekazał przedsiębiorstwo synowi Henrykowi. Następnie Henryk Kruk dynamicznie powiększał zakres działalności przedsiębiorstwa rodzinnego $\mathrm{m}$. in. wprowadzając nowe maszyny, poszerzając asortyment oraz budując sieć własnych dostawców niezbędnych surowców. Od 1958 r. Henryk Kruk zaczął poszerzać zakres produkcji i asortymentu. W 1974 r. przedsiębiorstwo zostało przekazane w ręce syna Henryka Kruka - Wojciecha, pod zarządzaniem którego dynamicznie się rozwijało.

W 1989 r. Wojciech Kruk wraz z grupą osób związanych ze środowiskiem jubilerskim założył Wielkopolskie Towarzystwo Handlowe „Atu” Sp. z o.o. W dniu 11 października 1993 r. Wojciech Kruk wniósł do majątku tej spółki majątek swojego przedsiębiorstwa. Jednocześnie firma spółki została zmieniona na W. KRUK Sp. z o.o. oraz nastąpiło podwyższenie kapitału zakładowego spółki. Udziały w podwyższonym kapitale zostały objęte przez trzy fundusze private equity zarządzane przez Enterprise Investors. W wyniku nawiązania współpracy kapitał spółki został podwyższony z kwoty 6062240 zł do kwoty 11887240 zł, w drodze utworzenia 36045 równych i niepodzielnych udziałów o wartości 160 zł każdy. Udziały te zostały objęte przez:

- Polish-American Enterprise Fund - 11286 udziałów,

- Polish Private Equity Fund I - 12742 udziały,

- Polish Private Equity Fund II - 12377 udziałów.

Następnie w dniu 26 listopada 1998 r. spółka została przekształcona w spółkę akcyjną działającą pod firmą $W$. KRUK SA. Kapitał zakładowy spółki wynosił 8172340 zł i dzielił się na 742940 akcji serii A o wartości nominalnej 11 zł każda. Akcje zostały objęte w następujących proporcjach:

- Wojciech Kruk - 371480 akcji

- Polish-American Enterprise Fund - 110560 akcji,

- Polish Private Equity Fund I- 124820 akcji,

- Polish Private Equity Fund II - 121240 akcji,

- Jan Rosochowicz - 14840 akcji.

W 2000 r. spółka przeprowadziła emisję akcji serii B oraz C, w wyniku której kapitał zakładowy spółki wzrósł do kwoty 11297704 zł. Akcje te zostały objęte przez:

- Polish-American Enterprise Fund - 91641 akcji serii B,

- Polish Private Equity Fund I - 56009 akcji serii B,

- Polish Private Equity Fund II - 56009 akcji serii B,

- Ewę Kruk - 56465 akcji serii C. 
W momencie przygotowywania prospektu emisyjnego związanego z pierwszą ofertą publiczną większość akcji spółki była w posiadaniu funduszy private equity zarządzanych przez Enterprise Investors (zob. wykres 3.14).
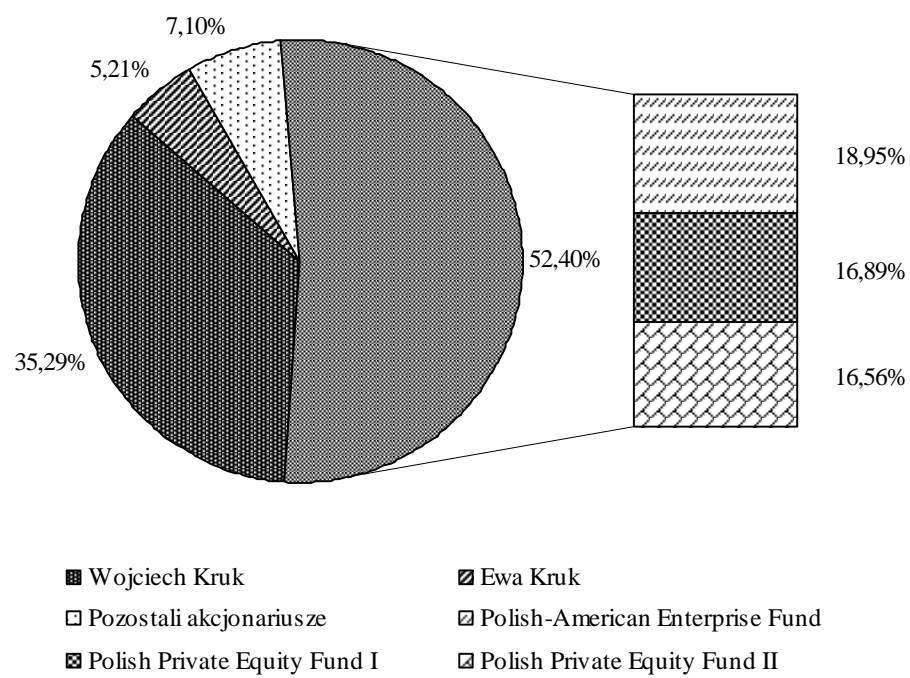

Wykres 3.14. Struktura akcjonariatu Grupy Kapitałowej W. KRUK

Źr ód ło: jak do wykresu 3.13 .

Warunki pierwszej oferty sprzedaży akcji spółki

Debiut giełdowy analizowanego emitenta związany był z wprowadzeniem do publicznego obrotu:

- 724940 akcji zwykłych na okaziciela serii A,

- 203659 akcji zwykłych na okaziciela serii B,

- 80465 akcji zwykłych na okaziciela serii C,

- 27668 akcji zwykłych na okaziciela serii D,

- 78250 akcji zwykłych na okaziciela serii E,

- od 426000 do 687000 akcji zwykłych na okaziciela serii $F$ oraz od 426000 do 687000 praw do akcji serii F.

Wartość nominalna wprowadzanych akcji wynosiła 11 zł.

W ramach publicznej oferty subskrypcji oferowane było 687000 akcji nowej emisji serii F, 78250 akcji serii E w ramach oferty menedżerskiej oraz 522759 akcji serii A i B będących własnością funduszy private equity zarządzanych przez Enterprise Investors. Oferta publiczna trwała od 17 do 25 czerwca 2002 r. Wstępny przedział cenowy, po jakim miały być oferowane akcje emitenta został określony w przedziale $35-43$ zł za jedną akcję, jednakże po analizie zgłaszanego popytu cena emisyjna została ustalona na poziomie dolnego ograniczenia i ostatecznie wynosiła 35 zł. 
Korzyści finansowe oferty dla funduszu i spółki

Akcje poznańskiej spółki jubilersko-odzieżowej zadebiutowały na warszawskiej giełdzie 2 lipca 2002 r. i straciły na wartości w pierwszym dni notowań 9,14\% . W ramach oferty publicznej 1239759 akcji inwestorzy łącznie objęli 861606 akcji spółki, w tym 610268 akcji serii F oraz 251338 akcji serii A sprzedawanych przez Enterprise Investors. Inwestorzy indywidualni objęli 373721 akcji oferowanych, przy czym składało się na nie 264699 akcji serii F i 109022 akcji sprzedawanych. W transzy inwestorów instytucjonalnych przydzielono 487885 akcji oferowanych, przy czym składały się na nie 345569 akcji serii F i 142316 akcji sprzedawanych. Podsumowując wyniki przeprowadzonej oferty J. Rosochowicz, prezes Grupy Kapitałowej W. KRUK stwierdził: Jesteśmy bardzo zadowoleni z przeprowadzonej emisji. Zgodnie z deklaracjami złożonymi $w$ prospekcie emisyjnym pozyskane środki przeznaczymy na dynamiczny rozwój sieci detalicznej.

Wynik oferty nie był jednak optymistyczny z punktu widzenia funduszy private equity zarządzanych przez Enterprise Investors. Brak odpowiedniego popytu na akcje spowodował, iż w wyniku zawartych transakcji zbyto zaledwie 251338 akcji z planowanych 522759 sztuk. Udział funduszy w kapitale zakładowym spółki zmniejszył się do poziomu nieznacznie przekraczającego $18 \%$ wobec planowanego całkowitego wyjścia z inwestycji.

Dalsze procesy redukcji udziału funduszu private equity w spółce portfelowej

Pomimo częściowego sukcesu oferty publicznej akcji Grupy Kapitałowej W. KRUK, bezpośrednio po debiucie Enterprise Investors deklarowało, iż nie zamierza zbytnio zwlekać z realizacją dezinwestycji: Planujemy sprzedać pozostałe akcje firmy $W$. KRUK do końca roku, ale nie jest to data graniczna na przeprowadzenie tej transakcji - stwierdził J. Siwicki, partner zarządzający w Enterprise Investors. Etap poszukiwania inwestorów zakończyliśmy wraz z publiczna subskrypcja. Ustalony zostat przedziat cenowy na poziomie 35-45 zt. Teraz będziemy oczekiwać na oferty - dodał.

Wbrew wielokrotnie wygłaszanym publicznie deklaracjom o planach szybkiej sprzedaży akcji okres zaangażowania kapitałowego funduszy private equity w spółce jednak wydłużał się. W grudniu 2005 r. Enterprise Investors poinformowało, że zamierza podjąć decyzję w zakresie dalszych planów dotyczących dezinwestycji po opublikowaniu wyników przez spółkę za 2005 r. i planów na 2006 r. J. Siwicki stwierdził, iż zamiarem Enterprise Investors jest zobaczyć jakie spótka będzie miata wyniki w tym roku, jaki będzie miała budżet w przyszłym $i$ wtedy podjać ewentualna decyzje, czy sprzedać akcje, komu, kiedy i za ile. [...] Od czasu do czasu zdarza się, że ktoś zgłasza zainteresowanie, ale aktywnych negocjacji na temat sprzedaży akcji nie prowadzimy. Chcemy się najpierw zorientować, jaki ta spótka ma potencjat i jak te akcje należałoby wycenić.

W dniu 6 marca 2006 r. Enterprise Investors poinformowało, iż zrealizowane zostało całkowite wyjście z inwestycji. I. Darbot, rzeczniczka Enterprise 
Investors powiedziała, iż Enterprise Investors sprzedały akcje W. KRUK instytucjom finansowym przez gietdę. Akcje zbyły wszystkie 3 fundusze zarządzane przez Enterprise Investors: Polish-American Enterprise Fund, Polish Private Equity Fund I oraz Polish Private Equity Fund II.

Efektywność zrealizowanej inwestycji

Enterprise Investors nie poinformowało dokładnie kto i na jakich warunkach kupił akcje od funduszy private equity. Do publicznej wiadomości nie zostały również udostępnione informacje na temat poziomu efektywności inwestycji, która trwała prawie 13 lat.

\subsubsection{Redukcja zaangażowania kapitałowego funduszu private equity w spółkę K2 Internet $S A$}

\section{Charakterystyka spółki}

Spółka K2 Internet $S A$ oferuje innowacyjne rozwiązania w obszarze marketingu. Jest ona partnerem największych organizacji w Polsce. Projektuje i wdraża rozwiązania stwarzające nowe możliwości rozwoju relacji pomiędzy markami i organizacjami, a ich klientami. Spółka tworzy różnego rodzaju rozwiązania, których nadrzędnym celem jest realizacja konkretnych celów marketingowych lub sprzedażowych klienta. Dwa główne obszary działalności analizowanej spółki stanowią e-marketing oraz media on-line, a usługi oferowane przez K2 Internet $S A$ pozwalają zapewnić kompleksową obsługę klientów w szeroko rozumianym obszarze komunikacji i sprzedaży on-line (zob. tab. 3.14).

Tabela 3.14

Usługi oferowane przez spółkę K2 Internet $S A$ na różnych etapach cyklu sprzedażowo-marketingowego

\begin{tabular}{|l|l|l|}
\hline \multicolumn{1}{|c|}{ Komunikacja marketingowa } & \multicolumn{1}{|c|}{ Transakcja } & \multicolumn{1}{|c|}{ Obsługa klienta } \\
\hline $\begin{array}{l}\text { Planowanie i zakup mediów } \\
\text { on-line }\end{array}$ & E-commerce & $\begin{array}{l}\text { Rozwój i utrzymanie serwisów } \\
\text { WWW }\end{array}$ \\
\hline Marketing afiliacyjny & $\begin{array}{l}\text { Enterprise Content Manage- } \\
\text { ment }\end{array}$ & Enterprise Content Management \\
\hline $\begin{array}{l}\text { Rozwój i utrzymanie serwi- } \\
\text { sów WWW }\end{array}$ & $\begin{array}{l}\text { Rozwój i utrzymanie serwi- } \\
\text { sów WWW }\end{array}$ & Business Process Management \\
\hline $\begin{array}{l}\text { Kreacja i strategia komuni- } \\
\text { kacji }\end{array}$ & Hosting zarządzany & Hosting zarządzany \\
\hline $\begin{array}{l}\text { Konsulting e-marketingowy } \\
\text { i usability }\end{array}$ & $\begin{array}{l}\text { Konsulting e-marketingowy } \\
\text { i usability }\end{array}$ & Kreacja i strategia komunikacji \\
\hline $\begin{array}{l}\text { Enterprise Content Manage- } \\
\text { ment }\end{array}$ & & $\begin{array}{l}\text { Konsulting e-marketingowy } \\
\text { i usability }\end{array}$ \\
\hline Hosting zarządzany & & \\
\hline
\end{tabular}

Ź r ó d ł o: prospekt emisyjny K2 Internet $S A$. 
Historia rozwoju analizowanej spółki, ze szczególnym uwzględnieniem roli funduszy private equity

W 1997 roku M. Lach wraz z wspólnikami założyli spółkę cywilną K2 Internet Provider, zajmującą się przede wszystkim dostarczaniem Internetu małym i średnim przedsiębiorstwom na rynku warszawskim, ale też usługami w zakresie e-marketingu. W 2000 r. właściciele spółki postanowili w pełni skoncentrować prowadzoną działalność gospodarczą na usługach e-marketingowych, W związku z tym działalność dostawcy Internetu została sprzedana. W dniu 8 czerwca 2000 r. zawiązali spółkę K2 Internet $S A$, pozyskali znaczących inwestorów finansowych: fundusz bmp $A G$ i fundusz $C E E V$.

We wrześniu 2000 r. dokonano podwyższenia kapitału spółki poprzez emisję 382510 nowych akcji:

- 92510 akcji serii B, które zostały objęte przez bmp AG i CEEV GmbH za gotowkę,

- 290000 akcji serii C, które zostały pokryte wkładem niepieniężnym w postaci zorganizowanej części przedsiębiorstwa spółki cywilnej K2 Internet Provider przez M. Lacha (241 464 akcji) i J. Żebrowskiego (48 536 akcji).

W kolejnych latach spółka K2 Internet $S A$ dynamicznie rozwijała prowadzoną działalność gospodarczą, sukcesywnie zdobywając nowych klientów.

W związku z ekspansją spółki zachodziła konieczność pozyskiwania dodatkowego kapitału. W 2002 r. nastąpiło podwyższenie kapitału zakładowego poprzez emisję 20000 akcji serii D objętych przez bmp AG, M. Lacha i J. Żebrowskiego. Kolejna emisja 73179 akcji serii E została objęta przez CEEV GmbH, bmp AG, M. Lacha i J. Żebrowskiego w 2003 r. Pod koniec 2005 r. dokonano kolejnego podwyższenia kapitału zakładowego w drodze emisji 30980 akcji serii F, które zostały objęte przez CEEV i bmp $A G$.

W marcu 2007 r. fundusz $C E E V G m b H$ zbył na rzecz bmp $A G$ posiadane w portfelu inwestycyjnym 317835 akcje serii A, B, C, E i F i tym samym zakończył inwestycję w spółce przestając być akcjonariuszem $K 2$ Internet $S A$

W okresie poprzedzającym realizację pierwszej oferty publicznej akcji największy udział w kapitale zakładowym analizowanej spółki miał fundusz private equity bmp $A G$ (zob. wykres 3.15).

Warunki pierwszej oferty sprzedaży akcji spółki

Na podstawie prospektu emisyjnego w ramach pierwszej oferty publicznej oferowanych było 750000 akcji, w tym:

- 330000 nowych akcji serii $\mathrm{H}$, zwykłych na okaziciela, oferowanych w ramach subskrypcji otwartej przez spółkę,

- 420000 dotychczasowych akcji zbywanych przez:

- bmp $A G-369300$ szt.

- M. Lacha - 32000 szt.

- J. Żebrowskiego - 18400 szt. 


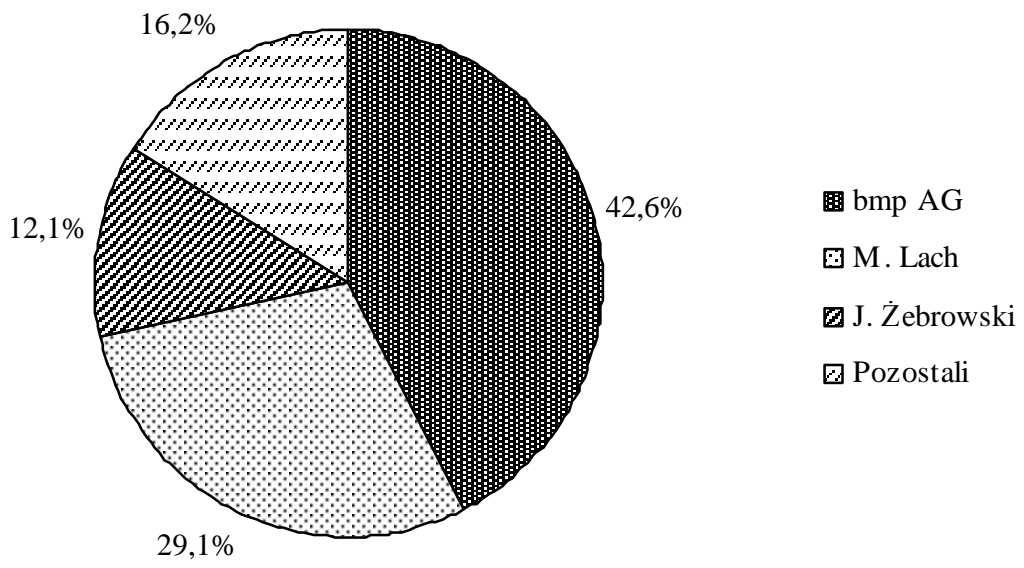

Wykres 3.15. Struktura akcjonariatu spółki K2 Internet $S A$ przed debiutem giełdowym Ź r ó d ł o: prospekt emisyjny K2 Internet $S A$.

Dodatkowo w zależności od wyników procedury budowy księgi popytu istniała możliwość podjęcia decyzji przez $b m p A G$ o zaoferowaniu do sprzedaży dodatkowo nie więcej niż 354960 akcji.

Początkowo przedział cenowy, po jakim oferowane były akcje został ustalony na poziomie $25-35$ zł za jedną akcję. W dniach 31 marca-4 kwietnia 2008 r. zarząd spółki przeprowadził tzw. roadshow i budowę księgi popytu, a ostateczna cena emisyjna na akcje sprzedawane została określona w dolnych granicach widełek, czyli na poziomie $25 \mathrm{zł}$.

Korzyści finansowe oferty dla funduszu i spółki

W ramach przeprowadzonej subskrypcji i sprzedaży akcji spółki właściciela zmieniło łącznie 588523 akcji, w tym:

- na 525000 akcji złożono zapisy w odpowiedzi na zaproszenia,

- na 63523 akcje złożono zapisy bez zaproszeń.

Dotychczasowi właściciele spółki, w tym fundusz private equity bmp $A G$, zbyli w ramach oferty zaledwie część planowanych do sprzedaży akcji. Stopa redukcji wynosiła $0 \%$, tzn. liczba przydzielonych akcji była równa liczbie akcji, na które złożono zapisy. Inwestorzy instytucjonalni i prywatni nabyli 330000 akcji pochodzących z nowej emisji (seria $\mathrm{H}$ ), zaś 258523 z pakietu posiadanego przez bmp AG. Kapitał pozyskany przez fundusz private equity ze zbycia akcji wyniósł prawie $6,5 \mathrm{mln}$ zł, a udział w kapitale zakładowym spółki został zredukowany do poziomu $22,96 \%$. Łączna wartość przeprowadzonej subskrypcji i sprzedaży rozumiana jako iloczyn przydzielonych papierów wartościowych objętych ofertą i ceny emisyjnej lub ceny sprzedaży wynosiła łącznie 14713075 zł. 
Dalsze procesy redukcji udziału funduszu private equity w spółce portfelowej

Pomimo niezrealizowania $\mathrm{w}$ pierwszej ofercie publicznej planów co do zakresu wyjścia z inwestycji, fundusz $b m p A G$ nie kontynuował bezpośrednio po debiucie giełdowym procesów redukcji zaangażowania kapitałowego w spółkę $K 2$ Internet $S A$, a wręcz przeciwnie, dokonywał w ramach transakcji rynkowych zakupów niewielkich ilości akcji. Właściwe wyjście z inwestycji nastąpiło dopiero w 2011 r. (zob. tab. 3.15).

Tabela 3.15

Operacje na akcjach spółki $K 2$ Internet $S A$ dokonywane przez bmp $A G$ po debiucie giełdowym

\begin{tabular}{|c|c|c|c|c|c|}
\hline Data & $\begin{array}{l}\text { Dokonujący } \\
\text { transakcji }\end{array}$ & Rodzaj transakcji & $\begin{array}{l}\text { Wolu- } \\
\text { men }\end{array}$ & $\begin{array}{c}\text { Liczba akcji } \\
\text { pozostająca } \\
\text { w posiadaniu } \\
\text { po transakcji }\end{array}$ & $\begin{array}{c}\text { Udział } \\
\text { w kapitale } \\
\text { zakładowym } \\
\text { po transakcji }\end{array}$ \\
\hline $\begin{array}{l}17.06 .2008 \\
-24.06 .2008\end{array}$ & bmp $A G$ & $\begin{array}{l}\text { Zakup akcji w ramach } \\
\text { transakcji sesyjnych }\end{array}$ & 1300 & 466337 & 22,97 \\
\hline $\begin{array}{l}3.07 .2008 \\
-10.12 .2008\end{array}$ & bmp $A G$ & $\begin{array}{l}\text { Zakup akcji w ramach } \\
\text { transakcji sesyjnych }\end{array}$ & 6515 & 472852 & 23,29 \\
\hline 12.12.2008 & bmp $A G$ & $\begin{array}{l}\text { Zbycie przez przenie- } \\
\text { sienie akcji do spółki } \\
\text { zależnej - transakcja } \\
\text { dokonana w trybie } \\
\text { pozagiełdowym }\end{array}$ & 465000 & 7852 & 0,39 \\
\hline 12.12.2008 & $\begin{array}{l}\text { bmp Media } \\
\text { Investors } A G \\
\& \text { Co. KGaA }\end{array}$ & $\begin{array}{l}\text { Nabycie przez prze- } \\
\text { niesienie akcji do } \\
\text { spółki zależnej - } \\
\text { transakcja dokonana w } \\
\text { trybie pozagiełdowym }\end{array}$ & 465000 & 465000 & 22,9 \\
\hline $\begin{array}{l}17.01 .2008 \\
-19.01 .2010\end{array}$ & $\begin{array}{l}\text { bmp Media } \\
\text { Investors } A G \\
\& \text { Co. } K G a A\end{array}$ & $\begin{array}{l}\text { Zakup akcji w ramach } \\
\text { transakcji sesyjnych }\end{array}$ & 19928 & 484928 & 23,89 \\
\hline 20.01.2010 & $\begin{array}{l}\text { bmp Media } \\
\text { Investors } A G \\
\& \text { Co. KGaA }\end{array}$ & $\begin{array}{l}\text { Zbycie poprzez giełdę } \\
\text { na rzecz funduszu } \\
\text { inwestycyjnego } Q U- \\
\text { ERCUS Parasolowy } \\
\text { SFIO }\end{array}$ & 120000 & 364928 & 17,97 \\
\hline $\begin{array}{l}26.01 .2010 \\
-7.04 .2011\end{array}$ & $\begin{array}{l}\text { bmp Media } \\
\text { Investors } A G \\
\& \text { Co. KGaA }\end{array}$ & $\begin{array}{l}\text { Zakup akcji w ramach } \\
\text { transakcji sesyjnych }\end{array}$ & 1072 & 366000 & 18,07 \\
\hline 8.04 .2010 & $\begin{array}{l}\text { bmp Media } \\
\text { Investors } A G \\
\text { \& Co. KGaA }\end{array}$ & $\begin{array}{l}\text { Zbycie poprzez giełdę } \\
\text { na rzecz inwestorów } \\
\text { finansowych - średnia } \\
\text { cena za akcję } 26,01 \mathrm{zł}\end{array}$ & 366000 & 0 & 0 \\
\hline
\end{tabular}

Ź r ó d ł o: opracowanie własne na podstawie raportów bieżących spółki K2 Internet SA. 


\section{Efektywność zrealizowanej inwestycji}

Fundusz bmp $A G$ zakończył inwestycję w 2011 r. przez sprzedaż polskim inwestorom finansowym $w$ ramach przyspieszonej budowy księgi popytu wszystkich posiadanych ówcześnie akcje spółki, stanowiących 18,07\% jej kapitału. W komunikacie prasowym podano, iż inwestycja w to przedsiębiorstwo uchodzi za jedną z najbardziej udanych w historii tego funduszu. Łącznie bmp $A G$ zrealizowało wewnętrzną stopę zwrotu w wysokości około 35\% oraz 6,5-krotny zwrot zainwestowanego kapitału. Podsumowując transakcję J. Spyrka, partner bmp AG odpowiedzialny za inwestycję i wieloletni członek Rady Nadzorczej K2 Internet SA powiedział: Jesteśmy dumni z faktu, że mieliśmy szansę brać udział w pomyślnym rozwoju, w wyniku którego udato się zbudować firmę o wiodacej pozycji na rynku. Dziękujemy zespołowi K2 za dotychczasowa wspótprace, która w niektórych dziedzinach - czy to $w$ Radzie Nadzorczej, czy poprzez wspótpracę w projektach opracowanych przez lub dotyczacych $\mathrm{K} 2$ - będzie kontynuowana.

\subsubsection{Wnioski z analizy przypadków}

Przedstawione efekty transakcji wyjścia z inwestycji w spółki portfelowe Travelplanet.pl SA, K2 Internet SA, Opoczno SA oraz Grupy Kapitałowej $W . K R U K$ wskazują, iż fundusze private equity napotykają znaczące bariery w procesie realizacji dezinwestycji za pośrednictwem GPW w Warszawie SA.

Główne zidentyfikowane ograniczenia sprawnej realizacji wyjścia z inwestycji przez fundusze private equity za pośrednictwem GPW w Warszawie związane są ze stroną popytową rynku. W przypadku pierwszych ofert publicznych akcji spółek K2 Internet SA, Opoczno SA oraz Grupy Kapitałowej W. KRUK nie udało się bowiem zrealizować planów sprzedaży akcji, gdyż popyt był niewystarczający. Na rynku uplasowana została tylko część oferowanych akcji.

Przypadek Opoczno SA, spółki z portfela inwestycyjnego funduszy Credit Suisse oraz Enterprise Investors pokazał, iż poszczególne podmioty chcące zadebiutować na warszawskiej giełdzie często muszą konkurować o zainteresowanie inwestorów. Kapitał z rynku w dużej mierze jest absorbowany przez liczne oferty związane z prywatyzacją spółek będących własnością Skarbu Państwa. W okresach, kiedy na rynku plasowanych jest wiele ofert jednocześnie, sprzedaż akcji po oczekiwanej cenie jest niezwykle utrudniona.

Z kolei przypadek Travelplanet.pl SA oraz Grupy Kapitałowej W. KRUK uwidoczniły problemy ze sprzedażą akcji na rynku wtórnym w okresach dekoniunktury. Polski rynek giełdowy jest bardzo wrażliwy na zmianę uwarunkowań makroekonomicznych, krajowych i zagranicznych. Znaczna część kapitału inwestowanego na warszawskiej giełdzie pochodzi od inwestorów zagranicznych. Realizacja procesu dezinwestycji w dobie kryzysu gospodarczego za pośrednictwem rynku kapitałowego jest niezwykle utrudniona i z reguły skutkuje wydłużeniem okresu zaangażowania kapitałowego funduszu w daną spółkę. 



\section{Rozdział 4}

\section{RYNKOWE EFEKTY PROCESÓW DEZINWESTYCJI ZREALIZOWANYCH METODĄ PIERWSZEJ OFERTY PUBLICZNEJ}

Badania empiryczne nad efektami procesów dezinwestycji zrealizowanych metodą pierwszej oferty publicznej przyjęły formę rozpoznania trzech obszarów badawczych:

- rentowności kapitału własnego spółek portfelowych funduszy private equity,

- kosztów pierwszych ofert publicznych analizowanych spółek oraz

- stóp zwrotu z akcji oferowanych w pierwszych ofertach publicznych spółek portfelowych funduszy private equity.

Te trzy kwestie są kluczowe dla oceny skutków dezinwestycji zarówno dla samego funduszu private equity, jak i dla przedsiębiorstw udziałowych, w których zaangażowanie kapitałowe funduszu zostało zakończone za pośrednictwem publicznego rynku papierów wartościowych.

\subsection{Rentowność kapitału własnego spółek portfelowych funduszy private equity objętych procesami dezinwestycji na publicznym rynku papierów wartościowych}

Wspieranie rozwoju przedsiębiorstw udziałowych następuje nie tylko przez dopływ środków pieniężnych, lecz również poprzez know-how w zakresie zarządzania $^{1}$ oraz inne formy wsparcia kapitałem menedżerskim ${ }^{2}$. W wyniku zakończonej dezinwestycji przedsiębiorstwa udziałowe tracą wsparcie finansowe

${ }^{1}$ L. Lew a n d ow s k a, Niekonwencjonalne formy finansowania przedsiębiorczości, ODiDK Sp. z o.o., Gdańsk 2000, s. 111.

2 Zob. J. Ortgiese, Value Added by Venture Capital Firms, JOSEF EUL VERLAG, Lohmar-Köln 2007, s. 47. 
oraz kadrowe ze strony funduszu. Tego rodzaju sytuacja w znaczący sposób wpływać może na standing finansowy przedsiębiorstw portfelowych.

Analiza zagranicznej literatury przedmiotu wskazuje, iż po zrealizowaniu publicznych ofert sprzedaży akcji ma miejsce pogorszenie kondycji finansowej przedsiębiorstw, których akcje zostały wprowadzone do publicznego obrotu ${ }^{3}$.

Do oceny zakresu oraz trwałości zmian kondycji finansowej spółek portfelowych funduszy private equity następujących po debiucie giełdowym zastosowany został współczynnik rentowności kapitału własnego. W kontekście determinant efektywności i wartości przedsiębiorstw współczynnik ten jest bardzo ważną zmienną w formułowaniu, realizacji i kontrolowaniu strategii finansowych zmierzających do zapewnienia właścicielom określonych korzyści kapitałowych i dywidendowych oraz wzrostu wartości rynkowej przedsiębiorstwa ${ }^{4}$. Rentowność kapitału własnego jest uznawana za najważniejszych syntetycznych mierników oceny efektywności prowadzonej działalności gospodarczej oraz instrumentów zarządzania przedsiębiorstwem, a jego zmiany odzwierciedlają podejmowaną aktywność przedsiębiorstwa w sferze finansowej, produkcyjnej i marketingowej ${ }^{5}$.

\subsubsection{PODSTAWY METODYCZNE BADAŃ NAD ZMIANAMI RENTOWNOŚCI KAPITAŁU WŁASNEGO SPÓŁEK PORTFELOWYCH FUNDUSZY PRIVATE EQUITY}

Badania empiryczne, mające na celu weryfikację postawionej hipotezy badawczej wskazującej, iż w spółkach portfelowych funduszy private equity poddanych dezinwestycji metodą pierwszej oferty publicznej po debiucie na giełdzie papierów wartościowych następuje okresowe zmniejszenie rentowności kapitału

${ }^{3}$ B. Jain, O. Kini, The post-issue operating performance of IPO firms, „Journal of Finance" 1994, Vol. 49, s. 1699-1726; W. Mikkels on, M. Partch, K. Sh ah, Ownership and operating performance of companies that go public, „Journal of Financial Economics” 1997, Vol. 44, s. 281-307; S. T e o h, I. W e lc h, T. W ong, Earnings management and the long-run market performance of initial public offerings, ,Journal of Finance” 1998, Vol. 53, s. 1935-1974; M. Pa ga no, F. Pan ett a, L. Zing a les, Why do companies go public? An empirical analysis, „Journal of Finance” 1998, Vol. 53, s. 27-64; J. Coakley, L. Had as s, A. W ood, Post-ipo operating performance, venture capitalists and market timing, Discussion Paper No.04-16, University of Essex 2004; J. C a i, C. J. W e i, The investment and operating performance of Japanese initial public offerings, „Pacific-Basin Finance Journal” 1997, Vol. 5, s. 389-417; K. K u t s u n a, H. Okamura, M. Cowling, Ownership structure pre- and post-IPOS and the operating performance of JASDAQ companies, „Pacific-Basin Finance Journal” 2002, Vol. 10, s. 163-181.

${ }^{4}$ A. S aj nóg, Operacyjny $i$ strategiczny wymiar ocen zróżnicowania rentowności kapitału własnego spótek przemystowych, [w:] J. D u raj (red.), Przedsiębiorstwo na rynku kapitałowym, Wydawnictwo Uniwersytetu Łódzkiego, Łódź 2010, s. 238.

${ }^{5}$ J. D u raj, A. S aj nóg, Rentowność kapitału własnego giełdowych spótek przemystowych, Wydawnictwo Uniwersytetu Łódzkiego, Łódź 2011, s. 11. 
własnego, zostały przeprowadzone na grupie 23 przedsiębiorstw, których pierwsze notowanie na GPW w Warszawie odbyło się w latach 2002-2008. Przyjęcie takiego okresu badawczego spowodowane jest potrzebą pełniejszego rozpoznania zmian rentowności kapitału własnego w przynajmniej 3-letnim okresie po debiucie giełdowym spółki.

We wskazanym okresie na warszawskim parkiecie miały miejsce 24 pierwsze notowania akcji spółek, których akcjonariuszami bezpośrednio przed przeprowadzeniem publicznej ofert sprzedaży akcji były fundusze private equity i jednostki te spełniały przyjęte w rozprawie kryteria wyboru (zob. tab. 3.3). Jednakże, dążąc do zachowania porównywalności analizowanych zmiennych w grupie badanych podmiotów w latach przed i po debiucie giełdowym, z dalszych badań wyeliminowano spółkę $A B S A$, ze względu na zmianę w tej spółce roku obrotowego $\mathrm{w}$ analizowanym okresie badawczym ${ }^{6}$.

W weryfikacji hipotezy badawczej wykorzystana została tradycyjna formuła współczynnika rentowności kapitału własnego, w której wartość wygenerowanego przez przedsiębiorstwo wyniku netto w danym okresie odniesiona została do średniej arytmetycznej wartości księgowej kapitałów własnych. Współczynnik rentowności kapitału własnego jest syntetyczną miarą efektywności gospodarowania zasobami właścicieli. Jej wielkość i zmiany zależą od wielu czynników i warunków działania przedsiębiorstwa. Dla potrzeb analizy przyczynowej wykorzystana została tzw. analiza piramidalna ${ }^{7}$, a współczynnik rentowności kapitału własnego został poddany dezagregacji do trzech czynników i przedstawiony w następującej formule:

$$
\begin{aligned}
& R O E_{n}=\frac{E A T_{n}}{\overline{E_{n}}}=R O S_{n} \times A U_{n} \times E M_{n} \\
& R O E_{n}=\frac{E A T_{n}}{S_{n}} \times \frac{S_{n}}{T A_{n}} \times \frac{\overline{T A_{n}}}{\overline{E_{n}}}
\end{aligned}
$$

\footnotetext{
${ }^{6}$ Zgodnie z brzmieniem Uchwaty $n r$ 28/2006 Nadzwyczajnego Walnego Zgromadzenia $A B S A$ rok obrotowy spółki rozpoczyna się 1 lipca każdego roku kalendarzowego, a kończy 30 czerwca następnego roku kalendarzowego. Rok obrotowy rozpoczęty 1 stycznia 2007 kończy się 30 czerwca 2008 r., obejmuje więc 18 miesięcy. Dane prezentowane we wcześniejszych sprawozdaniach finansowych obejmują 12 miesięcy i nie są w związku z tym porównywalne.

${ }^{7}$ Zob. M. Marcin kow ska, Ocena dziatalności instytucji finansowych, Difin, Warszawa 2007, s. 287-290; R. B orowiecki (red.), Pomiar i ocena procesów kreowania wartości w badaniu efektywności przedsiębiorstwa, Fundacja Uniwersytetu Ekonomicznego w Krakowie, Kraków 2009, s. 70-79.
} 
gdzie:

$R O E_{n}$ - współczynnik rentowności kapitału własnego w roku $n$,

$E A T_{n}$ - wynik netto w roku obrotowym $n$,

$E M_{n}$ - mnożnik kapitałowy w roku $n$,

$R O S_{n}$ - wskaźnik rentowności sprzedaży w roku $n$,

$A U_{n}$ - wskaźnik produktywności majątku w roku $n$,

$S_{n} \quad-$ przychody ze sprzedaży w roku $n$,

$\bar{E}_{n} \quad-$ średni stan kapitału własnego w roku $n$,

$\overline{T A_{n}}$ - średni stan aktywów ogółem w roku $n$.

Do liczbowego określenia wpływu zmian wskaźnika rentowności sprzedaży, mnożnika kapitałowego oraz wskaźnika produktywności majątku na zmiany współczynnika rentowności kapitałów własnych wykorzystana została metoda kolejnych podstawień ${ }^{8}$. Jej aplikacja wymagała zastosowania następującej dyscypliny badawczej:

1) ustalenie odchylenia łącznego pomiędzy wartością współczynnika rentowności kapitału własnego osiągniętą w danym roku a jego wielkością z roku poprzedzającego, czyli:

$$
O_{R O E_{n}}=R O E_{n}-R O E_{n-1}
$$

gdzie:

$O_{R O E_{n}}$ - odchylenie łączne współczynnika rentowności kapitału własnego w roku $n$,

$R O E_{n-1}$ - współczynnik rentowności kapitału własnego w roku poprzednim, stanowiącym bazę odniesienia,

pozostałe oznaczenia jak wyżej.

2) określenie czynników wpływających na odchylenie łączne i związek przyczynowy zachodzący między tymi zmiennymi:

$$
f\left(R O E_{n}\right)=R O S_{n} \times A U_{n} \times E M_{n}
$$

${ }^{8}$ Szerzej na temat metody kolejnych podstawień oraz innych metod analizy przyczynowej: L. B ednarski, R. Borowiecki, J. Duraj, E. Kurtys, T. Waśniewski, B. Wersty, Analiza ekonomiczna przedsiębiorstwa, Wydawnictwo Akademii Ekonomicznej im. Oskara Langego we Wrocławiu, Wrocław 1996, s. 42-43, 54-58; A. Żwirbla, Metody badawcze analizy ekonomicznej. Studium metodologiczne, Wyższa Szkoła Humanistyczno-Ekonomiczna, Włocławek 2001, s. 44-94. 
3) przeprowadzenie kolejnych podstawień w odniesieniu do poszczególnych czynników oraz ustalenia wielkości odpowiednich odchyleń:

$$
\begin{aligned}
& O_{R O E_{n}}=O_{R O S_{n}}+O_{A U_{n}}+O_{E M_{n}} \\
& O_{R O S_{n}}=R O S_{n} \times A U_{n-1} \times E M_{n-1}-R O S_{n-1} \times A U_{n-1} \times E M_{n-1}=\left(R O S_{n}-R O S_{n-1}\right) \times A U_{n-1} \times E M_{n-1} \\
& O_{A U_{n}}=R O S_{n} \times A U_{n} \times E M_{n-1}-R O S_{n} \times A U_{n-1} \times E M_{n-1}=\left(A U_{n}-A U_{n-1}\right) \times R O S_{n} \times E M_{n-1} \\
& O_{E M_{n}}=R O S_{n} \times A U_{n} \times E M_{n}-R O S_{n} \times A U_{n} \times E M_{n-1}=\left(E M_{n}-E M_{n-1}\right) \times R O S_{n} \times A U_{n}
\end{aligned}
$$

gdzie:

$O_{R_{0 S}}$ - odchylenie cząstkowe będące wynikiem zmian wskaźnika rentowności sprzedaży,

$O_{A U_{n}}$ - odchylenie cząstkowe będące wynikiem zmian wskaźnika produktywności majątku,

$O_{E M_{n}}$ - odchylenie cząstkowe będące wynikiem zmian mnożnika kapita-
łów,

pozostałe oznaczenia jak wyżej.

4) zestawienie sumaryczne odchyleń cząstkowych i przeprowadzenie wnioskowania opartego na podejściu deterministycznym.

Analiza zmian tego wskaźnika objęła okres dwóch lat przed debiutem na GPW w Warszawie, rok pierwszego notowania $\left(n_{0}\right)$ oraz okres trzech kolejnych lat. W rozważaniach uwzględnione zostały wyłącznie okresy, w których obliczenie współczynnika w oparciu przyjętą metodykę badań i dostępność danych empirycznych było wykonalne. W sytuacji występowania ujemnej wartości kapitału własnego w wybranych okresach odstąpiono od obliczeń współczynnika9

\subsubsection{WYNIKI BADAŃ EMPIRYCZNYCH NAD RENTOWNOŚCIĄ KAPITAEU WŁASNEGO SPÓŁEK PORTFELOWYCH FUNDUSZY PRIVATE EQUITY}

Ocena rentowności kapitału własnego spółek portfelowych funduszy private equity wskazuje, iż w analizowanym okresie większość badanych przedsiębiorstw generowała dodatnie wyniki finansowe netto (zob. tab. 4.1).

\footnotetext{
${ }^{9}$ Dotyczy spółki Sfinks Polska SA w latach $n_{+2}, n_{+3}$.
} 
Liczba i struktura spółek portfelowych funduszy private equity według osiąganego wyniku finansowego netto

\begin{tabular}{|l|l|r|r|r|r|r|r|}
\hline \multirow{2}{*}{ Wyszczególnienie } & \multicolumn{7}{|c|}{ Analizowany okres } \\
\cline { 3 - 8 } & \multicolumn{1}{|c|}{$n_{-2}$} & \multicolumn{1}{|c|}{$n_{-1}$} & \multicolumn{1}{c|}{$n_{0}$} & \multicolumn{1}{c|}{$n_{+1}$} & \multicolumn{1}{c|}{$n_{+2}$} & \multicolumn{1}{c|}{$n_{+3}$} \\
\hline \hline \multirow{3}{*}{ Spółki rentowne } & liczba & 18 & 22 & 20 & 17 & 17 & 15 \\
\cline { 2 - 8 } & udział [\%] & 94,74 & 95,65 & 86,96 & 73,91 & 77,27 & 71,43 \\
\hline $\begin{array}{l}\text { Spółki deficyto- } \\
\text { we }\end{array}$ & liczba & 1 & 1 & 3 & 6 & 5 & 6 \\
\cline { 2 - 8 } & udział [\%] & 5,26 & 4,35 & 13,04 & 26,09 & 22,73 & 28,57 \\
\hline
\end{tabular}

Ź r ó d ło: opracowanie własne na podstawie sprawozdań finansowych badanych spółek.

W latach poprzedzających debiut na GPW w Warszawie tylko jedna spółka - CP Energia SA - osiągała stratę netto. W kolejnych badanych latach zauważalny jest wzrost liczby i udziału spółek deficytowych w porównaniu do okresu przed rozpoczęciem procesu wyjścia $\mathrm{z}$ inwestycji metodą pierwszej oferty publicznej przez fundusz private equity. W roku, w którym odbyło się pierwsze publiczne notowanie akcji spółki $\left(n_{0}\right)$, liczba przedsiębiorstw generujących stratę wzrosła do 3, a w kolejnym analizowanym okresie do 6.

Analizując średnie wartości współczynnika rentowności kapitału własnego spółek portfelowych funduszy private equity wprowadzonych do publicznego obrotu, zauważyć można występowanie znaczących różnic w poziomach rentowności kapitału własnego w latach przed i po debiucie giełdowym (zob. wykres 4.1$)^{10}$.

W okresie 2 lat poprzedzających pierwsze publiczne notowanie akcji emitowanych przez podmioty objęte badaniem średnia wartość współczynnika rentowności kapitału własnego wzrosła nieznacznie z 26,39\% do poziomu $26,98 \%$. W roku debiutu spółki na giełdzie średnia rentowność kapitału własnego w analizowanych podmiotach uległa obniżeniu i wynosiła 14,62\%. Po pierwszym pełnym roku obrotowym posiadania statusu spółki publicznej średnia rentowność kapitału własnego spółek zmalała do poziomu 7,49\%. W kolejnym okresie przeciętna wartość analizowanego współczynnika nieznacznie wzrosła, aby po trzecim pełnym roku publicznych notowań osiągnąc średni poziom $2,50 \%$.

${ }^{10} \mathrm{Z}$ dalszej analizy wykluczone zostały spółki, w których ze względu na dostępność danych finansowych obliczenie analizowanych wskaźników nie było możliwe. Sytuacja taka dotyczyła następujących spółek:

- w okresie $n_{-2}$ : CP Energia SA, Bipromet SA, Sfinks SA, Techmex SA,

- w okresie $n_{+2}$ : Opoczno $S A$,

- w okresie $n_{+3}$ : Opoczno SA, Comp Rzeszów SA. 


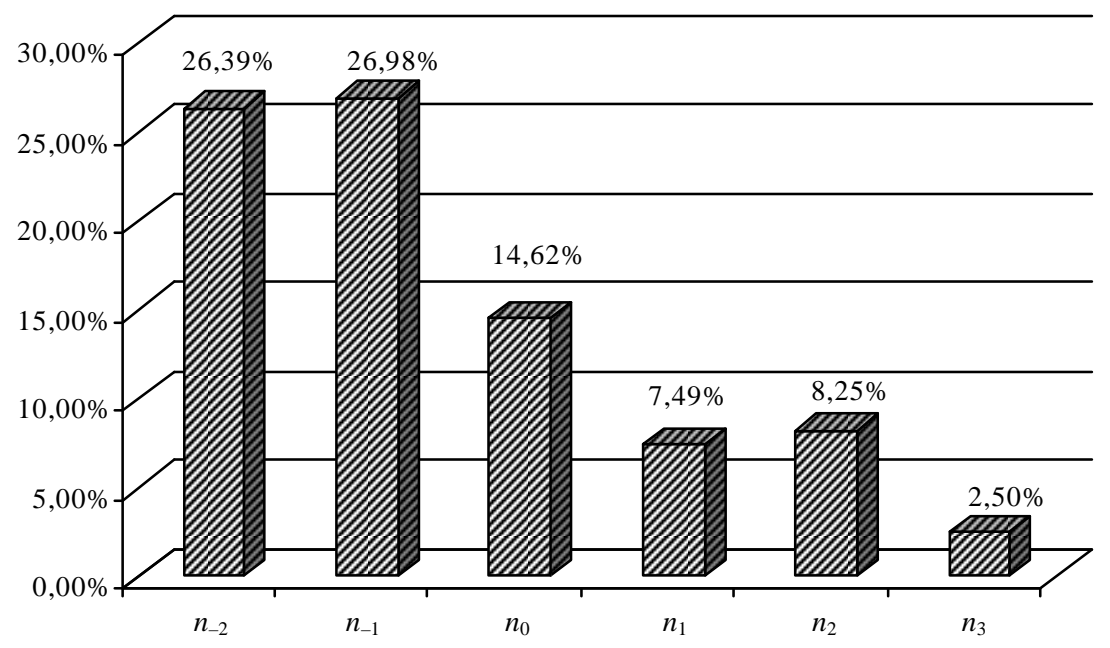

Wykres 4.1. Przeciętne wartości współczynnika rentowności kapitału własnego analizowanych przedsiębiorstw

Ź r ó d ło: opracowanie własne na podstawie sprawozdań finansowych badanych spółek.

Zawarte w tab. 4.2 wartości wybranych miar charakteryzujących wartość współczynników rentowności kapitału własnego badanych podmiotów w kolejnych latach potwierdzają występowanie znaczących zmian analizowanej zmiennej w okresie poprzedzającym debiut giełdowy spółki i po uzyskaniu przez nią statusu spółki publicznej. W latach poprzedzających pierwszą ofertę publiczną spółek portfelowych funduszy private equity, w połowie z nich współczynnik rentowności kapitału własnego był wyższy od $20 \%$. W roku debiutu giełdowego wartość mediany dla badanej zmiennej obniżyła się i wynosiła $14,4 \%$, aby w następnym okresie zmaleć do poziomu 5,9\%. W kolejnych analizowanych latach można zauważyć wzrost wartości mediany w badanej zbiorowości, jednakże jej wartość nie osiągnęła poziomu odnotowanego w roku pierwszego notowania, ani też w okresach go poprzedzających. Pozostałe miary położenia zaprezentowane $\mathrm{w}$ tab. 4.2, charakteryzujące rozkład efektywności wykorzystania kapitału własnego w badanych spółkach także potwierdzają wcześniejsze obserwacje.

Porównując jego wartość w roku poprzedzającym pierwsze notowanie akcji na GPW w Warszawie $\left(n_{-1}\right)$ i w roku następnym po debiucie giełdowym $\left(n_{+1}\right)$ aż w 91,3\% przypadków zaobserwowano spadek wartości analizowanego współczynnika (zob. wykres 4.2). Tylko w dwóch spółkach - Qumak-Sekom SA i $C P$ Energia $S A$ - odnotowano wzrost stopy zwrotu z kapitału własnego. 
Wartości wybranych statystyk opisowych współczynników rentowności kapitału własnego analizowanych przedsiębiorstw

\begin{tabular}{|l|r|r|r|r|r|r|}
\hline \multirow{2}{*}{\multicolumn{1}{|c|}{ Wyszczególnienie }} & \multicolumn{7}{c|}{ Analizowany okres } \\
\cline { 2 - 7 } & \multicolumn{1}{c|}{$n_{-2}$} & \multicolumn{1}{c|}{$n_{-1}$} & \multicolumn{1}{c|}{$n_{0}$} & $n_{+1}$ & $n_{+2}$ & $n_{+3}$ \\
\hline \hline Średnia arytmetyczna & 26,39 & 26,98 & 14,62 & 7,49 & 8,25 & 2,50 \\
\hline Mediana & 20,04 & 22,61 & 14,40 & 5,90 & 7,57 & 9,58 \\
\hline Odchylenie standardowe & 24,41 & 20,58 & 12,51 & 10,15 & 11,74 & 25,64 \\
\hline Kwartyl dolny & 11,82 & 14,70 & 7,29 & $-0,04$ & 0,32 & 3,21 \\
\hline Kwartyl górny & 37,88 & 38,09 & 24,31 & 14,33 & 17,59 & 17,00 \\
\hline Rozstęp kwartylny & 26,06 & 23,40 & 17,02 & 14,36 & 17,27 & 13,79 \\
\hline Minimum & $-10,38$ & $-15,51$ & $-12,74$ & $-7,60$ & $-18,99$ & $-72,41$ \\
\hline Maksimum & 92,65 & 72,97 & 36,88 & 33,33 & 24,51 & 26,82 \\
\hline Liczba spółek & 19 & 23 & 23 & 23 & 21 & 20 \\
\hline
\end{tabular}

Źr ó d ło: jak do tab. 4.1.

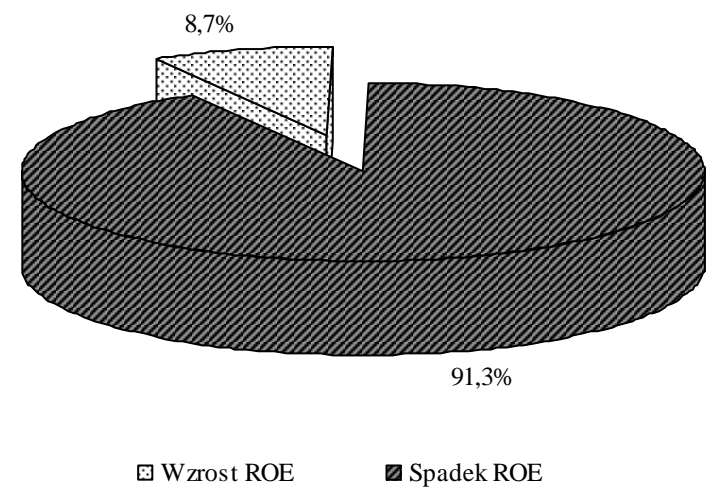

Wykres 4.2. Struktura analizowanych spółek portfelowych funduszy private equity według kierunku zmian współczynnika rentowności kapitału własnego w roku $n_{+1}$ w porównaniu do roku $n_{-1}$

Źr ó d ł o: opracowanie własne.

Dla potwierdzenia statystycznej istotności wyników z zakresie zmian poziomu rentowności kapitału własnego w okresie przed i po debiucie giełdowym przeprowadzony został test istotności różnic wartości średnich $t$-Studenta dla prób zależnych. Mając na uwadze treść hipotezy badawczej postawionej we wstępie rozprawy porównano wyniki otrzymane w okresach $n_{-1}$ oraz $n_{+1}$. 
Zakładając rozkład normalny badanych zmiennych sformułowano hipotezę zerową $H_{0}$ mówiącą o równości średnich:

$$
H_{0}: \mu_{n_{-1}}=\mu_{n_{+1}}
$$

wobec hipotezy alternatywnej $\mathrm{H}_{1}$ :

$$
H_{1}: \mu_{n_{-1}}>\mu_{n_{+1}}
$$

Rezultaty przeprowadzonych badań wskazują, iż istnieją przesłanki do odrzucenia hipotezy zerowej na korzyść hipotezy alternatywnej (zob. tab. 4.3).

Tabela 4.3

\begin{tabular}{|c|c|c|}
\hline Wyszczególnienie & $R O E_{n-1}$ & $R O E_{n+1}$ \\
\hline Średnia & 0,2698 & 0,0749 \\
\hline Wariancja & 0,0424 & 0,0103 \\
\hline Obserwacje & 23 & 23 \\
\hline t Stat & & 4,6427 \\
\hline $\mathrm{P}(\mathrm{T}<=\mathrm{t})$ jednostronny & & 0,0001 \\
\hline Test $\mathrm{T}$ jednostronny & & 1,7171 \\
\hline $\mathrm{P}(\mathrm{T}<=\mathrm{t})$ dwustronny & & 0,0001 \\
\hline Test t dwustronny & & 2,0739 \\
\hline
\end{tabular}

Wyniki testu $t$-Studenta $\mathrm{z}$ dwiema próbami zależnymi dla średnich

Źr ó d ło: jak do tab. 4.1.

Różnice w poziomie rentowności kapitału własnego w rozpatrywanej grupie przedsiębiorstw różnią się zatem w sposób istotny statystycznie. Rentowność kapitału własnego analizowanych spółek jest wyższa przed wprowadzeniem ich do publicznego obrotu w porównaniu z okresem późniejszym.

Na poziom wskaźnika rentowności kapitału własnego wpływ może mieć wiele, bardzo różnorodnych czynników. Rentowność kapitału własnego przedsiębiorstwa związana jest z efektywnością wykorzystania jego majątku, rentownością sprzedaży oraz strukturą pasywów.

Przedstawiony na wykresie 4.3 trójczynnikowy obraz rentowności przedsiębiorstw udziałowych funduszy private equity poddanych dezinwestycji metodą pierwszej oferty publicznej w latach poprzedzających i następujących po uzyskaniu statusu spółki publicznej wskazuje, że w analizowanym okresie największe średnie wartości wszystkich badanych wskaźników rentowności odnotowano w roku poprzedzającym wprowadzenie akcji spółki do publicznego obrotu. 


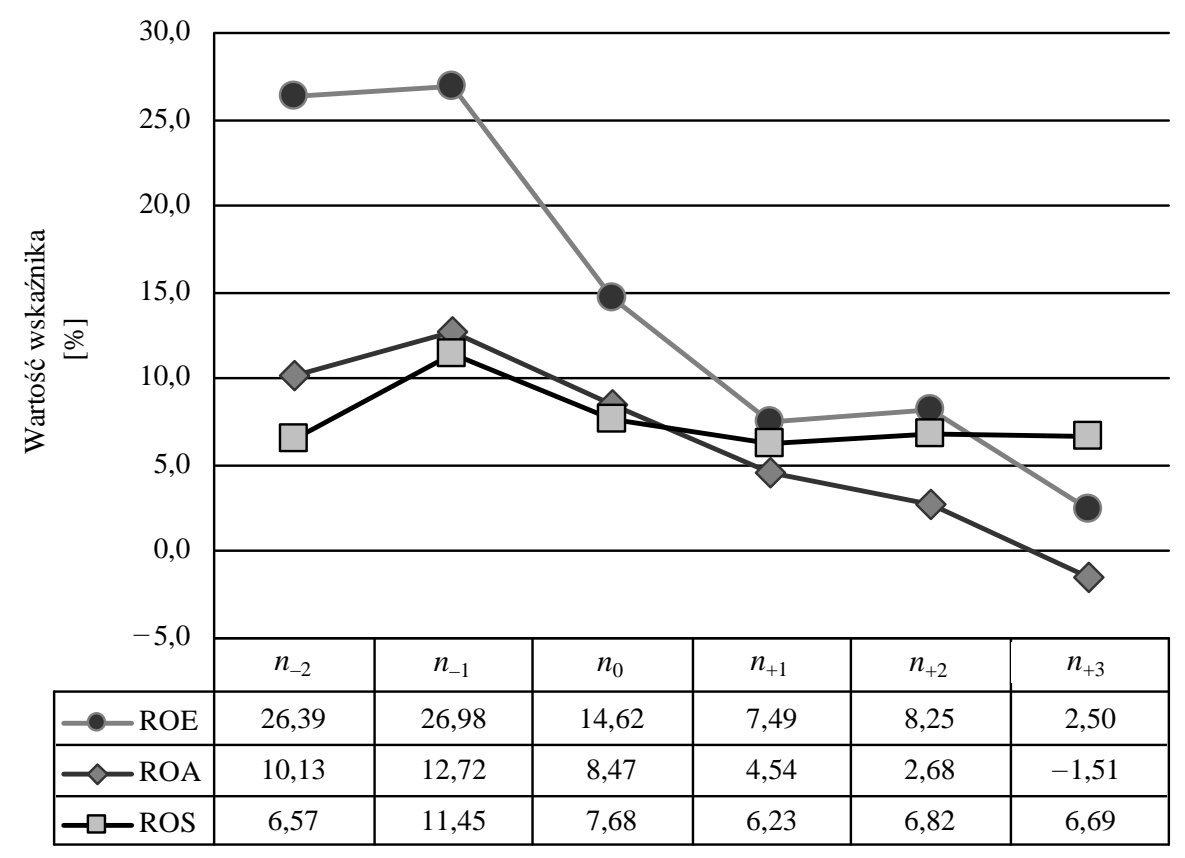

W y kres 4 4.3. Średnie wartości współczynników rentowności kapitału własnego, aktywów oraz sprzedaży badanych spółek portfelowych funduszy private equity

Ź r ó d ł o: opracowanie własne na podstawie sprawozdań finansowych badanych spółek.

Do czasu wprowadzenia akcji spółki do publicznego obrotu zauważalna jest poprawa efektywności zarówno w zakresie sprzedaży, jak i wykorzystania majątku ogółem mierzonego wskaźnikiem ROA. W roku debiutu giełdowego w porównaniu do roku poprzedniego średnie wartości wskaźników rentowności znacznie obniżyły się. Średnia wartość wskaźnika rentowności aktywów we wszystkich kolejnych latach ulegała zmniejszeniu, aby po zakończeniu trzeciego pełnego roku notowań spółek na GPW w Warszawie osiągnąć poziom $-1,51 \%$. Najniższy średni poziom wskaźnika rentowności sprzedaży odnotowano w okresie $n_{+1}$ i wynosił on $6,23 \%$. W kolejnych latach można zaobserwować, iż efektywność prowadzonych procesów sprzedażowych uległa niewielkiej poprawie.

Zmiany poziomu rentowności kapitału własnego mogą być wynikiem zmian struktury i źródeł finansowania prowadzonej działalności. Poziom mnożnika kapitałowego w rozpatrywanych spółkach wykazuje wyraźną tendencję spadkową od roku $n_{-2}$ do roku debiutu giełdowego włącznie. Kiedy mnożnik osiągnął minimum na poziomie 1,75 , nastąpiło odwrócenie trendu i pojawiły się systematyczne przyrosty wartości mnożnika kapitałów w kolejnych okresach (zob. wykres 4.4). 


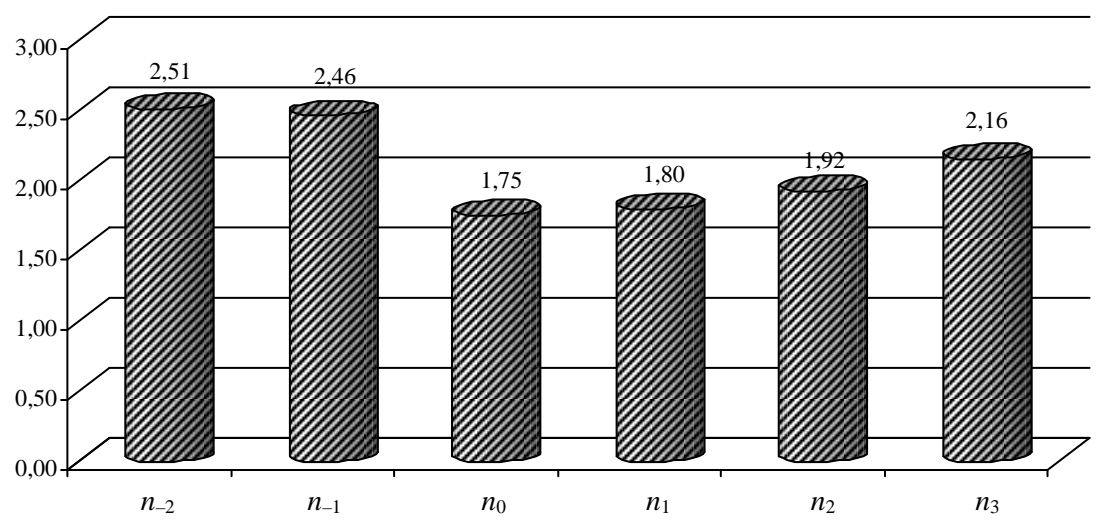

Wykres 4.4. Średnie wartości mnożników kapitałowych analizowanych przedsiębiorstw Źr ód ło: jak do wykresu 4.3 .

W ramach analizy przyczynowej kształtowania się rentowności kapitału własnego w spółkach wyznaczono całkowite bezwzględne zmiany omawianego wskaźnika w kolejnych latach. Zestawienie wybranych statystyk opisowych otrzymanych wyników wskazuje na zróżnicowanie poziomu zmian efektywności kapitału własnego w poszczególnych okresach. Największą zmianę omawianego wskaźnika odnotowano w roku debiutu giełdowego (zob. tab. 4.4).

Tabela 4.4

Odchylenia łączne współczynnika rentowności kapitału własnego badanych spółek

\begin{tabular}{|l|r|r|r|r|r|}
\hline \multirow{2}{*}{ Wyszczególnienie } & \multicolumn{5}{c|}{ Analizowany okres } \\
\cline { 2 - 6 } & \multicolumn{1}{c|}{$n_{-1} / n_{-2}$} & $n_{0} / n_{-1}$ & \multicolumn{1}{c|}{$n_{+1} / n_{0}$} & $n_{+2} / n_{+1}$ & $n_{+3} / n_{+2}$ \\
\hline \hline Średnia arytmetyczna & 2,58 & $-12,35$ & $-7,13$ & 0,44 & $-5,34$ \\
\hline Mediana & 1,71 & $-7,19$ & $-5,44$ & $-0,18$ & 1,14 \\
\hline Odchylenie standardowe & 20,34 & 16,95 & 12,24 & 12,69 & 22,61 \\
\hline Minimum & $-44,47$ & $-49,33$ & $-34,71$ & $-27,30$ & $-72,52$ \\
\hline Maksimum & 56,04 & 5,41 & 20,56 & 23,98 & 23,43 \\
\hline Liczba spółek & 19 & 23 & 23 & 21 & 20 \\
\hline
\end{tabular}

Źr ó d ło: jak do tab. 4.1.

Następnie dla analizowanych podmiotów w kolejnych okresach wyznaczono odchylenie cząstkowe, będące wynikiem zmian badanych zmiennych, tj. rentowności sprzedaży, produktywności aktywów oraz mnożnika kapitałów (zob. tab. 4.5). 
Odchylenia cząstkowe czynników determinujących rentowność kapitału własnego badanych spółek

\begin{tabular}{|c|c|c|c|c|c|}
\hline \multirow[b]{2}{*}{ Wyszczególnienie } & \multicolumn{5}{|c|}{ Analizowany okres } \\
\hline & $n_{-1} / n$ & $n_{0}$ & $n_{+1} /$ & & $n_{+3} /$ \\
\hline \multicolumn{6}{|c|}{ Odchylenie cząstkowe będące wynikiem zmian wskaźnika rentowności sprzedaży } \\
\hline Średnia arytmetyczna & 6,58 & $-2,51$ & $-4,97$ & $-0,15$ & $-1,83$ \\
\hline Mediana & 3,03 & 1,20 & $-2,36$ & $-1,60$ & 1,07 \\
\hline Odchylenie standardowe & 22,32 & 17,45 & 13,65 & 11,80 & 15,59 \\
\hline Minimum & $-33,41$ & $-64,01$ & $-36,07$ & $-32,15$ & $-49,63$ \\
\hline Maksimum & 72,42 & 23,32 & 25,44 & 20,75 & 22,45 \\
\hline \multicolumn{6}{|c|}{ Odchylenie cząstkowe będące wynikiem zmian wskaźnika produktywności majątku } \\
\hline Średnia arytmetyczna & 1,74 & $-4,57$ & $-2,29$ & 0,11 & $-2,58$ \\
\hline Mediana & 0,55 & $-2,38$ & $-1,63$ & $-0,08$ & $-0,27$ \\
\hline Odchylenie standardowe & 6,72 & 14,86 & 3,09 & 3,87 & 5,45 \\
\hline Minimum & $-9,43$ & $-63,20$ & $-11,20$ & $-9,12$ & $-18,82$ \\
\hline Maksimum & 13,59 & 14,54 & 1,06 & 10,92 & 3,27 \\
\hline \multicolumn{6}{|c|}{ Odchylenie cząstkowe będące wynikiem zmian mnożnika kapitałów } \\
\hline Średnia arytmetyczna & $-5,74$ & $-5,27$ & 0,13 & 0,48 & $-0,94$ \\
\hline Mediana & $-2,05$ & $-2,93$ & 0,02 & 0,27 & $-0,20$ \\
\hline Odchylenie standardowe & 9,66 & 7,25 & 0,85 & 1,17 & 5,02 \\
\hline Minimum & $-26,79$ & $-19,72$ & $-2,54$ & $-1,17$ & $-18,41$ \\
\hline Maksimum & 3,96 & 4,98 & 1,26 & 3,89 & 9,56 \\
\hline
\end{tabular}

Źr ó d ło: jak do tab. 4.1.

Analizując dane zawarte w tab. 4.5 można zauważyć, iż na wzrost średniego wskaźnika rentowności kapitału własnego w roku poprzedzającym debiut giełdowy pozytywny wpływ miały zmiany poziomu rentowności sprzedaży oraz produktywności aktywów. Odchylenie cząstkowe, będące wynikiem zmian mnożnika kapitałowego, wskazuje na zmniejszenie rentowności kapitału własnego średnio o 5,74 punktów procentowych (p.p.). W roku debiutu giełdowego zauważalny jest największy spośród wszystkich analizowanych okresów spadek rentowności kapitałów własnych - o 12,35 p.p. Został on wywołany zmianami wszystkich branych pod uwagę zmiennych. W kolejnym roku na zmniejszenie wartości wskaźnika rentowności kapitału własnego wpływ miały rentowność sprzedaży $(-4,97$ p.p.) oraz produktywność aktywów (-2,29 p.p.) (zob. wykres 4.5$)$.

Po drugim pełnym roku publicznych notowań spółek, wobec których fundusze private equity wykorzystały publiczną ofertę sprzedaży akcji jako metodę 
wyjścia z inwestycji, zauważyć można niewielkie, aczkolwiek pozytywne zmiany średniego poziomu rentowności kapitału własnego. Jednakże w ostatnim analizowanym okresie wśród rozpatrywanych podmiotów ponownie odnotowano spadek rentowności kapitału własnego. Łączne odchylenie badanego współczynnika na poziomie $-5,34$ p.p. było spowodowane wystąpieniem negatywnych zmian wszystkich czynników wziętych pod uwagę w badaniu.

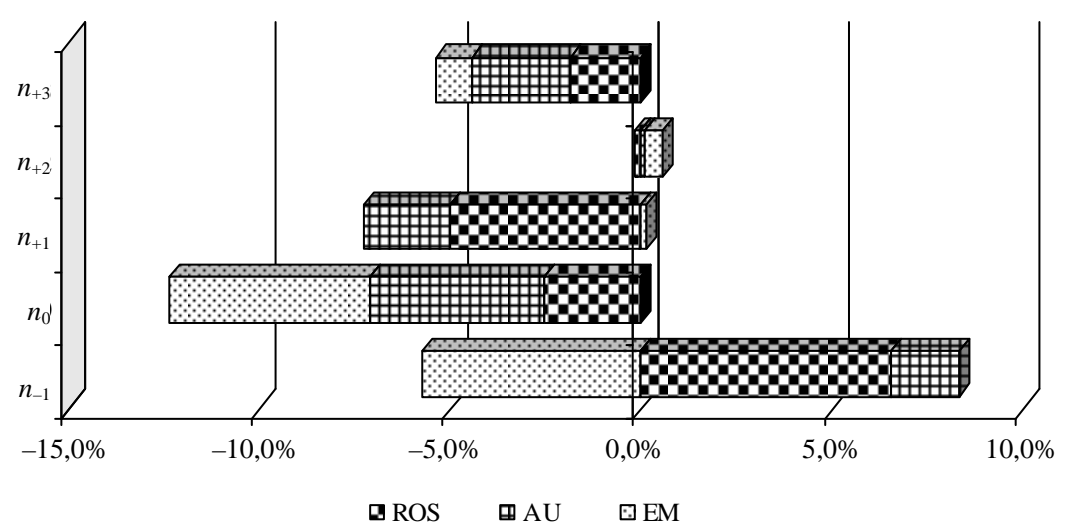

Wykres 4.5. Wpływ zmian rentowności sprzedaży, produktywności aktywów oraz mnożnika kapitałów na rentowność kapitału własnego analizowanych spółek

Ź ród ło: jak do wykresu 4.3.

Zmiany poziomu rentowności kapitału własnego analizowanych podmiotów są efektem łącznego wpływu zarówno zmiennych związanych z operacyjną sprawnością prowadzonej działalności, jak i zmian w zakresie struktury i źródeł finansowania. Kierunek i siła wpływu tych czynników były zróżnicowane w poszczególnych latach.

\subsection{Koszty przeprowadzenia pierwszych ofert publicznych}

Przygotowanie i przeprowadzenie pierwszej oferty publicznej związane jest z koniecznością poniesienia szeregu kosztów, które na ogół nie występują w przypadku realizacji dezinwestycji funduszu private equity przy zastosowaniu innych metod. Wysokość kosztów związanych z wprowadzeniem akcji spółki do publicznego obrotu może stanowić barierę dla wielu przedsiębiorstw udziałowych i znacząco wpływać na osiąganą przez fundusz private equity stopę zwrotu z zainwestowanego kapitału. 
Na łączne koszty przeprowadzenia pierwszej oferty publicznej składa się wiele różnorodnych grup kosztów, które można oceniać z wykorzystaniem różnych przekrojów analitycznych ${ }^{11}$. Z punktu widzenia celu badań koszty przeprowadzenia pierwszej oferty publicznej można podzielić na dwie główne grupy ${ }^{12}$ :

- koszty bezpośrednie - związane głównie z koniecznością ponoszenia wydatków na rzecz podmiotów zewnętrznych zaangażowanych w proces wprowadzania spółki do publicznego obrotu np. banków inwestycyjnych, audytorów oraz różnego rodzaju opłat administracyjnych,

- koszty pośrednie - przejawiające się w postaci niedowartościowania akcji oferowanych w ramach pierwszej oferty publicznej.

Wysokość kosztów bezpośrednich jest stosunkowo łatwa do oszacowania na etapie planowania publicznej oferty akcji, gdyż wynika głównie z umów o świadczenie określonego rodzaju usług bądź świadczeń oraz regulacji administracyjno-prawnych. Z kolei określenie pełnej wartości kosztów pośrednich możliwe jest dopiero po przeprowadzeniu oferty, a oddziaływanie spółki i jej akcjonariuszy na ich wysokość jest w znacznej mierze ograniczone.

Koszty pośrednie są kosztem rozumianym jako koszt utraconych możliwości $^{13}$. Natomiast koszty bezpośrednie ponoszone $\mathrm{w}$ związku z pierwszą publiczną ofertą akcji należą do grupy kosztów explicite. Dzięki odzwierciedleniu kosztów bezpośrednich w systemach rachunkowości przedsiębiorstw informacje o ich poziomie są możliwe do uzyskania. Stanowią one koszt w ujęciu księgowym, a obowiązki informacyjne w zakresie ponoszonych kosztów emisji i sprzedaży papierów wartościowych w związku z realizacją publicznych ofert sprzedaży akcji regulowane są przepisami prawa. Obecnie zgodnie z rozporządzeniem Ministra Finansów spółki, których akcje wprowadzane są do publicznego obrotu mają obowiązek przedstawiania łącznych kosztów emisji w podziale na przynajmniej następujące grupy ${ }^{14}$ :

a) przygotowania i przeprowadzenia oferty,

b) wynagrodzenia subemitentów, dla każdego oddzielnie,

c) sporządzenia prospektu emisyjnego, z uwzględnieniem kosztów doradztwa,

d) promocji oferty.

${ }^{11}$ Zob. J. S. Ang, J. C. B rau, Firm Transparency And The Costs Of Going Public, „The Journal of Financial Research", Spring 2002, Vol. XXV, No. 1, s. 4-5.

${ }^{12}$ J. R. Ritter, The Costs of Going Public, „Journal of Financial Economics”, North-Holland 1987, Vol. 19, s. 269.

${ }^{13}$ D. S u k a c z, Pierwsze oferty publiczne na rynkach kapitałowych, Wydawnictwa Fachowe CeDeWu.pl, Warszawa 2005, s. 46.

${ }^{14} \S 33$ ust. 1, pkt 12 Rozporządzenia Ministra Finansów z dnia 19 lutego 2009 r. w sprawie informacji bieżacych i okresowych przekazywanych przez emitentów papierów wartościowych oraz warunków uznawania za równoważne informacji wymaganych przepisami prawa państwa niebędącego państwem członkowskim, DzU 2009, nr 33, poz. 259. 
Ponadto podmioty te zobowiązane są do przedstawienia metod rozliczenia tych kosztów w księgach rachunkowych i sposobu ich ujęcia w sprawozdaniu finansowym ${ }^{15}$.

W literaturze przedmiotu spotkać można również inną klasyfikację kosztów wprowadzenia akcji spółki do publicznego obrotu, zwłaszcza z punktu widzenia podmiotów realizujących procesy dezinwestycji. Łączne koszty transakcyjne pierwszej oferty publicznej składają się z trzech grup kosztów, a mianowicie ${ }^{16}$ :

- kosztów pośrednictwa,

- kosztów presji cenowej oraz

- kosztów wszelkiej sygnalizacji.

Pierwsza wymieniona grupa kosztów wynika z zaangażowania podmiotów trzecich w proces realizacji oferty publicznej i może być sensu largo utożsamiana z opisanymi wcześniej kosztami bezpośrednimi. Koszty presji cenowej oraz koszty wszelkiej sygnalizacji nie znajdują bezpośredniego odzwierciedlenia w ewidencji księgowej, a wyrażają się one przez wpływ na obniżenie ceny, po jakiej akcje spółki są sprzedawane inwestorom w ramach oferty publicznej.

O występowaniu kosztów presji cenowej można mówić wtedy, gdy sprzedający akcje zmuszeni są do obniżenia ceny sprzedaży akcji na rynku pierwotnym do poziomu umożliwiającego wykreowanie takiego popytu, który umożliwi sprzedaż oczekiwanej ilości oferowanych papierów wartościowych. Prawdopodobieństwo powstania tego kosztu zależy od relatywnego rozmiaru zbywanych pakietów akcji. Presja cenowa może być tym większa, im większa część akcji spółki oferowana jest w ramach oferty ${ }^{17}$.

Koszt sygnalizacji powstaje, kiedy inwestorzy giełdowi łączą sprzedaż akcji przez dotychczasowych właścicieli spółki z faktem posiadania przez nich prywatnych informacji o danym przedsiębiorstwie. W opinii publicznej zbycie akcji spółki przez insiderów może być odebrane jako negatywny sygnał o kondycji finansowej emitenta i jego perspektywach rozwoju, a co za tym idzie pojawić się może presja na obniżenie ceny po jakiej akcje będą oferowane w ramach pierwszej oferty publicznej ${ }^{18}$.

Bez wątpienia tego rodzaju klasyfikacja kosztów realizacji pierwszej oferty publicznej jest bardzo atrakcyjna poznawczo. Nie może być ona jednak wykorzystana $w$ prowadzonych badaniach empirycznych ze względu na nieprzystawalność istniejącego w przedsiębiorstwach systemu rachunku kosztów do zarządzania kosztami pośrednictwa, kosztami presji cenowej oraz kosztami wszelkiej

15 Ibidem.

${ }^{16}$ D. J. C u m ming, J. G. M a c In to sh, Venture-capital exits in Canada and United States, „University of Toronto Law Journal” 2003, s. 129.

${ }^{17}$ Ibidem, s. 130.

${ }^{18}$ Ibidem, s. 130. 
sygnalizacji. Z tego względu w rozprawie do oceny kosztów realizacji pierwszej oferty publicznej zostało wykorzystane podejście J. R. Rittera.

\subsubsection{BEZPOŚREDNIE KOSZTY PIERWSZYCH OFERT PUBLICZNYCH SPÓŁEK PORTFELOWYCH FUNDUSZY PRIVATE EQUITY}

Na koszty bezpośrednie związane z przeprowadzeniem pierwszej oferty publicznej składają się przede wszystkim wynagrodzenie podmiotu oferującego i doradców, koszty związane z marketingiem i promocją oferty publicznej oraz opłaty sądowe i administracyjne ${ }^{19}$. Ze względu na fakt, iż część tych kosztów ma charakter względnie stały, a ich relatywna wielkość jest tym mniejsza im większa jest wartość publicznej oferty sprzedaży akcji spółki można mówić o występowaniu pewnego rodzaju efektu skali. Świadczy o nim zmniejszanie się względnego średniego kosztu realizacji publicznej oferty sprzedaży akcji spółek krajowych na rynku głównym GPW w Warszawie wraz ze wzrostem wartości oferty (zob. wykres 4.6).

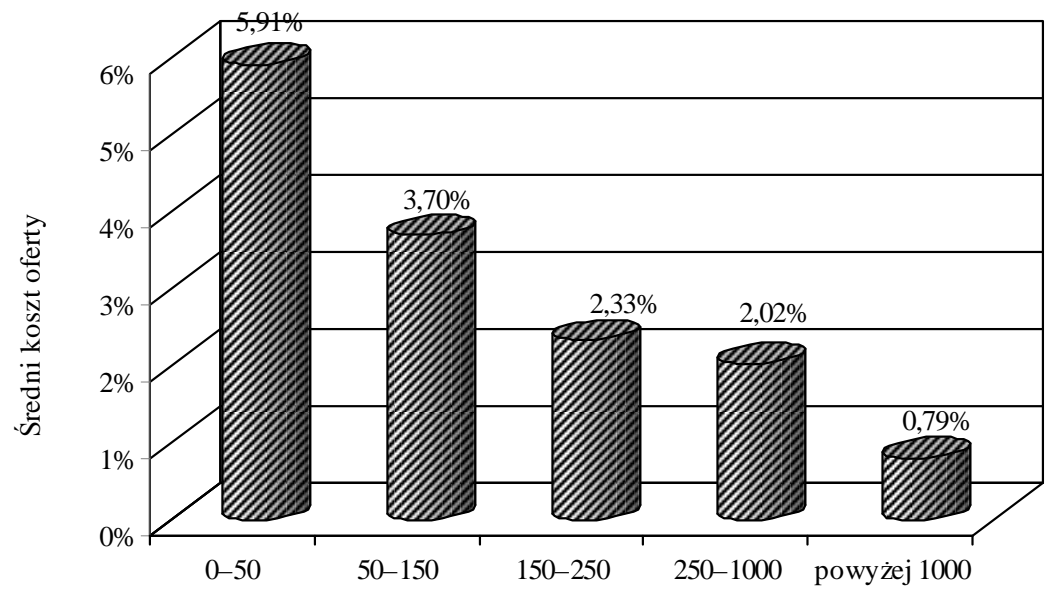

Wartość oferty

Wykres 4.6. Średni koszt oferty spółek krajowych na rynku głównym GPW w Warszawie w stosunku do wartości oferty w latach 2003-2010 (bez kosztów subemisji)

Ź r ó d ł o: Droga na giełdę, PricewaterhouseCoopers 2011, http://www.pwc.pl/pl/publikacje/ droga-na-gielde.jhtml, s. 19.

${ }^{19}$ Droga na gietdę, PricewaterhouseCoopers 2011, http://www.pwc.pl/pl/publikacje/drogana-gielde.jhtml, s. 19. 
Część kosztów ponoszonych w związku z realizacją publicznych ofert sprzedaży akcji ma charakter zmienny i wynika bezpośrednio z umów zawartych na warunkach rynkowych pomiędzy emitentem i wprowadzającym a domem maklerskim lub agencją public relations. Z kolei wysokość opłat związanych z realizacją procedur dopuszczenia i wprowadzenie papierów wartościowych do publicznego obrotu na rzecz GPW w Warszawie, Krajowego Depozytu Papierów Wartościowych oraz Komisji Nadzoru Finansowego jest określana regulaminami tych instytucji i aktami prawnymi (zob. tab. 4.6).

Tabela 4.6

Wysokość opłat na rzecz GPW w Warszawie, Krajowego Depozytu Papierów Wartościowych oraz Komisji Nadzoru Finansowego w związku z realizacją publicznej oferty sprzedaży akcji

\begin{tabular}{|c|c|c|c|}
\hline \multirow{2}{*}{ Instytucja } & \multirow{2}{*}{ Rodzaj opłaty } & \multicolumn{2}{|c|}{ Wysokość opłat } \\
\hline & & Rynek podstawowy & Rynek równoległy \\
\hline \multirow{6}{*}{$\begin{array}{l}\text { GPW } \\
\text { w Warszawie }\end{array}$} & $\begin{array}{l}\text { Opłata za wprowadzenie akcji do } \\
\text { obrotu giełdowego }\end{array}$ & $\begin{array}{l}0,03 \% \text { wartości emisyj- } \\
\text { nej (sprzedaży), } \\
\text { nie mniej niż } 8000 \mathrm{zł} \\
\text { i nie więcej niż } 96000 \mathrm{zł}\end{array}$ & $3000 \mathrm{zł}$ \\
\hline & $\begin{array}{l}\text { Opłata za wprowadzenie do } \\
\text { obrotu giełdowego PDA }\end{array}$ & $3000 \mathrm{zł}$ & $2000 \mathrm{zł}$ \\
\hline & $\begin{array}{l}\text { Opłaty za dopuszczenie akcji do } \\
\text { obrotu giełdowego }\end{array}$ & $3000 \mathrm{zł}$ & $2000 \mathrm{zł}$ \\
\hline & $\begin{array}{l}\text { Opłata za złożenie wniosku } \\
\text { o dopuszczenie papierów warto- } \\
\text { ściowych do obrotu giełdowego }\end{array}$ & $3000 \mathrm{zł}$ & $1000 \mathrm{zł}$ \\
\hline & Opłata roczna za notowanie akcji & $\begin{array}{l}\text { 0,02\% wartości rynko- } \\
\text { wej, nie mniej niż } \\
9000 \mathrm{zł} \mathrm{i} \mathrm{nie} \mathrm{więcej} \mathrm{niż} \\
70000 \mathrm{zł}\end{array}$ & $\begin{array}{l}0,02 \% \text { wartości ryn- } \\
\text { kowej, nie mniej niż } \\
3000 \mathrm{zł} \mathrm{i} \mathrm{nie} \mathrm{więcej} \\
\text { niż } 8000 \mathrm{zł}\end{array}$ \\
\hline & Opłata roczna za notowanie PDA & $3000 \mathrm{zl}$ & $2000 \mathrm{zl}$ \\
\hline \multirow{3}{*}{$\begin{array}{l}\text { Krajowy } \\
\text { Depozyt } \\
\text { Papierów } \\
\text { Wartościowych }\end{array}$} & Opłata za uczestnictwo emitenta & \multicolumn{2}{|l|}{$6000 \mathrm{zl}$} \\
\hline & Opłata z tytułu rejestracji akcji & \multicolumn{2}{|c|}{$\begin{array}{l}0,01 \% \text { wartości rynkowej, lecz nie mniej niż } \\
3000 \text { i nie więcej niż } 100000 \text { zł }\end{array}$} \\
\hline & Opłata z tytułu rejestracji PDA & \multicolumn{2}{|c|}{$\begin{array}{l}0,001 \% \text { wartości rynkowej, lecz nie mniej niż } \\
300 \text { zł i nie więcej niż } 10000 \mathrm{zł}\end{array}$} \\
\hline $\begin{array}{l}\text { Komisja } \\
\text { Nadzoru } \\
\text { Finansowego }\end{array}$ & $\begin{array}{l}\text { Opłata z tytułu wpisu do ewiden- } \\
\text { cji papierów wartościowych }\end{array}$ & \multicolumn{2}{|c|}{$\begin{array}{l}0,03 \% \text { wartości instrumentów finansowych } \\
\text { objętych daną ofertą publiczną nie większej } \\
\text { jednak niż równowartość w złotych } 12500 \\
\text { euro. }\end{array}$} \\
\hline
\end{tabular}

Ź r ó d ł o: opracowanie własne na podstawie Załącznik nr 2 i 3 do Regulaminu Giełdy (według stanu prawnego na dzień 20 czerwca 2012 r.), Załącznik nr 1 do Regulaminu Krajowego Depozytu Papierów Wartościowych (stan prawny na dzień 2 lipca 2012 r.), Rozporządzenie Ministra Finansów z dnia 16 marca 2010 r. w sprawie optat wnoszonych na rzecz. Komisji Nadzoru Finansowego przez podmioty nadzorowane prowadzace działalność na rynku kapitatowym, DzU 2010, nr 57, poz. 364. 
Przeprowadzona analiza bezpośrednich kosztów pierwszych publicznych ofert sprzedaży akcji spółek portfelowych funduszy private equity uwidoczniła szereg problemów utrudniających prowadzenie badań empirycznych.

Większość emitentów nie podawała w komunikatach podsumowujących ofertę, czy prezentowane wielkości poniesionych kosztów prezentowane są w wartości netto czy brutto. Spółki Magellan $S A$ oraz $A B S A$ podały zarówno wartości netto, jak i brutto. Z kolei spółka HTL Strefa SA do publicznej wiadomości przekazała wartość poniesionych kosztów oferty tylko w kwocie netto. Ostatecznie w badaniach uwzględniona została wartość kosztów w kwocie wykazanej w komunikacie podsumowującym ofertę publiczną akcji spółki lub w wartości netto, jeżeli taka informacja była dostępna.

Kolejną barierą w badaniach nad bezpośrednimi kosztami ofert publicznych analizowanych spółek był w przeważającej większości wypadków brak informacji o tym, czy raportowana wielkość kosztów obciąża wyłącznie emitenta czy również wprowadzającego oraz jaki jest stopień partycypacji poszczególnych podmiotów w łącznych kosztach oferty.

W przypadku ofert akcji W. KRUK SA oraz Sfinks $S A$ nie udało się dotrzeć do informacji o kosztach z nimi związanymi, a spółka $L S I$ Software SA nie przekazała informacji o metodzie rozliczania kosztów oferty w księgach rachunkowych.

Wprowadzenie po raz pierwszy akcji do publicznego obrotu spółek portfelowych funduszy private equity w latach 2002-2010 wiązało się z koniecznością poniesienia kosztów publicznej oferty sprzedaży akcji przekraczających średnio ponad 2 mln zł. W większości przypadków łączna wartość kosztów oferty kształtowała się na poniżej średniej, o czym świadczy prawostronna asymetria rozkładu tego kosztu wśród badanych podmiotów (zob. tab. 4.7).

Tabela 4.7

Wartość wybranych statystyk opisowych kosztów pierwszych ofert publicznych spółek portfelowych funduszy private equity w latach 2002-2010

\begin{tabular}{|l|r|r|r|}
\hline \multicolumn{1}{|c|}{ Wyszczególnienie } & $\begin{array}{c}\text { Łączna wartość } \\
\text { kosztów oferty }\end{array}$ & $\begin{array}{c}\text { Średni koszt przeprowa- } \\
\text { dzenia oferty na jednost- } \\
\text { kę papieru wartościowe- } \\
\text { go objętego subskrypcją }\end{array}$ & $\begin{array}{c}\text { Stosunek kosztów } \\
\text { oferty publicznej do } \\
\text { jej wartości }\end{array}$ \\
\hline \hline Średnia arytmetyczna & 2084093,93 & 1,39 & 0,0462 \\
\hline Odchylenie standardowe & 2595462,15 & 2,35 & 0,0333 \\
\hline Kwartyl dolny & 986189,61 & 0,28 & 0,0225 \\
\hline Mediana & 1258932,22 & 0,57 & 0,0333 \\
\hline Kwartyl górny & 2285883,20 & 1,30 & 0,0615 \\
\hline Minimum & 450124,00 & 0,09 & 0,0084 \\
\hline Maksimum & 13266177,58 & 11,50 & 0,1292 \\
\hline Liczba spółek & 24 & 24 & 24 \\
\hline
\end{tabular}

Ź r ó d ł o: opracowanie własne na podstawie raportów bieżących spółek. 
Analiza kosztu upublicznienia spółki wyrażonego jako udział kosztów pierwszej oferty publicznej $\mathrm{w}$ wartości zrealizowanej oferty sprzedaży akcji wskazuje, iż w grupie analizowanych podmiotów udział ten kształtował się średnio na poziomie $4,62 \%$, a w przypadku połowy badanych ofert kształtował się na poziomie poniżej 3,33\% (zob. tab. 4.7). Najniższy wskaźnik udziału odnotowany został $\mathrm{w}$ przypadku pierwszej oferty publicznej spółki COMP Rzeszów SA i nie przekraczał nawet $1 \%$. Najwyższy stosunek kosztów oferty do wartości oferowanych akcji zaobserwowany został podczas wprowadzenia po raz pierwszy do publicznego obrotu akcji spółki Travelplanet.pl i wynosił on 12,92\% (zob. wykres 4.7).

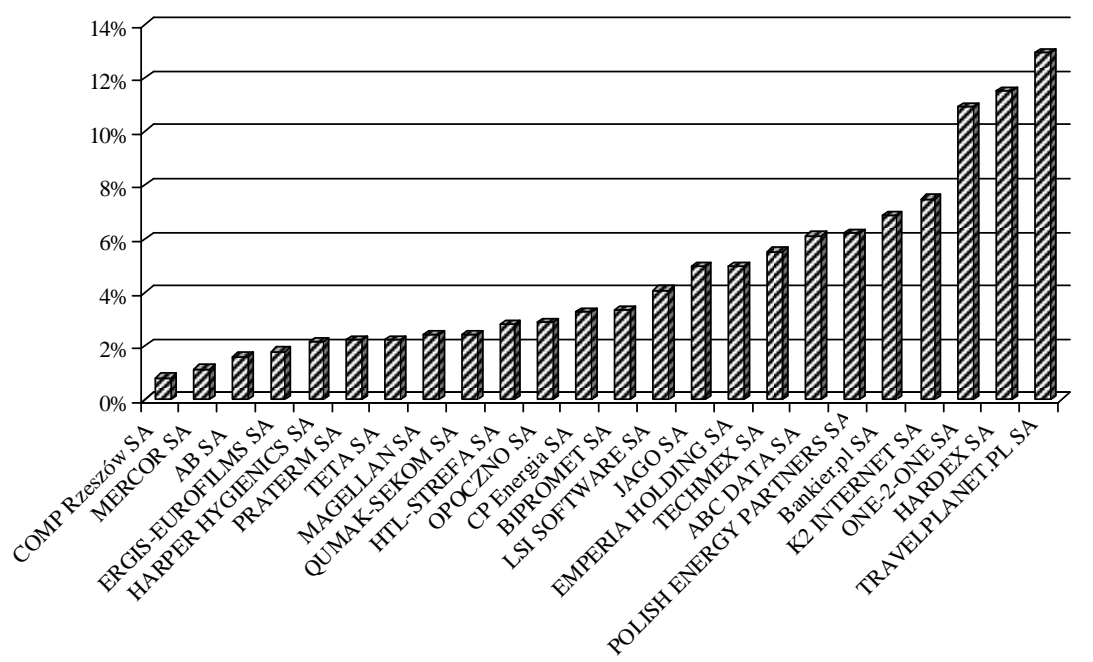

Wykres 4.7. Stosunek kosztów pierwszej oferty publicznej do jej wartości w spółkach portfelowych funduszy private equity w latach 2002-2010

Ź r ó d ł o: opracowanie własne na podstawie raportów bieżących spółek.

Analiza kosztów bezpośrednich wprowadzenia spółek portfelowych funduszy private equity na GPW w Warszawie wykazała także, iż w tej grupie podmiotów również można mówić o występowaniu pewnego rodzaju efektów skali. Z większymi publicznymi ofertami sprzedaży akcji związany był mniejszy względny koszt ich realizacji (zob. wykres 4.8).

Analiza struktury kosztów bezpośrednich upublicznienia badanych spółek pozwala dostrzec, iż niemal połowę stanowią koszty związane z przygotowaniem i przeprowadzeniem oferty. Istotną część środków pochłaniają również wydatki związane ze sporządzeniem prospektu emisyjnego, z uwzględnieniem przy tym kosztów doradztwa (zob. wykres 4.9). 


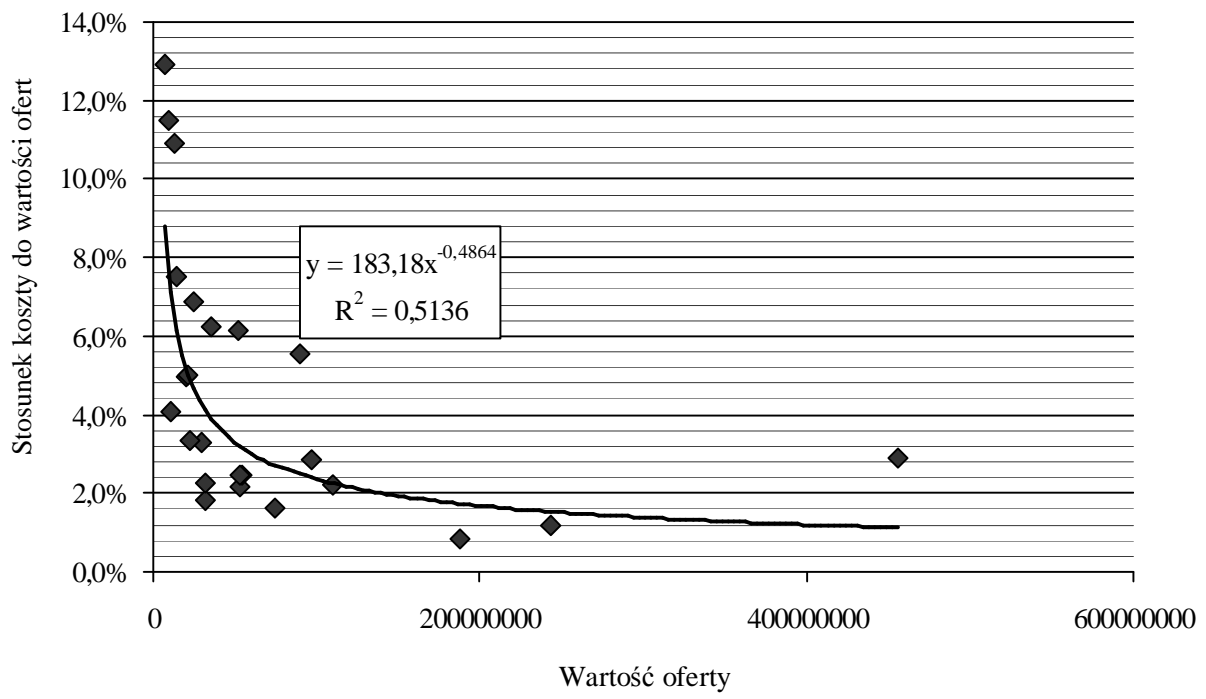

Wykres 4.8. Rozkład linii dopasowania względnego kosztu pierwszych ofert publicznych spółek portfelowych funduszy private equity na GPW w Warszawie w latach 2002-2010 do wartości oferty

Źr ód ło: jak do wykresu 4.7.

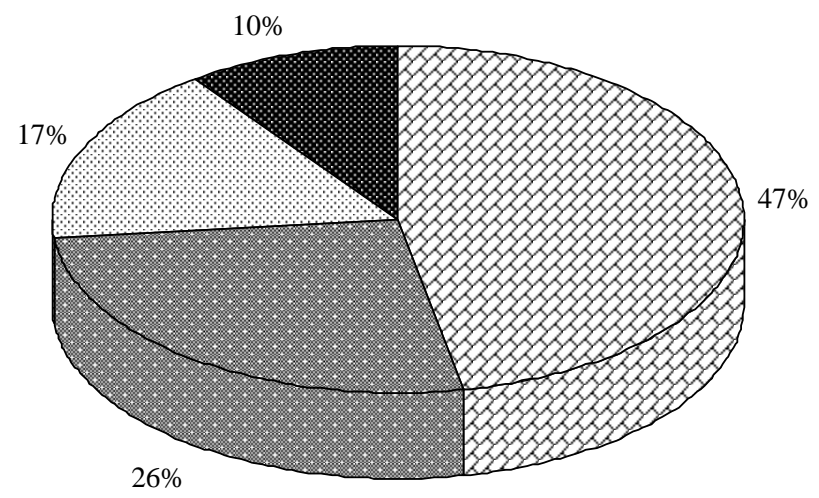

$\varangle$ Koszty przygotowania i przeprowadzenia oferty

圆 Koszty sporządzenia prospektu emisyjnego (z uwzględnieniem kosztów doradztwa)

圆 Koszty promocji oferty

Inne koszty

Wykres 4.9. Struktura kosztów pierwszych ofert publicznych spółek portfelowych funduszy private equity w latach 2002-2010

Źr ód ło: jak do wykresu 4.7. 
Podsumowując analizę wyodrębnionych kategorii kosztów bezpośrednich pierwszych ofert publicznych badanych spółek w wartościach absolutnych można zauważyć, iż średni koszt przygotowania i przeprowadzenia oferty wynosił ponad 980 tys. zł. Średni koszt sporządzenia prospektu emisyjnego wraz z kosztami doradztwa to wydatek przekraczający 550 tys. zł, a na promocję oferty przeznaczono średnio niespełna 350 tys. zł. (zob. tab. 4.8). Tylko cztery spółki podały informacje o występowaniu innych kosztów.

Tabela 4.8

Wartość wybranych statystyk opisowych poszczególnych rodzajów kosztów pierwszych ofert publicznych spółek portfelowych funduszy private equity w latach 2002-2010

\begin{tabular}{|l|r|r|r|r|}
\hline \multicolumn{1}{|c|}{ Wyszczególnienie } & $\begin{array}{c}\text { Koszty } \\
\text { przygotowania } \\
\text { i przeprowadzenia } \\
\text { oferty }\end{array}$ & $\begin{array}{c}\text { Koszty } \\
\text { sporządzenia } \\
\text { prospektu } \\
\text { emisyjnego } \\
\text { (z uwzględnie- } \\
\text { niem kosztów } \\
\text { doradztwa) }\end{array}$ & Koszty promocji \\
oferty & Inne koszty & \\
\hline \hline Średnia arytmetyczna & 980652,50 & 550490,15 & 345471,23 & 207480,10 \\
\hline Odchylenie standardowe & 841700,49 & 681298,38 & 574326,43 & 967569,31 \\
\hline Kwartyl dolny & 472339,95 & 224492,00 & 139842,95 & 0,00 \\
\hline Mediana & 667139,01 & 345313,42 & 210690,00 & 0,00 \\
\hline Kwartyl górny & 1232778,25 & 593396,31 & 268547,00 & 0,00 \\
\hline Minimum & 163095,00 & 131559,86 & 7676,00 & 0,00 \\
\hline Maksimum & 3624640,00 & 3448587,18 & 2919734,56 & 4747999,84 \\
\hline
\end{tabular}

Źr ó d ło: jak do tab. 4.7.

Badane jednostki informowały $w$ raportach podsumowujących pierwsze oferty publiczne, iż w większości przypadków koszty upublicznienia spółki pomniejszyły ich kapitał zapasowy (17 spółek), zgodnie z zapisami Ustawy o rachunkowości $i^{20}$. W przypadku 3 spółek koszty te zostały zapisane w ciężar kosztów działalności. Spółka Emperia Holding SA (występująca wówczas jako Eldorado $S A$ ) poinformowała, że koszty oferty publicznej zostały ujęte w księgach rachunkowych spółki jako wartości niematerialne i prawne i będą amortyzowane w okresie 5-letnim. Z kolei w spółce Bipromet SA koszty pierwszej oferty publicznej pomniejszyły zyski zatrzymane, a spółka $C P$ Energia $S A$ o wartość tych kosztów pomniejszyła kapitał rezerwowy.

W większości analizowanych transakcji badane spółki nie przekazały do publicznej wiadomości informacji o tym, jaka część kosztów związanych

${ }^{20}$ Art. 36 ust. 29 Ustawy z dnia 29 września 1994 r. o rachunkowości, DzU 1994, nr 12, poz. 591 z późn. zm. 
z przeprowadzeniem pierwszej oferty publicznej obciąża emitenta, a jaka część tych kosztów została poniesiona przez wprowadzających akcje do obrotu publicznego. W przypadkach, gdzie podana była wysokość kosztów poniesionych przez wprowadzających (np. Mercor SA, Bankier.pl SA, CP Energia SA, Polish Energy Partners $S A$ ) nie podano informacji w jakiej kwocie koszty te obciążają fundusze private equity zbywające akcje w ramach oferty, a jaka ich część przypada na pozostałych wprowadzających.

\subsubsection{POŚREDNIE KOSZTY PIERWSZYCH OFERT PUBLICZNYCH SPÓŁEK PORTFELOWYCH FUNDUSZY PRIVATE EQUITY}

\subsubsection{Eksplikacja niedowartościowania pierwszych ofert publicznych w literaturze przedmiotu}

Podejmując decyzję o realizacji dezinwestycji przez wprowadzenie akcji spółki do publicznego obrotu i ich sprzedaży za pośrednictwem rynku giełdowego dotychczasowi właściciele muszą rozważyć wiele, bardzo istotnych kwestii rzutujących na rozwój przedsiębiorstwa w przyszłości. Zasadniczym problemem wydaje się ustalenie ceny, po jakiej akcje spółki zostaną zaoferowane inwestorom na rynku pierwotnym. $Z$ punktu widzenia funduszu cena, po jakiej akcje zostaną wprowadzone do obrotu bezpośrednio może wpływać na wysokość zrealizowanego zysku kapitałowego oraz osiąganej stopy zwrotu z inwestycji. Dla spółki portfelowej może to być jedna $\mathrm{z}$ głównych determinant przyszłej struktury właścicielskiej przedsiębiorstwa oraz alokacji praw korporacyjnych w spółce ${ }^{21}$.

Powszechnie obserwowane jest zjawisko niedowartościowania, polegające na tym, iż w pierwszym dniu notowań giełdowych w licznych przypadkach kurs akcji debiutujących spółek w znaczny sposób wzrasta w porównaniu do ceny emisyjnej $^{22}$. Liczne badania naukowe potwierdzają, iż w statystycznie znaczący sposób inwestorzy są w stanie uzyskiwać ponadprzeciętne stopy zwrotu nabywając akcje w ofertach publicznych, na wielu rynkach i w długich okresach ${ }^{23}$.

${ }^{21}$ L. C. Fi eld, D. P. S hee ha n, IPO underpricing and outside blockholdings, ,Journal of Corporate Finance" 2004, Vol. 10, s. 265.

${ }^{22}$ Zob. A. Lju ng q vis st, IPO underpricing, [w:] B. E. Eck k o (red.), Handbook of Corporate Finance: Empirical Corporate Finance, Vol. A, Chapter 7, 2006, s. 8-10; T. Loughran, J. R. R it t e r, K. R y d q v i st, Initial public offerings: International insights, „Pacific-Basin Finance Journal" 1994, Vol. 2, s. 165-199; T. J. B o u 1 t o n, S. B. S m a r t, C. J. Zu t t e r, IPO underpricing and international corporate governance, ,Journal of International Business Studies” 2010, Vol. 41, s. 206-222.

${ }^{23}$ D. S u ka c z, Pierwsze oferty publiczne na rynkach kapitałowych, CeDeWu.pl, Warszawa 2005, s. 82. 
W literaturze przedmiotu formułowane są liczne teorie mające na celu wyjaśnienie, dlaczego pierwotni właściciele spółek wprowadzanych na rynek giełdowy, mając świadomość systematycznego niedowartościowania akcji oferowanych $w$ ramach pierwszych ofert publicznych, godzą się na transfer własnego bogactwa w postaci tzw. pieniędzy pozostawionych na stole (ang. money left on the table). Do najważniejszych podejść wyjaśniających zjawisko niedowartościowania pierwszych ofert publicznych należą teorie formułowane w oparciu o asymetrię informacji, uwarunkowania instytucjonalne, nadzór właścicielski oraz aspekty behawioralne ${ }^{24}$. Każde $\mathrm{z}$ wyróżnionych podejść zawiera odmienne podstawy wyjaśniające niedowartościowanie akcji oferowanych w ramach pierwszych ofert publicznych (zob. tab. 4.9).

Światowe badania naukowe nad zmianami kursu akcji w dniu debiutu na giełdzie nie dostarczają jednoznacznej odpowiedzi na pytanie o wpływ obecności funduszu private equity wśród akcjonariuszy spółki na stopień niedowartościowania jej walorów.

$\mathrm{Z}$ jednej strony badania pokazują, iż spółki z udziałem funduszy private equity charakteryzowały się mniejszym stopniem niedowartościowania akcji zbywanych w pierwszej ofercie publicznej niż pozostałe przedsiębiorstwa ${ }^{25}$. Sytuacja ta wynika stąd, że udział funduszu private equity w spółce świadczy o jej wysokiej jakości. Fundusze private equity dzięki rozległej sieci kontaktów biznesowych są w stanie pozyskać najlepszych partnerów do współpracy w ramach procesu pierwszej oferty publicznej. W tej sytuacji nie występuje konieczność ponoszenia dodatkowych kosztów w postaci ponadprzeciętnego niedoszacowania akcji w celu uplasowania oferty na rynku. Ponadto fundusze starają się wycenić akcje spółki według jej ,prawdziwej” wartości, dążąc jednocześnie do zmniejszenia stopnia asymetrii informacji pomiędzy spółką a nowymi inwestorami. W przypadku próby wprowadzenia potencjalnych inwestorów w błąd i złej wyceny oferowanych papierów wartościowych fundusz straciłby dobrą reputację, co w przyszłości mogłoby utrudnić wyjście z kolejnych inwestycji poprzez publiczny rynek papierów wartościowych. G. Kanatas i Ch. Stefanadis przedstawili teoretyczny model podejmowania decyzji związanych z wprowadzeniem spółki na giełdę wskazując, iż przy debiutach giełdowych spółek portfelowych funduszy private equity należy oczekiwać mniejszego niedowartościowania akcji w pierwszym dniu notowań ${ }^{26}$.

${ }^{24}$ A. Ljungqvist, op. cit., s. 2.

${ }^{25}$ W. L. M e g g i n s o n, K. A. W e is s, Venture capitalists certification in initial public offerings, „Journal of Finance” 1991, No. 46, s. 879-903; C. B. Barry, C. Muscarella, J. W. P e a v y, M. R. V ets u y e n s, The Role of Venture capital in the Creation of Public Companies: Evidence from the Going-Public Process, ,Journal of Financial Economics” 1990, Vol. 27, Issue 2, s. 447-471.

${ }^{26} \mathrm{G}$. Kan at as, Ch. Stef a $\mathrm{n}$ adis, Venture capital, IPO underpricing, and going-public decisions, Working Paper, Jones School of Management, 2005, s. 27. 


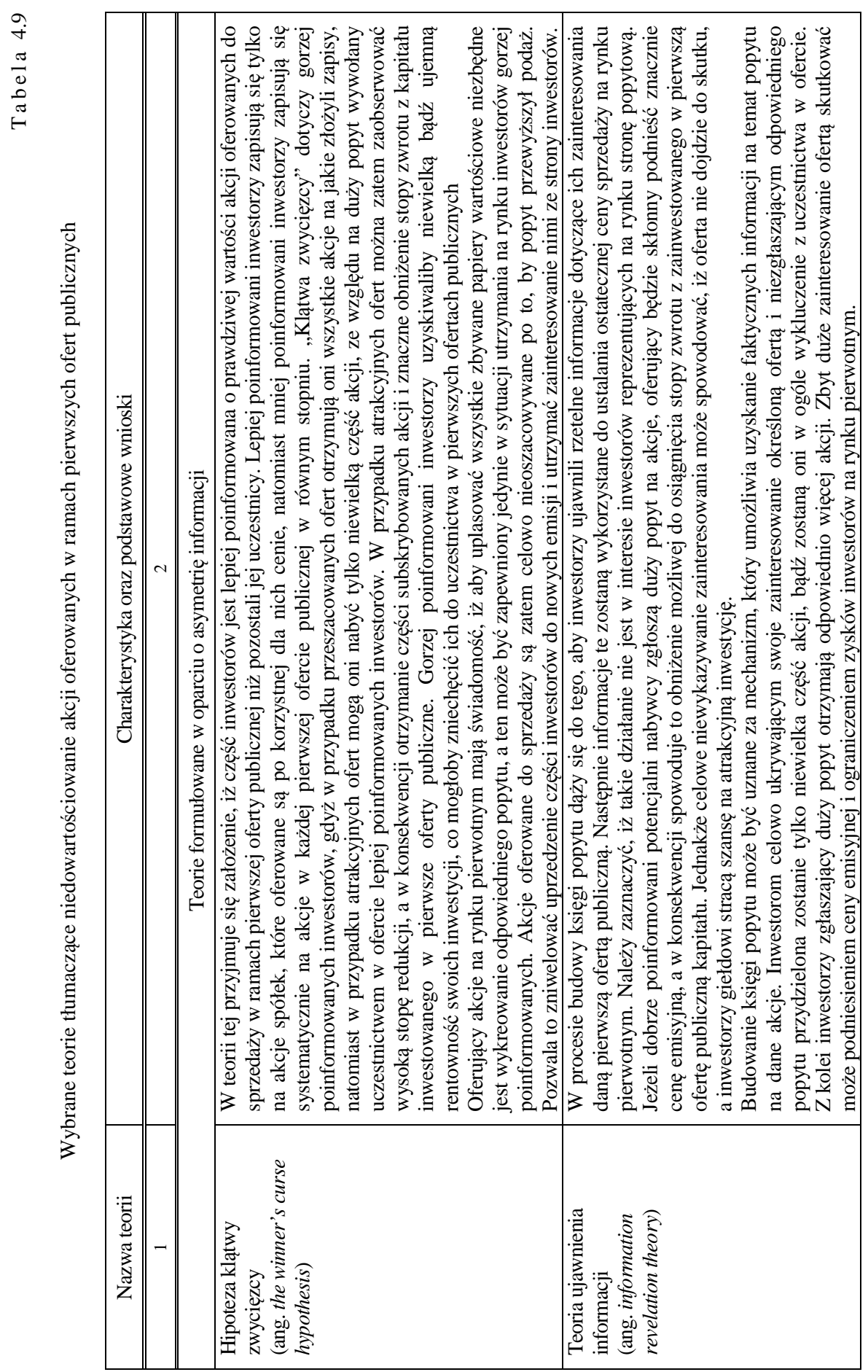




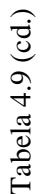

\begin{tabular}{|c|c|c|}
\hline 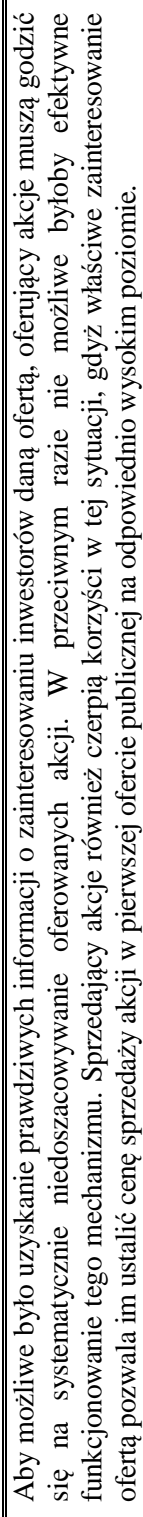 & 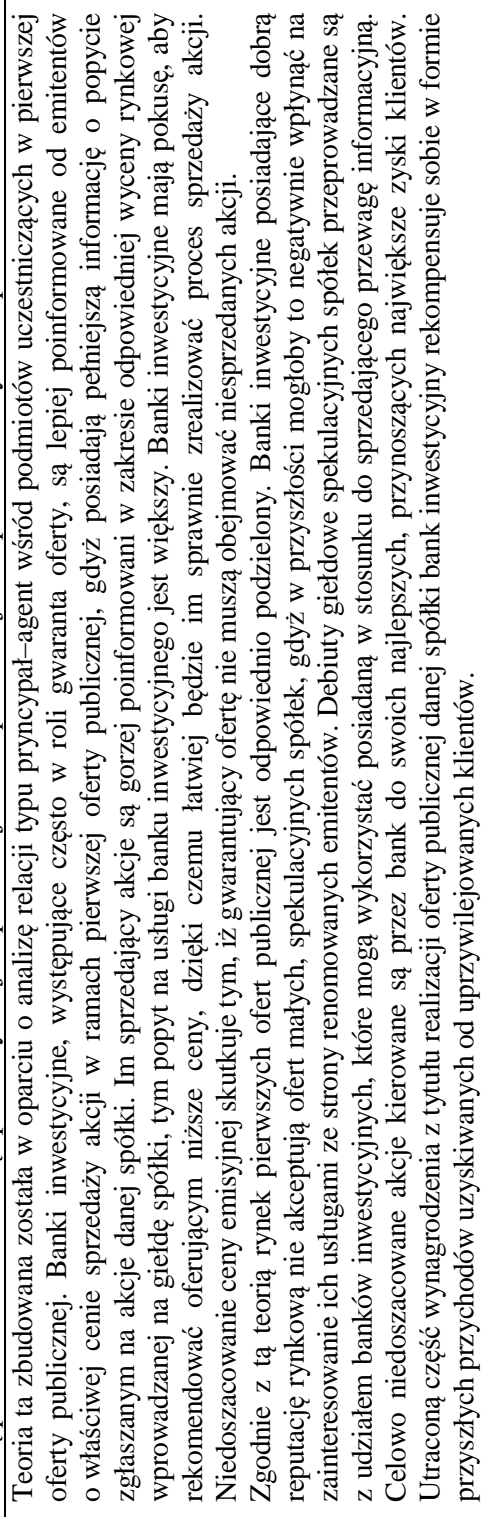 & 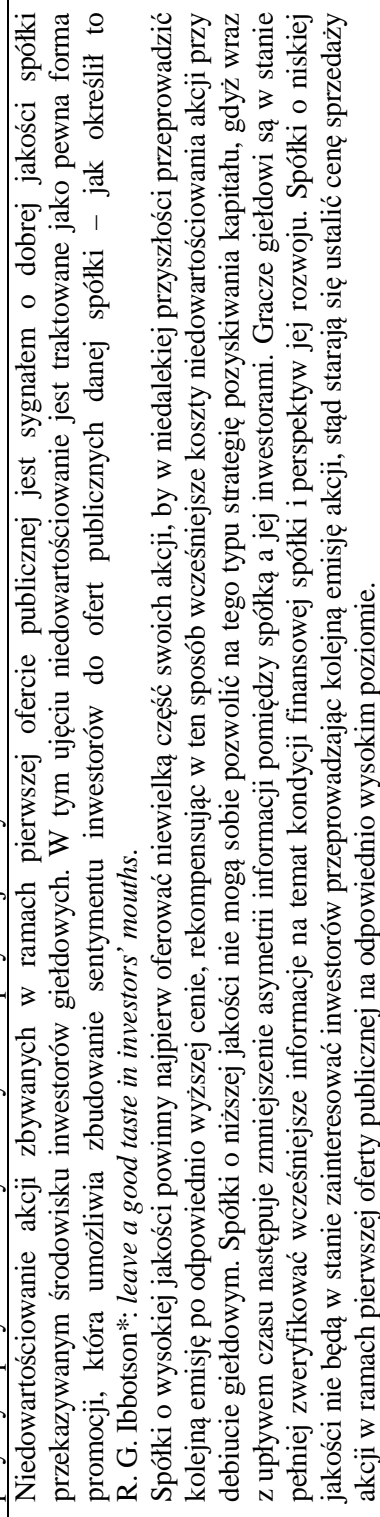 \\
\hline 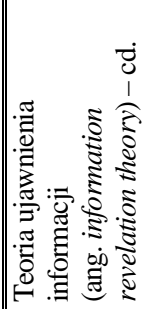 & 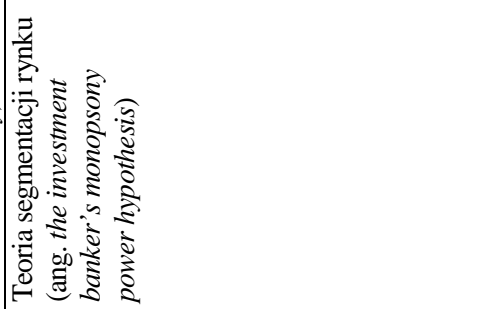 & 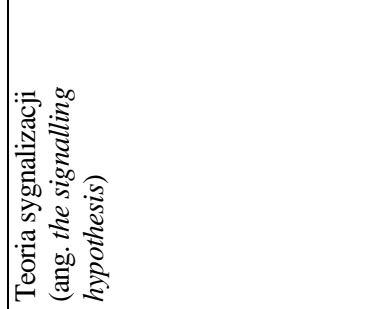 \\
\hline
\end{tabular}

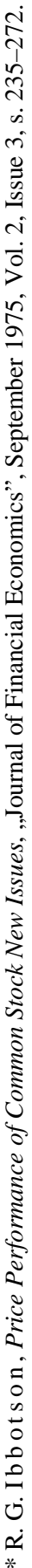




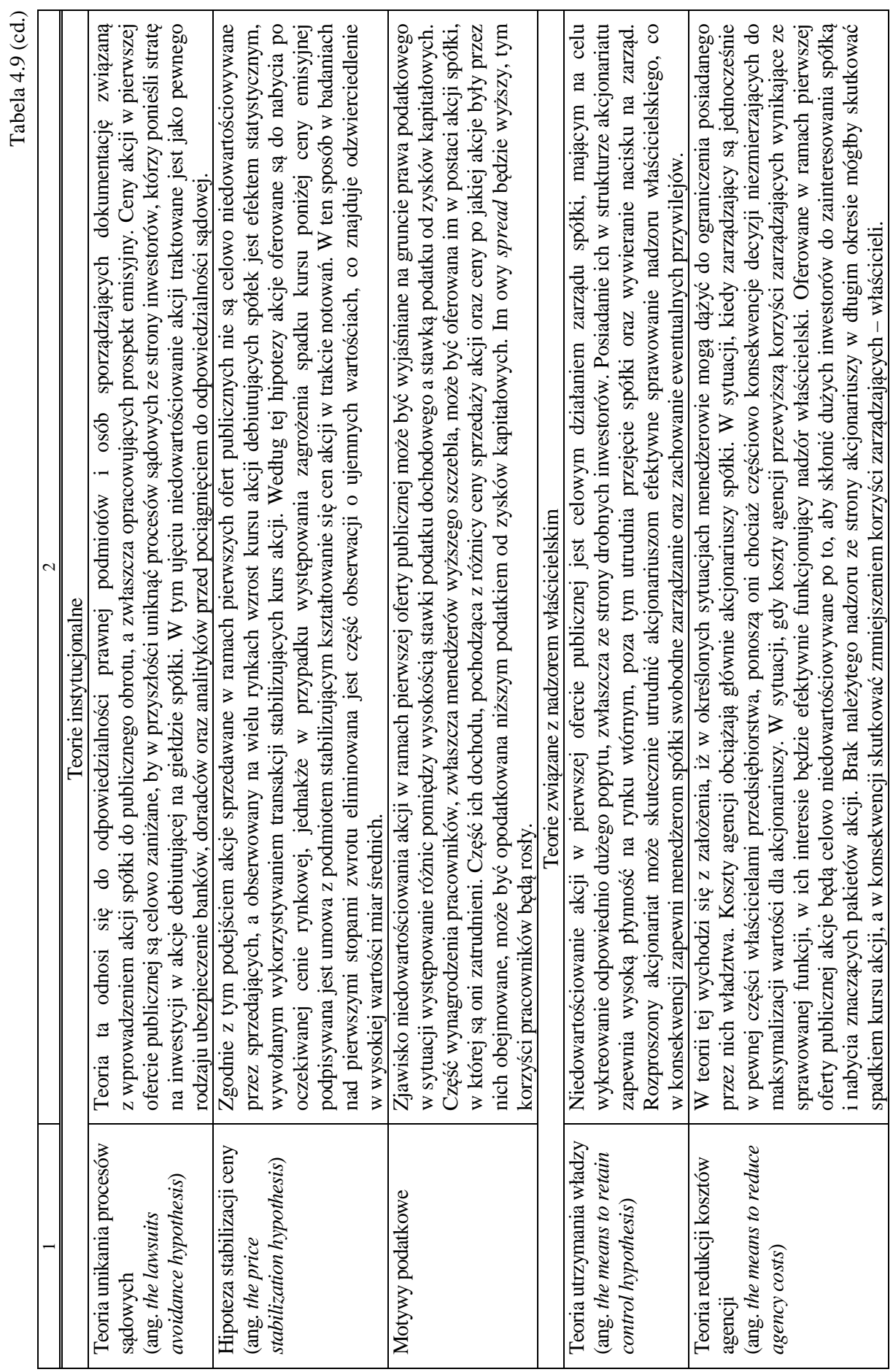




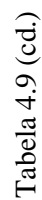

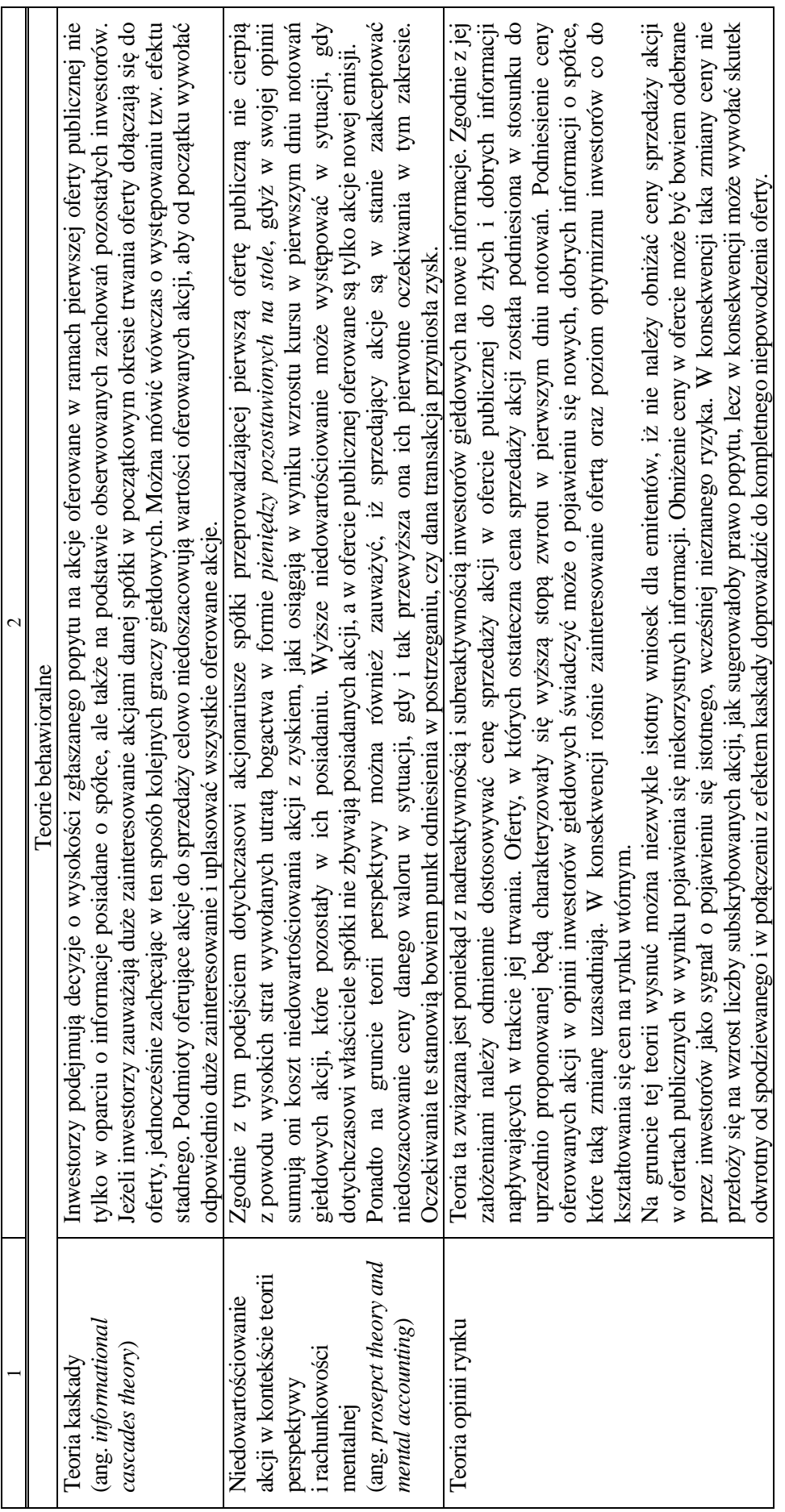

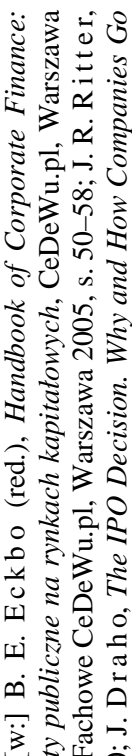

这它

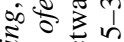

:

हो

ฐ

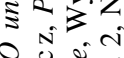

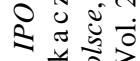

कि $\begin{array}{ll}0 \\ \text { in }\end{array}$

1
$20 \Omega$

on

$\Xi T$.

जा कि क

ये்

웡

西 0

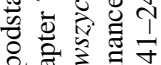

믕 $\because 0$ 的 \& $<$ है 釆

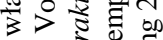

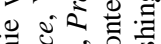
需 ०० 3 is

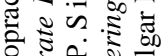
ठㅁ 0 这

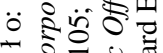
七0워 뇰

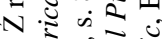
过告: 
Z drugiej jednak strony inne badania empiryczne wskazują, iż akcje spółek portfelowych funduszy private equity zbywane $\mathrm{w}$ ramach procesu dezinwestycji realizowanego metodą pierwszej oferty publicznej charakteryzują się wyższym stopniem niedowartościowania w porównaniu $\mathrm{z}$ akcjami innych spółek. P. M. Lee i S. Wahal w oparciu o analizę pierwszych stóp zwrotu z akcji 6413 debiutów giełdowych wykazali, iż niedowartościowanie akcji spółek portfelowych funduszy private equity było średnio wyższe o 5,0-10,3 p.p. od pozostałych spółek w przyjętym okresie badawczym ${ }^{27}$. Inne prace również wskazują na większy stopień niedowartościowania w pierwszym dniu notowań akcji spółek z udziałem funduszy private equity w porównaniu z innymi spółkami ${ }^{28}$.

Ciekawą teorię, wyjaśniającą występowanie zjawiska niedowartościowania akcji w pierwszych ofertach publicznych spółek portfelowych funduszy private equity zaproponował P. Gompers ${ }^{29}$. Zgodnie z grandstanding hypothesis fundusze private equity, zwłaszcza te, które działają na rynku od stosunkowo krótkiego czasu, w celu wzmocnienia swojej reputacji mogą dążyć do wprowadzenia spółek portfelowych na giełdę, nawet w sytuacji, kiedy firmy te nie są jeszcze na to gotowe. Dla zminimalizowania ryzyka poniesienia fiaska debiutu, które rzutowałoby to na kolejne próby dezinwestycji poprzez giełdę oraz pozyskanie nowych kapitałów w przyszłości, fundusz świadomie godzi się na poniesienie dodatkowego kosztu w postaci niedowartościowania akcji spółki portfelowej.

Akumulacja kapitału reputacji na rynku kapitału podwyższonego ryzyka odgrywa niezwykle istotną rolę ${ }^{30}$. Fundusze private equity są zakładane na z góry określony czas, po którym zgromadzone kapitały wraz z wypracowanym zyskiem kapitałowym zwracane są inwestorom. Do tego, aby móc zakładać kolejne fundusze i pozyskiwać dalsze środki na swoją działalność, menedżerowie funduszu muszą udowodnić, iż posiadają określone przewagi konkurencyjne względem innych uczestników rynku i są w stanie skutecznie budować wartość spółek portfelowych oraz efektywnie zarządzać powierzonymi im zasobami.

${ }^{27}$ P. M. Le e, S. W a h a l, Grandstanding, certification and the underpricing of venture capital backed IPOs, ,Journal of Financial Economics” 2004, Vol. 73, No. 2, s. 375-407.

${ }^{28}$ P. Gompers, J. Lerner, The Venture capital Cycle, MIT Press, Cambridge Massachusetts 2006, s. 416; S. A. Franzke, Underpricing of Venture-Backed and Non Venture-Backed IPOs: Germany's Neuer Markt, RICAFE Working Paper No. 003; S. B. S m a rt, C J. Zu tter, Control as a Motivation for Underpricing: A Comparison of Dual- and Single-Class Ipos, August 2000. Presented at Tuck-JFE Contemporary Corporate Governance Conference. http://ssrn.com/abstract=236107; S. B. S m art, C. J. Zutter, Dual Class IPOs Are Underpriced Less Severely, „The Financial Review” 2008, Vol. 43, s. 85-106.

${ }^{29}$ P. Go mpers, Grandstanding in the venture capital industry, ,Journal of Financial Economics" 1996, Vol. 42, s. 133-156.

${ }^{30}$ Zob. D. H. H su, What Do Entrepreneurs Pay for Venture capital Affiliation?, „The Journal of Finance", August 2004, Vol. LIX, No. 4, s. 1805-1844; R. N a h a a, Venture capital reputation and investment performance, „Journal of Financial Economics”, November 2008, Vol. 90, Issue 2, s. 127-151. 
W konsekwencji udany debiut giełdowy spółki portfelowej wykorzystywany jest także jako ważny środek public relation.

P. Gompers zwraca uwagę, iż zwłaszcza nowe fundusze, funkcjonujące na rynku kapitału podwyższonego ryzyka od stosunkowo krótkiego czasu, mają skłonność do oportunistycznego wykorzystywania pierwszej oferty publicznej jako metody budowania kapitału reputacji, gdyż jest to niezwykle kosztowny środek promocji. Jedną z konsekwencji takiego działania są debiuty giełdowe względnie młodych spółek, które nie są odpowiednio przygotowane do funkcjonowania w warunkach publicznego rynku papierów wartościowych. Ponieważ akcje wprowadzane są do obrotu giełdowego na wczesnym etapie rozwoju przedsiębiorstw udziałowych, przeto nasila się problem asymetrii informacji. Wynika on z niewielkiej ilości informacji dotyczących funkcjonowania spółki, jakie zostały przekazane do publicznej wiadomości. Znaczącą konsekwencją wzrostu poziomu asymetrii informacji jest wyższy koszt niedowartościowania akcji oferowanych w ramach pierwszej oferty publicznej (zob. tab. 4.10).

Tabela 4.10

Porównanie charakterystyk pierwszych ofert publicznych „młodych” i „,doświadczonych” funduszy private equity - wybrane dane*

\begin{tabular}{|l|c|c|c|}
\hline \multicolumn{1}{|c|}{ Charakterystyka } & $\begin{array}{c}\text { Fundusze funkcjo- } \\
\text { nujące poniżej 6 lat } \\
\text { w momencie de- } \\
\text { biutu giełdowego } \\
\text { spółki }\end{array}$ & $\begin{array}{c}\text { Fundusze funkcjo- } \\
\text { nujące 6 lat lub } \\
\text { więcej w momen- } \\
\text { cie debiutu gieł- } \\
\text { dowego spółki }\end{array}$ & $\begin{array}{c}\text { p-value dla testu } \\
\text { o braku różnic }\end{array}$ \\
\hline \hline $\begin{array}{l}\text { Średni czas pomiędzy pierwszą ofertą } \\
\text { publiczną spółki a utworzeniem no- } \\
\text { wego funduszu (m-ce) }\end{array}$ & $\begin{array}{c}16,0 \\
{[12,0]}\end{array}$ & $\begin{array}{c}24,2 \\
{[24,0]}\end{array}$ & 0,001 \\
\hline $\begin{array}{l}\text { Średni wiek spółki portfelowej } \\
\text { w momencie debiutu giełdowego } \\
\text { (m-ce) }\end{array}$ & $\begin{array}{c}55,1 \\
{[42,0]}\end{array}$ & $\begin{array}{c}79,6 \\
{[64,0]}\end{array}$ & $\begin{array}{c}0,000 \\
{[0,000]}\end{array}$ \\
\hline $\begin{array}{l}\text { Średnia stopa zwrotu z akcji w pierw- } \\
\text { szym dniu notowań giełdowych }\end{array}$ & 0,136 & 0,073 & 0,001 \\
\hline $\begin{array}{l}\text { Srednia wielkość publicznej oferty } \\
\text { sprzedaży akcji (mln USD) }\end{array}$ & $\begin{array}{c}{[6,067]} \\
{[11,5]}\end{array}$ & $\begin{array}{c}21,8 \\
{[16,8]}\end{array}$ & $\begin{array}{c}0,013 \\
{[0,000]}\end{array}$ \\
\hline $\begin{array}{l}\text { Srednia liczba spółek portfelowych } \\
\text { danego funduszu, które wcześniej }\end{array}$ & 1 & 6 & $0,000]$ \\
zadebiutowały na giełdzie papierów & {$[0]$} & {$[4]$} & {$[0,000]$} \\
wartościowych & 99 & 240 & - \\
\hline Liczba podmiotów & & & \\
\hline
\end{tabular}

* próba obejmowała pierwsze oferty publiczne 433 spółek portfelowych funduszy venture capital w latach 1978-1987. Wartości podane w nawiasach kwadratowych dotyczą mediany.

Ź r ó d ł o: P. Go mpers, Grandstanding in the venture capital industry, ,Journal of Financial Economics" 1996, Vol. 42, s. 140. 
Zbyt wczesne wyjście funduszu private equity z inwestycji może uniemożliwić pełne wykorzystanie szans wzrostu wartości przedsiębiorstwa udziałowego. Negatywnym skutkiem będzie zatem redukcja zysku kapitałowego wypracowanego $\mathrm{w}$ toku całego procesu inwestycyjnego. Fundusze private equity posiadające ugruntowaną pozycję rynkową nie muszą wykorzystywać tego typu kosztownych narzędzi promocji dla udowodnienia swojej sprawności w budowaniu wartości przedsiębiorstw znajdujących się w ich portfolio.

\subsubsection{Metodyka badań nad niedowartościowaniem akcji w pierwszym dniu notowań giełdowych spółek portfelowych funduszy private equity}

Badania empiryczne nad kształtowaniem się rynkowych cen akcji spółek portfelowych funduszy private equity zostały przeprowadzone w oparciu o metodykę analizy zdarzeń. Analiza zdarzeń jest powszechnie stosowanym literaturze z zakresu finansów przedsiębiorstw sposobem badania reakcji rynku kapitałowego na zaistnienie określonych okoliczności, m. in. splitów akcji ${ }^{31}$, wykupów akcji własnych $^{32}$, wypłat dywidend ${ }^{33}$, emisji obligacji oraz akcji ${ }^{34}$, a także fuzji i przejęć ${ }^{35}$.

W pierwszym etapie badań empirycznych zostały określone kryteria, jakie powinny spełniać podmioty uwzględnione w badaniu. Do próby badawczej zakwalifikowane zostały spółki, których:

${ }^{31}$ D. L. Ikenberry, G. Rankine, E. K. Stice, What Do Stock Splits Really Signal?, „Journal of Financial and Quantitative Analysis” 1996, Vol. 31, s. 357-375.

${ }^{32} \mathrm{~A} . \mathrm{P}$ i e lo c h, Wptyw ogłoszenia decyzji o wykupie akcji wtasnych na wartość rynkowa spót$e k$ notowanych na GPW w Warszawie, [w:] E. Urbańczyk, E. Mioduchowska- Jaroszewicz (red.), Strategie $i$ determinanty wzrostu wartości przedsiębiorstwa, „Zeszyty Naukowe nr 685" pt. Finanse, rynki finansowe, ubezpieczenia nr 46, Uniwersytet Szczeciński, Szczecin 2011, s. 569-579; G. Grullo n, R. Mich a ely, Dividends, Share Repurchases, and the Substitution Hypothesis, „The Journal of Finance”, August 2002, Vol. 57, s. 1649-1684; K. Ch a n, D. L. Ike n berry, I. Lee, Y. W a ng, Share repurchases as a potential tool to mislead investors, „Journal of Corporate Finance” 2010, Vol. 16, s. 137-158.

${ }^{33}$ R. D. B o e h me, S. M. S or e s c u, The Long-run Performance Following Dividend Initiations and Resumptions: Underreaction Or Product of Chance?, „The Journal of Finance” 2002, Vol. 57, No. 2, s. 871-900; J. How, K. Ng o, P. V e r hoe ve n, Dividend initiations and long-run IPO performance, ,Australian Journal of Management” 2011, Vol. 36, No. 2, s. 267-286.

${ }^{34}$ A. B rav, Inference in Long-Horizon Event Studies: A Bayesian Approach with Applicationto Initial Public Offerings, ,The Journal of Finance” 2000, Vol. 55, No. 5, s. 1979-2016.

${ }^{35}$ M. Rhodes-Kropf, D. T. Robin s on, S. V is w a n th a n, Valuation waves and merger activity: The empirical evidence, ,Journal of Financial Economics” 2005, Vol. 77, s. 561-603; M. L. Mitchell, E. Stafford, Managerial decisions and long-term stock price performance, „The Journal of Business” 2000, Vol. 73, s. 287-329. 
- pierwsze notowanie odbyło się w latach 2002-2010,

- nie były notowane wcześniej na NewConnect lub MST-CeTo,

- przed dopuszczeniem do publicznego obrotu przeprowadziły publiczną ofertę sprzedaży akcji i/lub publiczną subskrypcję akcji,

- posiadają główną siedzibę działalności w Polsce.

W latach 2002-2010 na warszawskim parkiecie do publicznego obrotu po raz pierwszy wprowadzono akcje łącznie 281 spółek, z czego 216 zostało zakwalifikowanych do dalszych badań (zob. schemat 4.1).

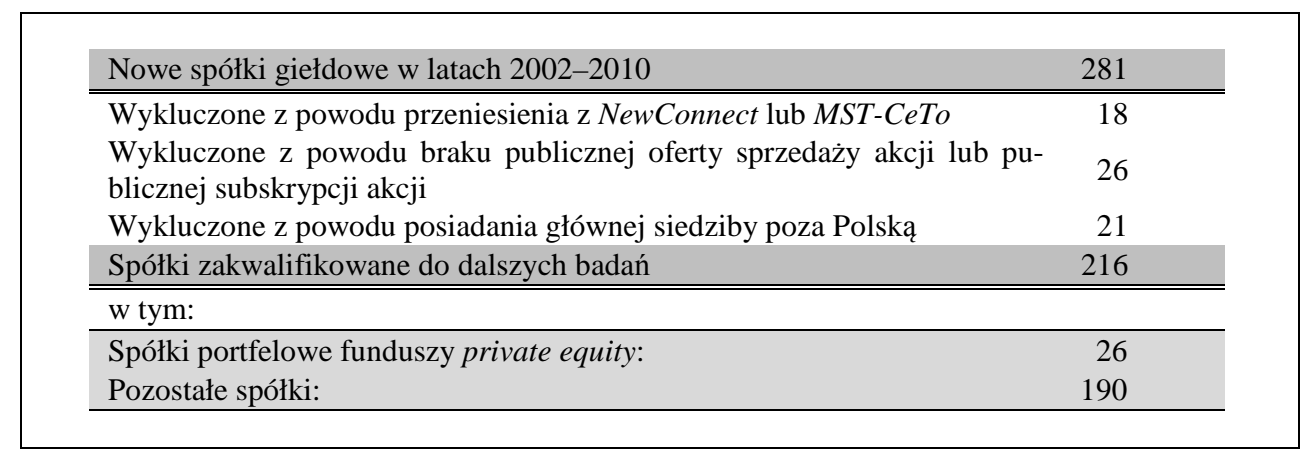

Schemat 4.1. Schemat budowy próby badawczej

Ź r ód ło: opracowanie własne na podstawie raportów bieżących spółek, prospektów emisyjnych oraz http://www.gpw.pl oraz Ewidencji instrumentów finansowych Komisji Nadzoru Finansowego, http://www.knf.gov.pl.

Kolejną czynnością wynikającą z przyjętej metodyki jest precyzyjne określenie algorytmów matematycznych, umożliwiających weryfikację postawionej hipotezy badawczej. Niedowartościowanie akcji oferowanych w ramach pierwszej oferty publicznej danej spółki wyrażone zostało prostą stopą zwrotu z akcji w pierwszym dniu notowań, czyli:

$$
R_{i, t_{1}}=\frac{P_{i, t_{1}}-P_{i, e}}{P_{i, e}}=\frac{P_{i, t_{1}}}{P_{i, e}}-1
$$

gdzie:

$R_{i, t_{1}}$ - prosta stopa zwrotu z akcji $i$-tej spółki w pierwszym dniu notowań,

$P_{i, t_{1}} \quad$ - cena zamknięcia akcji $i$-tej spółki po pierwszym dniu notowań,

$P_{i, e} \quad$ - cena emisyjna akcji $i$-tej spółki.

Jeżeli w procesie pierwszej oferty publicznej spółka korzystała z praw do akcji (PDA) to w badaniach kurs PDA traktowany był równoważnie z kursem 
akcji. Jeżeli $\mathrm{w}$ dniu debiutu giełdowego notowane były oba rodzaje papierów wartościowych, uwzględniona została cena zamknięcia akcji.

W celu wnioskowania dla wydzielonych w ramach próby badawczej grup podmiotów, ustalone stopy zwrotu w pierwszym dniu notowań poszczególnych spółek zostały następnie zagregowane i podzielone przez liczbę emitentów $\mathrm{z}$ danej grupy. Pozwoliło to na ustalenie średniego niedowartościowania akcji, które zostało określone jako średnia prosta stopa zwrotu w pierwszym dniu giełdowych notowań na warszawskim parkiecie, a do jego obliczenia wykorzystano następującą formułę:

$$
\overline{R_{t_{1}}}=\frac{1}{n} \sum_{i=1}^{n} R_{i, t_{1}}=\frac{1}{n} \sum_{i=1}^{n}\left(\frac{P_{i, t_{1}}}{P_{i, e}}-1\right)
$$

gdzie:

$\overline{R_{t_{1}}}$ - średnia prosta stopa zwrotu z akcji w pierwszym dniu notowań,

$n \quad$ - liczba spółek,

pozostałe oznaczenia jak wyżej.

Niedowartościowanie wyznaczone w oparciu o powyżej wskazane formuły, poza czynnikami specyficznymi dla danej spółki lub grupy spółek uwzględnia również zmiany uwarunkowań ogólnorynkowych, jakie miały miejsce $\mathrm{w}$ dniu debiutu giełdowego. Dla wyeliminowania wpływu tego czynnika na otrzymane wyniki zachodzi konieczność skorygowania niedowartościowania mierzonego prostą stopą zwrotu $\mathrm{z}$ akcji $\mathrm{w}$ pierwszym dniu notowań o tzw. normalną stopę zwrotu. Powstała w ten sposób skorygowana stopa zwrotu z pierwszego dnia notowań akcji została wyznaczona w następujący sposób:

$$
A R_{i, t_{1}}=R_{i, t_{1}}-E\left(R_{i, t_{1}} \mid X_{t_{1}}\right)
$$

gdzie:

$A R_{i, t_{1}} \quad$ - skorygowana stopa zwrotu z akcji $i$-tej spółki w pierwszym dniu notowań,

$E\left(R_{i, t_{1}} \mid X_{t_{1}}\right)$ - normalna stopa zwrotu,

pozostałe oznaczenia jak wyżej.

W literaturze przedmiotu występuje wiele różnorodnych podejść do wyznaczania normalnej stopy zwrotu. Ogólnie podejścia te można podzielić na dwie grupy, modele statystyczne i modele ekonomiczne. W analizie zdarzeń szeroko są wykorzystywane zwłaszcza model stałej średniej stopy zwrotu (ang. Constant 
Mean Return Model), model rynkowy (ang. Market Model), model wyceny aktywów kapitałowych (ang. Capital Asset Pricing Model) oraz model wyceny arbitrażowej (ang. Arbitrage Pricing Theory) ${ }^{36}$.

Do analizy niedowartościowania akcji w pierwszym dniu notowań aplikacja wskazanych rozwiązań jest niemożliwa ze względu na brak informacji o cenach rynkowych akcji spółki poprzedzających zdarzenie. Ze względu na specyfikę pierwszych ofert publicznych do wyznaczenia normalnych stóp zwrotu stosuje się model indeksowy, według którego normalna stopa zwrotu z akcji określonej spółki będzie równa stopie zwrotu z portfela rynkowego. Jako jej odpowiednik najczęściej wykorzystuje się stopę zwrotu z indeksu danej giełdy, jednakże należy zaznaczyć, że możliwe są również inne rozwiązania. W realizowanych badaniach jako stopa zwrotu z portfela rynkowego wykorzystana została stopa zwrotu z WIG w dniu pierwszego notowania danej spółki. Zastosowane formuły dla poszczególnych spółek, jak i grup podmiotów przybrały zatem postać:

$$
\begin{aligned}
& A R_{i, t_{1}}=\frac{P_{i, t_{1}}}{P_{i, e}}-\frac{W I G_{i, t_{1}}}{W I G_{i, t_{0}}} \\
& \overline{A R_{t_{1}}}=\frac{1}{n} \sum_{i=1}^{n} A R_{i, t_{1}}=\frac{1}{n} \sum_{i=1}^{n}\left(\frac{P_{i, t_{1}}}{P_{i, e}}-\frac{W I G_{i, t_{1}}}{W I G_{i, t_{0}}}\right)
\end{aligned}
$$

gdzie:

$\overline{A R_{t_{1}}}$ - średnia skorygowana stopa zwrotu $\mathrm{z}$ akcji $\mathrm{w}$ pierwszym dniu notowań,

$W I G_{i, t_{1}}$ - wartość indeksu $W I G$ na zamknięciu pierwszego dnia notowań i-tej spółki,

$W I G_{i, t_{0}}$ - wartość indeksu WIG na zamknięciu sesji poprzedzającej pierwszy dzień notowań $i$-tej spółki,

pozostałe oznaczenia jak wyżej.

Przedstawione powyżej i zastosowane w badaniach rozwiązanie metodyczne wydaje się nie budzić kontrowersji w sytuacji, kiedy od momentu zakończenia zapisów potencjalnych nowych akcjonariuszy na akcje spółki do pierwszego jej notowania na giełdzie upływa stosunkowo krótki okres ${ }^{37}$. Jednakże w sytuacji, kiedy okres ten wydłuża się, wydaje się zasadnym zwrócenie uwagi, iż na decyzje inwestorów dotyczące ich zachowania podczas debiutu giełdowego spółki wpływ mogą mieć czynniki zaistniałe w tym czasie. Z związku z powyż-

${ }^{36}$ A. C. M ackin lay, Event Studies in Economics and Finance, ,Journal of Economic Literature", March 1997, Vol. XXXV, s. 17-19.

${ }^{37}$ M. Ko oli, J-M. S u ret, The Underpricing of Initial Public Offerings: Further Canadian Evidence, Scientific Series CIRANO, Montreal 2001, s. 7. 
szym w badaniach wykorzystana zostanie również formuła oceny zmiany cen akcji spółki w pierwszym dniu jej notowań uwzględniająca modyfikację ogólnych warunków panujących na rynku wtórnym w okresie pomiędzy zakończeniem zapisów na akcje danej spółki a jej pierwszym notowaniem. Ponownie dla zobrazowania warunków panujących na rynku użyty został indeks WIG, a wykorzystane algorytmy obliczeniowe przyjęły następującą postać:

$$
\begin{aligned}
& A R_{i, t z_{1}}=\frac{P_{i, t_{1}}}{P_{i, e}}-\frac{W I G_{i, t_{1}}}{W I G_{i, t z}} \\
& \overline{A R_{t z_{1}}}=\frac{1}{n} \sum_{i=1}^{n} A R_{i, t_{1}}=\frac{1}{n} \sum_{i=1}^{n}\left(\frac{P_{i, t_{1}}}{P_{i, e}}-\frac{W I G_{i, t_{1}}}{W I G_{i, t z}}\right)
\end{aligned}
$$

gdzie:

$A R_{i, t z_{1}}$ - stopa zwrotu $\mathrm{z}$ akcji $i$-tej spółki w pierwszym dniu notowań skorygowana o zmianę warunków rynkowych w okresie od zakończenia zapisów na akcje spółki do zamknięcia jej notowań w dniu debiutu,

$\overline{A R_{t z_{1}}} \quad$ - średnia stopa zwrotu $\mathrm{z}$ akcji w pierwszym dniu notowań skorygowana o zmianę warunków rynkowych w okresie od zakończenia zapisów na akcje do zamknięcia notowań w dniu debiutu,

$W I G_{i, t z}$ - wartość indeksu WIG w dniu zakończenia zapisów na akcje $i$-tej spółki,

pozostałe oznaczenia jak wyżej.

Przeprowadzona została również weryfikacja istotności statystycznej obliczonych stóp zwrotu z akcji w pierwszym dniu notowań giełdowych. Sformułowane zostały dwie hipotezy statystyczne, a mianowicie:

$$
\begin{aligned}
& H_{0}: A R_{t}=0 \\
& H_{1}: A R_{t}>0
\end{aligned}
$$

Do weryfikacji postawionych powyżej hipotez wykorzystany został parametryczny test $t_{\text {stat }}$ dla wartości średniej w populacji o jednostronnym obszarze odrzucenia, oparty na statystyce $t$-Studenta wyznaczonej zgodnie ze wzorem ${ }^{38}$ :

${ }^{38}$ H. Gu r g u l, Analiza zdarzeń na rynkach akcji, Oficyna a Wolters Kluwer Business, Warszawa 2012, s. 51. 


$$
t_{\text {stat }}=\frac{A R_{t_{1}}}{\hat{S}\left(\overline{A R_{t_{1}}}\right)} \sqrt{n}
$$

gdzie:

$\hat{S}\left(\overline{A R_{t_{1}}}\right)$ - odchylenie standardowe skorygowanej stopy zwrotu z akcji pozostałe oznaczenia jak wyżej.

Przy założeniu rozkładu normalnego analizowanych stóp zwrotu oraz prawdziwości hipotezy statystycznej $H_{0}$ statystyka testowa $t_{\text {stat }}$ ma rozkład $t$-Studenta o $n-1$ stopniach swobody. Jeżeli hipoteza zerowa zostanie odrzucona to nadzwyczajna stopa zwrotu istotnie różni się od 0 , a otrzymany wynik będzie istotny statystycznie. Dla wyznaczonych stóp zwrotu przedstawiono wartość statystyki testowej $t_{\text {stat }}$ wraz z prawdopodobieństwem krytycznym ${ }^{39}$.

Ostatnim etapem badań było wykonanie obliczeń i interpretacja otrzymanych wyników.

\subsubsection{Wyniki badań empirycznych nad niedowartościowaniem pierwszych ofert publicznych spótek portfelowych funduszy private equity}

Analiza stóp zwrotu $\mathrm{z}$ akcji spółek w pierwszym dniu notowań wymaga, aby w pierwszym rzędzie przedstawić ogólną charakterystykę pierwszych ofert publicznych badanych przedsiębiorstw. W analizowanym okresie ponad $12 \%$ spółek, które zadebiutowały na GPW w Warszawie były przedsiębiorstwami, w których akcjonariuszami były fundusze private equity. W 2002 r. spółki portfelowe funduszy private equity stanowiły ponad $66 \%$ wszystkich nowych spółek giełdowych. Chociaż taki wynik może wydawać się wysokim, to należy wziąć jednak pod uwagę, że w tym roku debiut na publicznym rynku papierów wartościowych miały zaledwie 3 spółki, z czego w 2 spółkach akcjonariuszami były fundusze private equity. Na szczególną uwagę zasługują debiuty spółek w latach 2005-2006. W okresie tym zadebiutowało 66 spółek, a niemalże co piąta nowa spółka na warszawskim parkiecie korzystała ze wsparcia funduszy private equity (zob. tab. 4.11).

${ }^{39} \mathrm{~W}$ literaturze przedmiotu stosowane są również inne testy parametryczne i nieparametryczne, np. zob. A. P. S e r r a, Event Study Tests. A Brief Survey, Working Papers da FEP No. 117, May 2002, s. 4; C. J. Corr a d o, Event studies: A methodology review, „Accounting and Finance” 2011, Vol. 51, s. 207-234; K. R. A h e r n, Sample selection and event study estimation, „Journal of Empirical Finance" 2009, Vol. 16, s. 481-482. 
Tabela 4.11

Nowe spółki giełdowe w latach 2002-2010 uwzględnione w badaniach

\begin{tabular}{|c|c|c|c|c|c|}
\hline \multirow{2}{*}{ Rok } & \multirow{2}{*}{$\begin{array}{c}\text { Liczba nowych } \\
\text { spółek ogółem }\end{array}$} & $\begin{array}{c}\text { Spółki bez wsparcia funduszy } \\
\text { private equity }\end{array}$ & $\begin{array}{c}\text { Spółki portfelowe funduszy } \\
\text { private equity }\end{array}$ \\
\cline { 3 - 6 } & & liczba & udział [\%] & liczba & udział [\%] \\
\hline \hline 2002 & 3 & 1 & 33,33 & 2 & 66,67 \\
\hline 2003 & 4 & 4 & 100,00 & 0 & 0,00 \\
\hline 2004 & 31 & 28 & 90,32 & 3 & 9,68 \\
\hline 2005 & 34 & 29 & 85,29 & 5 & 14,71 \\
\hline 2006 & 32 & 24 & 75,00 & 8 & 25,00 \\
\hline 2007 & 58 & 54 & 93,10 & 4 & 6,90 \\
\hline 2008 & 24 & 22 & 91,67 & 2 & 8,33 \\
\hline 2009 & 10 & 10 & 100,00 & 0 & 0,00 \\
\hline 2010 & 20 & 18 & 90,00 & 2 & 10,00 \\
\hline Razem & 216 & 190 & 87,96 & 26 & 12,04 \\
\hline
\end{tabular}

Ź r ód ło: opracowanie własne na podstawie raportów bieżących spółek, prospektów emisyjnych oraz http://www.gpw.pl.

W analizowanym okresie łączna wartość ${ }^{40}$ ofert sprzedaży akcji debiutujących na warszawskim parkiecie spółek portfelowych funduszy private equity wynosiła $1796,8 \mathrm{mln}$ zł. Ponad 30\% tej sumy przypada na 2005 r. Mimo iż w kolejnym roku liczba debiutujących spółek portfelowych funduszy private equity wzrosła, to wartość ofert sprzedaży akcji w 2006 r. spadła o ponad $25 \%$ w porównaniu z rokiem poprzednim, z poziomu niespełna $549,8 \mathrm{mln}$ zł do 411,3 mln zł (zob. wykres 4.10).

Średnia wartość oferty sprzedaży akcji przez spółki portfelowe funduszy private equity w latach 2002-2010 wynosiła $69,1 \mathrm{mln}$ zł. Z kolei oferty ponad połowy spółek przekroczyły sumę $33,5 \mathrm{mln}$ zł. W analizowanym okresie najmniejszą wartość miała oferta sprzedaży akcji Travelplanet.pl SA - $6666660 \mathrm{zł}$ - spółki portfelowej funduszu private equity zarządzanego przez MCI Managment SA. Natomiast najwyższą wartość, wynoszącą prawie $456 \mathrm{mln}$ zł, miała oferta sprzedaży akcji spółki Opoczno SA. Przedsiębiorstwo to wchodziło w skład portfela funduszu zarządzanego przez Enterprise Investors. Debiut giełdowy obu spółek miał miejsce w 2005 r. (zob. tab. 4.12).

\footnotetext{
${ }^{40}$ Liczona jako iloczyn liczby akcji i ceny emisyjnej.
} 


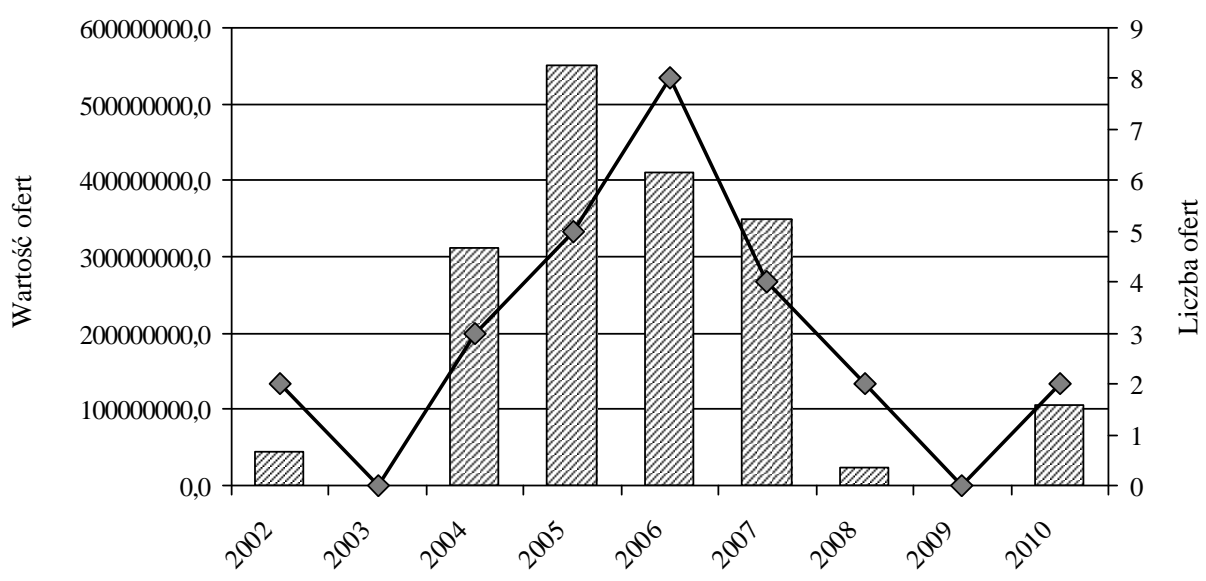

Wykres 4.10. Wartość ofert i liczba nowych spółek z udziałem funduszy private equity na GPW w Warszawie w latach 2002-2010

Ź r ó d ł o: opracowanie własne na podstawie www.gpw.pl oraz Raportów Rocznych Komisji Papierów Wartościowych i Giełd za lata 2004-2002.

Tabela 4.12

Wartości wybranych statystyk opisowych pierwszych ofert publicznych spółek portfelowych funduszy private equity w latach 2002-2010

\begin{tabular}{|l|c|}
\hline \multicolumn{1}{|c|}{ Wyszczególnienie } & Wartość statystyki \\
\hline \hline Średnia arytmetyczna & 69106262,42 \\
\hline Mediana & 33529612,00 \\
\hline Odchylenie standardowe & 96064941,67 \\
\hline Kwartyl dolny & 21612622,00 \\
\hline Kwartyl górny & 74093925,00 \\
\hline Rozstęp kwartylny & 52481303,00 \\
\hline Minimum & 6666660,00 \\
\hline Maksimum & 455965950,00 \\
\hline Liczba spółek & 26 \\
\hline
\end{tabular}

Źr ódło: opracowanie własne na podstawie www.gpw.pl oraz Raportów Rocznych Komisji Papierów Wartościowych i Giełd za lata 2004-2002.

Badania empiryczne pokazały, iż przeważająca część pierwszych ofert publicznych zrealizowanych na GPW w Warszawie charakteryzowała się niedowartościowaniem akcji w pierwszym dniu notowań. Zarówno w grupie podmiotów korzystających z finansowania typu private equity, jak i w przypadku pozo- 
stałych spółek przeważająca liczba ofert publicznych charakteryzowała się niedowartościowaniem akcji w pierwszym dniu notowań giełdowych. W obu badanych grupach rozkład stóp zwrotu był prawostronnie ukośny. Należy zwrócić jednakże uwagę, iż udział podmiotów, które uzyskały dodatnią stopę zwrotu w pierwszym dniu notowań na warszawskim parkiecie jest niższy wśród spółek portfelowych funduszy private equity w stosunku do pozostałych spółek. Powyższe konstatacje są prawdziwe niezależnie od zastosowanej miary niedowartościowania akcji (zob. tab. 4.13).

Tabela 4.13

Rozkład stóp zwrotu w pierwszym dniu notowań akcji na GPW w Warszawie w latach 2002-2010

\begin{tabular}{|l|c|c|c|c|c|c|c|}
\hline \multirow{2}{*}{ Wyszczególnienie } & \multicolumn{1}{|c|}{$\begin{array}{c}\text { Spółki portfelowe } \\
\text { funduszy } \\
\text { private equity }\end{array}$} & \multicolumn{2}{c|}{ Pozostałe spółki } & \multicolumn{2}{c|}{ Razem } \\
\cline { 2 - 7 } & liczba & udział [\%] & liczba & udział [\%] & liczba & udział [\%] \\
\hline \hline \multicolumn{7}{|c|}{ Prosta stopa zwrotu } \\
\hline Dodatnia stopa zwrotu & 17 & 65,38 & 138 & 72,63 & 155 & 71,76 \\
\hline Ujemna stopa zwrotu & 6 & 23,08 & 49 & 25,79 & 55 & 25,46 \\
\hline Zerowa stopa zwrotu & 3 & 11,54 & 3 & 1,58 & 6 & 2,78 \\
\hline Razem & 26 & 100,00 & 190 & 100,00 & 216 & 100,00 \\
\hline \multicolumn{7}{|c|}{ Skorygowana stopa zwrotu } \\
\hline Dodatnia stopa zwrotu & 19 & 73,08 & 142 & 74,74 & 161 & 75,54 \\
\hline Ujemna stopa zwrotu & 7 & 26,92 & 48 & 25,26 & 55 & 25,46 \\
\hline Zerowa stopa zwrotu & 0 & 0,00 & 0 & 0,00 & 0 & 0,00 \\
\hline Razem & 26 & 100,00 & 190 & 100,00 & 216 & 100,00 \\
\hline & Skorygowana stopa zwrotu II & & 72,22 \\
\hline Dodatnia stopa zwrotu & 18 & 69,23 & 138 & 72,63 & 156 & 27,78 \\
\hline Ujemna stopa zwrotu & 8 & 30,77 & 52 & 27,37 & 60 & 0,00 \\
\hline Zerowa stopa zwrotu & 0 & 0,00 & 0 & 0,00 & 0 & 100,00 \\
\hline Razem & 26 & 100,00 & 190 & 100,00 & 216 & \\
\hline
\end{tabular}

Ź r ó d ł o: opracowanie własne na podstawie raportów bieżących spółek, http://www.gpw.pl oraz http://www.gpwinfostrefa.pl.

Zaprezentowane w tab. 4.14 wyniki podstawowych statystyk opisowych niedowartościowania $\mathrm{w}$ pierwszym dniu notowań wskazują, że prosta stopa zwrotu osiągnięta podczas pierwszego notowania przez spółki portfelowe funduszy private equity wynosiła średnio $12,44 \%$. W przypadku spółek, które nie korzystały ze wsparcia funduszy private equity średnia prosta stopa zwrotu z akcji w dniu debiutu była wyższa i wynosiła $15,64 \%$. W przypadku spółek portfelowych funduszy private equity $\mathrm{w}$ ponad połowie badanych przedsiębiorstw wzrosły kursy akcji w pierwszym dniu notowań o 1,78\%. Z kolei podczas debiutu na warszawskim parkiecie pozostałych spółek, ponad połowa z nich 
osiągnęła wzrost kursu akcji o 7,6\%. Proste stopy zwrotu w pierwszym dniu giełdowych notowań spółek portfelowych funduszy private equity charakteryzowały się mniejszym stopniem zróżnicowania niż zmiany kursu akcji pozostałych spółek.

Tabela 4.14

Wartości statystyk opisowych niedowartościowania akcji w pierwszym dniu notowań w latach 2002-2010 na GPW w Warszawie

\begin{tabular}{|c|c|c|c|}
\hline Wyszczególnienie & Prosta stopa zwrotu & $\begin{array}{c}\text { Skorygowana stopa } \\
\text { zwrotu }\end{array}$ & $\begin{array}{c}\text { Skorygowana stopa } \\
\text { zwrotu II }\end{array}$ \\
\hline \multicolumn{4}{|c|}{ Spółki portfelowe funduszy private equity } \\
\hline Średnia arytmetyczna & 0,1244 & 0,1257 & 0,1276 \\
\hline Statystyka t & 2,2219 & 2,2381 & 2,2739 \\
\hline p-value & 0,0178 & 0,0172 & 0,0159 \\
\hline Odchylenie standardowe & 0,2855 & 0,2865 & 0,2861 \\
\hline Mediana & 0,0178 & 0,0326 & 0,0384 \\
\hline Kwartyl dolny & 0,0000 & $-0,0130$ & $-0,0290$ \\
\hline Kwartyl górny & 0,1375 & 0,1323 & 0,1283 \\
\hline Minimum & $-0,0914$ & $-0,0731$ & $-0,0711$ \\
\hline Maksimum & 1,3125 & 1,3289 & 1,3262 \\
\hline Liczba spółek & 26 & 26 & 26 \\
\hline \multicolumn{4}{|c|}{ Pozostałe spółki } \\
\hline Średnia arytmetyczna & 0,1564 & 0,1554 & 0,1475 \\
\hline Statystyka t & 5,0844 & 5,0782 & 4,9110 \\
\hline p-value & 0,0000 & 0,0000 & 0,0000 \\
\hline Odchylenie standardowe & 0,4241 & 0,4219 & 0,4139 \\
\hline Mediana & 0,0760 & 0,0690 & 0,0727 \\
\hline Kwartyl dolny & $-0,0031$ & $-0,0033$ & $-0,0104$ \\
\hline Kwartyl górny & 0,1928 & 0,1884 & 0,1881 \\
\hline Minimum & $-0,7407$ & $-0,7261$ & $-0,7813$ \\
\hline Maksimum & 4,8133 & 4,7821 & 4,6654 \\
\hline Liczba spółek & 190 & 190 & 190 \\
\hline
\end{tabular}

Ź r ó d ł o: opracowanie własne na podstawie raportów bieżących spółek, http://www.gpw.pl oraz http://www.gpwinfostrefa.pl.

Wyniki badań empirycznych z wykorzystaniem skorygowanych stóp zwrotu również potwierdzają, iż spółki portfelowe funduszy private equity charakteryzują się niższym poziomem niedowartościowania akcji w pierwszym dniu notowań giełdowych w porównaniu z pozostałymi spółkami. Średnia stopa zwrotu $\mathrm{z}$ akcji pierwszego dnia notowań skorygowana o zmianę indeksu WIG w dniu debiutu wynosiła $\mathrm{w}$ grupie spółek portfelowych funduszy private equity $12,57 \%$, a dla pozostałych spółek ta zmienna kształtowała się na poziomie $15,54 \%$. 
Z kolei średnia stopa zwrotu, uwzględniająca zmianę warunków rynkowych pomiędzy dniem zakończenia zapisów na akcje spółek korzystających ze wsparcia funduszy private equity a dniem ich debiutu na warszawskim parkiecie wynosiła $12,76 \%$ i była niższa $\mathrm{w}$ stosunku do pozostałych spółek o niespełna 2 punkty procentowe. Do analogicznych wniosków o poziomie niedowartościowania akcji w grupie badanych podmiotów skłania wartość mediany.

$\mathrm{W}$ analizowanym okresie stopień niedowartościowania akcji w pierwszym dniu notowań spółek wykorzystujących fundusze private equity do finansowania rozwoju oraz pozostałych nowych spółek giełdowych w poszczególnych latach kształtował się na zróżnicowanym poziomie. Analizując dane zawarte w tab. 4.15 można dostrzec, iż w przeważającej mierze średnie stopy zwrotu w pierwszym dniu notowań z akcji spółek portfelowych funduszy private equity były niższe niż $w$ przypadku pozostałych spółek. Wyjątek stanowią jednakże debiuty giełdowe przeprowadzone w 2005 r. oraz w 2010 r. Wówczas to średnie stopy zwrotu w pierwszym dniu notowań wykazywały bowiem większe wartości dla spółek portfelowych funduszy private equity niż dla pozostałych spółek. W 2003 r. oraz w 2009 r. nie są możliwe bezpośrednie porównania obu badanych zbiorowości. Należy zaznaczyć, iż do interpretacji wyników zawartych w tab. 4.15 należy podchodzić z dużą dozą ostrożności ze względu na mało liczne próby badawcze $\mathrm{w}$ rocznych interwałach.

Wyniki te nie mogą być nie tylko uogólniane lecz nie mogą także stanowić pełnej podstawy odniesienia do analiz międzysektorowych. Analizy takie są jednak niezbędne do pełniejszego rozpoznania strategii dezinwestycji funduszy private equity.

Podejmując próbę ich przeprowadzenia należy zdać sobie przeto sprawę, iż wyniki takich analiz mogą mieć w tej sytuacji tylko charakter informacyjny.

Uzupełnieniem analizy kształtowania się niedowartościowania akcji w pierwszym dniu notowań spółek portfelowych funduszy private equity, a także odmienności tego zjawiska względem pozostałych spółek jest analiza międzysektorowa. Można bowiem postawić pytanie, czy istnieją różnice w zakresie oceny poszczególnych sektorów przez inwestorów, wyrażające się dyferencjacją stóp zwrotu z akcji w dniu debiutu.

Analiza międzysektorowa badanych spółek może przybrać jednakże tylko ograniczony zakres, ze względu na niewielką liczebność podmiotów w poszczególnych sektorach. Stąd wnioskowanie na podstawie obliczeń jest znacznie ograniczone $^{41}$. Podział sektorowy został przyjęty za Ewidencja instrumentów finansowych prowadzoną przez Komisję Nadzoru Finansowego ${ }^{42}$.

${ }^{41}$ Dalsze badania będą prowadzone wyłącznie w oparciu o proste stopy zwrotu, gdyż w toku dotychczasowych rozważań nie było istotnych różnic we wnioskowaniu na podstawie prostych i skorygowanych stóp zwrotu.

${ }^{42} \mathrm{http}: / /$ www.knf.gov.pl/dla_rynku/Rejestry_i_Ewidencje/index.html. 


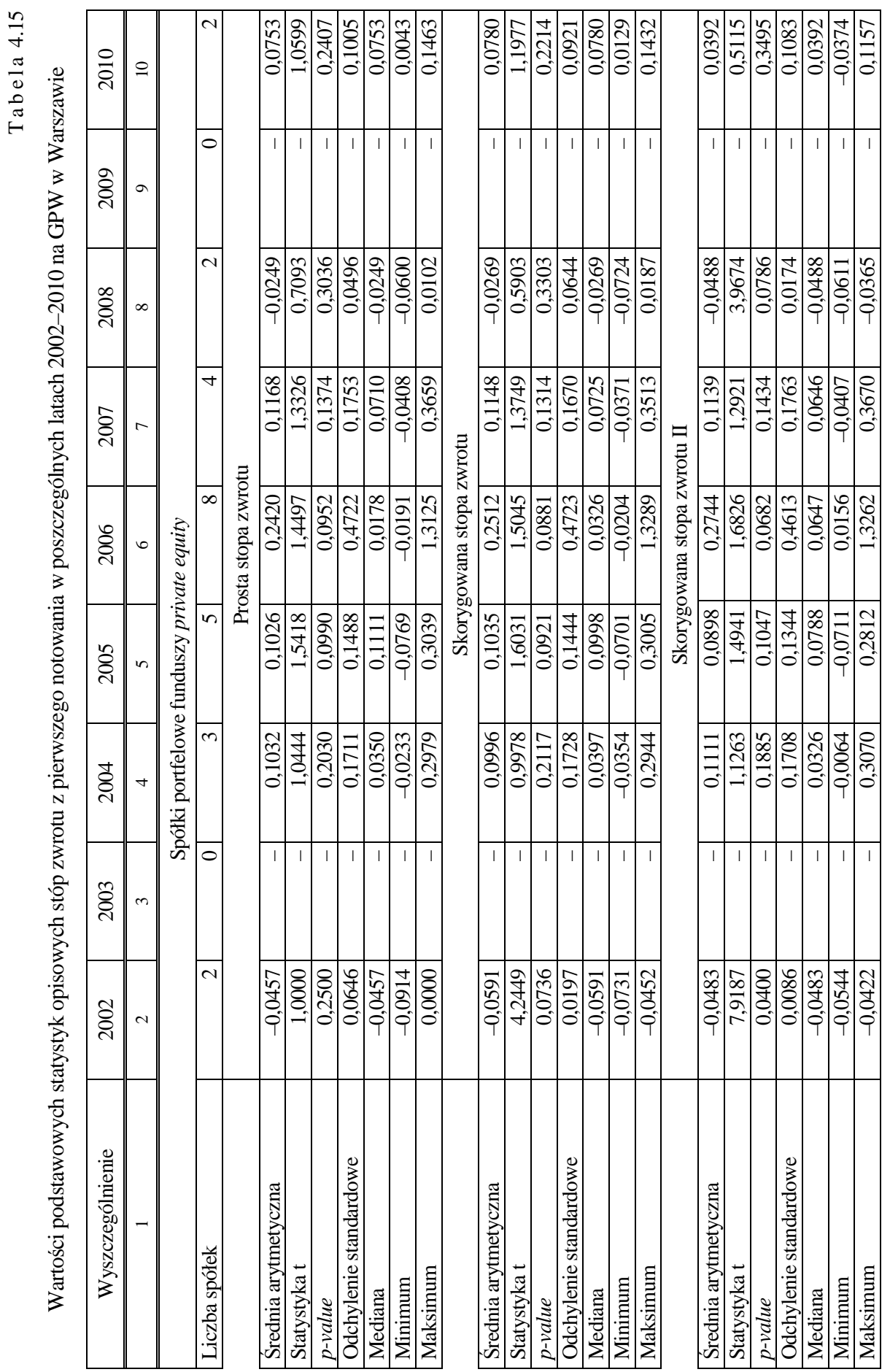




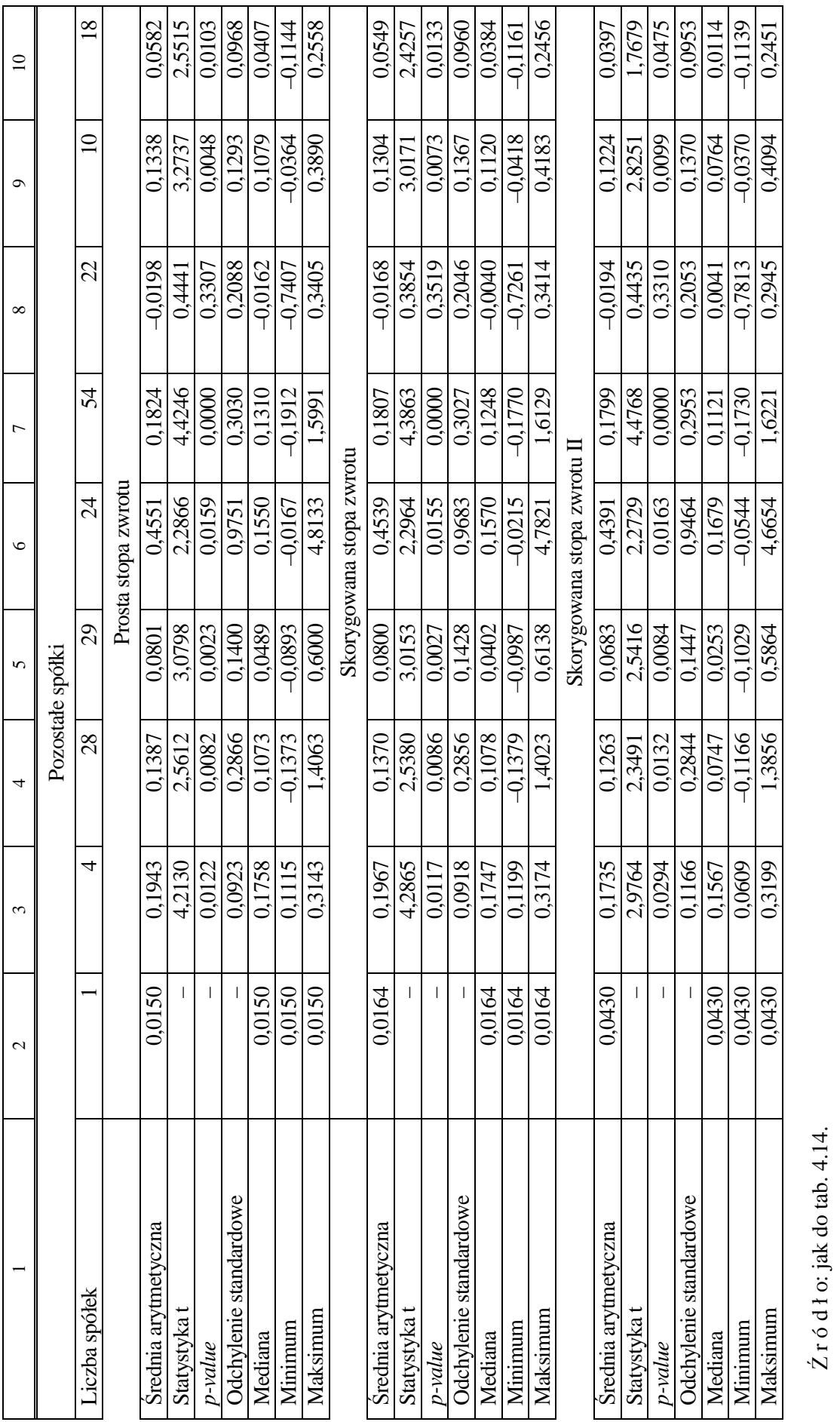


Spółki portfelowe objęte procesami dezinwestycji za pośrednictwem publicznego rynku papierów wartościowych prowadziły swoją działalność w 8 sektorach gospodarki, z czego najliczniej reprezentowany był sektor informatyka (zob. wykres 4.11).

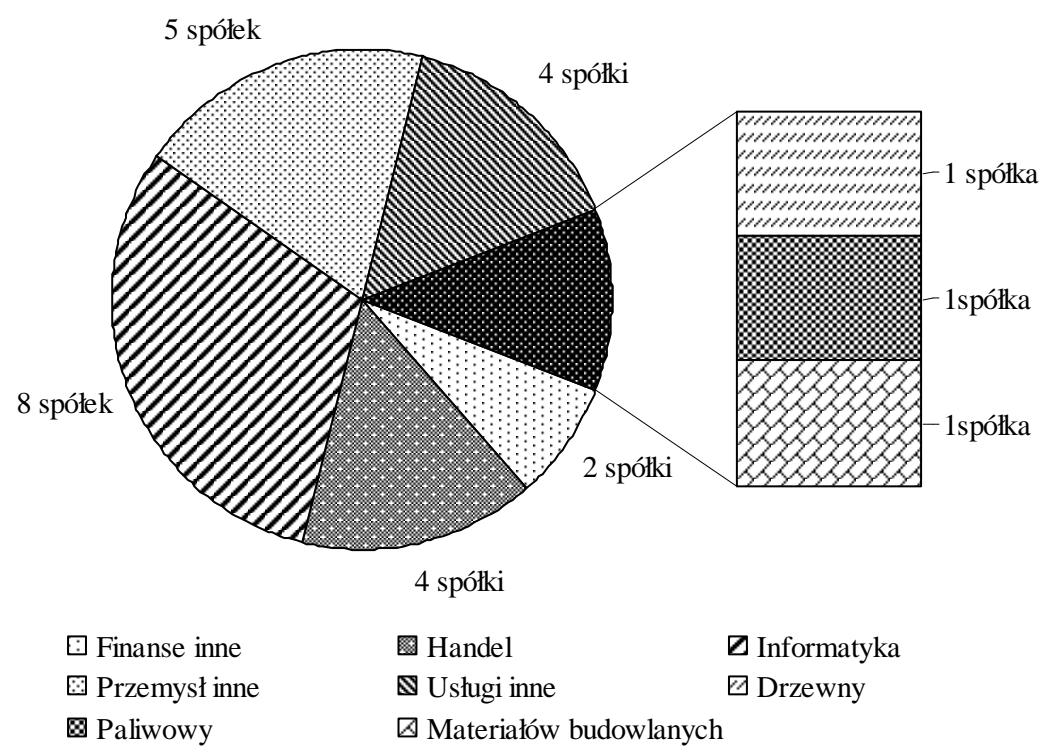

Wykres 4.11. Sektorowy rozkład pierwszych ofert publicznych spółek portfelowych funduszy private equity w latach 2002-2010 na GPW w Warszawie

Ź r ódło: opracowane własne na podstawie Ewidencji instrumentów finansowych Komisji Nadzoru Finansowego, http://www.knf.gov.pl.

Na podstawie informacji przedstawionych na wykresie 4.11 można wskazać, iż poza sektorem informatyka najliczniej reprezentowanym wśród badanych przedsiębiorstw udziałowych funduszy private equity jest sektor przemył inne (5 spółek). Po 4 spółki zostały zaliczone do sektorów usługi inne oraz handel natomiast sektor finanse inne reprezentowały zaledwie 2 spółki. Pozostałe trzy spółki prowadziły inną działalność, jednakże ze względu liczbę podmiotów w poszczególnych sektorach nie zostały one uwzględnione w analizie sektorowej stóp zwrotu w pierwszym dniu notowań na warszawskim parkiecie.

Analizując poziom niedowartościowania pierwszych ofert publicznych spółek portfelowych funduszy private equity można zaobserwować znaczne zróżnicowanie niedowartościowania akcji w pierwszym dniu notowań giełdowych pomiędzy poszczególnymi sektorami (zob. tab. 4.16). 
Wśród spółek portfelowych funduszy private equity najwyższymi stopami w pierwszym dniu notowań giełdowych charakteryzowały się podmioty z sektora przemysł inne, gdzie średnia wartość analizowanej zmiennej wyniosła prawie $35 \%$ (zob. tab. 4.16).

Tabela 4.16

Statystyki opisowe prostych stóp zwrotu w pierwszym dniu notowań giełdowych w wybranych sektorach w latach 2002-2010

\begin{tabular}{|l|c|c|c|c|c|}
\hline \multicolumn{7}{|c|}{ Wyszczególnienie } & $\begin{array}{c}\text { Finanse } \\
\text { inne }\end{array}$ & Handel & Informatyka & $\begin{array}{c}\text { Przemysł } \\
\text { inne }\end{array}$ & Usługi inne \\
\hline \hline \multicolumn{7}{|c|}{ Spółki portfelowe funduszy private equity } \\
\hline Średnia arytmetyczna & 0,0505 & 0,0252 & 0,1340 & 0,3496 & 0,0272 \\
\hline Statystyka t & 17,6667 & 0,4562 & 1,7075 & 1,3856 & 0,8508 \\
\hline$p$-value & 0,0180 & 0,3396 & 0,0657 & 0,1191 & 0,2287 \\
\hline Mediana & 0,0505 & 0,0087 & 0,0113 & 0,1463 & 0,0193 \\
\hline Odchylenie standardowe & 0,0040 & 0,1107 & 0,2219 & 0,5641 & 0,0640 \\
\hline Minimum & 0,0476 & $-0,0914$ & $-0,0600$ & $-0,0769$ & $-0,0408$ \\
\hline Maksimum & 0,0533 & 0,1750 & 0,5500 & 1,3125 & 0,1111 \\
\hline Liczba spółek & 2 & 4 & 8 & 5 & 4 \\
\hline \multicolumn{7}{|c|}{ Pozostałe spółki } & \\
\hline Średnia arytmetyczna & 0,3560 & 0,0759 & 0,1354 & 0,0945 & 0,2352 \\
\hline Statystyka t & 2,2342 & 3,3817 & 2,8334 & 3,0142 & 1,2489 \\
\hline$p$-value & 0,0280 & 0,0014 & 0,0055 & 0,0039 & 0,1116 \\
\hline Mediana & 0,2558 & 0,0517 & 0,0795 & 0,0664 & 0,0676 \\
\hline Odchylenie standardowe & 0,4780 & 0,1052 & 0,2084 & 0,1331 & 0,9601 \\
\hline Minimum & $-0,0954$ & $-0,1043$ & $-0,1336$ & $-0,1000$ & $-0,7407$ \\
\hline Maksimum & 1,4063 & 0,3761 & 0,6450 & 0,3405 & 4,8133 \\
\hline Liczba spółek & 9 & 22 & 19 & 18 & 26 \\
\hline
\end{tabular}

Źr ó d ło: jak do tab. 4.14 .

Na wynik w tej grupie przedsiębiorstw w znacznym stopniu wpłynęła spółka $H T L-S t r e f a S A$, gdyż kurs akcji tej spółki na zamknięcie pierwszego dnia notowań wynosił 83,25 zł wobec ceny emisyjnej na poziomie 36 zł. Kolejne miejsce pod względem wysokości niedowartościowania akcji w dniu debiutu giełdowego zajmowały spółki z sektora informatyka. W większości analizowanych sektorów oferty publiczne przedsiębiorstw udziałowych funduszy private equity charakteryzowały się niższym poziomem niedowartościowania akcji. 


\subsubsection{Alokacja kosztu niedowartościowania akcji w pierwszych ofertach publicznych spótek portfelowych funduszy private equity}

Poszukiwanie odpowiedzi na pytanie, jaka część kosztu powstałego w postaci niedowartościowania akcji spółek objętych procesami dezinwestycji $\mathrm{w}$ formie pierwszej oferty publicznej jest ponoszona przez fundusze private equity jest bardzo ważną częścią analizy efektywności procesów dezinwestycji.

Rozpoznany stopień niedowartościowania akcji zbywanych w ramach pierwszych ofert publicznych znajduje bowiem swoje odzwierciedlenie w postaci części utraconego zysku kapitałowego i tym samym negatywnie wpływa na wysokość stopy zwrotu z inwestycji uzyskiwanej przez fundusze private equity. Koszt utraconych możliwości powstały w wyniku niedowartościowania akcji zbywanych w ramach pierwszej oferty publicznej nie obciąża wyłącznie funduszu private equity. W ofercie publicznej z reguły sprzedawana jest tylko część akcji emitenta, a powstały koszt niedowartościowania alokowany jest głównie na akcje zbywane.

$\mathrm{W}$ ofertach publicznych spółek portfelowych funduszy private equity można wskazać trzy główne źródła pochodzenia akcji sprzedawanych, a mianowicie akcje będące własnością funduszu, akcje pierwotnych właścicieli spółki oraz akcje powstałe w wyniku nowej emisji. Obiektem powstałego w ofercie kosztu niedowartościowania akcji będą tylko akcje istniejące w okresie bezpośrednio poprzedzającym realizację pierwszej oferty publicznej. Koszt niedowartościowania związany z emisją nowych akcji będzie asygnowany na akcjonariuszy będących właścicielami akcji spółki w okresie poprzedzającym jej debiut giełdowy.

Badania empiryczne nad alokacją kosztu powstałego w wyniku niedowartościowania akcji w ofertach publicznych spółek portfelowych funduszy private equity zostały przeprowadzone $\mathrm{w}$ oparciu o metodykę zaproponowaną przez C. B. Barry'ego, który zajmował się kwestią podziału badanego kosztu pomiędzy akcjonariuszy, którzy sprzedawali akcje w ofercie publicznej oraz tych, którzy zdecydowali się nie zbywać akcji w ramach oferty ${ }^{43}$. W późniejszym okresie ten sposób rozpoznania alokacji kosztu niedowartościowania był również wykorzystany przez innych badaczy problemu m. in. do analizy zależności pomiędzy niedowartościowaniem, strukturą właścicielską oraz nadzorem korporacyjnym spółek ${ }^{44}$.

Poziom niedowartościowania akcji $\mathrm{w}$ ofercie publicznej na potrzeby badań został określony $\mathrm{w}$ postaci stopy zwrotu $\mathrm{z}$ akcji $\mathrm{w}$ dniu debiutu giełdowego skorygowanej o stopę zwrotu z portfela rynkowego w tym dniu. Jako odzwierciedlenie

${ }^{43}$ C. B. B arry, Initial Public Offering Underpricing: The Issuer's View-A Comment, „,The Journal of Finance", September 1989, Vol. 44, No. 4, s. 1099-1103.

${ }^{44}$ M. J. B renn an, J. Franks, Underpricing, ownership and control in initial public offerings of equity securities in the UK, „Journal of Financial Economics”, September 1997, Vol. 45, Issue 3, s. 391-413. 
zmian wartości portfela rynkowego wykorzystano zmianę indeksu WIG. Niedowartościowanie akcji poszczególnych spółek zostało wyrażone wzorem:

$$
u_{i}=A R_{i, t_{1}}=\frac{P_{i, t_{1}}}{P_{i, e}}-\frac{W I G_{i, t_{1}}}{W I G_{i, t_{0}}}
$$

gdzie:

$u_{i}$ - niedowartościowanie akcji $i$-tej spółki w dniu debiutu giełdowego,

pozostałe oznaczenia jak wyżej.

Gdyby akcjonariusze sprzedający akcje w ofercie publicznej zdecydowali się na sprzedaż akcji nie po cenie emisyjnej, a po cenie zamknięcia z pierwszego dnia notowań, wówczas nie ponieśliby oni kosztu niedowartościowania. Ów zmaterializowany koszt implicite w postaci całkowitego kosztu niedowartościowania akcji $\mathrm{w}$ ofercie publicznej może być przedstawiony zatem postaci

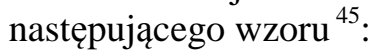

$$
\begin{aligned}
& T C_{u}=u P_{e}\left(N S_{N E W}+\underset{\text { SOLD }}{P R E-I P O} N S\right)=u P_{e \text { SOLD }} N S \\
& \text { SOLD } N S=\left(N S_{N E W}+{ }_{\text {SOLD }}^{P R E-I P O} N S\right)
\end{aligned}
$$

gdzie:

$T C_{u} \quad-$ łączny koszt niedowartościowania akcji spółki $\mathrm{w}$ ofercie publicznej,

$N S_{N E W} \quad-$ liczba akcji nowej emisji,

${ }_{S O L D}^{P R E-I P O} N S$ - liczba starych akcji sprzedawana w ofercie publicznej,

${ }_{S O L D} N S \quad$ - liczba akcji sprzedawanych w ofercie publicznej ogółem,

pozostałe oznaczenia jak wyżej.

Koszt implikowany przez niedowartościowanie akcji w dniu debiutu dotyczy określonej części wartości przedsiębiorstwa, gdyż w pierwszej ofercie publicznej z reguły oferowana do zakupu jest tylko część akcji danej spółki, stąd też:

${ }^{45}$ Schemat obliczeń przedstawiony został dla pojedynczej spółki. W prezentowanych w tej części opracowania wzorach dla uzyskania lepszej czytelności zrezygnowano z indeksu dolnego $i$ oznaczającego konkretną spółkę. 


$$
u_{p}=\frac{T C_{u}}{{ }^{P R E-I P O} N S \times P_{e}}=u \frac{S O L D}{} N S
$$

gdzie:

$u_{p} \quad-$ udział kosztu niedowartościowania w wartości ogółem spółki przed debiutem giełdowym, wycenionej według ceny emisyjnej,

${ }^{P R E-I P O} N S$ - liczba akcji przed upublicznieniem spółki,

pozostałe oznaczenia jak wyżej.

W kolejnym etapie oceny alokacji kosztu niedowartościowania akcji należy obliczyć, jaka część zidentyfikowanego kosztu niedowartościowania przypada na akcjonariuszy, którzy podjęli decyzję o wyjściu ze spółki i sprzedaży posiadanych $\mathrm{w}$ portfelu inwestycyjnym akcji oraz tych, którzy zdecydowali się na kontynuację zaangażowania kapitałowego w spółkę.

W sytuacji, gdy pierwsza oferta publiczna nie jest związana z emisją nowych akcji, całkowity koszt niedowartościowania akcji w dniu debiutu ponoszony jest przez inwestorów sprzedających $\mathrm{w}$ ofercie publicznej posiadane papiery wartościowe. Jednakże emisja nowych akcji z dyskontem wpływa na obniżenie wartości dotychczas istniejących akcji, stąd koszt niedowartościowania akcji powstały w wyniku nowej emisji przypadający na jedną dotychczasową akcję wynosi:

$$
u_{n}=\frac{u N S_{N E W} P_{e}}{{ }^{P R E-I P O} N S},
$$

gdzie:

$u_{n}$ - koszt niedowartościowania akcji powstały w wyniku nowej emisji przypadający na jedną dotychczasową akcję,

pozostałe oznaczenia jak wyżej.

Koszt niedowartościowania przypadający na jedną złotówkę dotychczasowych akcji, wycenionych według ceny emisyjnej, będących własnością akcjonariuszy, którzy zdecydowali się na nie sprzedawać akcji w ofercie można wyrazić następującym równaniem:

$$
u_{r}=\frac{u N S_{N E W} P_{e}}{{ }^{P R E-I P O} N S} \times P_{e}^{-1}=\frac{u N S_{N E W}}{P R E-I P O} N S
$$

gdzie:

$u_{r}$ - niedowartościowanie akcji podmiotów niesprzedających posiadanych akcji w pierwszej ofercie publicznej,

pozostałe oznaczenia jak wyżej. 
Właściwe określenie poziomu niedowartościowania dotychczasowych akcji spółki zbywanych w ramach pierwszej oferty publicznej jest zagadnieniem bardziej złożonym. Koszt ten jest bowiem implikowany w pewnej mierze emisją nowych akcji. Można przeto za M. J. Brennanem oraz J. Franksem przyjąć założenie, iż kurs akcji na zamknięciu w dniu debiutu giełdowego skorygowany o zmianę warunków rynkowych byłby wyższy w sytuacji braku emisji nowych akcji, czyli $^{46}$ :

$$
P_{t_{1}}+\left(u N S_{N E W} P_{e} /{ }^{P R E-I P O} N S\right) .
$$

Względne niedowartościowanie akcji zbywanych w pierwszej ofercie publicznej przez dotychczasowych akcjonariuszy przyjmuje zatem następującą postać:

$$
\begin{aligned}
& u_{d}=\frac{P_{t_{1}}+\left(u N S_{N E W} P_{e} /{ }^{P R E-I P O} N S\right)-P_{e}}{P_{e}} \\
& u_{d}=\frac{P_{t_{1}}-P_{e}}{P_{e}}+\frac{u N S_{N E W}}{{ }^{P R E-I P O} N S} \\
& u_{d}=u+u_{r}
\end{aligned}
$$

gdzie:

$u_{d}$ - niedowartościowania akcji zbywanych w pierwszej ofercie publicznej przez pierwotnych właścicieli spółki,

pozostałe oznaczenia jak wyżej.

Dzieląc akcjonariuszy analizowanych spółek na dwie główne grupy, a mianowicie fundusze private equity oraz pozostałych akcjonariuszy można wskazać, jaka część całkowitego kosztu niedowartościowania akcji przypada na wyszczególnione podmioty:

$$
\begin{aligned}
& C_{P E}=\left({ }^{A F T E R-I P O} N S_{P E} u_{r}+{ }_{S O L D} N S_{P E} u_{d}\right) P_{e} \\
& C_{O}=\left({ }^{A F T E R-I P O} N S_{\text {OTHER }} u_{r}+{ }_{\text {SOLD }} N S_{\text {OTHER }} u_{d}\right) P_{e} \\
& T C_{u}=C_{P E}+C_{O}
\end{aligned}
$$

${ }^{46}$ M. J. B rennan, J. Franks, op. cit., s. 401. 
gdzie:

$C_{P E} \quad-$ koszt niedowartościowania ponoszony przez fundusz private equity,

$C_{O} \quad-$ koszt niedowartościowania ponoszony przez pozostałych akcjonariuszy,

${ }^{A F T E R-I P O} N S_{P E} \quad$ - liczba akcji pozostająca w posiadaniu funduszu private equity po debiucie giełdowym spółki portfelowej,

${ }_{S O L D} N S_{P E} \quad-$ liczba akcji zbyta przez fundusz private equity w pierwszej publicznej ofercie sprzedaży akcji,

${ }^{A F T E R-I P O} N S_{\text {OTHER }}$ - liczba akcji pozostająca w posiadaniu pozostałych akcjonariuszy po debiucie giełdowym spółki,

${ }_{S O L D} N S_{\text {OTHER }}$ - liczba akcji zbyta przez pozostałych akcjonariuszy w pierwszej publicznej ofercie sprzedaży akcji,

pozostałe oznaczenia jak wyżej.

Różniczkując koszt niedowartościowania akcji oferowanych w pierwszej ofercie publicznej przez poszczególne grupy akcjonariuszy spółki względem $u$ można wyznaczyć jego koszt krańcowy. Dla rozpatrywanych grup akcjonariuszy będzie on następujący:

$$
\begin{aligned}
& \frac{\partial C_{P E}}{\partial u}=\left(\frac{N S_{N E W}}{{ }^{P R E-I P O} N S}+\frac{\text { SOLD }}{N S_{P E}}\right) N S_{P E} P_{e} \\
& \frac{\partial C_{O}}{\partial u}=\left(\frac{N S_{N E W}}{{ }^{P R E-I P O} N S}+\frac{\text { SOLD } N S_{\text {OTHER }}}{N S_{\text {OTHER }}}\right) N S_{\text {OTHER }} P_{e}
\end{aligned}
$$

gdzie:

$N S_{P E} \quad$ - liczba akcji posiadanych przez fundusz private equity ogółem,

$N S_{\text {OTHER }}$ - liczba akcji znajdujących się w posiadaniu pozostałych akcjonariuszy ogółem,

pozostałe oznaczenia jak wyżej.

Analizując powyższe równania można wskazać, iż krańcowy koszt niedowartościowania akcji $\mathrm{w}$ ofercie publicznej dla funduszu private equity jest tym wyższy, im większy jest stosunek liczby akcji nowej emisji w porównaniu do liczby starych akcji (wzrost rozwodnienia) oraz im większy jest stopień dezinwestycji realizowanej w ramach pierwszej oferty publicznej. 


\subsubsection{Wyniki badań empirycznych nad alokacją kosztu niedowartościowania akcji w pierwszych ofertach publicznych spółek portfelowych funduszy private equity}

Analiza kształtowania poziomu kosztu niedowartościowania dla spółek portfelowych funduszy private equity, w których dezinwestycja została przeprowadzona przez warszawski rynek giełdowy wykazała, iż średnio koszt ten kształtował się on na poziomie 12,63 mln zł, co stanowiło ponad 5\% wartości spółki, przy wycenie jej akcji według ceny emisyjnej (zob. tab. 4.17).

Tabela 4.17

Wartość wybranych statystyk opisowych zmiennych $T C_{u}$ oraz $u_{p}$ w pierwszych ofertach publicznych spółek portfelowych funduszy private equity w latach 2002-2010

\begin{tabular}{|l|c|c|}
\hline \multicolumn{1}{|c|}{ Wyszczególnienie } & $\begin{array}{c}T C_{u} \\
\text { [tys. zł] }\end{array}$ & $u_{p}$ \\
\hline \hline Średnia arytmetyczna & 12633,15 & 0,0507 \\
\hline Odchylenie standardowe & 32774,84 & 0,0952 \\
\hline Kwartyl dolny & $-168,47$ & $-0,0044$ \\
\hline Mediana & 1977,14 & 0,0155 \\
\hline Kwartyl górny & 4341,11 & 0,0413 \\
\hline Minimum & $-4244,41$ & $-0,0597$ \\
\hline Maksimum & 129407,09 & 0,3268 \\
\hline Liczba spółek & 26 & 26 \\
\hline
\end{tabular}

Ź r ó d ł o: opracowanie własne na podstawie raportów bieżących spółek, http://www.gpw.pl oraz http://www.gpwinfostrefa.pl.

Analizując miary położenia zawarte w tab. 4.17 można zauważyć, że kwartyl górny w przypadku całkowitego kosztu niedowartościowania oraz udziału tego kosztu w wartości ogółem spółki wycenionej po cenie emisyjnej kształtuje się poniżej średniej. Rozkład obu badanych wielkości jest więc mocno prawoskośny. W przypadku 75\% analizowanych spółek, całkowity koszt niedowartościowania kształtował się poniżej 4,3 mln zł. Najwyższy całkowity koszt niedowartościowania akcji wystąpił w przypadku pierwszej oferty publicznej spółki HTL-Strefa SA i wynosił on ponad $129,4 \mathrm{mln}$ zł, co stanowiło ponad $32 \%$ jej wartości przy wycenie według ceny na rynku pierwotnym.

Średnie niedowartościowanie akcji w analizowanych pierwszych ofertach publicznych dla akcjonariuszy, którzy zdecydowali się nie sprzedawać posiadanych w spółce akcji wynosiło 2,58\% w pierwszym dniu notowań, natomiast niedowartościowanie akcji zbywanych w ramach realizowanego procesu dezinwestycji wynosiło średnio 15,15\% w analogicznym okresie (zob. tab. 4.18). 
Niedowartościowanie akcji niesprzedawanych i zbywanych w pierwszych ofertach publicznych spółek portfelowych funduszy private equity w latach 2002-2010

\begin{tabular}{|l|c|c|}
\hline \multicolumn{1}{|c|}{ Wyszczególnienie } & $u r$ & $u d$ \\
\hline \hline Średnia arytmetyczna & 0,0258 & 0,1515 \\
\hline Odchylenie standardowe & 0,0599 & 0,3383 \\
\hline Kwartyl dolny & $-0,0005$ & $-0,0204$ \\
\hline Mediana & 0,0034 & 0,0420 \\
\hline Kwartyl górny & 0,0225 & 0,1376 \\
\hline Minimum & $-0,0423$ & $-0,1154$ \\
\hline Maksimum & 0,2114 & 1,5403 \\
\hline Liczba spółek & 26 & 26 \\
\hline
\end{tabular}

Ź r ó d ł o: jak do tab. 4.17.

Porównując dane zawarte w tab. 4.18 ze średnim poziomem niedowartościowania akcji w ofertach publicznych spółek portfelowych funduszy private equity (zob. tab. 4.14) można wskazać, że niedowartościowanie akcji zbywanych jest wyższe, niż wskazywały tradycyjnie stosowane miary niedowartościowania w postaci prostych oraz skorygowanych stóp zwrotu. Z kolei w analogicznej sytuacji średni poziom niedowartościowania akcji, które nie są zbywane $\mathrm{w}$ związku $\mathrm{z}$ wprowadzeniem ich do publicznego obrotu jest znacznie przeszacowywany.

Tabela 4.19

Statystyki opisowe kosztu niedowartościowania funduszy private equity oraz pozostałych akcjonariuszy w analizowanych ofertach

\begin{tabular}{|l|c|c|}
\hline \multicolumn{1}{|c|}{ Wyszczególnienie } & $\begin{array}{c}\text { Cpe } \\
\text { [tys. zł] }\end{array}$ & $\begin{array}{c}\text { Co } \\
\text { [tys. zł] }\end{array}$ \\
\hline \hline Średnia arytmetyczna & 7618,39 & 5014,75 \\
\hline Odchylenie standardowe & 17362,78 & 16649,65 \\
\hline Kwartyl dolny & $-35,40$ & $-73,15$ \\
\hline Mediana & 1164,13 & 234,31 \\
\hline Kwartyl górny & 3529,05 & 674,08 \\
\hline Minimum & $-2137,58$ & $-2106,84$ \\
\hline Maksimum & 58313,11 & 73347,36 \\
\hline Liczba spółek & 26 & 26 \\
\hline
\end{tabular}

Źr ó d ło: jak do tab. 4.17.

Rozważając alokację kosztu niedowartościowania pomiędzy fundusze private equity i pozostałych akcjonariuszy można zauważyć, że w analizowanych ofertach publicznych średnio jego większa część obciąża fundusze private 
equity. Realizacja dezinwestycji w formie pierwszej oferty publicznej za pośrednictwem warszawskiej giełdy w analizowanym okresie wiązała się dla funduszu private equity z koniecznością poniesienia kosztu niedowartościowania akcji w pierwszym dniu notowań w wysokości średnio 7,62 mln zł. Z kolei dla pozostałych akcjonariuszy koszt ten był średnio niższy o blisko 2,6 mln zł i wynosił niewiele ponad 5,01 mln zł. Kwartyl dolny, mediana i kwartyl górny również kształtują się na wyższym poziomie w przepadku kosztu niedowartościowania obciążającego fundusze private equity (zob. tab. 4.19).

Można wskazać dwie zasadnicze przyczyny zaistniałej sytuacji. Pierwszą $\mathrm{z}$ nich jest posiadanie przez fundusze private equity $\mathrm{z}$ reguły większościowych udziałów w spółkach przed wprowadzeniem ich akcji publicznego obrotu. Drugą zaś jest większa skłonność funduszy private equity niż pozostałych akcjonariuszy do sprzedawania posiadanych akcji, gdyż ich intencją jest wyjście z inwestycji i realizacja oczekiwanego zysku kapitałowego.

Zarządzający funduszami private equity, opracowując strategiczny plan zakończenia zaangażowania kapitałowego w spółkę portfelową, powinni uwzględnić w swoich analizach efektywności inwestycji również wartość pośrednich kosztów związanych z pierwszymi ofertami publicznymi, gdyż mogą one znacząco wpłynąć na poziom efektywności danej inwestycji.

\subsection{Wyniki badań nad zmianami stóp zwrotu z pierwszych ofert publicznych spółek portfelowych funduszy private equity}

\subsubsection{PRZEWARTOŚCIOWANIE PIERWSZYCH OFERT PUBLICZNYCH W PERSPEKTYWIE ŚREDNIO- I DŁUGOTERMINOWEJ \\ - WNIOSKI Z BADAŃ LITERATUROWYCH}

Efektywność inwestycji funduszy private equity determinowana jest ogółem środków uzyskanych ze sprzedaży posiadanych w portfelu inwestycyjnym papierów wartościowych. Jak pokazały wcześniej przedstawione badania, w toku procesów dezinwestycji realizowanych za pośrednictwem publicznego rynku papierów wartościowych, zaledwie część akcji będących własnością funduszy zbywana jest $w$ ramach pierwszej oferty sprzedaży. W przeważającej liczbie analizowanych transakcji fundusze private equity pozostawały akcjonariuszami spółek po ich debiucie giełdowym. W tym kontekście dużego znaczenia dla wdrażania skutecznych procesów wyjść z inwestycji nabiera rozpoznanie kształtowania się giełdowych kursów akcji spółek portfelowych funduszy private equity w perspektywie średnio- i długoterminowej. 
Na wielu giełdach papierów wartościowych obserwowane jest występowanie ujemnych nadzwyczajnych stóp zwrotu z inwestycji w akcje spółek realizujących pierwsze oferty publiczne w porównaniu do całego rynku ${ }^{47}$. Obszerne badania empiryczne w tym zakresie dla polskiego rynku giełdowego przeprowadził P. Siwek ${ }^{48}$. Na podstawie analizy kształtowania się kursów giełdowych 130 spółek, które zakończyły pierwsze oferty publiczne w latach 1995-2003 wykazał on, iż stopy zwrotu z akcji tych spółek zachowywały się gorzej niż rynek (mierzony stopami zwrotu z indeksu WIG).

W literaturze przedmiotu można wskazać cztery główne teorie objaśniające występowanie tego zjawiska. Są to:

- teoria różnorodności opinii (hipoteza rozbieżnych opinii na temat wartości spółki, ang. the divergence of opinion hypothesis) - nabywców akcji sprzedawanych w pierwszych ofertach publicznych cechuje duży optymizm w zakresie wyceny spółki i perspektyw jej rozwoju, w odróżnieniu do pesymistycznych inwestorów niepartycypujących w ofercie. Wraz z upływem czasu, w wyniku pojawiania się nowych informacji o spółce, rozbieżności w ocenach obu grup inwestorów niwelują się, co w konsekwencji skutkuje obniżeniem rynkowych cen akcji.

- teoria „promotora” (hipoteza nakręconych emisji, ang. the impresario hypothesis) - w tym podejściu zwraca się uwagę, iż rynek debiutów giełdowych podlega pewnym modom. W celu zapewnienia odpowiedniego popytu na akcje w pierwszej ofercie publicznej, zbywane walory są celowo niedoszacowywane. W efekcie takiego działania pierwsze stopy zwrotu są ponadprzeciętnie wysokie, jednakże z upływem czasu w wyniku wyceny rynkowej, zmiany kursu akcji takich spółek są coraz mniejsze.

- teoria rozgrzanego rynku (teoria okazji czasowej, ang. the windows of opportunity hypothesis) - teoria ta opiera się na spostrzeżeniu, iż na rynkach kapitałowych występują tzw. okresy rozgrzanego rynku (ang. hot-issue market). W okresach tych panuje dobra koniunktura, a inwestorów cechuje ponadprzeciętny optymizm. Spółki starają się wykorzystać sprzyjające okoliczności i zrealizować publiczne oferty sprzedaży akcji właśnie wtedy, uzyskując wówczas większe wpływy ze sprzedaży akcji. W okresach ,rynku niedźwiedzia” akcje tych spółek podlegają względnie silniejszej przecenie, a stopy zwrotu z akcji w długim terminie są dla tych emisji najniższe.

${ }^{47}$ Zob. J. A. Schuster, IPOs: Insights from Seven European Countries, Discussion Paper 461, Financial Markets Group, London School of Economics and Political Science, London 2003, s. 1-39; P. Siwek, Praktyka pierwszych ofert publicznych $w$ Polsce, Wydawnictwa Fachowe CeDeWu.pl, Warszawa 2005, s. 59; A. B rav, C. Geczy, P. A. Gompers, Is the abnormal return following equity issuances anomalous?, „Journal of Financial Economics” 2000, Vol. 56, s. 209-249; S. X.Zheng, Are IPOs really overpriced?, „Journal of Empirical Finance” 2007, Vol. 14, s. 287-309.

${ }^{48}$ P. S i we k, op. cit., s. 151-163. 
- teoria negatywnego wpływu kosztów emisji (ang. IPO issuer costs) - spółki wprowadzające po raz pierwszy akcje do publicznego obrotu obciążane są znaczącymi kosztami przeprowadzenia i organizacji pierwszej oferty publicznej. Ich wysokość negatywnie wpływa na długoterminową wycenę rynkową spółki ${ }^{49}$.

Warto zwrócić uwagę również na badania nad porównaniem długoterminowych stóp zwrotu z akcji spółek giełdowych emitujących nowe akcje i spółek nieprzeprowadzających nowych emisji. Zostały one zapoczątkowane przez J. R. Rittera we wczesnych latach dziewięćdziesiątych XX w. ${ }^{50}$ Autor ten udowodnił, iż w trzyletniej perspektywie inwestycyjnej zwrot z akcji spółek przeprowadzających pierwsze oferty publiczne jest niższy w porównaniu do inwestycji w akcje spółek podobnych do nich pod względem kapitalizacji oraz branży, jednakże znajdujących się już w publicznym obrocie. Inne badania również potwierdziły, iż kupno akcji spółek przeprowadzających emisje nowych akcji w długim okresie przynosi gorsze wyniki inwestycyjne w stosunku do alternatywnej inwestycji w papiery wartościowe spółek giełdowych o zbliżonej kapitalizacji, jednakże nieprzeprowadzających emisji nowych ${ }^{51}$.

Ponieważ wyniki powyższych badań są w opozycji do hipotezy efektywnego rynku kapitałowego ${ }^{52}$ spotkały się one $\mathrm{z}$ dużym zainteresowaniem środowiska naukowego i były przyczynkiem do podjęcia licznych badań w zakresie kształtowania się stóp zwrotu z inwestycji w akcje spółek realizujących publiczne oferty sprzedaży akcji. Liczne analizy prowadzone w późniejszym okresie wykazały, iż przy zastosowaniu innych kryteriów doboru spółek do próby porównawczej, zjawisko przeszacowania cen w akcji spółek realizujących pierwsze oferty publiczne w porównaniu za spółkami nieprzeprowadzającymi nowych emisji akcji nie występuje ${ }^{53}$, a nawet przy zastosowaniu specyficznych kryteriów doboru można zaobserwować zjawisko długoterminowego niedowartościowania takich walorów ${ }^{54}$.

${ }^{49}$ D. J. Cu mming, S. A. Joh an, Venture capital and Private equity Contracting. An International Perspective, Elsevier 2009, s. 587-588; P. S i w e k, op. cit., s. 60-61; D. S u k a c z, op. cit., s. 108.

${ }^{50}$ J. R. Ritter, The Long-Run Performance of Initial Public Offerings, „Journal of Finance", March 1991, Vol. XLVI, No. 1, s. 3-27.

${ }^{51}$ T. Loughran, J. R. Ritter, The new issues puzzle, „The Journal of Finance” 1995, Vol. L, No. 1, s. 23-51.

${ }^{52}$ E. F. F a m a, Efficient Capital Markets: II, „The Journal of Finance”, December 1991, Vol. 46, No. 5, s. 1575-1617.

${ }^{53} \mathrm{~A} . \mathrm{B} \mathrm{rav}, \mathrm{P}$. Go m pers, Myth or reality? The long-run underperformance of initial public offerings: Evidence from venture and nonventure capital-backed companies, „The Journal of Finance" 1997, Vol. 52, s. 1791-1821; A. B rav, C. Geczy, P. A. Gompers, op. cit., s. 209 -249; E. B. Eckbo, Ø. Nor1i, Liquidity risk, leverage and long-run IPO returns, „Journal of Corporate Finance" 2005, Vol. 11, s. 1-35; S. X. Z h en g, op. cit., s. 287-309.

${ }^{54}$ S. X. Z h en g, op. cit., s. 287-309. 
W badaniach nad kształtowaniem się stóp zwrotu z akcji spółek przeprowadzających pierwsze oferty publiczne A. Brav, P. Gompers postawili pytanie o wpływ obecności funduszy private equity w strukturze akcjonariatu debiutujących spółek na kształtowanie się ich kursów giełdowych w perspektywie długoterminowej ${ }^{55}$. Po przeprowadzonej analizie 934 pierwszych ofert publicznych spółek z udziałem funduszy private equity oraz 3407 debiutów giełdowych z lat 1972-1992 badacze ci zauważyli, iż stopy zwrotu z akcji spółek portfelowych funduszy private equity kształtowały się odmiennie w porównaniu z pozostałymi emitentami. Chociaż w obu grupach spółek po upływie 5 lat odnotowane zostały ujemne stopy zwrotu w porównaniu ze zwrotem rynkowym, to strata na akcjach spółek z udziałem funduszy private equity była mniejsza.

Do podobnych wniosków o pozytywnym wpływie funduszy private equity na realizowane $\mathrm{w}$ długoterminowej perspektywie stopy zwrotu $\mathrm{z}$ inwestycji w akcje spółek przeprowadzających pierwsze oferty publiczne doszli W. Bessler oraz M. Seim po analizie ponad 500 debiutów na europejskich giełdach papierów wartościowych ${ }^{56}$. Wyniki tych badań wskazują, iż spółki wprowadzane do publicznego obrotu z udziałem funduszy private equity przynoszą większy zysk swoim inwestorom w porównaniu $\mathrm{z}$ pozostałymi debiutantami, a ich akcje są w długoterminowej perspektywie znacznie mniej przeszacowane. Co więcej, w początkowym okresie notowań (około pierwszych 16 miesięcy) stopy zwrotu będące wynikiem implementacji strategii buy\&hold dla tych spólek przewyższają ogólny zwrot rynkowy.

Przedstawione powyżej wyniki badań A. Brava, P. Gompersa oraz W. Besslera i M. Seima nad kształtowaniem się giełdowych stóp zwrotu z inwestycji w akcje spółek portfelowych funduszy private equity, zdają się potwierdzać formułowaną przez W. L. Megginsona, K. A. Weissa hipotezę o kluczowej roli kapitału reputacji $\mathrm{w}$ procesach dezinwestycji realizowanych za pośrednictwem publicznego rynku papierów wartościowych ${ }^{57}$.

Fundusze private equity dbają o to, aby na rynek giełdowy trafiały akcje najlepszych spółek, a w przygotowanie ich debiutów giełdowych angażowane są podmioty o najlepszej opinii rynkowej oraz renomowane fundusze inwestycyjne. Ponadto nowi właściciele partycypują we wzroście wartości tych spółek wynikającym z unikatowej zdolności funduszy private equity do budowania trwałych przewag konkurencyjnych przedsiębiorstw udziałowych. Wszystkie te działania mają na celu aprecjację kapitału reputacji, dzięki któremu możliwe będzie efektywne przeprowadzenie kolejnych wyjść z inwestycji za pośrednictwem rynku kapitałowego.

${ }^{55}$ A. B rav, P. Gompers, op. cit., s. 1791-1821.

${ }^{56} \mathrm{~W}$. B essler, M. S e im, The performance of venture-backed IPOs in Europe, „Venture capital: An International Journal of Entrepreneurial Finance" 2012, s. 1-25,

DOI:10.1080/13691066.2012.702447

${ }^{57}$ W. L. Meggin so n, K. A. W e is s, op. cit., s. 879-903. 


\subsubsection{PRZYJĘTE W BADANIACH EMPIRYCZNYCH ROZWIĄZANIA METODYCZNE}

Badanie kształtowania się stóp zwrotu z akcji w średnim- i długim terminie, podobnie jak badanie niedowartościowania akcji w pierwszym dniu notowań giełdowych, zostało przeprowadzone w oparciu o metodykę analizy zdarzeń. Analogicznie jako zdarzenie została przyjęta pierwsza publiczna oferta spółki, a proces selekcji podmiotów wchodzących do próby badawczej był tożsamy $\mathrm{z}$ podejściem wskazanym na schemacie 4.1 .

Informacje dotyczące poziomu dziennych stóp zwrotu z akcji poszczególnych spółek oraz stóp zwrotu opisujących zmiany indeksu WIG na poszczególnych sesjach giełdowych wykorzystane $\mathrm{w}$ badaniu pochodziły $\mathrm{z}$ internetowego portalu informacyjnego http://www.gpwinfostrefa.pl, prowadzonego przez Polską Agencję Prasową we współpracy z GPW w Warszawie. Ostatnia sesja giełdowa uwzględniona w badaniach odbyła się 30 marca 2012 r. W badaniach notowanie praw do akcji (PDA) było traktowane równorzędnie z notowaniem akcji, aczkolwiek jeżeli oba rodzaje papierów wartościowych były notowane jednocześnie, do obliczeń wykorzystana została stopa zwrotu $\mathrm{z}$ akcji.

Badania nad kształtowaniem się stóp zwrotu z akcji analizowanych spółek w perspektywie średnio- i długoterminowej objęły trzy wymiary analityczne w postaci skumulowanych anormalnych stóp zwrotu, stóp zwrotu będących efektem realizacji strategii kup i trzymaj oraz wskaźnika względnego bogactwa.

W pierwszej kolejności do oceny średnio- i długoterminowych efektów pierwszych ofert publicznych wykorzystane zostały skumulowane anormalne stopy zwrotu $(C A R)$. Punktem wyjścia powyższej analizy było wyznaczenie stóp zwrotu z akcji poszczególnych spółek na kolejnych sesjach, rozpoczynając od drugiego dnia notowań giełdowych, a następnie wyznaczenia wartości średnich dla poszczególnych grup analizowanych spółek, korygując uzyskane wyniki o stopę zwrotu z portfela porównawczego. Podobnie jak w badaniach nad niedowartościowaniem akcji w pierwszym dniu notowań jako benchmark przyjęty został indeks WIG. Powyższe działania można wyrazić następującym zapisem:

$$
\begin{aligned}
& A R_{i, t}=\frac{P_{i, t}}{P_{i, t-1}}-\frac{W I G_{i, t}}{W I G_{i, t-1}} \\
& \overline{A R_{t}}=\frac{1}{n} \sum_{i=1}^{n} A R_{i, t}=\frac{1}{n} \sum_{i=1}^{n}\left(\frac{P_{i, t}}{P_{i, t-1}}-\frac{W I G_{i, t}}{W I G_{i, t-1}}\right)
\end{aligned}
$$

Dla pokazania średnio- i długoterminowych tendencji w zakresie kształtowania się stóp zwrotu w analizowanych przekrojach klasyfikacyjnych przepro- 
wadzona została agregacja otrzymanych wyników, co pozwoliło na pokazanie stóp zwrotu w sposób narastający. Otrzymana w ten sposób skumulowana nadzwyczajna stopa zwrotu wyznaczona została zgodnie ze wzorem:

$$
\overline{C A R_{\langle 2, T\rangle}}=\sum_{t=2}^{T} \overline{A R_{t}}
$$

gdzie:

$\overline{C A R_{\langle 2, T\rangle}}-\begin{aligned} & \text { przeciętna skumulowana stopa zwrotu w okresie od } 2 \text { dnia } \\ & \text { notowan, }\end{aligned}$

pozostałe oznaczenia jak wyżej.

Ponadto sformułowana powyżej hipoteza badawcza zweryfikowana została z wykorzystaniem stóp zwrotu wynikających z realizacji tzw. strategii kup i trzymaj (ang. buy\&hold return, BHR). W badaniach empirycznych założono strategię inwestycyjną polegającą na zakupie akcji spółek przeprowadzających pierwszą ofertę publiczną po cenie zamknięcia z pierwszego dnia notowań i przyjęciu długoterminowego horyzontu inwestycyjnego. Stopa zwrotu wynikająca z tej strategii wyznaczona została według następującej formuły:

$$
B H R_{T}^{I P O, i}=\prod_{t=2}^{T}\left(1+R_{i, t}\right)-1 .
$$

Do wyznaczenia średniej stopy zwrotu wynikającej z realizacji przyjętej strategii inwestycyjnej dla poszczególnych grup spółek zastosowany został wzór:

$$
\overline{B H R_{T}^{I P O}}=\frac{1}{n} \sum_{i=1}^{n} B H R_{T}^{I P O, i}
$$

Normalne stopy zwrotu dla rozpatrywanej strategii zostały wyznaczone w oparciu o indeks WIG:

$$
B H R_{T}^{W I G, i}=\prod_{t=2}^{T}\left(1+R_{W I G, t}\right)-1
$$

W celu pomiaru efektu cenowego w przyjętym oknie zdarzenia wynikającego z implementacji strategii buy\&hold dla poszczególnych spółek, $B H R_{T}^{I P O, i}$ stopa została skorygowana o stopę zwrotu z portfela odzwierciedlającego zmianę warunków ogólnorynkowych $B H R_{T}^{W I G, i}$, czyli: 


$$
\begin{aligned}
& B H A R_{T}^{I P O, i}=B H R_{T}^{I P O, i}-B H R_{T}^{W I G, i} \\
& B H A R_{T}^{I P O, i}=\prod_{t=2}^{T}\left(1+R_{i, t}\right)-\prod_{t=2}^{T}\left(1+R_{W I G, t}\right) \\
& \overline{B H A R_{T}^{I P O}}=\frac{1}{n} \sum_{i=1}^{n} B H A R_{T}^{I P O, i}
\end{aligned}
$$

W ramach badań podjęta została próba weryfikacji istotności statystycznej uzyskanych wyników zakresie stóp zwrotu wynikających z implementacji strategii kup i trzymaj ${ }^{58}$. Sformułowane zostały dwie hipotezy statystyczne:

$$
\begin{aligned}
& H_{0}: B A H R_{t}=0 \\
& H_{1}: B A H R_{t}<0
\end{aligned}
$$

Do weryfikacji postawionych powyżej hipotez wykorzystany został parametryczny test $t_{\text {stat }}$ o jednostronnym obszarze odrzucenia, którego statystyka wyznaczona została zgodnie ze wzorem:

$$
t_{\text {stat }}=\frac{B A H R_{t}}{\hat{S}\left(\overline{B A H R_{t}}\right)} \sqrt{n}
$$

gdzie:

$\hat{S}\left(\overline{B A H R_{t}}\right)-$ odchylenie standardowe stopy zwrotu $B A H R$,

pozostałe oznaczenia jak wyżej.

Zakładając rozkład normalny stóp zwrotu uzyskanych na wdrożeniu strategii buy\&hold oraz prawdziwość hipotezy statystycznej $H_{0}$ statystyka testowa $t_{\text {stat }}$ ma rozkład $t$-Studenta o $n-1$ stopniach swobody. Odrzucenie hipotezy $H_{0}$ oznacza, iż nadzwyczajna stopa zwrotu $B A H R$ wyznaczona dla poszczególnych grup spółek istotnie różni się od 0 , a otrzymany wynik będzie istotny statystycznie.

${ }^{58}$ Zastosowana procedura testowania istotności statystycznej została zaczerpnięta z A. P. S e r ra, op. cit., s. 4. W literaturze przedmiotu stosowane są również inne testy parametryczne i nieparametryczne, np. zob. C. J. Corrado, op. cit., s. 207-234, K. R. Ahern, op. cit., s. $481-482$. 
W literaturze przedmiotu z zakresu badań nad kształtowaniem się stóp zwrotu $\mathrm{z}$ akcji $\mathrm{w}$ średnim i długim okresie wykorzystywany jest również zaproponowany przez J. R. Rittera wskaźnik względnego bogactwa (ang. wealth relative $)^{59}$. Wskaźnik ten pokazuje sposób, w jaki kształtowała się efektywność inwestycji w formie kup i trzymaj w określoną klasę aktywów w porównaniu do inwestycji w portfel będący benchmarkiem.

$$
W R_{T}=\frac{1+\overline{B H R_{T}^{I P O}}}{1+\overline{B H R_{T}^{W G G}}}=\frac{\frac{1}{n} \sum_{i=1}^{n}\left(\prod_{t=2}^{T}\left(1+R_{i, t}\right)\right)}{\frac{1}{n} \sum_{i=1}^{n}\left(\prod_{t=2}^{T}\left(1+R_{W I G, t}\right)\right)}
$$

W zależności od wartości tego wskaźnika dla rozpatrywanej grupy spółek można formułować następujące wnioski:

- $W R_{T}>1$ - zwrot $\mathrm{z}$ inwestycji w akcje analizowanych spółek przewyższa zwrot $\mathrm{z}$ inwestycji w akcje spółek z portfela porównawczego,

- $W R_{T}=1$ - stopy zwrotu w oba porównywane portfele inwestycyjne są sobie równe,

- $W R_{T}<1$ - stopa zwrotu $\mathrm{z}$ inwestycji w akcje analizowanych spółek jest niższa $\mathrm{w}$ odniesieniu do stopy zwrotu $\mathrm{z}$ inwestycji $\mathrm{w}$ akcje wchodzące $\mathrm{w}$ skład portfela porównawczego.

Ostatnim etapem badań było przeprowadzenie procedur obliczeniowych zgodnie z zaprezentowanymi powyżej formułami oraz interpretacja otrzymanych wyników.

\subsubsection{WYNIKI BADAŃ EMPIRYCZNYCH NAD ZMIANAMI STÓP ZWROTU Z PIERWSZYCH OFERT PUBLICZNYCH SPÓŁEK PORTFELOWYCH FUNDUSZY PRIVATE EQUITY}

Rozpoznanie rynkowych efektów realizowanych procesów dezinwestycji za pośrednictwem publicznego rynku kapitałowego przy użyciu skumulowanych anormalnych stóp zwrotu wskazuje, iż kurs akcji spółek portfelowych funduszy private equity $\mathrm{w}$ okresie następującym po debiucie giełdowym charakteryzuje się tendencją spadkową (zob. wykres 4.12).

\footnotetext{
${ }^{59}$ J. R. Ritt e r, The Long-Run Performance..., op. cit., s. 3-27.
} 


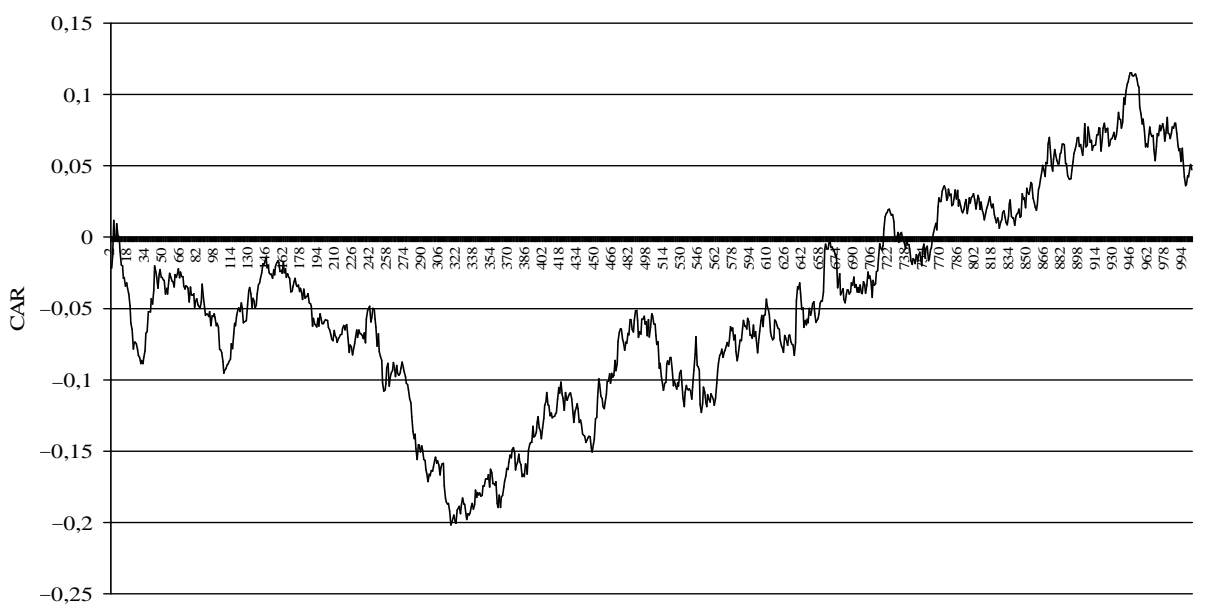

Wykres 4.12. Skumulowane anormalne stopy zwrotu z akcji spółek portfelowych funduszy private equity dla pierwszych ofert publicznych w latach 2002-2010

Ź r ó d ł o: opracowanie własne na podstawie http://www.gpwinfostrefa.pl.

Analizując informacje zawarte na wykresie 4.12 można zauważyć, iż skumulowana nadzwyczajna stopa zwrotu $\mathrm{z}$ akcji spółek portfelowych funduszy private equity w okresie do 145 dnia notowań charakteryzowała się zarówno wyraźnymi falami spadkowymi, jak i wzrostowymi, jednakże odznaczała się przeważnie wartościami ujemnymi. W kolejnych sesjach giełdowych można zaobserwować wyraźny trend spadkowy, który osiągnął swoje minimum na poziomie $-20,06 \%$ w 321 dniu notowań. Następnie można zaobserwować odwrócenie tendencji spadkowej i długotrwały trend wzrostowy skumulowanej anormalnej stopy zwrotu trwający aż do 950 dnia notowań na warszawskiej giełdzie. Jednakże zaznaczyć należy, że trwałe przekroczenie analizowanej miary powyżej poziomu zerowego nastąpiło dopiero po 762 sesji giełdowej, co w przeliczeniu na czas kalendarzowy daje około 3 lata. Na końcu badanego okresu, tzn. 1000 dzień notowań giełdowych stopa $\overline{C A R}$ kształtowała się na poziomie $4,81 \%$.

Porównując kształtowanie się skumulowanych anormalnych stóp zwrotu $\mathrm{z}$ akcji spółek portfelowych funduszy private equity ze skumulowanymi stopami zwrotu z akcji pozostałych spółek można zauważyć występowanie odmiennych tendencji w tym zakresie (zob. wykres 4.13).

Na podstawie danych przedstawionych na wykresie 4.13 można wskazać, iż skumulowane anormalne stopy zwrotu z akcji pozostałych spółek, w większości analizowanych dni notowań giełdowych kształtowały się na dodatnim poziomie. Zakres wahań analizowanej zmiennej dla tej grupy spółek jest znacznie mniejszy niż w przypadku spółek portfelowych funduszy private equity. Z kolei porównując ze sobą obie grupy spółek wyraźnie widać, że skumulowane anormalne stopy zwrotu z akcji spółek portfelowych funduszy private equity aż do 661 sesji gieł- 
dowej stale kształtują się poniżej stopy $\overline{C A R}$ wyznaczonej dla pozostałych podmiotów. Po upływie około 2 lat i 8 miesięcy od debiutu giełdowego poziom skumulowanej anormalnej stopy zwrotu z akcji spółek portfelowych funduszy private equity wzrósł powyżej poziomu odnotowanego dla innych emitentów.

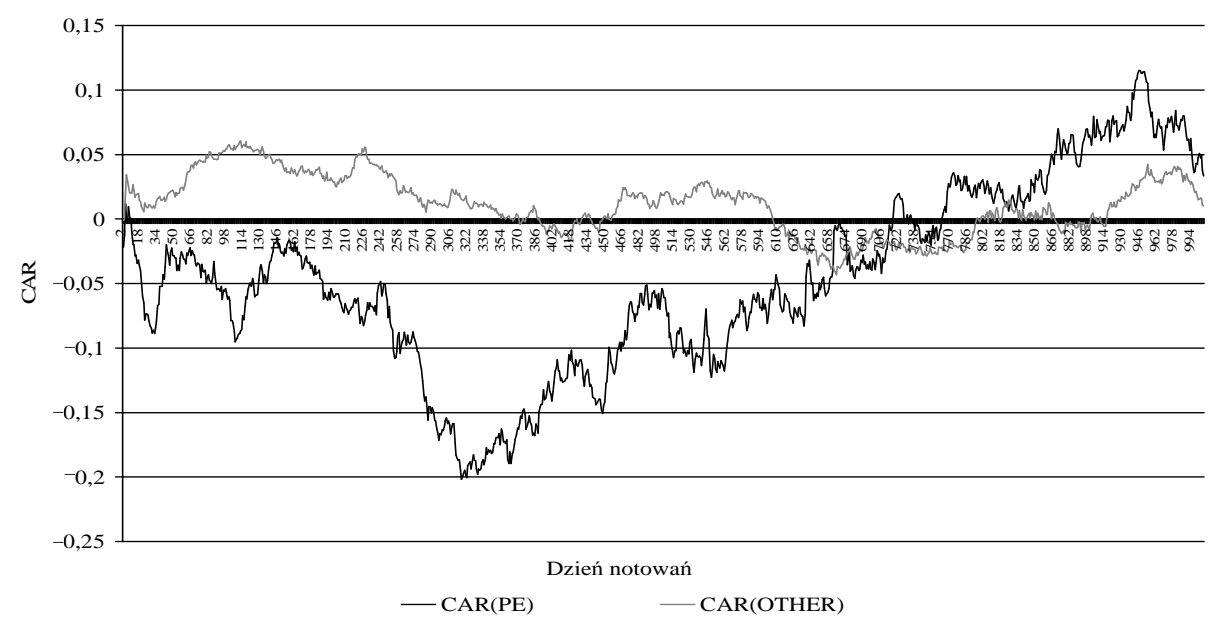

Wykres 4.13. Skumulowane anormalne stopy zwrotu spółek giełdowych debiutujących na GPW w Warszawie w latach 2002-2010

Źr ód ło: jak do wykresu 4.12 .

Porównanie efektów zastosowania wskazanej wcześniej długoterminowej strategii inwestycyjnej typu kup i trzymaj dla spółek portfelowych funduszy private equity również nie wypada korzystnie, gdyż średnie realizowane stopy zwrotu z inwestycji w akcje innych emitentów w przypadku zamknięcia pozycji we wskazanym w tab. 4.20 dniu kształtowały się na wyższym poziomie.

$\mathrm{W}$ okresie pierwszych trzech lat notowań giełdowych inwestycje w akcje spółek portfelowych funduszy private equity przynosiły wyraźnie mniejsze korzyści dla inwestorów. Największą różnicę można zaobserwować w przypadku zamknięcia przyjętej pozycji po upływie około 2 lat (500 dzień). Stopa zwrotu $\mathrm{z}$ inwestycji $\mathrm{w}$ spółki portfelowe funduszy private equity kształtowałaby się wówczas na poziomie $-0,96 \%$, wobec $36,81 \%$ zwrotu z portfela alternatywnego. Na tak wysoki wynik inwestycji w pozostałe spółki wpłynął nadzwyczaj korzystnie kształtujący się kurs akcji spółki PC Guard SA w tym okresie. Po wyeliminowaniu tej spółki z próby badawczej, zanotowana stopa zwrotu z tego portfela wynosiłaby $13,47 \%$, co oznacza i tak poziom znacznie przewyższający efektywność przyjętej strategii inwestycyjnej w akcje spółek portfelowych funduszy private equity. Po upływie około 4 lat od debiutu giełdowego analizowane stopy zwrotu z inwestycji w obie grupy spółek są ujemne, a różnica pomiędzy nimi wyraźnie się zmniejszyła. 
Tabela 4.20

Średnie anormalne stopy zwrotu z akcji dla strategii buy\&hold dla spółek realizujących pierwsze oferty publiczne w latach 2002-2010

\begin{tabular}{|c|c|c|c|c|c|c|c|c|}
\hline $\begin{array}{c}\text { Wyszcze- } \\
\text { gólnienie }\end{array}$ & \multicolumn{3}{|c|}{$\begin{array}{c}\text { Spółki portfelowe funduszy } \\
\text { private equity }\end{array}$} & \multicolumn{3}{c|}{ Pozostałe spółki } \\
\hline $\begin{array}{c}\text { Dzień } \\
\text { notowań }\end{array}$ & $\begin{array}{c}\text { liczba } \\
\text { spółek }\end{array}$ & $\begin{array}{l}\text { BHAR } \\
\text { IPO }\end{array}$ & $\begin{array}{c}\text { statysty- } \\
\text { ka t }\end{array}$ & $p$-value & $\begin{array}{c}\text { liczba } \\
\text { spółek }\end{array}$ & $\begin{array}{l}B H A R_{T}^{I P O} \\
\text { staty- } \\
\text { styka t }\end{array}$ & $p$-value \\
\hline \hline 25 & 26 & $-0,0797$ & 3,6200 & 0,0007 & 190 & $-0,0304$ & 2,7426 & 0,0033 \\
\hline 75 & 26 & $-0,0540$ & 1,6733 & 0,0534 & 190 & 0,0153 & 0,7003 & 0,2423 \\
\hline 150 & 26 & $-0,0384$ & 0,6323 & 0,2665 & 190 & 0,0116 & 0,3639 & 0,3582 \\
\hline 250 & 26 & $-0,0759$ & 0,9766 & 0,1691 & 190 & 0,0265 & 0,5325 & 0,2975 \\
\hline 500 & 24 & $-0,0096$ & 0,0587 & 0,4768 & 172 & 0,3681 & 1,3999 & 0,0817 \\
\hline 750 & 22 & $-0,0554$ & 0,3549 & 0,3631 & 158 & 0,0198 & 0,2076 & 0,4179 \\
\hline 1000 & 18 & $-0,0618$ & 0,3034 & 0,3826 & 138 & $-0,0504$ & 0,5134 & 0,3043 \\
\hline
\end{tabular}

Ź r ó d ł o: opracowanie własne na podstawie http://www.gpwinfostrefa.pl.

Tabela 4.21

Wybrane statystyki opisowe stóp $B A H R$ dla spółek, które zrealizowały oferty publiczne sprzedaży akcji w latach 2002-2010

\begin{tabular}{|c|c|c|c|c|c|c|c|}
\hline \multirow{2}{*}{$\begin{array}{l}\text { Wyszczególnienie } \\
\text { Dzień notowania }\end{array}$} & \multicolumn{7}{|c|}{ Spółki portfelowe funduszy private equity } \\
\hline & 25 & 75 & 150 & 250 & 500 & 750 & 1000 \\
\hline Średnia arytmetyczna & 0,0797 & $-0,0540$ & $-0,0384$ & $-0,0759$ & $-0,0096$ & $-0,0554$ & $-0,0618$ \\
\hline Statystyka t & 3,6200 & 1,6733 & 0,6323 & 0,9766 & 0,0587 & 0,3549 & 0,3034 \\
\hline$p$-value & 0,0007 & 0,0534 & 0,2665 & 0,1691 & 0,4768 & 0,3631 & 0,3826 \\
\hline Mediana & $-0,0562$ & $-0,0759$ & $-0,0104$ & $-0,0602$ & $-0,1001$ & $-0,0705$ & $-0,3443$ \\
\hline Odchylenie & 0,1123 & 0,1644 & 0,3098 & 0,3964 & 0,8019 & 0,7324 & 0,8644 \\
\hline Minimum & $-0,3204$ & $-0,3851$ & $-0,7546$ & $-0,7863$ & -1 & $-1,3642$ & $-0,8032$ \\
\hline Maksimum & 0,1265 & 0,3337 & 0,7017 & 0,6884 & 2,2314 & 2,1495 & 2,8140 \\
\hline \multirow[t]{2}{*}{ Liczba spółek } & 26 & 26 & 26 & 26 & 24 & 22 & 18 \\
\hline & \multicolumn{7}{|c|}{ Pozostałe spółki } \\
\hline Śred & & 0,0153 & 0,0116 & 0,0265 & 0,3681 & 0,0198 & $-0,0504$ \\
\hline Statystyka t & 2,7476 & 0,7003 & 0,3639 & 0,5325 & 1,3999 & 0,2076 & 0,5134 \\
\hline$p$-value & 0,0033 & 0,2423 & 0,3582 & 0,2975 & 0,0817 & 0,4179 & 0,3043 \\
\hline Mediana & $-0,0478$ & \begin{tabular}{|l|}
$-0,0243$ \\
\end{tabular} & $-0,0677$ & $-0,0701$ & $-0,1801$ & $-0,2436$ & $-0,3207$ \\
\hline Odchylenie standardow & 0,1525 & 0,3012 & 0,4392 & 0,6854 & 3,4483 & 1,2001 & 1,1542 \\
\hline Minimum & $-0,5618$ & $-0,5718$ & $-0,8883$ & $-1,0842$ & $-1,5405$ & $-1,9839$ & $-2,4298$ \\
\hline & 0,9919 & 1,7389 & 2,7185 & 5,6055 & 40,2755 & 7,7736 & 6,0533 \\
\hline Liczba spółek & 190 & 190 & 190 & 190 & 172 & 158 & 138 \\
\hline
\end{tabular}

Źr ó d ło: jak do tab. 4.20 . 
Kontynuując analizę kształtowania się stóp zwrotu typu kup i trzymaj można zauważyć, iż wartości tej zmiennej dla spółek portfelowych funduszy private equity są w mniejszym stopniu zróżnicowane $\mathrm{w}$ porównaniu do pozostałych emitentów (zob. tab. 4.21).

W przypadku stóp $B A H R$ wyznaczonych dla pozostałych spółek we wszystkich okresach mediana przyjmuje wartość ujemną, co oznacza że rozpatrywana długoterminowa strategia inwestycyjna w przypadku ponad połowy przedsiębiorstw generuje straty. Co więcej, dla tego portfela inwestycyjnego w przypadku zamknięcia pozycji inwestycyjnej po okresie 2 i 3 lat od daty debiutu giełdowego mediana kształtuje się na poziomie znacznie niższym niż w przypadku spółek portfelowych funduszy private equity.

Dla rozpoznania permanencji uzyskiwanych ze strategii kup i trzymaj stóp zwrotu zastosowany został przekrój analityczny względem roku debiutu giełdowego spółki. Otrzymane wyniki wskazują, iż osiągane stopy zwrotu z inwestycji nie są stabilne względem czasu wprowadzenia akcji do publicznego obrotu (zob. tab. 4.22).

Wnioskowanie dla poszczególnych lat ze względu na liczbę debiutów giełdowych może być dokonywane w ograniczonym zakresie. Jednakże biorąc pod uwagę okresy, w których odnotowano najwięcej obserwacji, czyli 2004-2008 można zauważyć występowanie wahań anormalnych stóp zwrotu uzyskiwanych $\mathrm{z}$ realizacji strategii kup i trzymaj w zależności od roku debiutu.

W związku z poszukiwaniem czynników mogących różnicować uzyskiwane efekty z inwestycji w akcje spółek przeprowadzających pierwsze oferty publiczne przeprowadzona została międzysektorowa analiza średnich stóp BAHR. Ze względu na ograniczoną liczbę spółek reprezentujących poszczególne sektory gospodarki jej zakres ograniczony został do spółek prowadzących działalność w 4 najliczniej reprezentowanych w grupie spółek portfelowych funduszy private equity sektorach (zob. tab. 4.23).

Można wskazać, iż w sektorach handel i przemysł inne generalnie lepsze długoterminowe wyniki inwestycyjne mierzone stopą $B A H R$ można było osiągnąc lokując kapitał w akcje spółek portfelowych funduszy private equity niż w walory pozostałych spółek (wyjątek stanowią wyniki dla 250 dnia notowań w sektorze handel). Spostrzeżenie to potwierdza zarówno wartość średniej arytmetycznej, jak i mediany. Natomiast w sektorach informatyka oraz usługi inne dla spółek $\mathrm{z}$ udziałem funduszy private equity w porównaniu do pozostałych spółek zaobserwowane zostały w przeważającej części niższe wartości statystyk opisowych dla analizowanej zmiennej (zob. tab. 4.23).

Wykorzystując wskaźnik bogactwa do oceny rynkowych efektów pierwszych ofert publicznych spółek portfelowych funduszy private equity w perspektywie średnio- i długoterminowej można zauważyć, iż efektywność inwestycji w akcje spółek portfelowych funduszy private equity wyrażona tą miarą jest niższa w porównaniu z papierami wartościowymi emitowanymi przez pozostałe spółki (zob. wykres 4.14). 
Tabela 4.22

Wybrane statystyki opisowe stóp $B A H R$ dla spółek, które zrealizowały pierwsze oferty publiczne sprzedaży akcji w latach 2002-2010 według roku debiutu giełdowego

\begin{tabular}{|c|c|c|c|c|c|c|c|c|c|}
\hline Dzień & Rok & $\begin{array}{c}\text { Średnia } \\
\text { arytmetyczna }\end{array}$ & $\begin{array}{c}\text { Statystyka } \\
\mathrm{t}\end{array}$ & $p$-value & Mediana & $\begin{array}{l}\text { Odchylenie } \\
\text { standardowe }\end{array}$ & Min & num & $\begin{array}{l}\text { Liczba } \\
\text { spółek }\end{array}$ \\
\hline 1 & 2 & 3 & 4 & 5 & 6 & 7 & 8 & 9 & 10 \\
\hline \multicolumn{10}{|c|}{ Spółki portfelowe funduszy private equity } \\
\hline \multirow{9}{*}{250} & 2002 & $-0,2743$ & 1,0211 & 0,2467 & $-0,2743$ & 0,3799 & $-0,5430$ & $-0,0057$ & 2 \\
\hline & 2003 & - & - & - & - & - & - & - & 0 \\
\hline & 2004 & $-0,3424$ & 12,4034 & 0,0032 & $-0,3410$ & 0,0478 & $-0,3910$ & $-0,2953$ & 3 \\
\hline & 2005 & $-0,0117$ & 0,0545 & 0,4796 & 0,2282 & 0,4780 & $-0,7667$ & 0,4083 & 5 \\
\hline & 2006 & 0,0332 & 0,1690 & 0,4353 & 0,0861 & 0,5553 & $-0,7863$ & 0,6884 & 8 \\
\hline & 2007 & $-0,1145$ & 2,0096 & 0,0690 & $-0,1239$ & 0,1140 & $-0,2332$ & 0,0230 & 4 \\
\hline & 2008 & 0,0745 & 0,6664 & 0,3129 & 0,0745 & 0,1581 & $-0,0373$ & 0,1862 & 2 \\
\hline & 2009 & 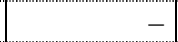 & - & - & - & - & - & - & 0 \\
\hline & 2010 & $-0,1482$ & 0,5022 & 0,3518 & $-0,1482$ & 0,4173 & $-0,4432$ & 1469 & 2 \\
\hline \multirow{9}{*}{500} & 2002 & $-0,2650$ & 0,3136 & 0,4033 & $-0,2650$ & 1,1949 & $-1,1099$ & 0,5800 & 2 \\
\hline & 2003 & - & - & - & - & - & - & $=$ & 0 \\
\hline & 2004 & $-0,3250$ & 0,6440 & 0,2928 &, 1204 & 0,8740 & $-1,3319$ & 2367 & 3 \\
\hline & 2005 & 0,5885 & 0,9632 & 0,1950 & 0,6333 & 1,3663 & $-1,3180$ & 2314 & 5 \\
\hline & 2006 & $-0,0282$ & 0,1615 & 0,4381 & $-0,1096$ & 0,4943 & $-0,6776$ & 0,8130 & 8 \\
\hline & 2007 & $-0,2054$ & 2,5551 & 0,0418 & $-0,1932$ & 0,1608 & $-0,3867$ & $-0,0484$ & 4 \\
\hline & 2008 & $-0,3106$ & 2,7640 & 0,1105 & $-0,3106$ & 0,1589 & $-0,4229$ & $-0,1982$ & 2 \\
\hline & 2009 & - & - & - & - & - & - & - & 0 \\
\hline & 2010 & - & - & - & - & - & - & - & 0 \\
\hline \multirow{9}{*}{750} & 2002 & $-0,2551$ & 0,2406 & 0,4248 & 0,2551 & 1,4995 & $-1,3154$ & 0,8052 & 2 \\
\hline & 2003 & - & - & - & - & - & - & - & 0 \\
\hline & 2004 & $-0,6875$ & 1,0161 & 0,2475 & $-0,6875$ & 0,9570 & $-1,3642$ & $-0,0109$ & 2 \\
\hline & 2005 & 0,7241 & 1,4636 & 0,1198 & 0,4356 & 0,9895 & $-0,1244$ & 2,1495 & 4 \\
\hline & 2006 & $-0,0808$ & 0,5926 & 0,2860 & $-0,1407$ & 0,3856 & $-0,5115$ & 0,5515 & 8 \\
\hline & 2007 & $-0,2667$ & 1,7742 & 0,0871 & $-0,3588$ & 0,3007 & $-0,5085$ & 0,1591 & 4 \\
\hline & 2008 & $-0,2584$ & 0,6946 & 0,3068 & $-0,2584$ & 0,5262 & $-0,6305$ & 0,1136 & 2 \\
\hline & 2009 & - & - & - & - & - & - & - & 0 \\
\hline & 2010 & - & - & - & - & - & - & - & 0 \\
\hline \multirow{9}{*}{1000} & 2002 & $-0,5708$ & 2,4566 & 0,1231 & $-0,5708$ & 0,3286 & $-0,8032$ & $-0,3384$ & 2 \\
\hline & 2003 & - & - & - & - & - & - & - & 0 \\
\hline & 2004 & $-0,7057$ & - & - & $-0,7057$ & - & $-0,7057$ & $-0,7057$ & 1 \\
\hline & 2005 & 0,5765 & 0,7645 & 0,2501 & $-0,0790$ & 1,5081 & $-0,3501$ & 2,8140 & 4 \\
\hline & 2006 & 0,0303 & 0,1077 & 0,4592 & $-0,3213$ & 0,6897 & $-0,5673$ & 0,9956 & 6 \\
\hline & 2007 & $-0,2890$ & 1,8683 & 0,0793 & $-0,4047$ & 0,3094 & $-0,5037$ & 0,1568 & 4 \\
\hline & 2008 & $-0,5970$ & - & - & $-0,5970$ & - & $-0,5970$ & $-0,5970$ & 1 \\
\hline & 2009 & - & - & - & - & - & - & - & 0 \\
\hline & 2010 & - & - & - & - & - & - & - & 0 \\
\hline
\end{tabular}


Tabela 4.22 (cd.)

\begin{tabular}{|c|c|c|c|c|c|c|c|c|c|}
\hline 1 & 2 & 3 & 4 & 5 & 6 & 7 & 8 & 9 & 10 \\
\hline \multicolumn{10}{|c|}{ Pozostałe spółki } \\
\hline \multirow{9}{*}{250} & 2002 & 1,4416 & - & - & 1,4416 & - & 1,4416 & 1,4416 & 1 \\
\hline & 2003 & $-0,5277$ & 3,0736 & 0,0272 & $-0,5291$ & 0,3434 & $-0,8296$ & $-0,2232$ & 4 \\
\hline & 2004 & $-0,1718$ & 1,5662 & 0,0645 & $-0,2853$ & 0,5803 & $-0,8522$ & 1,5356 & 28 \\
\hline & 2005 & 0,2704 & 1,5526 & 0,0659 & 0,1351 & 0,9378 & $-0,7531$ & 3,5965 & 29 \\
\hline & 2006 & 0,1074 & 1,0533 & 0,1516 & 0,0170 & 0,4994 & $-0,6728$ & 1,1886 & 24 \\
\hline & 2007 & $-0,0413$ & 1,0583 & 0,1474 & $-0,0590$ & 0,2868 & $-0,4104$ & 1,3206 & 54 \\
\hline & 2008 & 0,3250 & 1,2435 & 0,1137 & 0,0309 & 1,2259 & $-0,7144$ & 5,6055 & 22 \\
\hline & 2009 & $-0,2136$ & 1,2218 & 0,1264 & $-0,1573$ & 0,5530 & $-1,0842$ & 0,8955 & 10 \\
\hline & 2010 & $-0,1496$ & 3,0109 & 0,0039 & $-0,2228$ & 0,2108 & $-0,4015$ & 0,3040 & 18 \\
\hline \multirow{9}{*}{500} & 2002 & 4,4045 & - & - & 4,4045 & - & 4,4045 & 4,4045 & 1 \\
\hline & 2003 & $-1,1070$ & 7,2741 & 0,0027 & $-1,2004$ & 0,3044 & $-1,3533$ & $-0,6741$ & 4 \\
\hline & 2004 & 0,2697 & 0,9814 & 0,1675 & $-0,2280$ & 1,4539 & $-1,3897$ & 3,2684 & 28 \\
\hline & 2005 & 2,2473 & 1,5135 & 0,0707 & 0,3364 & 7,9961 & $-1,5405$ & 40,2755 & 29 \\
\hline & 2006 & $-0,2187$ & 2,7605 & 0,0056 & $-0,2420$ & 0,3881 & $-0,7360$ & 0,9924 & 24 \\
\hline & 2007 & $-0,0752$ & 1,2995 & 0,0998 & $-0,1766$ & 0,4210 & $-0,5086$ & 2,3647 & 53 \\
\hline & 2008 & 0,1753 & 0,9000 & 0,1892 & $-0,0270$ & 0,9136 & $-1,2958$ & 2,7871 & 22 \\
\hline & 2009 & $-0,3455$ & 2,1062 & 0,0322 & $-0,4217$ & 0,5187 & $-1,0211$ & 0,5263 & 10 \\
\hline & 2010 & $-0,5581$ & - & - & $-0,5581$ & - & $-0,5581$ & $-0,5581$ & 1 \\
\hline \multirow{9}{*}{750} & 2002 & 2,4336 & - & - & 2,4336 & - & 2,4336 & 2,4336 & 1 \\
\hline & 2003 & $-1,5192$ & 6,5059 & 0,0037 & $-1,5851$ & 0,4670 & $-1,9839$ & $-0,9228$ & 4 \\
\hline & 2004 & 0,4578 & 1,0694 & 0,1473 & $-0,1453$ & 2,2242 & $-1,7524$ & 7,7736 & 27 \\
\hline & 2005 & 0,2122 & 1,0437 & 0,1533 & 0,0859 & 1,0367 & $-1,5278$ & 2,0649 & 26 \\
\hline & 2006 & $-0,2782$ & 4,2508 & 0,0002 & $-0,3614$ & 0,3206 & $-0,7448$ & 0,7122 & 24 \\
\hline & 2007 & $-0,0406$ & 0,4123 & 0,3409 & $-0,2145$ & 0,7167 & $-0,6952$ & 4,2050 & 53 \\
\hline & 2008 & $-0,0301$ & 0,1556 & 0,4389 & $-0,2476$ & 0,8852 & $-1,1023$ & 2,6614 & 21 \\
\hline & 2009 & $-0,8217$ & 2721,8 & 0,0001 & $-0,8217$ & 0,0004 & $-0,8220$ & $-0,8214$ & 2 \\
\hline & 2010 & - & - & - & - & - & - & - & 0 \\
\hline \multirow{9}{*}{1000} & 2002 & 3,5939 & - & - & 3,5939 & - & 3,5939 & 3,5939 & 1 \\
\hline & 2003 & $-1,8236$ & 5,3006 & 0,0066 & $-2,0030$ & 0,6881 & $-2,4298$ & $-0,8586$ & 4 \\
\hline & 2004 & 0,4190 & 1,2041 & 0,1199 & $-0,0278$ & 1,7743 & $-1,6391$ & 5,4644 & 26 \\
\hline & 2005 & 0,0372 & 0,2857 & 0,3887 & $-0,0186$ & 0,6641 & $-0,9309$ & 1,9834 & 26 \\
\hline & 2006 & $-0,3663$ & 4,4393 & 0,0001 & $-0,4087$ & 0,4042 & $-0,8564$ & 1,1389 & 24 \\
\hline & 2007 & $-0,1163$ & 0,8488 & 0,2000 & $-0,3108$ & 0,9787 & $-0,7634$ & 6,0533 & 51 \\
\hline & 2008 & $-0,0662$ & 0,1576 & 0,4405 & $-0,4401$ & 1,0291 & $-0,7100$ & 2,0037 & 6 \\
\hline & 2009 & - & - & - & - & - & - & - & 0 \\
\hline & 2010 & - & - & - & - & - & - & - & 0 \\
\hline
\end{tabular}

Ź r ó d ło: jak do tab. 4.20. 
Tabela 4.23

Wybrane statystyki opisowe stóp $B A H R$ dla spółek, które zrealizowały pierwsze publiczne oferty sprzedaży akcji w latach 2002-2010 - ujęcie sektorowe

\begin{tabular}{|c|c|c|c|c|c|}
\hline $\begin{array}{c}\text { Dzień } \\
\text { notowań }\end{array}$ & Miara & $\begin{array}{c}\text { Spółki portfe- } \\
\text { lowe fundu- } \\
\text { szy private } \\
\text { equity } \\
\end{array}$ & $\begin{array}{l}\text { Pozostałe } \\
\text { spółki }\end{array}$ & $\begin{array}{c}\text { Spółki portfe- } \\
\text { lowe fundu- } \\
\text { szy private } \\
\text { equity } \\
\end{array}$ & $\begin{array}{c}\text { Pozostałe } \\
\text { spółki }\end{array}$ \\
\hline & & \multicolumn{2}{|c|}{ Handel } & \multicolumn{2}{|c|}{ Informatyka } \\
\hline \multirow{4}{*}{250} & Średnia arytmetyczna & $-0,0489$ & 0,0342 & $-0,1213$ & 0,0297 \\
\hline & $p$-value & 0,4218 & 0,3692 & 0,1871 & 0,3788 \\
\hline & Mediana & $-0,0998$ & 0,1200 & $-0,0439$ & $-0,0130$ \\
\hline & Liczba spółek & 4 & 22 & 8 & 19 \\
\hline \multirow{4}{*}{500} & Średnia arytmetyczna & 0,0706 & $-0,1867$ & $-0,1872$ & 2,4086 \\
\hline & $p$-value & 0,4366 & 0,0606 & 0,2463 & 0,1630 \\
\hline & Mediana & 0,3795 & $-0,1834$ & $-0,1062$ & $-0,1767$ \\
\hline & Liczba spółek & 4 & 21 & 7 & 17 \\
\hline \multirow{4}{*}{750} & Średnia arytmetyczna & $-0,0052$ & $-0,2317$ & $-0,2932$ & 0,0374 \\
\hline & $p$-value & 0,4958 & 0,1418 & 0,1601 & 0,4530 \\
\hline & Mediana & 0,2447 & $-0,4124$ & $-0,2744$ & $-0,3536$ \\
\hline & Liczba spółek & 4 & 21 & 6 & 17 \\
\hline \multirow{4}{*}{1000} & Średnia arytmetyczna & $-0,0454$ & $-0,0558$ & $-0,1801$ & $-0,1341$ \\
\hline & $p$-value & 0,4520 & 0,4271 & 0,2905 & 0,2465 \\
\hline & Mediana & $-0,0979$ & $-0,4643$ & $-0,4193$ & $-0,2604$ \\
\hline & Liczba spółek & 4 & 19 & 5 & 16 \\
\hline & & \multicolumn{2}{|c|}{ Przemysł inne } & \multicolumn{2}{|c|}{ Usługi inne } \\
\hline \multirow{4}{*}{250} & Średnia arytmetyczna & $-0,0855$ & $-0,1316$ & 0,1828 & 0,1854 \\
\hline & $p$-value & 0,3555 & 0,0222 & 0,2366 & 0,2162 \\
\hline & Mediana & 0,0230 & $-0,1540$ & 0,1691 & $-0,0441$ \\
\hline & Liczba spółek & 5 & 18 & 4 & 26 \\
\hline \multirow{4}{*}{500} & Średnia arytmetyczna & 0,3930 & $-0,2252$ & 0,2092 & 0,1444 \\
\hline & $p$-value & 0,2851 & 0,0804 & 0,3287 & 0,2537 \\
\hline & Mediana & $-0,1035$ & $-0,1604$ & $-0,1093$ & $-0,1728$ \\
\hline & Liczba spółek & 4 & 17 & 4 & 23 \\
\hline \multirow{4}{*}{750} & Średnia arytmetyczna & 0,3986 & $-0,1449$ & $-0,0845$ & 0,0642 \\
\hline & $p$-value & 0,2728 & 0,2180 & 0,3680 & 0,4096 \\
\hline & Mediana & $-0,1407$ & $-0,2835$ & $-0,2135$ & $-0,1580$ \\
\hline & Liczba spółek & 4 & 14 & 4 & 22 \\
\hline \multirow{4}{*}{1000} & Średnia arytmetyczna & 0,6992 & $-0,3268$ & $-0,3948$ & 0,1037 \\
\hline & $p$-value & 0,2887 & 0,0117 & 0,0223 & 0,4089 \\
\hline & Mediana & $-0,2233$ & $-0,3562$ & $-0,3163$ & $-0,2455$ \\
\hline & Liczba spółek & 3 & 13 & 3 & 16 \\
\hline
\end{tabular}

Źr ó d ło: jak do tab. 4.20 . 


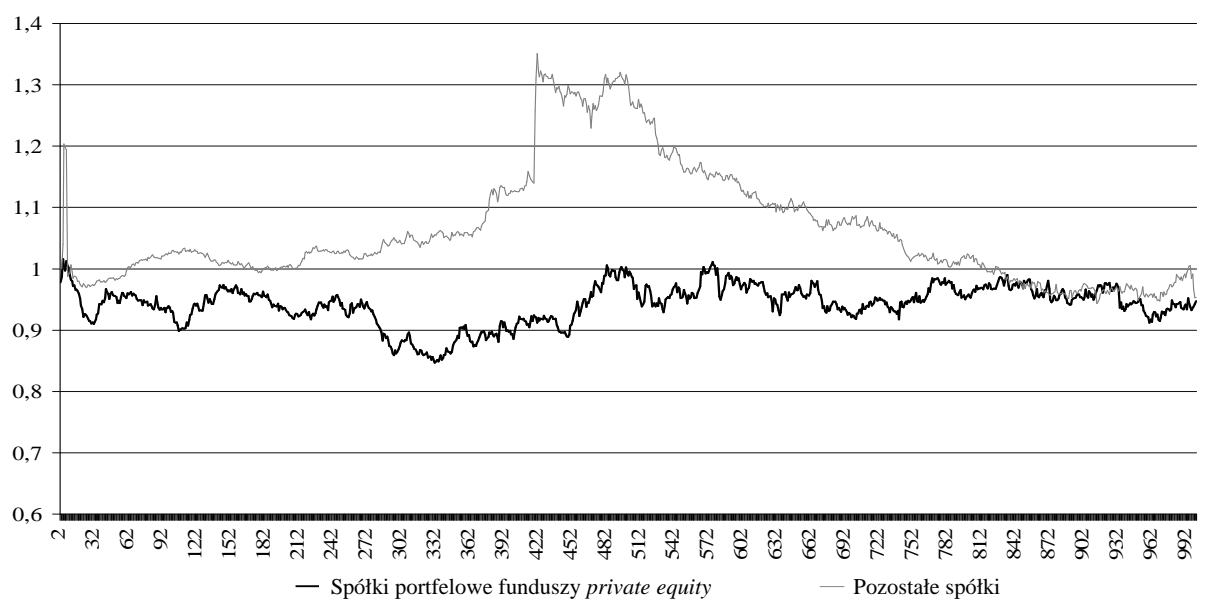

Wykres 4.14. Wskaźnik bogactwa $W R_{T}$ dla spółek giełdowych debiutujących na GPW w Warszawie w latach 2002-2010

Źr ó d ło: jak do wykresu 4.12.

Na wykresie 4.14 widać wyraźnie, iż niemalże od samego początku notowań giełdowych wartość wskaźnika bogactwa dla spółek portfelowych funduszy private equity kształtuje się poniżej 1 . Oznacza to, iż lokowanie kapitału w akcje tych podmiotów dla graczy giełdowych nie okazałoby się korzystną strategią inwestycyjną. Na zdecydowanie wyższym poziomie analizowany wskaźnik kształtował się w przypadku pozostałych spółek. Dopiero po upływie ponad 3 lat od debiutu giełdowego ewidentne różnice pomiędzy dwoma analizowanymi grupami przedsiębiorstw zostały zniwelowane.

Względna niższa efektywność strategii inwestycyjnej polegającej na zakupie akcji spółek portfelowych funduszy private equity na zamknięciu w pierwszym dniu notowań giełdowych związana może być z negatywnie odbieraną przez inwestorów potencjalną podażą akcji ze strony funduszu. Przedsiębiorstwa objęte procesami dezinwestycji za pośrednictwem warszawskiej giełdy nie tworzą homogenicznej grupy pod względem możliwej podaży akcji. Wyniki badań empirycznych nad realizowanymi strategiami wskazują, iż w przypadku części spółek fundusze realizują całkowite wyjście z inwestycji, niwelując to ryzyko związane z pojawieniem się dodatkowej ilości akcji spółki na rynku. Badania empiryczne przeprowadzone z wykorzystaniem stóp $B A H R$ wskazują na występowanie różnic w kształtowaniu się stóp zwrotu z inwestycji w akcje spółek w zależności od przyjętej przez fundusz private equity strategii dezinwestycji (zob. tab. 4.24).

Średnie stopy zwrotu wynikające z implementacji strategii inwestycyjnej typu kup i trzymaj w grupie spółek, gdzie zrealizowane zostało całkowite wyjście z inwestycji w większości rozpatrywanych momentów są dodatnie (zob. tab. 4.24). Inwestorzy giełdowi sprzedając akcje właśnie w tym dniu notowań zreali- 
zowaliby zysk. Spostrzeżenie to potwierdza wartość średniej arytmetycznej oraz mediany. Całkowicie odmiennie sytuacja ta wygląda wśród spółek, gdzie dezinwestycja przyjęła postać częściowej redukcji zaangażowania kapitałowego. W większości wybranych do analizy dniach notowań giełdowych średnia arytmetyczna stopa BAHR kształtuje się poniżej 0. Co więcej mediana we wszystkich wskazanych momentach ma wartość ujemną.

Tabela 4.24

Wybrane statystyki opisowe stóp $B A H R_{T}$ dla spółek portfelowych funduszy private equity, które zrealizowały pierwsze oferty publiczne sprzedaży akcji w latach 2002-2010 w zależności od przyjętej strategii dezinwestycji

\begin{tabular}{|l|r|r|r|r|r|r|r|r|}
\hline \multirow{2}{*}{ Wyszczególnienie } & \multicolumn{7}{c|}{ Dzień notowań } \\
\cline { 2 - 9 } & \multicolumn{1}{|c|}{25} & 75 & 150 & \multicolumn{1}{c|}{250} & 500 & 750 & 1000 \\
\hline \hline & \multicolumn{7}{|c|}{ Całkowite wyjście z inwestycji } \\
\hline Średnia arytmetyczna & $-0,0955$ & 0,0098 & 0,0513 & 0,1111 & $-0,0367$ & 0,0393 & 0,1358 \\
\hline Mediana & $-0,0958$ & 0,0024 & 0,0249 & 0,2442 & 0,0665 & 0,0134 & $-0,0403$ \\
\hline Odchylenie standardowe & 0,1296 & 0,2477 & 0,4281 & 0,5005 & 0,6759 & 0,3717 & 0,6424 \\
\hline Minimum & $-0,3204$ & $-0,3851$ & $-0,7546$ & $-0,7667$ & $-1,3180$ & $-0,4161$ & $-0,5673$ \\
\hline Maksimum & 0,1265 & 0,3337 & 0,7017 & 0,6884 & 0,8130 & 0,5515 & 0,9956 \\
\hline Statystyka t & 2,0839 & 0,1118 & 0,3389 & 0,6276 & 0,1535 & 0,2587 & 0,5179 \\
\hline$p$-value & 0,0378 & 0,4571 & 0,3723 & 0,2751 & 0,4412 & 0,4031 & 0,3133 \\
\hline Liczba spółek & 8 & 8 & 8 & 8 & 8 & 6 & 6 \\
\hline & \multicolumn{7}{|c|}{ Częściowe wyjście z inwestycji } \\
\hline Średnia arytmetyczna & $-0,0727$ & $-0,0823$ & $-0,0783$ & $-0,1590$ & 0,0039 & $-0,0909$ & $-0,1606$ \\
\hline Mediana & $-0,0434$ & $-0,0777$ & $-0,0691$ & $-0,0952$ & $-0,1096$ & $-0,1451$ & $-0,4201$ \\
\hline Odchylenie standardowe & 0,1070 & 0,1084 & 0,2453 & 0,3228 & 0,8788 & 0,8367 & 0,9671 \\
\hline Minimum & $-0,3012$ & $-0,2689$ & $-0,3832$ & $-0,7863$ & $-1,3319$ & $-1,3642$ & $-0,8032$ \\
\hline Maksimum & 0,0974 & 0,1369 & 0,6557 & 0,4083 & 2,2314 & 2,1495 & 2,8140 \\
\hline Statystyka t & 2,8822 & 3,2210 & 1,3541 & 2,0902 & 0,0179 & 0,4346 & 0,5753 \\
\hline$p$-value & 0,0052 & 0,0025 & 0,0967 & 0,0260 & 0,4930 & 0,3350 & 0,2883 \\
\hline Liczba spółek & 18 & 18 & 18 & 18 & 16 & 16 & 12 \\
\hline
\end{tabular}

Źr ó d ło: jak do tab. 4.20 .

Do rozpoznania odmiennego kształtowania się kursów akcji spółek portfelowych funduszy private equity w zależności od tego, czy realizacja zysku funduszu przyjęła postać częściowego czy całkowitego wyjścia z inwestycji wykorzystany został również wskaźnik względnego bogactwa. Wyznaczenie tej miary efektywności inwestycji w akcje analizowanych spółek publicznych w kolejnych dniach notowań pozwoliło zauważyć wyraźne zróżnicowanie efektywności inwestycji w akcje spółek portfelowych funduszy private equity w zależności od stopnia realizowanego wyjścia z inwestycji w okresie od około 40 do 450 notowania giełdowego (zob. wykres 4.15). 


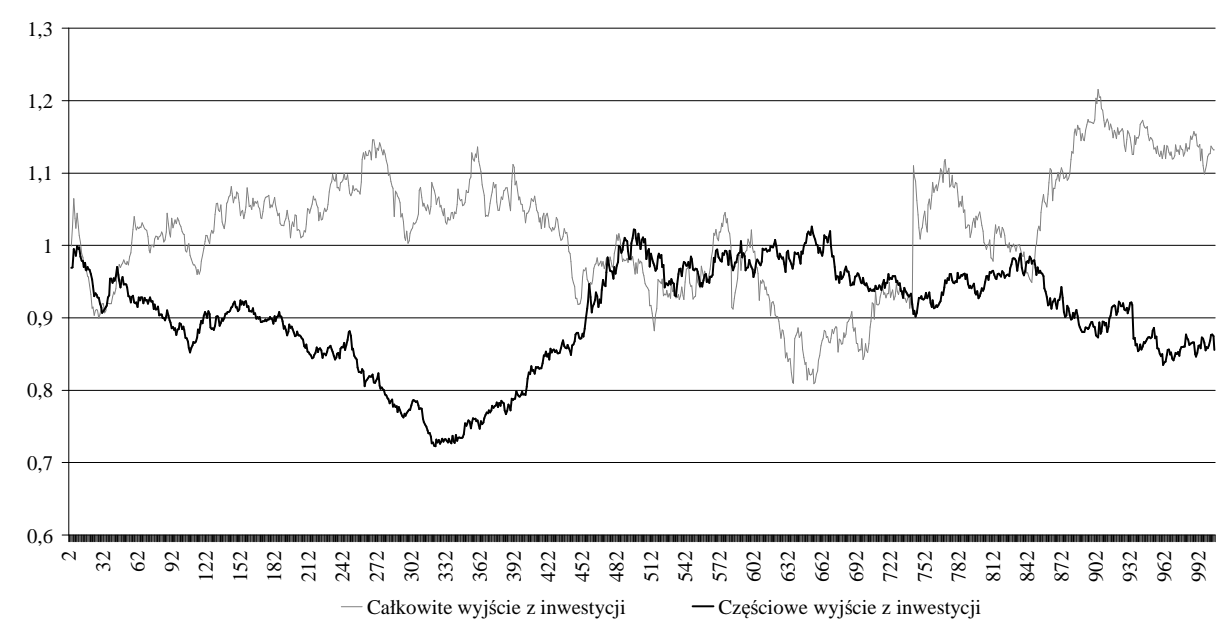

Wykres 4.15. Wskaźnik bogactwa $W R_{T}$ dla spółek portfelowych funduszy private equity debiutujących na GPW w Warszawie w latach 2002-2010 w zależności od zakresu zrealizowanej dezinwestycji

Ź ród ło: jak do wykresu 4.12 .

Przedstawione na wykresie 4.15 wyniki wskazują, że inwestycja w akcje spółek portfelowych, w których fundusze zrealizowały strategię częściowego wyjścia $\mathrm{z}$ inwestycji w ramach pierwszej oferty publicznej cechuje się wartościami wskaźnika względnego bogactwa na poziomie poniżej 1 niemalże w całym analizowanym okresie. Dla inwestorów, którzy obraliby przyjętą w badaniach strategię buy\&hold wobec tych spółek oznaczałoby to konieczność zanotowania strat na danym portfelu inwestycyjnym. Zdecydowanie korzystniejszą strategią inwestycyjną okazałaby się inwestycja w akcje spółek wobec których fundusze private equity zrealizowały całkowite wyjście $\mathrm{z}$ inwestycji $\mathrm{w}$ ciągu roku od debiutu giełdowego. Pomimo że w tym przypadku można również wskazać okresy, kiedy taka inwestycja przyniosłaby stratę to w przeważającej części wskaźnik względnego bogactwa dla tej grupy spółek znajduje się na poziomie przewyższającym wartość wyznaczoną dla przedsiębiorstw udziałowych, w których podjęto decyzję o częściowym wyjściu z inwestycji funduszu private equity. 



\section{ZAKOŃCZENIE}

Dezinwestycja jest ostatnim etapem procesu inwestycyjnego funduszy private equity, które aktywnie działając na rynku kapitału podwyższonego ryzyka chcą osiągnąc nadzwyczajne stopy zwrotu z zainwestowanego w spółki portfelowe kapitału finansowego i menedżerskiego. Dezinwestycja stanowi niezwykle ważny moment $\mathrm{w}$ całym cyklu życia dotychczasowego przedsiębiorstwa udziałowego. Z jednej strony oznacza dla spółki zakończenie współpracy z inwestorem strategicznym, który wcześniej udostępniał niezbędny kapitał pieniężny oraz wsparcie kapitałem menedżerskim, z drugiej zaś otwiera nowy okres i warunki działania przedsiębiorstwa portfelowego jako w pełni samodzielnej jednostki. Dezinwestycja jest zwieńczeniem wcześniejszych wysiłków wszystkich podmiotów zaangażowanych $\mathrm{w}$ proces pomnażania wartości rynkowej spółek portfelowych. Przebiega ona $\mathrm{z}$ różnym natężeniem i realizowana jest w rożnych formach. Jednym ze sposobów realizacji dezinwestycji funduszy private equity jest metoda pierwszej oferty publicznej.

Analiza działalności funduszy private equity wskazuje na ich wzrastającą rolę na polskim rynku kapitałowym oraz na istotne znaczenie GPW w Warszawie $\mathrm{w}$ procesie dezinwestycji. Wprowadzenie spółki portfelowej na giełdę, a następnie sprzedaż posiadanych przez fundusz akcji za jej pośrednictwem traktowane jest przez polskie firmy zarządzające funduszami private equity jako jedna z podstawowych i ważnych metod wyjścia z inwestycji. Między działalnością funduszy private equity a funkcjonowaniem GPW w Warszawie występują korzystne relacje. Mający miejsce rozwój rynku kapitałowego wspiera ekspansję działalności funduszy private equity, zapewniając im atrakcyjną ścieżkę wyjścia $\mathrm{z}$ inwestycji. $\mathrm{Z}$ drugiej strony, fundusze dążąc do wprowadzenia akcji spółek portfelowych do publicznego obrotu wspierają rozwój tego rynku.

W latach 2002-2010 wśród nowych spółek, które pojawiły się na GPW w Warszawie w wyniku realizacji pierwszej oferty publicznej ponad 12\% stanowiły przedsiębiorstwa, które do sfinansowania rozwoju na wcześniejszych etapach wykorzystały środki pochodzące $\mathrm{z}$ funduszy private equity. Mając na uwadze rozmiary oraz relatywnie skromne doświadczenia polskiego rynku kapitału podwyższonego ryzyka wynik ten należy uznać za ważny, a fundusze priva- 
te equity określić jako jednostki wspierające w sposób istotny rozwój polskiego rynku kapitałowego.

Badania nad procesami dezinwestycji realizowanymi metodą pierwszej oferty publicznej wykazały, iż w warunkach polskiego publicznego rynku papierów wartościowych fundusze private equity nie stosują homogenicznych strategii redukcji zaangażowania kapitałowego w spółki portfelowe.

Redukcja zaangażowania kapitałowego funduszu private equity w przedsiębiorstwo udziałowe osiągana przez wprowadzenie akcji spółki do obrotu giełdowego, a następnie ich sprzedaż za pośrednictwem publicznego rynku papierów wartościowych przybiera zróżnicowany zakres. Pierwsza oferta publiczna jako metoda dezinwestycji jest wykorzystywana głównie do implementacji strategii częściowego wyjścia z inwestycji funduszu private equity. Całkowite zbycie papierów wartościowych przedsiębiorstwa udziałowego zwykle następuje w terminie późniejszym. Znacząca część analizowanych inwestycji funduszy private equity nie została zakończona. Wydłużający się okres pomiędzy debiutem giełdowym a całkowitą redukcją zaangażowania kapitałowego funduszu private equity $\mathrm{w}$ spółkę portfelową świadczy o występowaniu ograniczeń w swobodnej sprzedaży posiadanych akcji za pośrednictwem krajowego publicznego rynku papierów wartościowych.

Badania empiryczne przeprowadzone na grupie przedsiębiorstw objętych procesami dezinwestycji $\mathrm{w}$ drodze publicznej sprzedaży akcji poprzez GPW w Warszawie wskazują na występowanie zróżnicowanych efektów tych przedsięwzięć.

W spółkach portfelowych funduszy private equity poddanych dezinwestycji metodą pierwszej oferty publicznej po debiucie giełdowym zaobserwowane zostało okresowe zmniejszenie rentowności kapitału własnego. Przyczyną zmian tej rentowności było zmniejszenie sprawności operacyjnej oraz zmiana struktury finansowania tych jednostek gospodarczych. Zaobserwowany spadek rentowności kapitału własnego miał trwały charakter, a uzyskane wyniki były istotne statystycznie.

Analiza kosztów przeprowadzenia pierwszych ofert publicznych badanych spółek portfelowych funduszy private equity uwidoczniła, iż przeciętny bezpośredni koszt oferty wynosił przeszło $2 \mathrm{mln}$ zł, a prawie połowa tej kwoty przeznaczana była na wydatki związane $\mathrm{z}$ przygotowaniem i przeprowadzeniem oferty. Udział kosztów bezpośrednich w wartości oferty zmniejszał się wraz z jej wzrostem.

Badania empiryczne pierwszych ofert publicznych zrealizowanych w latach 2002-2010 na GPW w Warszawie potwierdziły, iż stopa zwrotu z akcji spółek portfelowych funduszy private equity w pierwszym dniu notowań giełdowych jest niższa od stóp zwrotu z akcji pozostałych spółek w dniu ich debiutu giełdowego. Na efektywność podejmowanych przez fundusze private equity działań inwestycyjnych wpływ ma koszt implicite będący wynikiem zaobserwowanego 
niedowartościowania akcji oferowanych do nabycia w ramach pierwszej oferty publicznej. Dla analizowanych przedsiębiorstw koszt ten wyniósł średnio ponad 5\% wartości spółki, przy wycenie jej akcji według ceny emisyjnej. Wyniki badań empirycznych wskazują, że koszt niedowartościowania akcji zbywanych w ramach pierwszej oferty publicznej przedsiębiorstwa udziałowego alokowany jest głównie na fundusz private equity.

Wyniki badań empirycznych nad kształtowaniem się kursów akcji spółek portfelowych funduszy private equity w średnim i długim okresie wskazują, iż stopy zwrotu z akcji tych podmiotów kształtują się średnio poniżej stóp zwrotu z akcji pozostałych spółek. Sytuacja ta utrzymuje się w okresie około trzech lat od pierwszego notowania na giełdzie papierów wartościowych. Przyczyną występowania odmiennego kształtowania się kursów akcji spółek wprowadzonych do publicznego obrotu w celu realizacji procesów dezinwestycji może być ryzyko związane $\mathrm{z}$ dodatkową podażą akcji z portfela inwestycyjnego funduszu private equity. Ryzyko to występuje w sytuacji, kiedy redukcja zaangażowania kapitałowego funduszu private equity w spółkę portfelową nie została zakończona. W praktyce dezinwestycji występuje znaczne zróżnicowanie poziomu stóp zwrotu z akcji spółek portfelowych poddanych pełnemu i częściowemu wyjściu z inwestycji funduszu private equity. Zwłaszcza w okresie dwóch początkowych lat notowań giełdowych w spółkach, wobec których zastosowana została strategia pełnego wyjścia z inwestycji funduszu private equity, obserwowane są wyższe długoterminowe stopy zwrotu z akcji w porównaniu ze spółkami portfelowymi funduszy private equity, w których zrealizowana została formuła częściowego wyjścia z inwestycji.

Przedstawiona synteza wyników analizy literatury przedmiotu oraz badań empirycznych może być uznana za ważną podstawą odniesienia dla przyszłych badań kierunków, efektów, determinant i sposobów realizacji procesów dezinwestycji funduszy private equity. 



\section{BIBLIOGRAFIA}

A d a m c z y k J., Społeczna odpowiedzialność przedsiębiorstw, PWE, Warszawa 2009.

A h e r n K. R., Sample selection and event study estimation, „Journal of Empirical Finance” 2009, Vol. 16.

Akerlof A., The Market for 'Lemons': Quality Uncertainty and the Market Mechanism, „The Quarterly Journal of Economics” 1970, Vol. 84, No. 3.

Ang J. S., Brau J. C., Firm Transparency And The Costs Of Going Public, „The Journal of Financial Research", Spring 2002, Vol. XXV, No. 1.

A n s on M. J. P., The Handbook of Alternative Assets, John Wiley\&Sons, 2002.

B a li c ki A., Analiza przeżycia i tablice wymieralności, PWE, Warszawa 2006.

Ball E., Chiu H-H., S mith R., Exit Choices of Venture-Backed Firms: IPO v. Acquisition, 2008, http://ssrn.com/abstract=1301288.

B arnes E., McCarthy Y., Grandstanding in the UK Venture capital Industry, EFMA 2002 London Meetings.

B arry B., Initial Public Offering Underpricing: The Issuer's View-A Comment, „The Journal of Finance", September 1989, Vol. 44, No. 4.

B arry B., Muscarella C., Pe avy J. W., Vetsu ypens M. R., The Role of Venture capital in the Creation of Public Companies: Evidence from the Going-Public Process, ,Journal of Financial Economics" 1990, Vol. 27, Issue 2.

$\mathrm{B}$ a scha A., Walz U., Convertible securities and optimal exit decisions in venture capital finance, ,Journal of Corporate Finance” 2001, Vol. 7.

B a y ar O., Che mmanur T. J., IPOs versus Acquisitions and the Valuation Premium Puzzle: A Theory of Exit Choice by Entrepreneurs and Venture capitalists, ,Journal of Financial and Quantitative Analysis", August 2010.

Bednarski L., Borowiecki R., Duraj J., Kurtys E., Waśniewski T., Wersty B., Analiza ekonomiczna przedsiębiorstwa, Wydawnictwo Akademii Ekonomicznej im. Oskara Langego we Wrocławiu, Wrocław 1996.

B erle A. A., Means G. C., The modern corporation and private property, Macmillan, New York, 1932.

B e s sler W., S e i m M., The performance of venture-backed IPOs in Europe, „Venture capital: An International Journal of Entrepreneurial Finance" 2012.

B i ls ki I., Innowacje w kreowaniu zdolności konkurencyjnej przedsiębiorstwa, Wydawnictwa Uczelniane Uniwersytetu Technologiczno-Przyrodniczego, Bydgoszcz 2007.

B i e $\mathrm{n}$ z C., Le it e T. E., A Pecking Order of Venture capital Exits, April 2008.

B i e n z C., W a 1 z U., Venture capital Exit Rights, CFS Working Paper No. 05, 2009.

B 1 a ck B. S., Gils o n R. J., Venture capital and the structure of capital markets: Banks versus stock markets, ,Journal of Financial Economics” 1998, Vol. 47.

B loomfield S., Venture capital Funding. A Practical Guide to Raising Finance, Kogan Page Limited 2005. 
B oehme R. D., Sorescu S. M., The Long-run Performance Following Dividend Initiations and Resumptions: Underreaction Or Product of Chance?, „The Journal of Finance” 2002, Vol. 57, No. 2.

B or ow i e cki R. (red.), Pomiar i ocena procesów kreowania wartości w badaniu efektywności przedsiębiorstwa, Fundacja Uniwersytetu Ekonomicznego w Krakowie, Kraków 2009.

B orowi ecki R., Jaki A., Misiołek K., Rojek T., Nadzór korporacyjny w procesie kreowania wartości i rozwoju przedsiębiorstwa, Wydawnictwo ABRYS, Kraków 2005.

B ottazzi L., D a R in M., Hell mann T., Who are the active investors? Evidence from venture capital, ,Journal of Financial Economics” 2008, Vol. 89.

$\mathrm{B}$ oulto n J., S mart S. B., Zutter C. J., IPO underpricing and international corporate governance, ,Journal of International Business Studies” 2010, Vol. 41.

Brander J. A., A mit R., Antweiler W., Venture-Capital Syndication: Improved Venture Selection vs. the Value-Added Hypothesis, „Journal of Economics\&Management Strategy” 2002, Vol. 11, No. 3.

B rau C., Francis B., Kohers N., The Choice of IPO versus Takeover: Empirical Evidence, „Journal of Business” 2003, Vol. 76, No. 4.

Brav A., Geczy C., Gompers P. A., Is the abnormal return following equity issuances anomalous?, „Journal of Financial Economics” 2000, Vol. 56.

B rav A., Gompers P. A., Myth or reality? The long-run underperformance of initial public offerings: Evidence from venture and nonventure capital-backed companies, „The Journal of Finance" 1997, Vol. 52.

B rav A., Inference in Long-Horizon Event Studies: A Bayesian Approach with Applicationto Initial Public Offerings, „The Journal Of Finance” 2000, Vol. 55, No. 5.

Brennan M. J., Franks J., Underpricing, ownership and control in initial public offerings of equity securities in the UK, ,Journal of Financial Economics”, September 1997, Vol. 45, Issue 3.

Brzozowska K., Business Angels na rynku kapitatowym. Motywacje, inwestowanie, efekty, CeDeWu, Warszawa 2008.

$\mathrm{Ca}$ i J., W ei, C. J., The investment and operating performance of Japanese initial public offerings, „Pacific-Basin Finance Journal” 1997, Vol. 5.

Central and Eastern Europe Statistics 2009-2011, An EVCA Special Paper.

Chan K., Ikenberry D. L., Lee I., W ang Y., Share repurchases as a potential tool to mislead investors, ,Journal of Corporate Finance” 2010, Vol. 16.

Ci j j a - Zn a mi row s k K. Kkonomiczne ograniczenia rozwoju rynku kapitałowego w Polsce, Wydawnictwo KUL, Lublin 2004.

Cle if i e Ch. C., Venture capital in Europe, [w:] J. M. Gib b, Venture capital Markets for Regeneration of Industry, Amsterdam 1984.

Coakley J., Had as s L., Wood A., Post-ipo operating performance, venture capitalists and market timing, Discussion Paper No.04-16, University of Essex, 2004.

C och $\mathrm{r}$ a n e J. H., The risk and return of venture capital, ,Journal of Financial Economics” 2005, Vol. 75.

Corrado J., Event studies: A methodology review, „Accounting and Finance” 2011, Vol. 51.

$\mathrm{Cu}$ mming D. (red.), The Oxford Handbook of Entrepreneurial Finance, Oxford University Press, New York 2012.

$\mathrm{Cu} \mathrm{mming}$ D. J., J o h an S. A., Information asymmetries, agency costs and venture capital exit outcomes, „Venture capital” 2008, Vol. 10, No. 3.

Cumming D. J., Fleming G., Schwienbacher A., Liquidity Risk and Venture capital Finance, „Financial Management” 2005, Vol. 34, Issue 4.

Cumming D. J., Fleming G., Schwienbacher A., Legality and venture capital exits, „Journal of Corporate Finance” 2006, Vol. 12.

Cumming D. J., Fleming G., Suchard J-A., Venture Capitalist Value-added Activities, Fundraising and Drawdowns, ,Journal of Banking\&Finance” 2005, Vol. 29. 
Cumming D. J., Joh an S. A., Venture capital and Private equity Contracting. An International Perspective, Elsevier 2009.

Cumming D. J., MacIntosh J. G., A cross-country comparison of full and partial venture capital exits, ,Journal of Banking\&Finance” 2003, Vol. 27.

$\mathrm{Cumming}$ D. J., Mac Intosh J. G., Venture capital investment duration in Canada and the United States, ,Journal of Multinational Financial Management” 2001, Vol. 11.

Cumming D. J., Mac Intosh J. G., Venture-capital exits in Canada and United States, „University of Toronto Law Journal" 2003.

Da Silva Ros a R., Lee P., Skott M., Walter T., Competition in the Market for Takeover Advisers, „Australian Journal of Management” 2004, Vol. 29.

$\mathrm{D}$ a s S. R., J a g a n nath an M., S a rin A., Private equity returns: An empirical examination of the exit of venture-backed companies, ,Journal of Investment Management” 2003, Vol. 1, No. 1.

De Cle rcq D., Di mov D., Internal Knowledge Development and External Knowledge Access in Venture Capital Investment Performance, ,Journal of Management Studies”, May 2008, Vol. 45.

De Clercq D., Manigart S., The venture capital post-investment phase: Opening the black box of involvement, [w:] H. Lan d s trö m (red.), Handbook of research on Venture capital, Edward Elger, 2007.

Draho J., The IPO Decision. Why and How Companies Go Public, Edward Elgar Publishing, 2005.

Droga na gietde, PricewaterhouseCoopers, 2011, http://www.pwc.pl.

Droga na giełdę. Jak przygotować spótkę do emisji publicznej, praca zbiorowa ekspertów BDO, Difin, Warszawa 2008.

Duraj J., Papiernik-Wojdera M., Przedsiębiorczość i innowacyjność, Difin, Warszawa 2010.

D u raj J., Przedsiębiorstwo na rynku kapitałowym, PWE, Warszawa 1996.

Duraj J., S ajnóg A., Rentowność kapitału własnego giełdowych spótek przemystowych, Wydawnictwo Uniwersytetu Łódzkiego, Łódź 2011.

E c k b o B., N orli Ø., Liquidity risk, leverage and long-run IPO returns, „Journal of Corporate Finance" 2005, Vol. 11.

Eckermann M., Venture capitalists' Exit Strategies under Information Asymmetry. Evidence from the U.S. Venture capital Market, Deutscher Universität-Verlag, Wiesbaden 2006.

Eis enhardt M., Agency theory. An assessment and review, „The Academy of Management Review" 1989, Vol. 14, No. 1.

EVCA Yearbook 2003-2011, European Private Equity\&Venture Capital Association, Zaventem, Belgium.

F a ma E. F., Efficient Capital Markets: II, „The Journal of Finance”, December 1991, Vol. 46, No. 5 .

F a m a E. F., J en se n M. C., Separation of ownership and control, ,Journal of Law and Economics" 1983, Vol. 26, No. 2.

Fenn G. W., Liang N., Prowse S., The Economics of the Private equity Market, „Federal Reserve Bulletin", January 1996.

Field L. C., She eh a n D. P., IPO underpricing and outside blockholdings, „Journal of Corporate Finance" 2004, Vol. 10.

Fran zke A., Underpricing of Venture-Backed and Non Venture-Backed IPOs: Germany's Neuer Markt, RICAFE Working Paper No. 003.

Fra se r-S a m p s on G., Private equity as an Asset Class, WilleyFinance, 2007.

Frąck owi ak W. (red.), Fuzje i przejęcia, PWE, Warszawa 2009.

Gifford S., The allocation of limited entrepreneurial attention, Kulwer Academic Publisher, 1998. 
$\mathrm{Gi}$ ot $\mathrm{P} ., \mathrm{Schwienbacher} \mathrm{A.,} \mathrm{IPOs,} \mathrm{trade} \mathrm{sales} \mathrm{and} \mathrm{liquidations:} \mathrm{Modeling} \mathrm{venture} \mathrm{capital}$ exits using survival analysis, ,Journal of Banking and Finance” 2007, Vol. 31.

Glad stone D., Glad st on e L., Venture capital Handbook: An Enterpreneur's Guide to Raising Venture capital, Financial Times Prentice Hall, Londyn-New York 2001.

Go mpers P. A., Grandstanding in the venture capital industry, ,Journal of Financial Economics" 1996, Vol. 42.

Go mpers P. A., Optimal Investment, Monitoring, and the Staging of Venture capital, „Journal of Finance" 1995, Vol. 50, Issue 5.

Go mpers P. A., Le rn er J., The Determinants of Corporate Venture capital Success: Organizational Structure, Incentives, and Complementarities, NBER Working Paper No. 6725, http://www.nber.org/papers/w6725.pdf.

Gompers P. A., Lerner J., The Venture Capital Cycle, MIT Press, Cambridge Massachusetts 2006.

Gompers P. A., Lerner J., The Venture Capital Revolution, „The Journal of Economic Perspectives" 2001, Vol. 15, No. 2.

Gorm an M., S a hlman W., What do venture capitalists do?, „Journal of Business Venturing”, July 1989, Vol. 4, No. 4.

Goryn i M., Przedsiębiorstwo w nowej ekonomii instytucjonalnej, „Ekonomista” 1999, nr 6.

Groh, A. P., von Liechtenstein H., How Attractive is Central Eastern Europe for Risk Capital Investors?, „Journal of International Money and Finance” 2009, Vol. 28, No. 4.

Grullon G., Michaely R., Dividends, Share Repurchases, and the Substitution Hypothesis, „The Journal of Finance”, August 2002, Vol. 57, No. 4.

Grzywacz J., Okońska A., Venture capital a potrzeby kapitałowe matych i średnich przedsiębiorstw, Szkoła Główna Handlowa w Warszawie, Warszawa 2005.

Gule r I., Throwing Good Money after Bad? Political and Institutional Influences on Sequential Decision Making in the Venture Capital Industry, ,Administrative Science Quarterly” 2007, Vol. 52.

Gurgul H., Analiza zdarzeń na rynkach akcji, Oficyna a Wolters Kluwer business, Warszawa 2012.

Hanoun a P. E., S arin A., Shapiro A. C., Value of Corporate Control: Some International Evidence, USC Finance\&Business Econ. Working Paper No. 01-4, 2001.

$\mathrm{He} 11 \mathrm{mann}$ T., A theory of strategic venture investing, „Journal of Financial Economics” 2002, Vol. 64.

Hochberg Y. V., Ljungqvist A., Lu Y., Venture Capital Networks and Investment Performance, „The Journal of Finance” 2007, Vol. 62, No. 1

How J., Ng o K., V erh o e ven P., Dividend initiations and long-run IPO performance, „Australian Journal of Management" 2011, Vol. 36, No. 2.

H s u H., What Do Entrepreneurs Pay for Venture capital Affiliation?, „The Journal of Finance”, August 2004, Vol. LIX, No. 4.

Ib b ot s o n G., Price Performance of Common Stock New Issues, ,Journal of Financial Economics", September 1975, Vol. 2, Issue 3.

Ikenberry D. L., R ankine G., S ti ce E. K., What Do Stock Splits Really Signal?, „Journal of Financial and Quantitative Analysis" 1996, Vol. 31.

IPO Watch Europe - Review of the year 2008, PricewaterhouseCoopers, 2009.

IPO Watch Europe - Review of the year 2010, PricewaterhouseCoopers, 2011.

Jain B., Kini O., The post-issue operating performance of IPO firms, „Journal of Finance” 1994, Vol. 49.

J an i cka M., Liberalizacja przeptywów kapitałowych w gospodarce światowej. Przypadek Polski, Wydawnictwo Uniwersytetu Łódzkiego, Łódź 2010.

J an i cka M., Wptyw procesów prywatyzacyjnych na rozwój rynku kapitałowego $w$ Polsce, „Acta Universitatis Lodziensis", Folia Oeconomica 151, Wydawnictwo Uniwersytetu Łódzkiego, Łódź 2000. 
Jen sen M. C., Meckling W. H., Theory of the Firm: Managerial Behavior, Agency Costs and Ownership Structure, „Journal of Financial Economics”, October 1976, Vol. 3, No. 4.

J ė żak J. (red.), Struktury i formy sprawowania władzy w spótkach kapitałowych, Wydawnictwo Uniwersytetu Łódzkiego, Łódź 2005.

Jeżak J., Ład korporacyjny. Doświadczenia oraz kierunki rozwoju, Wydawnictwo C. H. Beck, Warszawa 2010.

Jobman D. R., The Handbook of Alternative Investment, John Wiley\&Sons, Inc., New York 2002.

Jóźw i a k J., P od gór s k i J., Statystyka od podstaw, PWE, Warszawa 2000.

$\mathrm{K}$ a n a t a $\mathrm{G}$., S te $\mathrm{f}$ a $\mathrm{n}$ a is Ch., Venture capital, IPO underpricing, and going-public decisions, Working Paper, Jones School of Management, 2005.

Kaplan S. N., S trö mberg P., Characteristics, Contracts, and Actions: Evidence from Venture capitalist Analyses, ,The Journal of Finance” 2004, Vol. LIX, No. 5.

Kaplan S., S trö mberg P., Financial Contracting Theory Meets the Real World: An Empirical Analysis of Venture capital Contracts, ,Review of Economic Studies” 2002.

Kierunek - Giełda: przebieg procesu wchodzenia spótek na Giełdę Papierów Wartościowych $w$ Warszawie w latach 2004-2006, Raport KPMG/GPW, Warszawa 2006.

K i m W., W e i s b a ch M. S., Do firms go public to raise capital?, NBER Working Paper Series, Working Paper 11197, http://www.nber.org/papers/w11197.

Kochalski C., Koszty w przedsiębiorstwie zarzadzanym przez wartość. Ujęcie modelowe, Wydawnictwo Akademii Ekonomicznej w Poznaniu, Poznań 2006.

Kooli M., Suret J-M., The Underpricing of Initial Public Offerings: Further Canadian Evidence, Scientific Series CIRANO, Montreal 2001.

Kornasiewicz A., Venture capital $w$ krajach rozwiniętych $i w$ Polsce, CeDeWu, Warszawa 2004.

Koźmiński A. K., Piotrowski W. (red.), Zarzadzanie, Teoria i Praktyka, Wydawnictwo Naukowe PWN, Warszawa 2004.

$\mathrm{Kr}$ aft V., Erfolgreiches Managment von Private equity-Investitionen in Turnarounds und Restrukturierungen, Universität St. Gallen Working Paper, 2001.

Kutsuna, K., Ok a mur a H., Cowling M., Ownership structure pre- and post-IPOS and the operating performance of JASDAQ companies, „Pacific-Basin Finance Journal” 2002, Vol. 10.

La Porta R., Lopez-de-Silanes F., Shleifer A., Vishny R., Investor protection and corporate governance, „Journal of Financial Economics” 2000, Vol. 58.

L a n d s $\mathrm{r}$ ö m H., Handbook of Research on Venture capital, Edward Elger, 2007.

Landström H., Venture capital Investment Process in a Decision Theory Framework, [w:] J. M. V e c in a, SME's Internalization, Networks and Strategy, Avebury 1995.

Lee P. M., Wahal S., Grandstanding, certification and the underpricing of venture capital backed IPOs, ,Journal of Financial Economics” 2004, Vol. 73, No. 2.

Le wandowska L., Finansowanie w kontekście pozycji konkurencyjnej firmy, [w:] J. Duraj (red.), Przedsiębiorstwo na rynku kapitałowym, Wydawnictwo Uniwersytetu Łódzkiego, Łódź 2008.

Lewandowska L., Niekonwencjonalne formy finansowania przedsiębiorczości, ODiDK Sp. z o.o., Gdańsk 2000.

Ljungqvist A., IPO underpricing, [w:] B.E. Eckbo (red.), Handbook of Corporate Finance: Empirical Corporate Finance, Vol. A, Chapter 7, 2006.

Loughran T., Ritter J. R., Rydqvist K., Initial public offerings: International insights, „Pacific-Basin Finance Journal” 1994, Vol. 2.

Loughran T., Ritter J. R., The new issues puzzle, „The Journal of Finance” 1995, Vol. L, No. 1.

Machała R., Przejęcia i fuzje. Wpływ na wartość firm, Oficyna Wydawnicza „UNIMEX”, Wrocław 2007. 
Mackinlay C., Event Studies in Economics and Finance, „Journal of Economic Literature”, March 1997, Vol. XXXV.

Maier B., Walker D. A., The role of venture capital in financing small business, „Journal of Business Venturing" 1987, Vol. 2, Issue 3.

Marcin kow sk a M., Ocena działalności instytucji finansowych, Difin, Warszawa 2007.

M a r c in kow sk a M., Wptyw wtadztwa korporacyjnego na tworzenie wartości przedsiębiorstwa, [w:] S. Rudolf (red.), Rola nadzoru korporacyjnego w kreowaniu wartości przedsiębiorstwa, Wydawnictwo Uniwersytetu Łódzkiego, Łódź 2008.

Mayera C., S choorsb K., Y afeh Y., Sources of funds and investment activities of venture capital funds: Evidence from Germany, Israel, Japan and the United Kingdom, „Journal of Corporate Finance" 2005, Vol. 11.

Meggins on W. L., We is s K. A., Venture capitalists certification in initial public offerings, „Journal of Finance” 1991, No. 46.

Meule man M., Wright M., Manigart S., Lockett A., Private equity Syndication: Agency Costs, Reputation and Collaboration, „Journal of Business Finance\&Accounting”, June/July 2009, Vol. 36(5)\&(6).

Me yer T., Math on et P.-Y., Beyond the J-curve. Managing a Portfolio of Venture capital and Private equity Funds, John Wiley\&Sons, 2005.

Mikkels on W., Partch M., Shah K., Ownership and operating performance of companies that go public, ,Journal of Financial Economics” 1997, Vol. 44.

Mikołajc zyk B., Krawc z y k M., Aniołowie Biznesu w sektorze MSP, Difin, Warszawa 2007.

Mikołajek-Gocjena M., IPO jako źródto finansowania rozwoju spótki, Szkoła Główna Handlowa w Warszawie, Warszawa 2008.

Mitchell M. L., Stafford E., Managerial decisions and long-term stock price performance, „The Journal of Business” 2000, Vol. 73.

Müller R., Turner J. R., The impact of principal-agent relationship and contract type on communication between project owner and manager, ,International Journal of Project Management" 2003, Vol. 23.

$\mathrm{N}$ ah a t a R., Venture capital reputation and investment performance, „Journal of Financial Economics", November 2008, Vol. 90, Issue 2.

Nermend K., Kuciński A., Pozycja Giełdy Papierów Wartościowych w Warszawie na tle europejskich parkietów, „Studia i Materiały Polskiego Stowarzyszenia Zarządzania Wiedzą” 2011, nr 56.

$\mathrm{Neus}$ W., W al z U., Exit timing of venture capitalists in the course of an initial public offering, „Journal of Financial Intermediation” 2005, Vol. 14.

Ortgiese J., Value Added by Venture Capital Firms, JOSEF EUL VERLAG, Lohmar-Köln 2007.

Pagano M., Panetta F., Zingales L., Why Do Companies Go Public? A Empirical Analysis, „The Journal of Finance” 1998, Vol. LIII, No. 1.

P anfil M., Fundusze private equity. Wptyw na wartość spótki, Difin, Warszawa 2005.

Panfil M., Globalizacja inwestycji venture capital, [w:] A. Szablewski (red.), Migracja kapitatu w globalnej gospodarce, Difin, Warszawa 2009.

Panfil M., Mezzanine jako źródto finansowania dla przedsiębiorstwa, CEO Magazyn Top Menedżerów, czerwiec 2008.

Pastusiak R., Przedsiębiorstwo na rynku kapitatowym. Operacje giełdowe rynku publicznego i niepublicznego, Wydawnictwa Fachowe CeDeWu.pl, Warszawa 2010.

Penc J., Zarzadzanie innowacyjne. Sterowanie zmianami $w$ procesie integracji europejskiej, Wyższa Szkoła Studiów Międzynarodowych w Łodzi, Łódź 2007.

Peters B., Early exits: Exit strategies for entrepreneurs and angel investors (but maybe not venture capitalists), Canada 2009. 
Pieloch A., Wptyw ogłoszenia decyzji o wykupie akcji własnych na wartość rynkowa spótek notowanych na GPW w Warszawie, [w:] E. Urbańczyk, E. Mioduchowska- Jaroszewicz (red.), Strategie i determinanty wzrostu wartości przedsiębiorstwa, ,Zeszyty Naukowe nr 685" pt. Finanse, rynki finansowe, ubezpieczenia nr 46, Uniwersytet Szczeciński, Szczecin 2011.

Pietraszewski M., Proces inwestycyjny realizowany przez fundusze private equity, Wyższa Szkoła Humanistyczno-Ekonomiczna we Włocławku, Włocławek 2007.

Poślad M., Thiel S., Zwoliński T., Akcje i obligacje korporacyjne - oferta publiczna i rynek regulowany, Komisja Papierów Wartościowych i Giełd, Warszawa 2006.

P ov al y S., Private equity exits: Divestment process management for leveraged buyouts, Springer, Berlin Heidelberg 2007.

Pratt S. E., Guide to Venture capital Sources, Wydanie 5, Capital Publishing, Wellesley (MA), 1981.

Przybylska-Kapuścińska W., Mozalewski M., Kapitat wysokiego ryzyka, PWE, Warszawa 2011.

$\mathrm{R}$ a u P. R., Investment bank market share, contingent fee payments, and the performance of acquiring firms, ,Journal of Financial Economics” 2000, Vol. 56.

Regulamin Giełdy, www.gpw.pl.

Regulamin Krajowego Depozytu Papierów Wartościowych, www.kdpw.pl.

R e t k a M., Opcje lepsze niz premia, „Rzeczpospolita”, 26 sierpnia 2011.

Rhodes-Kropf M., Robinson D. T., Viswanathan S., Valuation waves and merger activity: The empirical evidence, „Journal of Financial Economics” 2005, Vol. 77.

Ritter J. R., Initial Public Offerings, „Contemporary Finance Digest”, Spring 1998, Vol. 2, No. 1.

R it te r J. R., The Costs of Going Public, „Journal of Financial Economics”, North-Holland 1987, Vol. 19.

R it t e r J. R., The Long-Run Performance of Initial Public Offerings, „Journal of Finance”, March 1991, Vol. XLVI, No. 1.

Ritter J. R., Welch I., A Review of IPO Activity, Pricing and Allocations, „The Journal of Finance" 2002, Vol. LVII, No. 4.

Ross S. A., The economic theory of agency. The principal's problem, „American Economic Review" 1973, Vol. 63, No. 2.

Rozporzadzenie Komisji (WE) Nr 809/2004 z dnia 29 kwietnia 2004 r. wykonujace dyrektywe 2003/71/WE Parlamentu Europejskiego $i$ Rady $w$ sprawie informacji zawartych w prospektach emisyjnych oraz formy, wtaczenia przez odniesienie i publikacji takich prospektów emisyjnych oraz rozpowszechniania reklam, DzUrz UE 2004, L 149/1.

Rozporzadzenie Ministra Finansów z dnia 16 marca 2010 r. w sprawie opłat wnoszonych na rzecz Komisji Nadzoru Finansowego przez podmioty nadzorowane prowadzace działalność na rynku kapitałowym, DzU 2010, nr 57, poz. 364.

Rozporzadzenie Ministra Finansów z dnia 19 lutego 2009 r.w sprawie informacji bieżacych i okresowych przekazywanych przez emitentów papierów wartościowych oraz warunków uznawania za równoważne informacji wymaganych przepisami prawa państwa niebędacego państwem członkowskim, DzU 2009, nr 33, poz. 259.

Rynek fuzji i przejęć. Polska na tle Europy Środkowej. Edycja 2010, Badanie KPMG i DealWatch.

Rynek fuzji i przejęć. Polska na tle Europy Środkowo-Wschodniej. I pótrocze 2010, Badanie KPMG i DealWatch.

S ahlman W. A., Structure of venture-capital organizations, ,Journal of Financial Economics” 1990, Vol. 27.

S aj nóg A., Operacyjny i strategiczny wymiar ocen zróżnicowania rentowności kapitału wtasnego spótek przemysłowych, [w:] J. Duraj (red.), Przedsiębiorstwo na rynku kapitałowym, Wydawnictwo Uniwersytetu Łódzkiego, Łódź 2010. 
S a mborski A., Finansowanie przedsiębiorstw poprzez emisje papierów wartościowych - diagnoza uwarunkowań i zależności, Wydawnictwo Akademii Ekonomicznej w Katowicach, Katowice 2007.

S a mborski A., Governance w przedsiębiorstwie w kontekście społecznej odpowiedzialności, „Przegląd organizacji” 2012, nr 1.

$\mathrm{S}$ chertler A., European venture capital markets: Fund providers and investment characteristics, ,Applied Financial Economics” 2005, Vol. 15.

Schuster A., IPOs: Insights from Seven European Countries, Discussion Paper 461, Financial Markets Group, London School of Economics and Political Science, London 2003.

$\mathrm{Schwienbacher}$ A., An empirical analysis of venture capital exits in Europe and United States, EFA 2002 Berlin Meetings Discussion Paper, 2005.

$\mathrm{Sch}$ ienbacher A., Innovation and venture capital exits, „The Economic Journal” 2008, Vol. 118, Royal Economic Society.

S e r r a P., Event Study Tests. A Brief Survey, Working Papers da FEP No. 117, May 2002.

S i w e k P., Praktyka pierwszych ofert publicznych w Polsce, CeDeWu.pl, Warszawa 2005.

$\mathrm{S}$ mart B., Zutter C. J., Control as a Motivation for Underpricing: A Comparison of Dual- and Single-Class Ipos, August 2000. Presented at Tuck-JFE Contemporary Corporate Governance Conference.

S mart B., Zutter C. J., Dual Class IPOs Are Underpriced Less Severely, „The Financial Review" 2008, Vol. 43.

S ob ań ska K., Si eradzan P., Inwestycje private equity/venture capital, Key Text, Warszawa 2004.

S ob otn ik R., Pierwsza oferta publiczna - zmieniajace się trendy, [w:] A. S z able w s ki (red.), Migracja kapitału w globalnej gospodarce, Difin, Warszawa 2009.

S okołowska E., Alternatywne formy inwestowania na rynku papierów wartościowych, $\mathrm{Wy-}$ dawnictwo Naukowe Uniwersytetu Mikołaja Kopernika, Torun 2010.

S trad o m ski M., Finansowanie obce firm rodzinnych na rynku niedoskonatym, PWE, Warszawa 2010.

Sukacz D., Pierwsze oferty publiczne na rynkach kapitałowych, Wydawnictwa Fachowe CeDeWu.pl, Warszawa 2005.

Survey of the Economic and Social Impact of Management Buyouts\&Buyins in Europe, Research Paper EVCA, Zaventem, Belgium 2001.

Survey of the Economic and Social Impact of Venture capital in Europe, Research Paper EVCA, Zaventem, Belgium 2002.

$\mathrm{S}$ we droe L. E., Ki zer J., The only guide to alternative investments you'll ever need, Bloomberg Press, New York 2008.

S zerszen ow ic z L., K ac z yńska J., Trend: Ile kosztuje władza nad spótka, Harvard Bussines Review Polska, http://www.hbrp.pl.

S z y mań ski M., Nogalski B., Obrona przed wrogim przejęciem, Wolters Kluwer, Warszawa 2011.

Ś wi derska J., Quasi-fundusze venture capital. Publiczne wsparcie innowacyjnych MSP, Difin, Warszawa 2008.

Ta mowic z P., Venture capital - kapitat na start, Polska Agencja Rozwoju Przedsiębiorczości, Gdańsk 2004.

Te oh S., Welch I., Wong T., Earnings management and the long-run market performance of initial public offerings, „Journal of Finance” 1998, Vol. 53.

Ustawa z dnia 15 września 2000 r. Kodeks spółek handlowych, DzU 2000, nr 94, poz. 1037 z późn. zm.

Ustawa z dnia 25 marca 2011 r. o zmianie niektórych ustaw zwiazanych z funkcjonowaniem systemu ubezpieczeń społecznych, DzU 2011, nr 75, poz. 398. 
Ustawa z dnia 29 lipca 2005 r. o ofercie publicznej $i$ warunkach wprowadzania instrumentów finansowych do zorganizowanego systemu obrotu oraz o spótkach publicznych, DzU 2005, nr 184, poz. 1539.

Ustawa z dnia 29 września 1994 r. o rachunkowości, DzU 1994, nr 12, poz. 591 z późn. zm.

Ustawa z dnia 4 marca 2005 r. o Krajowym Funduszu Kapitatowym, DzU 2005, nr 57, poz. 491.

Venture Impact - The Economic Importance of Venture capital Backed Companies to the U.S. Economy, National Venture capital Association, 2009.

W all J., S mith J., Better exits, Price Waterhouse Corporate Finance for EVCA, 1997.

Waszczyk B., Fundusze agresywne caty czas $w$ odstawce, Open Finance, http://www.open.pl/news/fundusze_agresywne_caly_czas_w_odstawce.html.

$\mathrm{W}$ ę c ł a w ski J., Venture capital. Nowy instrument finansowania przedsiębiorstw, Wydawnictwo Naukowe PWN, Warszawa 1997.

Wonglimpiyarat J., The influence of capital market laws and initial public offering (IPO) process on venture capital, „European Journal of Operational Research” 2009, Vol. 192, Issue 1.

Wójcik-Mazur A., Analiza rozwoju systemu finansowego w Polsce na tle państw europy środkowo-wschodniej w latach 2006-2009, ,Zeszyty Naukowe Politechniki Śląskiej, Organizacja i Zarządzanie nr 59" 2011.

W rońs k a E. M., Asymetria informacyjna. Potrzeba i znaczenie budowania relacji z inwestorami $w$ procesie tworzenia wartości dla akcjonariuszy, [w:] J. Duraj (red.), Wartość i kapitat spótek akcyjnych, „Acta Universitatis Lodziensis”, Folia Oeconomica 262, Wydawnictwo Uniwersytetu Łódzkiego, Łódź 2012.

Wrzesiński M., Fuzje i przejęcia. Wykup lewarowany (LBO) i menedżerski (MBO). Uwarunkowania rozwoju w Polsce, Wydawnictwo K. E. LIBER, Warszawa 2000.

Wrzesiński M., Kapitat podwyższonego ryzyka. Proces inwestycyjny $i$ efektywność, Szkoła Główna Handlowa w Warszawie, Warszawa 2008.

$\mathrm{Z}$ a sęp a P., Venture capital - sposoby dezinwestycji, CeDeWu.pl Wydawnictwa Fachowe, Warszawa 2010.

Zh e n g S. X., Are IPOs really overpriced?, ,Journal of Empirical Finance” 2007, Vol. 14.

Zi ółk ow ska B., Proces tworzenia jednolitego rynku finansowego w UE, [w:] J. D u raj (red.), Przedsiębiorstwo na rynku kapitałowym, Wydawnictwo Uniwersytetu Łódzkiego, Łódź 2008.

Żwirbla A., Metody badawcze analizy ekonomicznej. Studium metodologiczne, Wyższa Szkoła Humanistyczno-Ekonomiczna, Włocławek 2001.

\section{Strony internetowe:}

Blog MCI Investments SA: http://mci.biznes.net.

European Private Equity and Venture Capital Association: http://www.evca.eu.

Giełda Papierów Wartościowych w Warszawie SA: http://www.gpw.pl.

GPWInfoStrefa: http://www.gpwinfostrefa.pl.

Komisja Nadzoru Finansowego: http://www.knf.gov.pl.

Krajowy Fundusz Kapitałowy: http://www.kfk.org.pl.

Polskie Stowarzyszenie Inwestorów Kapitałowych: http://www.ppea.org.pl.

Portal finansowy IPO.pl: http://www.ipo.pl.

PricewaterhouseCoopers: http://www.pwc.pl.

Serwis wykupów menedżerskich AVALLON Sp. z o.o.: http://www.mbo.pl. 


\section{SPIS TABEL}

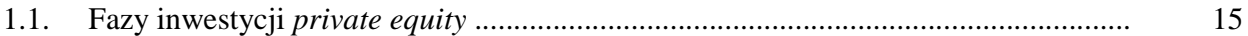

1.2. Stadia rozwoju przedsiębiorstw pozyskujących finansowanie private equity ............. 29

1.3. Charakterystyka głównych odbiorców kapitału z funduszy private equity ................. 31

1.4. Formy wpływu funduszy private equity na rozwój spółek portfelowych ..................... 36

1.5. Wybrane wskaźniki przedstawiające efekty zaangażowania inwestorów private equity w spółki portfelowe ................................................................................

1.6. Kluczowe ograniczenia w zakresie inwestowania kapitału przez fundusze private equity $\mathrm{w}$ przedsiębiorstwa udziałowe

1.7. Inwestycje private equity w polskie przedsiębiorstwa w latach 2007-2010 według poszczególnych segmentów

2.1. Klauzule stosowane $\mathrm{w}$ umowach inwestycyjnych przez fundusze private equity związane z procesem dezinwestycji

2.2. Wady i zalety pierwszej oferty publicznej jako metody wyjścia z inwestycji funduszy private equity

2.3. Wady i zalety dezinwestycji realizowanych na rynku fuzji i przejęć

2.4. Główne rodzaje wykupów stosowane jako formy dezinwestycji funduszy private equity

2.5. Liczba i wartość transakcji zrealizowanych na rynku fuzji i przejęć w okresie od 2008 r. do pierwszej połowy $2010 \mathrm{r}$.

2.6. Przeciętne wartości mnożników transakcyjnych w okresie od 2008 r. do pierwszej połowy $2010 \mathrm{r}$.

2.7. Największe transakcje na rynku fuzji i przejęć w Polsce ogłoszone w okresie od 1 stycznia 2009 r. do 30 czerwca 2010 r.

2.8. Podstawowe informacje charakteryzujące rozwój GPW w Warszawie w latach 1991-2011

2.9. Liczba i wartość pierwszych ofert publicznych na poszczególnych giełdach w krajach Unii Europejskiej w latach 2007-2010

2.10. Ujęcie sektorowe pierwszych publicznych ofert sprzedaży akcji na rynkach kapitałowych Unii Europejskiej w latach 2007-2010 [w \%]

2.11. Struktura dezinwestycji funduszy private equity w Polsce w latach 2007-2010 - ujęcie market 
2.12. Struktura dezinwestycji funduszy private equity $\mathrm{w}$ segmencie venture capital w Polsce w latach 2007-2010 - ujęcie market

2.13. Struktura dezinwestycji funduszy private equity w segmencie buyout\&growth w Polsce w latach 2007-2010 - ujęcie market

2.14. Struktura dezinwestycji funduszy private equity w Europie Środkowo-Wschodniej w latach 2007-2010 - ujęcie market

3.1. Kluczowe determinanty wyboru momentu wyjścia $\mathrm{z}$ inwestycji

3.2. Czas trwania procesu inwestycyjnego funduszy private equity $\mathrm{w}$ zależności od metody dezinwestycji (w latach)

3.3. Podmioty zakwalifikowane do badań empirycznych (skład próby badawczej) ..........

3.4. Wartość podstawowych statystyk opisowych udziału funduszu private equity w kapitale zakładowym spółki portfelowej bezpośrednio przed wprowadzeniem na GPW w Warszawie

3.5. Udział akcji zbywanych przez fundusze private equity bezpośrednio w publicznej ofercie sprzedaży w kapitale zakładowym analizowanych podmiotów

3.6. Udział funduszu private equity w kapitale zakładowym spółki po wprowadzeniu na GPW w Warszawie

3.7. Okres kontynuacji zaangażowania kapitałowego funduszu private equity w spółkę portfelową po jej debiucie giełdowym

3.8. Stopień dezinwestycji realizowanej przez fundusze private equity w drodze pierwszej oferty publicznej - wybrane statystyki opisowe

3.9. Stosunek liczby akcji nowej emisji do liczby akcji istniejących przed pierwszą ofertą publiczną - statystyki opisowe

3.10. Struktura pierwszej oferty publicznej spółek portfelowych według źródła pochodzenia sprzedawanych akcji - statystyki opisowe .

3.11. Oferta rynkowa spółki Travelplanet.pl SA w 2005 r.

3.12. Operacje na akcjach spółki Travelplanet.pl $S A$ dokonywane przez fundusze zarządzane przez MCI Management SA po debiucie giełdowym spółki

3.13. Zaktualizowany harmonogram pierwszej oferty publicznej Opoczno $S A$.

3.14. Usługi oferowane przez spółkę K2 Internet $S A$ na różnych etapach cyklu sprzedażowo-marketingowego

3.15. Operacje na akcjach spółki K2 Internet $S A$ dokonywane przez bmp $A G$ po debiucie giełdowym

4.1. Liczba i struktura spółek portfelowych funduszy private equity według osiąganego wyniku finansowego netto

4.2. Wartości wybranych statystyk opisowych współczynników rentowności kapitału własnego analizowanych przedsiębiorstw

4.3. Wyniki testu $t$-Studenta $\mathrm{z}$ dwiema próbami zależnymi dla średnich 
4.4. Odchylenia łączne współczynnika rentowności kapitału własnego badanych spółek

4.5. Odchylenia cząstkowe czynników determinujących rentowność kapitału własnego badanych spółek

4.6. Wysokość opłat na rzecz GPW w Warszawie, Krajowego Depozytu Papierów Wartościowych oraz Komisji Nadzoru Finansowego w związku z realizacją publicznej oferty sprzedaży akcji

4.7. Wartość wybranych statystyk opisowych kosztów pierwszych ofert publicznych spółek portfelowych funduszy private equity w latach 2002-2010

4.8. Wartość wybranych statystyk opisowych poszczególnych rodzajów kosztów pierwszych ofert publicznych spółek portfelowych funduszy private equity w latach 2002-2010

4.9. Wybrane teorie tłumaczące niedowartościowanie akcji oferowanych w ramach pierwszych ofert publicznych ...

4.10. Porównanie charakterystyk pierwszych ofert publicznych „,młodych” i „doświadczonych" funduszy private equity - wybrane dane

4.11. Nowe spółki giełdowe w latach 2002-2010 uwzględnione w badaniach

4.12. Wartości wybranych statystyk opisowych pierwszych ofert publicznych spółek portfelowych funduszy private equity w latach 2002-2010

4.13. Rozkład stóp zwrotu w pierwszym dniu notowań akcji na GPW w Warszawie w latach 2002-2010

4.14. Wartości statystyk opisowych niedowartościowania akcji w pierwszym dniu notowań w latach 2002-2010 na GPW w Warszawie

4.15. Wartości podstawowych statystyk opisowych stóp zwrotu z pierwszego notowania w poszczególnych latach 2002-2010 na GPW w Warszawie

4.16. Statystyki opisowe prostych stóp zwrotu w pierwszym dniu notowań giełdowych w wybranych sektorach w latach 2002-2010 .

4.17. Wartość wybranych statystyk opisowych zmiennych $T C_{u}$ oraz $u_{p}$ w pierwszych ofertach publicznych spółek portfelowych funduszy private equity w latach 2002-2010

4.18. Niedowartościowanie akcji niesprzedawanych i zbywanych w pierwszych ofertach publicznych spółek portfelowych funduszy private equity w latach 2002-2010

4.19. Statystyki opisowe kosztu niedowartościowania funduszy private equity oraz pozostałych akcjonariuszy w analizowanych ofertach

4.20. Średnie anormalne stopy zwrotu z akcji dla strategii buy\&hold dla spółek realizujących pierwsze oferty publiczne w latach 2002-2010

4.21. Wybrane statystyki opisowe stóp $B A H R$ dla spółek, które zrealizowały pierwsze oferty publiczne sprzedaży akcji w latach 2002-2010 
4.22. Wybrane statystyki opisowe stóp $B A H R$ dla spółek, które zrealizowały pierwsze oferty publiczne sprzedaży akcji w latach 2002-2010 według roku debiutu giełdowego

4.23. Wybrane statystyki opisowe stóp $B A H R$ dla spółek, które zrealizowały pierwsze publiczne oferty sprzedaży akcji w latach 2002-2010 - ujęcie sektorowe

4.24. Wybrane statystyki opisowe stóp $B A H R_{T}$ dla spółek portfelowych funduszy private equity, które zrealizowały pierwsze oferty publiczne sprzedaży akcji w latach 2002-2010 w zależności od przyjętej strategii dezinwestycji 


\section{SPIS SCHEMATÓW}

1.1. Struktura rynku kapitału podwyższonego ryzyka .................................................. 20

1.2. Segmenty rynku private equity .............................................................................. 22

1.3. Inwestycje private equity w poszczególnych fazach rozwoju przedsiębiorstw ......... 28

1.4. Finansowanie private equity na różnym etapie rozwoju przedsiębiorstwa ................ 30

1.5. Unifikacja wybranych ujęć cyklu inwestycyjnego funduszy private equity ............... 38

1.6 Etapy procesu inwestowania przez fundusze private equity zgromadzonych środków w spółki portfelowe ................................................................................ $\quad 42$

2.1. Konwersja kapitału w procesie inwestycyjnym funduszu private equity ................... 52

2.2 Sekwencja działań w procesie pierwszej oferty publicznej ........................................ 58

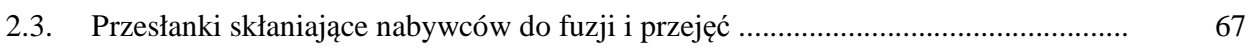

2.4. Schemat realizacji transakcji wykupu menedżerskiego .............................................

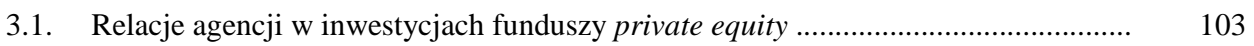

3.2. Asymetria informacji w procesie dezinwestycji ...................................................... 107

3.3. Metody dezinwestycji a asymetria informacji ....................................................... 108

3.4. Klasyfikacja czynników wpływających na wybór metody dezinwestycji funduszy private equity

4.1. Schemat budowy próby badawczej ......................................................................... 197 


\section{SPIS WYKRESÓW}

1.1. Znaczenie funduszy venture capital oraz finansowania typu buyout capital w rozwoju przedsiębiorstw udziałowych

1.2. Napływ nowego kapitału do funduszy private equity w Europie Środkowo-Wschodniej w latach 2004-2010 (w mln EURO)

1.3. Przekrój geograficzny źródeł kapitału funduszy private equity w Polsce w latach 2004-2010

1.4. Źródła kapitału funduszy private equity według typów kapitałodawców w Polsce w latach 2004-2010

1.5. Wartość kapitału zainwestowanego przez fundusze private equity w Europie Środkowo-Wschodniej w latach 2004-2008 (w mln EURO)

1.6. Stosunek inwestycji private equity do PKB w wybranych krajach europejskich, Europie oraz Europie Środkowo-Wschodniej w 2010 r. (w \%)

1.7. Inwestycje private equity w Polsce w latach 2007-2010 według segmentów ...

1.8. Sektorowe ujęcie inwestycji private equity w Polsce w latach 2007-2010 .......... 49

2.1. Motywy debiutów giełdowych

2.2. Ujęcie sektorowe polskiego rynku fuzji i przejęć w okresie od 2009 r. do pierwszej połowy $2010 \mathrm{r}$.

2.3. Udział poszczególnych grup inwestorów w obrotach na GPW w Warszawie w latach 2006-2011

2.4. Udział poszczególnych grup inwestorów w obrotach na GPW w Warszawie w latach 2006-2011 w półrocznych interwałach (w \%)

2.5. Udział poszczególnych rodzajów krajowych inwestorów instytucjonalnych w obrotach na GPW w Warszawie w latach 2006-2011 w półrocznych interwalach (w \%)

2.6. Liczba debiutów i wartość indeksu WIG na GPW w Warszawie w latach 1991-2011

2.7. Liczba i wartość pierwszych ofert publicznych na giełdach w krajach Unii Europejskiej w latach 2007-2010 w interwałach kwartalnych

2.8 Wyjścia z inwestycji funduszy mających siedzibę w Polsce w latach 2002-2010 ... 
2.9. Udział poszczególnych metod dezinwestycji w łącznej wartości wyjść z inwestycji funduszy private equity mających siedzibę w Polsce w latach 2002-2010

2.10. Zastosowanie poszczególnych metod dezinwestycji w procesach wyjść z inwestycji funduszy private equity mających siedzibę w Polsce według liczby przedsiębiorstw w latach 2002-2010

2.11. Metody dezinwestycji stosowane przez fundusze private equity mające siedzibę w Polsce w latach 2002-2010

2.12. Kwota dezinwestycji według segmentu rynku kapitału podwyższonego ryzyka w latach 2007-2010

2.13. Średnia wartość dezinwestycji przypadająca na jedno przedsiębiorstwo w latach 2007-2010

2.14. Wartość dezinwestycji funduszy private equity w Europie w latach 2008-2010 ......

3.1. Wybór momentu wyjścia z inwestycji według ogólnej teorii dezinwestycji

3.2. Funkcja prawdopodobieństwa wyjścia $\mathrm{z}$ inwestycji metodą pierwszej oferty publicznej (IPO), sprzedaży przedsiębiorstwa inwestorowi strategicznemu (TS) oraz likwidacji (Liquidation) inwestycji w zależności od branży, w której spółka portfelowa prowadzi działalność

3.3. Udział funduszu private equity w kapitale zakładowym analizowanych spółek bezpośrednio przed wprowadzeniem na GPW w Warszawie

3.4. Struktura debiutów giełdowych spółek portfelowych funduszy private equity według kryterium zbywania akcji spółki portfelowej przez fundusz private equity $\mathrm{w}$ ofercie publicznej

3.5. Struktura debiutów giełdowych spółek portfelowych funduszy private equity według kryterium powiązania z emisją nowych akcji

3.6. Długość okresu lock-up dla funduszy private equity w analizowanych spółkach ....

3.7. Stopień dezinwestycji realizowanej przez fundusze private equity w drodze

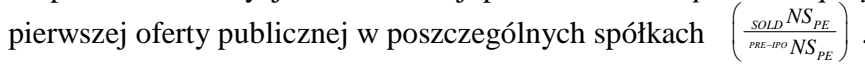

3.8. Stosunek liczby akcji nowej emisji do liczby akcji istniejących przed pierwszą ofertą publiczną w poszczególnych spółkach $\left(\frac{N S_{N E W}}{{ }_{\text {PRE-FOT } T N S}}\right)$

3.9. Struktura pierwszych ofert publicznych spółek portfelowych według źródła pochodzenia sprzedawanych akcji

3.10 Struktura oferty w poszczególnych spółkach

3.11 Struktura akcjonariatu Travelplanet.pl SA

3.12. Struktura pierwszej publicznej oferty sprzedaży akcji spółki Opoczno SA

3.13. Udział grup produktowych w przychodach ze sprzedaży Grupy Kapitałowej W. KRUK w $2001 \mathrm{r}$.

3.14. Struktura akcjonariatu Grupy Kapitałowej W. KRUK

3.15. Struktura akcjonariatu spółki K2 Internet $S A$ przed debiutem giełdowym 
4.1. Przeciętne wartości współczynnika rentowności kapitału własnego analizowanych przedsiębiorstw

4.2. Struktura analizowanych spółek portfelowych funduszy private equity według kierunku zmian współczynnika rentowności kapitału własnego w roku $n_{+1}$ w porównaniu do roku $n_{-1}$

4.3. Średnie wartości współczynników rentowności kapitału własnego, aktywów oraz sprzedaży badanych spółek portfelowych funduszy private equity

4.4. Średnie wartości mnożników kapitałowych analizowanych przedsiębiorstw ........

4.5. Wpływ zmian rentowności sprzedaży, produktywności aktywów oraz mnożnika kapitałów na rentowność kapitału własnego analizowanych spółek

4.6. Średni koszt oferty spółek krajowych na rynku głównym GPW w Warszawie w stosunku do wartości oferty w latach 2003-2010 (bez kosztów subemisji) .......

4.7. Stosunek kosztów pierwszej oferty publicznej do jej wartości w spółkach portfelowych funduszy private equity w latach 2002-2010

4.8. Rozkład linii dopasowania względnego kosztu pierwszych ofert publicznych spółek portfelowych funduszy private equity na GPW w Warszawie w latach 2002-2010 do wartości oferty

4.9. Struktura kosztów pierwszych ofert publicznych spółek portfelowych funduszy private equity w latach 2002-2010 .

4.10. Wartość ofert i liczba nowych spółek z udziałem funduszy private equity na GPW w Warszawie w latach 2002-2010

4.11. Sektorowy rozkład pierwszych ofert publicznych spółek portfelowych funduszy private equity w latach 2002-2010 na GPW w Warszawie

4.12. Skumulowane anormalne stopy zwrotu $\mathrm{z}$ akcji spółek portfelowych funduszy private equity dla pierwszych ofert publicznych w latach 2002-2010 .

4.13. Skumulowane anormalne stopy zwrotu spółek giełdowych debiutujących na GPW w Warszawie w latach 2002-2010

4.14. Wskaźnik bogactwa $W R_{T}$ dla spółek giełdowych debiutujących na GPW w Warszawie w latach 2002-2010

4.15. Wskaźnik bogactwa $W R_{T}$ dla spółek portfelowych funduszy private equity debiutujących na GPW w Warszawie w latach 2002-2010 w zależności od zakresu zrealizowanej dezinwestycji 